\title{
Fossil Spatangoid Echinoids of Cuba
}

\section{PORTER M. KIER}




\title{
SERIES PUBLICATIONS OF THE SMITHSONIAN INSTITUTION
}

Emphasis upon publication as a means of "diffusing knowledge" was expressed by the first Secretary of the Smithsonian. In his formal plan for the Institution, Joseph Henry outlined a program that included the following statement: "It is proposed to publish a series of reports, giving an account of the new discoveries in science, and of the changes made from year to year in all branches of knowledge." This theme of basic research has been adhered to through the years by thousands of titles issued in series publications under the Smithsonian imprint, commencing with Smithsonian Contributions to Knowledge in 1848 and continuing with the following active series:

\author{
Smithsonian Contributions to Anthropology \\ Smithsonian Contributions to Astrophysics \\ Smithsonian Contributions to Botany \\ Smithsonian Contributions to the Earth Sciences \\ Smithsonian Contributions to the Marine Sciences \\ Smithsonian Contributions to Paleobiology \\ Smithsonian Contributions to Zoology \\ Smithsonian Studies in Air and Space \\ Smithsonian Studies in History and Technology
}

In these series, the Institution publishes small papers and full-scale monographs that report the research and collections of its various museums and bureaux or of professional colleagues in the world of science and scholarship. The publications are distributed by mailing lists to libraries, universities, and similar institutions throughout the world.

Papers or monographs submitted for series publication are received by the Smithsonian Institution Press, subject to its own review for format and style, only through departments of the various Smithsonian museums or bureaux, where the manuscripts are given substantive review. Press requirements for manuscript and art preparation are outlined on the inside back cover.

\author{
S. Dillon Ripley \\ Secretary \\ Smithsonian Institution
}





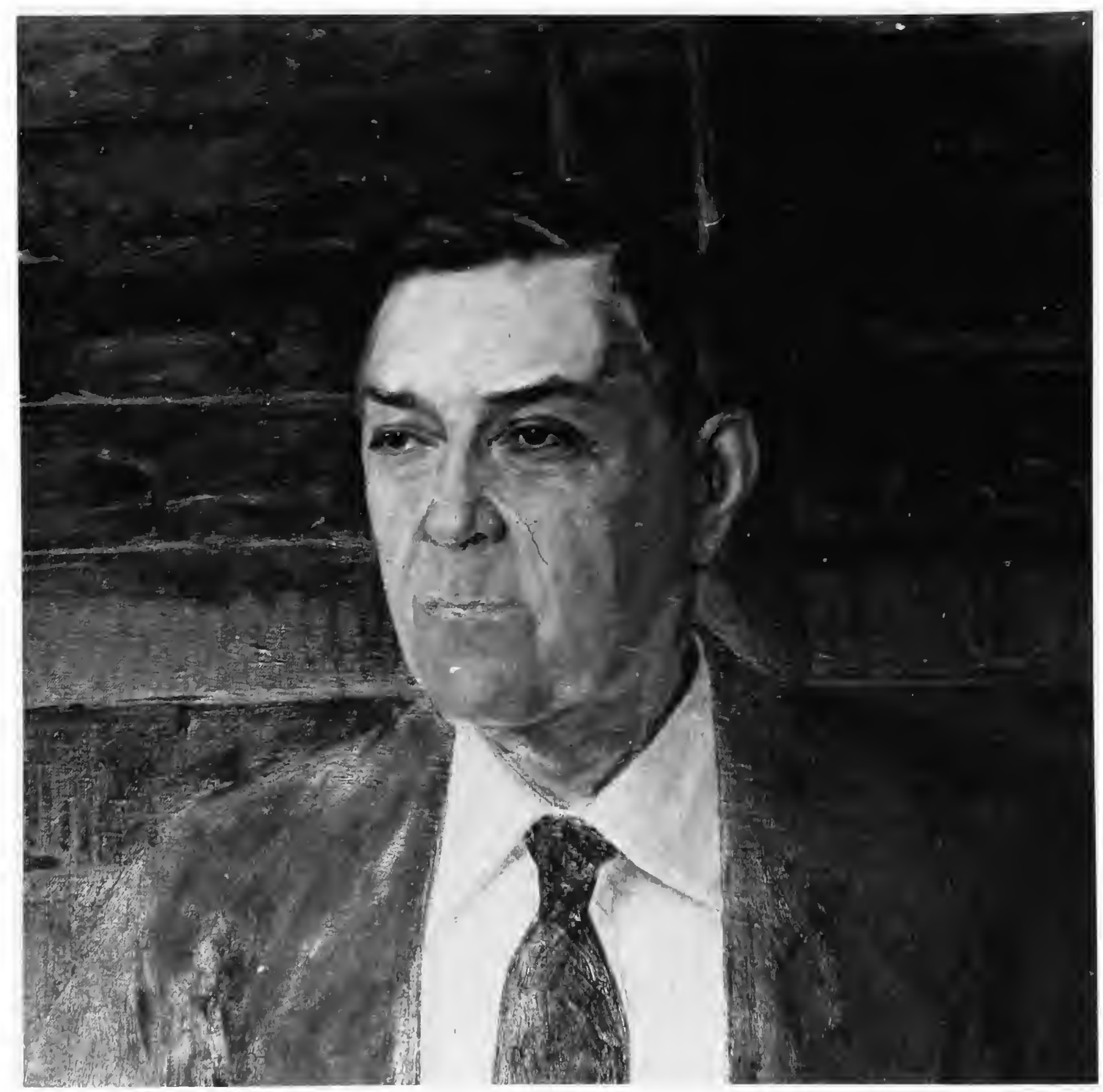

Mario Sánchez Roig

1890-1962 
SMITHSONIAN GONTRIBUTIONS TO PALEOBIOLOGY $\bullet$ NUMBER 55

\title{
Fossil Spatangoid Echinoids of Cuba
}

\author{
Porter M. Kier
}

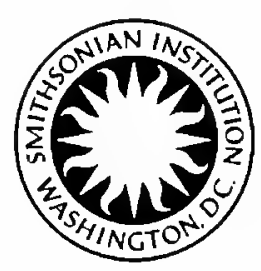

SMITHSONIAN INSTITUTION PRESS

City of Washington

1984 
Kier, Porter M. Fossil Spatangoid Echinoids of Cuba. Smithsonian Contributions to Paleobiology, number 55, 336 pages, frontispiece, 45 figures, 90 plates, 6 tables, 1984. - The fossil spatangoid echinoids of Cuba are described based for the most part on specimens in the Sanchez Roig Collection. Seventy-nine species are recognized including 10 from the Late Cretaceous, 36 from the Eocene, 20 from the Oligocene-Miocene, 11 from the Miocene, and 2 of uncertain age. Three of the Eocene species are new: Schizaster formelli, Linthia monteroae, and Antillaster albeari. A new genus of schizasterid is described, Caribbaster, with the Eocene Prenaster loveni Cotteau as the type-species. A new Asterostoma, A. pawsoni, is described from the Eocene of Jamaica.

The Eocene age of the Cuban echinoid-bearing localities is confirmed by the presence outside Cuba of many of the same species in beds dated on other fossils. Some evidence supports the Miocene determinations, but the echinoids are of little assistance in resolving the question whether the Cuban beds attributed to the Oligocene are Oligocene or Miocene. Cuban, and in general, the Caribbean Tertiary echinoid faunas are distinct from those in Europe and the Mediterranean. Many genera are confined to the Caribbean. The Cuban fauna is also different from that found nearby in Florida. This difference may be due to a suggested greater depth of water in Cuba.

Se describen los equinoideos espatangoideos de Cuba, incluyendo los especímenes de la Colección Sánchez Roig. Se reconocen setena y ocho especies: 10 del Cretáceo Superior, 36 del Eoceno, 20 del Oligo-Mioceno, 11 del Mioceno, y 2 cuya edad no se ha determinado con certeza. Tres de las especies del Eoceno son neuvas: Schizaster formelli, Linthia monteroae, y Antillaster albeari. Se establece un nuevo género de schizasterid, Caribbaster, y se elige a Prenaster loveni Cotteau, del Eoceno, como especie-tipo. También se describe una nueva especie de Asterostoma, A. pawsoni, del Eoceno de Jamaica.

La edad de los equinoideos cubanos del Eoceno ha sido confirmada por la presencia, en foraciones de áreas fuera de Cuba, de muchas de las mismas especies en localidades donde se hallan otros fósiles del Eoceno. Las determinaciones del Mioceno están basadas en ciertas evidencias, sin embargo, los equinoideos ofrecen poca ayuda para dilucidar la cuetión de si las formaciones cubanas que se atribuyen al Oligoceno son de este periodo o del Mioceno. Las faunas de equinoideos del Terciario de Cuba, y en general del Caribe, son muy distintas a las de Europa y del Mediterráneo. Muchos géneros están confinados al Caribe y la fauna cubana es, asimismo, muy diferente a la que se encuentra en la cercana Florida. Esta diferencia puede ser debida a la mayor profunidad, según se ha sugerido, de las aguas de Cuba.

OfFicial publication date is handstamped in a limited number of initial copies and is recorded in the Institution's annual report, Smithsomian Year. Series cover design: The trilobite Phacops rana Green.

Library of Congress Cataloging in Publication Data

Kier, Porter M.

Fossil Spatangoid echinoids of Cuba

(Smithsonian contributions to paleobiology ; no. 55)

Bibliography: $p$

Includes index.

Supt. of Docs. no.: SI 1.30:55

1. Spatangoida, Fossil. 2. Paleontology--Tertiary. 3. Paleontology-Cuba. I. Title. II Series.

QE701.S56 no. 55 [QE783.E2] 560s [563'.95] 83-600065 


\section{Contents}

Introduction $\ldots \ldots \ldots \ldots \ldots \ldots \ldots \ldots \ldots \ldots \ldots \ldots \ldots \ldots \ldots$

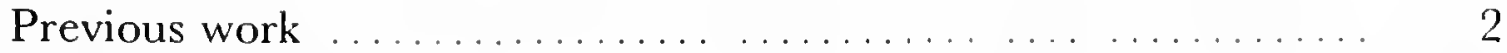

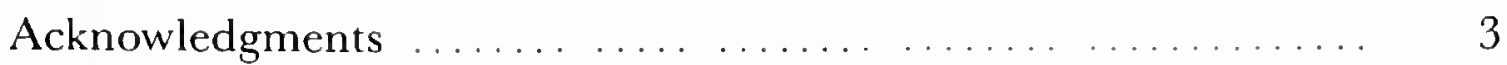

The Guban Echinoid Faunas $\ldots \ldots \ldots \ldots \ldots \ldots \ldots \ldots$

Cretaceous ............................... 4

Eocene ............................................. 4

Oligocene-Miocene $\ldots \ldots \ldots \ldots \ldots \ldots \ldots \ldots \ldots \ldots \ldots \ldots \ldots$

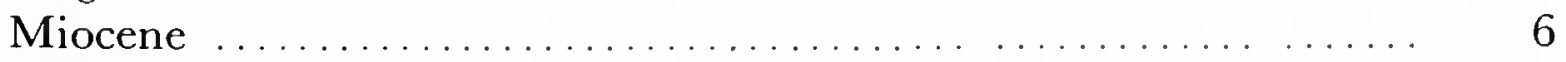

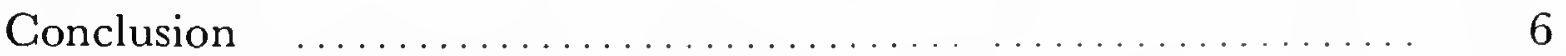

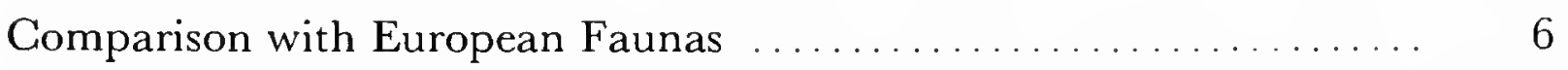

Comparison with Other Faunas in the Caribbean .............. 7

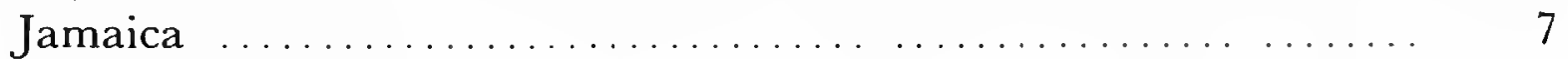

St. Bartholomew ................................ 8

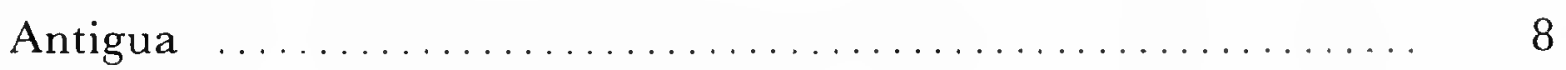

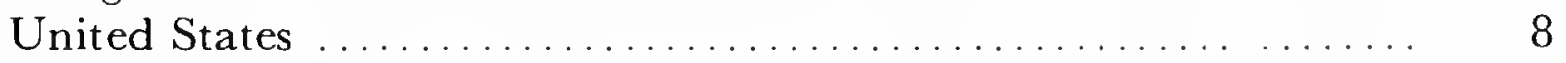

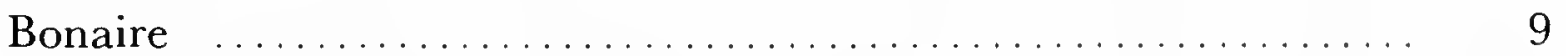

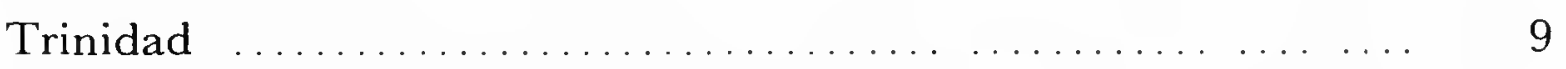

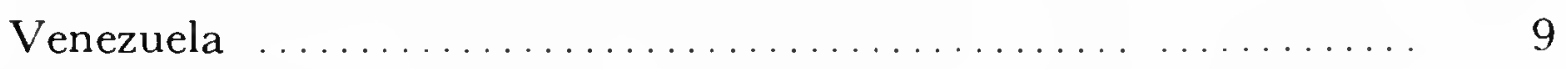

Puerto Rico ...................................... 9

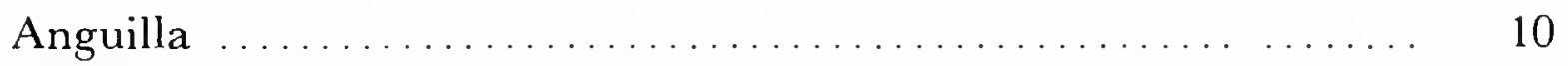

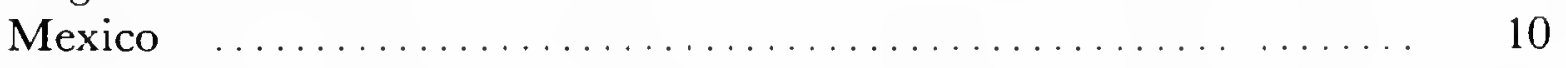

Costa Rica ........... . .......................... 10

Panama ............................................. 10

Order Disasteroida Mintz, $1968 \ldots \ldots \ldots \ldots \ldots \ldots \ldots \ldots \ldots \ldots \ldots \ldots$

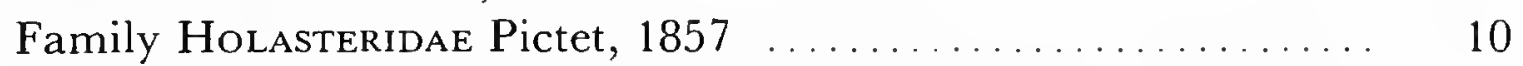

Genus Cardiaster Forbes, $1850 \ldots \ldots \ldots \ldots \ldots \ldots \ldots \ldots$

Genus Echinocorys Leske, 1778 .................... 12

Family Urechinidae Duncan, $1889 \ldots \ldots \ldots \ldots \ldots \ldots \ldots \ldots$

Genus Sanchezaster Lambert, 1924 .................... 13

Order Spatangoida Glaus, $1876 \ldots \ldots \ldots \ldots \ldots \ldots \ldots \ldots \ldots \ldots$

Suborder Toxasterina A.G. Fischer, $1966 \ldots \ldots \ldots \ldots \ldots \ldots \ldots$

Family Toxasteridae Lambert, $1920 \ldots \ldots \ldots \ldots \ldots \ldots \ldots . \ldots \ldots$

Genus Douvillaster Lambert, 1917 ..................... 15

Suborder Hemiasterina A.G. Fischer, $1966 \ldots \ldots \ldots \ldots \ldots \ldots . \ldots \ldots$

Family Hemiasteridae Clark, $1917 \ldots \ldots \ldots \ldots \ldots \ldots \ldots \ldots \ldots$

Genus Hemiaster L. Agassiz, $1847 \ldots \ldots \ldots \ldots \ldots \ldots \ldots . \ldots \ldots$

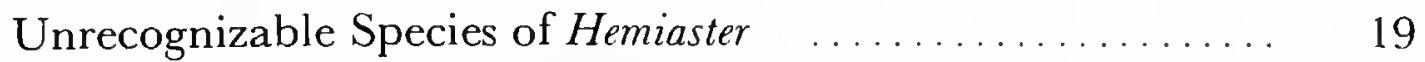

Family Paleopneustidae A. Agassiz, $1904 \ldots \ldots \ldots \ldots . \ldots . \ldots . \ldots 20$

Genus Pericosmus L. Agassiz, 1847 .................. . . 20

Key to Guban Species of Pericosmus ................. 22

Unrecognizable Species of Pericosmus ............... 35 
Family Schizasteridae Lambert, 1905 ...................... 35

Genus Schizaster L. Agassiz, 1836 ...................... 35

Unrecognizable Species of Schizaster ................... 58

Genus Agassizia L. Aggasiz and Desor, 1847 ............ 59

Key to Cuban Species of Agassizia .................... 61

Unrecognizable Species of Agassizia $\quad \ldots \ldots \ldots \ldots \ldots \ldots . . \ldots 6$

Genus Aguayoaster Sánchez Roig, 1952 .................. 67

Genus Caribbaster, new genus ....................... 67

Genus Lambertona Sánchez Roig, 1953 ................... 69

Genus Linthia Desor, 1853 .......................... 71

Unrecognizable Species of Linthia ................. $\quad 77$

Genus Prenaster Desor, 1853 .......................... $\quad 77$

Unrecognizable Species of Prenaster $\ldots \ldots \ldots \ldots \ldots \ldots . \ldots 78$

Suborder Micrasterina A.G. Fischer, $1966 \ldots \ldots \ldots \ldots \ldots \ldots \ldots . \ldots \ldots$

Family Micrasteridae Lambert, $1920 \ldots \ldots \ldots \ldots \ldots \ldots \ldots$

Genus Habanaster Lambert, 1924 .................... $\quad 79$

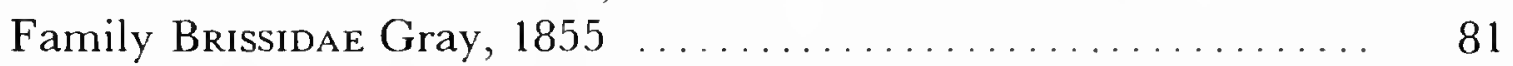

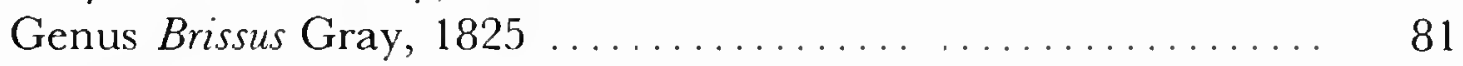

Genus Brissopsis L. Agassiz, 1847 ................... 86

Genus Cyclaster Cotteau, 1856 ..................... 88

Genus Eupatagus L. Agassiz, 1847 ... . ............... 93

Key to Cuban Species of Eupatagus _................. 95

Unrecognizable Species of Eupatagus . ................ 112

Genus Fernandezaster Sánchez Roig, 1952 .............. 112

Genus Hernandezaster Sánchez Roig, 1949 ............... 113

Genus Lajanaster Lambert and Sánchez Roig, 1924 ........ 114

Unrecognizable Species of Lajanaster .................. 115

Genus Macropneustes L. Agassiz, 1847 .................. 115

Genus Meoma Gray, $1851 \ldots \ldots \ldots \ldots \ldots \ldots \ldots \ldots \ldots \ldots$

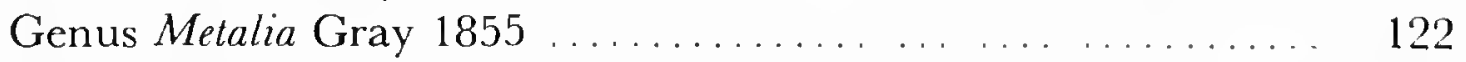

Genus Migliorinia Checchia-Rispoli, 1942 .............. 122

Genus Rojasia Sánchez Roig, 1951 ...................... 123

Suborder Asterostomatina A.G. Fischer, 1966 .............. 124

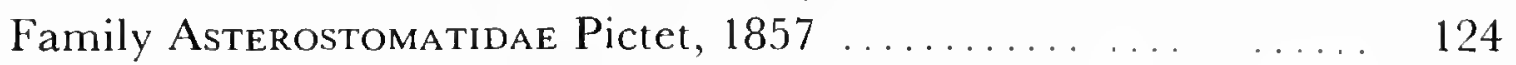

Genus Asterostoma L. Agassiz, 1847 ................... 124

Genus Antillaster Lambert, 1909 ..................... 131

Key to Cuban Species of Antillaster ...... . ....... 134

Unrecognizable Species of Antillaster $\ldots \ldots \ldots \ldots$

Genus Moronaster Sánchez Roig, 1952 ... . . $\quad \ldots \quad \ldots \quad \ldots \quad \ldots \quad 144$

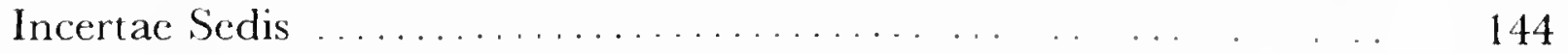

Genus Brissopatagus Cotteau, 1863 ...

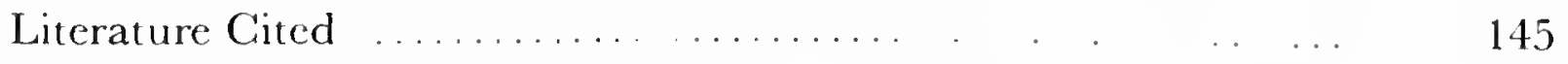

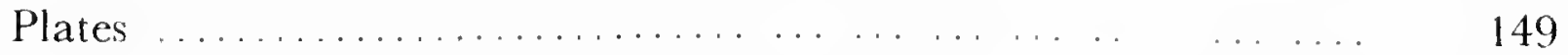

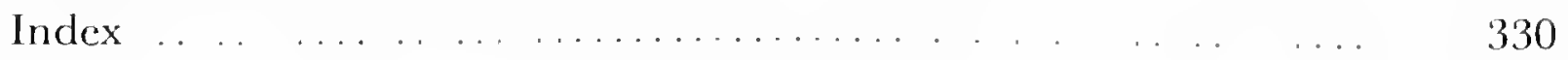




\title{
Fossil Spatangoid Echinoids of Cuba
}

\author{
Porter M. Kier
}

\section{Introduction}

An extraordinary total of 401 fossil echinoids have been described from Cuba. Most of the species are Eocene to Miocene, with 157 Eocene, 179 Oligocene, and 33 Miocene species. None has been reported from the Pliocene, but 10 are present in the Pleistocene. Twenty-two have been reported from the Cretaceous, but none are older.

Most of these species were described by Dr. Mario Sánchez Roig, a medical doctor in Havana, who over a period of thirty years amassed a large collection of echinoids. With great patience and perseverance, he collected thousands of specimens from all over Cuba. He dedicated all his free time to this effort, spending days at one site searching for specimens. Many professional and amateur collectors gave or sold him their specimens as his dedication to this work became known throughout Cuba. Workers in the quarries would save him any specimens that they found.

From 1920 to 1953 he described and illustrated in numerous publications this vast collection. Although not formally trained in the field, his research was equal in quality to that of echinologists elsewhere in the world. He maintained his own collection for many years, until it eventually became the property of the Cuban Academy of Sciences, which is now responsible for its care and curation.

Porter M. Kier, Department of Paleobiology, National Museum of Natural History, Smithsonian Institution, Washington, D.C. 20560.
Sánchez Roig did not have adequate photographic equipment; most of the illustrations of his 291 species are of poor quality. Consequently, echinoid workers outside Cuba have found it difficult to use his work. Generally his species have been ignored, and this great Cuban echinoid fauna has not received the attention that it deserves.

This present work is devoted to a redescription of all the Cuban fossil spatangoid echinoids-in particular those in the Sánchez Roig Collection. All Cuban specimens in other museums throughout the world have also been studied. These include specimens in the Cotteau and Lambert collections in France, the Palmer Collection at the Academy of Natural Science in Philadelphia, and the collection at the University of California in Berkeley. Also examined were the Cuban specimens (some identified and presented by Sánchez Roig) in the Smithsonian's National Museum of Natural History, the American Museum of Natural History, and the Museum of Comparative Zoology at Harvard. Furthermore, where possible, specimens from elsewhere in the Caribbean were studied for comparison with the Cuban echinoids. In particular, all the specimens of Jamaican Eocene echinoids in the great Arnold Collection at the Museum of Comparative Zoology were compared to the Cuban material.

Of 179 spatangoid species reported from Cuba, 61 (described by Sánchez Roig) are herein considered to be synonyms. This decision to place so many species in synonymy reflects a differing 
concept of what amount of variation can be expected within a species. Sánchez Roig, who had very few specimens of many of his species, could not know the extent of this variation. If in doubt, he seemed to prefer naming a new species. However, the number of species of the same genus from one locality is far higher than one would expect. For example, Sánchez Roig recognized 11 species of Eupatagus from his "Cervantes" locality. In my opinion the differences between these species either fall within the range of variation common to single species or result from postmortem deformation.

The validity of many species is difficult to determine because of the paucity of well-preserved specimens. It has been necessary to make numerous arbitary decisions with which another worker could disagree. For this reason the type specimens of the synonymized species are described and re-illustrated herein so that other workers can make their own judgments as to the validity of the species. Synomymized species are not redescribed unless the type specimens were available. A questionmark before the generic name indicates my uncertainty as to whether or not it is a synonym, such as?Eupatagus calistoides Sánchez Roig. Uncertainty of a generic identification is indicated by a question mark immediately after the generic name as in Linthia? avilensis Sánchez Roig.

The only way to increase the accuracy of the identification would be to obtain more specimens. However, many of the original localities are now covered with vegetation. Those sites that are still exposed yield few specimens. For example, Drs. Albear and Formell took me to the quarry at "Cervantes" where so many of Sánchez Roig's specimens were collected; only a few fragments of echinoids were located.

Not only is the number of specimens inadequate, but most are badly weathered. This is particularly unfortunate with the spatangoids because they lose their fascioles postmortem-an extremely important character in specific and generic identification. The position of the fascioles on many specimens must be inferred. One advantage of this weathering, however, is that it etches out the sutures, making the plate arrangement visible. The plate sutures on unweathered specimens are normally invisible.

All of the extant Cuban type specimens are described herein and re-illustrated. The description of species follows the procedures prescribed by Chesher (1968), who noted that many spatangoid characteristics remain the same regardless of the size of the specimen. These characters are, therefore, particularly useful in systematic comparisons. For example, the fascioles cross particular plates on the test and remain on those same plates throughout the growth of the echinoid. Therefore, Chesher (1968:5) recommended that echinoid workers always record which plate (numbered from the peristome) bore a part of a fasciole. Likewise the same plates will continue to surround the periproct, and specific plates will carry the first petaloid pores throughout the animal's life. Wherever possible, I have tried to determine these characters. Unfortunately the fascioles of many specimens are not visible; and on others not enough plate sutures are visible to allow a count of the number of plates to the peristome.

All the available specimens were used in the description. Unfortunately only one specimen each is known of many species, making it impossible to evaluate the extent of variation within a species.

An interpretation of the living habits of each genus is made possible by the discoveries of Smith (1980), whose comparative studies of living material have revealed the relationship between the character of a pore and the tubefoot that extends from it. One can discern on the basis of the fossil's pores, particularly in the anterior ambulacrum, whether and into what kind of sediment the spatangoid could burrow.

Previous Work. - The first published record of fossil echinoids in Cuba was by Parra in 1787, in which he included figures of some specimens. Sagra (1855) noted that species of echinoids described by d'Orbigny were also present in Cuba. Agassiz, in Agassiz and Desor (1847:22, 143, 144, 168) mentioned four species that occurred in Cuba including his new species, Asterostoma excen- 
tricum. Cotteau (1871) described two new species of Asterostoma from Cuba and redescribed A. excentricum.

Later, Michelin (1855) described a new species and mentioned two others as occurring in Cuba. Cotteau (1875), in his introduction to a monograph of the fossil echinoids of St. Bartholomew and Anguilla, briefly described 10 species from Cuba, 5 of which were new. Cortázar (1880) described one new Encope from Cuba. In 1881, Cotteau published a major monograph of fossil echinoids from Cuba, in which 20 species (5 of which were new) were described. Egozcue y Cia in Cotteau (1897) used Cotteau's descriptions and illustrations and reported some new occurrences for species previously known elsewhere. Forty-one species were included.

In 1922, Jackson completed a monograph on all the fossil echinoids of the West Indies. Fortyseven species were from Cuba, including three new species. Lambert (1928) described one new species of Echinoneus and noted the presence of an African species of Discoides in Cuba; in 1932 he described 9 more Cuban species. Weisbord (1934) described 22 new species, including 10 spatangoids, that he collected at 5 localities in Cuba. Finally, Žitt (1981) very skillfully redescribed 2 species of the spatangoid Aguayoaster and discussed their living habits.

Sánchez Roig started publishing on fossil echinoids in 1920 and continued until 1953. In 1949 he produced a monograph of all the known fossil echinoderms of Cuba with 309 species, 110 of which were his own new species, 14 of Palmer's, 5 of Lambert and Sánchez Roig's, and 2 of Lambert's. Subsequently, Sánchez Roig described 153 more species. All his echinoid papers are listed in the bibliography.

ACKNowledgments. - This volume is dedicated to Dr. Mario Sánchez Roig. His extreme dedication resulted in the assembly of one of the most important echinoid collections in the world. Without his efforts, the presence of this large echinoid fauna in Cuba might never have been known. His contributions to the study of fossil echinoids rank with those of Lambert, Cotteau, and d'Orbigny.
This revision could have never been accomplished without the help and full cooperation of the Cuban Academy of Sciences. I thank Dr. Wilfredo Torres Iribar, President of the Academy, for his support. Ing. Amelia Brito Rojas and Ing. Lenia Montero Zamora, directors of the Instituto de Geologia y Paleontologia, helped in every way possible. They provided access to the Sánchez Roig Collection (SRC) and gave permission to borrow specimens for preparation here in Washington. Drs. Francisco de Albear and Francisco Formell guided field trips to some of the more important Cuban echinoid localities. Dr. Albear was of great assistance in providing current stratigraphic information on Sánchez Roig's localities. Consuelo Diaz Otero and Rafaela Pérez aided me in my search for specimens in the Sánchez Roig Collection. Lic. Sergio Jorge Pastrana, Director of international relations of the Academy, working in conjunction with the Smithsonian Institution, made all the arrangements necessary for my visits to Havana to study the collection. Here at the Smithsonian, Ross Simons set up the original program for the exchange of scientists with the Cuban Academy and expedited subsequent travel to Havana. Finally Dr. Abelardo Moreno, the Director of the National Zoos and Aquaria, encouraged me throughout this study.

Mary Hurd Lawson, Smithsonian Institution, did all the photography, the computer programming, preparation of the bibliography, much of the literature search plus many other tasks too numerous to name. She did all these tasks with great skill and ingenuity.

I thank the following individuals who kindly lent specimens from their institutions: Richard P.S. Jefferies and David N. Lewis of the British Museum (Natural History), London, England; A. Prieur and L. David (Cotteau Collection) of the Université Claude Bernard, Lyons, France; Daniel Pajaud (Lambert Collection) of the Université Pierre et Marie Curie, Paris, France; Jean Roman of the Instutut de Paléontologie, Muséum National d'Histoire Naturelle, Paris, France (MNHN); C.G. Rümke and G.H.R. von Koenigswald of the Instituut voor Aardwetenschappen 
Ryksuniversiteit, Utrecht, The Netherlands; Peter Jung and John Saunders of the Naturhistorisches Museum, Basel, Switzerland; George Ubaghs of the Laboratorie de Paléontologie Animale, Université de Liége, Liége, Belgium; Charles E. Mitchell and Vickie Kohler of the Museum of Comparative Zoology, Havard University, Cambridge, Massachusetts (MCZ); Peter U. Rodda of the California Academy of Sciences, San Francisco, California; J. Wyatt Durham of the University of California, Berkeley, Museum of Paleontology (UCB); George Davis of the Academy of Natural Sciences of Philadelphia, Pennsylvania (ANSP); Bruce Haugh and Niles Eldredge of the American Museum of Natural History, New York, New York (AMNH); Peter Hoover of the Paleontological Research Institution, Ithaca, New York (PRI).

I thank Charles G. Messing and John Miller who sent me photographs of Paleopneustes, which were taken from a submarine. The manuscript was read by David Pawson and Richard Grant. I am indebted to both of them for their helpful suggestions. Edward Robinson of Robertson Research, Inc., Houston, Texas, provided information on the age of echinoid-bearing deposits in Jamaica.

Finally, I am indebted to Joan B. Horn, editor at the Smithsonian Institution Press, who with patience, persistence, and with her usual great skill edited this paper.

\section{The Cuban Echinoid Faunas}

Although 179 species of spatangoid echinoids have been reported from Cuba, only 79 species are recognized herein. This reduction is due partially to the loss of some of the type specimens, but mainly to the placing of many species in synonymy. No species are known to be older than the late Cretaceous from which 10 species have been reported. They are most common in the Eocene (36 species), decrease in number in the Oligocene-Miocene (20 species) and the Miocene (11 species). Two species, Meoma? brodermanni (Sánchez Roig) and Meoma antillarum (Cotteau), are of uncertain age.

\section{Cretaceous}

Cretaceous spatangoids are rare in the Caribbean. Only 10 species are recognizable from Cuba:

Cardiaster cubensis Jackson

C. palmeri Sánchez Roig

Echinocorys ovatus Leske

Douvillaster triangularis (Sánchez Roig)

Hemiaster?' gonzalezmunozi Sánchez Roig

$H$. herrerae (Lambert and Sánchez Roig)

$H$. madrugensis Weisbord

$H$. siboneyensis Weisbord

Linthia? avilensis Sánchez Roig

L. brodermanni Sánchez Roig

Only one species, Echinocorys ovatus, occurs outside of Cuba, but I suspect that the specimens of this species supposedly collected in Cuba came from the Chalk of western Europe. None of these Cretaceous species resembles any species from elsewhere in the Western Hemisphere.

\section{EOCENE}

The Cuban Eocene echinoid fauna includes the following spatangoid species:

Sanchezasler habanensis Lambert

Pericosmus atolladosae (Sánchez Roig)

Schizasler bathypetalus Arnold and Clark

S. camagueyensis (Weisbord)

S. cubilabellae (Weisbord)

$S$. formelli, new species

S. gerthi Pijpers

S. llagunoi Lambert and Sánchez Roig

S. nuevitasensis (Weisbord)

S. santanae Sánchez Roig

S. subcylindricus Cotteau

Agassizia clevei Cotteau

A. inflata Jackson

Aguayoaster aguayoi Sánchez Roig

A. nuevilasensis (Sánchez Roig)

Caribbaster loveni (Cotteau)

Lambertona lamberti (Sánchez Roig)

Linthia monteroae, new species

Prenaster parvus Palmer

Habanasler sanchezi Lambert

Brissus cabrerai (Sánchez Roig)

$B$. camagueyensis Weisbord

B. caobaense Sánchez Roig

$B$. durhami (Sánchez Roig)

Cyclaster drewryensis Cooke

C. sanchezi Lambert 
Macropneusles (Deakia) armadilloensis Sánchez Roig

Meoma antigua Arnold and Clark

Eupatagus alatus Arnold and Clark

E. siboneyensis Weisbord

E. turibacoensis Sánchez Roig

Rojasia rojasi Sánchez Roig

Asterostoma excentricum Agassiz

A. subcircularis Sánchez Roig

Antillaster albeari, new species

A. arnoldi Clark

Comparison of these echinoids with non-Cuban species confirms the age determination of Cuban localities that had been considered to be Eocene. The quarry at Loma Caoba, near San Diego de los Baños in Pinar del Rio Province, is considered middle to late Eocene. It contains 11 species of spatangoids, 7 of which occur in deposits elsewhere that are considered by all modern workers to be Eocene:

Schizaster bathypetalus Arnold and Clark

S. gerthi Pijpers

S. subcylindricus Cotteau

Agassizia inflata Jackson

Aguayoaster aguayoi Sánchez Roig

Brissus caobaense Sánchez Roig

B. durhami (Sánchez Roig)

Meoma antigua Arnold and Clark

Eupalagus alatus Arnold and Clark

Asterostoma excentricum Agassiz

Antillaster albeari, new species

Three of these species also occur in the Eocene of Jamaica: Schizaster bathypetalus, Meoma antigua, and Eupatagus alatus. Schizaster gerthi is present in Bonaire in beds considered to be late Eocene. Schizaster subcylindricus is present in the Eocene of St. Bartholomew and Jamaica. Agassizia inflata is present in the Eocene of St. Bartholomew and Jamaica and in the middle Eocene Castle Hayne Limestone of North Carolina. Asterostoma excentricum is also present in the Eocene of Jamaica.

Many specimens of Oligopygus also occur at Loma Caoba. This oligopygoid genus is found elsewhere only in the Eocene.

Many spatangoid species occur at another Eocene locality-Loma Calisto, Nuevitas, Camagüey Province, Cuba. The following spatangoids have been found there:

Schizaster camagueyensis (Weisbord)

Agassizia clevei Cotteau
Aguayoaster nuevitasensis (Sánchez Roig)

Caribbaster loven (Cotteau)

Brissus camagueyensis Weisbord

Eupatagus siboneyensis Weisbord

E. turibacoensis Sánchez Roig

Caribbaster loveni also occurs in the Eocene of Jamaica and St. Bartholomew. Aguayoaster nuevitasensis is probably a synonym of Aguayoaster aguayoi, which is found in the Eocene at Loma Caoba. Many specimens of Oligopygus also occur at Loma Calisto as does the clypeasteroid Tarphypygus, a genus apparently restricted to the Eocene of Cuba and Jamaica.

Three species that occur in Eocene strata in a deep cut north of Grua 9, Ramal, Camagüey Province are

Schizaster camagueyensis (Weisbord)

Cyclaster drewryensis Cooke

Eupatagus alatus Arnold and Clark

Cyclaster drewryensis is known from the early Oligocene of Alabama, but Schizaster camagueyensis occurs also in the Eocene at Loma Calisto. Eupatagus alatus is not only present in Eocene rocks at Loma Caoba but also in the Eocene of Jamaica. Finally, the Eocene Oligopygus occurs at this locality.

\section{Oligocene-Miocene}

The following species occur in beds considered by Sánchez Roig or Brodermann to be Oligocene:

Pericosmus aguayoi (Sánchez Roig)

$P$. blanquizalensis Sánchez Roig

$P$. camagueyanus Sánchez Roig

P. mortenseni (Sánchez Roig)

Schizaster carlagensis (Sánchez Roig)

S. egozcuei Lambert

S. munozi Sánchez Roig

S. rojasi Sánchez Roig

S. sanclamariae Sánchez Roig

Agassizia alveari Sánchez Roig

Brissus minulus (Sánchez Roig)

Brissopsis aguayoi Sánchez Roig

Macropneustes? (Macropneustes) palmeri (Sánchez Roig)

Meoma?' gomezmazae (Sánchez Roig)

Fernandezaster mortenseni Sánchez Roig

Eupatagus santanae Sánchez Roig

E. clever (Cotteau)

Antillaster fernandezi (Sánchez Roig)

A. lamberti Jeannet

A. vaughani (Jackson) 
Many of these species may be Miocene. In the last 20 years some workers, on the basis of the foraminifera and ostracodes, have placed most of what was thought to be the Cuban Oligocene into the Miocene. Unfortunately Sánchez Roig usually did not state from what formation his echinoids were collected. Brodermann (1949) revised some of Sánchez Roig's age determinations and gave a section listing formations he considered to be Oligocene. His early Oligocene Adelina Formation was considered middle Oligocene by Bermúdez and Hoffstetter (1959:7) and Bermúdez (1961:57) but early Miocene by Eames et al. (1962, fig. 5) and Eames and Savage (1975: 305). Brodermann (1949) placed the Colon Formation in the middle Oligocene, but Bermúdez (1961:74) put it in the Aquitanian, which he considered late Oligocene. Eames et al. (1962, fig. 2) and Eames and Savage (1975:415) regard the Aquitanian as early Miocene. Brodermann's late Oligocene included the Jaruco, Tarará, Cojímar, and Limonar-Capellanias formations, all of which are considered now to be Miocene. Bermúdez (1961:69, 72, 104, 108, 141) places these formations in the Aquitanian and Burdigalian; Brönnimann and Rigassi (1963:467) attribute a Miocene age to the Cojímar. Van den Bold (1965, table 5) places the Jaruco and Cojímar in the Miocene as does Albear (1980, personal communication). Eames and Savage (1975) consider them all to be Miocene. Therefore, herein, species that Sánchez Roig considered to be Oligocene will be dated as Oligocene-Miocene except when it is known from what formations they came, or when new information is available on the age of the locality.

Elsewhere in the Western Hemisphere, formations formerly considered Oligocene are now placed in the early Miocene by some workers. These formations will be dated herein as Oligocene-Miocene. Brönnimann and Rigassi (1963: 466) revised the age of some of Sánchez Roig's echinoid localities in the Cojímar and Marianao areas. In particular they considered the locality Finca "La Noria" and quarries at the entrance of Cojímar to be Miocene. The following spatan- goids occur at these localities and herein are considered Miocene:

Agassizia clevei Cotteau

Eupatagus sanchezi (Lambert)

Migliorinia habanensis (Sánchez Roig)

\section{Miocene}

Very few Miocene echinoids are known in the Caribbean basin outside of Cuba; therefore, the Cuban species from localities attributed to the Miocene (with no correlations outside the island) are of little use in confirming the age. The one exception is the collecting site at "Cervantes" farm near San José de las Lajas, Habana Province. Here a large number of specimens representing one-half of all the Miocene species in Cuba have been found. Included among them is Eupatagus cubensis (Cotteau), a species that is present in the Miocene Ponce Limestone of Puerto Rico. Miocene species include the following:

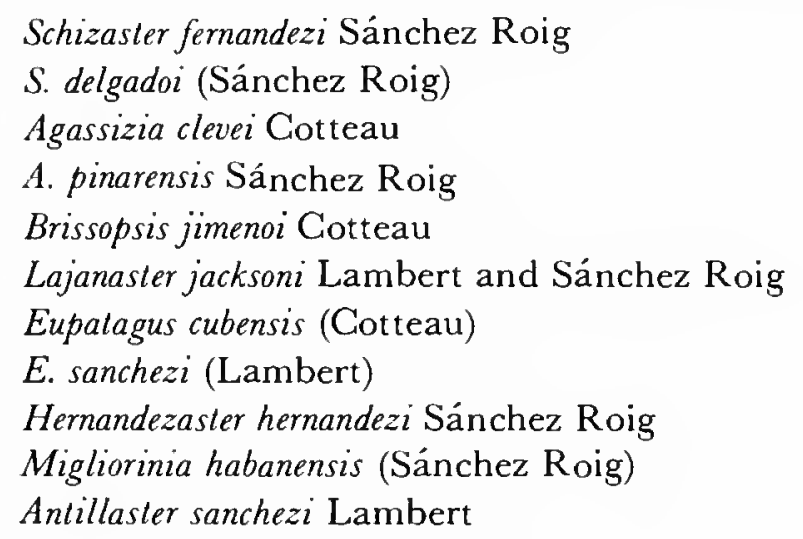

\section{Conclusion}

The Eocene age of the Cuban echinoid-bearing localities is confirmed by the presence outside Cuba of many of the same species in beds dated on other fossils. Some evidence supports the Miocene determinations, but the echinoids are of little assistance in resolving the question of whether the Cuban beds attributed to the Oligocene are Oligocene or Miocene.

\section{Comparison with European Faunas}

The Cuban and other Caribbean spatangoids of the Eocene to Miocene are quite distinct from 
those in Europe and the Mediterranean region. No species are definitely common, but then I have not seen specimens of many of the nonCaribbean species. The illustrations of many of these species are inadequate; and without seeing the specimens, one cannot be certain of any comparison of species. However, of the 17 Eocene spatangoid genera known from Cuba, eight are not present in Europe. They include Antillaster, Asterostoma, Fernandezaster, Caribbaster, Rojasia, Sanchezaster, Habanaster and Lambertona. All these genera, except for Lambertona, are found only in the Caribbean region. Lambertona is known also from New Zealand.

The genera Antillaster and Asterostoma are very well represented in Cuba and Jamaica by many specimens. Antillaster ranges from the Eocene through the Miocene and includes many species. No specimens of either genus have been recorded outside the Caribbean.

The provinciality of the Caribbean Tertiary echinoids is confirmed by the non-spatangoid echinoids. Among the clypeasteroids, the family Neolaganidae has never been found outside the Caribbean and Gulf of Mexico region. This family includes 7 Eocene-Oligocene genera and 13 species. This is also true of the family Protoscutellidae, Periarchus, and Protoscutella, which are very common in the Caribbean Eocene and are restricted to this region. In addition the Mellitidae, which are common as fossils in the Caribbean, do not occur in the European-Mediterranean region.

The order Oligopygoida is also confined to the Caribbean Eocene except for one species from Senegal.

\section{Comparison with Other Faunas in the Caribbean}

\section{JAMAICA}

The Jamaican echinoid fauna (Arnold and Clark, 1927, 1934) shares many species with Guba. Of the 39 spatangoid species in Jamaica, 9 species also occur in Cuba:
Schizaster bathypetalus Arnold and Clark

S. subcylindricus Cotteau ( $=$ S. brachypetalus Arnold and Clark) Agassizia inflata Jackson

Caribbaster loveni (Cotteau) (= Hypselaster perpleux Arnold and Clark)

Meoma antiqua Arnold and Clark

Eupatagus alatus Arnold and Clark

E. clevei (Cotteau) (=E. grandiflorus (Cotteau))

Asterostoma excentricum Agassiz

Antillaster arnoldi Clark

More of the species are very similar to Guban species and may be synonymous. The Jamaican specimens that Arnold and Clark referred to Schizaster dumblei Israelsky are very similar to Schizaster subcylindricus Cotteau, which occurs in Cuba. Caribbaster dyscritus is probably a synonym of Caribbaster loveni (Cotteau) (= Hypselaster perplexus Arnold and Clark). Eupatagus attenuatus Arnold and Clark appears to be similar to Eupatagus alatus Arnold and Clark, which also occurs in Cuba. Eupatagus longipetalus Arnold and Clark should be referred to Antillaster and is similar to the Cuban Antillaster vaughani Jackson. Finally Arnold and Clark's Victoriaster jamaicensis may be a synonym of the Cuban Lambertona lamberti Sánchez Roig.

The following Jamaican species are very different from any Guban species:

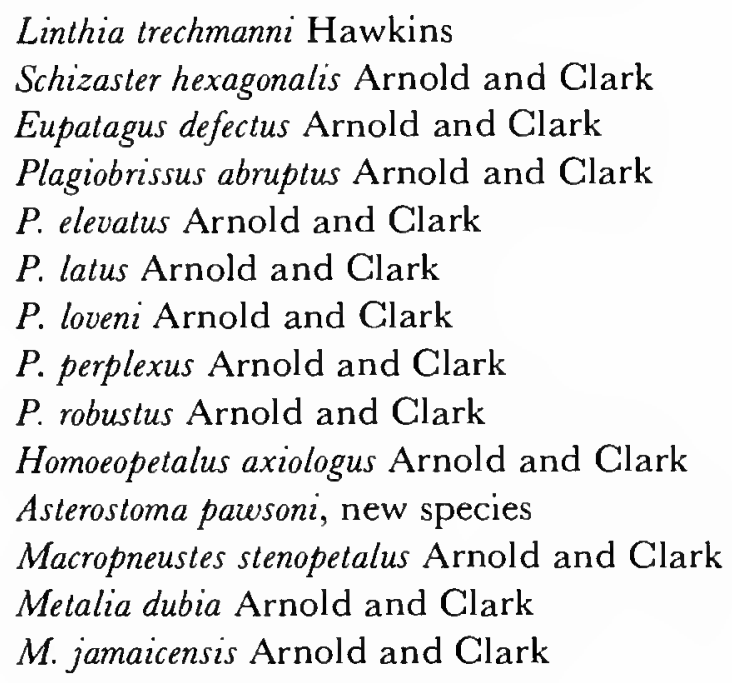

Eight of Arnold and Clark's species from Jamaica are based on material too poorly preserved for comparison with Cuban species:

Periaster elongatus Cotteau

Schizaster altissimus Arnold and Clark

Macropneustes angustus Arnold and Clark

M. parous Arnold and Clark 
Linthia obesa Arnold and Clark

Cyclaster sterea Arnold and Clark

Macropneustes dyscritus Arnold and Clark

$M$. sinuosus Arnold and Clark

In summary, of the 24 identifiable spatangoids from the Eocene of Jamaica, 9 species or 37 percent also occur in Cuba. Of the species of Eocene Cuban spatangoids, 25 percent occur also in Jamaica.

\section{St. Bartholomew}

The St. Bartholomew (Leeward Islands) echinoid fauna (Cotteau, 1875) is very similar to the Cuban. Four species occur in both places:

Schizaster subcylindricus Cotteau

Agassizia inflata Jackson

Caribbaster loveni (Cotteau)

Eupatagus clevei (= E. grandiflorus (Cotteau))

Two species occur in St. Bartholomew that are not present in Cuba: Schizaster antillarum Cotteau and Plagiobrissus loveni (Cotteau).

Antillaster cubensis (Cotteau), a Cuban species, is reported to occur in St. Bartholomew, but I have seen no specimens. Periaster elongatus Cotteau from St. Bartholomew is based on a holotype too poorly preserved for comparison. In summary, of the six recognizable species of spatangoids in the Eocene of St. Bartholomew, 5 species or 83 percent are also present in Cuba.

\section{Antigua}

Two spatangoids were reported by Jackson (1922:77, 97) from the Oligocene-Miocene of Antigua and Cuba: Schizaster clevei (Cotteau) and Antillaster vaughani (Jackson). I have seen no $\mathrm{Cu}$ ban specimens of $S$. clevei but there are several specimens from Cuba that can be referred to $A$. vaughani.

\section{United States}

The Eocene echinoid fauna of southeastern United States (Cooke, 1959; Kier, 1980) is surprisingly different from the Cuban, considering the proximity of the two regions. Forty species of
Cuban spatangoids and 23 American species are known, but only 3 have been found in both Cuba and the United States:

Agassizia clevei Cot teau (= A. floridana de Loriol)

A. inflata Jackson (= A. wilmingtonica Cooke)

Eupatagus clevei (Cotteau) (=E. ingens Zachos)

The American Schizaster beckeri Cooke is similar to Schizaster subcylindricus Cotteau, but all the rest of the recognizable American species are quite different.

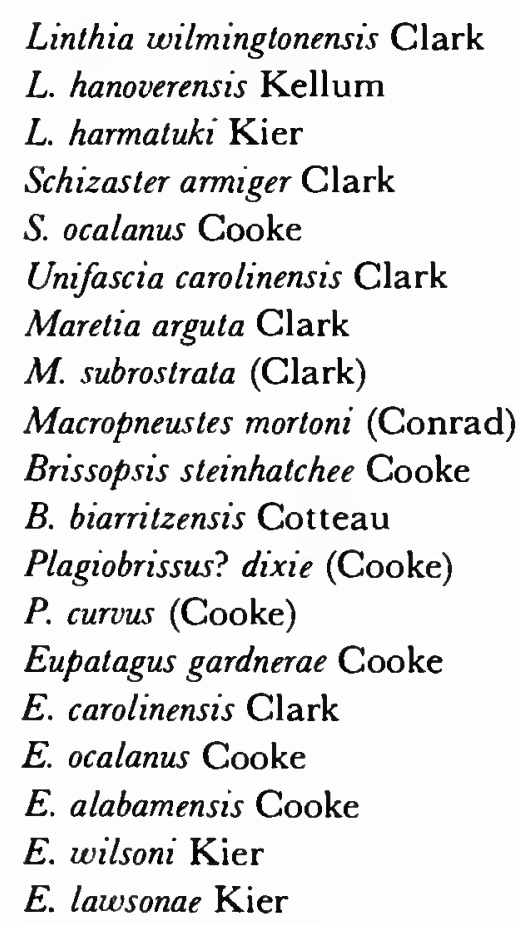

One American species, Linthia hollandi Barry, is based on such poor material that it cannot be compared to the Cuban. Further evidence of distinction between the two faunas is the absence of any specimens of Asterostoma and Antillaster in the United States. These genera are extremely well represented in Cuba.

The Oligocene-Miocene spatangoid fauna of Cuba is much larger than the American. Only one species, Cyclaster drewryensis Cooke, occurs in both countries. In Cuba it is found in the late Eocene. Also different from the Cuban species are the other four American species:

\footnotetext{
Agassizia mossomi Cooke

Lovenia alabamensis Cooke

Brissopsis blanpiedi Grant and Hertlein

Schizaster americanus Clark
}

Likewise the Cuban Miocene fauna is much 
larger than the American. Only three American spatangoid species are now recognized as being Miocene, but none of them occur in Cuba:

Lovenia clarki (Lambert)

Echinocardium orthonotum (Conrad)

Plagiobrissus holmesii (McCrady)

In summary, only 4 of the 34 Eocene-Miocene American spatangoid species occur in Cuba. It may be significant that no species of Pericosmus, Antillaster, or Asterostoma occur in the United States. These genera are represented by a large number of specimens in Cuba. Most living species of Pericosmus now occur in water 200-500 m deep. Although Antillaster and Asterostoma are now extinct, their lack of fascioles suggests they could not burrow but lived exposed on the sea floor. Presumably they lived in deep water. I know of no irregular echinoid with its test not covered that lives today in the shallower lighted part of the sea. Perhaps the available habitats were generally deeper in Cuba than in Florida. This might explain the great difference in their echinoid faunas.

Brönnimann and Rigassi (1963:465) estimated on the basis of the microfossils that the Eocene in the Havana region was deposited in depths of about $600 \mathrm{~m}$. They disagreed with Brodermann's (1949:309) inference from the echinoids that the early and middle Eocene Universidad Formation was deposited in shallow seas. They suggested that the "light tests of echinoids were capable of floating after death, similar to those of cephalopods, and thus could be transported from their original shallow-water habitat into the open sea." Echinoid tests do not float after death. It is much more reasonable to suggest that the echinoids were not living in shallow water.

Although the seas were deep in Cuba during the Eocene, Randazzo and Saroop (1976:287) propose that the Eocene of Florida, where most of the American Eocene spatangoids occur, was deposited in shallow water environments-at times even above the strand line. It is not surprising that the echinoid faunas are so different. In modern seas most of the species living in shallow water do not range below 50-100 m.

\section{BONAIRE}

Five Tertiary (Eocene) spatangoids are known from Bonaire (Pijpers, 1933). One of them, Schizaster gerthi Pijpers, occurs in Cuba. The specimens Pijpers referred to Agassizia conradi (Bouvé) appear to be conspecific with Agassizia inflata Jackson, which also occurs in Cuba. (The type specimen of $A$. conradi is unidentifiable (Cooke, 1959:75).) The other three specimens are distinct from any Cuban forms: Antillaster bonairensis Pijpers, Eupatagus aloysii (Pijpers), and Prenaster jeanneti Pijpers.

\section{TRINIDAD}

Two of the three spatangoids from Trinidad (Jeannet, 1928) also occur in Cuba, Brissopsis jimenoi Cotteau and Agassizia clevei Cotteau. The third species is Linthia caraibensis Jeannet.

\section{VENEZUELA}

Nine spatangoid species have been described from the Tertiary of Venezuela (Jeannet, 1928). Three of them occur in Cuba: Antillaster lamberti Jeannet, Eupatagus clevei (Cotteau), and Agassizia clevei Cotteau. Pericosmus stehlini Jeannet is very similar to the Cuban Pericosmus camagueyanus Sánchez Roig and may be a synonym. The other species are Brissus unicolor (Leske), Brissopsis antillarum Cotteau, Rhynobrissus rostratus Cooke, Brissoma vonderschmitti Jeannet, and Plagiobrissus lamberti Jeannet.

\section{Puerto Rico}

Four spatangoids have been reported in Puerto Rico (Jackson, 1922; Gordon, 1963). Three of these also occur in Cuba: Agassizia clevei Cotteau and Antillaster elegans (Jackson)-which Sánchez Roig (1949:182) cites as present in Cuba (I have not seen these specimens). The third, Eupatagus depressus Jackson, is a synonym of the Cuban $E$. cubensis. Paraster loveni (Cotteau) is not present in Cuba. 


\section{Anguilla}

The five spatangoids known from Anguilla (Cotteau, 1875) include one, Agassizia clevei Cotteau, also known from Cuba and two species, Schizaster clevei Cotteau and Schizaster loveni Cotteau, very similar to Schizaster munozi Sánchez Roig from Cuba. Meoma clevei (Cotteau) has been reported in both Cuba and Anguilla, but I have not seen any Cuban specimens. The Anguillan species, Brissopsis antillarum Cotteau and Brissus exiguus Cotteau, do not occur in Cuba.

\section{Mexico}

Twelve spatangoids are known from a wide area along the Gulf Coast of Mexico (Dickerson and Kew, 1917; Jackson, 1937), but in general the fauna is different from that of Cuba. Antillaster mexicanus (Jackson) appears to be a synonym of Antillaster vaughani (Jackson), which occurs in Cuba. The Mexican specimens referred to Agassizia clevei Cotteau are very similar to Agassizia inflata Jackson, which is present in Cuba. The other species appear to be different from Cuban species:

Schizaster dumblei Israelsky

S. crislatus Jackson

Lovenia dumblei Kew

L. mexicana Jackson

Plagiobrissus cumminsi (Kew)

Brissopalagus mexicanus (Kew)

Paraster lampicoensis Israelsky

Agassizia regia Israelsky

Macropneustes dubius Israelsky

Paleopneustes elevalus Israelsky (may be a synonym of Antillaster vaughani (Jackson)).

\section{Costa Rica}

All the spatangoids from Costa Rica are Miocene and were described by Durham (1961); none of them resemble Cuban species:

Pericosmus israelskyi Durham

Schizaster costaricensis Durham

Plagiobrissus costaricensis Durham

Schizobrissus kewi Durham

Plagiobrissus malavassii Durham

\section{PANAMA}

Only one of the four species from Panama (Jackson, 1918; Cooke, 1948) occurs in Cuba: Eupatagus clevei Cotteau). Two of the species are based on specimens too poorly preserved to be compared with Cuban material: Schizaster cristatus Jackson and Schizaster panamensis Jackson. Schizaster armiger Clark is unlike any species in Cuba.

\section{Order Disasteroida Mintz, 1968}

\section{Family Holasteridae Pictet, 1857}

\section{Genus Cardiaster Forbes, 1850}

Test low, apical system with anterior genital plates separated from posterior by junction of ocular plates II and IV, 4 genital pores; ambulacrum III not petaloid, paired ambulacral petals, pores of anterior poriferous zones smaller than posterior, pores comma-shaped; periproct marginal, marginal fasciole.

Two species are known of this genus in Cuba. One, Cardiaster palmeri Sánchez Roig, is easily distinguished from the other Western Hemisphere species of Cardiaster by its lack of an anterior groove. The other, Cardiaster cubensis Jackson, differs from Cardiaster deciper Cooke from the Maestrichtian of Arkansas in its more posterior apical system.

HABITAT. - This genus probably lived buried in coarse sediments. It was unable to maintain a burrow in mud because it lacked funnel-building tubefeet as indicated by the small pores in the dorsal part of ambulacrum III. Furthermore, its petals are not depressed as in typical mud-living species.

\section{Cardiaster cubensis Jackson}

Cardiasler cubensis Jackson, 1922:69, pl. 12: fig. 1.-Sánchez Roig, 1926:85; 1949:171.

Material.--The holotype and only known specimen is probably in an unknown private collection; I was unable to locate it. However, it 
was thoroughly described and well illustrated by Jackson.

Occurrence.-Cretaceous, from high slopes in the valley of Rio Yateras, about $21 \mathrm{mi}(33.6 \mathrm{~km})$ NE of Guantanamo, Oriente Province, Cuba.

Comparison with Other Species.-This species is easily distinguished from Cardiaster palmeri Sánchez Roig from the Late Cretaceous of Cuba by its deep anterior groove.

\section{Cardiaster palmeri Sánchez Roig}

Figure 1; Plate 1: figures 1-3

Cardiaster palmeri Sánchez Roig, 1949:172, pl. 5: figs. 3-5.Mortensen, 1950:53.

Material.-Only one specimen is in the collection (SRC 4024), and it is one of two syntypes figured by Sánchez Roig (1949, pl. 5: fig. 5). This specimen is designated the lectotype. Unfortunately, the posterior portion of this specimen is absent.

Shape and Size.-Length uncertain but other syntype had length of $51 \mathrm{~mm}$ according to Sánchez Roig. Width $53.0 \mathrm{~mm}$, height $26.3 \mathrm{~mm}$.

Apical System.-Anterior, distance from anterior margin $24.0 \mathrm{~mm}$. Genital plates 2, 3, separated from posterior genital plates by junction of ocular plates II, IV (Figure 1); 4 genital pores.

AmBulacra.-Anterior ambulacrum III not petaloid, in slight groove at anterior margin; porepairs not enlarged dorsally.

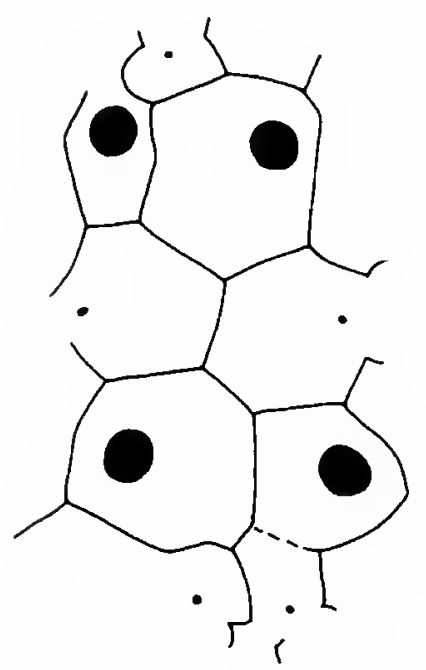

Figure 1.-Cardiaster palmen Sánchez Roig, apical system of the lectotype, SRC 4024, × 24 .
Anterior petals (II and IV) long, extending almost to margin; length $29.3 \mathrm{~mm}$, greatest width $8.7 \mathrm{~mm}$. Posterior poriferous zones much wider than anterior with greatest width $3.7 \mathrm{~mm}$; outer pore of pair slit-like. Anterior poriferous zone narrow with greatest width near end of petal where width $1.7 \mathrm{~mm} ; 110$ porepairs in petal.

Posterior petals (V and I) shorter than anterior, length $21.2 \mathrm{~mm}$, greatest width $7.0 \mathrm{~mm}$. Posterior poriferous zones much wider than anterior with width $2.7 \mathrm{~mm}$ as opposed to $1.1 \mathrm{~mm}$ in anterior poriferous zones; 80 porepairs in petal.

Phyllodes double pored, with large peripodia, number not clear.

Peristome.-Anterior, distance of anterior edge of opening to anterior margin $11.7 \mathrm{~mm}$; opening wider than high, width $8.7 \mathrm{~mm}$, height $3.6 \mathrm{~mm}$.

Periproct.-Not preserved.

Fascioles.-Although no fascioles are visible on the lectotype, their absence may be due to weathering. Sánchez Roig reports in the lost syntype a distinct marginal fasciole passing below the periproct.

Oral Plate Arrangement.-Sutures not clear.

Occurrence.-Late Cretaceous, lectotype from "Cantabria" farm, Agua district, Cienfuegos, Santa Clara (now Las Villas) Province, Cuba. Sánchez Roig reports other specimens from Palmer loc. 895P, N of Grua Esperanza, 150 m, $6 \mathrm{~km}$ E of Madruga, Habana Province; WNW of Central Perseverancia, $1.8 \mathrm{~km}$, on road to Aguada, in creek bank of Arroyo Vaquito, to 300 m N of culvert, Santa Clara (now Las Villas) Province; Km 2.2 WNW of Central Perseverancia, $50 \mathrm{~m}$ S of Linea Principal, abandoned water well, Santa Clara (now Las Villas) Province, Cuba.

Remarks.-This species differs from the typical Cardiaster in lacking a deep anterior notch, but Mortensen (1950:53) considers the presence of the marginal fasciole as confirmation of its generic assignment to Cardiaster. It resembles Cardiaster leonensis Stephenson from the late Maestrichtian of Texas, which has the least depressed anterior 
groove of any other species of this genus. It differs from this Texas species in having a larger higher test and shallower anterior groove. It differs from Cardiaster cubensis Jackson from the Cretaceous of Cuba in lacking an anterior groove.

\section{Genus Echinocorys Leske, 1778}

Test very high, ventral surface flat, apical system elongate, ambulacra subpetaloid, no fasciole or only a diffuse perianal fasciole; periproct inframarginal.

HABITAT.-Lacking well-developed petals and fascioles, Echinocorys probably could not borrow. Stephenson (1963:468) suggested that the echinoid lived on the surface of the sea bed, at most sunk into the sediment to just above the level of the ambitus. I suspect that this echinoid must have lived in deeper water. I know of no living irregular echinoid that occurs in shallow water with its test exposed. J.M. Hancock of King's College, London, an authority on the Chalk reports (1982, personal communication) that the Chalk in Britain where Echinocorys occurs was probably deposited at depths of 200-600 m.

\section{Echinocorys ovatus Leske cubensis Sánchez Roig}

Plate 1: figures 4, 5, 6

Echinocorys ovatus Leske cubensis Sánchez Roig, 1949:175, pl. 4: figs. 3,4 .

Material.-Holotype (SRC 4069) slightly deformed with apex pushed to the left when viewed from above. Test weathered, with plate sutures very clear.

Shape and Size.-Test $77 \mathrm{~mm}$ long, $67 \mathrm{~mm}$ wide, width $87 \%$ of length of test (L). Oral surface flat except where elevated just anterior of periproct.

Apical System.-Anterior, located at distance from anterior margin $44 \% \mathrm{~L}$, apical system with height equal to $14 \% \mathrm{~L}$; system elongate with anterior genital plates separated from posterior by junction of ocular plates II and IV; genital plate 2 larger than other genital plates.
Ambulacra.-Because of weathering not possible to tell length of petal; ambulacrum III similar to other ambulacra. Pores appear larger and porepairs are less separated from one another than one-half distance from apical system to margin in paired ambulacra: approximately one-half in ambulacrum III. Ambulacra dorsally of approximately same width as interambulacra; 80 plates in ambulacrum III, 90 in IV, 86 in V.

INTERAMBULACRUM.-41 plates each in interambulacrum 3 and 4; 48 in 5.

Peristome.-Anterior located at distance from anterior of test to anterior edge of peristome at distance equal to $20 \%$ L. Opening with width 9.1\% L, height $4.4 \% \mathrm{~L}$.

PERIPROCT.-Inframarginal, higher than wide; height $8.4 \% \mathrm{~L}$; width $6.6 \% \mathrm{~L}$. Located within interambulacral plates 7-9.

Oral Plate Arrangement.-Labrum with height $6.7 \% \mathrm{~L}$, extending posteriorly $2 / 3$ height of second adjacent ambulacral plates. Plates alternating.

Occurrence.-Late Cretaceous, Palenque, near Cienfuegos, Santa Clara (now Las Villa.)

\section{Echinocorys ovatus Leske villarensis Sánchez Roig}

Figure 2; Plate 2

Echinocorys ozatus Leske villarensis Sánchez Roig, 1949:176.

Material.-Only one specimen (SRC 4174) of this subspecies is in the collection. Although Sánchez Roig did not figure any specimens, this specimen is certainly the holotype. It is labelled as the type, with the locality cited by Sánchez Roig, and has the dimensions given by him. The specimen is well preserved except where flint covers the peristome.

Shape and Size.-Length $84 \mathrm{~mm}$, width 53 $\mathrm{mm}(63 \% \mathrm{~L})$, height $44 \mathrm{~mm}$ (53\% L); greatest width and height slightly anterior of center. Ventral surface flat except along interambulacrum 5 where slightly inflated and where depressed around peristome.

Apical System.-Anterior, distance from an- 
terior margin to center of system $31 \% \mathrm{~L} ; 4$ genital pores, anterior genital plates separated from posterior by ocular plates II and IV (Figure 2; Plate 2: figure 5). Apical system with length $18 \% \mathrm{~L}$, width $10 \% \mathrm{~L}$.

AMBUlaCRA.-No petals; porepairs adapically of approximately same size, smaller at margin and ventrally. Ambulacrum III with 78 plates, II with 86, I with 96. Ambulacrum III at greatest width $17 \%$ L, II $21 \%$ L, I $22 \%$ L. Phyllodes well developed with large peripodia with a prominent node separating pores of a pair; 10 peripodia in ambulacra II or IV, 7 in V or I, number unknown in III.

Peristome.-Opening obscured by flint.

PERIPROCT.-Inframarginal, distance of posterior margin from posterior edge of opening 3.7\% L. Opening with with length $7.9 \% \mathrm{~L}$, width $6.4 \%$ L.

Oral Plate Arrangement.-Labrum followed by single plate extending across interambulacra, third and subsequent plates alternating.

Occurrence.-According to Sánchez Roig, Late Cretaceous, Sancti Spiritus, near Ciudad, Santa Clara (now Las Villas) Province, Cuba.

REMARKs.-I suspect that this specimen did

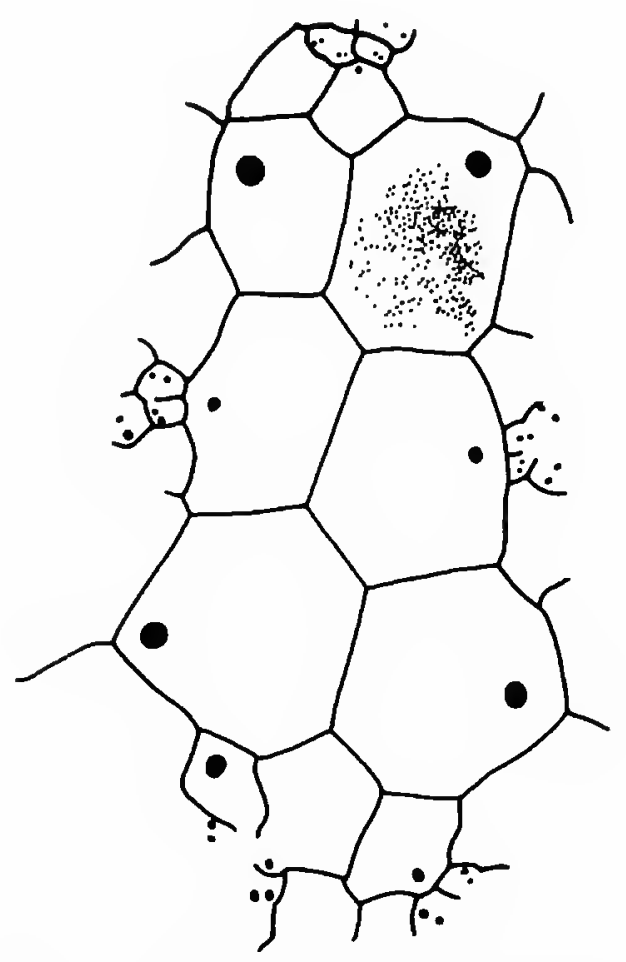

Figure 2.-Echinocorys ovatus Leske villarensis Sánchez Roig, apical system of the holotype, SRG $4174, \times 4$. not come from Cuba. It was collected, according to Sánchez Roig, by Dr. Ricardo de la Torre who also collected the holotype of Conoclypeus sanctispiritensis Sánchez Roig supposedly at the same locality. This latter species is a Conulus probably C. subrotundus Mantell, a western European species. Both holotypes have tests of the typical white color of Chalk echinoids. The matrix inside the holotype of $E$. ovatus villarensis is flint, identical to that found so commonly in Chalk echinoids. The matrix in the holotype of $C$. sanctispiritensis is chalk.

\section{Family Urechinidae Duncan, 1889}

\section{Genus Sanchezaster Lambert, 1924}

Test large, high, no petals, anterior ambulacrum narrower than others, in groove crossing margin, pores minute, single in all ambulacra, interambulacral plates similar in shape and size to ambulacral; apical system elongate; periproct supramarginal, small; peristome very anterior, small; marginal fasciole.

HaBitaT. - This echinoid could not have burrowed deeply. Its lack of petals and any funnelbuilding tubefeet suggest that it lived on the surface of the sea floor. Considering its lack of large spines for protection, it probably lived in deep water where the reduced light would help to protect it from predators.

Remarks. - This genus is very similar to Chelonechinus. Bather (1934:858) differentiated them on the following characters of Sanchezaster: (1) anterior sulcus, (2) transversely elliptical peristome, (3) periproct on ventral surface, (4) marginal fasciole, and (5) double ambulacral pores.

Bather saw only the Harvard specimen of this monotypic genus. My study of all available material convinces me that three of the supposed diagnostic features do not occur in Sanchezaster. The peristome is not well preserved on any of the specimens, but it does not appear to be any more transversely elliptical than in Chelonechinus. The periproct is supramarginal, not on the ventral surface. Finally the ambulacral pores are single, 
not double. The specimen that Bather studied has many small holes scattered irregularly over the ambulacral and interambulacral plates. These holes are apparently the result of postmortem erosion or organic action. One of the USNM specimens has its plates well preserved and only one pore is present in each ambulacral plate (Figure 3B; Plate 3: figure 4). The genera differ in that an anterior groove and a marginal fasciole are present in Sanchezaster. Perhaps these diffferences do not warrant generic separation.

It is not clear, but the labrum may be separated from the peristome by ambulacral plates. Sanchezaster is known only from Cuba.

\section{Sanchezaster habanensis Lambert}

Figure 3; Plates 3-5

Sanchezaster habanensis Lambert in Sánchez Roig, 1924a:14, pl. 3: fig. 1, pl. 4: fig. 1; 1926:86, pl. 14: fig. 1, pl. 15: fig. 1; 1949:174._-Mortensen, 1950:125, fig. 114._Fischer, 1966:U537, fig. 420-1.

Material.-I have studied the holotype (SRC 4958), two specimens (both paratypes) in the USNM, and a paratype in the Museum of Comparative Zoology, Harvard University. The holotype is a large, flattened specimen with its ventral side poorly preserved. One of the USNM paratypes is flattened and distorted showing most of the plates of the test. The second USNM specimen has only one-quarter of its plates preserved but appears to display well the profile shape of the test. The Harvard specimen is badly flattened, with the dorsal plates weathered.

Shape And Size.-Length 100 to $140 \mathrm{~mm}$, height probably approximately $55 \% \mathrm{~L}$, test high with steep sides; test appears to be wider than high. Test with very thin plates, thickness of plate 0.4 to $0.8 \% \mathrm{~L}$.

Apical System.-Because of distortion of the tests, it is not possible to be certain of the position of the apical system; but it appears to be nearly central. It is intact in none of specimens, but it appears to be elongate and not disjunct-probably similar to Chelonechinus suvae Bather (see Bather, 1934, fig. 1). Genital plate 2 (Figure 3A) is smaller than the other genital plates with a larger pore.

AmbUlacra.-No petals, a very small, single
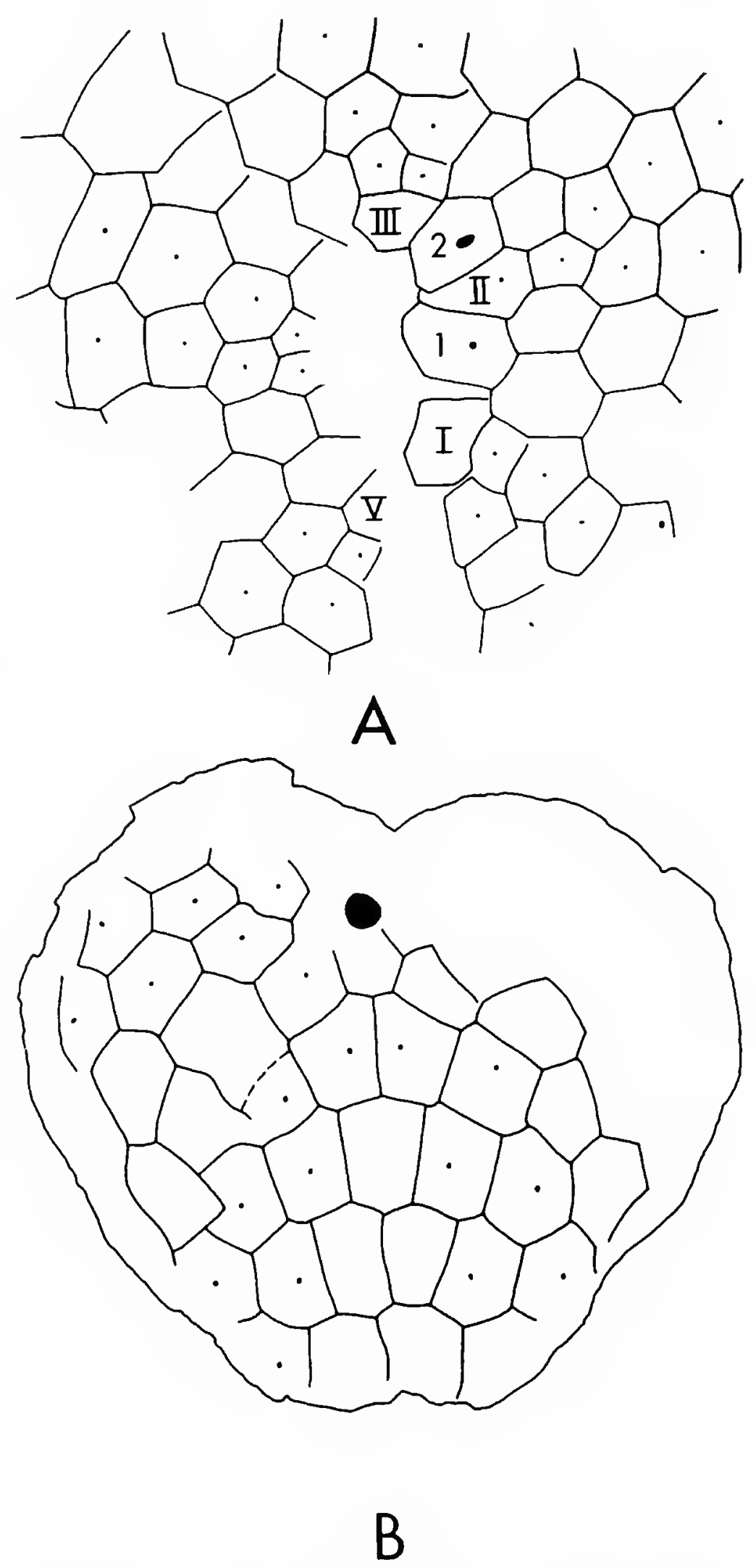

Figure 3.-Sanchezaster habanensis Lambert: A, apical region of the holotype, SRC $4958, \times 1.4$; B, ventral view of paratype, USNM $341249, \times 0.6$. The ocular plates are designated by Roman numerals, the genital plates by Arabic. 
pore near middle of each plate; ambulacra of approximately same width as interambulacra, dorsally, most plates hexagonal with a single node near center of each plate. Anterior ambulacrum III with smaller plates than in other ambulacra, grooved at margin. Each ambulacral column with 9-11 plates. No phyllodes.

Peristome.-Anterior, located at distance from anterior edge of opening to anterior margin equal to $8.0 \% \mathrm{~L}$ (est.). Opening probably circular, small with diameter $6.3 \% \mathrm{~L}$.

Periproct.-Preserved on USNM 341248, where it occurs above the margin with a trough extending down from the periproct to margin; opening small, wider than high, width estimated at $8.5 \% \mathrm{~L}$.

Fascioles.-A very distinct marginal fasciole with width $1.1 \% \mathrm{~L}$ passing around test below margin; crossing plate 2 in ambulacrum III.

Tuberculation.-Dorsally tubercles very small (Plate 3: figure 2), scattered irregularly over plates, scrobicules absent or very small. Tubercles around periproct (Plate 3: figure 3) larger, scrobiculate. Ventrally, tubercles larger, scrobiculate, eccentric as typical in spatangoids, more regularly arranged (Plate 3: figure 4); tubercles largest anterior of peristome.

Oral Plate Arrangement.-Plates of interambulacrum 5 not larger than adjacent ambulacral plates (Figure 3B). Labrum large, height 9.5\% $\mathrm{L}$, width $11 \% \mathrm{~L}$, separated from next plate of interambulacrum by junction of ambulacral plates. Although it is not certain because of the distortion of the specimens and subsequent displacement of the plates, the labrum appears to be separated from the peristome by the first ambulacral plates of ambulacra $\mathrm{V}$ and $\mathrm{I}$.

Occurrence.-Eocene, quarries of Tejar "Consuelo," Ciénaga, Habana Province, Cuba.

Comparison with Other Species.-No other species of this genus are known, but a specimen of Chelonechinus crassus Gregory from the Eocene or Oligocene of Barbados is very similar to $S$. habanensis. Only one specimen is known of the Barbados species, and it is very poorly preserved with few specific characters evident.

\section{Order Spatangoida Claus, 1876}

Suborder Toxasterina A.G. Fischer, 1966

Family ToXasteridaE Lambert, 1920

\section{Genus Douvillaster Lambert, 1917}

Test large, broad, with anterior groove, apical system ethmophract with four genital pores, five petals, pores in petal III transverse, peristome anterior near margin, periproct inframarginal, no fasciole or only traces of a peripetalous fasciole.

Only one species of this genus is known from Cuba and no others are known elsewhere in the Western Hemisphere.

HaBitat. - This genus lacks fascioles and funnel-building tubefeet (ambulacrum III is respiratory) and therefore could not maintain a burrow. Nichols (1959:425) suggested that Isomicraster, a genus very similar to Douvillaster, did not burrow or had only the lower part of its body submerged. Probably Douvillaster lived with its test shallowly covered in well-aerated, coarse sediment. It is unlikely that this echinoid would live with its test exposed. Only in deep water do modern irregular echinoids live on the surface of the seafloor with the test exposed.

\section{Douvillaster triangularis (Sánchez Roig), new combination}

\section{Plate 6}

Macraster triangularis Sánchez Roig, 1949:217, pl. 34: figs. 1, 2.

Material. - The figured holotype (SRC 4722) is the only specimen known. Although the specimen is compressed, the exterior is well preserved with much of the tuberculation preserved.

ShaPe AND Size.-Length $88 \mathrm{~mm}$, width $101 \%$ $\mathrm{L}$, height $43 \% \mathrm{~L}$ but originally higher before postmortem compression. Greatest width very anterior of center; greatest height at apical system. Anterior groove deep.

Apical System.-Slightly posterior of center, distance from anterior margin to center of genital 
pores $46 \%$ L. Four genital pores. Although the plates are not all discernible, genital plate 2 appears to separate the posterior genital plates but not the posterior ocular plates.

Ambulacra.-Anterior ambulacrum III petaloid, extending two-thirds distance to margin, length $40 \% \mathrm{~L}$, greatest width $6.3 \% \mathrm{~L}$. Pores conjugate, outer pore more elongate (Plate 6: figure 4) than inner, not arranged in chevrons; interporiferous zone slightly wider than single poriferous zone; 122 petaloid porepairs. In groove extending from apical system to peristome; depth of groove at margin $5.2 \%$ L. First petaloid porepair in plate 12 or 13 .

Anterior petals (II and IV) long, extending almost to margin, length $51 \% \mathrm{~L}$, curving anteriorly, in groove with greatest depth $2.9 \% \mathrm{~L}$, greatest width $8.4 \%$ L. Porepairs conjugate, outer pore more slit-like, with interporiferous zones slightly wider than poriferous; 164 petaloid porepairs.

Posterior petals (V and I) shorter, extending four-fifths distance from apical to margin, length $40 \%$ L, width $8.4 \%$ L; curving slightly posteriorly. Porepairs similar (Plate 6: figure 5) to anterior petals; 122 petaloid porepairs. Pores double beyond petals.

Peristome.-Situated near anterior margin, distance from margin to anterior edge of peristome $6.9 \%$ L. Opening very small, width $9.2 \% \mathrm{~L}$, height indeterminate because of distortion of test.

PERIPROCT.-Inframarginal, on sharply overhanging posterior truncation. Opening small, height $7.0 \% \mathrm{~L}$, width $7.1 \% \mathrm{~L}$; located within interambulacral plates 6-8.

Fascioles. - No fascioles. Tuberculation well preserved so that fascioles would be visible on this specimen if they had been originally present.

Oral Plate Arrangement.-Labrum large, narrow, high, with height $21 \%$ L. Plastron composed of two plates, long, narrow with combined length of $47 \% \mathrm{~L}$, width $30 \% \mathrm{~L}$.

Occurrence.-Cretaceous, Palmer loc. 128, silicified marine sediments, one league S of Santa Clara, Santa Clara (now Las Villas) Province, Cuba.
Comparison with Other Species.-I have compared this species with all the other species of the genus and it falls near Douvillaster variosulcatus (Gauthier) from the Albian of Algeria. Both species have a large, broad test and curved anterior petals, but the Cuban species differs in having a deeper anterior groove and shorter petal III and posterior petals.

REMARKS. - This species has an anterior petal (III) with pores that are transverse like those in the other petals. In Macraster the pores in this petal are arranged in chevrons. For this reason this species is transferred from Macraster to Douvillaster, a genus not previously known from the Americas.

\section{Suborder Hemiasterina A.G. Fischer, 1966}

\section{Family Hemiasteridae Clark, 1917}

\section{Genus Hemiaster L. Agassiz, 1847}

Test of medium size, broad, truncated posteriorly; apical system ethmophract as in Hemiaster (Hemiaster) or ethmolytic as in Hemiaster (Trachyaster), 4 genital pores; anterior ambulacrum III not petaloid, other ambulacra with well-developed petals, anterior longer than posterior; peripetalous fasciole.

Nine species from Cuba have been referred to Hemiaster (Hemiaster) or Hemiaster (Trachyaster); but the type specimens have been lost for five of them and they are not recognizable. One species (lamberti) is transferred to another genus (Linthia) and one (herrerae) is transferred from Opissaster to Hemiaster. The species are listed in Table 1.

Only one of the Cuban species is well enough known to permit comparison with other species in the Western Hemisphere: $H$. herrerae. It is quite similar to Hemiaster texanus Roemer from the Late Cretaceous of Texas but differs in having more flexuous anterior petals which distally turn more anteriorly.

Habitat.-Species of Hemiaster probably lived buried in mud. The crowded, enlarged peripodia dorsally in ambulacrum III indicate the presence 
TABLE 1.-Disposition herein of Cuban species of Hemiaster

$(T .=$ subgenus Trachyaster $)$

\begin{tabular}{l|ll}
\hline \multicolumn{1}{c|}{ Disposition } & \multicolumn{1}{c}{$\begin{array}{c}\text { Oligocene- } \\
\text { Miocene }\end{array}$} \\
\hline Recognized species & & \multicolumn{1}{c}{ Cretaceous } \\
& & H.? (T.) gonzalezmunozi \\
& & H. (T.) herrerae \\
& & H. madrugensis \\
Unrecognizable & H. siboneyensis \\
species & H. antillensis \\
& & H. dewalquei \\
Referred to other & H. (T.) minutus \\
genera & H. (T.) simpaticus \\
& & H. lamberti \\
& & (=Linthia brodermanni) \\
\hline
\end{tabular}

of funnel-building tubefeet. Likewise, the peripetalous fasciole and depressed petals would aid life in this habitat. According to Mortensen (1950: 377) modern hemiasterids are all deep sea forms occurring at depths of 140 to $400 \mathrm{~m}$ and probably all of them are mud-dwellers.

\section{Hemiaster (Hemiaster) madrugensis Weisbord}

Plate 8: figures 2-4

Hemiaster madrugensis Weisbord, 1934:35, pl. 3: figs. 4-6.Sánchez Roig, 1949:236.

I have studied the holotype and twelve paratypes of this species in the Paleontological Research Institution (PRI 3804) and have nothing to add to Weisbord's detailed description except the following dimensions of the holotype: length $30 \mathrm{~mm}$, width $29 \mathrm{~mm}$, height $22 \mathrm{~mm}$, distance from apical system to anterior margin $11 \mathrm{~mm}$, length of petal II $10 \mathrm{~mm}$, width of petal II 3.7 $\mathrm{mm}$, length of petal I $6.9 \mathrm{~mm}$, width of petal I $3.1 \mathrm{~mm}$, numbers of porepairs in petal II 58, number of porepairs in petal I 44. The first petaloid porepair in petal II is in plate 14 .

Occurrence.-Late Cretaceous, on the property of Central San Antonio, $150 \mathrm{~m}$ NW of the sugar cane loading rack at Esperanza switch, 10 $\mathrm{km} \mathrm{E}$ of the mill and town of Madruga, near the eastern boundary of Habana Province, Cuba.
Comparison with Other Species.-This species differs from $H$. herrerae (Lambert and Sánchez Roig), also from the Late Cretaceous of Cuba, in having a more anterior apical system, less flexuous anterior petals, and probably a narrower anterior ambulacrum. It is very different from any Hemiaster in North America.

\section{Hemiaster (Hemiaster) siboneyensis Weisbord}

Plate 8: figures 5-7

Hemiaster siboneyensis Weisbord, 1934:37, pl. 3: figs. 7-9.Sánchez Roig, 1949:237.

I have nothing to add to Weisbord's detailed description except the following dimensions of the holotype (Paleontological Research Institution, PRI 3805): length $24.8 \mathrm{~mm}$, width $26.1 \mathrm{~mm}$, height $19.6 \mathrm{~mm}$, distance apical system to anterior margin $11.5 \mathrm{~mm}$, length of petal II $9.5 \mathrm{~mm}$, width of petal II $3.4 \mathrm{~mm}$, length of petal I 4.6 $\mathrm{mm}$, width of petal I $3.0 \mathrm{~mm}$, number of porepairs in petal II 54, number of porepairs in petal I 36.

Occurrence.-Late Cretaceous, on the property of Central San Antonio, $150 \mathrm{~m}$ NW of the sugar loading racks at Esperanza switch, on private railroad of Central San Antonio, of Madruga, near the eastern boundary of Habana Province, Cuba. 
Comparison with Other Species.-This species is easily distinguished from Hemiaster madrugensis Weisbord with which it occurs, by its much shorter posterior petals and more posterior apical system.

\section{Hemiaster? (Trachyaster) gonzalezmunozi Sánchez Roig}

Plate 7: figures $1-3$

Hemiaster gonzalezmunozi Sánchez Roig, 1953c: 170, pl. 11: figs. 3,4 .

Material.-The holotype (SRC 4248) is the only known specimen and is extremely poorly preserved. Most of the test is broken away and the rest is very badly weathered.

Shape and Size. - Length $64.7 \mathrm{~mm}$, width $96 \%$ L, greatest width anterior to center, greatest height posterior.

Apical System.-Posterior, distance from anterior margin to center of genital pores $49 \%$ L. Appears to be ethmolytic with 4 genital pores but sutures not clear.

Ambulacra.-Anterior ambulacrum III depressed in deep groove; depth of groove at ambitus $8.8 \% \mathrm{~L}$; greatest width $11 \% \mathrm{~L}$. Region with enlarged pores extending almost to anterior groove; pores large.

Anterior petals (II and IV) long, extending almost to margin, length $43 \% \mathrm{~L}$; width $9.9 \% \mathrm{~L}$; petals flexuous, pores conjugate; interporiferous zones slightly wider than single poriferous zone; 96 porepairs in petal.

Posterior petals (V and I) short, slightly curved, length $24 \% \mathrm{~L}$, width $9.0 \% \mathrm{~L}$, in groove; 58 porepairs.

Peristome.-Not preserved, very anterior, just posterior to anterior groove.

Periproct.-High on vertical posterior truncation, height $14 \% \mathrm{~L}$, width $10 \% \mathrm{~L}$.

FASCIOLES.-Not preserved.

Occurrence.-Late Cretaceous, "Concepción de Montalvo" farm, Rodas, Las Villas Province, Cuba.

REMARKS. - The holotype is too poorly preserved to permit generic identification. As pres- ence or absence of fascioles is not known this species cannot be referred with any certainty to a genus. It resembles Hemiaster herrerae (Lambert and Sánchez Roig) except that the posterior petals in H.? gonzalezmunozi appear to be more divergent. The holotype is too poorly preserved to permit comparison with other species.

\section{Hemiaster (Trachyaster) herrerae (Lambert and Sánchez Roig), new combination}

\author{
Plate 7: figures 4-8; Plate 8: figure 1
}

Opissaster herrerae Lambert and Sánchez Roig in Sánchez Roig, 1926:126, pl. 40: figs. 1, 2, pl. 41: fig. 3; 1949:244.

Material. - The holotype and two other specimens referred to this species are in the Sanchez Roig Collection. The holotype (SRC 4857) is well preserved, except the exterior is weathered and abraded, obscuring the tuberculation and most of the fasciole.

A second topotypic specimen (SRC 4290) in the collection is not used in the following description because it may not be conspecific. The test is higher, its apical system less posterior, and the plates in the dorsal portion of ambulacrum III are higher. It is too poorly preserved for specific identification. The third specimen is also not conspecific with the holotype. Its apical system is much more anterior, and its ambulacrum III is narrower. The petals are shallower and the posterior is not highly inflated.

Shape and Size._Length $38 \mathrm{~mm}$, width $97 \%$ L, height $64 \% \mathrm{~L}$; greatest width central to slightly anterior, greatest height posterior.

Apical System.-Four genital pores (Plate 8: figure 1), ethmolytic, located posterior to center at distance from anterior margin to center of genital pores equal to $46 \% \mathrm{~L}$.

Ambulacra.-Anterior ambulacrum III not petaloid, in groove from apical system to peristome, depth of groove midway between apical system and margin $7.8 \% \mathrm{~L}$, width $15 \% \mathrm{~L}$; depth of groove at margin $7.0 \%$ L. Porepairs enlarged and in peripodia adapically (Plate 7: figure 8) high prominence separating pore of pair; 80 porepairs in this region; porepairs in single row 
with inner pore of pair less elongated than outer. First enlarged porepair in plate 6 ; pores paired throughout ambulacrum which has 90 plates.

Anterior petals (II and IV) extending twothirds distance from apical system to margin; length $42 \% \mathrm{~L}$, greatest width near extremity, $11 \%$ $\mathrm{L}$, in deep groove with depth $6.5 \% \mathrm{~L}$; petal flexuous. Pores conjugate, inner pore of pair larger than outer; interporiferous zone wider than single poriferous zone; 72 porepairs in petal; first petaloid porepair in plate 16; total of 102 plates in ambulacrum. Pores paired beyond petals.

Posterior petals ( $\mathrm{V}$ and I) short, extending onehalf distance from apical system to margin, length $26 \% \mathrm{~L}$, width $9.4 \% \mathrm{~L}$, in groove with depth $47 \%$ $\mathrm{L}$; petal straight. Interporiferous zone equal in width to single poriferous zone; 50 porepairs.

Peristome.-Anterior, located at distance from anterior margin to anterior edge of peristome equal to $14 \% \mathrm{~L}$; width of opening $16 \% \mathrm{~L}$; height unknown. Phyllodes with pores paired in peripodia; 12 in ambulacra II and IV, 5 in III, number uncertain in $\mathrm{V}$ or $\mathrm{I}$.

PERIPROCT.-Located high on posterior, opening higher than wide, height $14 \% \mathrm{~L}$, width $11 \%$ L.

Fascioles.-Peripetalous fasciole not curving into interambulacra, widest where it crosses ambulacrum III; fasciole crosses ambulacra II or IV on plate 15 , III on plates 4 and 5 .

Oral Plate Arrangement.-Labrum not preserved, rest of sutures not clear.

OCCURRENCE.-In the original description of this species, the age was given as Miocene. In Sánchez Roig (1949:245) it is recorded as Late Cretaceous, as it is by Brodermann (1949:325). On the label of the holotype, the age is written as Oligocene. The presence of double pores in the ambulacra beyond the petals indicates that the Cretaceous age is probably correct. Most spatangoids after the Eocene have single pores beyond the petals (Kier, 1974:28). Jesús del Monte, Tamarindo, Habana Province, Cuba.

Comparison with Other Species.-Hemiaster herrerae differs from Hemiaster madrugensis Weisbord also from the Late Cretaceous of Cuba in having a more posterior apical system, more flexuous anterior petals and apparently a wider anterior ambulacrum. Its test is probably lower than in Hemiaster siboneyensis Weisbord, also from the Late Cretaceous of Cuba; but the holotype of that species is badly distorted and its original shape is unknown. The anterior ambulacrum in $H$. herrerae is similar in the amount of its depression to $H$. gonzalezmunozi Sánchez Roig. The species may be similar but the holotype of $H$. gonzalezmunozi is so poorly preserved that comparison is not possible. $H$. herrerae is unlike any Hemiaster from North America.

Remarks.-Lambert and Sánchez Roig placed this species in Opissaster probably because they believed that the anterior genital pores were microscopic. Cleaning of the specimen shows that these pores are large. This species seems better assigned to Hemiaster (Trachyaster). Although Fischer (1966:U559) states that this subgenus is confined to the Tertiary, many of the species of Hemiaster from the Late Cretaceous, such as Hemiaster texanus Roemer, have the ethmolytic apical system that characterizes this subgenus.

\section{Unrecognizable Species of Hemiaster}

\section{Hemiaster antillensis Cotteau}

Hemiaster antillensis Cotteau, 1881:31, pl. 3: figs. 1-4.-Jackson, 1922:73.

Trachyaster antillensis (Cotteau).-Sánchez Roig, 1949:243.

The holotype has been lost.

OCCURRENCE.-Cotteau provisionally referred this species to the Eocene, but Sánchez Roig considered the species to be Late Cretaceous. Cienfuegos, Las Villas Province, Cuba.

\section{Hemiaster dewalquei Cotteau}

Hemiaster dewalquei Cotteau, 1881:30, pl. 2: figs. 7-9; 1897:75, pl. 3: figs. 7-9.-Jackson, 1922:73.

Hemiaster (Integraster) dewalquei Cotteau._Sánchez Roig, 1949:239.

The holotype of this species is no longer at Liège, Belgium (Georges Ubaghs, Université de Liège, 1982, personal communication) and no specimens are in the Sánchez Roig Collection.

Occurrence.-Eocene(?) of Cienfuegos, Las 
Villas Province, Cuba, but Brodermann (1949:323) considers it Cretaceous.

\section{Hemiaster globulosus Sánchez Roig}

Hemiaster (Integraster) globulosus Sánchez Roig, 1949:240, 241, pl. 42: figs. 11, 13.

Occurrence.-Oligocene-Miocene, "Santa Ana" farm, Majagua district, Ciego de Avila, Camagüey Province, Cuba.

Remarks.-One specimen (SRC 4196) is labelled as the type; but it clearly is not. The holotype was only $33 \mathrm{~mm}$ long according to Sánchez Roig, whereas this specimen is twice as large. It is clearly not conspecific with the holotype figured by Sánchez Roig. Its peristome is far more anterior. Sánchez Roig's illustrations are too poor to permit comparison of this species with other species of the genus.

\section{Hemiaster (Trachyaster) minutus Sánchez Roig}

Trachyaster minutus Sánchez Roig, 1949:241, pl. 42: figs. 6-8.

The holotype is lost and Sánchez Roig's illustrations are too poor to permit comparison with other species.

Occurrence.-Late Cretaceous, sugarhouse of Central dos Hermanos, Santa Clara (now Las Villas) Province, Cuba.

\section{Hemiaster (Trachyaster) simpaticus Sánchez Roig}

Trachyaster simpaticus Sáncbez Roig, 1949:242, pl. 42: figs. 3-5.

The holotype is lost and Sánchez Roig's illustrations are too poor for comparison with other species.

Occurrence.-Late Cretaceous, "Simpatía" farm, at limit of Damuji, Cienfuegos, Santa Clara (now Las Villas) Province, Cuba.

\section{Family Paleopneustidae A. Agassiz, 1904}

\section{Genus Pericosmus L. Agassiz, 1847}

Test generally moderately large, broad, with flattened ventral surface, domed dorsal surface; apical system ethmolytic with three genital pores, no pore in genital plate 2; anterior ambulacrum III with microscopic pores in most species; petals depressed, of approximately equal length, with occluded plates at ends, plates beyond petals with single pores; peripetalous and marginal fascioles present; sternum narrow; in some species first plate of interambulacrum 1 followed by single plate.

Habitat.-No living Pericosmus has been seen in its habitat, so we can only suggest how they live and how the fossil species may have lived. All of the living species, according to Mortensen (1951:167), have in their periproctal region large subanal tubefeet with disks. These are the funnelbuilding tubefeet described by Smith (1980:51). Their presence indicates that the echinoids maintained a sanitary drain and therefore presumably lived at least partially buried. Two of the nine living species have enlarged peripodia in the dorsal portion of the anterior ambulacrum, and the tubefeet possess disks (Mortensen, 1951:166). Again, according to Smith (1980:51) this kind of tubefoot is used for funnel building. These species presumably live completely buried and maintain a funnel to the substrate-water interface. The absence of a deep anterior groove, deep petals, and a subanal fasciole suggest that they probably live not very deeply buried and not in very fine sediments. The seven other living species lack these funnel-building tubefeet in their anterior ambulacrum and could not maintain a funnel. Presumably they live with just the top of their tests covered with sediment.

The fossil specimens from Cuba are generally badly weathered. It is not possible to determine the exact nature of the pores in the anterior ambulacrum. In most of them the pores are very small, with slight size difference between pores on the dorsal side and pores at the margin. Furthermore, they are not close together. According to Smith (1980:77), there is a pronounced change in size of the pores if funnel-building tubefeet are present; the pores are often close together. It can be assumed that most of these fossil species could not build a funnel. The presence of larger subanal porepairs indicates they could maintain a sanitary drain. It is probable that they lived buried 
with the dorsal part of the test slightly covered.

On the basis of our knowledge of the occurrence of the living species of Pericosmus, it can be suggested that the Cuban fossil species probably lived in tropical waters in depths over $100 \mathrm{~m}$. Eight of the nine living species of this genus live in tropical waters; the ninth is subtropical. Most live at depths of $200-500 \mathrm{~m}$ with the shallowest occurring at $18-70 \mathrm{~m}$.

Comparison with Other Species outside of Cuba.-Only two species of Pericosmus are known outside of Cuba in the Western Hemisphere: $P$. stehlini Jeannet from the middle Miocene of Venezuela and $P$. israelskyi Durham from the Miocene of Costa Rica. Pericosmus stehlini is very similar to $P$. camagueyanus from the Oligocene-Miocene of Cuba. The holotype of $P$. stehlini has a more anterior apical system and the tips of its petals appear to be wider. These differences are slight, and the species may be synonyms. $P$. israelskyi is quite different from all the Cuban species having a larger test with deeper petals.

REMARks.-Chesher (1968:159) showed the great similarity between Pericosmus and a group of genera including Paleopneustes. He reestablished for them the family Paleopneustidae, which he stated included genera having similarly shaped tests with domed dorsal surfaces and flattened ventral surfaces, apical systems with only three genital pores, phyllodes with double pores, some occluded plates at the ends of the petals and in interambulacrum 1 the first plate followed by a single plate. This more natural classification was later used by Henderson (1975) in his monograph on New Zealand spatangoids, and is followed herein.

In some of the Cuban species of Pericosmus (such as $P$. valenzuelai Sánchez Roig), the first two plates of interambulacrum 1 are not single but have the normal arrangement of a pair of plates following the first plate. In Pericosmus blanquizalensis Sánchez Roig, the first two plates are single. Unfortunately, the plate sutures are not visible on most of the Cuban species. It is therefore not possible to determine whether there is an evolutionary trend in this character.

Not all the species of Pericosmus have phyllodes with double pores. Mortensen (1951) shows single pores in $P$. akabanus Mortensen, $P$. cordatus Mortensen, $P$. keiensis Mortensen, $P$. tenuis Mortensen, $P$. melanostomus Mortensen, $P$. oblongus Mortensen, and $P$. mauritianus Mortensen. He shows double pores only in P. bidens Mortensen (1951, fig. 91a). I have seen only one specimen of a living Pericosmus: P. akabanus. Its pores beyond the petals and in the phyllodes are definitely single. The phyllodal pores give the first impression of being double because of a ridge dividing the peripodia, but actually only one pore is present. Only on well-preserved fossils is it possible to determine whether the pores are double or single. On badly weathered specimens, the larger pore of a porepair may be so enlarged as to include the smaller second pore, obscuring the fact that two pores were originally present.

Pericosmus is common in Cuba occurring in the Eocene, Oligocene-Miocene, and Miocene. Four species have been described from the Eocene. One of them, P. cubanus Palmer, has never been figured and its type specimen is lost. The other three are very similar and herein are considered synonymous: P. atolladosae (Sánchez Roig), P. rojasi Sánchez Roig, and $P$. zanolettii Sánchez Roig.

Five species of Pericosmus were described by Sánchez Roig or Lambert from the OligoceneMiocene but one of them, Pericosmus delgadoi, is herein referred to Schizaster. Two species that Sánchez Roig considered to belong to Mauritanaster ( $M$. marroquinensis Sánchez Roig and $M$. depressus Sánchez Roig) are herein referred to Pericosmus. Sánchez Roig's Linthia aquayoi and Antillaster mortenseni are also referred to Pericosmus. These eight species are all very similar and all of them may be synonymous. Because only one specimen is known of each of these species, the variation within a species is not known. It is therefore difficult to evaluate the significance of differences between the type specimens.

Pericosmus giganteus Sánchez Roig, Mauritanaster marroquinensis Sánchez Roig, and M. depressus Sánchez Roig are considered synonyms of Pericosmus aguayoi. Pericosmus blanquizalensis Sánchez Roig, $P$. mortenseni (Sánchez Roig), and $P$. camagueyanus Sánchez Roig are maintained as separate species; 
TABle 2.-Disposition herein of Cuban species of Pericosmus ( $M$. = genus Mauritanaster)

\begin{tabular}{|c|c|c|c|}
\hline Disposition & Miocene & $\begin{array}{l}\text { Oligocene- } \\
\text { Miocene }\end{array}$ & Eocene \\
\hline $\begin{array}{l}\text { Recognized species } \\
\text { (synonyms) }\end{array}$ & $\begin{array}{l}\text { P. aguayoi } \\
\quad(? \text { P. artemisae }) \\
(P . \text { valenzuelai })\end{array}$ & $\begin{array}{l}\text { P. aguayoi } \\
\quad(M . \text { depressus }) \\
\quad(M . \text { marroquinensis }) \\
\quad(P . \text { giganteus }) \\
\text { P. blanquizalensis } \\
\text { P. camagueyanus } \\
\text { P. mortenseni }\end{array}$ & $\begin{array}{l}P . \text { atolladosae } \\
\quad(P . \text { rojasi }) \\
(P . \text { zanolettii })\end{array}$ \\
\hline $\begin{array}{l}\text { Unrecognizable } \\
\text { species }\end{array}$ & P. roigi & & P. cubanus \\
\hline $\begin{array}{l}\text { Referred to other } \\
\text { genera }\end{array}$ & & $\begin{array}{l}\text { P. delgador } \\
\text { [to Schizaster] }\end{array}$ & \\
\hline
\end{tabular}

but they are very similar to each other and to $P$. aguayoi. No specimens are available of $P$. roigi Lambert so its affinities are not known. Although Sánchez Roig (1949:246) considered this species to be late Oligocene, Brönnimann and Rigassi (1963:466) place it in the Miocene. Sánchez Roig's two Miocene species, Pericosmus artemisae and $P$. valenzuelai, are considered herein as syn- onyms of $P$. aguayoi.

A summary of the present status of the Cuban species of Pericosmus is presented in Table 2. The following key may be useful, but it must be stressed that the differences between some of the species is slight. The significance of the differences is uncertain. I can see no evolutionary trends within the Cuban species.

\section{Key to Cuban Species of Pericosmus}

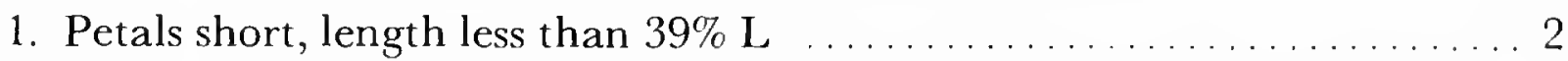

Petals long, length more than $39 \% \mathrm{~L} \ldots \ldots \ldots \ldots \ldots$

2. Petals slightly depressed, slight anterior groove

P. mortenseni (Sánchez Roig), new combination

Petals more depressed, distinct anterior groove . . . . . . . . . . . . . 3

3. Apical system anterior, petals slightly curved

Apical system central, petals straight

P. atolladosae (Sánchez Roig)

4. Apical system central

P. blanquizalensis Sánchez Roig

Apical system anterior

P. camagueyanus Sánchez Roig P. aguayoi (Sánchez Roig)

\section{Pericosmus aguayoi (Sánchez Roig), new combination}

Figures 4-6; Plates 9, 10, 11: figures 1-6

Linthia aguayoi Sánchez Roig, 1949:265, pl. 48: figs. 1, 2.

Mauritanaster depressus Sánchez Roig, 1949:228, pl. 33: fig. 1.

Pericosmus giganteus Sánchez Roig, 1952c:21, pl. 13: fig. 1; pl.

14: fig. 1.
Mauritanaster marroquinensis Sánchez Roig, 1953a:61, pl. 14: 2 figs.

Pericosmus valenzuelai Sánchez Roig, 1953c:167, pl. 10: fig. 5. Pericosmus arternusae Sánchez Roig, 1953c: 168, pl. 11: fig. 1.

Material.-Only one specimen, the holotype (SRG 4268), is in the Sánchez Roig Collection. The test is almost complete, not distorted, but 
badly weathered with most of the tuberculation eradicated. Only short traces of the fascioles are preserved.

Shape and Size.-Length $78 \mathrm{~mm}$, width $99 \%$ $\mathrm{L}$, height $60 \% \mathrm{~L}$, with greatest height at apical system, greatest width anterior of center.

Apical System.-Slightly anterior of center, distance from anterior margin to center of system $36 \% \mathrm{~L}$; ethmolytic, number of genital pores not clear.

Ambulacra.-Anterior ambulacrum III not petaloid; in groove deepening adorally, depth at margin $6.6 \%$ L. Pores minute.

Anterior petals (II and IV) extending over twothirds distance from apical system to margin, length $42 \% \mathrm{~L}$, greatest width $7.0 \% \mathrm{~L}$, in slight groove with depth $2.3 \% \mathrm{~L}$; petals curving very slightly anteriorly. Interporiferous zone slightly narrower than single poriferous zone; pores slightly conjugate, outer pore of pair more elongate than inner; 80 petaloid porepairs; not known in which plate first petaloid porepair occurs. Last $1 \frac{1}{2}$ plates in single poriferous zone of petal occluded, enclosed by first ambulacral plates beyond petal.

Posterior petals (V and I) only very slightly shorter than anterior, extending three-fifths distance from apical system to margin, length $40 \%$ $\mathrm{L}$; width $7.7 \% \mathrm{~L}$, depth of groove $1.1 \% \mathrm{~L}$. Petals curving anteriorly. Last $1 \frac{1}{2}$ plates in single poriferous zone of petal occluded, enclosed by first ambulacral plate beyond petal. Pores single in phyllodes but with ridge dividing peripodia. Two or three larger subanal porepairs on posterior margin in ambulacra $\mathrm{V}$ and $\mathrm{I}$.

Peristome.-Anterior, distance from anterior margin to anterior edge of peristome $17 \% \mathrm{~L}$, width $15 \% \mathrm{~L}$, height not more than $3.6 \% \mathrm{~L}$. Peristome depressed in ventral surface of test.

Periproct.-Inframarginal, on overhanging posterior truncation (Plate 10: figures 2, 4); opening with height $13 \% \mathrm{~L}$, width $14 \% \mathrm{~L}$.

FAscioles.-Short tracks present of both peripetalous and marginal fascioles; marginal fasciole crossing plate 4 in ambulacrum III.

Oral Plate Arrangement.-Labrum high, height $11 \% \mathrm{~L}$; rest of plate sutures not clear.
Occurrence.-Oligocene-Miocene, holotype of P. aguayor and M. depressus, "Santa Ana" farm, Majagua district, Ciego de Avila, Camagüey Province, Cuba; holotype of P. giganteus, "Pedro Hernandez" farm, Tamarindo, Morón, Camagüey Province, Cuba; holotype of $M$. marroquinensis, "Blanquizal" farm of the estate of Campanioni, Marroquín district, Morón, Camagüey Province, Cuba. Miocene, lectotype of $P$. valenzuelai and ?P. artemisae, "Sunset" farm (formerly "Gerona") on highway between Cayajabos and Artemisa, Pinar del Rio Province, Cuba.

Remarks. - This species is clearly a Pericosmus. Not only are its shape and petal arrangement typical of this genus, but it has the minute pores in ambulacrum III, occluded plates at the end of its petals, and marginal fasciole so characteristic of Pericosmus.

Sánchez Roig's holotype of Mauritanaster depressus is from the same locality as the holotype of $P$. aguayoi and appears to be conspecific. Superficially they appear to differ in that the test in $M$. depressus is lower, the apical system more posterior, and no fascioles are visible. However, I believe that postmortem compression flattened the test and shifted the apical system posteriorly. Weathering removed the fascioles. The specimens are similar in the length, width, and arrangement of their petals. An anterior petal in $M$. depressus has 70 porepairs as opposed to 80 in $P$. aguayoi; but the test in $P$. aguayoi is larger and more petaloid porepairs should be present. Both specimens have three genital pores and plates occluded at the end of their petals.

Likewise, Pericosmus giganteus Sánchez Roig, also from the Oligocene-Miocene of Cuba, appears to be a synonym of $P$. aguayoi. Their type specimens have tests with similar marginal outlines, similarly situated apical systems and peristomes, and petals of similar length and arrangement. They only differ in test heights; the test is lower in $P$. giganteus. However, as shown by McNamara and Philip (in press), the test can be relatively lower in larger specimens within a species in Pericosmus. Although the holotype of $P$. giganteus has $2 \frac{1}{2}$ plates occluded at the end of petal and the holotype of $P$. aguayol, only $1 \frac{1}{2}$, this difference is 
probably not significant. I have not been able to determine the variability of this character in $\mathrm{Per}$ icosmus because of the lack of specimens, but Chesher (1968:129) has found in a closely allied genus, Paleopneustes, that the number of occluded plates varies within a species.

The holotype of Mauritanaster marroquinensis Sánchez Roig is indistinguishable from the holotype of $P$. giganteus, which occurs in the OligoceneMiocene of the same region. Presumably because of the absence of fascioles, Sánchez Roig considered it to be a Mauritanaster and did not compare it to his $P$. giganteus, which he had described earlier. Because the specimen is so badly weathered, no fascioles are visible.

The Miocene Pericosmus valenzuelai Sánchez Roig appears to be a synonym of $P$. aguayoz. Their petals are similar in shape and length. The anterior petals in the holotype of $P$. aguayoi appear to be deeper and narrower, but this is due to postmortem compression. Their apical systems are in the same position and the marginal outline of their tests are similar. The lectotype of $P$. valenzuelai is much lower than the holotype of $P$. aguayo $i$ but only slightly lower than the type specimen of $P$. giganteus, a species considered herein to be a synonym of $P$. aguayoi. The lectotype is very similar in general appearance to the holotype of $P$. marroguinensis, another species considered a synonym of $P$. aguayoi.

Sánchez Roig's Pericosmus artemisae is from the same locality as $P$. valenzuelai. Its holotype and only known specimen has been lost. Sánchez Roig's photograph of it is very poor, but I can see no characters that distinguish it from $P$. valenzuelai. The shape of the test and arrangement of thc petals are similar. However, because of uncertainty of other specific characters, I only provisionally place it in synonymy with $P$. valenzuelai under $P$. aguayoi.

\section{SYNONYMS}

Pericosmus giganteus Sánchcz Roig

Figure 4; Plate 9

Material. - The holotype (SRC 4130), which is the only known specimen prcviously rcferred to this species, is moderately well preserved although slightly distorted and badly weathered.

ShaPe AND Size.-Length $91 \mathrm{~mm}$, width $94 \%$ $\mathrm{L}$, height $44 \% \mathrm{~L}$, with greatest width anterior of center, location of greatest height uncertain because of damage to test. The adoral surface is depressed anterior and lateral to the peristome.

Apical system.-Anterior, distance from anterior margin to center of system $40 \%$ L. Although much of the apical system is missing, no pore is present in genital plate 2.

Ambulacra.-Anterior ambulacrum III not petaloid, in groove from apical system to peristome, groove very shallow adapically but deepening crossing margin where depth $3.3 \%$ L. Pores in adapical region very small. Number of plates not discernible.

Anterior petals (II and IV) extending twothirds distance from apical system to margin, length $39 \% \mathrm{~L}$, greatest width $8.3 \% \mathrm{~L}$, in groove with depth $2.6 \%$ L. Petals curving slightly anteriorly, interporiferous zones narrower than single poriferous zone; pores slightly conjugate, outer pore of pair more elongate than inner; 80 petaloid

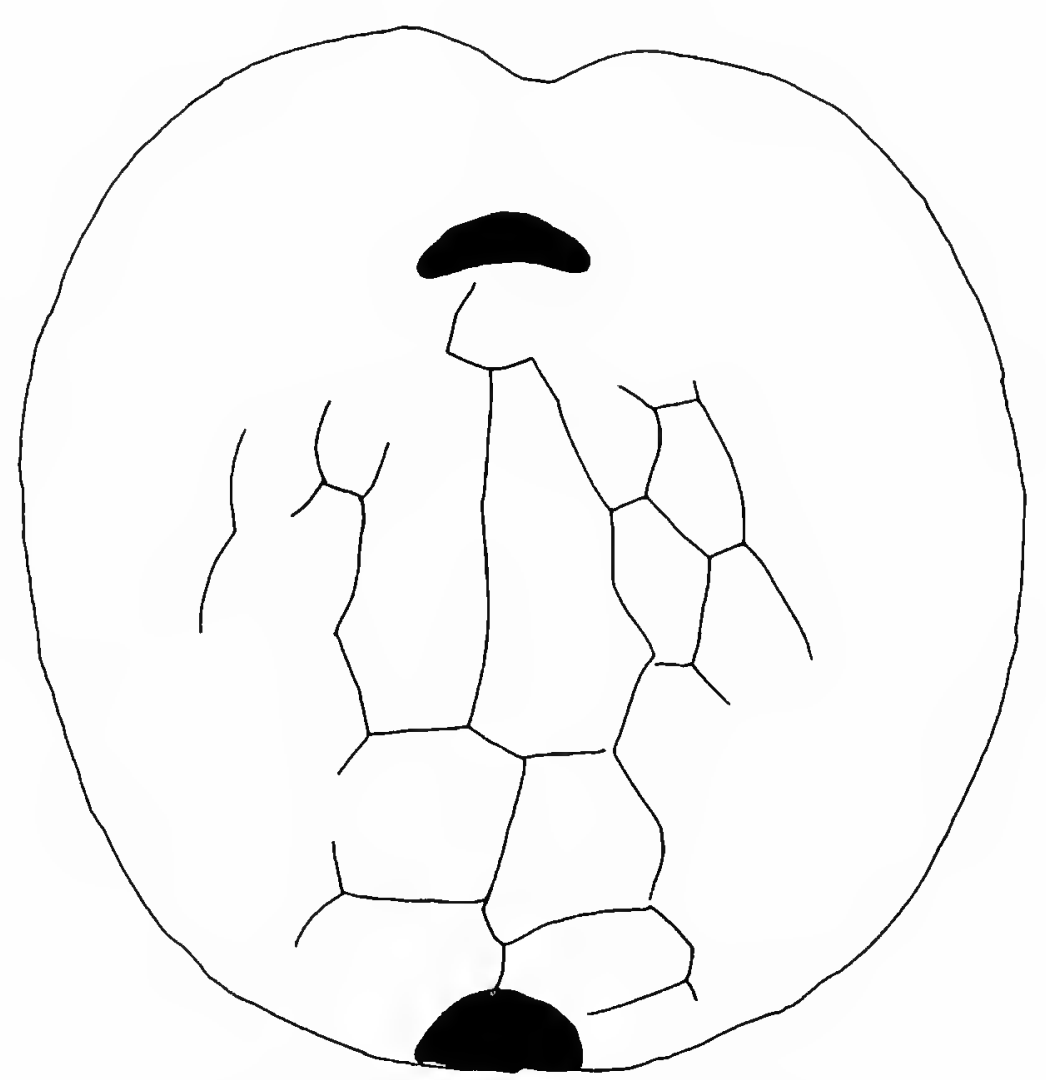

Figure 4.-Pericosmus aguayor (Sánchez Roig), ventral view of thc holotype of Pericosmus giganteus Sánchez Roig $(=P$. aguayoi) SRC $4130, \times 0.9$. 
porepairs; not clear in which plate first petaloid porepairs occur. Last $2 \frac{1}{2}$ plates in single poriferous zone of petal occluded, enclosed by first ambulacral plate beyond petal.

Posterior petals ( $\mathrm{V}$ and I) of approximately same length as anterior, extending less than twothirds distance from apical system to margin, length (est.) $40 \% \mathrm{~L}$, width $8.0 \% \mathrm{~L}$, depth of groove $1.6 \%$ L. Petals straight; number of petaloid porepairs unknown. Last $2 \frac{1 / 2}{2}$ plates in single poriferous zone of petal occluded, enclosed by first ambulacral plate beyond petal.

Peristome.-Anterior, located at distance from anterior margin to anterior edge of peristome equal to $16 \% \mathrm{~L}$, opening wider than high, width $17 \% \mathrm{~L}$, height $4.6 \% \mathrm{~L}$.

Periproct.-Located on overhanging truncation, visible from ventral side, wider than high, width $19 \% \mathrm{~L}$, height $12 \% \mathrm{~L}$; located within interambulacral plates 4-6.

Fascioles. - Test too weathered to show them but presumably both a peripetalous and marginal fasciole were present originally.

Oral Plate Arrangement.-Labrum extending posteriorly to one-third of height of second ambulacral plate; length $11 \% \mathrm{~L}$. Plastron long (Figure 4) composed of four plates: two sternal plates $37 \% \mathrm{~L}$ in length, combined width $29 \% \mathrm{~L}$; two episternal plates shorter $20 \%$ L, combined width $30 \%$ L. Sternal plates bordered by ambulacral plates 2-5.

Occurrence.-Oligocene-Miocene, "Pedro Hernandez" farm, Tamarindo, Morón, Camagüey Province, Cuba.

\section{Mauritanaster depressus Sánchez Roig}

Figure 5; Plate 10: figures 5, 6

Material.-The holotype (SRC 4139), which is the only known specimen, is very poorly preserved. The ventral surface is absent; the test is very badly weathered, fractured, and distorted by postmortem compression.

Shape AND Size.-Length $68.5 \mathrm{~mm}$, width (est.) $92 \% \mathrm{~L}$; height not possible to determine because of postmortem distortion.

Apical System.-Central, located at distance from anterior margin to center of genital pores equal to $48 \%$ L. Ethmolytic, genital plate 2 extending posteriorly separating posterior ocular plates; only three genital pores, no pore in genital plate 2.

AmBulacra.-Anterior ambulacrum III in deep groove at margin with depth estimated at $5.7 \% \mathrm{~L}$; porepairs small in adapical region but no further details visible because of fracturing. Anterior petals (II and IV) extending slightly more than two-thirds distance from apical system to margin; length $44 \% \mathrm{~L}$, width $7.7 \% \mathrm{~L}$, in groove with depth $4.5 \%$ L. Petals curving slightly anteriorly. Interporiferous zone width of single poriferous zone. Pores conjugate, outer pore more elongated than inner; 70 porepairs in petal; $1 / 2$ plate occluded in each poriferous zone (Figure 5) at end of petal.

Posterior petals ( $\mathrm{V}$ and I) straight; length unknown, width estimated at $10 \% \mathrm{~L}$, in groove. Number of petaloid porepairs unknown because of absence of end of petals.

Peristome.-Not preserved.

Periproct.-Not preserved but on posterior overhanging truncation; inframarginal.

Oral Plate Arrangement.-Not preserved.

FASCiOles.-None visible, but test so badly weathered that they would not have been preserved if originally present.

Occurrence.-Oligocene-Miocene, "Santa Ana" farm, Majagua district, Ciego de Avila, Camagüey Province, Cuba.

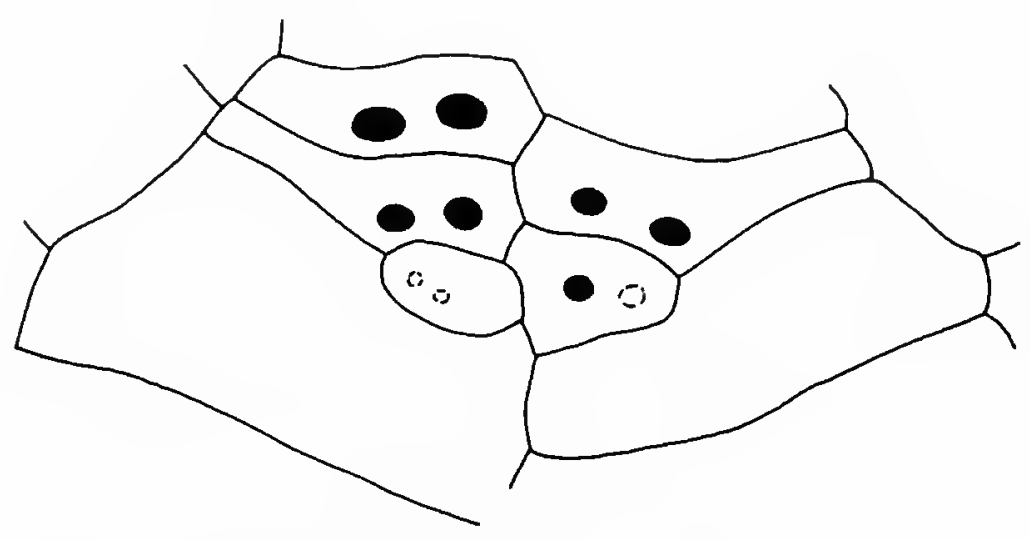

Figure 5.-Pericosmus aguayoi (Sánchez Roig), plate arrangement at end of petal IV of the holotype of Mauritanaster depressus Sánchez Roig (= P. aguayoi), SRC 4139, × 8 . 
Mauritanaster marroquinensis Sánchez Roig

Plate 11: figures 1-3

Material.-Only one specimen, the holotype (SRC 4357), in the Sánchez Roig Collection. This specimen is the one figured by Sánchez Roig (1953a, pl. 14) in the original description. It is very poorly preserved being badly weathered, not showing the fascioles or the plate sutures, and lacking its posterior. The ventral surface has been compressed.

Shape AND Size.-Length can only be estimated, $87.0 \mathrm{~mm}$; width $79.0 \mathrm{~mm}$ (est. 90\% L); height (est.) $49 \% \mathrm{~L}$ with the greatest height just posterior to the apical system. Ventral surface depressed anterior and lateral to the peristome.

Apical System.-Anterior, distance from anterior margin to center of system 32-mm (est. 37\% L); no details of system visible.

Ambulacra.-Anterior ambulacrum III not petaloid, in groove from apical system to peristome, groove very shallow adapically but deepening crossing margin where depth $3.1 \mathrm{~mm}$ (est. $3.6 \% \mathrm{~L}$ ). Nature of pores in dorsal region not discernible but apparently very small; number of plates not clear; width of ambulacrum at margin $8.9 \mathrm{~mm}$ (est. 10.2\% L).

Anterior petals (II and IV) extending over twothirds distance from apical system to margin, length $39.4 \mathrm{~mm}$ (est. $45 \% \mathrm{~L}$ ), greatest width 7.8 $\mathrm{mm}$ (est. $9.0 \% \mathrm{~L}$ ), in groove with depth $2.4 \mathrm{~mm}$, (est. $2.9 \%$ L). Petals curving slightly anteriorly; interporiferous zone narrower than single poriferous zone; pores slightly conjugate, outer pore of pair more elongate than inner; 82 petaloid porepairs; not known in which plate first petaloid porepair occurs. Last $2 \frac{1}{2}$ plates in single poriferous zone of petal occluded, enclosed by first ambulacral plate beyond petal.

Posterior petals ( $\mathrm{V}$ and $\mathrm{I}$ ) only very slightly longer than anterior, extending two-thirds distance from apical system to margin, length 41.7 $\mathrm{mm}$ (est. 48\% L); width $8.0 \mathrm{~mm}$ (est. 9.2\% L); depth of groove $2.3 \mathrm{~mm}$ (est. $2.6 \% \mathrm{~L}$ ). Petals straight; 86 petaloid porepairs. Last $2 \frac{1}{2}$ plates in single poriferous zone of petal occluded, enclosed by first ambulacral plate beyond petal.
Peristome.-Anterior, distance from anterior margin to anterior edge of peristome $16.0 \mathrm{~mm}$ (est. 18\% L); width $16.9 \mathrm{~mm}$ (est. 19\% L); height not known.

Periproct.-Not preserved.

FAscioles.-None preserved but test too weathered to show them if they had been originally present.

Oral Plate Arrangement.- Sutures not clear.

Occurrence.-Oligocene-Miocene, "Blanquizal" farm of the estate of Campanioni, Marroquín district, Morón, Camagüey Province, Cuba; "Las Cuevas" farm of Pedro Pozo, Marroquín district, Morón, Camagüey Province, Cuba.

\section{Pericosmus valenzuelai Sánchez Roig}

Figure 6; Plate 11: figures 4-6

Material.-One specimen, the lectotype (SRC 4021) (Sánchez Roig, 1953c: 167, pl. 10: fig. 5) is herein designated. The second cotype is missing. The lectotype is nearly complete except for the lack of part of the posterior. The test is very weathered resulting in the loss of the fascioles and the enhancing of the plate sutures.

Shape ANd Size.-Length $62.8 \mathrm{~mm}$, width 66.2 $\mathrm{mm}(105 \% \mathrm{~L})$, height $23.8 \mathrm{~mm}(38 \% \mathrm{~L})$; greatest height anterior to apical system; adoral surface flat.

Apical System.-Three genital pores, no pore in genital plate 2; ethmolytic (Figure 6A); located anterior of center at distance from anterior margin to center of genital pores equal to $34 \% \mathrm{~L}$.

Ambulacra.-Anterior ambulacrum III not petaloid, in groove from apical system to peristome, groove deepest at margin of test where depth equal to $4.1 \% \mathrm{~L}$. Character of pores not clear because of weathering of test; 42 plates.

Anterior petals (II and IV) long, extending almost to margin; length $42 \% \mathrm{~L}$. Petals straight, depressed in groove, depth $3.5 \% \mathrm{~L}$; petals narrow with greatest width $9.7 \% \mathrm{~L}$. Porepairs with outer pore slit-like; 74 petaloid porepairs; interporiferous zone at its greatest width slightly less wide than single poriferous zone. First petaloid porepair in plate 13; total of 98 plates in ambulacra 


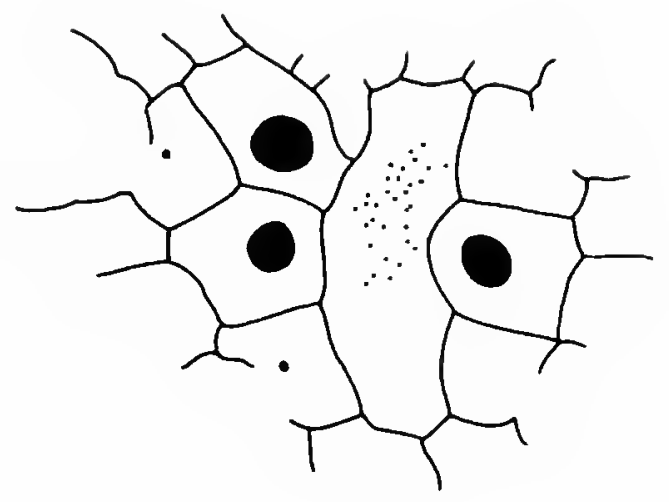

A

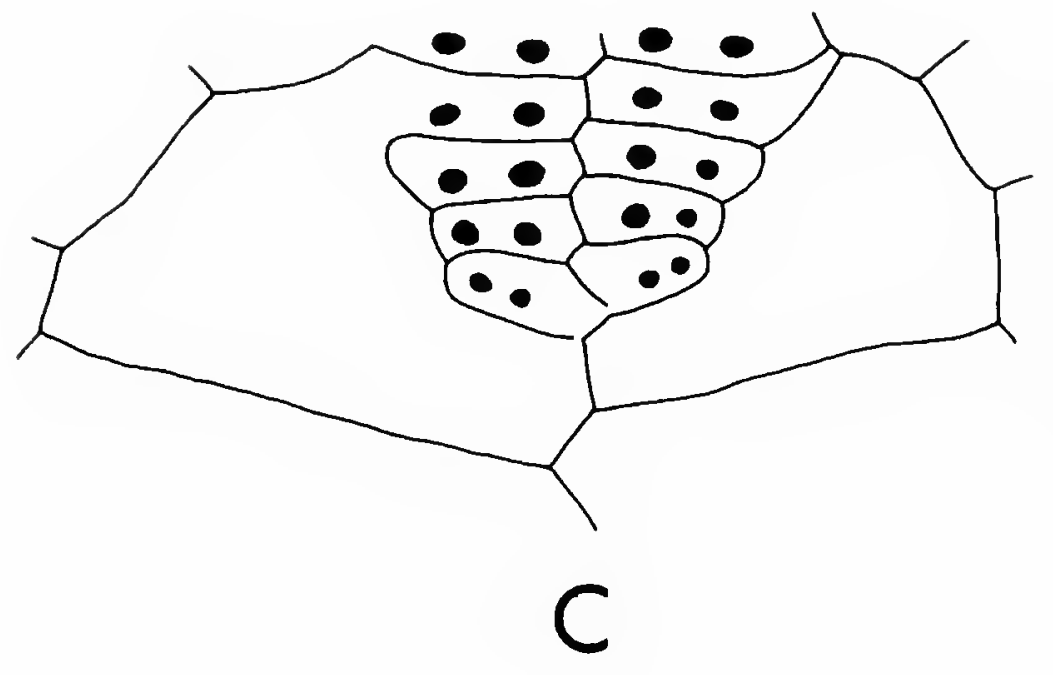

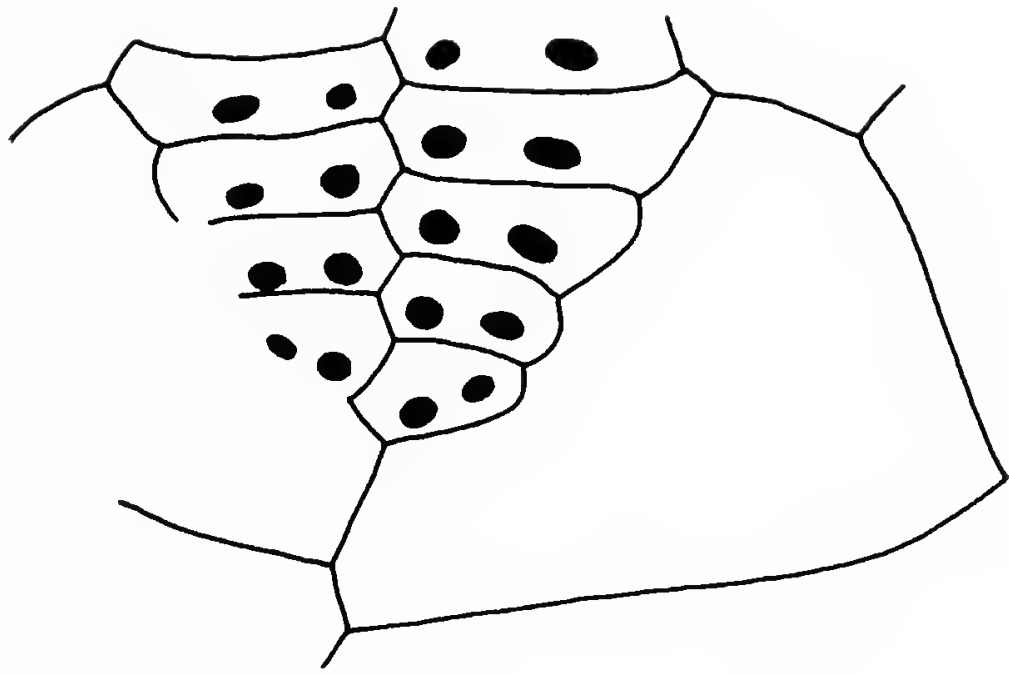

B

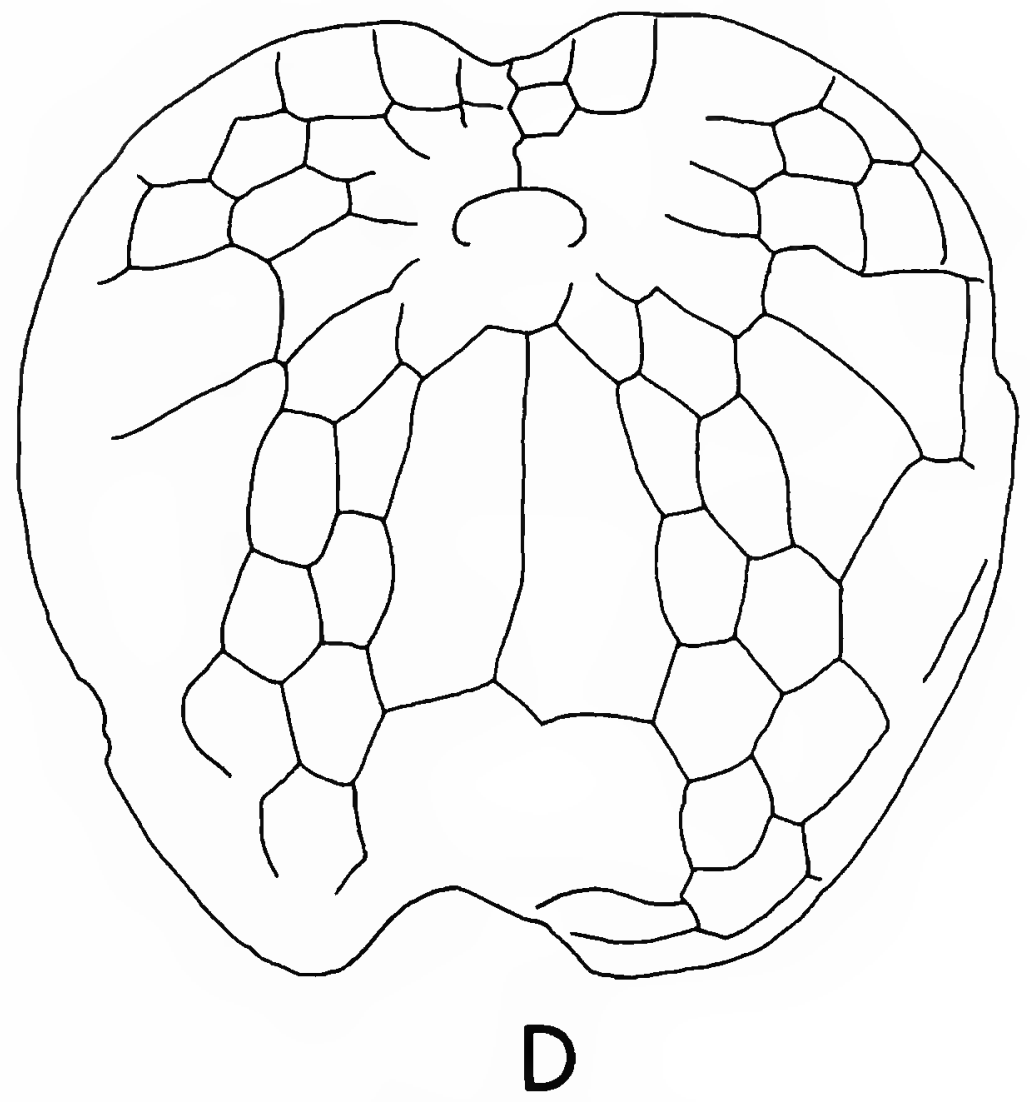

Figure 6.-Pericosmus aguayoi (Sánchez Roig), views of the holotype of Pericosmus valenzuelai Sánchez Roig (= P. aguayoi), SRC 4021: A, apical view, $\times 10$; B, end of petal I, $\times 10$; c, end of petal II, $\times 10$; D, ventral view, $\times 1.2$.

II or IV. Last $3^{1 / 2}$ plates in single poriferous zone of petal occluded (Figure 6c).

Posterior petals (V and I) approximately same length as anterior, extending two-thirds distance from apical system to posterior margin, length $42 \%$ L, width $91 . \%$ L. Petals straight, depressed in groove with depth $3.9 \% \mathrm{~L}, 74$ petaloid porepairs, first petaloid porepairs in plate 17; total of 106 plates in ambulacrum. Last $3 \frac{1 / 2}{2}$ plates in single poriferous zone of petal occluded, enclosed by first ambulacral plate beyond petal (Figure $6 \mathrm{~B})$.

Peristome.-Anterior, located at distance from anterior margin to anterior edge of peristome equal to $16 \% \mathrm{~L}$, opening wider than high, width $15 \% \mathrm{~L}$, height not known.

Periproct.-Unknown, test destroyed in this region. 
Fascioles.-Only short tract of peripetalous fasciole visible; marginal not visible presumably because test is badly weathered. Sánchez Roig (1949:168) reports both to be well preserved on cotype, which is now missing. Peripetalous fasciole would cross ambulacra II or IV on plates 11 or 12; ambulacra V or I on plates 15 or 16 .

Oral Plate Arrangement.-Labrum not preserved; plastron long (Figure 6D), composed of 4 plates: 2 sternal plates $40 \% \mathrm{~L}$ in length, combined width $33 \%$ L; 2 episternal plates shorter, $22 \% \mathrm{~L}$, combined width $37 \%$ L. Sternal plates bordered by ambulacral plates 2(?)-5; episternal pair, by ambulacral plates 5-7. In interambulacrum 1, first plate followed by pair of plates although plate $2 \mathrm{~b}$ nearly extends across interambulacrum (Figure 6D).

Occurrence.-Miocene, "Sunset" farm (formerly "Gerona") on highway between Cayajabos and Artemisa, Pinar del Rio Province, Cuba.

\section{Pericosmus atolladosae (Sánchez Roig), new combination}

Figures 7, 8; Plate 11: figures 7-9; Plate 12: FIGURES $1-8$

Linthia atolladosae Sánchez Roig, 1951:59, pl. 34: figs. 1, 2. Pericosmus rojasi Sánchez Roig, 1951:60, pl. 36: figs. 2, 3. Pericosmus zanolettii Sánchez Roig, 1953c:169, pl. 11: fig. 2.

Material. - The holotype (SRC 4190), which is figured, is the only specimen. It is nearly complete, not distorted, but badly weathered with most of the tuberculation absent.

Shape AND Size.-Length $64.0 \mathrm{~mm}$, width 61 $\mathrm{mm}(96 \% \mathrm{~L})$, height $35 \mathrm{~mm}(55 \% \mathrm{~L})$, with greatest width anterior, greatest height anterior of apical system.

Apical System.-Three genital pores, no pore in genital plate 2, ethmolytic; located slightly anterior of center at distance from anterior margin to center of genital pores equal to $38 \% \mathrm{~L}$.

AmbUlacra.-Anterior ambulacrum III not petaloid, in groove from apical system to peristome, groove deepest at margin of test where depth equal to $6.3 \% \mathrm{~L}$. Porepairs in dorsal portion of anterior ambulacrum larger than at ambitus, in peripodia with small node separating pores of pair; pores obliquely situated with inner pore of pair anterior to outer.

Anterior petals (II and IV) short, extending less than two-thirds distance from apical system to margin; length $37 \% \mathrm{~L}$. Petals slightly curved (convex anteriorly), depressed in groove of depth $1.9 \% \mathrm{~L}$; petals narrow with greatest width $8.0 \%$ L. Pores of pair conjugate with outer pores slitlike; 64 petaloid porepairs; interporiferous zone narrow, slightly more than one-half width of single poriferous zone; slight groove running length of petal in middle of interporiferous zone. Not possible to determine in which plate first petaloid porepairs occur.

Posterior petals ( $\mathrm{V}$ and I) slightly shorter than anterior; length $33 \% \mathrm{~L}$. Petals straight to very slightly curved posteriorly, depressed in shallow groove with depth $2.3 \% \mathrm{~L}, 56$ (est.) petaloid porepairs. Last 3 plates in single poriferous zone of petals occluded, enclosed by first ambulacral plate beyond petal.

Peristome.-Anterior, located at distance from anterior margin to anterior edge of peristome equal to $17 \% \mathrm{~L}$, opening wider than high, width $14 \% \mathrm{~L}$, height $5.0 \% \mathrm{~L}$.

Periproct.-Situated on overhanging posterior truncation, opening visible from below, wider than high, width $21 \% \mathrm{~L}$, height $13 \% \mathrm{~L}$. Truncation depressed below periproct.

Fascioles.-Only part of peripetalous fasciole visible because of weathering of test. Marginal fasciole narrow, encircling test above margin. Not clear which plates bear fascioles because of obscuring of plate sutures.

Oral Plate Arrangement.-Labrum with height equal to $9.1 \% \mathrm{~L}$; rest of plate sutures not clear.

Occurrence.-Eocene, type specimens of $P$. atolladosae and $P$. rojasi, "Atolladosa" farm, Majagua district, Ciego de Avila, Camagüey Province, Cuba; late Eocene, type specimen of $P$. zanolettii, Loma "Los Constantinos," "La Ventura" farm, Marroquin district, Moron, Camagüey Province, Cuba.

Remarks. - This species clearly is a Pericosmus. Not only is its shape and petal arrangement 
similar to this genus; but it has a marginal fasciole, three genital pores, minute pores in ambulacrum III, and its distal petaloid plates are occluded, features typical of Pericosmus.

Pericosmus atolladosae is very similar and probably conspecific with Pericosmus rojasi Sánchez Roig from the same locality. The holotypes have equally depressed, short petals with interporiferous zones of similar width. The apical system is anteriorly situated, and peristome and periproct are in the same relative positions. The difference in the height of their tests is probably not significant.

Likewise, Pericosmus zanolettii Sánchez Roig also from the Eocene of Cuba appears to be a synonym of $P$. atolladosae. The petals are indistinguishable and the differences in the shape of their tests probably fall well within the range of variation in a species of Pericosmus.

\section{SYNONYMS}

\section{Pericosmus rojasi Sánchez Roig}

Figure 7; Plate 12: figures 1-4

Material.-The holotype (SRC 4300) is the only specimen known of this species. It is very poorly preserved, being fractured, badly weathered, and abraded.

Shape ANd Size.-Length $52.5 \mathrm{~mm}$, width 49.2 $\mathrm{mm}(94 \% \mathrm{~L})$, height $35.4 \mathrm{~mm}(67 \% \mathrm{~L})$; test very high with greatest height posterior to apical system, greatest width anterior. Posterior truncation overhanging, sides smoothly rounded.

Apical System.-Three genital pores, no pore in genital plate 2; ethmolytic; located anterior of center at distance from anterior margin to center of genital pores equal to $34 \% \mathrm{~L}$.

Ambulacra.-Anterior ambulacrum III not petaloid; lying in groove from apical system to peristome, groove very shallow near apical system, deepest at margin of test depth equal to $4.2 \%$ L. Peripodia very slightly developed; number of plates not clear.

Anterior petals (II and IV) extending less than two-thirds distance from apical system to margin;
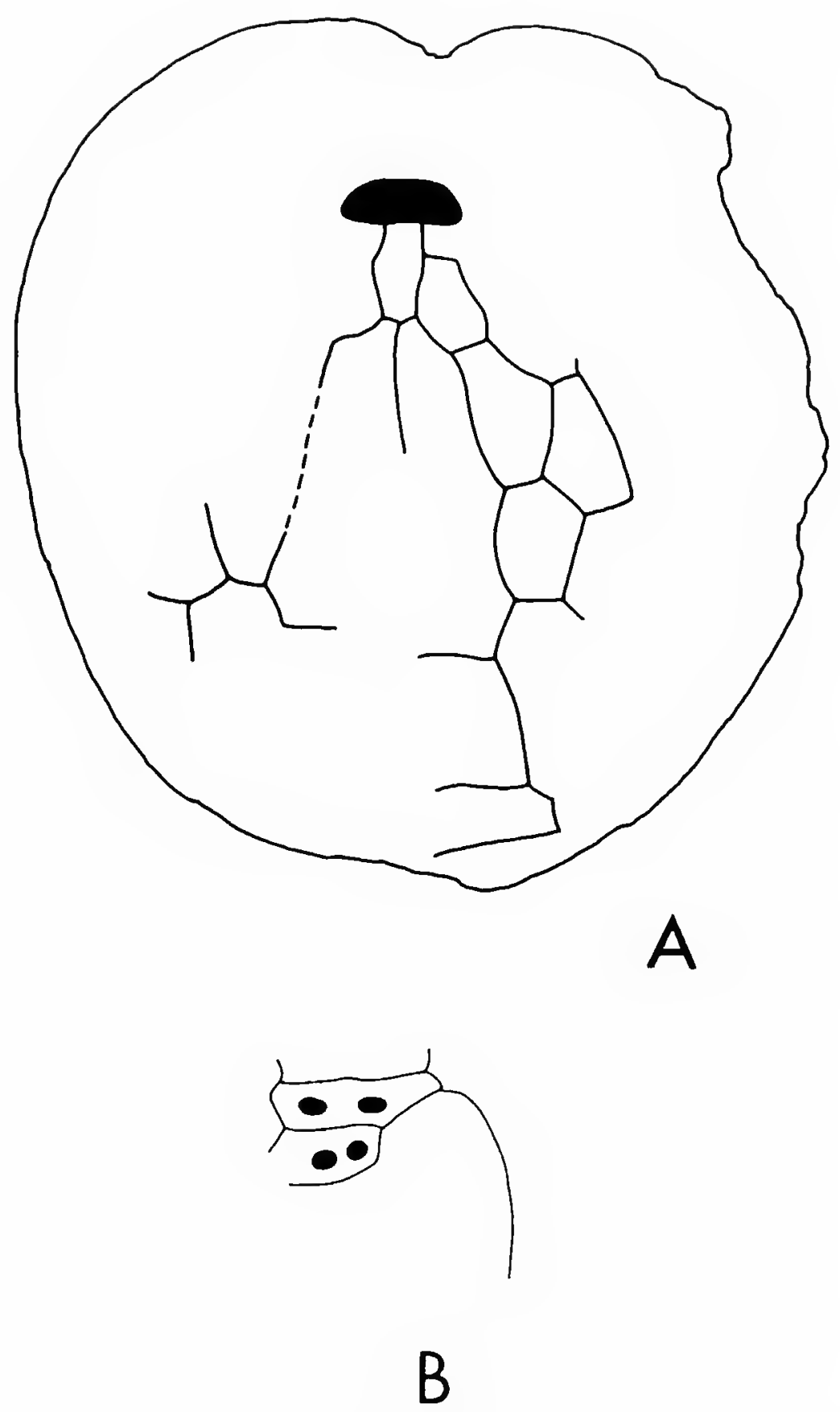

Figure 7.-Pericosmus atolladosae (Sánchez Roig), views of the holotype of Pericosmus rojasi Sánchez Roig ( $=P$. atolladosae), SRC 4300: A, ventral view, $\times 1.5 ; \mathbf{B}$, end of petal $\mathrm{I}, \times 8$.

length $31 \% \mathrm{~L}$, greatest width $8.4 \%$ L. Petals straight, in shallow groove, depth $2.1 \%$ L. Porepairs slightly conjugate with outer pore slit-like; 52 petaloid pores; interporiferous zone narrower than poriferous.

Posterior petals ( V and I) approximately same length as anterior, extending one-half distance from apical system to margin, length $28 \% \mathrm{~L}$, greatest width $7.4 \% \mathrm{~L}$. Petals straight in very shallow groove, 50 petaloid porepairs. Last $1 \frac{1 / 2}{2}$ plates in single poriferous zone of petal occluded 
(Figure $7 \mathrm{~B}$ ), enclosed by first ambulacral plate beyond petal.

Peristome.-Anterior, located at distance from anterior margin to anterior edge of peristome equal to $15 \% \mathrm{~L}$; opening wider than high, width $14 \% \mathrm{~L}$, height $5.7 \% \mathrm{~L}$.

Periproct.-Located on overhanging truncation, visible from ventral side; wider than high, width $17 \% \mathrm{~L}$, height $11 \% \mathrm{~L}$.

Fascioles.-Not preserved.

Oral Plate Arrangement.-Labrum (Figure $7_{A}$ ) extending posteriorly to posterior one-third of height of second ambulacral plate; length $12 \% \mathrm{~L}$. Plastron long (Figure 7A), composed of 4 plates: 2 sternal plates $39 \% \mathrm{~L}$ in length, combined width $27 \%$ L; 2 episternal plates, shorter, 18\% L (est.), combined width $29 \%$ L. Sternal plates bordered by ambulacral plates $2-5$, episternal pair by ambulacral plates 5-7. Not clear whether first 2 plates of interambulacrum 1 are single.

Occurrence.-Eocene, "Atolladosa" farm, Majagua district, Ciego de Avila, Camagüey Province, Cuba.

\section{Pericosmus zanolettii Sánchez Roig}

Figure 8; Plate 12: figures 5-8

Material.-Only one specimen (SRC 4239) is present in the Sánchez Roig Collection although Sánchez Roig mentions two cotypes in his original description. This specimen is figured in his description and is herein selected as the lectotype (Sánchez Roig, 1953c, pl. 11: fig 2). It is moderately well preserved and although weathered still retains traces of the fascioles.

Shape And Size. - Length $56.0 \mathrm{~mm}$, width 52.8 mm (94\% L), height $26.0 \mathrm{~mm}(46 \% \mathrm{~L})$. Greatest width anterior, greatest height posterior.

Apical System.-Three genital pores, no pore in genital plate 2; anterior, located at distance from anterior margin to center of genital pores equal to $37 \% \mathrm{~L}$.

Ambulacra.-Anterior ambulacrum III not petaloid, in groove from apical system to peristome, groove very shallow near apical system, deepest at margin of test where depth equal to $3.8 \% \mathrm{~L} ; 48$ plates.

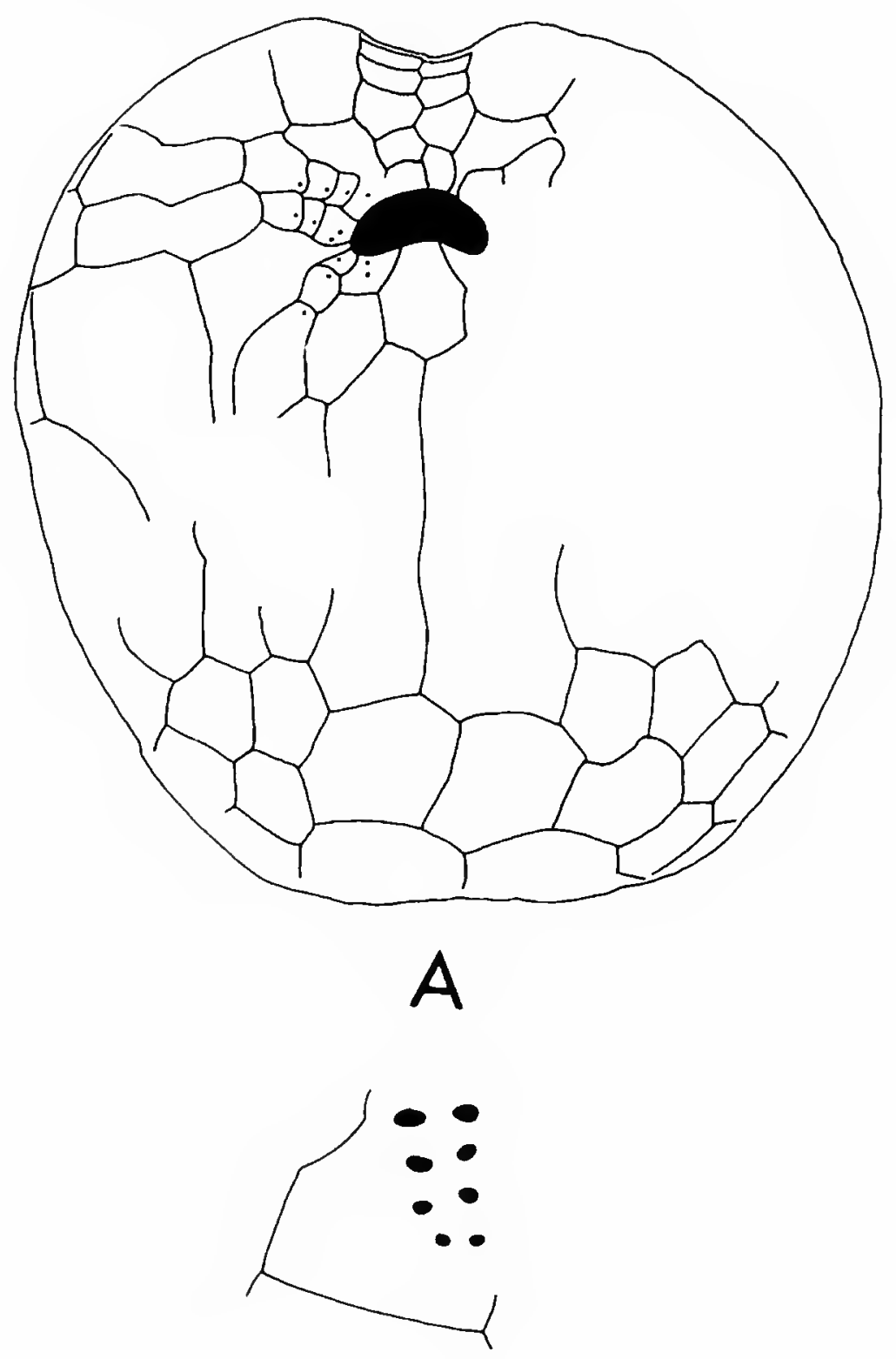

\section{B}

Figure 8.-Pericosmus atolladosae (Sánchez Roig), lectotype of Pericosmus zanolettii Sánchez Roig $(=P$. atolladosae $)$, SRC 4239: A, ventral view, $\times 1.5$; B, end of petal I, $\times 6$.

Anterior petals (II and IV) extending twothirds distance to margin; length $38 \% \mathrm{~L}$, width $8.2 \%$ L. Petals curve anteriorly, depressed in deep groove, depth $3.2 \%$ L. Outer pore of pair slit-like; 66 petaloid porepairs, interporiferous zones slightly narrower than poriferous. First petaloid porepair in plate 14; total of 92 plates in ambulacrum.

Posterior petals ( $\mathrm{V}$ and $\mathrm{I}$ ) shorter than anterior, extending one-half distance from apical system to margin; length $32 \%$ L, width $8.9 \%$ L. Petals curving posteriorly, depressed in groove with depth $2.7 \% \mathrm{~L} ; 56$ petaloid porepairs, first petaloid 
porepair in plate 18; total of 90 plates in ambulacrum. Last $2^{1 / 2}$ to $3 \frac{1 / 2}{2}$ plates in single poriferous zone of petal occluded (Figure 8B), enclosed by first ambulacral plate beyond petal.

Peristome.-Anterior, located at distance from anterior margin to anterior edge of peristome equal to $18 \% \mathrm{~L}$, opening wider than high, width $15 \% \mathrm{~L}$, height $4.8 \% \mathrm{~L}$.

Periproct.-Located on overhanging truncation, slightly visible from ventral side; wider than high, width $18 \% \mathrm{~L}$, height $11 \% \mathrm{~L}$, located within interambulacral plates 4-8.

Fascioles.-Peripetalous fasciole narrow, curving slightly into interambulacra $4,5,1$; crossing ambulacra II or IV on plate $13, \mathrm{~V}$ or I on plate 16 or 17 ; crossing interambulacra 4 or 1 on plates 11, 12. Marginal fasciole narrow passing around test adapical of margin and below periproct; crossing ambulacra II or IV on plates 8,9 ; $\mathrm{V}$ or I on 10, 11; crossing interambulacra 4 or 1 on plates 4,5 ; interambulacrum 5 on plates 4,5 .

Oral Plate Arrangement.-Labrum (Figure 8A) extending posteriorly to anterior two-thirds of height of second ambulacral plate, length $13 \% \mathrm{~L}$. Plastron long (Figure 8A) composed of 4 plates: 2 sternal plates, $42 \% \mathrm{~L}$ in length, combined width 29\% L (est.); 2 episternal plates shorter, 17\% L, combined width $30 \%$ L. Sternal plates bordered by ambulacral plates 2-5, episternal pair by plates 4,5 . First plate of interambulacra in contact with peristome.

Occurrence.-Late Eocene, Loma "Los Constantinos," "La Ventura" farm, Marroquín district, Morón, Camagüey Province, Cuba.

\section{Pericosmus blanquizalensis Sánchez Roig}

Figure 9; Plate 12: figures 9-11

Pericosmus blanquizalensis Sánchez Roig, 1952c:21, pl 13:fig. 2.

Material.-One specimen: the holotype and figured specimen (SRC 4106). The specimen is slightly crushed with part of the left side and posterior missing.

Shape And Size.-Length $60 \mathrm{~mm}$, width 59 mm (97\% L), height (est.) $24 \mathrm{~mm}(40 \% \mathrm{~L})$, with greatest height posterior of apical system. Ventral surface elevated at posterior of plastron.

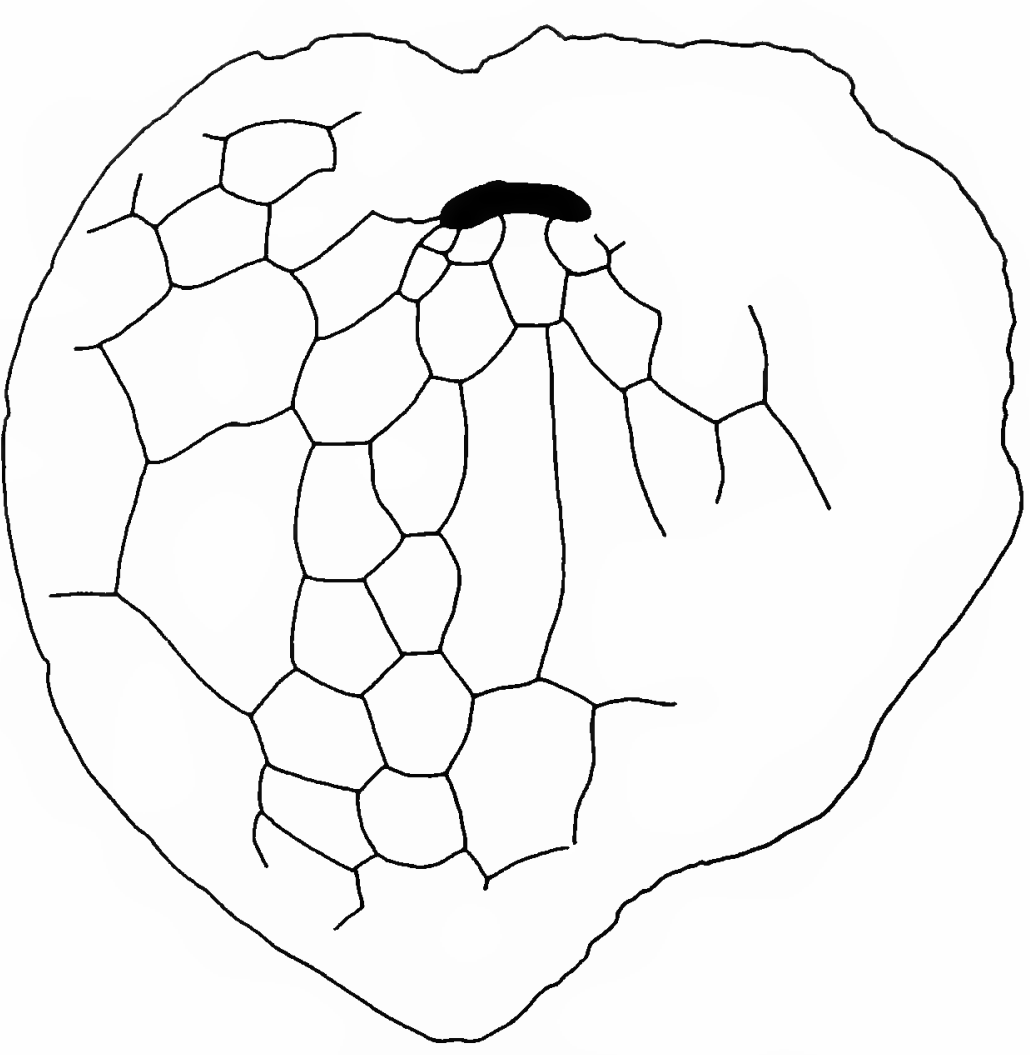

Figure 9.- Pericosmus blanquizalensis Sánchez Roig, ventral view of the holotype, SRC 4106, $\times 1.4$.

Apical System.- Three genital pores, no pore in genital plate 2, ethmolytic; located slightly posterior of center at distance from anterior margin to center of genital pores equal to $42 \% \mathrm{~L}$.

Ambulacra.-Anterior ambulacrum III not petaloid, in groove from apical system to peristome, groove deepest at margin of test where depth equal to $3.8 \% \mathrm{~L}$. Character of pores not clear because of weathering of test; 50 plates.

Anterior petals (II and IV) short, extending slightly more than over one-half distance from apical system to margin; length $31 \% \mathrm{~L}$. Petals straight, depressed in groove with depth $1.8 \% \mathrm{~L}$; petals narrow with greatest width $6.1 \%$ L. Pores conjugate with outer pore slit-like; 66 petaloid porepairs; interporiferous zone narrow, approximately one-half width of single poriferous zone; groove running length of petal in middle of interporiferous zone. First petaloid porepair in plate 14 or 15 ; total of $92-94$ plates in ambulacrum II or IV.

Posterior petals ( $\mathrm{V}$ or $\mathrm{I}$ ) slightly shorter than anterior petals; length $31 \% \mathrm{~L}$. Petals straight, depressed in shallow groove with depth $1.3 \% \mathrm{~L}$, 64 petaloid porepairs, first petaloid porepair in plate 18 or 19 ; total of $100-102$ plates in ambu- 
lacrum. Last $2 \frac{1}{2}$ plates in single poriferous zone of petals occluded, enclosed by first ambulacral plate beyond petal.

Pores paired beyond petals. Phyllodes with porepairs in well-developed peripodia with high ridge separating pores, 4 in ambulacrum III, 6 in II or IV, number uncertain in posterior ambulacra.

Peristome.-Anterior, located at distance from anterior margin to anterior edge of peristome equal to $12 \% \mathrm{~L}$ (est.), opening wider than high, width $15 \% \mathrm{~L}$, height $4.8 \% \mathrm{~L}$ (est.).

Periproct.-Unknown, test destroyed in this region.

Oral Plate Arrangement.-Labrum (Figure 9) extending posteriorly to anterior one-third of height of second ambulacral plate; length $10 \% \mathrm{~L}$. Plastron long (Figure 9) composed of 4 plates: 2 sternal plates $37 \% \mathrm{~L}$ in length, combined width 23\% L; 2 episternal plates shorter, $19 \%$ L, combined width $27 \% \mathrm{~L}$ (est.). Sternal plates bordered by ambulacral plates $2-5$, episternal by ambulacral plates 5-7. First and second plate of interambulacrum 1 not paired, second plate extending across interambulacrum.

Occurrence.-Oligocene-Miocene, "Blanquizal" farm, Tamarindo district, Morón, Camagüey Province, Cuba.

Comparison with Other Species. - This species is very similar and may be conspecific with Pericosmus mortenseni (Sánchez Roig) from the same locality. It differs in having more depressed petals and a deeper anterior groove, but these differences may be due to postmortem distortion. It differs from Pericosmus camagueyanus Sánchez Roig, also from the Oligocene-Miocene, by having narrower, deeper, and longer petals and a narrower labrum.

\section{Pericosmus camagueyanus Sánchez Roig}

Figure 10; Plate 13: figures 1-4

Pericosmus camagueyanus Sánchez Roig, 1949:246, pl. 38: figs. $1,2$.

Material. - There are 4 specimens in the Sánchez Roig Collection labelled as belonging to this

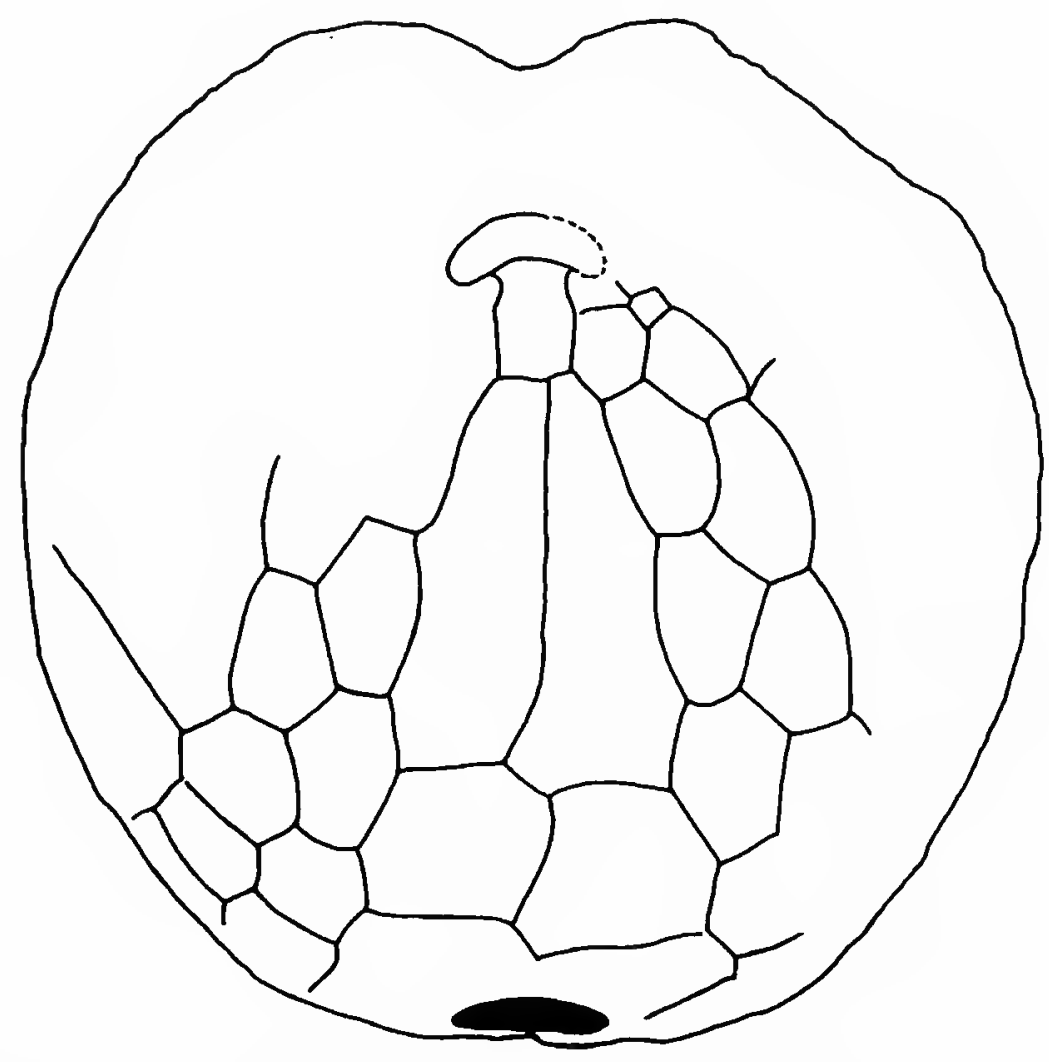

Figure 10.-Pericosmus camagueyanus Sánchez Roig, ventral view of the lectotype, SRC $4202, \times 1.5$.

species. One of them (SRC 4202) is labelled as a type and is from the type-locality. It is herein designated as the lectotype. The specimen figured in the original description is missing. The following description is based on the lectotype and not on the other specimens, because they do not appear to be conspecific with it.

Shape and Size._Length $69 \mathrm{~mm}$, width 65 $\mathrm{mm}$ (95\% L), height $29 \mathrm{~mm}$ (42\% L), greatest width and height anterior to center; ventral surface flat, margin sharp.

Apical System.-No genital pore in genital plate 2; present in genital 1 and 3, but genital 4 absent due to fracturing of test but presumably this genital had a pore; ethmolytic; located slightly anterior of center at distance from anterior margin to center of genital pores equal to $46 \% \mathrm{~L}$.

Ambulacra.-Anterior ambulacrum III not petaloid, in groove from apical system to peristome, groove very slight near apical system, deepest at margin of test where depth equal to $4.4 \%$ L. Peripodia very slightly developed; number of plates not clear. 
Anterior petals (II and IV) extending twothirds distance to margin; length $39 \% \mathrm{~L}$; width $9.1 \%$ L. Petals curving slightly anteriorly, slightly depressed in groove, depth $1.3 \%$ L. Porepairs slightly conjugate with outer pore only slightly more elongated than inner; 68 petaloid porepairs; interporiferous zone narrower than poriferous with greatest width near apical system, tapering distally. First petaloid porepair in plate 13; total of 92 plates in ambulacra II or IV.

Posterior petals (V and I) slightly longer than anterior extending slightly less than two-thirds distance from apical system to margin; length $40 \% \mathrm{~L}$, width $9 \% \mathrm{~L}$. Petals curving very slightly posteriorly, depressed in slight groove with depth $1.0 \% \mathrm{~L}, 74$ petaloid porepairs, first petaloid porepair in plate 15; total of 102 plates in ambulacrum. Last $3 \frac{1}{2}$ plates in single poriferous zone of petal occluded, enclosed by first ambulacral plate beyond petal.

Peristome.-Anterior, located at distance from anterior margin to anterior edge of peristome equal to $15 \% \mathrm{~L}$, opening wider than high, width $17 \% \mathrm{~L}$, height $4.8 \% \mathrm{~L}$.

Periproct.-Located on overhanging truncation, visible from ventral side; wider than high, width $17 \% \mathrm{~L}$, height $8.7 \% \mathrm{~L}$; located within interambulacral plates 4, 5 and perhaps 6 .

FAscioles. - Peripetalous fasciole narrow, curving sharply into interambulacra $1,4,5$; crossing ambulacra II or IV on plate $12, \mathrm{~V}$ or I on plate 14; not clear on which interambulacral plates. Marginal fasciole narrow, passing along margin of test and below periproct; crossing ambulacra II or IV on plate 8; ambulacra V or I on plate 9; interambulacrum $\mathrm{V}$ on plates 4,5 .

Oral Plate Arrangement.-Labrum (Figure 10) extending posteriorly to posterior one-third of height of second ambulacral plate; length $12 \% \mathrm{~L}$. Plastron long (Figure 10) composed of 4 plates: 2 sternal plates, $40 \% \mathrm{~L}$ in length, combined width $28 \%$ L; 2 episternal plates shorter, $19 \%$ L, combined width $34 \%$ L. Sternal plates bordered by ambulacral plates $2-5$, episternal by ambulacral plates 5, 6. Not clear whether first 2 plates of interambulacrum are single.

Occurrence.-Oligocene-Miocene, lectotype,
$12 \mathrm{~km}$ NE of Jatibonico, Camagüey Province, Cuba.

Comparison with Other Species.-Pericosmus camagueyanus is very similar to and may be conspecific with Pericosmus aguayoi (Sánchez Roig) also from the Cuban Oligocene-Miocene. Their petals are of similar length and arrangement. The anterior petals in the holotype of $P$. aguayo $i$ appear to be more depressed, but this is the result of postmortem distortion.

Likewise, the ventral side of test in P. camagueyanus is partially depressed by this distortion. The apical system is more central in $P$. camagueyanus. For this reason I do not synonymize the 2 species although this difference may fall within the range of variation within a species of Pericosmus. Pericosmus camagueyanus is very similar to $P$. blanquizalensis Sánchez Roig also from the Oligocene-Miocene of Cuba and differs only in the shape of its test with its greatest height anterior instead of posterior and its wider, shallower, and longer petals.

Pericosmus camagueyanus differs from the Miocene Cuban P. valenzuelai Sánchez Roig in having its apical system central not anterior and in having its petals in much shallower grooves.

\section{Pericosmus mortenseni (Sánchez Roig), new combination}

Figure 11; Plate 13: figures 5-7

Antillaster mortenseni Sánchez Roig, 1952c:20, pl. 14: figs. 2, 3.

MATERIAL. - The holotype (SRC 4185) is moderately well preserved with the test only slightly distorted but weathered, so that much of the tuberculation including most of the fascioles are eroded away.

Shape And Size.-Length $68 \mathrm{~mm}$, width 94\% $\mathrm{L}$, height $37 \% \mathrm{~L}$; greatest width anterior, greatest height at apical system; ventral surface flattened to depressed.

Apical System.-Three genital pores, no pore in genital plate 2, ethmolytic; located slightly anterior of center at distance from anterior margin to center of genital pores equal to $35 \% \mathrm{~L}$.

Ambulacra.-Anterior ambulacrum III not petaloid, in slight groove where crossing margin; 

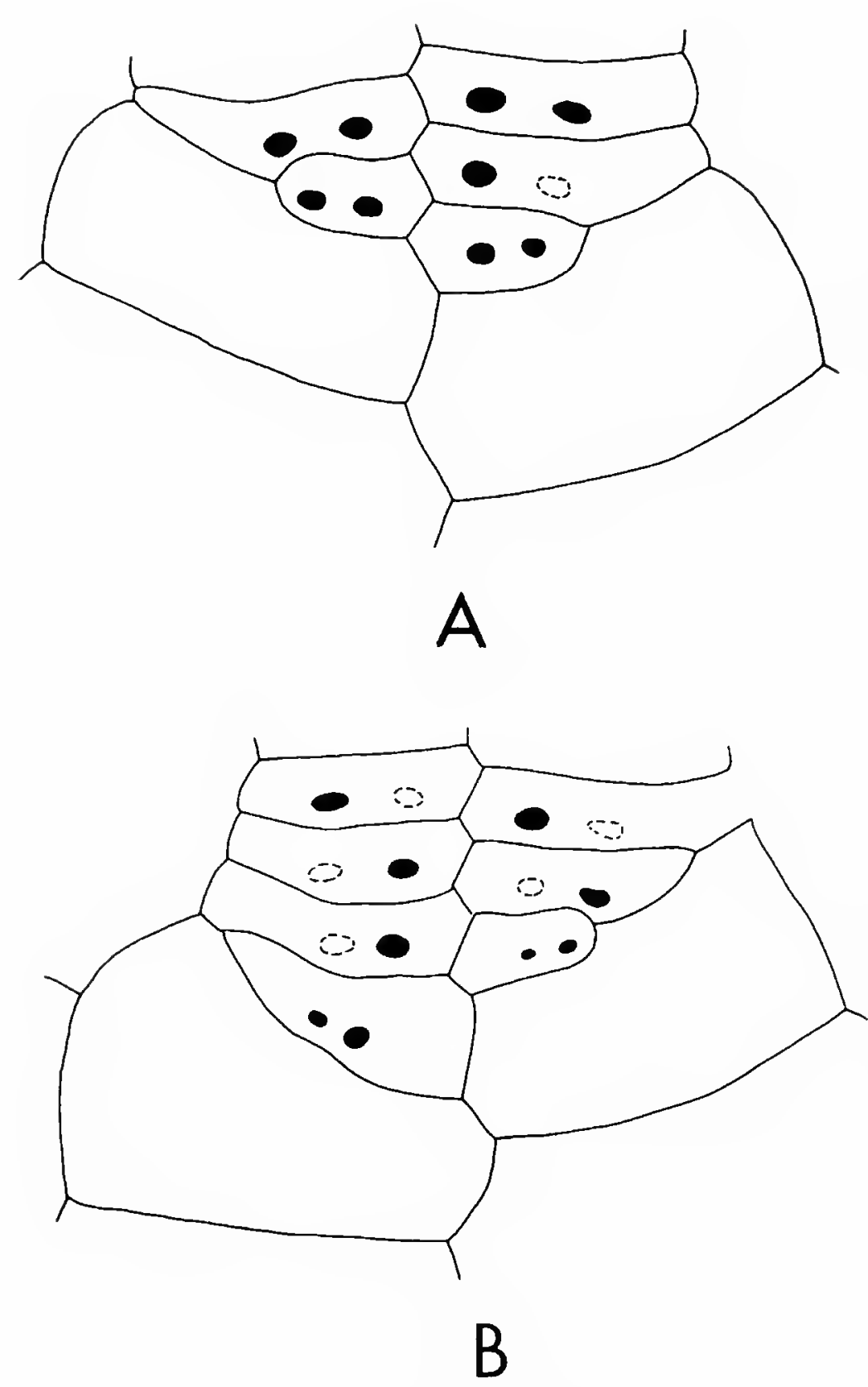

Figure 11.-Pericosmus mortenseni (Sánchez Roig), holotype, SRC 4185: A, end of petal II, $\times 10 ; \mathrm{B}$, petal IV, $\times 10$.

pores in dorsal region very small, nature of peripodia not clear; 50 plates in ambulacrum.

Anterior petals (II and IV) short, extending slightly more than one-half distance from apical system to margin, length $29 \% \mathrm{~L}$, width $8.1 \% \mathrm{~L}$; straight to curving very slightly anteriorly, slightly depressed; interporiferous zone approximately same width as poriferous. Pores conjugate with outer pore more elongate than inner; 60 petaloid porepairs; first petaloid porepair in plate 14 or 15; total of 73-74 plates in ambulacrum. Ambulacrum II with last $1 \frac{1 / 2}{2}$ plates in single poriferous zone of petal occluded, enclosed by first ambulacrum beyond petal (Figure 11A); am- bulacrum IV with $1 \frac{1}{2}$ in anterior poriferous zone, $2^{1 / 2}$ in posterior poriferous zone occluded (Figure $11 \mathrm{~B})$.

Posterior petals ( $\mathrm{V}$ and I) approximately same length as anterior petals; length $31 \% \mathrm{~L}$, width $8.5 \% \mathrm{~L}$, curving very slightly posteriorly; very slightly depressed; 64 petaloid porepairs; number of occluded plates not clear. Presence or absence of subanal pores not clear because of poor preservation.

Peristome.-Anterior, located at distance from anterior margin to anterior edge of peristome equal to $15 \% \mathrm{~L}$; opening wider than high; width $16 \% \mathrm{~L}$, height uncertain.

Periproct.-Located high on steeply inclined posterior truncation; visible from below; dimensions of opening unknown; wider than high.

FASCiOLes. - Peripetalous fasciole eroded away; only short track of marginal fasciole preserved.

Oral Plate Arrangement.-Most of plastron missing; sutures not clear in interambulacrum 1.

Occurrence.-Oligocene-Miocene, "Blanquizal" farm, Tamarindo, Morón, Camagüey Province, Cuba. Specimens SRC 4759 and SRC 4760 from "La Fortuna de Frederico Pozo", Marroquín, Morón, Camagüey Province, Cuba.

Comparison with Other Species. - This species is very similar to Pericosmus blanquizalensis Sanchez Roig from the same locality. The two holotypes have the same shape, the petals are of similar length, width, and arrangement, and the peristome is in similar position in both. The petals in $P$. blanquizalensis are more depressed and the anterior groove is deeper but these differences may be due to postmortem distortion. The more posterior position of the apical system in P. blanquizalensis may also be caused by distortion. $P$. mortensen differs from $P$. camagueyanus Sánchez Roig and P. aguayoi Sánchez Roig, both from the Oligocene-Miocene, in its shorter petals, which do not extend so near to the margin of the test.

Remarks.-Sánchez Roig probably referred this species to Antillaster because he thought it lacked fascioles and had 4 genital pores. Its marginal fasciole, 3 genital pores, and occluded plates at the end of its petals are characters typical of Pericosmus. 
There are 2 specimens in the Sanchez Roig Collection (SRC 4759 and 4760), which Sánchez Roig labelled (but never described) as representing a new species. They are similar in their dimensions and number of petaloid porepairs to the holotype of $P$. mortenseni and in no significant character do they differ.

\section{Unrecognizable Species of Pericosmus}

\section{Pericosmus cubanus Palmer}

Pericosmus cubanus Palmer in Sánchez Roig, 1949:248.

The type specimen has been lost and this species has never been figured.

Occurrence.-Late Eocene, "Junquito" farm, $200 \mathrm{~m} \mathrm{E}$ of San Antonio on the road from Maraguan, Camagüey Province, Cuba.

\section{Pericosmus roigi Lemoine}

Hemispatagus hoffmani-Sánchez Roig, 1920:5, fig. 24 [not Goldfuss, 1826].

Meoma roigi Lemoine, 1921:121.

Pericosmus roigi._Lambert in Lambert and Thiéry, 1925 [1909-1925]:513._Sánchez Roig, 1926:128, pl. 41: figs. 4, 5; 1949:245, pl. 38: figs. 3,4 .

The holotype and only known specimen is lost. Sánchez Roig's photograph is so poor and the holotype was so poorly preserved that it is not possible to determine the affinities of this species.

Occurrence.-Miocene, railroad station at Ceiba, railroad from Marianao, Habana Province, Cuba. Although Sánchez Roig (1949:246) and Brodermann (1949:325) consider this locality to be late Oligocene, Brönnimann and Rigassi (1963:466) state that the Cojímar Formation outcrops here. They date this formation as Miocene on the basis of foraminifera.

\section{Family ScHIZASTERIDAE Lambert, 1905}

\section{Genus Schizaster L. Agassiz, 1836}

Test with faint or deep anterior notch, ambulacrum III not petaloid with enlarged porepairs adapically. Anterior petals longer than posterior, all petals depressed; single pores beyond petals. Apical system with 2 or 4 genital pores, ethmolytic. Both peripetalous and latero-anal fascioles present.

Habitat.-These species of Schizaster no doubt lived buried in the sediment. The modern species, Schizaster doederleini (Chesher) has been reported (Kier, 1975:14) to live buried to a depth of 20$100 \mathrm{~mm}$ in mud. The fossil species share with this living species the following features, all of which indicate a burrowing habit: funnel-building tubefeet in the anterior ambulacrum (as indicated by presence of enlarged porepairs), depressed anterior ambulacrum and depressed well-developed petals, and presence of peripetalous and lateroanal fascioles. The thin tests and large plastrons also suggest a subsurface habitat. Modern species live in tropical to temperate waters from shallow depths to $900 \mathrm{~m}$.

Evolution.-The sixteen recognizable species of Schizaster from Cuba range from the Eocene through the Miocene. Although there are no obvious evolutionary trends, S. bathypetalus Arnold and Clark from the Eocene, S. cartagensis (Sánchez Roig) from the Oligocene-Miocene, and S. delgadoi (Sánchez Roig) from the Miocene all share large tests with deeply depressed petals. The Eocene S. llagunoi Lambert and Sánchez Roig and $S$. santanae Sánchez Roig are similar in size of test, position of apical system, and large number of enlarged porepairs in ambulacrum III to the late Oligocene-early Miocene S. munozi Sánchez Roig and the three species may be related. The Eocene $S$. subcylindricus Cotteau and S. camagueyensis Weisbord are obviously closely related and appear to be ancestral to the Miocene $S$. fernandezi Sánchez Roig; all share a posterior apical system, very short posterior petals, curved anterior petals, and few enlarged porepairs in ambulacrum III. The rest of the species appear to have no near relatives in Cuba or elsewhere.

Comparison with Other Species outside of Cuba.-Three of the species of Schizaster from Cuba are found elsewhere. S. gerthi Pijpers occurs in both Cuba and Bonaire, $S$. bathypetalus Arnold and Clark occurs in Cuba and Jamaica, and $S$. subcylindricus Cotteau occurs in Cuba, Jamaica, 
and St. Bartholomew. Schizaster munozi Sánchez Roig from the late Oligocene or early Miocene of Cuba is very similar to $S$. americanus Clark from the Oligocene (Vicksburg) of southeastern United States. It is also quite similar to $S$. clevei Cotteau from the Miocene of Anguilla. S. subcylindricus Cotteau is like $S$. beckeri Cooke from the late Eocene Ocala Limestone of Florida. The other Cuban species of Schizaster are distinctive with no close relatives.

Remarks.-Generally the genus Paraster or subgenus Schizaster (Paraster) has been used for species having 4 genital pores. Lambert and Thiéry (1909-1925:522) did not consider the number of genital pores of generic significance believing that the number varied within the same species. Although I have never seen any variation in the number of genital pores within a species (including hundreds of specimens of the living Paraster doederleini Chesher and many of the $\mathrm{Cu}-$ ban species), McNamara and Philip (1980:49) report this variation in some of their Australian species. Unfortunately the number of genital pores is uncertain (Henderson, 1975:14) in Schizaster studeri Agassiz, the type-species of the genus. McNamara and Philip (1980:49), however, define the subgenus Paraster on other characters. In their view, Paraster comprises species which differ from typical species of Schizaster in having a more shallow ambulacrum III, a more circular test, a less posteriorly situated apical system, and anterior petals that are straighter and that diverge more strongly. I have tried unsuccessfully to use their system for the Cuban species. Although some species fall readily into $S$. (Paraster) or $S$. (Schizaster), others have characters of both subgenera. For example, Schizaster bathypetalus Arnold and Clark has the deep anterior groove and curved anterior petals of a S. (Schizaster) and also has the central apical system of a $S$. (Paraster). $S$. cartagensis Sánchez Roig has the deep anterior groove of a $S$. (Schizaster) but also has the central apical system of a $S$. (Paraster). Schizaster subcylindricus Cotteau has the posterior apical system of a $S$. (Schizaster) and has the shallow anterior groove of a $S$. (Paraster). Furthermore, the num- ber of genital pores does not correlate with any other particular character. Therefore, in this paper, I abandon any effort to use the subgenus Paraster and refer all the species to Schizaster.

Thirty-seven species from Cuba have been referred to Paraster or Schizaster. Sixteen are recognized herein. The type specimens of ten species are lost or are too poorly preserved to permit recognition of their specific characters. One species is transferred to another genus and 8 species are considered to be synonyms. These species are listed in Table 3, except S. parkinsoni. Cotteau (1875:6; 1897:84) referred some Cuban specimens to Schizaster parkinsoni DeFrance, previously known from Europe. He did not illustrate any of the Cuban specimens and they are no longer in his collection, so it is not possible to confirm this occurrence.

\section{Schizaster bathypetalus Arnold and Clark}

Figures 12, 13; Plates 14, 15

Schizaster bathypetalus Arnold and Clark, 1927:58, 60, pl. 12: figs. 1-4.

Schizaster gigas Sánchez Roig, 1953a:66, pl. 20.

Schizaster pentagonalis Sánchez Roig, 1953a:65, pl. 19.

Occurrence.-Eocene, in the Spring Mount Region, S and W towards Seven Rivers, St. James Parish, Jamaica. Middle to late Eocene, Loma Caoba, San Diego de Los Baños, Pinar del Rio Province, Cuba.

Comparison with Other Species.-This species is easily distinguished from Schizaster subcylindricus Cotteau, which occurs with it at Loma Caoba by its far larger test, more central apical system with 4 genital pores, longer posterior petals and anterior petals that curve in an opposite direction. It differs from $S$. gerthi Pijpers also from Loma Caoba by its larger test, more divergent and longer posterior petals and more curved anterior petals.

Remarks.-I cannot distinguish $S$. gigas (Eocene of Cuba) from $S$. bathypetalus (Eocene of Jamaica). I have compared the Cuban specimens with the type specimen of the Jamaican species and they differ in no significant features. The 
TABLE 3.-Disposition of Cuban species of Schizaster

$(P .=$ genus Paraster $)$

\begin{tabular}{|c|c|c|c|}
\hline Disposition & Miocene $^{1}$ & $\begin{array}{l}\text { Oligocene- } \\
\text { Miocene }\end{array}$ & Eocene \\
\hline $\begin{array}{l}\text { Recognized species } \\
\text { (synonyms) }\end{array}$ & $\begin{array}{l}\text { S. delgador } \\
\text { S. fernandezi }\end{array}$ & $\begin{array}{l}\text { S. carlagensis } \\
\text { S. egozcuei } \\
\text { S. munozi } \\
\quad(P . \text { orienlalis) } \\
\quad \text { (P. tschopi) } \\
\quad \text { (S. guirensis) } \\
\quad \text { (S. riveroi) } \\
\quad \text { (S. salutis) } \\
\text { S. rojasi } \\
\text { S. sanctamariae }\end{array}$ & $\begin{array}{l}\text { S. bathypelalus } \\
\quad \text { (S. gigas) } \\
\quad \text { (S. pentagonalis) } \\
\text { S. camagueyensis } \\
\text { S. cubitabellae } \\
\text { S. formelli } \\
\text { S. gerthi } \\
\quad \text { (P. clarki) } \\
\text { S. llagunoi } \\
\text { S. nuevitasensis } \\
\text { S. santanae } \\
\text { S. subcylindricus }\end{array}$ \\
\hline $\begin{array}{l}\text { Unrecognizable } \\
\text { species }\end{array}$ & $\begin{array}{l}\text { S. cojimarensis } \\
\text { S. } \text { cubensis }^{2} \\
\text { S. habanensis } \\
\text { S. } \text { sierrai }^{-3}\end{array}$ & S. moronensis & $\begin{array}{l}\text { S. alcaldei } \\
\text { S. caobaense } \\
\text { S. pastelilloensis } \\
\text { S. pinarensis } \\
\text { S. sandiegensis }\end{array}$ \\
\hline $\begin{array}{l}\text { Referred to other } \\
\text { genera }\end{array}$ & $\begin{array}{l}\text { S. vedadoensis } \\
\quad(=\text { Migliorinia } \\
\text { habanensis })\end{array}$ & & \\
\hline
\end{tabular}

${ }^{1}$ Unless otherwise noted. ${ }^{2}$ Pliocene? ${ }^{3}$ Pleistocene.

holotype (Plate 15: figure 2) of $S$. bathypetalus has longer posterior paired petals than the lectotype (Plate 14: figure 6) of $S$. gigas, but this difference is due to the smaller size of the holotype. Among the Cuban specimens, the smaller specimens have relatively longer posterior petals than the larger specimens. For example, a specimen $73 \mathrm{~mm}$ long has posterior petals $26 \% \mathrm{~L}$; whereas, in a specimen $64 \mathrm{~mm}$ long the petals are $30 \% \mathrm{~L}$. Likewise, the holotype of $S$. bathypetalus is $58 \mathrm{~mm}$ long with posterior petals $34 \% \mathrm{~L}$; and the larger paratype is $72 \mathrm{~mm}$ long, with petals only $28 \% \mathrm{~L}$.

I have exposed the petals and apical system in the paratype of $S$. bathypetalus (Plate 15: figure 1). The apical system has 4 genital pores. The anterior ambulacrum has 76 enlarged porepairs; petal II, 78 porepairs; and petal I, 56 . The first petaloid porepair is in plate 18 or 19 in ambulacrum I, not discernible in other ambulacra.

S. pentagonalis Sánchez Roig, from the same locality as $S$. gigas, appears to be indistinguishable from $S$. gigas and S. bathypetalus. Sánchez Roig distinguished $S$. pentagonalis from $S$. gigas by its higher test and narrower anterior groove. However, Sánchez Roig's (1953, pl. 19) figured specimen was badly distorted and it was not possible to determine its original height. The height of the neotype of $S$. pentagonalis is very similar to that of the specimen of $S$. gigas. Likewise, there is no significant difference in the width of the anterior groove in the 2 species: a specimen of $S$. pentagonalis has a groove with a width $15 \% \mathrm{~L}$ and $S$. gigas has a groove $13 \% \mathrm{~L}$.

\section{SYNONYMS}

\section{Schizaster gigas Sánchez Roig}

Figure 12; Plate 14: figure 6; Plate 15: figures 3-7

Material._Sánchez Roig's figured specimen is no longer in the collection, and neither is a smaller cotype mentioned in his description. Two 
topotypic specimens identified by him are present, one of which is labelled as a cotype. This specimen (SRC 4946) is herein designated the lectotype. The description below is based on the following specimens, one (SRC 5001, Plate 15: figures 5-7) collected by Albear, Formell, and Kier at the type-locality, 3 topotypes in the USNM collections (Plate 15: figure 3) and one specimen, ANSP 16653 (Plate 15: figure 4), in the Palmer Collection at the Academy of Natural Sciences of Philadelphia. The lectotype is highly weathered, with the adoral posterior region broken away. The other specimen in the collection, the Palmer specimen, and one of the USNM specimens, have highly weathered but undistorted tests.

Shape and Size.- Test large, high with greatest height posterior, greatest width anterior, length 61 to $70 \mathrm{~mm}$, width 94 to $109 \% \mathrm{~L}$, greatest height 69 to $81 \%$ L. Posterior truncation nearly vertical, very high, anterior sloping steeply.

Apical System.-Central to slightly posterior, ethmolytic, genital plate 2 extending posteriorly separating posterior ocular plates; 4 genital pores (Figure 12).

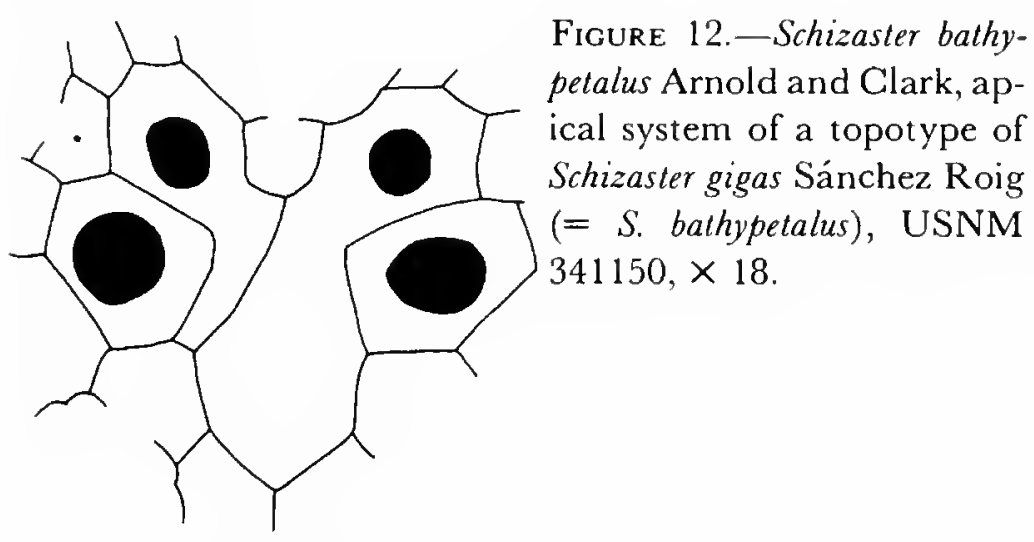

Ambulacra.-Anterior ambulacrum III not petaloid, in very deep groove extending from apical system to peristome; groove deepest and widest midway between apical system and test margin where width 13 to $18 \% \mathrm{~L}$, depth 11 to $12 \% \mathrm{~L}$; sides of groove nearly vertical. Pores paired only in adapical region where pores enlarged in peripodia with node separating pores of pair; enlarged porepairs present from apical system to approximately two-thirds distance to margin; porepairs in single row. First enlarged pores in plate 7, 84 enlarged porepairs in lectotype 63 $\mathrm{mm}$ long.

Anterior petals (II and IV) flexuous, curved convexly to anterior, extending two-thirds distance from apical system to margin, length 44 to $50 \% \mathrm{~L}$, greatest width 7.7 to $10 \% \mathrm{~L}$; in deep groove with greatest depth 5.2 to $7.4 \%$ L. Pores strongly conjugated, 78 petaloid porepairs in lectotype $63.3 \mathrm{~mm}$ long, 60 in specimen $60 \mathrm{~mm}$ long; interporiferous zone approximately same width as single poriferous zone; pores single beyond petals. Not possible to determine which plate bears first petaloid porepair.

Posterior petals (V and I) short, straight, extending slightly more than one-half distance from apical system to margin; length 24 to $31 \% \mathrm{~L}$, width 8.1 to $9.2 \% \mathrm{~L}$, depth of groove 4.4 to $6.0 \%$ $\mathrm{L} ; 54$ petaloid porepairs in lectotype $63.3 \mathrm{~mm}$ long, 46 in specimen $60 \mathrm{~mm}$ long.

Peristome.-Anterior, located at distance from anterior margin to anterior edge of peristome equal to 12 to $19 \% \mathrm{~L}$, opening wider than high, width 21 to $25 \% \mathrm{~L}$, height 3.5 to $5.1 \% \mathrm{~L}$.

Periproct.-Located high on nearly vertical posterior truncation, opening higher than wide.

Fascioles.-Peripetalous fasciole very wide where passing around extremities of petals, deeply indented in interambulacra. Latero-anal fasciole passing in deep lobe below periproct.

Oral Plate Arrangement.-Labrum short, length $7.6 \% \mathrm{~L}$; sternal plates very long, $61 \% \mathrm{~L}$, greatest combined width of both sternal plates $38 \%$ L. First plate in interambulacrum 2 followed by pair of plates.

Occurrence.-Middle to late Eocene, Loma Caoba, San Diego de los Baños, Pinar del Rio Province, Cuba.

\section{Schizaster pentagonalis Sánchez Roig \\ Figure 13: Plate 14: figures 1-5}

Material.-Both the figured specimen and cotype, for which the dimensions are given by Sánchez Roig, are lost. One topotypic specimen (SRC 4762) identified by Sánchez Roig remains in the Sánchez Roig Collection and it is herein 
described. The specimen is slightly compressed but its tuberculation is well enough preserved to show the fascioles.

Shape and Size.-Test very large, length 87.0 mm (est.), width $90 \mathrm{~mm}(104 \% \mathrm{~L})$, height $62 \mathrm{~mm}$ $(72 \% \mathrm{~L})$; greatest height posterior.

Apical System.-Ethmolytic, genital plate 2 extending posteriorly and separating posterior ocular plates; apparently 4 genital pores but test fractured in apical region covering part of system. Anterior, at distance from anterior margin to center of genital pores $34 \% \mathrm{~L}$.

Ambulacra.-Ambulacrum III not petaloid, in very deep groove extending from apical system to peristome; groove deepest and widest midway between apical system and margin where width $15 \% \mathrm{~L}$, depth $12 \% \mathrm{~L}$; sides of groove nearly vertical. Pores paired only in adapical region where pores enlarged in peripodia (Plate 14: figure 5) with node separating pores of pair; outer pore of pair more elongated than inner. Enlarged porepairs present from apical system to approximately two-thirds distance to margin; porepairs in single row; 88 porepairs in area with enlarged porepairs.

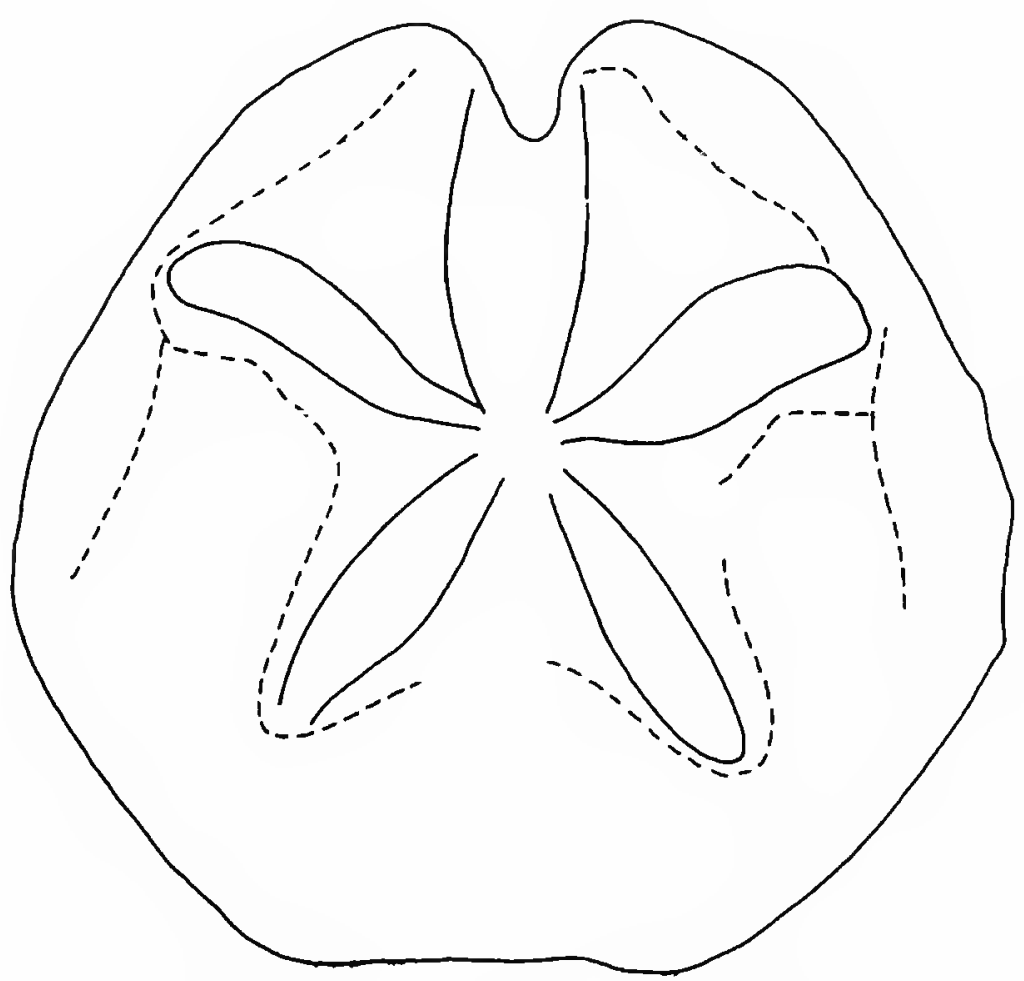

Figure 13.-Schizaster bathypetalus Arnold and Clark, dorsal view of a topotype of Schizaster pentagonalis Sánchez Roig (=S. bathypetalus), SRC $4762, \times 0.9$.
Anterior petals (II and IV) flexuous, curved convexly to anterior, extending slightly more than two-thirds distance from apical system to margin, length $46 \% \mathrm{~L}$, greatest width $8.4 \% \mathrm{~L}$, in deep groove with greatest depth $7.6 \%$ L. Pores strongly conjugated, 90 petaloid porepairs; interporiferous zone approximately same width as single poriferous zone; pores single beyond petals; first petaloid porepair in plate 10 or 11 .

Posterior petals (V and I) short, straight, extending approximately one-half distance from apical system to margin; length $30 \% \mathrm{~L}$, width $9.3 \%$ $\mathrm{L}$, depth of groove $5.3 \% \mathrm{~L} ; 64$ porepairs. Not possible to determine which plate bears first petaloid porepair.

Peristome.-Anterior, located at distance from anterior margin to anterior edge of peristome equal to $22 \% \mathrm{~L}$, opening wider than high, width $23 \%$ L, height (est.) $3.6 \%$ L. Phyllodes with welldeveloped peripodia (Plate 14: figure 4), single pore with high node adapical to pore; pit behind node giving appearance of second spore but in most ambulacral plates pit does not penetrate test; in peripodia figured on Plate 14: figure 4, second pore appears to pass under node to join main pore; on weathered specimens only single pore present; 8-10 phyllodal pores in ambulacrum II, 3-4 in III, 4-6 in I.

Periproct.-Located high on posterior truncation but area in region of periproct broken away and size and nature of opening not known.

FASC1OLES.-Peripetalous fasciole very wide where passing around extremities of petals, deeply indented in interambulacra (Figure 13), angular; crossing plate 10 in ambulacrum II. Latero-anal fasciole passing in deep lobe below periproct.

Oral Plate Arrangement.-Plate arrangement not discernible.

Occurrence.-Middle Eocene, Loma Caoba, San Diego de los Baños, Pinar del Rio Province, Cuba.

\section{Schizaster camagueyensis (Weisbord), new combination}

Plate 16: figures 1-3

Paraster camagueyensis Weisbord, 1934:68, pl. 7: figs. 9-11.Sánchez Roig, 1949:287. 
The holotype (PRI 3831) is in the Paleontological Research Institution. I have nothing to add to Weisbord's detailed description except the following dimensions of the holotype, which include 56 porepairs in petal IV and 32 in petal $\mathrm{V}$ :

\begin{tabular}{lcc}
\multicolumn{1}{c}{ Character } & $\mathrm{mm}$ & $\% \mathrm{~L}$ \\
Length & 22 & \\
Width & 19 & 89 \\
Height & 16 & 74 \\
Distance apical system from anterior & 15 & 68 \\
Width of peristome & 4.3 & 19 \\
Height of peristome & 1.0 & 4.5 \\
Distance peristome from anterior & 3.4 & 15 \\
Length petal IV & 9.0 & 40 \\
Length petal V & 3.5 & 16 \\
Width petal IV & 2.6 & 12 \\
Width petal V & 2.3 & 10
\end{tabular}

OCCURREnCE.-Late Eocene, poorly bedded to lenticular white marks, $4 \mathrm{~km}$ ENE of Loma Calisto, from cut along railroad between Nuevitas and Pastelillo, about $2 \mathrm{~km} \mathrm{SE}$ of Nuevitas railroad station; E of Arroyo Blanco, $150 \mathrm{~m}$, in road to Majagua; Grua Guruqu, $5 \mathrm{~km}$ N of C. Lugareno; deep cut $\mathrm{N}$ of Grua 9, Ramal Juan Criollo, 0.2 $\mathrm{km}$ SE of Arroyo Blanco on road to Majagua, Camagüey Province, Cuba.

Comparison with Other Species.-This species is very similar to $S$. subcylindricus from the Eocene of Jamaica and Cuba, differing only in having its apical system slightly more posterior and its petals slightly more depressed.

\section{Schizaster cartagensis (Sánchez Roig), new combination}

Plate 16: figures $4-7$

Paraster carlagensis Sánchez Roig, 1949, pl. 44: figs. 7, 8; 1952c:28.

Material.-The only specimen known is the holotype (SRC 4219). This specimen is badly weathered with only part of its fascioles preserved. The test is not distorted, but the posterior is broken away.

ShaPE AND SizE.-Length $65 \mathrm{~mm}$, width $94 \%$ L, height $66 \%$ L. Greatest width central, greatest height posterior.
Apical System.-Four genital pores, ethmolytic, central, at distance from anterior margin to center of genital pores equal to $49 \% \mathrm{~L}$.

Ambulacra.-Anterior ambulacrum III not petaloid, in groove from apical system to peristome, depth of groove midway between apical system and margin $7.3 \% \mathrm{~L}$, at margin $4.9 \% \mathrm{~L}$. Enlarged pores adapically with porepairs in peripodia, inner pore of pair anterior to outer, 44 porepairs in this region.

Anterior petals (II and IV) extending twothirds distance from apical system to margin, length $39 \% \mathrm{~L}$, width $9.0 \% \mathrm{~L}$; depressed in groove with depth $5.2 \%$ L. Petals curve slightly anteriorly; interporiferous zones slightly narrower than single poriferous zone; 68 porepairs in petal; first petaloid porepair in plate 13; 92 plates in ambulacrum.

Posterior petals ( $\mathrm{V}$ and $\mathrm{I}$ ) extending one-half distance from apical system to margin, length $28 \% \mathrm{~L}$, width $6.5 \% \mathrm{~L}$, depressed in groove with depth $4.3 \%$ L. Interporiferous zone narrower than single poriferous zone; 52 porepairs. Nature of phyllodes not clear.

Peristome.-Anterior, located at distance from anterior margin to anterior edge of peristome equal to $19 \% \mathrm{~L}$; width of opening $18 \% \mathrm{~L}$, height unknown.

Periproct.- Not preserved.

FAscioles._Only short portions of both fascioles preserved. Peripetalous fasciole widest where passing around anterior petals; deeply indented in interambulacra 4 and 1. Latero-anal fasciole very narrow in interambulacra 4 and 1 .

Oral Plate Arrangement.-Plate sutures not clear.

Occurrence.-Oligocene-Miocene, SSE of Cartagena, $1 \mathrm{~km} \mathrm{~N}$ side of railroad, Las Villas Province, Cuba.

Comparison with Other Species.-This species with its large test and long petals most resembles Schizaster bathypetalus Arnold and Clark from the Eocene of Cuba and Jamaica. It differs in having a much narrower anterior ambulacrum with far fewer porepairs and in having narrower petals with anterior petals straighter. It differs 
from Schizaster delgadoi (Sánchez Roig) also from the Oligocene-Miocene of Cuba in its central apical system and straighter anterior petals.

\section{Schizaster cubitabellae (Weisbord)}

Plate 17: Figures 1-3

Paraster cubitabellae Weisbord, 1934:72, pl. 7: figs. 15, 16.Sánchez Roig, 1949:285.

I have studied the holotype (PRI 3833), which is the only known specimen, and have nothing to add to Weisbord's long description except the following dimensions:

\begin{tabular}{lll}
\multicolumn{1}{c}{ Character } & $\mathrm{mm}$ & $\% \mathrm{~L}$ \\
Length & 28.0 (est.) & \\
Width & $26 \pm$ & 93 \\
Height & $22 \pm$ & 80 \\
Distance apical system from anterior & 13 & 48 \\
Length petal II & 10 & 37 \\
Width petal II & 3.8 & 13 \\
Length petal I & 4.9 & 17 \\
Width petal I & 3.6 (est.) & 12
\end{tabular}

There are 52 porepairs in petal II, 32 in petal I; and the first porepair in petal II occurs in plate 11. The number of genital pores is not known (only small part of apical system is preserved in the holotype).

Occurrence.-Late Eocene, from cut along the railroad between Nuevitas and Pastelillo, about $2 \mathrm{~km}$ SE of Nuevitas railroad station, $\mathrm{Ca}$ magüey Province, Cuba.

Comparison with Other Species.-This species is very similar to Schizaster subcylindricus Cotteau also from the Eocene of Cuba and may be conspecific, but too little is known of $S$. cubitabellae to be certain.

\section{Schizaster delgadoi (Sánchez Roig), new combination}

Figure 14; Plate 17: figures 4-6

Pericosmus delgadoi Sánchez Roig, 1953a:65, pl. 16: fig. 2.

Material. - The only specimen, the holotype (SRC 4211), is flattened (postmortem), with most of ventral posterior part of test missing.
Shape and Size.-Length $94.5 \mathrm{~mm}$, width 88.9 $\mathrm{mm}(94 \% \mathrm{~L})$; height indeterminate; greatest width anterior, greatest height posterior.

Apical System.-Posterior, distance from anterior margin to center of system equal to $56 \% \mathrm{~L}$; ethmolytic; number of genital pores not discernible.

AMBULACRA.-Anterior ambulacrum III not petaloid, in very deep groove with depth of $3.3 \%$ $\mathrm{L}$ midway between apical system and anterior margin. Enlarged porepairs adapically with porepairs in peripodia, inner pore of pair anterior to outer, region of ambulacrum with enlarged porepairs extending slightly more than one-half distance from apical system to anterior margin; 50 porepairs in this region.

Anterior petals (II and IV) extending threefifths distance from apical system to margin, length $35 \% \mathrm{~L}$, greatest width $6.8 \% \mathrm{~L}$, in very deep groove with depth $5.6 \% \mathrm{~L}$. Interporiferous zone slightly wider than single poriferous zone; pores conjugate, 60 porepairs in petal; not discernible

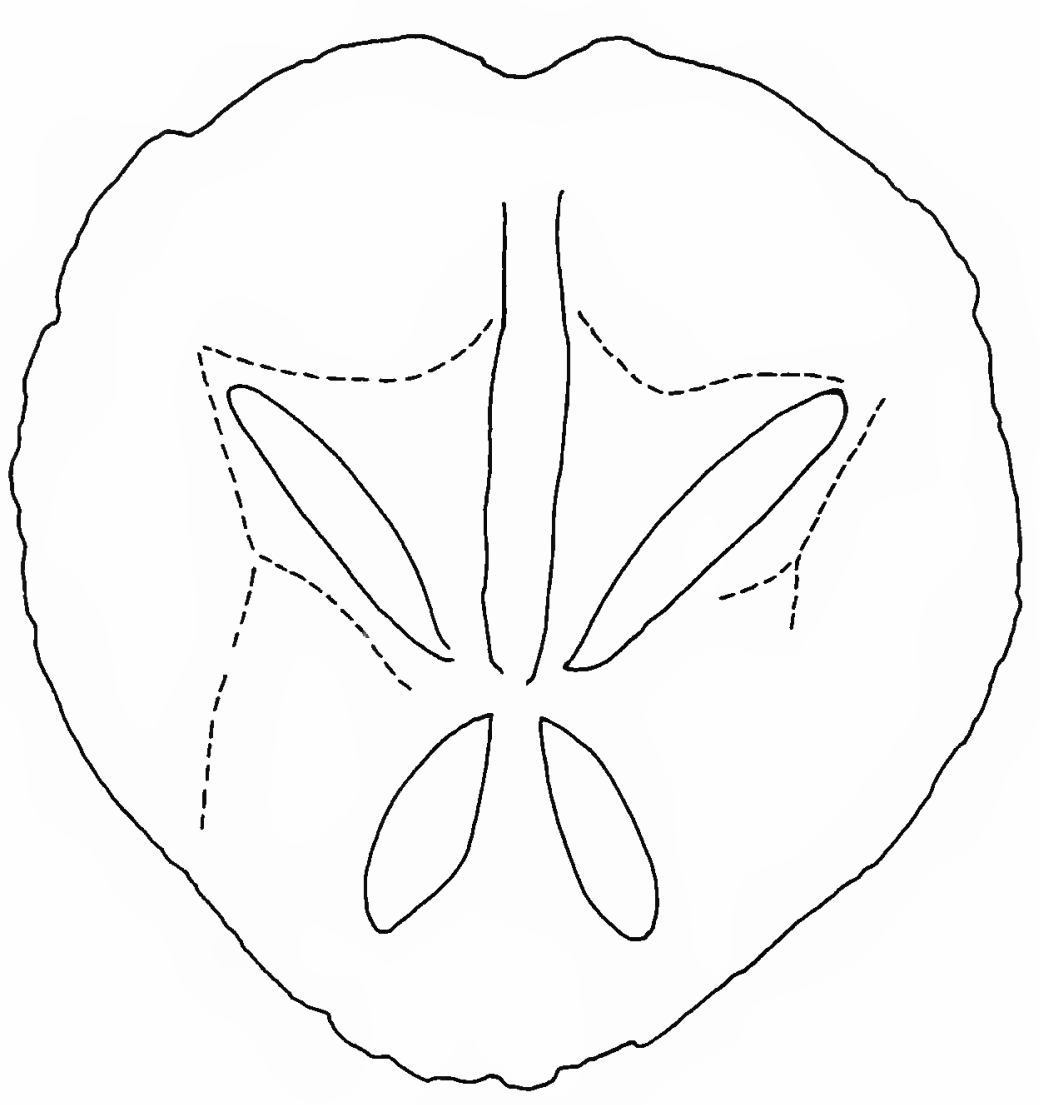

Figure 14.-Schizaster delgadoi (Sánchez Roig), dorsal view showing position of the fascioles (dashed lines) of the holotype, SRC $4211, \times 0.9$. 
which plate bears first porepair. Petals curving convexly to anterior.

Posterior petals (V and I) short, length $22 \% \mathrm{~L}$, straight, in deep groove with depth $5.1 \% \mathrm{~L}$; width $8.3 \%$ L. Interporiferous zone slightly wider than poriferous; 46 porepairs in petal.

Peristome.-Test crushed around peristome but peristome was situated very near anterior margin, with pronounced lip with flange along rim.

Periproct.-Not preserved.

FAscioles.-Traces (Figure 14) preserved of peripetalous and latero-anal fasciole. Peripetalous angular, deeply indented in interambulacra 4 and 1, slightly indented in 2 and 3. Latero-anal fasciole narrow, extending from peripetalous fasciole at midlength of petals II and IV.

Oral Plate Arrangement.-Not discernible.

Occurrence.-Late Oligocene, according to Sánchez Roig but Albear (1980, personal communication) considers this locality early to middle Miocene, "Cervantes" farm, San José de las Lajas, Habana Province, Cuba.

Remarks.-Sánchez Roig referred this species to Pericosmus because he thought it had a marginal fasciole. However, a latero-anal fasciole is present not a marginal fasciole. Furthermore, the distalmost plates in the petals are not occluded and the porepairs in ambulacrum III are very large, not minute as in Pericosmus. This species clearly belongs in the family Schizasteridae, and it is probably a Schizaster.

Comparison with Other Species.-This species resembles Schizaster bathypetalus Arnold and Clark from the Eocene of Cuba and Jamaica in its large size, but it differs in having a much more posteriorly situated apical system and narrower anterior ambulacrum and petals. It differs from Schizaster cartagensis (Sánchez Roig) in its more posterior apical system.

\section{Schizaster egozcuei Lambert}

Plate 18: Figures 1-4

Schizasler scillae.-Cotteau, 1897:82, pl. 26: figs. 4, 5, pl. 27: figs. 4-6.-Jackson, 1922:81. [Not Schizaster scillae Agassiz, 1847.]
Schizaster egozcuei Lambert in Lambert and Thiéry, 1925

[1909-1925]:527.—Sánchez Roig, 1926:132; 1949:275.

Material.-Only one specimen (SRC 4234) of this species is known. It is topotypic; and although it is labelled as the type, it does not have the dimensions of the specimens described by Cotteau. The specimen is very poorly preserved with most of the test absent, and the test is partially crushed.

Shape and Size.-Test large, length $55 \mathrm{~mm}$, wide with width $98 \% \mathrm{~L}$, height $57 \% \mathrm{~L}$ (but crushed). Greatest width anterior to center, greatest height posterior.

Apical System.-Posterior to center, located at distance from anterior margin to center of system equal to $56 \% \mathrm{~L}$; number of pores not clear.

AMBULACRA.-Anterior ambulacrum III not petaloid in very wide and deep groove adapically, greatest width $13 \% \mathrm{~L}$; adapical area of enlarged porepairs extending three-fourths distance from apical system to anterior margin.

Anterior petals (II and IV), extending twothirds distance from apical system to margin, length $35 \% \mathrm{~L}$, width $10 \% \mathrm{~L}$; flexuous, curving outwards distally. Number of porepairs not discernible.

Posterior petals (V and I) extending more than one-half distance from apical system to margin, length $21 \% \mathrm{~L}$, width $10 \% \mathrm{~L}$; curving slightly outward distally.

Peristome.-Anterior, no further details known because of crushing of test.

Periproct.-Located high on overhanging posterior truncation, visible from below.

FAscioles.-Not preserved because most of test broken away.

Occurrence.-Oligocene-Miocene, Cienfuegos, Santa Clara (now Las Villas) Province, Cuba.

Comparison with Other Species.-This species resembles Schizaster delgadoi Sánchez Roig from the Miocene of Cuba, but it is easily distinguished by its wider anterior ambulacrum and less divergent anterior petals. It is very similar to Schizaster munozz Sánchez Roig also from the Oligocene-Miocene of Cuba and may be conspecific. However, the topotype is so poorly preserved, 
being mainly an internal mold, that it is not possible to be certain of many of its specific characters.

REMARKS.-This species was described by Lambert for specimens that Cotteau had attributed to Schizaster scillae Agassiz. Lambert believed Cotteau's specimens were not conspecific with the type specimen of Agassiz's species.

\section{Schizaster fernandezi Sánchez Roig}

Plate 18: figures 5-11

Schizaster (Schizasler) fernandezi Sánchez Roig, 1952c:25, pl. 9: fig. 3.

Material.-Three specimens are in the Sánchez Roig Collection. The following description is based on the holotype and figured specimen (SRC 4148) and a topotype (SRC 4147). The holotype is moderately well preserved with part of the fascioles intact, but most of the ventral. surface of the test posterior to the peristome is missing. The topotype has more of the fascioles preserved but also lacks much of the ventral side of the test. The dimensions of the holotype are given first below.

Shape and Size.-Length 26, $28 \mathrm{~mm}$; width 25 $\mathrm{mm}$ (94\% L), $24 \mathrm{~mm}$ (87\% L); height $19 \mathrm{~mm}$ $(73 \% \mathrm{~L}), 19 \mathrm{~mm}(69 \% \mathrm{~L})$. Greatest width and height posterior to center.

Apical System.-Four genital pores, anterior pores much smaller than posterior; ethmolytic; located posterior to center at distance from anterior margin to center of genital pores equal to 62 , $56 \%$ L.

Ambulacra.-Anterior ambulacrum III not petaloid, in groove from apical system to peristome, depth of groove at margin 4.2 and $2.5 \% \mathrm{~L}$. Pores paired only in adapical region where pores enlarged in well-developed peripodia with ridge separating pores of a pair with approximately 28 porepairs in this region; porepairs in single row with inner pore of porepair more elongated than outer.

Anterior petals (II and IV) extending approximately two-thirds distance from apical system to margin; length 38 and $34 \%$ L, greatest width 13 and $13 \%$ L. Petal curved convexly with petal widening sharply just distal to midlength. Porepairs near apical system in anterior poriferous zone much smaller than opposite porepairs in posterior poriferous zone. Petals depressed in groove with depth 4.6 and $3.9 \% \mathrm{~L} ; 46$ and 40 porepairs; pores conjugate. Interporiferous zone at greatest width narrower than single poriferous zone. First petaloid porepair in plate 12 of holotype. Pores single beyond petals.

Posterior petals (V and I) very short, extending less than one-half distance from apical system to margin; length 17 and $18 \% \mathrm{~L}$, width 9.1 and $9.0 \%$ L. Petals straight, depressed in groove 2.7 and $2.5 \% \mathrm{~L} ; 24$ and 24 porepairs.

Peristome.-Anterior, located at distance from anterior margin to anterior edge of peristome equal to 19 and $20 \% \mathrm{~L}$; opening wider than high with width 24 and $20 \% \mathrm{~L}$.

Periproct.-Located high on posterior truncation; opening higher than wide with height 23 and (est.) 20\% L.

FAsCiOLES.-Peripetalous fasciole wide, with width just posterior to petal II 2.3 and $2.2 \% \mathrm{~L}$, curving sharply into interambulacra 1 and 4 but extending anteriorly in anterior lobe where crossing ambulacrum III. Fasciole crossing ambulacrum II or IV on plate 10 or 11. Latero-anal fasciole only preserved in short tracts.

Oral Plate Arrangement.-Plates not preserved.

Occurrence.-Miocene, "Las Cuevas" estate, Km 186 on highway from Pinar del Rio to Guane, Pinar del Rio Province, Cuba.

Comparison with Other Species.-This species resembles in its shape and arrangement of petals Schizaster subcylindricus Cotteau and Schizaster camagueyensis Weisbord both from the Eocene of Cuba. It differs in having 4 instead of 2 genital pores. Furthermore, its peristome is more posterior and its apical system more anterior.

\section{Schizaster formelli, new species}

Plate 24

MAterial.-The holotype (ANSP 16675a) and paratype (ANSP 16675b) are moderately well preserved with tests slightly distorted and fas- 
cioles preserved. The first dimensions given below are of the holotype.

Shape AND Size.-Length 23 and $20 \mathrm{~mm}$, width 96 and $99 \% \mathrm{~L}$, height 76 and $81 \% \mathrm{~L}$; greatest width anterior to center, greatest height posterior.

Apical System.-Central, located at distance from center of genital pores to anterior margin equal to 42 and $46 \%$ L. Four genital pores, ethmolytic; posterior genital pores much larger than anterior.

Ambulacra.-Anterior ambulacrum III not petaloid, in very deep groove particularly dorsally; greatest depth 8.8 and $9.3 \%$ L; 32 porepairs in adapical region in holotype, 28 in paratype.

Anterior petals (II and IV) extending slightly more than one-half distance from apical system to margin; length 32 and $33 \% \mathrm{~L}$; greatest width 14 and $15 \% \mathrm{~L} ; 44$ porepairs in petal in holotype; 40 in paratype. Interporiferous zones slightly narrower than poriferous zone; petals flexuous; petals deeply depressed. First petaloid porepair in plate 6.

Posterior petals (V and I) straight, short, extending one-third distance from apical system to margin, length 21 and $19 \% \mathrm{~L}$, width 11 and $12 \%$ $\mathrm{L} ; 30$ porepairs in holotype; 28 in paratype.

Peristome.-Anterior, distance from anterior edge of opening to anterior margin 23 and $25 \%$ L; width 18 and $21 \% \mathrm{~L}$; height 6.3 and $6.3 \% \mathrm{~L}$.

PERIPRoct.-High on vertical posterior truncation, higher than wide.

FAscioles.-Peripetalous fasciole wide, widest in anterior paired interambulacra; deeply inserted in posterior paired interambulacra. Lateroanal fasciole extending in deep lobe below periproct.

Occurrence.-Eocene, Palmer loc. 687a, 15 mi $(24 \mathrm{~km}) \mathrm{E}$ of Camagüey on Maraguan road from Guanabanito River, Camagüey Province, Cuba.

Comparison with Otiner Species.-Schizaster formelli is easily distinguished from the other $\mathrm{Cu}$ ban species of this genus. It differs from Schizaster santanae Sánchez Roig (also from the Eocene of Cuba) in its broader anterior ambulacrum, its greater posterior width and its broader, shorter petals. It differs from Schizaster llagunoi Lambert and Sánchez Roig in its shorter, broader petals and few enlarged porepairs in ambulacrum III.

\section{Schizaster gerthi Pijpers}

Plate 19

Schizaster gerthi Pijpers, 1933:96, fig. 157, pl. 1: fig. 19, pl. 2: figs. 10-12.

Paraster clarcki [sic] Sánchez Roig, 1949, pl. 44: figs. 6, 9; 1952c:28, 29.

I am unable to distinguish Sánchez Roig's Paraster clarki from this species from the late Eocene of Bonaire. I was able to compare Cuban specimens with 5 paratypes of the Bonaire species very kindly loaned to me from the University of Utrecht. They are alike in all characters including the number of pores in the petals and anterior ambulacrum, position of the apical system and peristome, shape of the test, and depression of the petals. A photograph of one of the paratypes of $S$. gerthi is on Plate 19: figure 6.

Occurrence.-Eocene, Loma Caoba, $5 \mathrm{~km} \mathrm{~S}$ of San Diego de los Baños, Pinar del Rio Province, Cuba; late Eocene, SE of Seroe Montagne, W. Bonaire.

Comparison with Other Species.-This species is distinguished from Schizaster subcylindricus Cotteau, which occurs with it at Loma Caoba, by its central apical system with 4 genital pores and its more divergent and flexuous petals. It differs from Schizaster bathypetalus Arnold and Clark by its smaller test, less flexuous anterior petals, and less divergent, shorter posterior petals.

\section{SYNONYM}

\section{Paraster clarki Sánchez Roig, emendation Plate 19: figures $1-5,7,8$}

Material.-No specimens of this species are present in the Sánchez Roig Collection, but there are 4 topotypic specimens in the USNM collections of the National Museum of Natural History, and 2 in the collections of the Academy of Nat- 
ural Sciences of Philadelphia, which appear to belong to this species.

Shape and Size.-Length 28 to $38 \mathrm{~mm}$ (mean $35 \mathrm{~mm}$ ), width 87 to $93 \% \mathrm{~L}$ (mean 90); height 63 to $77 \% \mathrm{~L}$ (mean 68). Greatest width central, greatest height posterior.

Apical System.-Central, located at distance from anterior margin to center of genital pores equal to 43 to $46 \%$ L (mean 45). Four genital pores, anterior pores much smaller than posterior, ethmolytic, genital plate 2 extending posteriorly separating posterior ocular plates.

AmbulaCRA. - Anterior ambulacrum III (Plate 19: figure 7) not petaloid, enlarged porepairs adapically extending to two-thirds distance from apical system to anterior margin; 38 enlarged porepairs in specimen $38 \mathrm{~mm}$ long; inner pore of pair anterior to outer; in deep depression adapically, depth 6.7 to $9.3 \% \mathrm{~L}$ (mean 7.7 ); at margin only slight groove; first porepair in plate 6 .

Anterior petals (II and IV) flexuous, with greatest width distal; extending two-thirds distance from apical system to margin, length 37 to $39 \%$ L (mean 38), greatest width 12 to $14 \% \mathrm{~L}$ (mean 13); depressed in groove with depth 4.5 to $6.6 \%$ $\mathrm{L}$ (mean 5.9). Interporiferous zone narrower than single poriferous zone; pores conjugate, 56 porepairs in petal of specimen $38 \mathrm{~mm}$ long; first petaloid porepair in plate 12 .

Posterior petals ( $\mathrm{V}$ and $\mathrm{I}$ ) extending less than one-half distance from apical system to margin, length 21 to $24 \% \mathrm{~L}$ (mean 22), width 8.5 to $11 \%$ L (mean 9.8); curving slightly posteriorly; 42 porepairs in specimen $38 \mathrm{~mm}$ long; depressed in groove 2.6 to $5.4 \% \mathrm{~L}$ (mean 4.4 ). Interporiferous zone slightly narrower than single poriferous zone. First petaloid porepair in plate 18 .

Phyllodes with well-developed peripodia with large single pore; ridge-like node behind pore (Plate 19: figure 8), pit on other side of node where second pore would have been; 9 phyllodal pores in ambulacrum II, 5 in I, number uncertain in III.

Peristome.-Anterior, located at distance from anterior margin to anterior edge of peristome equal to 17 to $22 \% \mathrm{~L}$ (mean 19). Opening with width 19 to $26 \% \mathrm{~L}$ (mean 22 ), height 6.3 to $9.3 \%$ L (mean 8).

Periproct.-Located high on tall vertical posterior truncation, on neotype height $18 \% \mathrm{~L}$, width $12 \%$ L. Occurring between interambulacral plates 5-9.

FASCIOLES.-Peripetalous fasciole sharply indented in posterior paired interambulacra, not indented in others, crossing ambulacrum III on plate 5, ambulacra II or IV on plate 11, ambulacra $\mathrm{V}$ or I on plate 17. Latero-anal fasciole passing in lobe below periproct at distance equal to height of periproct.

Oral Plate Arrangement.-Labrum low, height $9 \% \mathrm{~L}$, extending posteriorly two-thirds height of first ambulacral plate. Sternal plates long, length $61 \% \mathrm{~L}$, width $38 \% \mathrm{~L}$. In interambulacrum 2 first plate followed by pair of plates.

Occurrence.-Eocene, Loma Caoba, $5 \mathrm{~km} \mathrm{~S}$ of San Diego de Los Baños, Pinar del Rio Province, Cuba.

REMARKs. - The spelling of the species name is emended to agree with the name of Herbert L. Clark, for whom the species was named.

\section{Schizaster llagunoi Lambert and Sánchez Roig}

Figure 15; Plate 20: figures 1-4

Schizaster llagunoi Lambert and Sánchez Roig in Sánchez Roig, 1949:274.

Material.-Two specimens are in the Sánchez Roig Collection. One specimen (SRC 4217) is labelled as type and is from the type-locality. It is herein designated the lectotype (no specimens were figured in the original description) and the following description is based on it. The lectotype is moderately well preserved. Although the test is weathered, portions of the fascioles are preserved.

Shape ANd Size.-Length $52 \mathrm{~mm}$, width 50 mm (96\% L), height $38 \mathrm{~mm}$ ( $73 \%$ L). Greatest width central, greatest height posterior to center with posterior interambulacrum sharply elevated and test sloping anteriorly to margin.

Apical System.-Four genital pores (Figure $15 \mathrm{~A})$, ethmolytic, located slightly anterior of cen- 

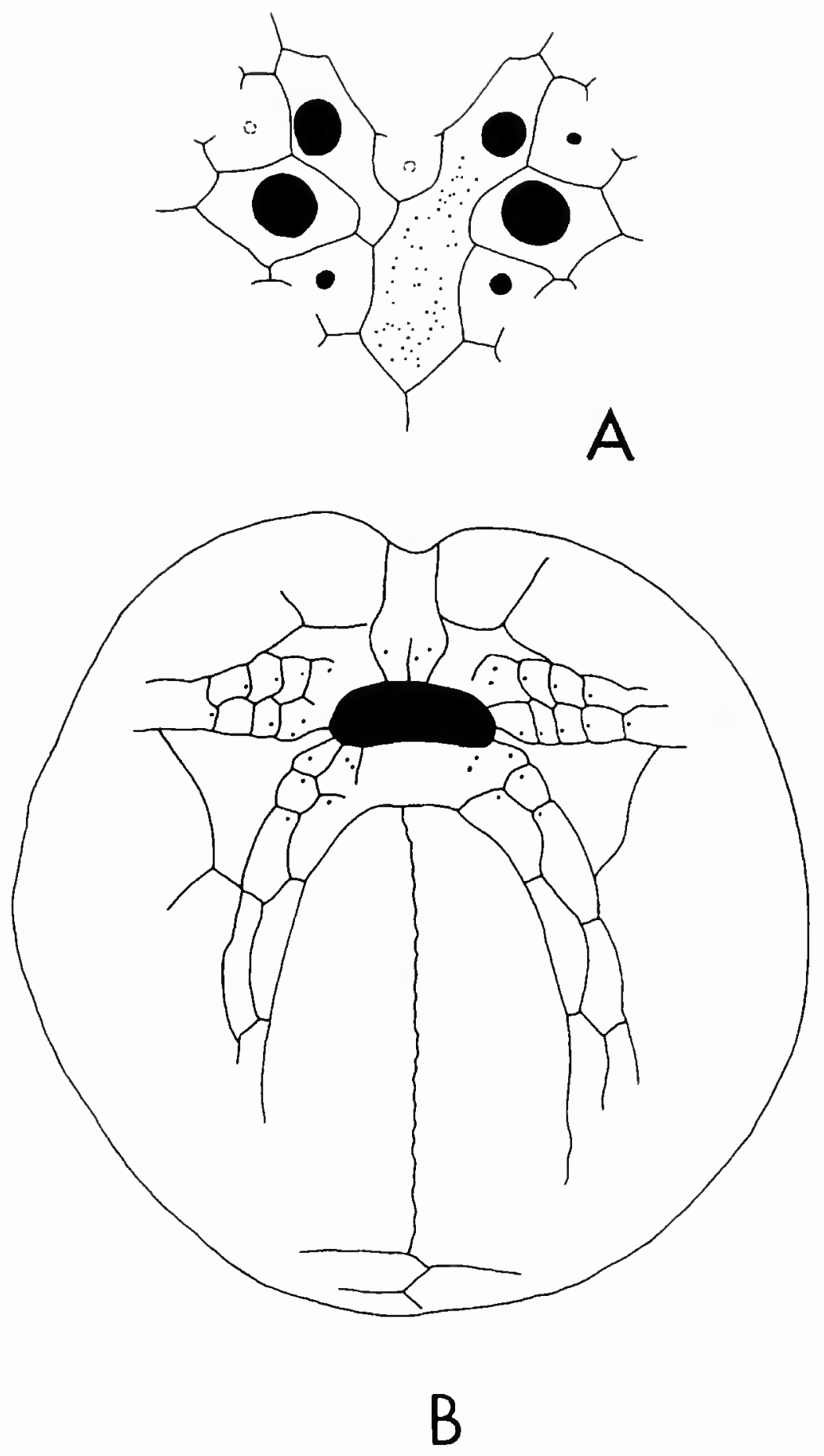

Figure 15.-Schizaster llagunoi Lambert and Sánchez Roig, lectotype, SRC 4217; A, apical view, $\times 12$; B, ventral view, $\times 1.6$.

ter at distance from anterior margin to center of genital pores equal to $45 \% \mathrm{~L}$.

Ambulacra.-Anterior ambulacrum III not petaloid, in groove from apical system to peristome, depth of groove at margin $3.8 \% \mathrm{~L}$. Pores paired and enlarged only in adapical region, approximately 56 porepairs in this area, porepairs in single row, inner pore more elongate than outer. First enlarged pores in plate 6, plates near peristome very high (Figure 15B); 66 plates in ambulacrum.

Anterior petals (II and IV) short, extending less than two-thirds distance from apical system to margin, length $35 \% \mathrm{~L}$, width $12 \% \mathrm{~L}$, depth $3.1 \%$ L. Petals curved convexly to anterior, depressed in groove; pores conjugate, pores of pair equally elongated transversely, 62 porepairs. Interporiferous zone at greatest width equal to width of poriferous zone. First petaloid porepair in plates 12,13 ; total of 86 plates in ambulacrum. Pores single beyond petals.

Posterior petals ( $\mathrm{V}$ and $\mathrm{I}$ ) short, extending less than one-half distance from apical system to margin, length $21 \% \mathrm{~L}$, width $8.2 \% \mathrm{~L}$. Petals curving posteriorly, depressed in groove with depth $3.2 \%$ L; 46 porepairs, first porepair in plate 20; total of 84 plates in ambulacrum.

Phyllodes single pored, 3 pores in ambulacrum III, 10 in II or IV, 6 in V or I.

Peristome.-Anterior, located at distance from anterior margin to anterior edge of peristome equal to $18 \% \mathrm{~L}$, opening wider than high, with width $19 \% \mathrm{~L}$, height $7.3 \% \mathrm{~L}$.

Periproct.-Located high on slightly overhanging posterior truncation. Opening higher than wide with height $17 \% \mathrm{~L}$, width $11 \% \mathrm{~L}$; located between interambulacral plates 5-8.

Fascioles.-Peripetalous fasciole wide, maximum width $2.1 \% \mathrm{~L}$, angular, curving sharply into interambulacra, 1, 4, 5; position on anterior interambulacra not known. Fasciole crosses ambulacra II or IV on plates 11, 12, ambulacra V or I on plate 19 , interambulacra 1 and 4 on plates 5 8 , interambulacrum on plate 12 . Latero-anal fasciole passes below periproct, approximately as wide as peripetalous fasciole; crosses ambulacrum $\mathrm{V}$ or $\mathrm{I}$ on plate 11 , interambulacrum 5 on plates 5 and 6.

Oral Plate Arrangement.-Labrum broad, short, length $9.4 \% \mathrm{~L}$ (est.), extending back to posterior edge of first adjacent ambulacral plate. Plastron broad (Figure 15B), sternal plates with combined length $52 \% \mathrm{~L}$, width $35 \% \mathrm{~L}$; bordered by ambulacral plates 2-7. First plate of interambulacra in contact with peristome (Figure 15B). 
In interambulacrum 2 first plate followed by pair of plates.

Occurrence.-According to Brodermann (1949:328) middle Eocene and late Oligocene, estate of Doña Juana, Santiago de las Vegas, Habana Province, Cuba. Lambert and Sánchez Roig in Sánchez Roig (1949:276) state that the species occurs at Palmer's localities 2889, 2891. According to Palmer (1948:160) these localities are $2.9 \mathrm{~km} \mathrm{E}$ of San Antonio de las Vegas, Habana Province, Cuba, and are middle Eocene.

Comparison with OTher Species.-This species is very similar to Schizaster munozi Sánchez Roig from the late Oligocene or early Miocene of Cuba and differs only in possessing a more inflated area behind the apical system and less divergent posterior petals. It is possible that these differences were caused by postmortem compression of the lectotype of S. llagunoi. S. llagunoi closely resembles Schizaster santanae Sánchez Roig, also from the Eocene of Cuba, but it is definitely a different species. Its anterior ambulacrum is wider and it has many more enlarged porepairs, there being 56 in the lectotype of $S$. llagunoi and only 42 in the lectotype of $S$. santanae.

\section{Schizaster munozi Sánchez Roig}

Figures 16-18; Plate 20: figures 5-8; Plates 21, 22; Plate 23: figure 1

Schizaster munozi Sánchez Roig, 1949:277, pl. 43: figs. 1-3. Schizaster salutis Sánchez Roig, 1949:278, pl. 45: figs. 3, 4. Schizaster guirensis Sánchez Roig, 1949:278, pl. 43: figs. 4, 5. Paraster orientalis Sánchez Roig, 1949:289, pl. 46: figs. 2, 3.

Paraster tschopi Palmer in Sánchez Roig, 1949:290, pl. 46: fig. 1.

Schizaster (Aplospatangus) riveroi Sánchez Roig, 1952a:27, pl. 15: figs. 4,5 .

Material.-Only one specimen in the collection is referred to this species, the holotype (SRC 4224). Although the specimen is highly weathered and the apical area is missing, the test is not distorted. It is figured on Plate 22: figures 1-3.

Shape And Size.-Length $61 \mathrm{~mm}$, width 57 mm (93\% L), height $39 \mathrm{~mm}$ (65\% L). Greatest width central to slightly anterior, greatest height

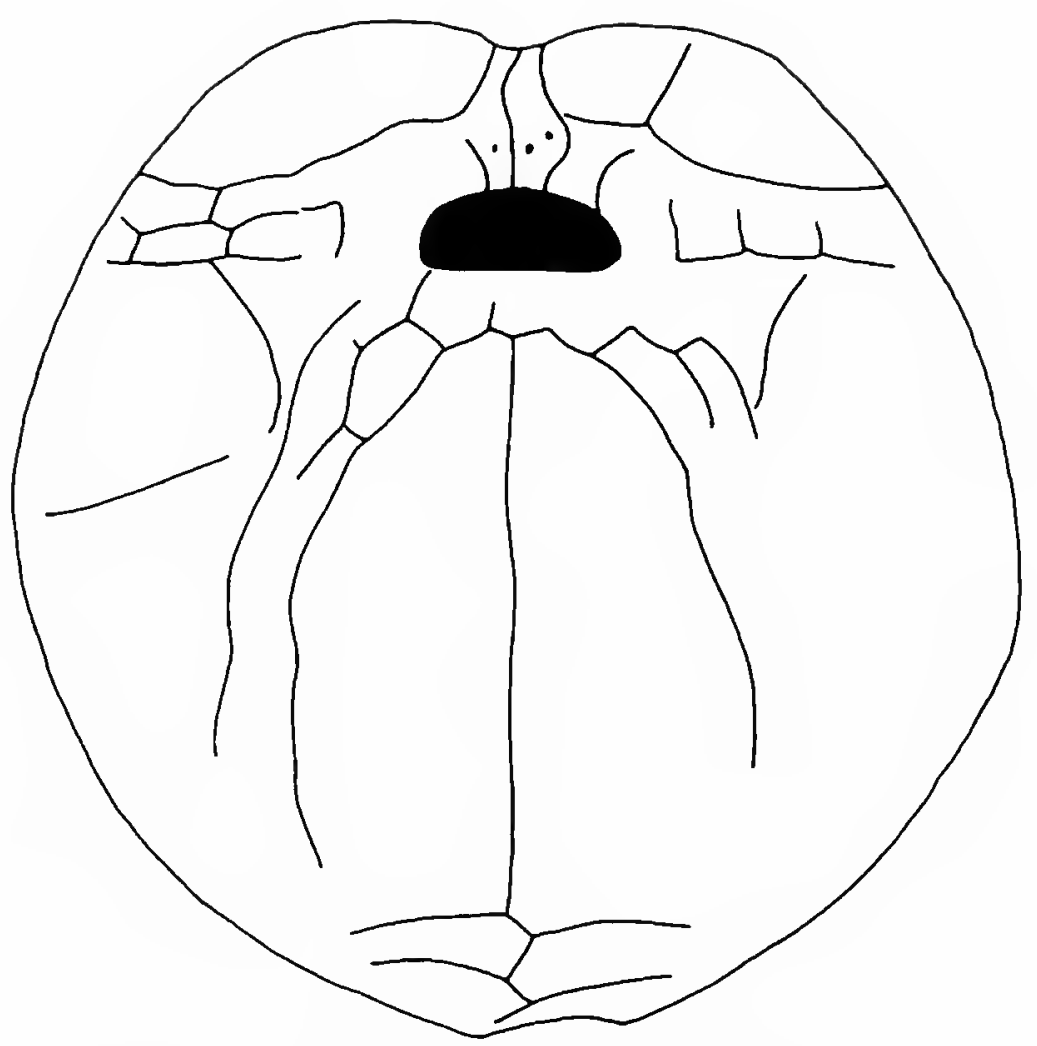

FIGURE 16.-Schizaster munozi Sánchez Roig, ventral view of the holotype, SRC $4224, \times 1.4$.

posterior to center with test sloping anteriorly to margin.

Apical System.-Absent from holotype but situated slightly posterior to center.

Ambulacra.-Anterior ambulacrum III not petaloid, in groove from apical system to peristome, groove deepest adapically where depth $6.1 \% \mathrm{~L}$, groove at margin $3.3 \% \mathrm{~L}$; greatest width of groove midway from apical system to margin where width $13 \%$ L. Pores paired only in adapical region where pores enlarged in peripodia with node separating pores of pair; inner pore more elongate than outer; enlarged pores present from apical system to approximately two-thirds distance to margin; porepairs in single row. First enlarged porepair in plate 6 , plates near peristome very high.

Anterior petals (II and IV) short, extending less than two-thirds distance from apical system to margin, length 35\% L (est.), width $11 \%$ L. Petals curved convexly to anterior, depressed in groove; pores strongly conjugate, outer pore of pair slightly more elongated transversely than inner. Interporiferous zone at greatest width slightly 
narrower than single poriferous zone. First petaloid porepair in plate 12 or 13 . Pores single beyond petals.

Posterior petals (V and I) short, extending less than one-half distance from apical system to margin, length $21 \%$ L (est.), width $8.7 \%$ L. Petals straight or curving very slightly posteriorly, depressed in groove with depth $3.9 \% \mathrm{~L} ; 44$ porepairs (est.).

Phyllodes single pored, 3 pores in ambulacrum III, 8 in II or IV, number not discernible in $\mathrm{V}$ or I.

Peristome.-Anterior, located at distance from anterior margin to anterior edge of peristome equal to $14 \% \mathrm{~L}$, opening wider than high, with width $19 \% \mathrm{~L}$.

Periproct.-Located high on slightly overhanging posterior truncation. Opening higher than wide with height $21 \% \mathrm{~L}$ (est.), width $13 \% \mathrm{~L}$; located between interambulacral plates 5-9.

Fascioles.-Peripetalous fasciole wide, greatest width where passing around petal V, I where width $3.8 \% \mathrm{~L}$, angular, curving sharply into interambulacra 1, 4; anteriorly across 2 and 3, straight across 5. Crosses ambulacrum III on plate 4 or 5, ambulacrum II or IV on plates 9, 10. Latero-anal fasciole destroyed by weathering.

Oral Plate Arrangement.-Labrum broad, short, length $5.6 \% \mathrm{~L}$ (est.), extending back to posterior two-thirds of first ambulacral plate (Figure 16). Plastron broad, sternal plates with combined width $40 \% \mathrm{~L}$, length $55 \% \mathrm{~L}$; bordered by ambulacral plates 1-5. First interambulacral plates in contact with peristome; in interambulacrum 2 first plate followed by pair of plates.

Occurrence.-Late Oligocene-early Miocene, quarry near Cabezas, Matanzas Province, Cuba. The lectotype of $S$. salutis is from the early Miocene, Lastra estate, La Salud, Habana Province, Cuba. The lectotype of $S$. guirensis is from the early Miocene, estate of María Teresa, Km 4041, on highway from San Antonio de los Baños to Guira, Habana Province, Cuba. The holotype of $S$. riveroi is from the early Miocene at a quarry on the outskirts of Cardenas, Matanzas Province, Cuba. The lectotype of $S$. orientalis is from the late
Oligocene-early Miocene, roadcut in Central Highway, $\mathrm{Km} 753.5 \mathrm{E}$ of Habana, $18.5 \mathrm{~km}$ W of Holguín, Oriente Province, Cuba. The holotype of $S$. tschopi is from the Oligocene-Miocene, $\mathrm{Km}$ 202 United Railroad, $0.5 \mathrm{~km} \mathrm{~S}$ of $\mathrm{Km} 213$ on Central highway, $23 \mathrm{~km} \mathrm{E}$ of Colon church, Matanzas Province, Cuba.

Comparison with Other Species.-This species is very similar to Schizaster americanus (Clark) from the Oligocene (Vicksburg) of southeastern United States. Although the anterior ambulacrum in the holotype of $S$. americanus is narrower than in $S$. munozi, this specimen is much smaller than the holotype of the Cuban species. In larger specimens of $S$. americanus, the width of this ambulacrum is similar to the Cuban species. There appear to be more enlarged porepairs in the anterior ambulacrum of $S$. munozi with 46 in a specimen of $S$. munozi $33.3 \mathrm{~mm}$ long as opposed to only 36 in the holotype of $S$. americanus which is $36 \mathrm{~mm}$ long.

I cannot distinguish Schizaster munozi from $S$. clevei Cotteau from the Miocene Anguilla Formation of Anguilla. I have examined the holotype of $S$. cleve $i$ in the USNM collections and there are no differences. However, the holotype is crushed and I hesitate for this reason to synonymize formally the two species. Schizaster loveni Cotteau, also from the Anguilla Formation of Anguilla, is very similar to $S$. munozi differing only in having shorter posterior petals. If more specimens were available of the 2 species from Anguilla, it might be seen that only one species was present with the length of the posterior petals being quite variable.

Schizaster munozi differs from S. llagunoi Sánchez Roig only in its less inflated region posterior to the apical system and more divergent petals. It is possible that these differences are not real but were caused by postmortem compression of the lectotype of $S$. llagunoi.

REMARKs. - This species is indistinguishable from Schizaster salutis Sánchez Roig from the early Miocene. In all characters the two species are similar including length, curvature, and depth of the petals, width and depth of the anterior ambulacrum, shape and position of the peristome 
and periproct, and oral plate arrangement. Although the test is lower in the lectotype of $S$. salutis than the holotype of $S$. munozi, it has been depressed by postmortem compression. Schizaster salutis is considered herein a synonym of $S$. munozi.

Schizaster munozi is likewise indistinguishable from Schizaster riveroi Sánchez Roig from the Miocene of Cuba. In no way do the species differ and $S$. riveroi is, therefore, considered a synonym of $S$. munozi.

I cannot distinguish the lectotype of Paraster orientalis (Sánchez Roig) from S. munozi. Its petals and anterior ambulacrum are identical and the tests have similar shapes. Although the apical system appears to be more posterior, this is probably due to postmortem distortion. The test of the lectotype is partially crushed with the dorsal surface shifted posteriorly. $P$. orientalis is herein considered a synonym of $S$. munozi.

Paraster tschopi Palmer from the Oligocene or Miocene of Cuba also appears to be a synonym of $S$. munozi. The peristome of the holotype of $P$. tschopr appears to be lower but this is due to postmortem distortion of its test. I can see no other significant differences between them.

S. munozi is likewise very similar to Schizaster guirensis Sánchez Roig from the early Miocene. The lectotype of $S$. guirensis differs from the holotype of $S$. munozi only in its greater size. $S$. guirensis is herein considered a synonym of $S$. munozi.

\section{SYNONYMS}

\section{Paraster orientalis Sánchez Roig}

\section{Figure 17; Plate 22: figures 7-9}

Material.-One specimen in the Sánchez Roig Collection. This specimen (SRC 4254) is labelled the type and is figured by Sánchez Roig (1949, pl. 46: fig. 2). It is herein selected as the lectotype. The other specimen figured by Sánchez Roig (1949, pl. 46: fig. 3) is missing. The lectotype is very poorly preserved, being flattened and fractured.

Shape and Size.-Length $33 \mathrm{~mm}$, width 32 mm (98\% L), height $49 \% \mathrm{~L}$, but test crushed.

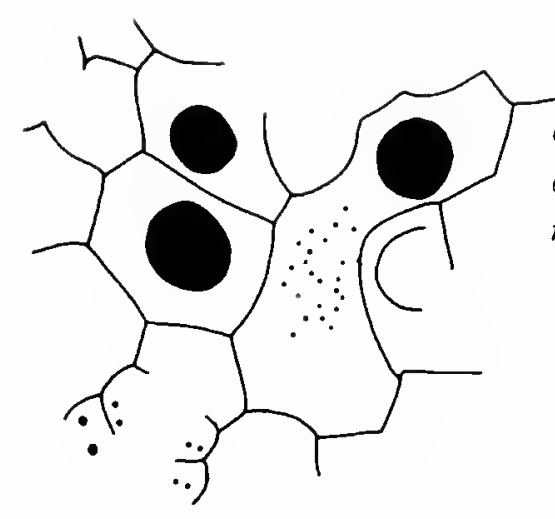

FiguRE 17.-Schizaster munozz Sánchez Roig, apical system of the lectotype of Paraster orientalis Sánchez Roig ( $=S$. munozi), SRC 4254, $\times 7$.

Greatest width anterior to center.

Apical System.-Four genital pores (Figure 17), ethmolytic, located posterior to center at distance from anterior margin to center of genital pores equal to $59 \% \mathrm{~L}$.

Ambulacra.-Anterior ambulacrum III not petaloid, in groove from apical system to peristome, depth of groove greatest midway between apical system and margin where depth $6.9 \% \mathrm{~L}$, at margin groove shallow, only $3.3 \% \mathrm{~L}$. Groove wide, with greatest width one-third distance from apical system to anterior margin, width $15 \% \mathrm{~L}$. Pores enlarged in adapical area situated in welldeveloped peripodia with ridge separating pores of a pair; 46 porepairs in this region.

Anterior petals (II and IV) extending threefifths distance from apical system to margin; length $38 \% \mathrm{~L}$, greatest width near extremity of petal where $11 \%$ L. Petals flexuous, depressed in groove of depth $4.8 \%$ L. Pores conjugate with 52 porepairs in petal; porepairs in anterior poriferous zone near apical system much smaller than in posterior. Interporiferous zone narrower than poriferous. Not possible to determine number of plate with first petaloid porepair.

Posterior petals (V and I) short, length $22 \% \mathrm{~L}$; slightly flexuous, depressed in groove with depth $3.0 \% \mathrm{~L} ; 42$ porepairs in petal.

Peristome.-Anterior wide (width $25 \% \mathrm{~L}$ ), opening low but not measurable because of postmortem distortion of test.

Periproct.-Located high on posterior truncation but dimensions unknown because of poor preservation.

Fascioles.-Peripetalous fasciole prominent, of variable width, where passing around anterior 
petals very wide with width $6.9 \% \mathrm{~L}$, narrowing down to a width $2.1 \% \mathrm{~L}$ in interambulacra 4 and 1; curving sharply into interambulacra 4 and 1 extending anteriorly crossing ambulacrum III. Latero-anal fasciole passing around posterior at distance below periproct equal to $12 \% \mathrm{~L}$.

Oral Plate Arrangement.-Sutures of labrum not clear. Sternal plates long, length estimated $58 \% \mathrm{~L}$, greatest combined width of both plates $41 \%$ L. In interambulacrum 2 first plate followed by pair of plates.

Occurrrence.-Oligocene-Miocene, roadcut in Central Highway, $\mathrm{Km} 753.5 \mathrm{E}$ of Habana, $18.5 \mathrm{~km}$ W of Holguín, Oriente Province, Cuba.

\section{Paraster tschopi Palmer \\ Plate 21: figures 1-4}

Material.-Only one specimen, the holotype (SRC 4255), is in the Sánchez Roig Collection. This specimen is very well preserved showing clearly the tuberculation and fascioles. It is slightly crushed resulting in distortion around the periproct and peristome. A topotype is in the MCZ (4040). The first dimension given below is of the holotype.

Shape AND Size.-Length 58 and $56 \mathrm{~mm}$; width $59 \mathrm{~mm}(101 \% \mathrm{~L}), 52 \mathrm{~mm}$ (94\% L); height $35 \mathrm{~mm}(60 \% \mathrm{~L}), 35 \mathrm{~mm}(61 \% \mathrm{~L})$. Greatest width anterior, greatest height posterior.

Apical System.-Four genital pores, ethmolytic, central, located at distance from anterior margin to center of genital pores equal to 50 and $56 \% \mathrm{~L}$.

AmbUlacra.-Anterior ambulacrum III not petaloid, in groove from apical system to peristome, deepest adapically where greatest depth 5.8 and $10 \% \mathrm{~L}$, greatest width 11 and $11 \% \mathrm{~L}$.

Pores greatly enlarged adapically where situated in well-developed peripodia, pores of pair separated by ridge; 50 and 46 porepairs in this region; porepairs in single row with inner pore of pair situated anterior to outer, more elongated; first enlarged porepair in plates 7 and 8 .

Anterior petals (II and IV) extending approximately three-fifths distance from apical system to margin; length 38 and $36 \% \mathrm{~L}$, greatest width near extremity of petal, 8.9 and $10 \% \mathrm{~L}$, depth 5.3 and $7.0 \% \mathrm{~L}$; petals slightly flexuous. Interporiferous zone almost as wide as single poriferous zone; pores conjugate, 58 and 72 porepairs in petal; first porepair in plate 13 or 14 .

Posterior petals ( $\mathrm{V}$ and $\mathrm{I}$ ) very short, extending less than one-half distance from apical system to margin; length 21 and $20 \% \mathrm{~L}$, width 7.9 and $9.0 \%$ $\mathrm{L}$, depth 3.8 and $3.8 \% \mathrm{~L} ; 46$ and 46 porepairs in petal.

Phyllodes with well-developed peripodia with high node behind each single pore and pit where second pore would have been; in topotype 10 pores in phyllode II, 3 in III, 5-6 in V.

Peristome.-Anterior, located on topotype at distance from anterior margin to anterior edge of peristome equal to $23 \% \mathrm{~L}$. Opening on topotype with width $15 \% \mathrm{~L}$ and height $6 \% \mathrm{~L}$.

Periproct.-Located high on overhanging posterior truncation, opening with width (est.) 8.7\% L, height (est.) 13\% L.

FAscioles.-Peripetalous fasciole with greatest width where passing around anterior petals, width $4.5 \% \mathrm{~L}$; curving sharply into interambulacra 4 and 1; slightly indented in 5, curving anteriorly around ambulacrum III. Crossing ambulacra II and IV on plates 12 and 13, ambulacrum III on plate 5. Latero-anal fascioles passing in deep lobe below periproct at distance from lower edge of periproct $17 \% \mathrm{~L}$.

Oral Plate Arrangement.-Labrum with length $12 \% \mathrm{~L}$; sternal plates with length $59 \% \mathrm{~L}$; width $37 \% \mathrm{~L}$.

Occurrence.-Oligocene-Miocene, Palmer locality 1553, Km 202 United Railroad, $0.5 \mathrm{~km} \mathrm{~S}$ of $\mathrm{Km} 213$ on Central Highway, $23 \mathrm{~km} \mathrm{E}$ of Colon church, Matanzas Province, Cuba.

\section{Schizaster guirensis Sánchez Roig Plate 23: figure 1}

Material.-The specimen (SRC 4251), figured by Sánchez Roig (1949, pl. 43: fig. 5), is herein selected as the lectotype. The dorsal sur- 
face is well preserved although slightly distorted by postmortem compression. The ventral surface is badly fractured with the peristome largely destroyed.

Shape and Size.-Length $77 \mathrm{~mm}$, width 70 mm $(91 \% \mathrm{~L})$, height $42 \mathrm{~mm}(55 \% \mathrm{~L})$.

Apical System.-Posterior, distance of apical system from anterior margin equal to $56 \% \mathrm{~L}$. The posterior position may be due to postmortem distortion. Four genital pores, ethmolytic, genital plate 2 extending posteriorly separating posterior ocular plates.

Ambulacra.-Anterior ambulacrum III not petaloid, in wide deep groove; many enlarged porepairs adapically, 84 porepairs, region with enlarged porepairs with length equal to $41 \% \mathrm{~L}$, width $13 \% \mathrm{~L}$, depth at midlength $7 \% \mathrm{~L}$; depth of notch at anterior margin $2.4 \% \mathrm{~L}$.

Anterior petals (II and IV) extending twothirds distance from apical system to margin, length $34 \% \mathrm{~L}$, width $9.4 \% \mathrm{~L}$, flexuous; depressed in deep groove with greatest depth $4.1 \% \mathrm{~L}$; pores strongly conjugate, outer pore of pair slightly more elongated transversely than inner. Interporiferous zone at greatest width slightly narrower than single poriferous zone; 74 porepairs. Pores single beyond petals.

Posterior petals (V and I) short, extending slightly more than one-half distance from apical system to margin, petals curving slightly posteriorly; length $25 \% \mathrm{~L}$, width $9.2 \% \mathrm{~L}$; depressed in groove with depth $3.5 \% \mathrm{~L}$.

Peristome.-Anterior, distance from anterior edge of opening to anterior margin $17 \%$ L. No other details preserved.

Periproct.-Located high on slightly overhanging posterior truncation. Opening higher than wide with height $11 \% \mathrm{~L}$, width $8.8 \% \mathrm{~L}$.

FASCIOLES.-Peripetalous fasciole wide, greatest width where passing around petal V, I; angular, curving sharply into interambulacra 1 and 4. Latero-anal fasciole narrower.

Oral Plate Arrangement.-Not discernible.

Occurrence.-Early Miocene, María Teresa farm, $\mathrm{Km}$ 40-41, on highway from San Antonio de los Baños to Guira, Habana Province, Cuba.

\section{Schizaster riveroi Sánchez Roig \\ Figure 18: Plate 21: figures 5-8}

Material.-Only one specimen known, the holotype (SCR 4194). It is moderately well preserved with much of the tuberculation preserved although weathering has removed part of the test. The specimen is slightly depressed on the left side of the test.

Shape and Size.-Length $57 \mathrm{~mm}$, width 52 mm (92\% L), height $38 \mathrm{~mm}(66 \% \mathrm{~L})$; greatest width anterior, greatest height posterior. Elevated node on interambulacral plates above margin.

Apical System.-Four genital pores, apical system broad, ethmolytic, central, located at distance from anterior margin to center of genital pores equal to $50 \% \mathrm{~L}$.

AmBUlaCRA.-Anterior ambulacrum III not petaloid, in groove extending from apical system to peristome, deepest midway between apical system and margin where depth $11 \% \mathrm{~L}$, width $12 \%$ L. Pores greatly enlarged adapically but nature of pores obscured by heavy weathering. There appear to be four columns of plates in adapical region; this is probably an artifact of weathering.

Anterior petals (II and IV) short, extending slightly more than one-half distance from apical system to margin, length $33 \% \mathrm{~L}$, width $11 \% \mathrm{~L}$, in deep groove $4.9 \%$ L. Petals flexuous, 58 petaloid porepairs, pores conjugate, interporiferous zone as wide as poriferous.

Posterior petals (V and I) straight, short, length $16 \% \mathrm{~L}$, width $8.2 \% \mathrm{~L}$. Number of petaloid porepairs not clear because of heavy weathering. Petals depressed in groove with depth $3.8 \% \mathrm{~L}$. Not possible to determine number of plates between end of petals and peristome. Phyllodes not clear.

Peristome.-Anterior, located at distance from anterior margin to anterior edge of peristome equal to $14 \% \mathrm{~L}$, opening labiate, wider than high, width $19 \% \mathrm{~L}$, height $5.9 \%$ L.

PERIPROCT. - Located slightly higher than midheight of overhanging posterior truncation. Opening higher than wide, height $11 \% \mathrm{~L}$, width 
8.0\% L; located between plates 5-8.

FAscioles.-Peripetalous fasciole very wide, especially as it passes around extremities of petals; width at end of petal II $5.7 \% \mathrm{~L}$, petal I $4.4 \% \mathrm{~L}$;
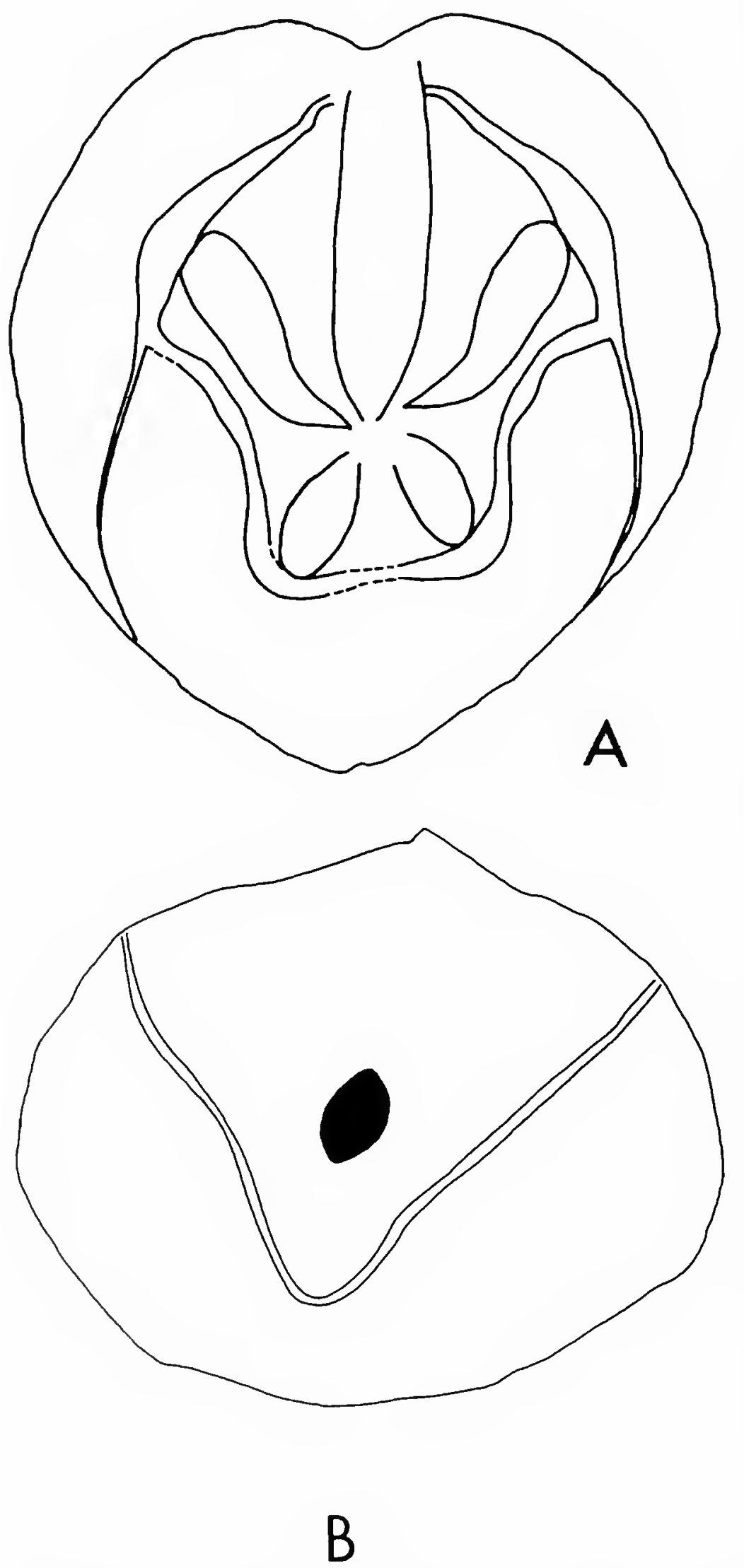

Figure 18.--Schizaster munozi Sánchez Roig, holotype, of Schizasler riveroi Sánchez Roig (=S. munozi), SRC 4194: A, dorsal view, $\times 1.5$; , rear view, $\times 1.5$. curving sharply into interambulacra (Figure 18), anteriorly around ambulacrum III. Latero-anal fasciole narrow band passing in deep lobe below periproct. Width of fasciole in interambulacrum 4, 1, 1.0\% L; distance from lower edge of periproct to fasciole $14 \%$ L. Not clear on which plates fascioles occur.

Oral Plate Arrangement.-Labrum short, length $8.9 \% \mathrm{~L}$; sternal plates long with height $58 \% \mathrm{~L}$, combined width $41 \% \mathrm{~L}$.

Occurrence.-Early Miocene, quarry on outskirts of Cardenas, Matanazas Province, Cuba.

\section{Schizaster salutis Sánchez Roig \\ Plate 22: figures 4-6}

MAterial. - The one specimen (SRC 4187), figured by Sánchez Roig (1949, pl. 45: fig. 4), is herein selected as the lectotype. This specimen is moderately well preserved with the tuberculation present, but the petals are partially removed by weathering.

Shape And Size.-Test $55 \mathrm{~mm}$ long, width 50 mm (92\% L), height $32 \mathrm{~mm}$ (59\% L). Dorsal surface sloping anteriorly.

Apical System.-Central, 4 genital pores, ethmolytic, genital plate 2 extending posteriorly separating posterior ocular plates.

AMBULACRA.-Anterior ambulacrum III not petaloid, in wide deep groove; many enlarged porepairs, length of region with enlarged porepair $36 \% \mathrm{~L}$, width $13 \% \mathrm{~L}$.

Anterior petals (II and IV) extending slightly more than two-thirds distance to margin, length $33 \% \mathrm{~L}$, width $9.8 \% \mathrm{~L}$, flexuous, depressed in deep groove; pores strongly conjugate, outer pore of pair slightly more elongated transversely than inner. Interporiferous zone at greatest width slightly narrower than single poriferous zone. Pores single beyond petals. Not possible to determine number of plate with first petaloid porepair.

Posterior petals (V and I) short, extending slightly more than one-half distance from apical system to margin, length $23 \% \mathrm{~L}$, width $8.1 \% \mathrm{~L}$, depressed in groove. Phyllodes with well-developed peripodia with large node behind each sin- 
gle pore with pit in position where second pore would have been.

Peristome.-Anterior, distance from anterior margin to anterior edge of peristome $19 \% \mathrm{~L}$; width of opening $20 \% \mathrm{~L}$, height $6.0 \% \mathrm{~L}$.

Periproct.-Located high on overhanging posterior truncation, height $13 \% \mathrm{~L}$, width $11 \% \mathrm{~L}$.

Fascioles.-Peripetalous fasciole wide, reaching greatest width as it passes around petals; angular, curving sharply into interambulacra 4 and 1. Latero-anal fasciole narrower, passing below periproct.

Oral Plate Arrangement.-Labrum not preserved. Sternal plates long, $58 \% \mathrm{~L}$, width $38 \% \mathrm{~L}$. In interambulacrum 2 first plate followed by pair of plates.

OcCurRence.-Early Miocene, Lastra farm, La Salud, Habana Province, Cuba.

\section{Schizaster neuvitasensis (Weisbord), new combination}

Plate 23: figures 2-5

Paraster nuevitasensis Weisbord, 1934:67, pl. 7: figs. 7, 8.Sánchez Roig, 1949:283.

Material. - I have nothing to add to Weisbord's description except to note that there are 50 porepairs in petal II, 34 in I, and 40 enlarged porepairs in ambulacrum III.

Phyllodes with well-developed peripodia; wellpreserved peripodia having a high ridge-like node behind pore with a pit on side opposite pore (Plate 23: figure 5); 9 peripodia in ambulacrum II, 5 in I. Ventral tubercles well preserved: illustrated on Plate 23: figure 5.

Occurrence.-Late Eocene, Weisbord's loc. 714, from lenticular marls between Nuevitas and Pastelillo along railroad cut, about $2 \mathrm{~km}$ SE of Nuevitas railroad station, Camagüey Province, Cuba.

Comparison with Other Species. - The holotype and only known specimen is badly crushed, making it difficult to compare with other species. It appears to differ from Schizaster camagueyensis (Weisbord) (which occurs at the same locality with it) in having fewer porepairs in its petals.
The holotype of $S$. nuevitasensis is $39 \mathrm{~mm}$ long, whereas the holotype of $S$. camagueyensis is only 22 $\mathrm{mm}$ long, but both have approximately the same number of petaloid porepairs.

\section{Schizaster rojasi Sánchez Roig}

Figure 19: Plate 25: figures 1-4

Schizaster (Aplospatangus) rojasi Sánchez Roig, 1952c:25, pl. 15: figs. 1-3.

Material._Specimen SRC 4186, figured in the original description, is herein selected as the lectotype. It is well preserved with its test only slightly distorted (in the posterior region).

Shape and Size.-Length $52 \mathrm{~mm}$, width $97 \%$ $\mathrm{L}$, height $52 \% \mathrm{~L}$; greatest width anterior, greatest height posterior; margin sharp.

Apical System.-Posterior, located at distance from anterior margin to center of genital pores equal to $59 \% \mathrm{~L} ; 4$ genital pores.

Ambulacra.-Anterior ambulacrum III not petaloid, in deep, wide groove, greatest width $18 \% \mathrm{~L}$, greatest depth adapically $6.7 \% \mathrm{~L}$, depth of groove at margin $5.1 \% \mathrm{~L}$; adapical area of

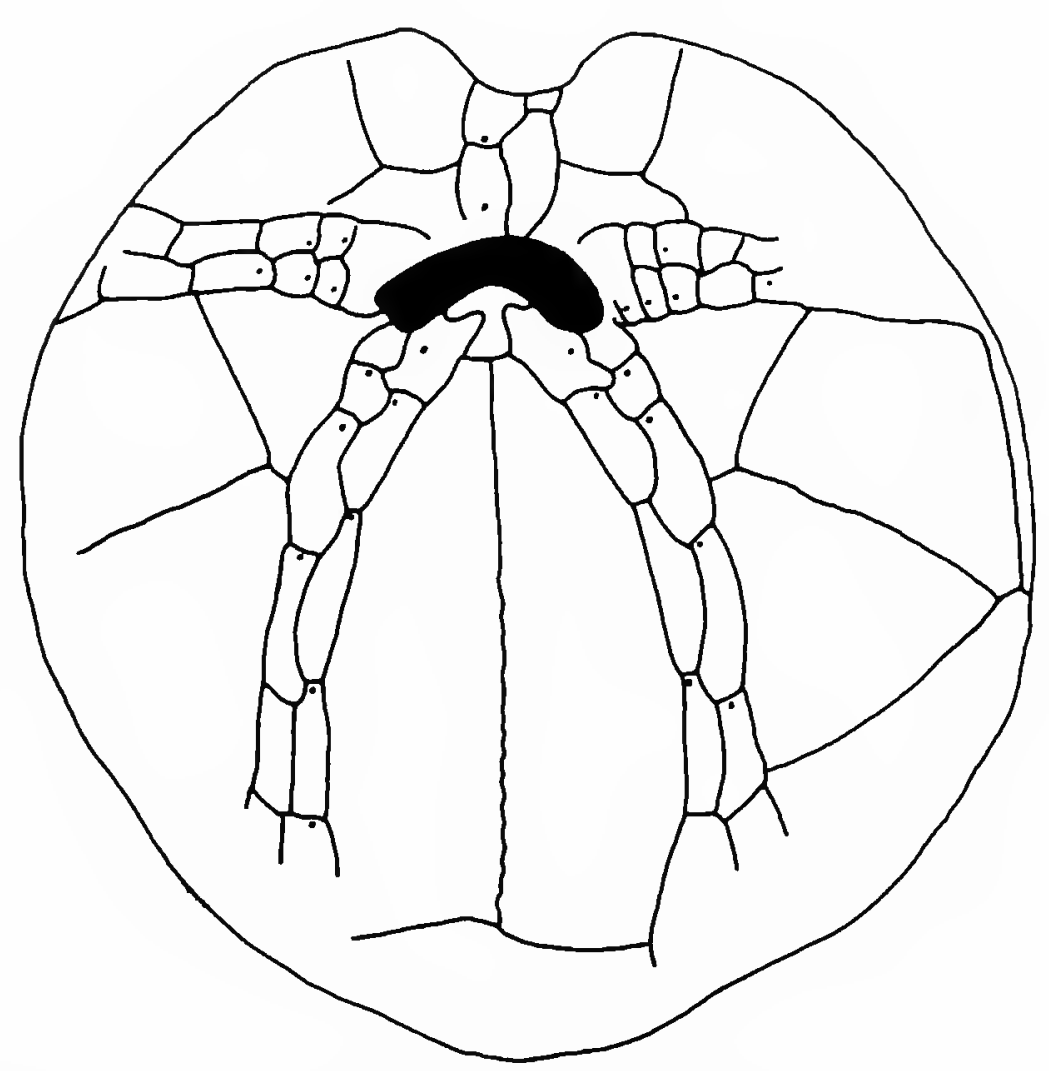

Figure 19.-Schizaster rojasi Sánchez Roig, ventral view of the lectotype, SRC $4186, \times 1.6$. 
enlarged porepairs extending more than twothirds distance from apical system to margin; 70 porepairs in this region; first enlarged porepair in plate 7 or 8 .

Anterior petals (II and IV) extending slightly less than two-thirds distance from apical system to margin, petals flexuous curving outwards distally, length $39 \% \mathrm{~L}$, width $8.6 \% \mathrm{~L}$, depressed in groove with greatest depth $3.6 \% \mathrm{~L}$; interporiferous zone only slightly narrower than single poriferous zone; 74 petaloid conjugate porepairs, first petaloid pore in plate 12; 96 plates in ambulacrum.

Posterior petals ( $\mathrm{V}$ and I) very short, curving slightly inward, length $19 \% \mathrm{~L}$, width $7.7 \% \mathrm{~L}$, depth $3.6 \% \mathrm{~L}$; interporiferous zone slightly narrower than single poriferous zone; 42 petaloid porepairs; first petaloid porepair in plate 19; 78 plates in ambulacrum.

Phyllodes composed of well-developed peripodia with single large pore; each pore has ridgelike node behind with pit on other side where second pore would have been; 10 phyllodal pores in ambulacrum II, 5 in I, 3 perhaps 4 in III.

Peristome.-Anterior, distance from anterior margin to anterior edge of opening $20 \%$ L; width $21 \% \mathrm{~L}$, height $4.6 \% \mathrm{~L}$.

Periproct.-Located high on overhanging posterior truncation, visible from below; between interambulacral plates 6-9.

FAscioles.-Peripetalous fasciole sharply indented in posterior paired interambulacra, crossing ambulacrum III on plate 4 or 5. Latero-anal fasciole largely eroded away.

Oral Plate Arrangement.-Labrum (Figure 19) low, height $8.5 \% \mathrm{~L}$, extending posteriorly onehalf height of first adjacent ambulacral plate. Sternal plates high and wide, height $58 \% \mathrm{~L}$, width $34 \% \mathrm{~L}$; bordered by ambulacral plates $1-6$. In interambulacrum 2 first plate followed by pair of plates.

Occurrence.-Oligocene-Miocene, "Blanquizal" farm, Cuatro Caminos, Marroquín, Morón, Camagüey Province, Cuba.

Comparison with Other Species.-This species is most similar to Schizaster egozcuei Lambert also from the late Oligocene-early Miocene of Cuba having a similar marginal outline but differs in its more divergent anterior petals and shorter posterior petals. It differs from $S$. munozi also from the Oligocene-Miocene of Cuba in having a wider anterior ambulacrum; but in most of its other characters the two species are similar. This species may be a synonym of $S$. munozi, but more specimens must be studied.

\section{Schizaster sanctamariae Sánchez Roig}

Plate 25: figures 5-8

Schizaster sanctamariae Sánchez Roig, 1949:272, pl. 44: figs. 4,5 .

Material.-The holotype (SRC 4161) is moderately well preserved showing the shape of the test. Plate sutures not clear on most of test.

Shape AND Size.-Length $30 \mathrm{~mm}$, width 26 $\mathrm{mm}(87 \% \mathrm{~L})$, height $20 \mathrm{~mm}(67 \% \mathrm{~L})$. Greatest width anterior of center, greatest height posterior.

Apical System.-Four genital pores, anterior pores much smaller than posterior, ethmolytic, located slightly anterior of center; distance from anterior margin to center of genital pores equal to $48 \% \mathrm{~L}$.

Ambulacra.-Anterior ambulacrum III not petaloid, in deep groove from apical system to peristome, depth of groove at margin $5.3 \% \mathrm{~L}$. Pores paired only in adapical region where pores enlarged in large peripodia with approximately 38 porepairs; inner pore of pair elongated, outer circular. Adapically, ambulacrum widest near midlength between apical system and anterior margin.

Anterior petals (II and IV) extending almost two-thirds distance between apical system and margin, length $34 \% \mathrm{~L}$, greatest width $13 \% \mathrm{~L}$; deeply depressed in groove with depth $5.0 \% \mathrm{~L}$. Petal curved convexly to anterior, pores of pair equally elongated transversely, 48 porepairs. Interporiferous zone at greatest width slightly narrower than single poriferous zone. Not possible to determine number of plates between end of petals and peristome. 
Posterior petal (V and I) short, extending onehalf distance from apical system to margin, length $24 \%$ L, width $11 \%$ L. Petals straight, depressed in groove with depth $4.3 \% \mathrm{~L} ; 34$ porepairs.

Phyllodes with single pores, 3 pores in ambulacrum III, 7 or 8 in II or IV, 6 in V or I. Peripodia with large ridge-like node behind pore; pit on other side of node giving impression of second pore.

Peristome.-Anterior, located at distance from anterior margin to anterior edge of peristome equal to $14 \% \mathrm{~L}$, opening wider than high with width $21 \% \mathrm{~L}$, height $8.6 \% \mathrm{~L}$.

Periproct.-Located high on nearly vertical posterior truncation. Opening higher than wide with height $19 \% \mathrm{~L}$ (est.), width $13 \% \mathrm{~L}$.

Fascioles.-Only short tracts of fascioles preserved on test. Peripetalous fasciole narrow, curving sharply into interambulacra 4, 1 not visible elsewhere. Latero-anal fasciole narrow, passing below periproct.

Oral Plate Arrangement.-Labrum broad, short, length $7.6 \% \mathrm{~L}$, extended back to posterior one-third of first ambulacral plate. Plastron broad, width $38 \% \mathrm{~L}$, length indeterminate.

Occurrence.-According to Brodermann (1949:328), this species is from the OligoceneMiocene; $1.75 \mathrm{mi}(2.8 \mathrm{~km}) \mathrm{N}$ of Santa Maria del Rosario, Habana Province, Cuba.

Comparison with Other Species.-This species is easily distinguished from most of the other Cuban species of this genus by its narrower test.

\section{Schizaster santanae Sánchez Roig}

Figure 20; Plate 26

Schizaster santanae Sánchez Roig, 1949:281, pl. 45: figs. 5-7.

Material.-Two specimens were figured by Sánchez Roig. Specimen SRC 4266 (his figures $6,7)$ is herein designated the lectotype. The other specimen is no longer in the collection. The lectotype is moderately well preserved showing portions of the fascioles.

Shape AND Size.-Length $42.0 \mathrm{~mm}$, width 41 $\mathrm{mm}(98 \% \mathrm{~L})$, height $29 \mathrm{~mm}(70 \% \mathrm{~L})$. Greatest width anterior to center, greatest height posterior of apical system with posterior interambulacrum sharply inflated and test sloping anteriorly to margin.

Apical System.-Four genital pores (Figure 20), ethmolytic, located slightly anterior to center at distance from anterior margin to center of genital pores equal to $42 \% \mathrm{~L}$.

Ambulacra.-Anterior ambulacrum III not petaloid, in groove from apical system to peristome; groove at greatest width $11 \% \mathrm{~L}$, depth at margin $2.6 \% \mathrm{~L}$. Pores paired only in adapical region where the 42 porepairs are enlarged; peripodia well developed with large protuberance separating pores of pair; porepairs in single row. First enlarged pores in plate 6 or 7 , plates near peristome very high; 54 or 56 plates in ambulacrum.

Anterior petals (II or IV) short, extending less than two-thirds distance from apical system to margin, length $30 \%$ L. Greatest width $11 \%$ L, narrowing sharply adapically; petals curving slightly anteriorly, depressed in groove of depth $3.3 \%$ L. Pores strongly conjugate, pores of pair equally elongated transversely, 50 porepairs, interporiferous zone at greatest width near end of petal, width less than width of poriferous zone. First petaloid porepair in plate 11 or 12 ; total of 77 plates in ambulacrum. Pores single beyond petals.

Posterior petals ( $\mathrm{V}$ and I) short, extending approximately one-third distance from apical system to margin, length $21 \% \mathrm{~L}$, width $8.3 \% \mathrm{~L}$; in groove with depth $3.3 \% \mathrm{~L}$. Petals curve slightly posteriorly; 40 porepairs; number of plate with first petaloid porepairs not discernible.

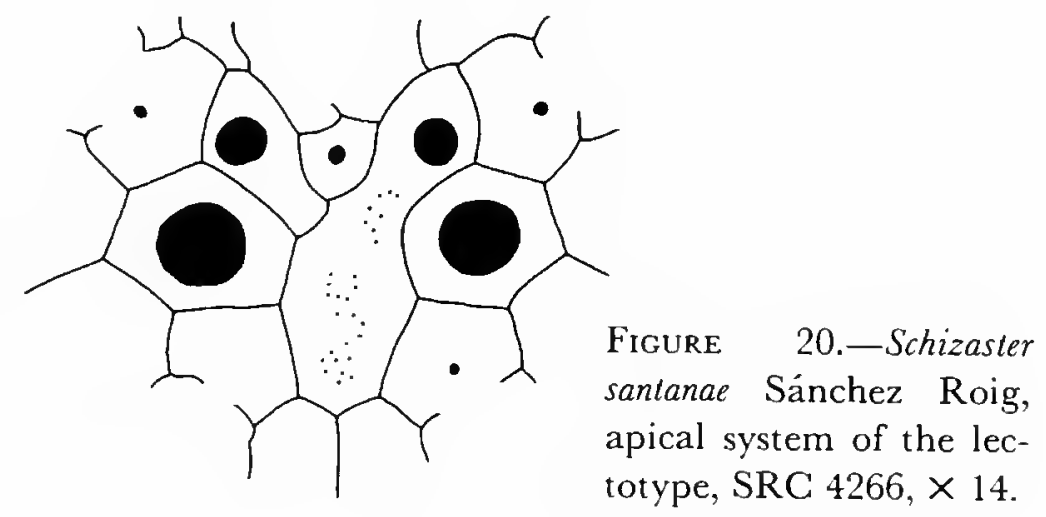


Phyllodes single pored, 3 pores in ambulacrum III, 10 in II or IV, 6 in V or I; peripodia large with single large pore with big, thick ridge-like node behind pore, small pit on other side of node where second pore would be.

Peristome.-Anterior, located at distance from anterior margin to anterior edge of peristome equal to $19 \% \mathrm{~L}$, opening wider than high, width $17 \% \mathrm{~L}$.

Periproct.-Located high on slightly overhanging posterior truncation. Opening higher than wide with height $14 \% \mathrm{~L}$, width $11 \% \mathrm{~L}$.

Fascioles.-Peripetalous fasciole narrow, curving sharply into interambulacra 4 and 1, not discernible on rest of test; crossing ambulacra II or IV on plate 10 or 11 , not clear in other ambulacra or interambulacra. Latero-anal fasciole narrow, only small portion preserved.

Oral Plate Arrangement.-Labrum broad and short, length $14 \% \mathrm{~L}$. Sternal plates long, length estimated at $58 \% \mathrm{~L}$. In interambulacrum 2 first plate followed by pair of plates.

Occurrence.-According to Brodermann (1949:328), this species is from the middle to late Eocene, "Santa Ana" estate, Ciego de Avila, Majagua district, Camagüey Province, Cuba.

Comparison with Other Species. - This species strongly resembles Schizaster llagunoi Lambert and Sánchez Roig from the middle Eocene of Cuba but is definitely a different species. S. santanae has a narrower anterior ambulacrum with only 42 enlarged porepairs in its lectotype as opposed to 56 in the lectotype of $S$. llagunoi. It also resembles Schizaster munozi Sánchez Roig but likewise differs in its narrower anterior ambulacrum with far fewer enlarged porepairs.

\section{Schizaster subcylindricus Cotteau}

Figure 21; Plates 27, 28: figures 1-4

Schizaster subcylindricus Cotteau, 1875:31, pl. 5: figs. 14-17.Guppy, 1882:197._Jackson, 1922:78, pl. 13: fig. 10, pl. 14: figs. 1, 2.-Sánchez Roig, 1949:281.

Schizaster brachypetalus Arnold and Clark, 1927:59, pl. 11: figs. $14-16$.

In the USNM collections, there are many specimens that are indistinguishable from the type specimens of this species known previously from St. Bartholomew. Likewise, I have compared the type specimen of $S$. subcylindricus and the Cuban specimens to the type specimens of Schizaster brachypetalus Arnold and Clark from the Eocene of Jamaica and they are all indistinguishable. The type specimens of both species are illustrated herein on Plate 27: figures 1, 2, and Plate 28:

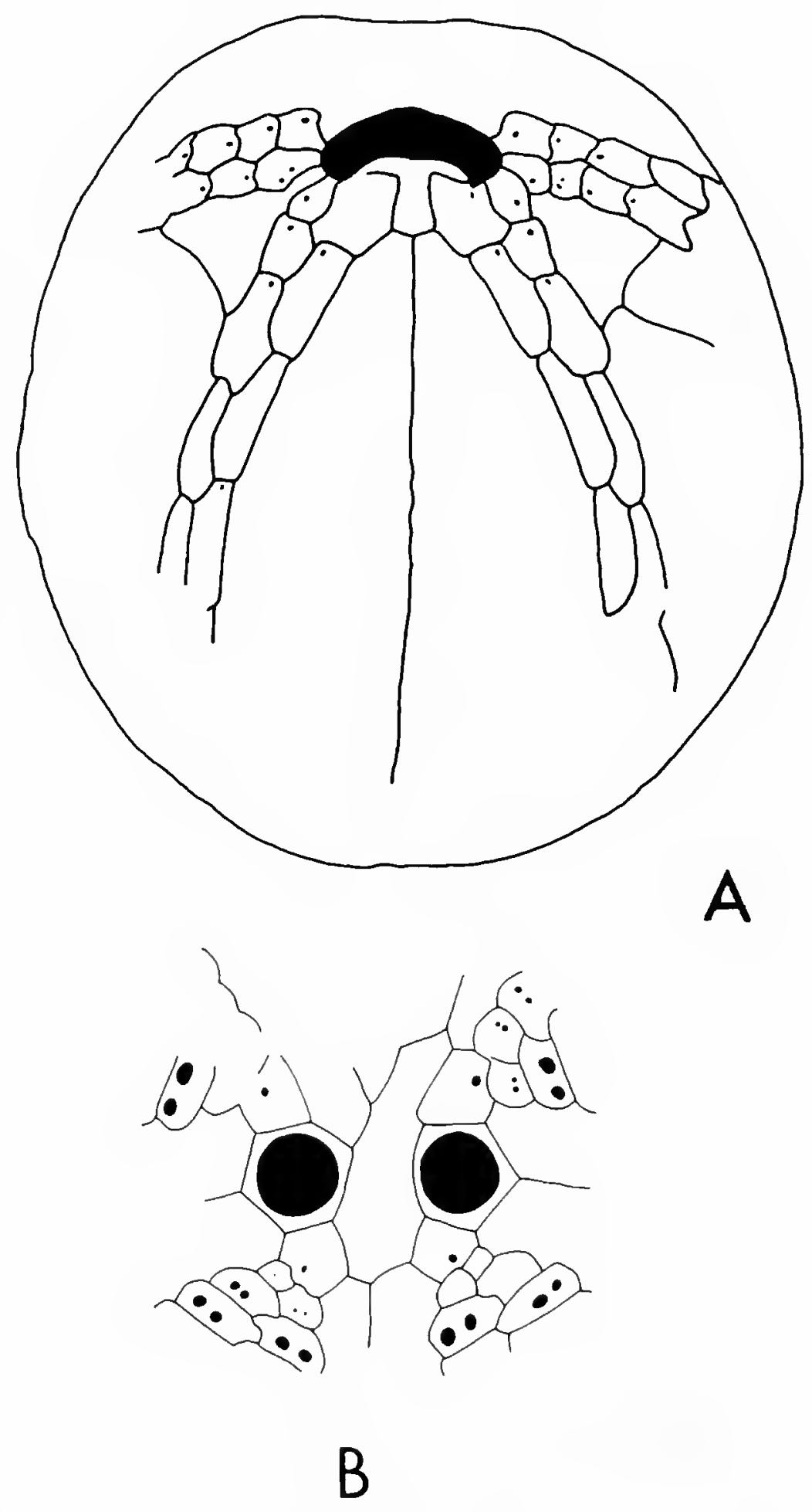

Figure 21.-Schizaster subcylindricus Cotteau, USNM 563308, Eocene, Loma Caoba, $5 \mathrm{~km} \mathrm{~S}$ of San Diego de Los Baños, Pinar del Rio Province: A, ventral view, $\times 3.5$; $\mathrm{B}$, apical view, $\times 14$. 
figures 1-4. The following description is based on 38 specimens from the same Cuban locality. The specimens have undistorted tests, but most of them are badly weathered obscuring the tuberculation.

Shape And Size.-Length 18 to $34 \mathrm{~mm}$ (mean $28 \mathrm{~mm}$ ), width 88 to $98 \% \mathrm{~L}$ (mean 93\%); height 70 to $82 \%$ L (mean $76 \%$ ), greatest width central, greatest height posterior.

Apical System.-Posterior, located at distance from anterior margin to center of genital pores equal to 48 to $62 \%$ L (mean 55\%); 2 genital pores, ethmolytic (Figure 21B) with genital plate 2 extending posteriorly separating posterior ocular plates.

Ambulacra.-Anterior ambulacrum III not petaloid, in deep groove adapically, slight groove at margin. Porepairs enlarged adapically, 32 porepairs in specimen $26 \mathrm{~mm}$ long, 34 in specimen $32 \mathrm{~mm}$ long, porepairs in well-developed peripodia with high ridge separating each pore, inner pore of pair more anterior and more elongate; first enlarged porepair in plate 6 .

Anterior petals (II and IV) flexuous, long, wide, extending more than two-thirds distance from apical system to margin, length 34 to $43 \% \mathrm{~L}$ (mean 39\%); greatest width 11 to $16 \% \mathrm{~L}$ (mean $13 \%)$; interporiferous zone one-half width poriferous zone. Poriferous zone at greatest width 5.7 to $8.1 \% \mathrm{~L}$ (mean $6.7 \%$ ), both pores of pair slit-like, 48 porepairs in petal of specimen $20 \mathrm{~mm}$ long, 60 in specimen $32 \mathrm{~mm}$ long. Porepairs in anterior poriferous zones smaller adapically than in posterior zones. Petal depressed in groove with depth 2.7 to $5.6 \% \mathrm{~L}$ (mean $4.3 \%$ ). First petaloid porepair in plate 11 .

Posterior petals (V and I) short, straight, length 15 to $22 \% \mathrm{~L}$ (mean $19 \%$ ); width 8.1 to $12 \% \mathrm{~L}$ (mean 10\%); depressed in groove with depth 1.2 to $4.3 \% \mathrm{~L}$ (mean 2.7\%); interporiferous zone slightly more than one-half width of poriferous zone; 28 porepairs in petal in specimen $20 \mathrm{~mm}$ long, 38 in specimen $32 \mathrm{~mm}$ long.

Peristome.-Anterior, distance from anterior edge of opening to anterior margin equal to 10 to $20 \% \mathrm{~L}$ (mean 15\%); width of opening 17 to $23 \%$ $\mathrm{L}$ (mean 20\%).
Periproct.-Located high on overhanging posterior truncation, slightly visible from below; opening higher than wide.

Fascioles.-Peripetalous fasciole slightly indented in posterior paired interambulacra, passing straight across posterior interambulacrum, passing far anteriorly and low around anterior margin; crossing plate 4 in ambulacrum III. Latero-anal fasciole passing in deep lobe below periproct at distance below periproct greater than height of periproct.

Oral Plate Arrangement.-Labrum long (Figure 21 $\mathrm{A}$ ); on specimen $33 \mathrm{~mm}$ long, labrum $5.5 \mathrm{~mm}$ long $(16 \% \mathrm{~L})$; first 2 plates of plastron $16.1 \mathrm{~mm}$ long (49\% L), width $12.8 \mathrm{~mm}$ long (39\% L).

Occurrence. - Eocene, St. Bartholomew Limestone, St. Bartholomew; middle to late Eocene, Loma Caoba, $5 \mathrm{~km}$ S of San Diego de los Baños; Km 186 on railroad to Guane, Pinar del Rio Province, Cuba. Schizaster brachypetalus is known from the Eocene of Jamaica near Abingdon, SW of Green Harbour, Hanover Parish, and from St. James Parish.

Comparison with Other Species.-This species is very similar to Schizaster camagueyensis Weisbord also from the Eocene of Cuba. It differs only in having its apical system less posteriorly situated and in having less depressed petals. The two species may be synonyms but too few specimens are known of $S$. camagueyensis to be able to know the variation within the species.

Schizaster subcylindricus is very similar and obviously closely related to Ditremaster beckeri (Cooke) from the late Eocene Ocala Limestone of Florida. They only differ in that the anterior petals in $S$. subcylindricus are slightly shorter and the apical system more anterior. These petals in $D$. becker $i$ have a length equal to $48 \% \mathrm{~L}$ as opposed to $34-41 \% \mathrm{~L}$ (mean $37.5 \%$ ) in S. subcylindricus. Ditremaster beckeri should be referred to Schizaster. Its latero-anal fasciole is distinct, whereas, no latero-anal fasciole is present in Ditremaster. Schizaster subcylindricus differs from $S$. antillarum Cotteau also from the Eocene of St. Bartholomew in having its apical system more posterior, a narrower test, and its peristome more anterior. 
Remarks.-On one specimen the second plate in interambulacrum 2 is single, not paired (Figure $21 \mathrm{~A})$. The plate arrangement in interambulacrum 2 is visible on 4 other specimens and in all of them a pair of plates follows the first plate. In one of them, however, only a small portion of a second plate is in contact with the first plate.

\section{Unrecognizable Species of Schizaster}

\section{Schizaster alcaldei Sánchez Roig}

Schizaster alcaldei Sánchez Roig, 1949:273; 1951:64, pl. 39: figs. 10,11 .

Occurrence. - Late Eocene, central Soledad, Cienfuegos, Santa Clara (now Las Villas) Province, Cuba.

REMARKs. - The holotype is lost and there are no topotypic specimens well enough preserved to permit redescription of this species. Sánchez Roig's illustrations are too poor to permit comparison of this species with other species of this genus.

\section{Schizaster caobaense Sánchez Roig}

Schizaster caobaense Sánchez Roig, 1949:273, pl. 44: fig. 2.

Material.-Although 12 specimens labelled as belonging to this species are in the Sánchez Roig Collection, none are the type and most do not belong to Schizaster. Sánchez Roig's illustration shows a specimen with its petals filled with matrix. He gives no side or bottom views. Too little is known of this species to determine its affinities.

OcCurrence.-Eocene, Caraballo quarry, Loma Caoba, San Diego de los Baños, Pinar del Rio Province, Cuba.

\section{Schizaster cojimarensis Sánchez Roig}

Schizasier cojimarensis Sánchez Roig, 1949:270, pl. 44: figs. $1,3$.

Material. - No specimens of this species are in the Sánchez Roig Collection; therefore, it is not possible to redescribe it. Sánchez Roig's illustra- tions are too poor to permit comparison of this species with other species of the genus.

Occurrence.-Miocene, "La Noria" farm, Cojimar, Habana Province, Cuba. Although Sánchez Roig (1949:270) and Brodermann (1949:327) consider this locality to be late Oligocene, Brönnimann and Rigassi (1963:466) state that the Cojímar Formation outcrops here. They date it as Miocene on the basis of foraminifera. Albear (1981, personal communication) agrees with this latter date.

\section{Schizaster cubensis d'Orbigny}

$$
\text { Plate 28: figure } 5
$$

Schizaster cubensis d'Orbigny in Agassiz and Desor, 1847:22.Sagra, 1855: pl. 8: figs. 4, 6.-Gray, 1855:61.-Michelin, 1855:759._Sánchez Roig, 1949:280.

Hemiaster cubensis (d'Orbigny).-Cotteau, 1881:41, pl. 4: figs. 1-3; 1897:73, pl. 25: figs. 1-3._Jackson, 1922:73.

I have studied fragments of the holotype (MNHN 11934) in the Muséum National d'Histoire Naturelle and can see traces of a lateroanal fasciole, indicating that this species should be referred to Schizaster. The fragments are too incomplete to permit a redescription of this species.

Occurrence.-Pliocene or Recent from Cuba according to Cotteau. The specimen is so well preserved that I doubt if it is older, although Sánchez Roig reports this species from the early Miocene, Medina quarries, at Vedado, Habana Province, Cuba.

\section{Schizaster habanensis Sánchez Roig}

Schizaster habanensis Sánchez Roig, 1949:270, pl. 45: figs. 1, 2.

One specimen in the Sánchez Roig Collection is labelled as being this species, but it is not the type; neither is it topotypic. Sanchez Roig's illustrations do not show sufficient details to permit comparison of this species with others.

Occurrence.-Miocene, National Home for the Aged, Casa Blanca, Habana Province, Cuba. Although Sánchez Roig (1949:271) and Brodermann (1949:327) consider this locality to be late 
Oligocene, Brönnimann and Rigassi (1963:466) report that the Cojimar Formation outcrops there. They assign a Miocene age to this formation on the basis of foraminifera.

\section{Schizaster moronensis Sánchez Roig}

Schizaster moronensis Sánchez Roig, 1951:58, pl. 36: figs. 4, 5.

Material. - No specimens of this species are in the Sánchez Roig Collection; therefore, a redescription of this species is not possible. Sánchez Roig's illustrations show that the apical system is very posteriorly eccentric, with very short posterior petals, flexuous anterior petals, and very anterior peristome. It resembles Schizaster camagueyensis (Weisbord) from the late Eocene of Cuba, but $S$. moronensis appears to have narrower petals.

Occurrence.-Oligocene-Miocene, "Las Cuevas" farm of Pedro del Pozo, Realengo, Charco Hondo, Morón, Camagüey Province, Cuba.

\section{Schizaster pastelilloensis (Weisbord), new combination \\ Plate 28: figures 6-8}

Paraster pastelilloensis Weisbord, 1934:70, pl. 7: figs. 12-14.Sánchez Roig, 1949:284.

The holotype (PRI 3832) is the only specimen known of this species. It is badly distorted and it is not possible to compare it to other species of this genus from Cuba.

Occurrence.-Late Eocene, from cut along the railroad between Nuevitas and Pastelillo, about $2 \mathrm{~km}$ SE of Nuevitas railroad station, Camagüey Province, Cuba.

\section{Schizaster pinarensis (Sánchez Roig), new combination}

Paraster pinarensis Sánchez Roig, 1953c: 173-174, pl. 12: figs. 3,4 .

Material. - The only specimen (SRC 4197) of this species in the Sanchez Roig Collection is labelled as the type (it carries the red dot usually placed on type-specimens) and is from the typelocality. It is not the specimen figured by Sánchez Roig; it is far longer than Sánchez Roig's cotype. Its peristome is more posterior than the specimen figured by Sánchez Roig. It does not appear to be the same species. It is, therefore, not possible to know the characters of this species.

Occurrence.-Middle-late Eocene, "La Caoba" farm, Loma Caoba, San Diego de los Baños, Pinar del Rio Province, Cuba.

\section{Schizaster sandiegensis (Sánchez Roig), new combination}

Paraster sandiegensis Sánchez Roig, 1949:288-289; 1951, pl. 40: figs. $6,7$.

Material.-No specimens are present of this species in the Sánchez Roig Collection. Without seeing specimens, it is not possible to know the characters of this species. Sánchez Roig's illustrations are too poor to permit comparison of this species with others of this genus.

Occurrence.-Eocene, Loma Caoba, $3 \mathrm{~km} \mathrm{~S}$ of San Diego de los Baños, E of the old road to the quarry, Pinar del Rio Province, Cuba.

\section{Schizaster sierrai (Sánchez Roig), new combination}

Paraster sierrai Sánchez Roig, 1951:63, pl. 40: fig. 1

Material. - No specimens of this species are in the Sánchez Roig Collection. It is not possible to know the characters of this species.

Occurrence.-Pleistocene, Buenaventura, between Jaguey Grande and Bahía de Cochinos, between Las Villas and Matanzas Provinces, Cuba.

\section{Genus Agassizia L. Agassiz and Desor, 1847}

Test small to medium size, high, plates thin; apical system ethmolytic with four genital pores; anterior ambulacrum and petals flush to slightly depressed, pores in anterior poriferous zones of petals smaller than in posterior; both peripetalous and latero-anal fascioles.

Habitat.-The two living species of Agassizia 
are restricted to tropical American seas at depths from littoral to $900 \mathrm{~m}$. Nothing is known of their living habits except for the report by Lewis (1963:361) that Agassizia excentrica Agassiz appears to ingest loose bottom material at random. I opened a dead test of the Recent Agassizia scrobiculata Valenciennes. Its gut was packed with coarse shell fragments.

Species of Agassizia probably live buried in sand. Serafy (1979:90) reports that $A$. excentrica was collected on an algal sand bottom and specimens of Agassizia scrobiculata Valenciennes in the USNM collections were collected on sand. However, Agassizia probably lacks the ability to maintain a burrow in mud. The pores and peripodia in the dorsal part of the anterior ambulacrum are small, only slightly larger than those below the margin of the test, indicating a slight development in the funnel-building tubefeet (Smith, 1980) necessary for maintenance of a tunnel through mud to the surface. I have examined specimens of the Recent $A$. scrobiculata and note that although the tubefeet in the anterior ambulacrum have discs and rods, these tubefeet are small and there are few of them. They are largest near the margin. Their scarcity, small size, and slight development adapically would make it difficult for this echinoid to maintain a long tunnel in mud. Furthermore, the fact that the ambulacra, including the petals, are not depressed in deep grooves is further evidence that these echinoids lived in coarser sediments. Mud-living species (Kier, 1975), such as Schizaster doederleini (Chesher), Moira atropos (Lamarck), and Brissopsis elongata Mortensen, have depressed petals and anterior ambulacra. They all have many welldeveloped funnel-building tubefeet.

Evolution.-No clear evolutionary trends are apparent among the Cuban species of Agassizia, except that the Eocene species all have their apical system very posterior with short posterior petals; whereas, some of the later species, such as the late Oligocene-Miocene Agassizia alveari Sánchez Roig, have a central apical system and longer posterior petals.

Comparison with Species of Agassizia outside of Cuba.-Two of the Cuban species occur elsewhere. A. clevei is known from Anguilla, Puerto Rico, and southeastern United States. $A$. inflata has been found in St. Bartholomew, Jamaica, and North and South Carolina. A. alveari and A. pinarensis are distinct from any other species in the Western Hemisphere.

ReMARKs.-Eleven species of Agassizia have been reported from Cuba. Four are recognized as valid herein (Table 4). Three are not recognizable because their type-specimens have been lost. Three are considered synonyms of Agassizia clevei Cotteau and two are synonyms of Agassizia inflata Jackson, not previously reported from Cuba.

Table 4.-Disposition herein of Cuban species of Agassizia

\begin{tabular}{|c|c|c|c|c|}
\hline Disposition & Miocene & $\begin{array}{l}\text { Oligocene- } \\
\text { Miocene }\end{array}$ & $\begin{array}{l}\text { Eocene- } \\
\text { Miocene }\end{array}$ & Eocene \\
\hline $\begin{array}{l}\text { Recognized species } \\
\text { (synonyms) }\end{array}$ & A. pinarensis & A. alveari & 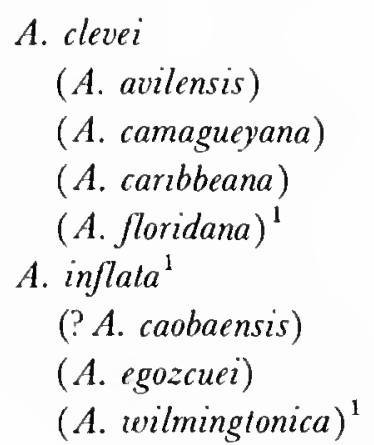 & \\
\hline $\begin{array}{l}\text { Unrecognizable } \\
\text { species }\end{array}$ & & $\begin{array}{l}\text { A. guanensis } \\
\text { A. lamberti }\end{array}$ & & A. flexuosa \\
\hline
\end{tabular}

${ }^{1}$ Species not previously reported from Cuba. ${ }^{2}$ Age uncertain. 
Agassizia is easily distinguished by the presence of smaller pores in the anterior poriferous zones of the anterior petals. Some workers, including Cooke (1959:75) and Fischer (1966:U574), use
Anisaster as a subgenus of Agassizia for those species in which some of the pores are not reduced in this anterior zone. This division is not used herein.

\section{Key to Cuban Species of Agassizia}

1. No large pores in anterior poriferous zones of anterior petals . . . . . . 2 Some large pores in anterior poriferous zones of anterior petals ..... 3

2. Central apical system .................. pinarensis Sánchez Roig Posterior apical system $\ldots \ldots \ldots \ldots \ldots \ldots \ldots \ldots . \ldots . \ldots . \ldots$. clevei Cotteau

3. Short posterior petals ................... A. inflata Jackson Long posterior petals .................. alveari Sánchez Roig

\section{Agassizia alveari Sánchez Roig}

Figure 22; Plate 33: figures 6-9

Agassizia alveari Sánchez Roig, 1949:258, pl. 41: fig. 7

MATERIAL.—The specimen (SRC 4084) figured by Sánchez Roig is herein designated the lectotype. It is moderately well preserved with its test undistorted and the surface well enough preserved to show the fascioles. Two other topotypic specimens are used in the following description. A third topotype is in the MCZ (4118).

Shape AND Size.-Length 24 to $35 \mathrm{~mm}$, width 83 to $92 \% \mathrm{~L}$, height 74 to $77 \% \mathrm{~L}$; greatest width central, greatest height anterior. Dorsal surface smoothly inflated.

Apical System.-Posterior, located at distance from anterior margin to center of genital pores equal to 48 to $54 \% \mathrm{~L} ; 4$ genital pores ethmolytic, genital plate 2 extending posteriorly separating posterior ocular plates.

AMBULACRA.-Anterior ambulacrum III not petaloid, not in groove, pores only slightly enlarged adapically, in very small peripodia; porepairs widely spaced, dorsal plates very high.

Anterior petals (II and IV) long, extending almost to margin, length 44 to $47 \% \mathrm{~L}$, width 7.6 to $9 \% \mathrm{~L}$; petals curving anteriorly; depressed in very slight groove. Pores greatly reduced in size in anterior poriferous zone, only distal 4 porepairs enlarged but still not as large as pores in poriferous zone; interporiferous zones no wider than single poriferous zone; outer pore of pair more elongate than inner; 52 porepairs in specimen 24 $\mathrm{mm}$ long, 56 in specimen $29 \mathrm{~mm}$ long, 60 in specimen $35 \mathrm{~mm}$ long. Pores single beyond petals.

Posterior petals (V and I) straight, short, extending four-fifths distance from apical system to margin, length 40 to $42 \% \mathrm{~L}$, width 8.5 to $10 \% \mathrm{~L}$, depressed in slight groove. Adapically anterior poriferous zones with porepairs somewhat smaller than in posterior poriferous zones; 46 porepairs in specimen $24 \mathrm{~mm}$ long, 52 in specimen $29 \mathrm{~mm}$ long, 58 in specimen $35 \mathrm{~mm}$ long.

Phyllodes single pored with well-developed peripodia, number of pores not clear.

Peristome.-Anterior, located at distance from anterior margin to anterior edge of opening 17 to $20 \% \mathrm{~L}$, width 16 to $24 \% \mathrm{~L}$, height 8.2 to $9.4 \% \mathrm{~L}$.

Periproct.-Marginal, slightly visible from below; opening wider than high, width 18 to $22 \% \mathrm{~L}$.

FASCIOLES. - Peripetalous fasciole passing anteriorly inframarginally at great distance from anterior petals, then curving sharply adapically (Figure 22) in posteriorly paired interambulacra. Latero-anal fasciole passing posteriorly in deep lobe below periproct at distance slightly greater than height of periproct.

Oral Plate Arrangement.-Plate sutures not clear but labrum appears to be short, plastron large.

Occurrence.-Oligocene-Miocene, $42 \mathrm{~km} \mathrm{~W}$ of Ciego de Avila, $419.7 \mathrm{~km}$ on central highway, Camagüey Province, Cuba.

Comparison with Other Species.-This spe- 

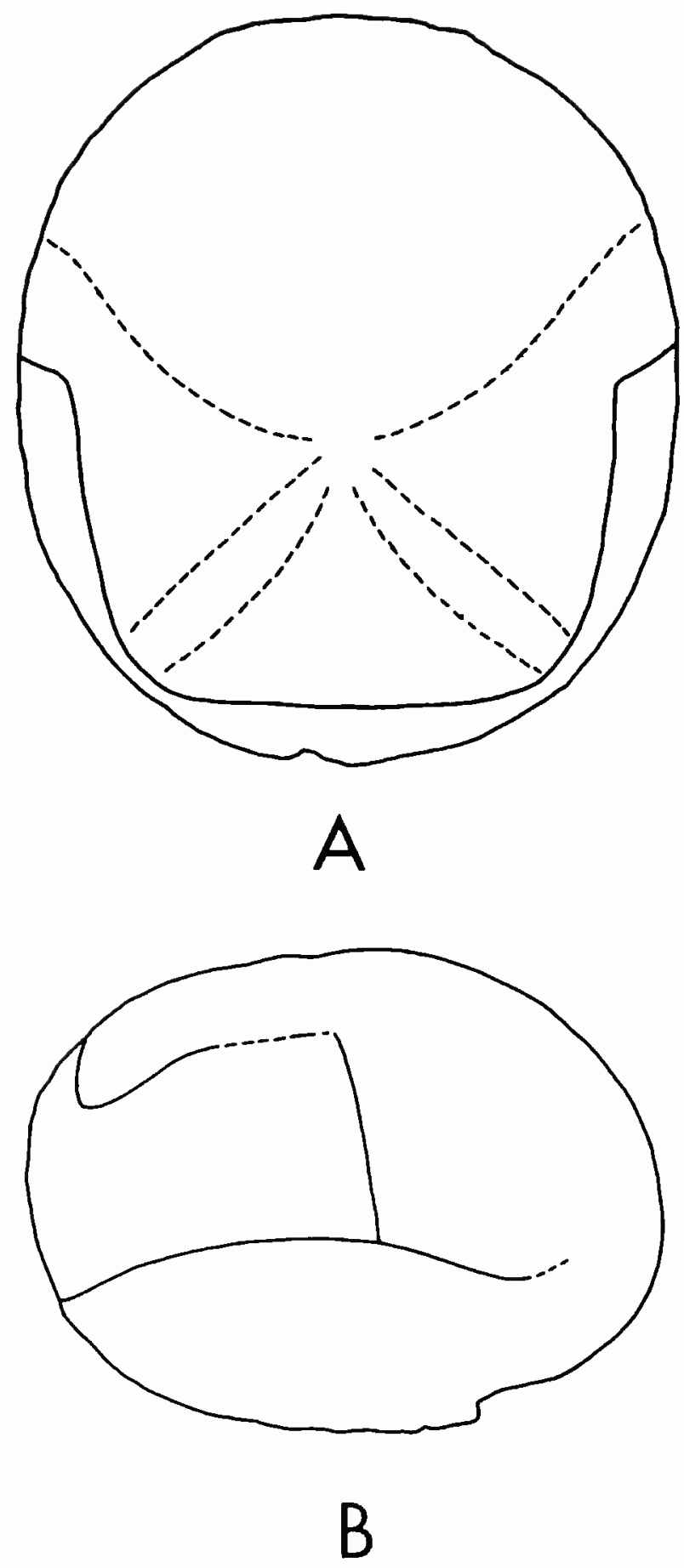

Figure 22.-Agassizia alvear Sanchez Roig, positions of the fascioles of the lectotype, SRC 4084, × 2: A, ventral view; B, side view.

cies is easily distinguished from all other Cuban and most of the Western Hemisphere species of Agassizia by its very long posterior petals. It is found with $A$. inflata from which it is distinguished by its longer posterior petals and more central apical system. Agassizia porifera (Ravenel) from the Pleistocene of Florida and South Carolina has long posterior petals but differs from $A$. alveari in lacking large pores in the anterior poriferous zone of the anterior petals, in its wider and larger test, and more anterior apical system.

\section{Agassizia clevei Cotteau}

Figure 23; Plates 29-31

Agassizia clevei Cotteau, 1875:33, pl. 6: figs. 2-8 [in part, not figs. 9, 10].-Jackson, 1922:71, pl. 12: figs. 5-7.—Sánchez Roig, 1949:256.-Gordon, 1963:640, fig. 1, pl. 80: figs. 13.

Agassizia floridana de Loriol, 1887:398, pl. 17: figs. 9-9f.Cooke, 1942:44, pl. 3: figs. 1-4.-Fischer, 1951:73, pl. 6: figs. 3, 4.-Cooke, 1959:75, pl. 32: figs. 1-4.

Agassizia caribbeana Weisbord, 1934:238, pl. 8: figs. 1-6.

Agassizia avilensis Sánchez Roig, 1949:260, pl. 41: figs. 4-6, 8.

Agassizia camagueyana Weisbord, 1934:247, pl. 9: figs. 5, 6.-Sánchez Roig, 1949:253.

Material.-I have studied many specimens of Agassizia floridana de Loriol from the late Eocene of Florida and cannot distinguish them in any way from the types of $A$. clevei from the Miocene of Anguilla. The Cuban and Floridian specimens are identical in shape of the test, arrangement of petals, number of petaloid porepairs, absence of petaloid porepairs in the anterior poriferous zones of the anterior petals, position and shape of peristome, and position of the apical system. I searched for differences with particular care, since the Floridian specimens are late Eocene and the types of $A$. clevei are from the Miocene Anguilla Formation in Anguilla. Echinoids do not commonly have such a wide stratigraphic range.

The types of $A$. clevei and specimens from Florida previously referred to $A$. floridana are illustrated for comparison with each other on Plate 29: figures 6, 7, and Plate 31 : figure 8.

I have examined the holotype (Plate 31 : figures 1-3) and paratype (Plate 31: figures 4-6) of Agassizia caribbeana and agree with Cooke (1959:75) that it is a synonym of A. floridana. Weisbord's description (1934:238) is detailed and requires only the inclusion of the following statistics: holotype with length of $35 \mathrm{~mm}$ has 20 porepairs in posterior poriferous zone of anterior petal; 32 in both zones of posterior petal. Paratype $21 \mathrm{~mm}$ long with 18 porepairs in posterior poriferous zone of anterior petal; 26 in both zones of posterior petal.

Sánchez Roig's holotype (Plate 29: figures 4,5) and topotype (Plate 29: figures 1-3) of $A$. avilensis are very similar to specimens of $A$. floridana from 
the late Eocene, Crystal River Formation of Florida. The dimensions of the Cuban and Floridian specimens were placed on scattergrams. In the following characters the two species were inseparable: length, width, height of test, length of anterior petals, length of posterior petals, position of apical system, number of porepairs in the petals, and the position of the fascioles. They differ only in that the petals in the Cuban specimens are slightly wider. As there are only 2 Cuban specimens, it is not possible to know the significance of this difference. The 2 species are too similar to be differentiated on the basis of the evidence now available.

The holotype (Plate 31: figure 7) of Agassizia camagueyana Weisbord from the Oligocene-Miocene of Cuba appears to me to be only a flattened A. clevei.

Cooke (1959:75) considered Agassizia inflata Jackson and Agassizia egozcuei Lambert, from the Eocene St. Bartholomew Limestone of St. Bartholomew, to be synonyms of Agassizia floridana. I have seen the holotype of $A$. inflata ( $A$. egozcuei is based on material conspecific with $A$. inflata). Although they are similar in many ways, $A$. inflata can be distinguished by its more anterior apical system and by possessing a few enlarged porepairs in the anterior poriferous zones of its anterior petals. In none of 17 specimens studied of $A$. floridana were any large porepairs present in the anterior poriferous zones.

Jackson (1937:233) referred 2 specimens from the Oligocene-Miocene of Mexico to $A$. clevei. These specimens have a few larger pores in the anterior poriferous zones of the anterior petals that are not found in $A$. clevei. These 2 specimens are very similar to Agassizia inflata Jackson.

Occurrence.-The type specimens of $A$. cleve $i$ came from the Miocene Anguilla Formation of Anguilla. Sánchez Roig (1949:257) reports this species from "La Noria" farm, Cojímar, Habana Province, Cuba. According to Brönnimann and Rigassi (1963:466), this locality is in the Miocene Cojímar Formation. Gordon (1963:640) refers to this species' specimens from the Miocene of Puerto Rico.

Sánchez Roig's specimens of $A$. avilensis came from the Oligocene-Miocene, Carretera Central, both sides, $425.5 \mathrm{~km}$ E of Habana, $36.1 \mathrm{~km} \mathrm{~W}$ of Ciego between Ciego de Avila and Jatibonico, Camagüey Province, Cuba.

Weisbord's specimens of $A$. caribbeana came from the late Eocene, Loma Calisto, and between Nuevitas and Pastelillo, Camagüey Province, Cuba. His holotype of $A$. camagueyana is from the Oligocene-Miocene at $\mathrm{Km} 440$, central highway, between Jatibonico and Ciego de Avila, Camagüey Province, Cuba. The American specimens of $A$. floridana come from the late Eocene Ocala Limestone of Florida and Georgia (see Cooke, 1959:75, for detailed locality data).

One specimen (Plate 30: figures 5-7) of this species (MCZ 4124) is from Palmer's locality 1081, Oligocene-Miocene, in roadcuts at Arroyo la Palma, $8.2 \mathrm{~km}$ SE of bridge over Río Zaza or $12.8 \mathrm{~km}$ SE of Sancti Spiritus.

\section{SYNONYM \\ Agassizia avilensis Sánchez Roig}

Figure 23; Plate 29: figures 1-5, Plate 30: figures 1-4

Material.- Three specimens in the Sánchez Roig Collection are referred to this species. The holotype (SRC 4749) and only specimen figured by Sánchez Roig is beautifully preserved showing the fascioles and other surface detail. It is slightly compressed. A second topotypic specimen (SRC 4750 ) is also well preserved and shows the original shape of the test. A third specimen (SRC 4222), from Palmer's locality 1081, may belong to this species, but it is too poorly preserved to be identified with certainty. It is not used in this description. One topotype (4121) is in the MCZ (Plate 30: figures 1-4). The first dimension given below refers to the holotype; the second is for the topotype SRC 4750.

Shape AND Size.-Length 25 and $26 \mathrm{~mm}$, width 22 and $24 \mathrm{~mm}$ (91 and 92\% L); height of topotype $21 \mathrm{~mm}(83 \% \mathrm{~L})$. Greatest width central, greatest height posterior.

Apical System.-Four genital pores, ethmolytic with genital plate 2 extending far beyond the posterior ocular plates. Apical system posterior of 
center at distance from anterior margin to center of genital plates equal to 57 and $67 \% \mathrm{~L}$.

Ambulacra.-Anterior ambulacrum III not petaloid, adapically in very shallow groove not extending to margin. Porepairs in adapical region only slightly enlarged, in peripodia, with pore-
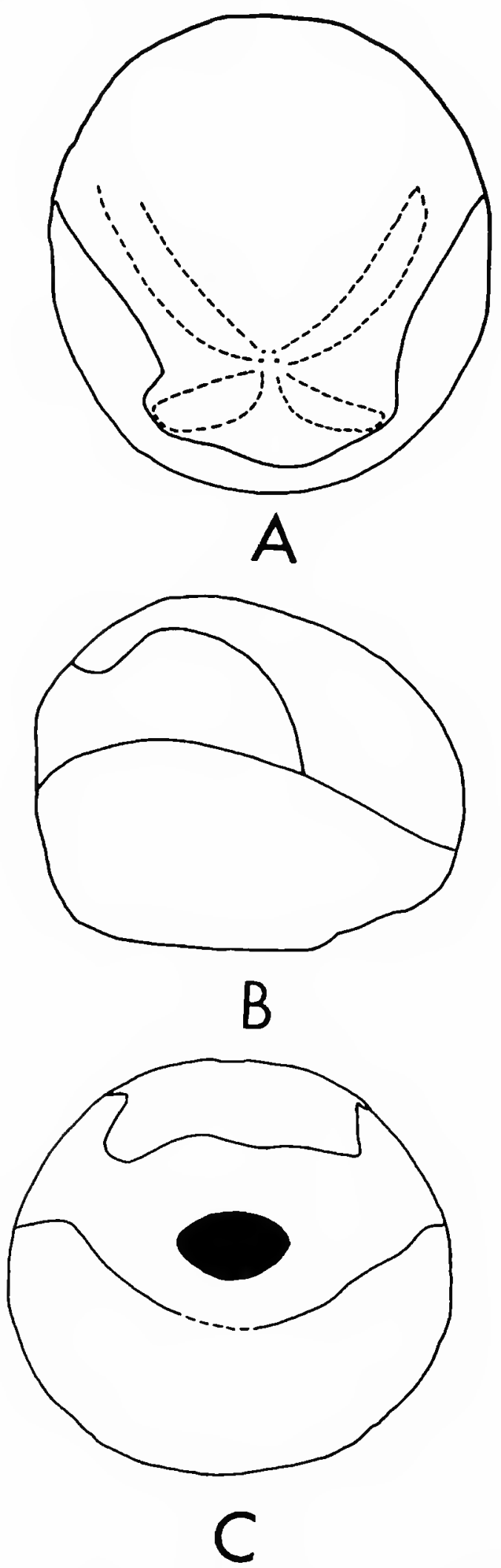

Figure 23.-Agassizia clevei Cotteau, topotype of Agassizia avllensis Sánchez Roig (= A. clevei), SRC 4750, × 2: A, dorsal view; $B$, side view; $c$, rear view. pairs widely separated longitudinally from each other because of great height of plates; no clear demarcation between area with enlarged pores and area adoral with slightly smaller porepairs; 40 and 40 plates in ambulacrum.

Anterior petals (II and IV) extending more than two-thirds distance from apical system to margin, length 51 and $56 \%$ L; greatest width 9.3 and $8.9 \% \mathrm{~L}$, curving in convex arc; depressed in very shallow groove. Porepairs of anterior poriferous zone greatly reduced in size, no large pores in anterior zone; porepairs of posterior poriferous zones not conjugate, outer pore of pair more elongate than inner; 44 and 48 porepairs in petal including anterior poriferous zone; first petaloid porepair in plate 13. Total of 68 plates in ambulacrum in holotype.

Posterior petals ( $\mathrm{V}$ and $\mathrm{I}$ ) very short, extending less than one-half distance from apical system to margin, length 23 and $28 \%$ L. Petals wide, 12 and $12 \% \mathrm{~L}$, in shallow groove. Interporiferous zone narrow, less than one-half width of single poriferous zone. Petal straight with 26 and 32 porepairs.

Peristome.-Anterior, located at distance from anterior margin to anterior edge of peristome equal to 17 and $10 \% \mathrm{~L}$; opening wider than high, width 25 and $25 \% \mathrm{~L}$, height unknown.

Periproct.-Located high on vertical posterior truncation, opening wider than high; on topotypic specimen width $22 \% \mathrm{~L}$, height $15 \% \mathrm{~L}$.

Fascioles.-Peripetalous fasciole narrow, width $2.3 \% \mathrm{~L}$, with 4 longitudinal rows of nodes; curving sharply into interambulacra 4 and 1, straight across interambulacrum 5; from ends of anterior plates, fascioles curve down to junction with latero-anal fasciole, anteriorly passing below margin, far distant from ends of anterior petals (Figure 23A, B); crossing ambulacrum III on plate 3 or 4 , II or IV on 8. Latero-anal fasciole passing in deep lobe (Figure 23c) below periproct; at greatest width $1.9 \% \mathrm{~L}$ with 6 longitudinal rows of nodes.

Oral Plate Arrangement.-Plate sutures not clear, but labrum appears to be very short; plastron very large.

Occurrence.-Oligocene-Miocene, Carretera Central, both sides, $425.5 \mathrm{~km}$ E of Habana, 36.1 
$\mathrm{km} \mathrm{W}$ of Ciego between Ciego de Avila and Jatibonico, Camagüey Province, Cuba.

\section{Agassizia inflata Jackson}

Plate 32

Agassizia clevei Cotteau, 1875:33 [part], pl. 6: figs. 9, 10 [not figs. 3-8].

Agassizia inflata Jackson, 1922:70, pl. 12: figs. 2-4.

Agassizia egozcuei Lambert in Lambert and Thiéry, 1925 [1909-1925]:596.

Agassizia wilmingtonica Cooke, 1942:46, pl. 5: figs. 9-13; 1959:76, pl. 32: figs. 10-13._Kier, 1980:43, fig. 19, pl. 15: figs. $1-10$.

?Agassizia caobaensis Sánchez Roig, 1953c:172, pl. 12: figs. 1, 2.

Material.-Fourteen Cuban specimens in the USNM collections are indistinguishable from the holotype of this species from St. Bartholomew and USNM specimens from Jamaica.

Likewise, no differences could be found from a comparison of the Cuban specimens and the type specimen of $A$. inflata with many specimens of Agassizia wilmingtonica Cooke from the middle Eocene of North and South Carolina. Scattergrams plotting the dimensions of all the major characters revealed no separation between the $A$. inflata specimens and those of $A$. wilmingtonica from North Carolina.

The type specimen of Agassizia caobaensis Sánchez Roig is not in the Sánchez Roig Collection. One cannot be certain of its specific characters, but all the specimens I have seen from its typelocality belong to $A$. inflata.

Occurrence.-Eocene, St. Bartholomew Limestone, St. Bartholomew; Late Eocene, 3.5 $\mathrm{km}$ SE of San Diego de los Baños, Pinar del Rio Province, Cuba. Oligocene-Miocene, $43.1 \mathrm{~km} \mathrm{~W}$ of Ciego de Avila, Camagüey Province, Cuba. In the USNM collections of the Smithsonian are 4 specimens from Jamaica that are indistinguishable from the Cuban specimens. These specimens are labelled as having been collected by B.W. Arnold in Jamaica-no further stratigraphic or geographic data are given. $A$. wilmingtonica occurs in the middle Eocene Castle Hayne and Santee Limestones of North and South Carolina (see Kier, 1980:44 for localities).
Comparison with Other Species.-Agassizia inflata is very similar to $A$. clevei from elsewhere in Cuba and from Anguilla, Puerto Rico, Mexico, Florida, and Georgia. A. inflata differs in having its apical system more anterior and in having a few enlarged petaloid pores in the anterior poriferous zones at the end of the anterior petals. No enlarged pores are present in $A$. clevei.

Agassizia regia Israelsky from Mexico differs in having its anterior petals curving more convexly and in having smaller pores in the anterior poriferous zones of the anterior petals.

\section{Agassizia pinarensis Sánchez Roig}

Figure 24; Plate 33: figures 1-5

Agassizia pinarensis Sánchez Roig, 1952c:22, pl. 6: figs. 6, 7.

Material.-The holotype (SRC 4160) and only known specimen is well preserved with its test not distorted and its tuberculation well preserved showing the fascioles.

Shape ANd Size.-Length $22.8 \mathrm{~mm}$, width 21.0 mm (92\% L), height $19.1 \mathrm{~mm}$ (84\% L). Greatest width and height central.

Apical System.-Four genital pores ethmolytic, centrally located at distance from anterior margin to center of genital pores equal to $41 \% \mathrm{~L}$.

Ambulacra.-Anterior ambulacrum III not petaloid, adapically in very shallow groove; porepairs in dorsal region widely separated because of great height of plates; approximately 22 plates in dorsal region.

Anterior petals (II and IV) long, extending almost to margin, length $19 \%$ L; petal depressed in slight groove, petals narrow, greatest width $11 \% \mathrm{~L}$, curving in convex arc. Porepairs of anterior poriferous zones greatly reduced in size, no large pores in anterior zone; porepairs of posterior poriferous zones not conjugate, outer pore of pair more elongate than inner; 46 porepairs in petal including anterior poriferous zone.

Posterior petals (V and I) very short, extending less than one-half distance from apical system to margin, length $32 \%$ L. Petals wide, width $12 \% \mathrm{~L}$, in shallow groove. Interporiferous zone narrow, one-half width of single poriferous zone. Petals 
straight with 30 porepairs. First petaloid porepair in plate 15; total of 58 plates in ambulacrum. Last $1 \frac{1 / 2}{2}$ plates in single poriferous zone of petal occluded, enclosed by first ambulacral plate beyond petal.

Phyllodes with large peripodia, number of pores in each phyllode not clear.

Peristome.-Anterior, located at distance from anterior margin to anterior edge of peristome equal to $18 \% \mathrm{~L}$; opening wider than high, width $22 \% \mathrm{~L}$, height $8.8 \% \mathrm{~L}$.
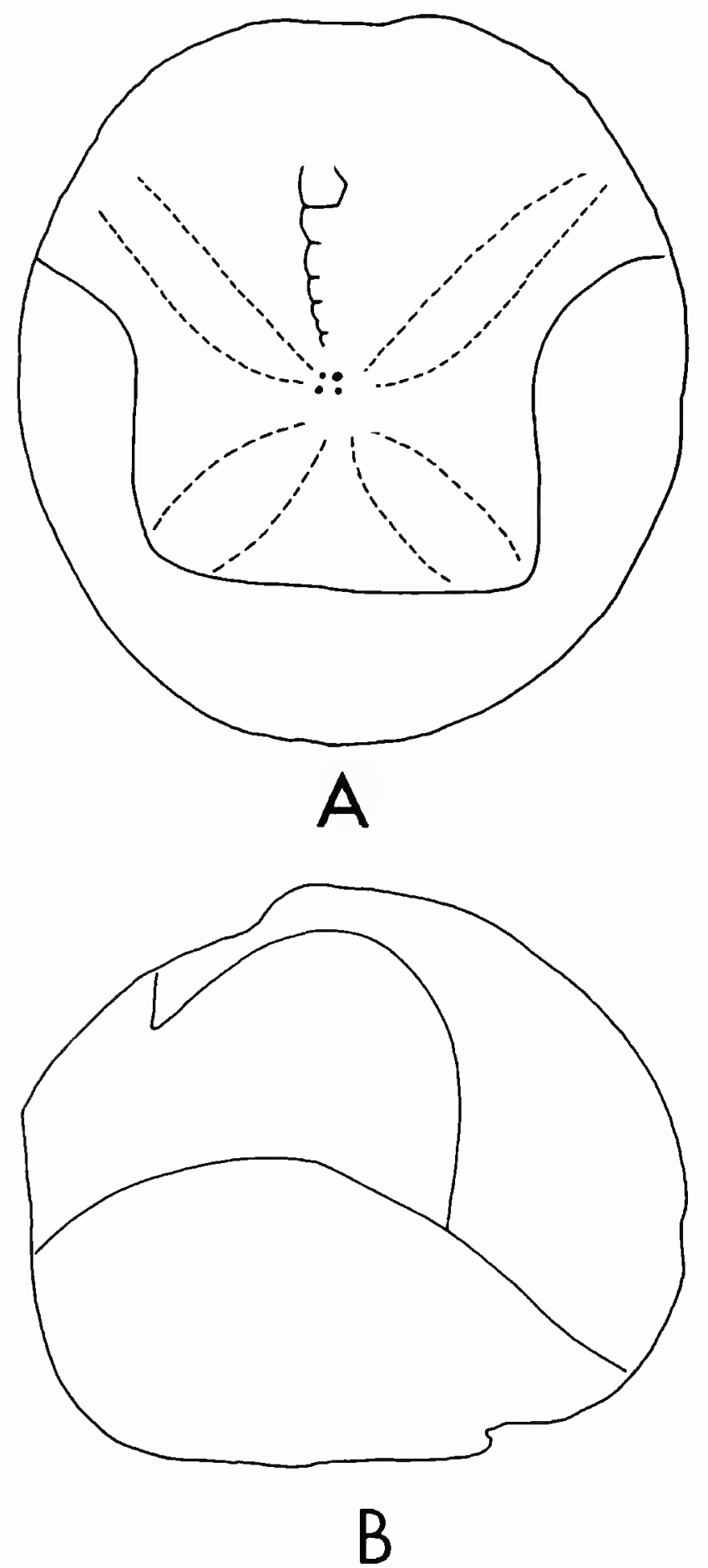

Figure 24.-Agassizza prnarensis Sánchez Roig, holotype, SRC 4160, × 3: A, dorsal view; B, right side.
Periproct.-Located high on posterior truncation; opening wider than high, width $22 \% \mathrm{~L}$, height $15 \% \mathrm{~L}$.

Fascioles._Peripetalous fasciole (Figure 23) broad, width $2.6 \% \mathrm{~L}$, curving sharply into interambulacra 4 and 1, straight across interambulacrum 5; from ends of anterior petals fasciole curves sharply adorally to junction with lateroanal fasciole; anteriorly fasciole curves adorally passing around anterior of test below margin (Figure 24B); crossing ambulacrum III on plate 3 or 4 , II or IV on 7 or $8, \mathrm{~V}$ or I on 14. Latero-anal fasciole passing in deep lobe below periproct; crossing ambulacra $\mathrm{V}$ or I on plate 10 .

Oral Plate Arrangement.-Labrum broad, short, length $6.6 \% \mathrm{~L}$. Rest of plate sutures difficult to discern, but plastron appears to be large.

Occurrence.-Miocene, extreme $\mathrm{N}$ of Consolación del Sur, Pinar del Rio Province, Cuba.

Comparison with Other Species.-This species is easily distinguished from Agassizia clevei Cotteau by its rounder, wider, higher test with its greatest height central rather than posterior and its steeper anterior surface. Furthermore, in $A$. pinarensis the apical system is central, whereas, in A. clevei it is very posteriorly situated. It is distinguished from Agassizia inflata by its more central apical system and absence of any enlarged petaloid pores in the anterior poriferous zones of the anterior petals. It differs from the Oligocene-Miocene Cuban species Agassizia alveari Sánchez Roig in having much shorter posterior petals and lacking enlarged pores in its anterior poriferous zones of its anterior petals. It is very similar in general appearance to Agassizia mossomi Cooke from the late Oligocene-early Miocene of southeastern United States but differs in having no enlarged pores in the anterior poriferous zones of the anterior petals.

\section{Unrecognizable Species of Agassizia Agassizia flexuosa Sánchez Roig} Agassizia flexuosa Sánchez Roig, 1949:257, pl. 41: figs. 9, 10.

No specimens of this species are present in the Sánchez Roig Collection. From Sánchez Roig 
figures this species appears to be very similar to Agassizia clevei Cotteau.

Occurrence.-Eocene, "La Concepción" farm, Guadalupe district, Morón, Camagüey Province, Cuba.

\section{Agassizia guanensis Sánchez Roig}

Agassizia guanensis Sánchez Roig, 1951:62, pl. 39: figs. 4, 5.

Occurrence.-Oligocene-Miocene, "Las Cuevas" farm, San Juan and Martínez, Pinar del Rio Province, Cuba. Sánchez Roig reports two paratypes from Km 186 at Guane, Pinar del Rio Province, Cuba.

Remarks.-Only one specimen (SRC 4242) is labelled in the Sánchez Roig Collection as belonging to this species. However, this specimen belongs to a different species, Caribbaster loveni (Cotteau), for it has 2 genital pores and lacks the reduced porepairs in the anterior poriferous zones that are characteristic of Agassizia. No specimens are known of Agassizia guanensis.

\section{Agassizia lamberti Palmer}

Agassizia lamberti Palmer in Sánchez Roig, 1949:261, pl. 41: fig. 11 .

No specimens of this species are present in the Sánchez Roig Collection. A specimen identified by Palmer as being this species is in the Academy of Natural Sciences of Philadelphia (ANSP 16611). This specimen is indistinguishable from Agassizia clevei Cotteau. However, this specimen is not from the type-locality, so I cannot assume it to be conspecific with the lost type specimen.

Occurrence.-Late Eocene according to Paimer (in Sánchez Roig, 1949:261) but Oligocene according to Brodermann (1949:316), SE of Cartagena, $3 \mathrm{~km}$ on road to Lajas, Santa Clara (now Las Villas) Province, Cuba.

\section{Genus Aguayoaster Sánchez Roig, 1952}

Test small, highly inflated; apical system very anterior, ethmolytic with 4 genital pores; anterior paired petals transverse; peripetalous and lateroanal fascioles.
HaBitat.-Žitt (1981) described in detail his views of the mode of life of this genus. He suggests that its fascioles denoted a burrowing existence and that it maintained a respiratory funnel.

REMARKS.-Žitt (1981) has re-examined the type-species of this genus and has found a lateroanal fasciole, necessitating the transfer of the genus from the Brissidae (Fischer, 1966) to the Schizasteridae. Žitt also determined that Sánchez Roig's Prenaster nuevitassensis belongs in this genus.

\section{Aguayoaster aquayoi Sánchez Roig}

Aguayoaster aguayoi Sánchez Roig, 1952b:11, pl. 8: figs. 3, 57.-Žitt, 1981:274, pls. 1, 2, pl. 3: figs. 1, 2, pl. 4.

Zítt has redescribed in careful detail this species and has extensively illustrated it.

Occurrence.-Middle Eocene, Carabollos quarries, Loma Caoba, San Diego de los Baños, Pinar del Rio Province, Cuba.

\section{Aguayoaster nuevitasensis (Sánchez Roig)}

Prenaster nuevitasensis Sánchez Roig, 1949:252, pl. 42: figs. $1,2$.

Aguayoaster nuevitasensis Sánchez Roig)._Žítt, 1981:279, pl. 3: figs. 3-6.

This species has been redescribed and re-illustrated by Žitt who suggests that it may be a synonym of Aguayoaster aguayoi.

Occurrence.-Eocene, Loma de Calisto, Nuevitas, Camagüey Province, Cuba.

\section{Genus Caribbaster, new genus}

Test small, highly inflated; apical system ethmolytic with two genital pores; ambulacrum III not petaloid, pores enlarged dorsally in peripodia, petals straight, slightly depressed, anterior petals longer than posterior; peristome very eccentric anteriorly, periproct high on posterior truncation; labrum long, narrow, in interambulacrum 1 first plate followed by single plate; peripetalous and latero-anal fascioles.

TyPe-Species. - Caribbaster loveni (Cotteau).

Habitat.-Caribbaster has peripetalous and latero-anal fascioles and larger pores and peripodia dorsally in ambulacrum III indicating that fun- 
nel-building tubefeet were present there. These characters suggest that this echinoid could live in a burrow. The small size of the peripodia in ambulacrum III and lack of an anterior groove and deeply depressed petals probably indicate that the echinoid could not live in fine sediment.

Comparison with Other Genera.-In having both a peripetalous and latero-anal fasciole, this genus belongs to the Schizasteridae. It resembles Prenaster, but differs in having two instead of four genital pores.

Remarks.-Schizaster dyscritus Arnold and Clark (1927:61) from the Eocene of Jamaica should be referred to Caribbaster. It has a peripetalous and latero-anal fasciole and has only two genital pores. Likewise, its petal arrangement and general appearance is very similar to Caribbaster loveni (Cotteau).

\section{Caribbaster loveni (Cotteau), new combination}

\section{Figure 25; Plate 34}

Prenaster loveni Cotteau, 1875:34, pl. 6: figs. 11-15.-Jackson, 1922:72, pl. 12: figs. 8, 9.

Hypselaster perplexus Arnold and Clark, 1927:56, pl. 11: figs. 8-10.

Three Cuban specimens, one from the Academy of Natural Sciences of Philadelphia and two from the USNM Collections of the Smithsonian are similar in all respects to the holotype of $C$. loveni from St. Bartholomew in the USNM Collections and to the holotype from Jamaica of Hypselaster perplexus Arnold and Clark. These Cuban specimens are better preserved than the Jamaican and St. Bartholomew specimens and show fascioles not seen previously. Photographs (Plate 34: figures 5, 6) are included of the holotype of C. loven . Cotteau (1875, pl. 6: fig. 12) shows 4 genital pores in his drawing of this specimen, but there are only 2. Photographs are also provided (Plate 34: figures 7-10) of the holotype of Hypselaster perplexus along with a drawing (Figurc 25) of the ventral plate arrangcment of another Jamaican specimen.

No specimens are present in the Sanchez Roig Collection of Prenaster sanchezi Lambert; but from

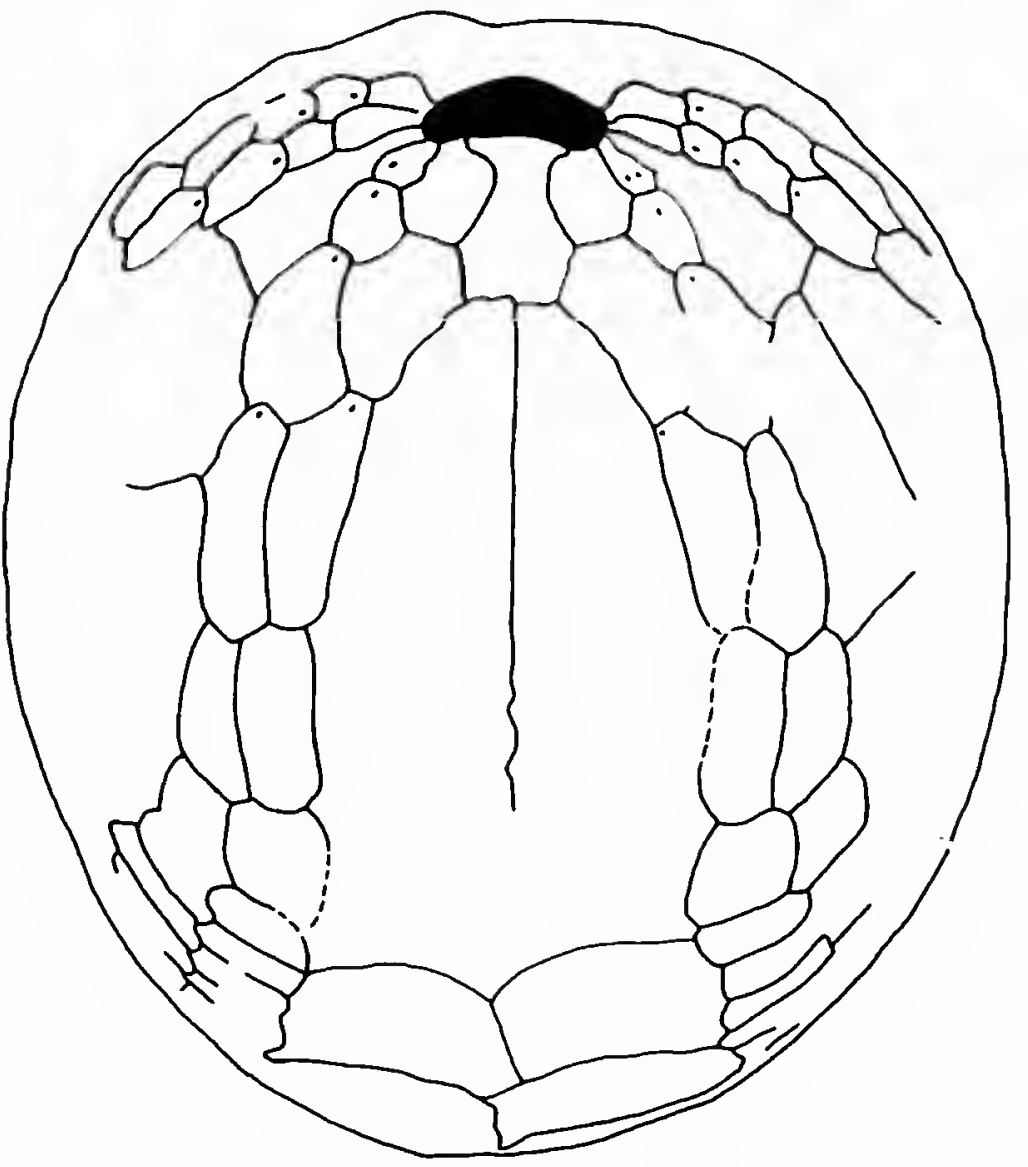

Figure 25.-Caribbaster loveni (Cotteau), ventral view of $\mathrm{Hyp}$ selaster perplexus Arnold and Clark $(=C$. loveni $)$, MCZ 3292 from Jamaica, $\times 5$.

the photographs in Sánchez Roig (1949, pl. 46: figs. 4-6), it appears to be similar to Caribbaster loven .

The description below is based on the three Cuban specimens.

Shape And Size.-Length $17 \mathrm{~mm}$ to $24 \mathrm{~mm}$, width 88 to $91 \% \mathrm{~L}$, height 77 to $82 \% \mathrm{~L}$; test highly inflated, with smoothly rounded sides, steep anterior surface.

Apical System.-Central, center of system located at distance from anterior margin 42 to $45 \%$ $\mathrm{L}$, ethmolytic with 2 genital pores, no pores in anterior genital plates.

Ambulacra.-Anterior ambulacrum III not petaloid, in very shallow groove, 46 plates in holotype $25 \mathrm{~mm}$ long; enlarged pores in dorsal portion of anterior ambulacrum in larger peripodia.

Anterior petals (II and IV) long, extending almost to margin, length 43 to $50 \%$ L, greatest width $15 \% \mathrm{~L}$; width of interporiferous zones equal 
to width of single poriferous zone; 52 porepairs in specimen $17 \mathrm{~mm}, 54$ in specimen $18 \mathrm{~mm}$, and 64 in specimen $25 \mathrm{~mm}$ long; first porepair in plate 12.

Posterior petals ( $\mathrm{V}$ and $\mathrm{I}$ ) extending more than one-half distance from apical system to margin, length 32 to $36 \% \mathrm{~L}$, width 11 to $13 \% \mathrm{~L}$; interporiferous zones of all petals slightly depressed forming a median groove in each petal.

Phyllodes very well developed with large peripodia, peripodia with high ridge dividing pores of peripodium, one pore much larger than other, in some peripodia only one pore; 12 peripodia in ambulacrum II, 4 in III, 8 in I.

Peristome.-Very anterior, distance from anterior edge of opening to anterior margin $11 \% \mathrm{~L}$; opening small, width 16 to $18 \% \mathrm{~L}$, height $8.5 \% \mathrm{~L}$.

Periproct.-High on posterior truncation, opening with height $16 \% \mathrm{~L}$, width $13 \% \mathrm{~L}$.

Fascioles.-Peripetalous fasciole wide, slightly indented in interambulacra; only short traces of latero-anal fasciole preserved.

Oral Plate Arrangement.-Labrum long, length $21 \% \mathrm{~L}$, extending posteriorly to anterior of third adjacent ambulacral plate. Length of sternal plates not clear; first plate of interambulacrum 1 followed by single plate.

Occurrence-Late Eocene, E of Arroyo Blanco, $150 \mathrm{~m}$, in road to Majagua, Camagüey Province, Cuba. A MCZ specimen is from Palmer locality 1003, Eocene, $2.1-2.2 \mathrm{mi}(3.5 \mathrm{~km}) \mathrm{N}$ of Carratera Central on road to San Diego de los Baños, Pinar del Rio Province, Cuba. Holotype of Hypselaster perplexus Arnold and Clark, Eocene, Spring Mount, St. James Parish, Jamaica. According to the 1958 geological map of Jamaica, this region lies in the middle Eocene Yellow Limestone. Eocene, St. Bartholomew Limestone, St. Bartholomew.

Specimen SRC 4242 in the Sánchez Roig Collection is labelled as the type specimen of Agassizia guanensis Sánchez Roig, but it is Caribbaster loveni (Cotteau). Its locality is from the Oligocene, "Las Cuevas" farm, San Juan and Martínez, Pinar del Rio Province, Cuba. This is the locality for the holotype of Agassizia guanensis, but Caribbaster loveni is only known from the Eocene. This specimen probably came from another locality and was misplaced in the tray with $A$. guanensis.

The holotype of Prenaster loveni is from the Eocene of St. Bartholomew.

\section{Genus Lambertona Sánchez Roig, 1953}

Lambertona Sánchez Roig, 1953b:257.-Henderson, 1975:24. Pericosmus (Lambertona) Fischer, 1966:U568.

Test large, low with deep anterior notch; apical system slightly posterior with 3 genital pores; anterior ambulacrum III not petaloid, deeply depressed, pores minute; petals narrow, deeply depressed, posterior petals much shorter than anterior; peristome very anterior, labiate with pronounced lip; peripetalous fasciole; labrum short not extending posteriorly beyond first adjacent ambulacral plate.

Habitat.-Presumably species of Lambertona lived buried in fine sediment. The presence of the peripetalous fasciole and deeply depressed petals indicate a buried life habit. The large peripodia in the dorsal portion of the ambulacrum indicate presence of funnel-building tubefeet. This fact combined with the presence of a marl matrix within the test of the holotype of $L$. lamberti suggest that this echinoid lived in fine sediment.

Comparison with Species outside of Cuba.Lambertona lamberti is very similar to the holotype of Victoriaster jamaicensis Arnold and Clark of unknown age in Jamaica. This specimen is a mold so the existence or lack of a latero-anal fasciole is unknown. Its short posterior petals and posteriorly situated apical system are features similar to $L$. lamberti and unlike Victoriaster. This species should be referred to Lambertona. It may be a synonym of $L$. lamberti, but its holotype shows too few specific characters to permit this determination.

Three species of Lambertona have been reported by Henderson from New Zealand. Lambertona lyoni (Hutton) from the Oligocene strongly resembles L. lamberti but differs in its more posterior apical system and more divergent posterior petals. Lambertona perplexa Henderson from the Miocene has 
much shorter anterior petals, more divergent posterior petals, a more posteriorly situated apical system, and a deeper anterior notch. Lambertona perdita Henderson of uncertain age also has much shorter anterior petals and a deeper notch.

Henderson refers the Australian Linthia mooraboolensis Pritchard to Lambertona. McNamara (1982, personal communication) considers the species a synonym of Victoriaster gigas.

REMARKs.-Fischer (1966:U568) considered Lambertona and Victoriaster subgenera of Pericosmus, presumably because of the supposed presence of marginal fascioles in their type-species. However, McNamara and Philip (in press) report that the type-species of Victoriaster, V. gigas McCoy, has a latero-anal fasciole, not a marginal fasciole. They refer the genus to the Schizasteridae.

Henderson (1975:24) suggested that the "marginal" fasciole of the type-species of Lambertona, $L$. lamberti, was probably a remnant of a latero-anal faciole and that Lambertona should, therefore, be referred to the Schizasteridae. He also noted that the 3 species of Lambertona from New Zealand lack a latero-anal fasciole.

I have studied the holotype and 2 beautifully preserved specimens of $L$. lamberti in the USNM Collections and in none of them is there any sign of latero-anal or marginal fascioles. The tuberculation is well preserved in all 3 specimens. If these fascioles had been present originally, they undoubtedly would be visible now. In spite of the absence of this fasciole, Lambertona should probably continue to be referred to the Schizasteridae. As pointed out by Henderson, Lambertona resembles the well-known schizasterid, Brisaster, which lacks a latero-anal fasciole in some adults. Furthermore, this genus strongly resembles Victoriaster, which has a latero-anal fasciole and is clearly a schizasterid. Victoriaster is confined to the Miocene; whereas, Lambertona is present in the EoceneMiocene, suggesting that Victoriaster descended from Lambertona with the introduction of the latero-anal fasciole in the Oligocene.

Henderson (1975:64) suggested that Lambertona originated in the Pacific and that its presence in Cuba was due to its derivation from the west via the Central American seaway. However, the $\mathrm{Cu}$ - ban species is early Eocene and the New Zealand species are Oligocene and Miocene indicating that Lambertona probably originated in the Caribbean. Likewise all the species of Victoriaster, a genus probably descended from Lambertona, are Miocene and Australian.

\section{Lambertona lamberti (Sánchez Roig)}

Figure 26; Plates 35, 36

Victoriaster lamberti Sánchez Roig, 1924a:16, pl. 1: fig. 1, pl. 2: fig. 1; 1949:249, pl. 39: fig. 1, pl. 40: fig. 1.-Mortensen, 1951:170, fig. 81 .

Lambertona lamberti (Sánchez Roig).-Sánchez Roig, 1953b:257, pls. 27, 28.-Fischer, 1966:U568, fig. 452la,b.-Henderson, 1975:24.

Material._Sánchez Roig designated 3 different specimens as the holotype. The specimen figured in Sánchez Roig (1953b, pls. 27, 28) was not included in his original description and therefore cannot be considered as a primary type. The specimen whose ventral surface is figured in Sánchez Roig (1924a, pl. 2) is stated therein to be the holotype but is not the same specimen (although published as being the holotype) whose dorsal surface is figured in plate 1 of the same paper. That specimen (SRC 4959) is presently in the Sánchez Roig Collection and has no ventral surface. It is the only specimen of this species now in the Sánchez Roig Collection and is herein selected as the lectotype. This specimen, although lacking its ventral surface, is only slightly weathered and its tubercles and fasciole are well pre-

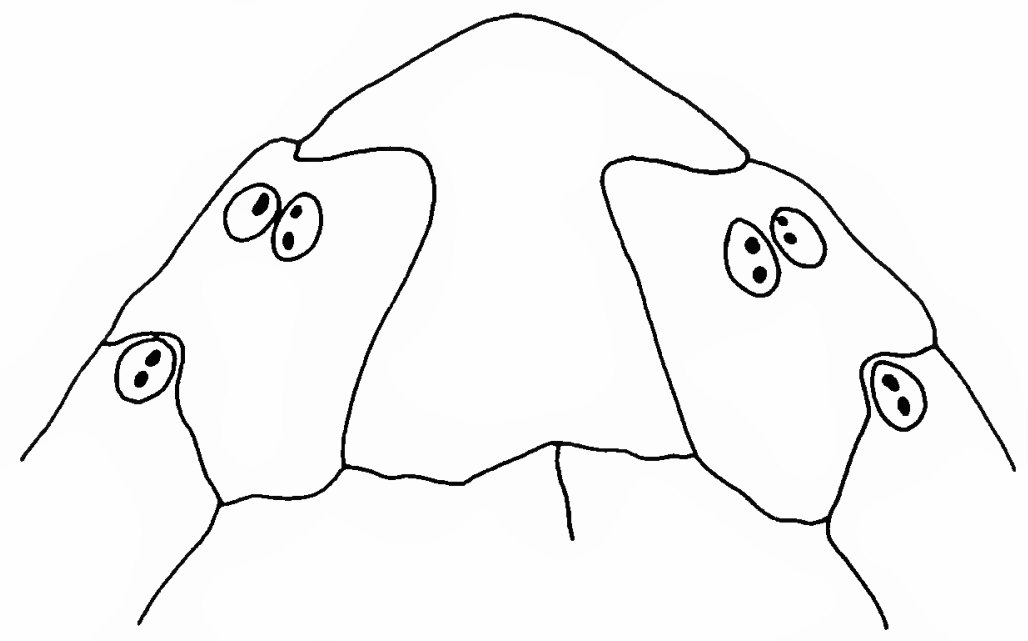

Figure 26.--Lamberiona lamberti (Sánchez Roig) labrum of a paralectotype, USNM $352864, \times 3$. 
served. Two additional specimens are in the Smithsonian (USNM 352864, 352870), the latter of which is labelled as a cotype. Although these specimens lack their posterior portions, they are beautifully preserved, USNM 352864 still having many spines attached (Plate 36: figure 3).

Shape AND Size.-Length of lectotype $130 \mathrm{~mm}$, width $136 \mathrm{~mm}$, and height estimated at $35 \mathrm{~mm}$. Greatest width anterior, greatest height posterior at apical system.

Apical System.-Central, located in lectotype at distance from anterior margin to center of genital pores equal to $55 \% \mathrm{~L}$. On lectotype only left part of apical system preserved showing pores in genital plates 3 and 4; total number not known.

AmBUlacra.-Anterior ambulacrum III not petaloid, in very deep groove with depth midway from apical system to margin estimated at $9.8 \%$ $\mathrm{L}$, depth at margin estimated at $11 \%$ L. Porepairs largest adapical to fasciole; pores in peripodia, inner pore smaller, anterior to outer pore of pair; 52 plates in ambulacrum.

Anterior petals (II and IV) long, narrow, extending four-fifths distance from apical system to margin, length $47 \% \mathrm{~L}$, width $3.5 \% \mathrm{~L}$; petals curving slightly anteriorly; in groove with depth $3.6 \%$ $\mathrm{L}$; width of interporiferous zone less than width of single poriferous zone; pores conjugate, 83 porepairs in petal. Pores beyond petals double.

Posterior petals (V and I) much shorter than anterior, extending one-half distance from apical system to margin, length $20 \% \mathrm{~L}$, width $3.7 \% \mathrm{~L}$; 54 porepairs in petal.

Phyllodes with porepairs in large peripodia (Plate 34: figure 2).

Peristome.-Very anterior, distance from anterior margin to anterior edge of peristome estimated at $18 \% \mathrm{~L}$. Opening labiate with pronounced lip, width $9.2 \% \mathrm{~L}$.

Periproct.- Not visible on any specimens examined but according to Sánchez Roig (1949: 250) marginal, oval.

Fascioles-Peripetalous fasciole widest where crossing around end of anterior petals, angular course, indented in posterior paired interambulacra. No marginal or latero-anal fasciole.

Tuberculation and Spines.-No large tuber- cles within peripetalous fasciole. Tubercles very small dorsally, larger on anterior margin; largest dorsally where mamelons eccentric anteriorly on large raised scrobicules. Ventral spines slim, length $10 \mathrm{~mm}$ (Pl. 35: fig. 3).

Oral Plate Arrangement.-Labrum (Figure 26) mushroom-shaped, height $8.8 \% \mathrm{~L}$, width $9.0 \%$ $\mathrm{L}$, followed by 2 large plastron plates, incomplete so dimensions not available. Labrum not extending posteriorly beyond first adjacent ambulacral plate.

Occurrence.-Early Eocene, quarries of Tejar Consuelo, Cerro, Ciénaga, Habana Province, Cuba.

Comparison with Other Species.-This species is very similar in its shape and petal arrangement to Lambertona jamaicensis (Arnold and Clark) of unknown age from Jamaica (but probably Eocene considering that most Jamaican fossil echinoids are this age). The Jamaican holotype and only known specimen is too poorly preserved to determine whether it is conspecific with the Cuban species.

REMARks.-Sánchez Roig (1949:249) reported that preservation did not permit the observation of a marginal fasciole, but later (1953b:257) noted that the marginal fasciole was thin, sinuous, and incomplete. I have studied the holotype and 2 other beautifully preserved specimens, and in none of them is there any sign of a marginal or latero-anal fasciole. These specimens have their tuberculation well preserved; and had these fascioles been originally present, they would have been visible.

\section{Genus Linthia Desor, 1853}

Test commonly small, heart-shaped, anterior ambulacrum III not petaloid, depressed with groove at margin; apical system ethmolytic with 4 genital pores, petals of almost equal length; peripetalous fasciole sharply indented between petals, latero-anal fasciole present.

Eight species from Cuba have been referred to Linthia. Two, Linthia aguayoi Sánchez Roig and Linthia atolladosae Sánchez Roig, are referred to Pericosmus. Linthia avilensis Sánchez Roig probably 
is not a Linthia. Its type is too poorly preserved for generic identification. The type specimens have been lost of Linthia garciai Sánchez Roig and Linthia cretacica Sánchez Roig. Linthia alta Sánchez Roig and Linthia gonzalezmunozi Sánchez Roig are considered as synonyms of Linthia brodermanni Sánchez Roig. One new species, Linthia monteroae, is described.

In summary two Cuban species of Linthia are recognized definitely. One of them, L. brodermanni, is very similar to Linthia variabilis Slocum from the late Cretaceous of Texas and southeastern United States.

Habitat.-Species of Linthia probably lived buried in mud. The crowded and enlarged porepairs in the dorsal portion of ambulacrum III indicate the presence of funnel-building tubefeet necessary for living in a burrow in mud. The depressed petals, anterior groove, and fascioles are also indicative of the capability of living in fine sediment.

\section{Linthia? avilensis Sánchez Roig}

Plate 40: figures 5-7

Linthıa avilensis Sánchez Roig, 1949:264; 1951:64, pl. 40: fig. 8.

Material.-The holotype (SRC 4158), which is the only known specimen is very poorly preserved. The test is badly weathered lacking all traces of the fascioles. Most of the apical system is absent and most of the posterior surface is broken away.

Shape AND Size.-Length $38.0 \mathrm{~mm}$, width $96 \%$ L, height $68 \%$ L. Greatest height posterior to center, greatest width central to slightly posterior. Posterior truncation appears to be vertical to slightly overhanging.

Apical System.-Only the posterior part of the apical system is preserved showing the two posterior genital pores. Although Sánchez Roig (1949:264) reported 4 genital porcs, it is not known whether the anterior genital plates were perforated (that part of the apical system is not preserved on the holotype). Apical system ethmolytic, located at distance from anterior margin to center of genital pores equal to $56 \% \mathrm{~L}$.

Ambulacra.-Anterior ambulacrum III not petaloid, in groove extending from apical system to peristome, groove deepest adapically where width of groove $13 \% \mathrm{~L}$. Pores largest in adapical portion, with first enlarged porepair in plate 6 or 7.

Anterior petals (II and IV) extending twothirds distance from apical system to margin; petals not of equal length (probably result of distortion), petal II with length $37 \%$ L, petal IV $38 \%$ L. Petals curving distally with greatest width, $13 \% \mathrm{~L}$, near end of petal; in deep groove. Width of interporiferous zone less than width of single poriferous zone. Pores conjugate with 56 (est.) porepairs in petal.

Posterior petals (V and I) short, extending less than one-half distance from apical system to margin, length $18 \% \mathrm{~L}$; straight, width $10 \% \mathrm{~L}$. Interporiferous zone at widest almost as wide as single poriferous zone; 30 porepairs in petal. Not clear whether pores beyond petals are single or double.

PERISTOME.-Anterior, located at distance from anterior margin to anterior edge of peristome equal to $57 \% \mathrm{~L}$, opening wider than high with width $23 \% \mathrm{~L}$, height $7.9 \% \mathrm{~L}$.

Periproct.-Not preserved.

FAScioles.-Slight indentations distal to end of petal II indicate probable presence of peripetalous and perhaps a latero-anal fasciole.

Oral Plate Arrangements.-Labrum short, broad, extending posteriorly two-thirds height of first adjacent ambulacral plate.

Occurrence.-Late Cretaceous, "Maniadero" farm, $7.5 \mathrm{~km}$, W Jicotea, Camagüey Province, Cuba.

REMARKs.-The generic identity of this species is uncertain because of insufficient knowledge about the presence of a latero-anal fasciole or the number of genital pores. It does not appear to be a Linthia because its anterior petals are more flexuous and its posterior petals are shorter than commonly found in this genus. It superficially resembles Schizaster. Its Cretaceous age is doubtful; the short posterior petals and the depth and shape of all petals suggest a later occurrence. 


\section{Linthia brodermanni Sánchez Roig}

Figures 27, 28; Plates 37-39

Linthia brodermanni Sánchez Roig, 1949:263, pl. 49: figs. 2, 4. Micraster elevatus Sánchez Roig, 1949:218, pl. 47: figs. 4, 5. Hemiaster lamberti Sánchez Roig, 1949:238, pl. 35: figs. 7, 8. Linthia alta Sánchez Roig, 1949:266, pl. 49: figs. 3, 5.

?Linthia gonzalezmunozi Sánchez Roig, 1952c:23, pl. 9: fig. 1.

Material.-Three specimens. SRC 4851 (Sánchez Roig, 1949, pl. 49: fig. 2) is herein designated the lectotype. It is very well preserved; whereas, the lectoparatype, SRC 4858 (Sánchez Roig, 1949, pl. 49: fig. 4), is fractured with part of the dorsal surface missing. The lectotype of Hemiaster lamberti (SRC 4864) (Sánchez Roig, 1949, pl. 35: fig. 7), herein designated, is fairly complete but badly weathered. The second cotype figured by Sánchez Roig (1949, pl. 35: fig. 8) is missing.

Shape and Size. - Length 44 to $45 \mathrm{~mm}$ (mean $44.5 \mathrm{~mm}$ ); greatest width anterior of center, width 97 to $99 \%$ L; height 50 to $59 \%$ L, greatest height posterior to center; posterior truncation nearly vertical; marginal outline slightly angular.

Apical System.-Four genital pores, ethmolytic (Figure 27A); located at distance from anterior margin to center of genital pores equal to 32 to $34 \% \mathrm{~L}$.

Ambulacra.-Anterior ambulacrum III not petaloid, in groove from apical system to peristome, groove deepest at margin of test where depth equal to 5.0 to $7.7 \%$ L. Pores paired throughout entire length of all ambulacra. Pores largest in adapical portion of ambulacrum with 38 to 42 porepairs in this region; greatly reduced in size between this portion and the phyllode.

Anterior petals (II and IV) long, extending almost to margin; length 37 to $42 \%$ L, width 11 to $12 \% \mathrm{~L}$. Petals straight to slightly curved, depressed in groove, depth 2.2 to $5.4 \% \mathrm{~L}$; petals narrow with greatest width 11 to $12 \% \mathrm{~L}$. Pores conjugate with outer pores slit-like; 60 porepairs in specimen $44.1 \mathrm{~mm}$ long; interporiferous zone at its greatest equal in width to single poriferous zone. First petaloid porepair in plate 14 .

Posterior petals (V and I) short, extending slightly less than one-half distance from apical
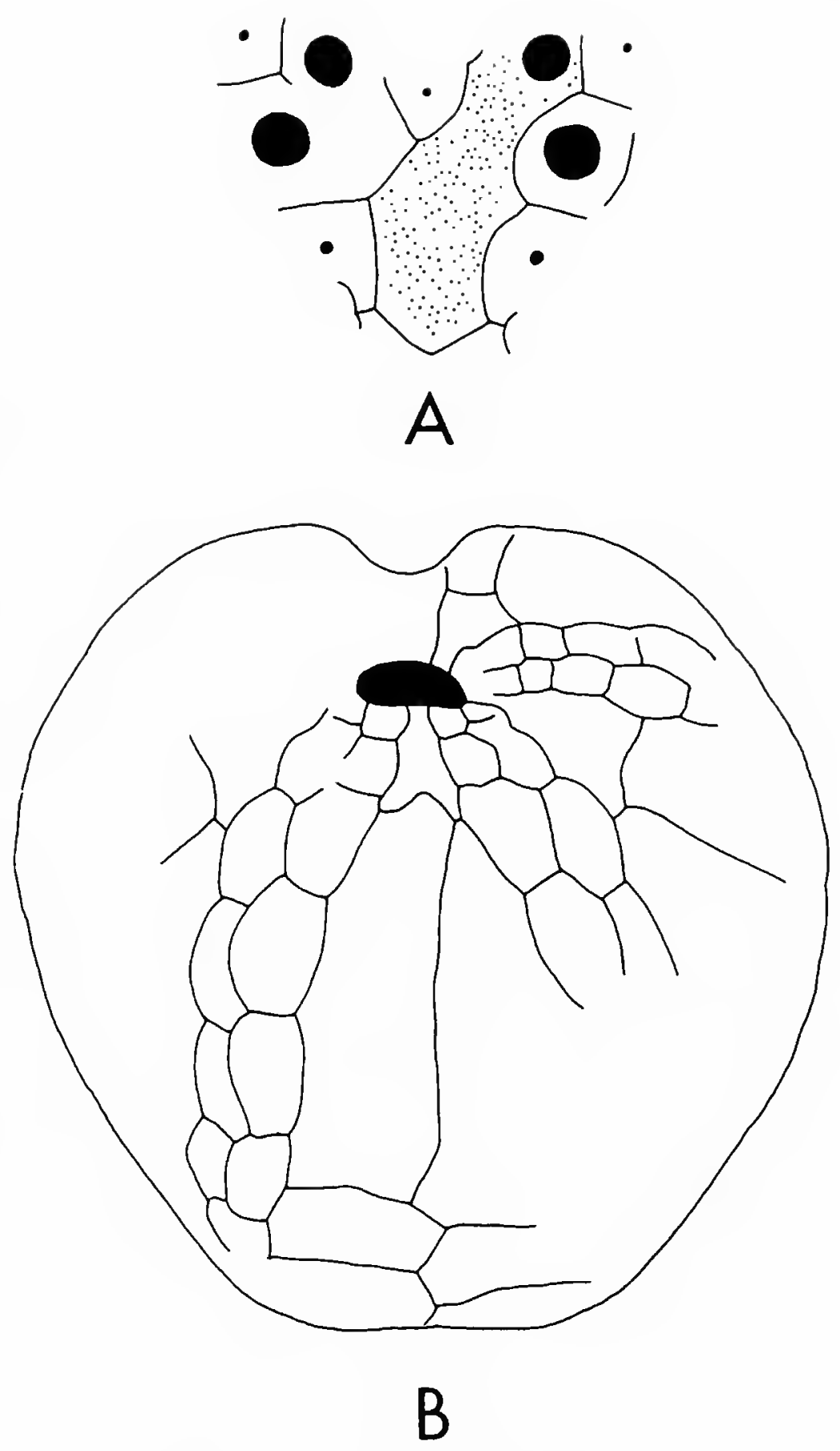

Figure 27.-Linthia brodermanni Sánchez Roig: A, apical system of the lectotype, SRC $4851, \times 8$; , ventral side of the lectotype of Hemiaster lamberti Sánchez Roig $(=L$. brodermanni), SRC 4864, × 2 .

system to posterior margin; length 27 to $28 \% \mathrm{~L}$; width 10 to $12 \% \mathrm{~L}$. Petals curving slightly towards midline; depressed in groove with depth 1.3 to $3.2 \% \mathrm{~L} ; 52$ porepairs in specimen $44 \mathrm{~mm}$ long.

Peristome.-Anterior, located at distance from anterior margin to anterior edge of peristome equal to 15 to $17 \% \mathrm{~L}$, opening wider than high with width 11 to $15 \% \mathrm{~L}$, height 6.0 to $6.8 \% \mathrm{~L}$.

Periproct.-Located high on nearly vertical truncation, slightly visible from above. Opening 
higher than wide, height 12 to $14 \% \mathrm{~L}$, width 9.3 to $11 \% \mathrm{~L}$; occurs within plates 4-7.

Fascioles.-Peripetalous fascioles narrow, curving sharply into interambulacra 1 and 4, but not into interambulacra 2 or 3 . Fasciole crosses ambulacra II or IV on plates 12 or 13 , ambulacra $\mathrm{V}$ or I on plates 17 or 18 , position on interambulacra not clear. Lateroanal fasciole passes below periproct at distance from periproct equal to less than height of periproct; fasciole very narrow, only present on unweathered portions of test.

Oral Plate Arrangement.-Labrum extending posteriorly to two-thirds height of third ambulacral plate (Figure 27B); length of labrum 12 to $14 \% \mathrm{~L}$. Two sternal plates long, 51 to $52 \% \mathrm{~L}$; bordered by ambulacral plates 3-6. First plate of interambulacra 1, 2, 3, 4 extending to peristome. Phyllodes with 5 large porepairs in ambulacrum III, 10 or 11 in II or IV, 6 or 7 in V or I.

Occurrence.-Late Cretaceous, lectotypes of $L$. brodermanni and $H$. lamberti and holotypes of $L$. alta and Micraster elevatus from west edge of Batey Dos Hermanos, in mulberry patch (Palmer loc. 1833), Las Villas Province, Cuba. Lectoparatype of $L$. brodermanni from fields $1 / 2 \mathrm{~km}$ of $\mathrm{W}$ of Central Manuelita, along cane railroad (Palmer loc. 1729), Las Villas Province, Cuba. Holotype of $L$. gonzalezmunozi, provisionally referred to this species, from Late Cretaceous (Senonian) at Abra de Castellón, Cumanayagua, Las Villas Province, Cuba.

Comparison with Other Species.-Linthia brodermanni resembles in general appearance $L$. variabilis Slocum from the late Cretaceous (Maestrichtian) of Texas and southeastern United States but differs in having narrower petals, narrower ambulacrum III, and a more anterior apical system.

L. brodermanni differs from Linthia monteroae, new species, also from the Cretaceous of Cuba, in having a lower test, broader petals and a smaller peristome. It differs from Linthia alabamensis Clark from the Paleocene of Alabama in having a smaller test with its greater width and height more posterior and in having longer posterior petals.
Remarks. - The lectotype (Plate 38: figures 46) of Hemiaster lamberti is indistinguishable from the types of Linthia brodermanni. It was collected at the same locality as the lectotype of $L$. brodermanni. Because its test is weathered, the latero-anal fasciole is not present. Presumably this is why Sánchez Roig placed it in Hemiaster.

Although the holotype of Linthia alta Sanchez Roig is much higher than the type specimens of $L$. brodermanni, it appears to be conspecific. It comes from the same locality as the types of $L$. brodermanni and is similar in all charaeters exeept its height and size. The petals are of similar length, width, and shape with similar number of porepairs relative to the size of the test. The labrum also extends back to two-thirds the height of the third adjacent ambulacral plate. The fascioles are similar in location and cross the same or almost the same ambulacral plates. The peristome is similar in position, size, and outline.

Linthia brodermanni is very similar to Linthia gonzalezmunozi Sánchez Roig, also from the Cretaceous of Cuba, differing only in having a slightly shallower anterior notch and slightly narrower test. The species may be conspecific but not enough specimens are available to be able to know the significance of these minor differences. For this reason L. gonzalezmunozi is only provisionally considered a synonym of $L$. brodermanni.

Micraster elevatus Sánchez Roig is from the same locality as $L$. brodermanni and is certainly a synonym. It is identical in all respects.

\section{SYNONYMS}

\section{Linthia alta Sánchez Roig}

Figure 28; Plate 39: figures 1-3

Material. - the holotype and only known specimen (SRC 4223) is moderately well preserved; the fascioles are visible. The test is slightly distorted, the right side being somewhat compressed. The posterior is broken away and most of the right oral side is absent.

Shape and Size.-Length uncertain, approximately $60 \mathrm{~mm}$, width $57 \mathrm{~mm}$, height $43 \mathrm{~mm}$ (76\% 
W). Greatest width anterior to center, greatest height posterior to apical system.

Apical System.-Four genital pores, ethmolytic, located $18 \mathrm{~mm}$ from anterior margin, at distance equal to $32 \% \mathrm{~W}$.

Ambulacra.-Anterior ambulacrum III not petaloid, in deep groove from apical system to peristome, depth of groove at anterior margin 2.7 $\mathrm{mm}(4.7 \% \mathrm{~W})$. Pores paired throughout length of ambulacrum with pores largest in adapical portion with approximately 52 porepairs between apical system and peripetalous fasciole; 8 porepairs between fasciole and peristome; 60 in ambulacrum.

Anterior petals (II and IV) long, extending almost to margin, length $28 \mathrm{~mm}(50 \% \mathrm{~W})$. Petals straight, depressed in groove with greatest depth $1.4 \mathrm{~mm}(2.4 \% \mathrm{~W})$, width $5.6 \mathrm{~mm}(9.8 \% \mathrm{~W})$. Both outer and inner pore of pair slightly elongated transversely, not clear whether or not conjugate; 82 porepairs in petal. Interporiferous zone approximately same width as poriferous; 108 porepairs in abulacrum.

Posterior petals ( $\mathrm{V}$ and I) short, extending onehalf distance from apical system to margin, length $20 \mathrm{~mm}(36 \% \mathrm{~W})$. Petals straight, depressed in groove with depth $1.6 \mathrm{~mm}(2.8 \% \mathrm{~W})$, width 5.4 $\mathrm{mm}(9.4 \% \mathrm{~W}), 64$ porepairs.

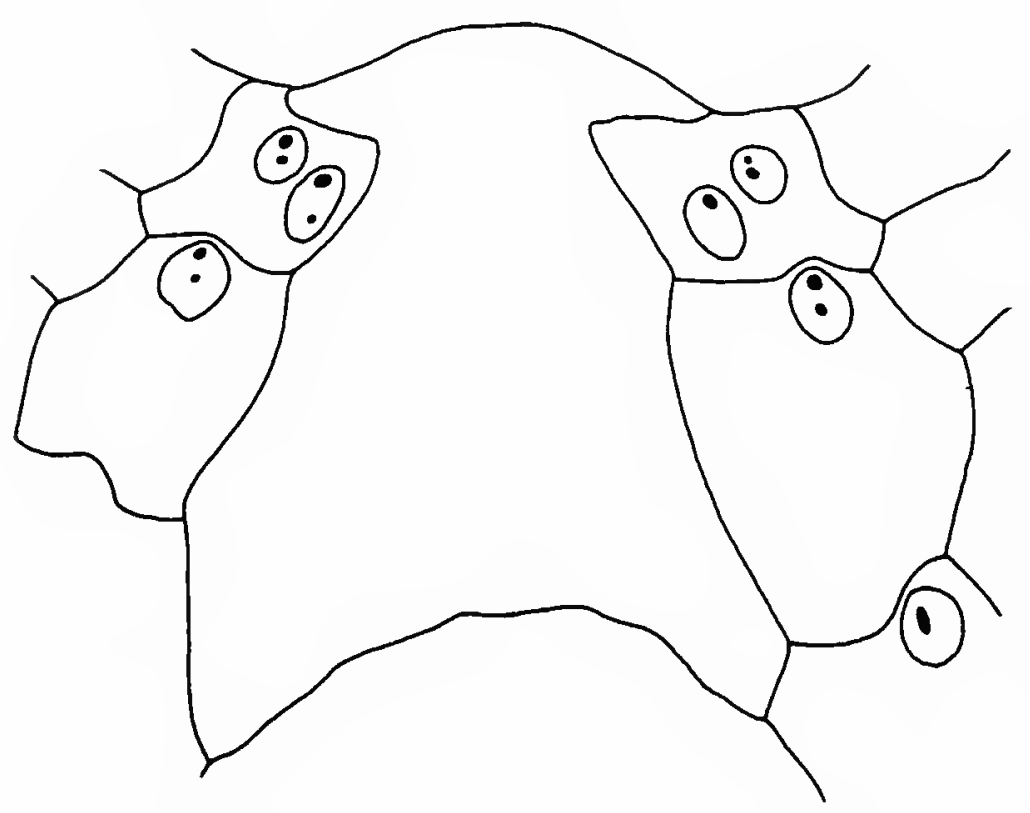

FIGURE 28.-Linthia brodermanni Sánchez Roig, labrum of holotype of Linthia alta Sánchez Roig (= L. brodermanni), SRC $4223, \times 6$.
Peristome-Located at distance from anterior margin to anterior edge of peristome equal to $10.0 \mathrm{~mm}(18 \% \mathrm{~W})$. Width of opening $8.9 \mathrm{~mm}$ $(16 \% \mathrm{~W})$, height $4.0 \mathrm{~mm}(7.0 \% \mathrm{~W})$. Phyllodes with 4 large peripodia in ambulacrum III, 12 in II, 7 or 8 in I.

Periproct,-Not preserved.

FAscioles.-Peripetalous fascioles narrow, deeply re-entering interambulacra 1, 4, and 5; crossing ambulacra II or IV on plates 12 or 13, ambulacrum III on plates 4 or 5 . Only short portion of latero-anal fasciole preserved.

Oral Plate Arrangement.-Labrum large, height $6.9 \mathrm{~mm}(12 \% \mathrm{~W})$, extending posteriorly to two-thirds height of third adjacent ambulacral plate (Figure 28).

Occurrence.-Late Cretaceous, $\mathrm{W}$ edge of $\mathrm{Ba}$ tey Dos Hermanos, in mulberry patch (Palmer loc. 1833), Las Villas Province, Cuba.

\section{Linthia gonzalezmunozi Sánchez Roig}

Plate 39: figures 4-7

Material.-The holotype is the only known specimen (SRC 4247) and is very poorly preserved. Much of the surface of the test is absent due to weathering. Most of the tuberculation is obliterated with only small portions of the fascioles present.

Shape and Size.-Length $30 \mathrm{~mm}$, width 31 mm (105\% L), height $22 \mathrm{~mm}$ (73\% L). Greatest width central, greatest height central, posterior to apical system. Posterior truncation slightly overhanging; marginal outline slightly angular.

Apical System.-Four genital pores, ethmolytic, located at distance from anterior margin to center of genital pores equal to $35 \% \mathrm{~L}$.

AMBULACRA.-Anterior ambulacrum III not petaloid, in groove from apical system to peristome, depth of groove at midlength from apical system to margin $6.7 \% \mathrm{~L}$, depth of groove at margin 9.7\% L. Pores paired throughout length of ambulacrum with pores largest in adapical portion with approximately 40 porepairs in this region; greatly reduced in size between this portion and the phyllode. 
Anterior petals (II and IV) long, extending slightly more than two-thirds distance from apical system to margin, length $42 \% \mathrm{~L}$. Petals straight, depressed in groove with greatest depth nearer apical system, depth $3.7 \% \mathrm{~L}$, width $10 \% \mathrm{~L}$. Both outer and inner pore of porepair slit-like; 64 porepairs in petal. Interporiferous zone very slightly wider than poriferous zone.

Posterior petals ( $\mathrm{V}$ and I) short, extending onehalf distance between apical system and posterior margin, length $30 \% \mathrm{~L}$, width $9.4 \%$ L. Petals straight, depressed in groove with depth $2.7 \% \mathrm{~L}$; 44 porepairs.

Peristome.-Incompletely preserved, located at distance from anterior margin to anterior edge of peristome equal to $16 \% \mathrm{~L}$, opening wider than high with width $22 \% \mathrm{~L}$, height $9.7 \% \mathrm{~L}$ (est.).

Periproct.-Located high on slightly overhanging posterior truncation. Opening higher than wide with height $20 \% \mathrm{~L}$, width $12 \% \mathrm{~L}$.

FAscioles.-Only small portions of peripetalous and latero-anal fascioles preserved. Because of poor preservation of test it is not possible to know which plates they cross.

Oral Plate Arrangement.-Unknown, most of plates absent.

Occurrence.-Late Cretaceous (Senonian), Abra de Castellón, Cumanayagua, Las Villas Province, Cuba.

\section{Micraster elevatus Sánchez Roig}

Plate 38: figures 1-3

Material.-One specimen, the holotype (SRC 4256), which is well preserved except for absence of the front of the specimen. The test is not distorted and the tuberculation is preserved showing the fascioles.

Shape And Size.-Length unknown, width 62 $\mathrm{mm}$, height $43 \mathrm{~mm}$; greatest width anterior, greatest height posterior.

Apical System.-Probably anterior, 4 genital pores, ethmolytic with genital plate 2 extending posteriorly separating posterior ocular plates.

AmBUlacra.-Anterior ambulacrum III not petaloid. Anterior petals (II and IV) straight in groove; interporiferous zones approximately same width as single poriferous zones; pores conjugate. Petal extending almost to margin, length 33.5 mm, width $6.2 \mathrm{~mm}$; 88 porepairs in petal. Posterior petals ( $\mathrm{V}$ and $\mathrm{I}$ ) short, extending slightly more than one-half distance from apical system to margin, length $24.0 \mathrm{~mm}$, width $6.0 \mathrm{~mm} ; 70$ porepairs.

Peristome.-Absent.

PERIPROCT.-Located high on nearly vertical truncation, height of opening $7.1 \mathrm{~mm}$, width 5.6 mm.

Fascioles. - Peripetalous fasciole narrow, curving sharply in posterior paired interambulacra. Latero-anal fasciole passes below periproct at distance equal to slightly less than height of periproct.

Occurrence.-Late Cretaceous, W edge of Batey Dos Hermanos, Las Villas Province, Cuba.

\section{Linthia monteroae, new species}

$$
\text { Plate 40: figures 1-4 }
$$

Material.-One specimen (ANSP 16656), moderately well preserved, not distorted and showing most of the features of its test.

Shape AND Size.-Length $56 \mathrm{~mm}$, width $96 \%$ $\mathrm{L}$, test very high with height $73 \%$ L. Greatest width anterior of center; greatest height posterior.

Apical System.-System slightly anterior of center; 4 genital pores, ethmolytic.

AmBULACRA.-Anterior ambulacrum III not petaloid, in deep, wide groove from apical system to peristome, depth at groove midway from apical system to margin $8.1 \% \mathrm{~L}$, width $15 \% \mathrm{~L}$; depth of groove at margin $7.3 \% \mathrm{~L}$; 56 enlarged porepairs, first enlarged porepair in plate 7 .

Anterior petals (II and IV) long, extending almost to margin, length $45 \% \mathrm{~L}$, greatest width $9.8 \% \mathrm{~L}$, petals curve convexly anteriorly; 70 porepairs in petals II, first porepair in plate 12 or 13. Posterior petals ( $\mathrm{V}$ and I) short, extending approximately one-half distance from apical system to margin, length $31 \% \mathrm{~L}$, greatest width $9.8 \%$ $\mathrm{L}$; 62 porepairs in petal I. Interporiferous zones slightly wider than single poriferous zone. 
Peristome.-Anterior, located at distance from anterior margin to anterior edge of peristome equal to $18 \% \mathrm{~L}$, opening wider than high, crescent shaped, width $23 \% \mathrm{~L}$, height $8.1 \% \mathrm{~L}$.

PERIPROCT.-Located high on posterior truncation, which slopes forward making periproct slightly visible dorsally. Opening higher than wide, height $20 \%$ L, width $13 \%$ L.

Fascioles.-Peripetalous fasciole deeply inserted between petals crossing plate 5 in ambulacrum III, plate 11 in ambulacrum II. Lateroanal fasciole passing in deep trough below periproct.

Oral Plate Arrangement.-Labrum very short, not extending posterior to first adjacent ambulacral plate.

Occurrence.-Eocene (Palmer loc. 1085), E of Arroyo Blanco, $150 \mathrm{~m}$, in road to Majagua, Camagüey Province, Cuba.

Comparison with Other Species.-This species differs from Linthia brodermanni Sánchez Roig from the Cretaceous of Cuba in its higher test, with height $73 \% \mathrm{~L}$ as compared to $50-59 \% \mathrm{~L}$ in L. brodermanni, in its far wider peristome $23 \% \mathrm{~L}$ versus $11-15 \% \mathrm{~L}$, and narrower petals with width $9.8 \% \mathrm{~L}$ versus $11-12 \% \mathrm{~L}$.

\section{Unrecognizable Species of Linthia}

\section{Linthia cretacica Sánchez Roig}

Linthia cretacica Sánchez Roig, 1949:264, pl. 47: figs. 1-3.

No specimens of this species are now in the Sánchez Roig Collection and I have been unable to find any elsewhere.

Occurrence.-Late Cretaceous, approximately $3 \mathrm{mi}(4.8 \mathrm{~km}) \mathrm{S}$ of Santa Clara, Santa Clara (now Las Villas) Province?, Cuba.

\section{Linthia garciai Sánchez Roig}

Linthia garciai Sánchez Roig, 1952c:24, pl. 9: fig. 2.

No specimens of this species are now in the Sánchez Roig Collection and I have found none elsewhere.
Occurrence.-Late Eocene, Báguanos, Holguín, Santiago de Cuba, Oriente Province, Cuba.

\section{Genus Prenaster Desor, 1853}

Test small, ovoid, inflated; apical system anterior, ethmolytic, with 4 genital pores; lateroanal and peripetalous fascioles present, the latter extending onto oral side anteriorly.

Remarks.-Five specimens of Prenaster have been described, but no specimens are now known of three of them. Sánchez Roig's illustrations are too poor to permit their comparison with each other or with other species of this genus. The one species redescribed herein, Prenaster parous Palmer, is distinct from the only other species, Prenaster jeanneti Pijpers, known from the Caribbean region. This genus has never been found in North America. Sánchez Roig's Prenaster nuevitasensis is transferred by Žitt (1981) to Aguayoaster.

HaBitat.-No species of this genus are alive today, but because this echinoid has peripetalous and latero-anal fascioles, large peripodia dorsally in ambulacrum III indicating presence of funnelbuilding tubefeet, and depressed petals, it is reasonable to suggest that it lived buried in fine sediment.

\section{Prenaster parvus Palmer}

Plate 41: figures 1-5

Prenaster parous Palmer in Sánchez Roig, 1949:251, pl. 42: fig. 12.

MATERIaL.-The holotype is no longer present in the Sánchez Roig Collection. The following description is based on 2 topotypic specimens at the Academy of Natural Sciences of Philadelphia. Both are moderately well preserved, with undistorted tests and with enough of the tuberculation preserved to show the position of the fascioles. Measurements for ANSP 16649 are noted first.

Shape AND Size.-Length 24 and $23 \mathrm{~mm}$; width 87 and $87 \% \mathrm{~L}$; height 74 and $73 \% \mathrm{~L}$. Greatest height and width anterior.

Apical System.-Anterior, distance of system from anterior margin 19 and $18 \%$ L; 4 genital 
pores, anterior pores much smaller than posterior; ethmolytic.

Ambulacra.-Anterior ambulacrum II not petaloid, in shallow groove extending from apical system to peristome, greatest width 11 and $12 \%$ L; dorsally peripodia well developed with high ridge separating pores (Plate 41: figure 5).

Anterior petals (II and IV) extending almost to the margin, length 43 and $47 \% \mathrm{~L}$, greatest width 11 and $12 \% \mathrm{~L}$, highly divergent, forming arc of 180 degrees; interporiferous zones narrower than single poriferous zone; 58 porepairs in larger specimen, 54 in smaller. First petaloid porepair in plate 12.

Posterior petals (V and I) extending one-half distance from apical system to margin, length 44 and $43 \% \mathrm{~L}$, greatest width 11 and $12 \% \mathrm{~L}$; petals slightly divergent distally; 56 porepairs in larger specimen, 54 in smaller.

Phyllodes present but not preserved well enough to permit description.

Peristome.-Anterior, distance from anterior edge of peristome to anterior margin 19 and $18 \%$ L; width of opening 21 and $18 \% \mathrm{~L}$, height 12 and $10 \% \mathrm{~L}$.

Periproct.-Supramarginal, opening large, higher than wide, height $25 \% \mathrm{~L}$, width $16 \% \mathrm{~L}$.

Fascioles.-Peripetalous fasciole narrow, indented in interambulacra extending deeply around ambulacrum III onto ventral surface. Latero-anal fasciole narrower than peripetalous, passing posteriorly below periproct.

Oral Plate Arrangement.-Labrum, broad, short, length $5.6 \% \mathrm{~L}$; sternal plates long, length $55 \% \mathrm{~L}$, combined width $35 \% \mathrm{~L}$; first plate of interambulacrum 2 followed by pair of plates.

Occurrence.-Late Eocene (Palmer loc. 1085), E of Arroyo Blanco, $150 \mathrm{~m}$, in road to Majagua, Camagüey Province, Cuba. Sánchez Roig (1949:252) cites the locality for the specimen he received from Palmer as San Diego de los Baños, $3 \mathrm{~km}$ from cross roads of central highway; quarries near Puente, Pinar del Rio Province, Cuba. I suspect that this locality may not be correct. Palmer's specimens are not from there, and $I$ have not seen any specimens of this species in a large collection of specimens from that locality.

Comparison with Other Species.-I have compared this species with 4 specimens of Prenaster jeanneti Pijpers from the Eocene of Bonaire (Dutch West Indies). It is easily distinguished by its far more anterior peristome, less pointed anterior margin, and wider, more depressed petals. Photographs of the Bonaire species are included on Plate 41: figures 6-8.

\section{Unrecognizable Species of Prenaster}

Prenaster clarki Sánchez Roig, emendation Prenaster clarcki [sic] Sánchez Roig, 1949:252, pl. 46: figs. $7,8$.

The type specimen is lost and no other specimens are known of this species. The original illustrations are so poor that it is not possible to compare this species with others of this genus.

Occurrence.-Late Eocene, Loma Caoba, San Diego de los Baños, Pinar del Rio Province, Cuba.

\section{Prenaster elongatus Sánchez Roig}

Prenaster elongatus Sánchez Roig, 1949:250, pl. 50: figs. 3, 4.

The type specimen is lost and no other specimens are known of this species.

Occurrence.-Brodermann (1949:326) states Cretaceous; Campos del Central Manuelita, 1/2 km SW of station, Santa Clara (now Las Villas) Province, Cuba. From Sánchez Roig's photographs, this species appears very similar to Prenaster parvus Sánchez Roig from the Eocene. This genus has never been found in rocks older than Eocene; and I, therefore, doubt this Cretaceous determination. Sánchez Roig considered the locality early Eocene.

\section{Prenaster sanchezi Lambert}

Prenaster sanchezi Lambert in Sánchez Roig, 1949:251, pl. 46: figs. 4-6. 
The type specimen is lost and no other specimens are known. Sánchez Roig's illustrations are too poor to form the basis for a comparison of this species with other species of this genus.

Occurrence.-Eocene, Loma de Calisto, Nuevitas, Camagüey Province, Cuba.

\section{Suborder Micrasterina A.G. Fischer, 1966}

\section{Family Micrasteridae Lambert, 1920}

\section{Genus Habanaster Lambert, 1924}

Test small, high, apical system ethmophract with 2 or 3 genital pores; no petals, phyllodes present, peristome large, anterior, labrum long, plastron mesamphisternous; no peripetalous fasciole; subanal fasciole prominent.

Mortensen (1950:173) regarded Habanaster as incertae sedis because the structure of both the apical system and the plastron was unknown. Wagner and Durham (1966:U542) considered placement of the family as uncertain and placed the genus among the holasteroids. I have seen specimens showing clearly the apical system and plastron, and Habanaster definitely is a spatangoid. Its apical system is not elongate or disjunct and its plastron is amphisternous as typically spatangoid. As it has a subanal fasciole, Habanester is here referred to the suborder Micrasterina and to the family Micrasteridae. It most resembles Ovulaster in that both genera lack petals. Only one species of this genus is known and it is confined to Cuba.

HaBitat.-The well-developed subanal fasciole indicates that Habanaster could burrow, which is surprising considering the absence of petals. Presumably it could only burrow in wellaerated coarser sediments.

\section{Habanaster sanchezi Lambert}

Figure 29; Plate 42

Habanaster sanchezi Lambert in Sánchez Roig, 1924a:12, pl. 5: figs. 1-4.-Lambert and Thiéry, 1909-1925:429, pl. 14: figs. 11-15._Sánchez Roig, 1926:89, pl. 16: figs. 1-4; 1949:177.-Mortensen, 1950:172, figs. 135-137.
Material.-One topotypic specimen (SRC 4081) in the Sánchez Roig Collection is labelled the type and is herein designated as the lectotype. According to Sánchez Roig (1924a:13), cotypes were deposited in the United States National Museum Collection, the British Museum, and in the Lambert Collection in Paris. The following description is based on the lectotype, the paratype in the USNM collection, and 20 specimens collected in 1978 by Francisco de Albear, Kier, and Francisco Formell. The specimens are very well preserved. One specimen (MCZ 4079) is in the Museum of Comparative Zoology.

Shape AND Size.-Length 21 to $12 \mathrm{~mm}$ (mean 17); width $90 \%$ L (S.D. 2.67, C.V. 16.54, N. 17); height $83 \%$ L (S.D. 2.50, C.V. 16.88, N. 17). Greatest width anterior, greatest height posterior; oral surface smoothly rounded.

APICAL SySTEM.-Slightly anterior of center, at distance from anterior margin in center of system $17 \%$ L (S.D. 0.84, C.V 23.13, N. 17). Two or 3 genital pores, 15 specimens with pores in genital plates 1 and $3 ; 4$ with pores in genital plates 1, 2, 3 ; no specimens with a pore in genital plate 4 . Ethmophract (Figure 29B) with genital plate 2 not separating genital plates 4,1 .

Ambulacra.-No petals but ambulacrum III differing from other ambulacra in having porepairs in slightly more depressed peripodia; porepairs undifferentiated except in phyllode where pores larger with more developed peripodia, 5 porepairs in phyllode; 28 porepairs in ambulacrum III in specimen $21 \mathrm{~mm}$ long.

Other ambulacra with no petals; porepairs not enlarged on dorsal surface, undifferentiated except for increase in size and presence in peripodia in phyllodes; 6 porepairs in phyllode in ambulacra II or IV; 4 in V or I; 28 plates in ambulacrum II or IV, 32 in V or I in specimen $20 \mathrm{~mm}$ long. Ambulacra $\mathrm{V}$ and $\mathrm{I}$ in contact apically separating first plate of interambulacrum 5 from apical system (Figure 29A).

Peristome.-Anterior, distance from anterior margin to anterior edge of peristome $20 \%$ L (S.D. 0.63 , C.V. 17.99, N. 17); opening large, width $15 \%$ L (S.D. 0.34 , C.V. 12.98 , N. 17); height $11 \%$ 
L (S.D. 0.24, C.V. 12.71, N. 17); slight rim around opening (Plate 42: figure 6).

Periproct,-Located high on slight posterior truncation with slight sulcus below opening; width $14 \%$ L (S.D. 0.44 , G.V. 17.69, N. 17); height $13 \%$ L (S.D. 0.29, C.V. 12.61, N. 17); located between interambulacral plates $5 \mathrm{~b}, 6 \mathrm{~b}$, 5 a.
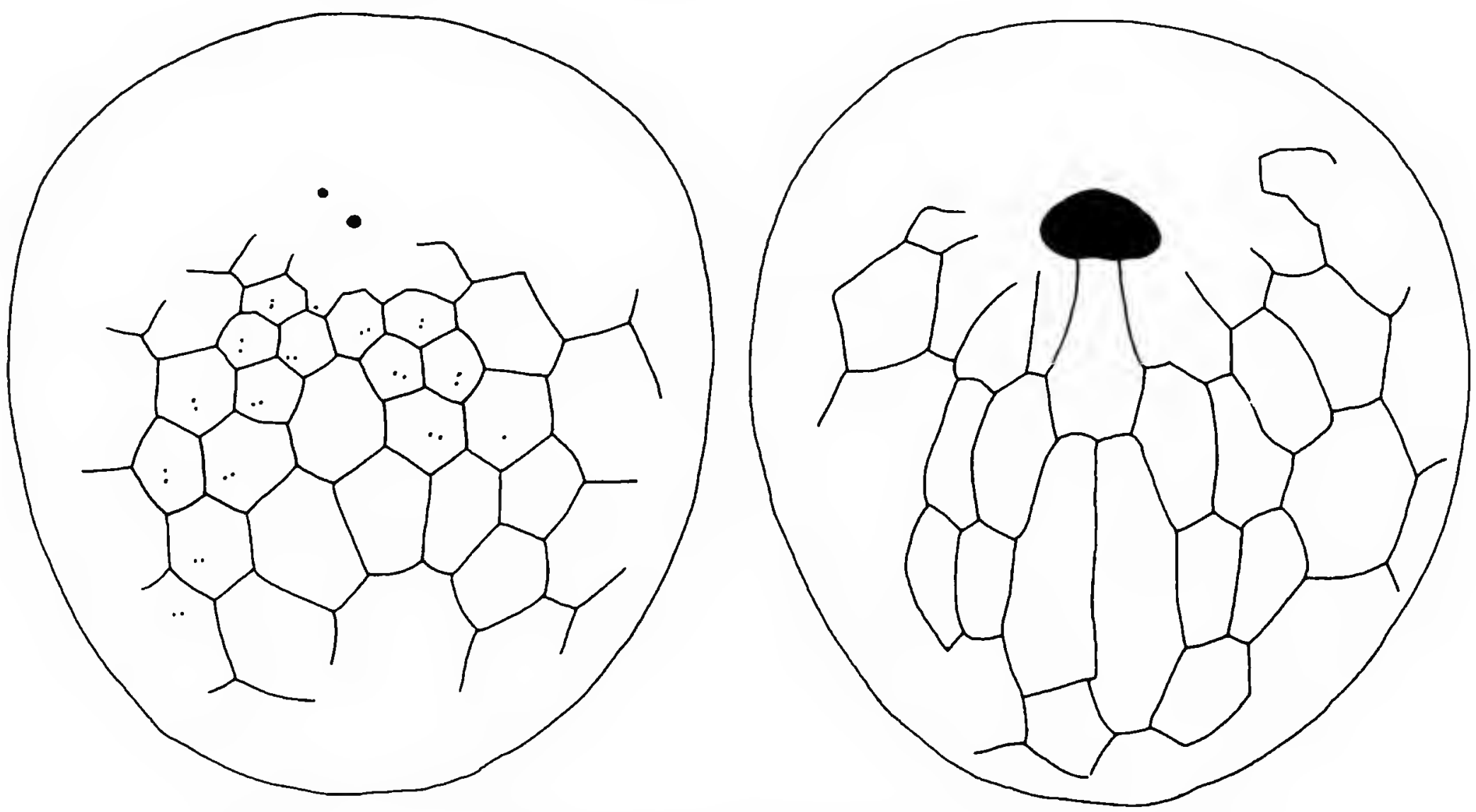

A

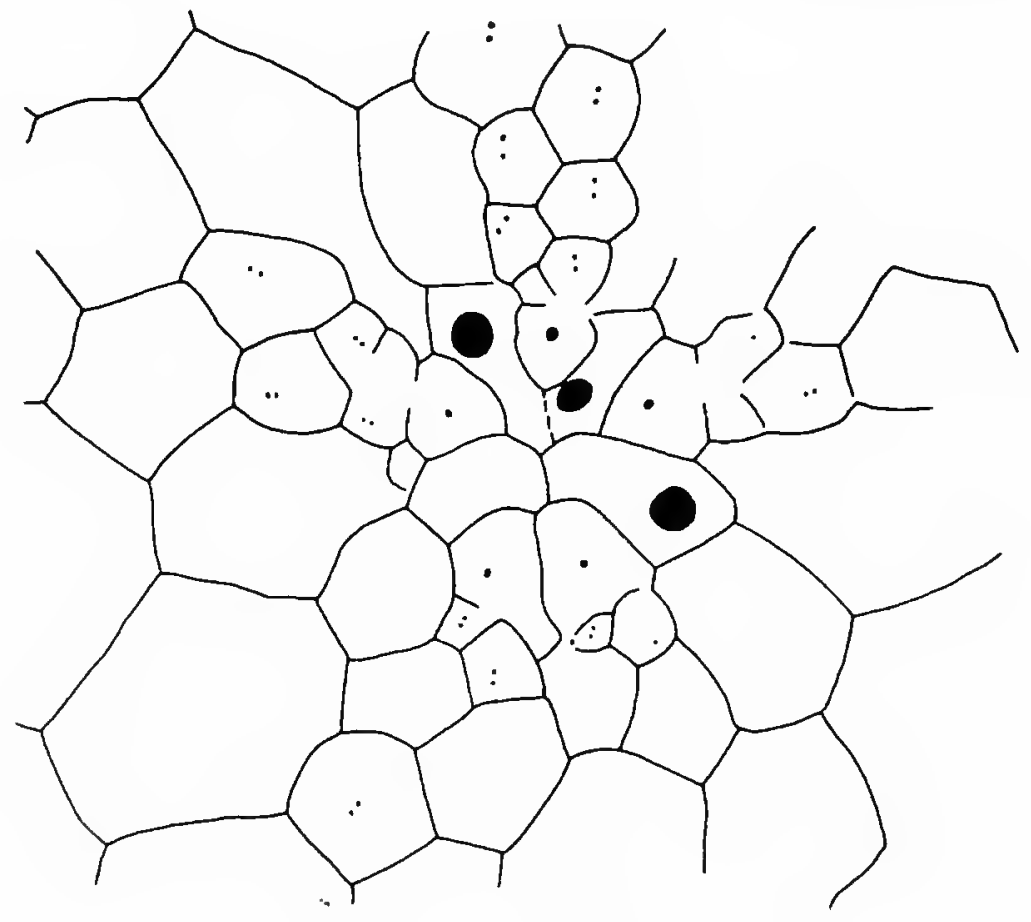

B

FIgure 29.-Habanaster sanchezi Lambert: A, dorsal view of USNM 351802, Eocene, Mariel, quarry of Morro Cement Plant, at corner of workings, N end of N-S cliff, Pinar del Rio Province, $\times 4$; B, apical system of USNM 351803, $\times 22$; , ventral view of USNM 351801 , Eocene, Loma Entanto, $\times 4$. 
Fascioles.-No peripetalous fasciole. Subanal fasciole prominent, circular, width of area enclosed including width of fasciole, $30 \%$ L (S.D. 0.78 , C.V. 14.62, N. 16); height $29 \%$ L (S.D. 0.75 , C.V. 14.46, N. 15); width of fasciole 5.8\% L (S.D. 0.18, C.V. 16.77, N. 16). Fasciole crossing interambulacrum 5 plates 3b, 4b, 2a, 3a, 4a; ambulacrum I plates $4 \mathrm{a}, 5 \mathrm{a}$, ambulacrum $\mathrm{V}$ plates, $4 \mathrm{~b}$, 5b. Fasciole encloses 2 enlarged porepairs.

Tuberculation.-Tubercles on dorsal side very small, of equal size; tubercles on ventral side much larger, largest on anterior part of sternum, posterior part of labrum. Tubercles within area enclosed by subanal fasciole larger than in area surrounding fasciole (Plate 42: figure 2); tubercles perforate, crenulate. Pits common on ventral side, very deep in ambulacra $\mathrm{V}$ and $\mathrm{I}$ and anterior part of labrum (Plate 42: figure 6).

Oral Plate Arrangement.-Plastron mesamphisternous with sternal plates similar but succeeding plates alternating (Figure 29c); labrum long, length $22 \%$ L (S.D. 0.81, C.V. 20.45, N. 16), narrow extending posteriorly to first third of second adjacent ambulacral plate (Figure 29c). Sternum narrow with width $22 \%$ L (S.D. 0.71 , C.V. 18.08, N. 16). First plate of paired interambulacra in contact with peristome.

Occurrence. - Late Eocene, Brodermann (1949:322) considered this species to be early to middle Eocene, but it is found in the Jabaco Formation, which according to Bermúdez and Hoffstetter (1959:54) is late Eocene. Furthermore, the specimens I collected in 1978 were from yellow marls, which Francisco de Albear (1981, personal communication) placed in the late Eocene. Quarry of "Consuelo" tileworks, Cerro, Cienaga, Habana Province, Cuba; "Cuba y Cantera Grande," park on bank of Almendares River, Habana Province, Cuba; cut on $\mathrm{W}$ side of Avenida de los Presidentes near the University of Habana (Palmer loc. 941), Habana Province, Cuba; marls with numerous Lepidocyclinas and one Pauropygus, $4.65 \mathrm{~km}$ W of Guanajay on road to Mariel (Palmer loc. 1102), Pinar del Rio Province, Cuba; quarry of Morro Cement Plant, at corner of workings, $\mathrm{N}$ end of N-S cliff, Mariel, Pinar del Rio Province, Cuba; coarse lime gravel with many foraminifera, Cayo Alto of Loma Guainabo, $6 \mathrm{~km} \mathrm{~W}$ of Yaguajay, Santa Clara (now Las Villas) Province, Cuba.

\section{Family Brissidae Gray, 1855}

\section{Genus Brissus Gray, 1825}

Test elongate, no anterior groove or very shallow one; apical system anterior, ethmolytic, with 4 genital pores, anterior ambulacrum not petaloid, anterior petals transverse, petals depressed; peripetalous and subanal fascioles; labrum short, first plate of interambulacrum 1 followed by single plate.

Habitat.-According to Mortensen (1951:507) Brissus lives buried in a coarse gravelly bottom. William M. Kier (1981, personal communication) reports finding Brissus obesus Verrill buried in coarse sand to gravel in the Gulf of California. As it has both peripetalous and subanal fascioles, it would be expected that Brissus could burrow. The absence of large pores and peripodia in the dorsal part of ambulacrum III indicates a lack of funnelbuilding tubefeet. This lack probably means that Brissus cannot live in fine sediment. Modern species occur in shallow water in tropical to temperate areas.

Comparison with Species Outside of Cuba.No other Eocene or Oligocene species of Brissus are known from the Western Hemisphere. Brissus glenni Cooke from the Pleistocene of South Carolina is easily distinguished from the Cuban species by its far larger test and deeper petals. Brissus exiguus Cotteau from the Miocene of Anguilla is based on two deformed specimens making it difficult to be certain of its specific characters. Its apical system is less anterior than in B. cabrerai, $B$. durhami, and $B$. caobaense. Its petals are narrower than those of $B$. camagueyensis and $B$. minutus.

ReMARKs.-In Brissus, the first plate in interambulacrum 1 is apparently always followed by a single plate. This plate arrangement occurs in all the specimens of Brissus I have studied in which the plate arrangement was visible, including the living species Brissus unicolar (Leske), Brissus latecarinatus (Leske), Brissus obesus Verrill, and 
Brissus gigas Fell. The same is true in the fossil species, Brissus latidunensis Clegg, from the Miocene and Brissus minutus (Sánchez Roig) from the Oligocene-Miocene. Lovén (1874, pl. 4: fig. 43) illustrated the arrangement in Brissus scillae Lovén $(=B$. unicolor).

Four Cuban species have been referred to Brissus and three others are transferred herein from other genera. The type specimen of Brissus sagrae Lambert in Lambert and Thiéry (1925 [19091925]:497) has been lost and the illustrations of this species are too poor to permit comparison with the other species of Brissus from Cuba. Brissoides minutus Sánchez Roig, Crucibrissus cabrerar Sánchez Roig, and Sandiegoaster durhami Sánchez Roig are referred to Brissus. Sánchez Roig (1949:235) reports a specimen of Brissus brissus (Leske) (= B. unicolor) from the Pleistocene of Cuba, but this specimen is no longer in the Sánchez Roig Collection.

Four of these species are from the Eocene. Only one other species of Brissus is known elsewhere from the Eocene, and that is Brissus fabiani Lambert from Italy. Probably Brissus originated in the Cuban region, later spreading around the world.

I suspect that not all of these fossil species are distinct. Brissus caobaense occurs at the same locality as $B$. durhami, and both species are very similar. Two species, $B$. camagueyensis and $B$. minutus, are based on small specimens and their differences from the other species may stem from their smaller size.

\section{Brissus cabrerai (Sánchez Roig), new combination}

Figure 30; Plate 43: figures 1-3

Crucibrissus cabrerai Sánchez Roig, 1953a:67, pls. 10, 13, 21.

Material.-Only one specimen is present in the collection, a cotype (SRG 4191). This specimen was figured by Sánchez Roig (1953a, pl. 21) and is herein selected as the lectotype. It is poorly preserved, being badly weathered with all the tubercles removed dorsally and with part of the posterior surface broken away.
Shape and Size.-Test high with steep sides; length estimated $90 \mathrm{~mm}$, width $80 \% \mathrm{~L}$, height $56 \% \mathrm{~L}$; greatest width anterior, greatest height posterior to apical system along inflated surface in posterior interambulacrum. Although posterior surface broken away in lectotype, the cotype figured by Sánchez Roig (1953a, pl. 13) has a pointed posterior margin.

Apical System.-Anterior, distance from anterior margin to center of genital pores $17 \% \mathrm{~L}$; ethmolytic, genital plate 2 extending posteriorly separating posterior ocular plates (Figure 30); 4 genital pores.

Figure 30.-Brissus cabreral (Sánchez Roig), apical system of the lectotype, SCR 4191, $\times$ 23.

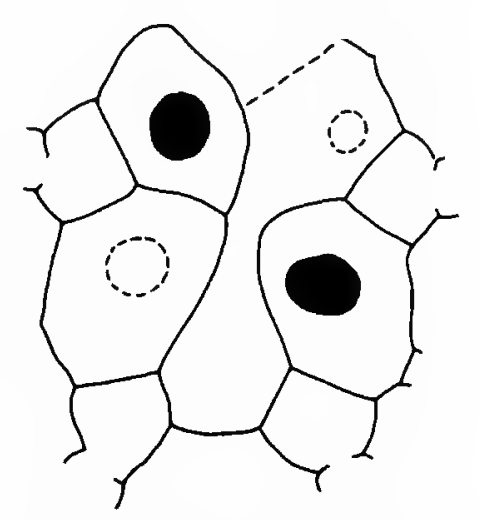

Ambulacra.-Anterior ambulacrum III not petaloid, not in groove; pores microscopic in dorsal region.

Anterior petals (II and IV) narrow, straight, widely divergent, almost flush with surface of test; length $40 \% \mathrm{~L}$, width $5.9 \% \mathrm{~L}$; interporiferous zones narrow, slightly less width of single poriferous zone. Test too weathered to permit determination whether or not pores conjugate; 84 porepairs in petal. Dorsally, pores smaller in anterior poriferous zone.

Posterior petals (V and I) narrow, diverging slightly from each other; length $46 \% \mathrm{~L}$, width $5.1 \% \mathrm{~L} ; 96$ porepairs in petal.

Peristome.-Anterior, located at distance from margin to anterior edge of opening equal to $21 \%$ L; labiate, width $18 \% \mathrm{~L}$, height $5.2 \% \mathrm{~L}$.

Periproct.-Not preserved on lectotype but located high on posterior truncation.

Fascioles.-Peripetalous fasciole not preserved on lectotype; test too weathered dorsally. Short track of subanal fasciole present forming lobe below periproct. 
Oral Plate Arrangement.-No sutures visible.

Occurrence.-Late Eocene, Armadillo farm, Marroquín district, Camagüey Province, Cuba.

Remarks.-Sánchez Roig referred this species to Crucibrissus, a genus in the family Hemiasteridae. He was not aware of the presence of a subanal fasciole. This species with its transversely oriented anterior petals appears to be a typical Brissus.

Among the Cuban species of Brissus, it resembles $B$. durham sánchez Roig, also from the Eocene, in its large test, but differs in its higher test, smaller pores in petals, and less anteriorly situated peristome.

\section{Brissus camagueyensis Weisbord}

\section{Plate 43: figures 4-6}

Brissus camagueyensis Weisbord, 1934:76, pl. 9: figs. 1, 2.Sánchez Roig, 1949:234.

Only one specimen is known of this species, which was carefully described by Weisbord. There are 52 porepairs in petal IV, 64 in petal V.

Occurrence.-Late Eocene, in road cut at Loma Calisto, approximately $800 \mathrm{~m}$ SW of the S end of town of Neuvitas, on the road leading toward Belén, Camagüey Province, Cuba.

\section{Brissus caobaense Sánchez Roig}

Figure 31; Plate 44: figures 1-4

Brissus caobaense Sánchez Roig, 1953c:163, pl. 7: fig. 5, pl. 8: figs. $1,2$.

Material.-Although the species was based on two cotypes, only one is still in the collection. This specimen (SRC 4726) was figured by Sánchez Roig (1953c, pl. 8: figs. 1, 2) and is selected here as the lectotype. This specimen is moderately well preserved, having an undistorted but highly weathered test with only portions of the fascioles preserved.

Shape AND Size.-Length $63 \mathrm{~mm}$, width 52 mm $(82 \% \mathrm{~L})$, height $31 \mathrm{~mm}(49 \% \mathrm{~L})$; greatest width central, greatest height posterior.
Apical System.-Anterior, located at distance from anterior margin to center of genital pores equal to $20 \% \mathrm{~L}$; 4 genital pores, ethmolytic.

AmBUlaCRA.-Anterior ambulacrum III not petaloid, in very shallow groove from apical system to peristome; pores minute.

Anterior petals (II and IV) extending almost to margin, length $30 \% \mathrm{~L}$, width $7.6 \% \mathrm{~L}$ transverse forming 180 degree angle; 62 petaloid porepairs.

Posterior petals (V and I) straight, extending three-fourths distance from apical system to margin, length $44 \% \mathrm{~L}$, width $8.1 \% \mathrm{~L}$; 80 petaloid porepairs.

Petals in groove with depth $2.9 \% \mathrm{~L}$ (petai II),
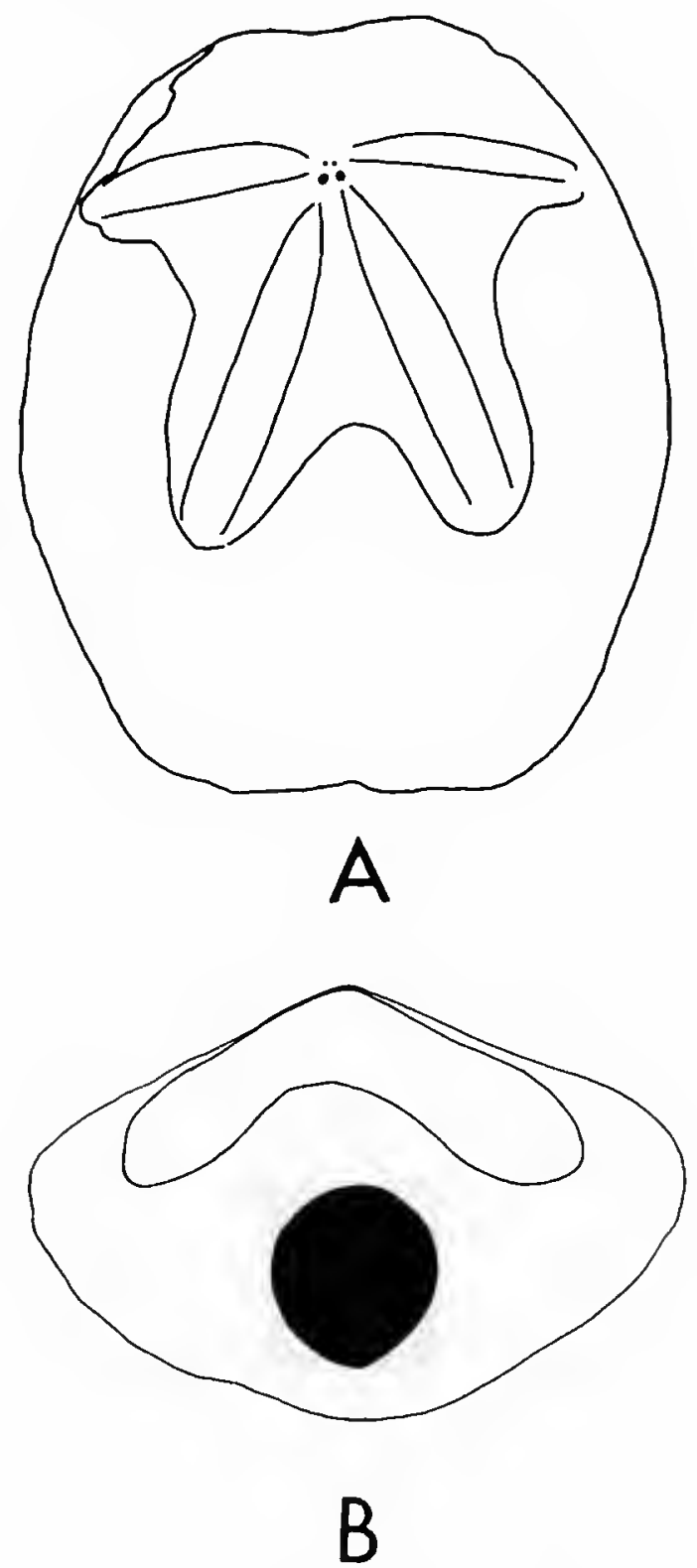

Figure 31.-Brissus caobaense Sánchez Roig, positions of the fascioles of the lectotype, SRC 4726, A, dorsal view; B, rear view. 
$1.9 \% \mathrm{~L}$ (petal I); interporiferous zones narrow, one-half width of single poriferous zone.

Peristome.-Anterior, located at distance from anterior margin to anterior edge of peristome equal to $19 \% \mathrm{~L}$, opening large with width $21 \% \mathrm{~L}$, height uncertain.

Periproct. - Inframarginal, high on overhanging posterior truncation. Opening appears to be very large but may be enlarged by postmortem fracturing; height $20 \% \mathrm{~L}$, width $20 \% \mathrm{~L}$.

Fascioles.-Peripetalous fasciole deeply indented (Figure 31A) in interambulacra 4, 5, and 1, passing anteriorly around ambulacrum III at margin, slightly indented in interambulacra 2, 3. Subanal fasciole broad with large lateral lobes (Figure $31 \mathrm{~B}$ ), width $48 \% \mathrm{~L}$ (estimated at $30 \mathrm{~mm}$ ). Not possible to discern which plates crossed by fascioles.

Oral Plate Arrangement.-Labrum partially broken away; plastron long and narrow, combined plates with length $52 \% \mathrm{~L}$, width $54 \%$ $\mathrm{L}$ (plastron $33 \mathrm{~mm}$ long, $19 \mathrm{~mm}$ wide).

Occurrence.-Middle Eocene. Albear (1980, personal communication) considers this locality middle to late Eocene, Loma Caoba, San Diego de los Baños, Pinar del Rio Province, Cuba.

Comparison with Other Species.-This species is very similar to Brissus durhami Sánchez Roig from the same locality. Although the lectotype of $B$. caobaense is smaller and narrower, these differences may reflect variation within individuals of the same species. I suspect that the two species are synonymous, but more specimens must be studied before a decision can be made.

Brissus caobaense differs from B. camagueyensis Weisbord from the Eocene of Camagüey Province. The lectotype of $B$. caobaense has a lower test, more depressed petals, a slight anterior groove, and a more anterior apical system. The species appear to be distinct but some of these differences may result from difference in size of the type specimens.

\section{Brissus durhami (Sánchez Roig)}

Plate 44: figures 5-8

Sandiegoasler durhami Sánchez Roig, 1952b:12, pl. 5: fig. 2, pl. 6: fig. 2, pl. 7: fig. 2.

Brissus durhami._Fischer, 1966:U582.
Material.-Only one specimen known, the holotype (SRC 4055), which has an undistorted but poorly preserved test. It is highly weathered and fractured.

Shape AND Size.-Length $80 \mathrm{~mm}$, width 72 mm (91\% L), height $43 \mathrm{~mm}$ (54\% L). Greatest width central to slightly posterior, greatest height posterior.

Apical System.-Anterior, located at distance from anterior margin to center of genital pores equal to $22 \% \mathrm{~L} ; 4$ genital pores, ethmolytic.

Ambulacra.-Anterior ambulacrum III not petaloid, flush with test, no groove; pores minute.

Anterior petals (II and IV) transverse, subtending angle of $180^{\circ}$; extending two-thirds distance from apical system to margin, length $33 \% \mathrm{~L}$. Petals narrow, width $5.6 \% \mathrm{~L}$, with interporiferous zone narrower than poriferous; pores conjugate, outer pore slightly more elongate than inner, 62 porepairs in each petal. Plates in posterior poriferous zone wider than plates in anterior.

Posterior petals (V and I) slightly curved, extending slightly more than one-half distance from apical system to margin, length $47 \% \mathrm{~L}$, width $6 \%$ L. Plates in anterior posterior poriferous zones slightly wider than plates in posterior; 72 porepairs in each petal. All petals slightly depressed.

FAscioles.-Because of weathering, only short traces of the fascioles are present. Peripetalous fasciole indented in interambulacra 4 and 1 , crossing ambulacrum III above margin. Subanal fasciole present but too little preserved to know shape of area circumscribed by it.

Oral Plate Arrangement.-Plate sutures obscured.

Occurrence.-Middle to late Eocene; Albear (1980, personal communication) considers this locality middle to late Eocene, Caraballo quarry, Loma Caoba, San Diego de los Baños, Pinar del Rio Province, Cuba.

Comparison with Other Species.-Brissus durhami and B. caobaense Sánchez Roig occur together at the same locality and may be synonymous. $B$. durhami differs in having a narrower test with its width $72 \% \mathrm{~L}$ as opposed to $82 \% \mathrm{~L}$ in other species. This difference may be individual variation.

Remarks.-Fischer (1966:U582) considered Sandiegoaster, of which S. durhami (= Brissus dur- 
hami) is the type-species, a synonym of Brissus. I agree with Fischer for I can see no character in this species distinguishing it from Brissus.

\section{Brissus minutus (Sánchez Roig), new combination}

Figure 32; Plate 45: figures 1-3

Brissoides minutes Sánchez Roig, 1949:205.

Neopatagus minutus._Sánchez Roig, 1953b:261.

Material.-Holotype (SRC 4954) and only known specimen well preserved with undistorted test. Ornamentation removed by weathering.

Shape And Size.-Length $24 \mathrm{~mm}$, width 82\% L, height $64 \%$ L; greatest width anterior, dorsal surface inflated with steep sides.

Apical System.-Anterior, ethmolytic (Figure 32c) with genital plate 2 extending posteriorly separating posterior ocular plates, 4 genital pores. System located at distance from anterior margin to center of genital pores equal to $24 \% \mathrm{~L}$.

Ambulacra.-Anterior ambulacrum III not petaloid; pores minute in dorsal region; 44 plates in ambulacrum.

Anterior petals (II and IV) short, length $31 \%$

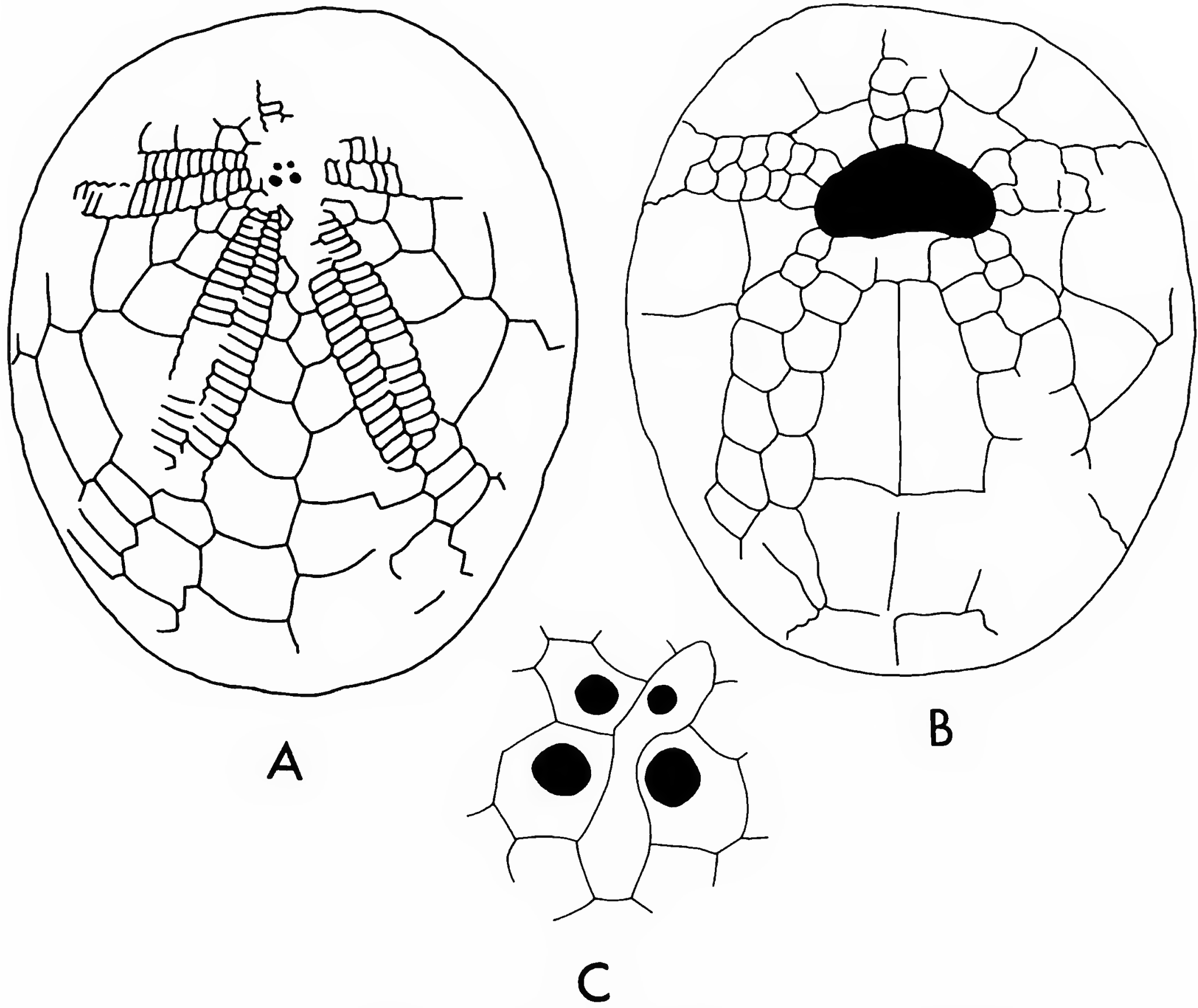

Figure 32.-Brissus minutus (Sánchez Roig), plate arrangement (many sutures are not visible) of the holotype, SRC 4954:, A, dorsal view, $\times 4$; B, ventral view, $\times 4$; c, apical system, $\times 22$. 
$\mathrm{L}$, width $10 \% \mathrm{~L}$; petals transverse, subtending angle of $180^{\circ}$. Interporiferous zones very narrow, almost one-half width of poriferous zone, pores conjugate; 36 petaloid porepairs, first petaloid porepair in plate 13 .

Posterior petals (V and I) short, extending slightly more than one-half distance from apical system to margin; length $39 \% \mathrm{~L}$, width $11 \% \mathrm{~L}$; 44 petaloid porepairs; first petaloid porepair in plate 18. Last plate bearing petaloid porepair of outer poriferous (Va and Ib) occluded (Figure 32A).

Peristome.-Large, anterior, distance from anterior margin to anterior edge of opening equal to $21 \% \mathrm{~L}$; width $26 \% \mathrm{~L}$, height $13 \% \mathrm{~L}$.

Periproct.-Marginal, slightly visible from above, higher than wide, height $29 \% \mathrm{~L}$, width $18 \% \mathrm{~L}$; occurring between interambulacral plates 6-10.

FAscioles._-Probably peripetalous and subanal present but removed by weathering.

Tuberculation.-No large tubercles dorsally.

Oral Plate Arrangement.-Labrum short, broad, length $7.1 \% \mathrm{~L}$, width $13 \% \mathrm{~L}$, extending posteriorly two-thirds height of first adjacent ambulacral plate (Figure 32B). First pair of plastron plates with height $32 \% \mathrm{~L}$, combined width $25 \%$ L; second pair with height $20 \%$ L, combined width $28 \% \mathrm{~L}$. In interambulacrum 1 first plate followed by single plate.

Occurrence.-Oligocene-Miocene, "Santa Ana" farm, Majagua district, Ciego de Avila, Camagüey Province, Cuba.

Comparision with Other Species.-Brissus minutus has similar petals in size and arrangement to those of $B$. camagueyensis Weisbord from the late Eocene of Cuba. The test of $B$. camagueyensis seems to be thicker posteriorly, but this difference may only be the result of postmortem distortion.

\section{Genus Brissopsis L. Agassiz, 1847}

Test small to large, clongate; apical system ethmolytic, number of genital plates and pores variablc; antcrior ambulacrum dcprcsscd, forming notch at anterior margin, pores minutc; pctals of about equal size, dcprcssed, confluent in some species with porepairs reduced adapically where petals nearly meet; peristome anterior; periproct marginal; peripetalous, subanal fascioles, in some species anal branches; labrum short, episternal plates almost one-half length of sternal plates.

Habitat.-These Cuban species of Brissopsis probably lived buried in fine sediment. Their morphological features would have enabled this mode of life: anterior ambulacrum with funnelbuilding tubefeet, depressed petals, and presence of a peripetalous and a subanal fasciole. The modern Brissopsis elongata Mortensen has been reported (Kier, 1975:16) alive buried deeply in mud. Modern species live in tropical and temperate seas at depths from 12-2980 m.

Comparison with Species outside of Cuba.Two species of this genus are recognized herein from Cuba. Both are easily distinguished from the three fossil United States species, one fossil Anguillan species, and one fossil Costa Rican species of Brissopsis.

Although Sánchez Roig (1949:223) reports Brissopsis antillarum Cotteau from Cuba, no specimens are present now in the Sánchez Roig Collection. I therefore cannot confirm this occurrence.

\section{Brissopsis aguayoi Sánchez Roig \\ Plate 45: figures 4-7}

Brissopsis aguayoi Sánchez Roig, 1952c:15, pl. 6: figs. 1, 2.

Material.-Only one specimen, the holotype (SRC 4720), is known. This specimen is poorly preserved, badly fractured and weathered but not distorted.

Shape And Size.-Length $35 \mathrm{~mm}$, width 31 $\mathrm{mm}(90 \% \mathrm{~L})$, height $16 \mathrm{~mm}(45 \% \mathrm{~L})$, with greatest width anterior of center, greatest height posterior of center.

Apical System.-Four genital pores, located at distance from anterior margin to center of genital pores, equal to $38 \% \mathrm{~L}$; in deep trough with petals; plate sutures not visible.

AmBUlacra.-Anterior ambulacrum III, not petaloid, in groove; porepairs enlarged and in pcripodia but number not clear. 
Anterior petals (II and IV) very broad adapically, short, extending one-half distance from apical system to anterior margin, length $20 \% \mathrm{~L}$. Anterior poriferous zone of petal with pores greatly reduced in size adapically; of the 17 porepairs in the anterior poriferous zone, the 9 distal porepairs are large, the 8 adapical porepairs are minute. This reduction does not occur in the posterior poriferous zone in which all the pores are large. Petals sharply curving with posterior poriferous zones joining anterior poriferous zones of posterior petals to form arc; 34 plates in petal.

Posterior petals ( $\mathrm{V}$ and $\mathrm{I}$ ) short, extending slightly more than one-half distance from apical system to margin, length $25 \%$ L. Posterior or inner porepairs of each petal greatly reduced in size adapically; 7 or 8 of distal porepairs large, 14 adapical porepairs minute; 42 plates in petal.

Petals deeply depressed with apical system; depth of groove at apical system $4.3 \%$ L. Pores single beyond petals.

Peristome.-Anterior, located at distance from anterior margin to anterior edge of peristome equal to $20 \% \mathrm{~L}$. Opening wide, width $20 \% \mathrm{~L}$, height $5.7 \% \mathrm{~L}$.

PERIPROCT.-Located high on vertical posterior truncation; opening higher than wide, height $17 \%$ L, width $15 \% \mathrm{~L}$.

FAscioles. - Test too weathered to preserve peripetalous fasciole; short trace of subanal fasciole visible.

Oral Plate Arrangement.-Plate sutures not clear.

Occurrence.-Oligocene-Miocene, "Las Cuevas de Pedro Pozo" farm, Realengo, Charco Hondo, Morón, Camagüey Province, Cuba.

Comparison with Other Species. - This species is easily distinguished from the other species of this genus known from Cuba, the Miocene $B$. jimenoi Cotteau. It differs in its smaller, higher and wider test, shorter anterior petals, and more anterior apical system. It differs from Brissopsis antillarum Cotteau from the Miocene of Anguilla in its much shorter anterior petals. Likewise its shorter petals distinguish it from Brissopsis steinhatchee Cooke from the late Eocene of Florida.

Brissopsis aguayoi is much different from Brissop- sis blanpiedi Grant and Hertlein from the Oligocene-Miocene of Mississippi. Its anterior petals are much shorter, more deeply depressed and its test is much wider. It differs from the Eocene specimens from Alabama that Cooke (1959:85) referred to Brissopsis biarritzensis Cotteau in its more anterior apical system, more depressed petals, and shorter and narrower anterior petals. Brissopsis aguayoi has a smaller test with much shorter petals than the unnamed specimen from the Miocene of Costa Rica that Durham (1961:484) referred to Brissopsis.

\section{Brissopsis jimenoi Cotteau}

Plate 46: figures 1, 2

Brissopsis jimenoi Cotteau, 1875:6; 1881:33, pl. 3: figs. 5-9; 1897:79, pl. 24: figs. 5-9.-Jackson, 1922:81.-Jeannet, 1928:12, pl. 1: fig. 35.—Sánchez Roig, 1949:225.

Material.-I have studied the specimen in the Cotteau Collection at the Université Claude Bernard, Lyons, France, figured by Cotteau (1881, pl. 3: fig. 9). It is a mold of the interior of the test with only a few fragments of the original test present. It is herein selected as the lectotype.

Shape And Size.-Test $84 \mathrm{~mm}$ long, width $76 \%$ $\mathrm{L}$ with greatest width anterior of center, height $30 \% \mathrm{~L}$.

Apical System.-Central, located at distance from anterior margin to center of genital pores equal to $49 \% \mathrm{~L}$; small, appears from mold to be ethmolytic with genital 2 extending far posteriorly, 4 genital pores.

Ambulacra.-Anterior ambulacrum III not petaloid, in groove extending from apical system to margin; 34 enlarged pores on dorsal surface. Anterior petals (II and IV) very curved, depressed in groove, short, length $27 \% \mathrm{~L}$, width $6.8 \% \mathrm{~L}$; interporiferous zone narrower than single poriferous zone; 50 porepairs in petal; porepairs greatly reduced in size adapically in anterior poriferous zones.

Posterior petals (V and I) confluent for twothirds length of petals, sharing common groove; curving away from each other distally; short, length $22 \% \mathrm{~L}$, width at end of petal $5.5 \% \mathrm{~L} ; 46$ 
porepairs in petal; porepairs greatly reduced in size adapically where petals confluent.

Peristome.-Anterior, distance from anterior edge of peristome to anterior margin $21 \% \mathrm{~L}$; width of opening $16 \% \mathrm{~L}$, height $6.4 \% \mathrm{~L}$.

Periproct.-Inframarginal, on overhanging posterior truncation; more details not discernible because of poor preservation.

FAScioles.-Not preserved.

Oral Plate Arrangements.-Labrum with length $7 \% \mathrm{~L}$; sternal plates, first plates of plastron, with length estimated at $38 \% \mathrm{~L}$, combined width $31 \% \mathrm{~L}$; episternal plates, second plates of plastron, width length $16 \% \mathrm{~L}$, combined width $31 \%$.

Occurrence.-Miocene, Cienfuegos, San Martin, Santa Clara (now Las Villas) Province, Cuba. Early or middle Miocene, Delhitrace-Silverstream, Trinidad.

Comparison with Other Species.-This species differs from Brissopsis aguayoi Sánchez Roig from the Oligocene-Miocene of Cuba in its larger, lower, and longer anterior petals with length $27 \%$ $\mathrm{L}$ versus $20 \%$ in B. aguayoi. It is distinguished from Brissopsis antillarum Cotteau from the Miocene Anguilla Formation of Anguilla by its shorter petals. Its anterior petals extend little over onehalf the distance from the apical system to the margin, but in $B$. antillarum these petals extend two-thirds this distance. Furthermore, the test in $B$. jimenoi is larger, more elongate, and lower. Brissopsis jimenoi has a much lower test and less divergent and more curved petals than the specimen from the Miocene of Costa Rica that Durham (1961:484) referred to Brissopsis as a new but unnamed species. Brissopsis jimenoi is easily distinguished from Brissopsis steinhatchee Cooke from the late Eocene of Florida. It differs in its much less divergent anterior petals, which are longer than the posterior petals. In the Floridian species, the posterior petals are longer than the anterior. In addition, the apical system is central, and the test is larger and lower in B. jimenoi. Brissopsis jimenoi differs from the Eocene specimens of Alabama that Cooke (1959:85) referred to Brissopsis biarritzensis Cotteau in its much larger, lower test and narrower petals. The Cuban species has much shorter petals and a larger test than the Mississi- pian Brissopsis blanpiedi Grant and Hertlein from the middle Oligocene.

\section{Genus Cyclaster Cotteau, 1856}

Palmeraster Sánchez Roig, 1949:268.

Test small, heart-shaped; apical system ethmophract, 3 genital pores, no pore in genital plate 2; anterior ambulacrum III not petaloid, petals short, closed; peripetalous and subanal fascioles present labrum long, narrow.

HaBitat.-Species of this genus probably live buried in fine sediment. The presence of a subanal and a peripetalous fasciole would provide the circulation necessary in a burrow. The porepairs are larger and in well-developed peripodia in the dorsal portion of the anterior ambulacrum indicating that these echinoids had funnel-building tubefeet so necessary for the maintenance of a burrow in fine sediment. Although no modern species has been seen in its habitat, Baker (1969:269) reports that the living Cyclaster regalis Baker was collected in sandy mud. The genus is confined today to tropical seas. C. regalis was collected in 115 to $260 \mathrm{fm}$.

Remarks. - The type-species of Palmeraster appears to be a synonym of the type-species of Cyclaster. Palmeraster is, therefore, herein considered a synonym of Cyclaster. Six species of these genera have been described from Cuba. No specimens are available of one of them, Palmeraster herrerai Sánchez Roig. Palmeraster palmeri Sánchez Roig, Palmeraster zanolettii Sánchez Roig, Palmeraster herrerai Sánchez Roig and Cylaster brodermanni Sánchez Roig are herein considered synonyms of Cyclaster drewryensis Cooke.

Cyclaster drewryensis Cooke occurs also in the early Oligocene of Alabama. Cyclaster sterea Arnold and Clark from Jamaica is based on too poor a specimen for comparison with the Cuban species.

\section{Cyclaster drewryensis Cooke}

Figure 33; Plate 46: figures 3-6; Plate 47

Cyclaster drewryensis Cooke, 1942:50, pl. 3: figs. 9-11; 1959:68, pl. 28: figs. $1-4$. 
Cyclaster brodermanni Sánchez Roig, 1949:221, pl. 35: figs. $1,2$.

Palmeraster palmeri Sánchez Roig, 1949:269, pl. 31: figs: 24.--Mortensen, 1950:354, figs. 251a-c.-Fischer, 1966: U555, fig. 437-1c.

Palmeraster zanolettii Sánchez Roig, 1952b:17, pl. 5: figs. 3, 4. ?Palmeraster herrerai Sánchez Roig, 1952b:17, pl. 1: figs. 2, 3.

Occurrence.-Late Eocene, type specimens of Cyclaster brodermanni from Palmer loc. 1640, deep cut $\mathrm{N}$ of Grua 9, Ramal Juan Criollo, Camagüey Province, Cuba. Other specimens collected by Palmer and not in the USNM are from Palmer loc. 1670, just NW of switch in Ciego Caballo, Central Jatibonico, Santa Clara (now Las Villas) Province, Cuba; Palmer locs. 1431, 1433, S slope of Loma La Quinta, $0.2 \mathrm{~km} \mathrm{SE} \mathrm{of} \mathrm{Arroyo} \mathrm{Blanco}$ on road to Majagua, Camagüey Province, Cuba; Palmer loc. 1655, E of switch on Ramal Valle, 2 $\mathrm{km}$ or $1 \mathrm{~km} \mathrm{~W}$ of Valle 1, Camagüey Province, Cuba; Palmer loc. 1086, Loma La Quinta, E of Arroyo Blanco on road to Majagua, Camagüey Province, Cuba.

Specimens of Palmeraster palmeri from late Eocene, Finca Concepción, Morón, Camagüey Province, Cuba.

Specimens of Palmeraster zanolettii from late Eocene, Armadillo farm, corral Marroquín, Marroquín district, Morón, Camagüey Province, Cuba.

The holotype of Palmeraster herrerai from the late Eocene at "La Rabona" farm, Tamarindo district, Morón, Camagüey Province, Cuba.

The type specimens of $C$. drewryensis from early Oligocene, Red Bluff clay, Drewry and Whatley, Alabama.

REMARKS. - I cannot see any significant difference between the American specimens of this species and the Cuban specimens that have been referred to Cyclaster brodermanni. All the specimens have tests of similar shape and petais of similar length with a similar number of porepairs. Although the apical system of the holotype of $C$. drewryensis is more posterior than in the Cuban specimens, that of the other American specimens (i.e., the paratype (USNM 154148) and figured specimen (USNM 559882)) is as equally anterior as in the Cuban specimens. Perhaps, if a large number of specimens were available, significant differences might be apparent between the $\mathrm{Cu}$ ban and American specimens; none are apparent now.

Photographs of a paratype of $C$. drewryensis, not figured before, are on Plate 46: figures 5, 6 .

Sánchez Roig's Palmeraster palmeri appears to be a synonym of $C$. brodermanni. Unfortunately, the type specimens of $P$. palmeri are lost but 6 topotypic specimens are present in the University of California, Museum of Paleontology (UCB A8394a). One of these is illustrated on Figure 33; Plate 47: figures 1-4. These specimens are indistinguishable specifically from a specimen of $C$. brodermanni (ANSP 16651) and from Sánchez Roig's photographs and description of $P$. palmeri. They all share an ethmophract apical system with 3 genital pores, identically shaped tests, ambulacrum III with few enlarged pores, short straight petals, a very long labrum extending back to the posterior part of the third adjacent ambulacral plate and identically positioned and shaped peristomes and periprocts. Sánchez Roig reported the absence of any fascioles but his specimens were probably too weathered to show them. They are barely discernible on the specimens I have studied from his type-locality of $P$. palmeri. The petals are shorter in a specimen of Cyclaster brodermanni than in a specimen of Palmeraster palmeri, but this is presumably due to the much smaller size of the $C$. brodermanni specimen.

Because $P$. palmeri is the type-species of Palmeraster Sánchez Roig (1949), that genus becomes a junior synonym of Cyclaster Cotteau, 1856.

Palmeraster zanoletti Sánchez Roig is indistinguishable from C. brodermanni. Although the type specimen is lost, 2 topotypic specimens in the USNM collections are similar in all respects to $C$. brodermanni.

Although no specimens are available of Palmeraster herrarai Sánchez Roig (also from the late Eocene of Cuba), Sánchez Roig's illustrations show a specimen very similar to $C$. brodermanni. $P$. herrerai is provisionally considered a synonym, of C. brodermanni and C. drewryensis. 


\section{SYNONYMS}

\section{Cyclaster brodermanni Sánchez Roig}

Plate 46: figures 3-6

Material. - The type specimen is lost. Two extremely well-preserved specimens from the type-locality that clearly belong to this species are in the Palmer Collection at the Academy of Natural Sciences of Philadelphia (ANSP 1665la, b). The following description is based on these two specimens. (Five topotypic specimens (4063) are also at the MCZ.)

Shape And Size.-Length 25 and $26 \mathrm{~mm}$, width 90 and $92 \% \mathrm{~L}$; height 71 and $72 \% \mathrm{~L}$. Greatest width anterior, greatest height posterior.

Apical System.-Anterior, located at distance from anterior margin to center of genital pores equal to 34 and $34 \% \mathrm{~L}$. Three large genital pores, no pore in genital plate 2; ethmophract.

Ambulacra.-Anterior ambulacrum III not petaloid, in very shallow groove from apical system to peristome. Pores paired throughout all ambulacra. Pores enlarged in only short section of ambulacrum III, with length extending approximately one-third to one-half distance from apical system to margin; 20 to 22 porepairs in region with enlarged porepairs; 40 plates in ambulacrum.

Anterior petals (II and IV) straight, short, extending one-half distance from apical system to margin, length 26 and $27 \% \mathrm{~L}$; width 13 and $12 \%$ L. Interporiferous zones slightly narrower than single poriferous zones; pores conjugate; 36 and 40 petaloid porepairs; first petaloid porepair to plate 15 or 16 . Double pores in ambulacra beyond petals.

Posterior petals (V and I) straight, approximately same length as anterior, length 26 and $29 \% \mathrm{~L}$, extending less than one-half distance from apical system to margin; width 12 and $12 \% \mathrm{~L} ; 38$ and 46 petaloid porepairs. Both pair of petals depressed in slight grooves.

Peristome.-Anterior, located at distance from anterior margin to anterior edge of peristome equal to 17 and $16 \% \mathrm{~L}$, opening wider than high; width 12 and $12 \% \mathrm{~L}$; height 4.4 and $3.5 \% \mathrm{~L}$.
Periproct.-Located high on nearly vertical posterior truncation. Opening higher than wide, height 12 and $13 \% \mathrm{~L}$, width 10 and $10 \% \mathrm{~L}$. Enclosed by interambulacral plates 6-8.

FAscioles.-Peripetalous fasciole a broad band sharply indented in interambulacra 4 and 1 , slightly indented in interambulacrum 5, fasciole incomplete anterior of anterior petals (II and IV) passing only partially into interambulacra 2, 3; no fasciole near to or crossing ambulacrum III. The absence of this fasciole is not because it has been removed by weathering. The test in ANSP $16651 \mathrm{a}$ is extremely well preserved and the tuberculation is present in this anterior region, but no fasciole is present. Four other crushed topotypic specimens (in the MCZ and not used in this description) have this region well preserved and no fasciole is visible here on them.

Subanal fasciole a broad band circumscribing a bilobed area with width 39 and $36 \%$ L, situated very ventral from periproct; distance from ventral edge of periproct to fasciole 23 and $20 \% \mathrm{~L}$.

Oral Plate Arrangement.-Labrum very long, length 21 and $23 \% \mathrm{~L}$, extending to posterior of second adjoining ambulacral plate. Rest of oral plate sutures not clear on topotypic specimens.

Occurrence.-Late Eocene, type specimens from Palmer loc. 1640, deep cut N of Grua 9, Ramal Juan Criollo, Camagüey Province, Cuba. Other specimens collected by Palmer and not in the USNM Collections are from Palmer loc. 1670, just NW of switch to Cieto Caballo, Central Jatibonico, Santa Clara (now Las Villas) Province, Cuba; Palmer locs. 1431 and 1433, S slope of Loma La Quinta, $0.2 \mathrm{~km}$ SE of Arroyo Blanco on road to Majagua, Camagüey Province, Cuba; Palmer loc. 1655, E of switch on Ramal Valle, 2 $\mathrm{km}$ or $1 \mathrm{~km} \mathrm{~W}$ of Valle 1, Camagüey Province, Cuba; Palmer loc. 1086, Loma La Quinta, E of Arroyo Blanco on road of Majagua, Camagüey Province, Cuba.

\section{Palmeraster palmeri Sánchez Roig \\ Figure 33; Plate 47: figures 1-4}

Material.-The type specimens have been lost; but 6 topotypic specimens identified by Sán- 
chez Roig are in the Museum of Paleontology, University of California. One of them (UCBA8394a) is described here. It is well preserved with no postmortem distortion, but weathering has removed all trace of the fascioles. The other specimens are poorly preserved and are not used in this description.
Shape And Size.-Length $33.0 \mathrm{~mm}$, width 30 mm (91\% L), height $23 \mathrm{~mm}$ (70\% L). Greatest width anterior, greatest height posterior; sides steep, smoothly rounded.

Apical System.-Anterior, located $11.7 \mathrm{~mm}$, from anterior margin to center of genital pores, $36 \%$ L. Three large genital pores, no pore in

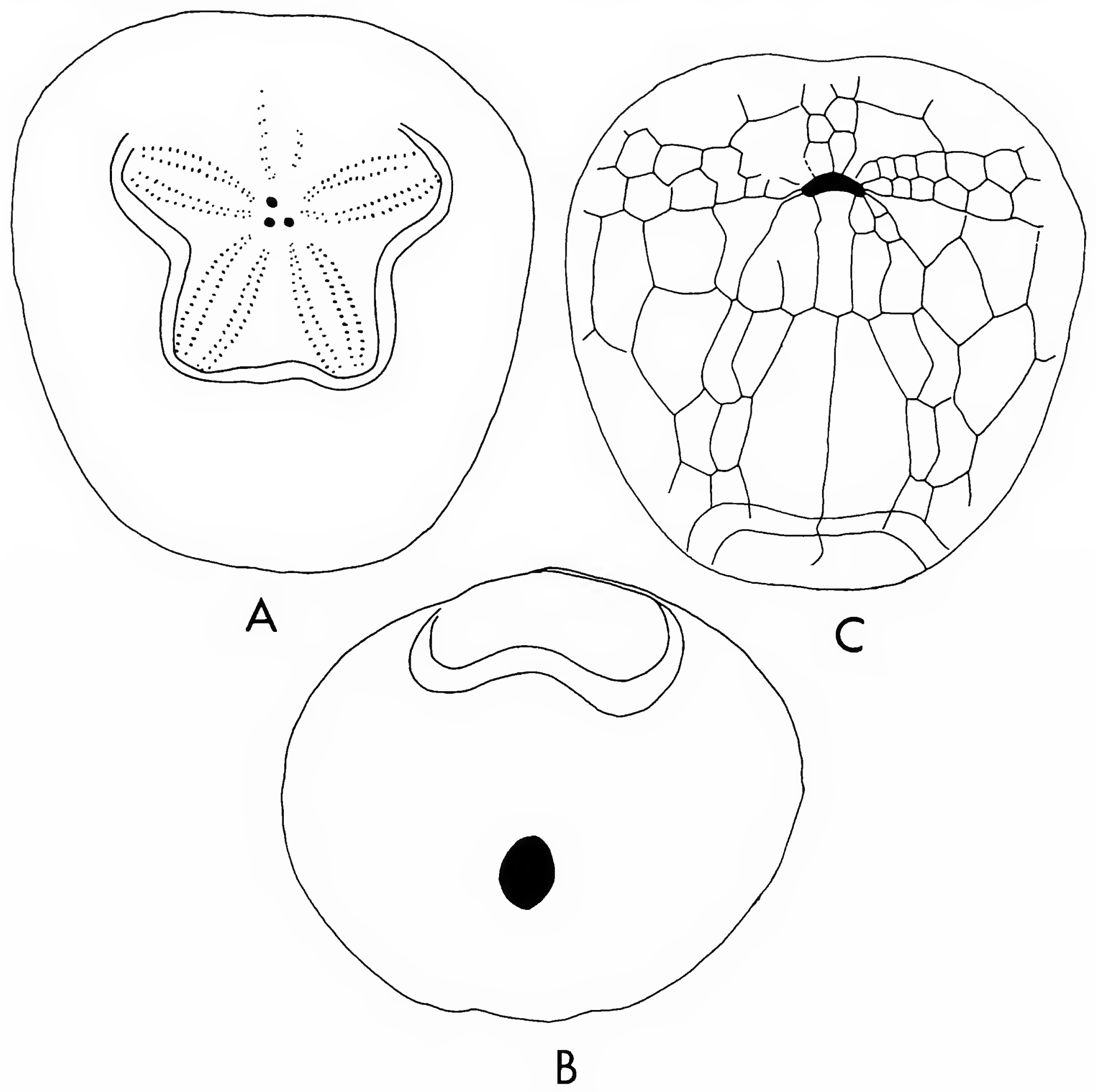

FIGURE 33.-Cyclaster drewryensis Cooke, topotype of Palmeraster palmeri Sánchez Roig (=C. drewryensis), UCB A8394a, $\times$ 4: A, dorsal view; B, rear view; C, ventral view. 
genital plate 2; ethmophract.

Ambulacra.-Anterior ambulacrum III not petaloid, in very shallow groove from apical system to peristome. Pores paired throughout all ambulacra. Pores enlarged in only short section of ambulacrum III with length approximately one-third distance from apical system to margin; 24 porepairs in region with enlarged porepairs; 54 plates in ambulacrum.

Anterior petals (II and IV) straight, short, extending almost two-thirds distance from apical system to margin, length $9.5 \mathrm{~mm}(29 \% \mathrm{~L})$, width $2.9 \mathrm{~mm}(8.8 \% \mathrm{~L})$. Interporiferous zones approximately same width as single poriferous zone; pore conjugate; 52 petaloid porepairs; first petaloid porepair in plate 16. Double pores in all ambulacra beyond petals.

Posterior petals (V and I) straight, approximately same length as anterior, length $9.0 \mathrm{~mm}$ $(27 \% \mathrm{~L})$, extending approximately one-half distanced from apical system to margin; width 3.0 $\mathrm{mm}(9.1 \% \mathrm{~L}) ; 50$ petaloid porepairs. Both pair of petals depressed in slight groove.

Peristome.-Very anterior, located at distance from anterior margin to anterior edge of peristome equal to $5.5 \mathrm{~mm}(17 \% \mathrm{~L})$; opening wider than high; width $3.4 \mathrm{~mm}$ (10\% L).

Periproct.-Located high on nearly vertical posterior truncation. Opening higher than wide, height $3.4 \mathrm{~mm}(10 \% \mathrm{~L})$, width $3.1 \mathrm{~mm}(9.4 \% \mathrm{~L})$.

Fasciole.-Not preserved.

Oral Plate Arrangement.-Labrum very long, length $7.8 \mathrm{~mm}(24 \% \mathrm{~L})$. Rest of plate sutures not clear.

Occurrence.-Late Eocene, Finca Concepción, Morón, Camagüey Province, Cuba.

\section{Cyclaster sanchezi Lambert}

Plate 48: figures 1-4

Cyclaster sanchezi Lambert in Sánchez Roig, 1926:113, pl. 38 : figs. 1, 2; 1949:218.

Material. - The holotype is lost. The one specimen in the collection (SRC 5452) is herein described. This specimen is only slightly distorted with most of its test intact. Seventeen other spec- imens are in the USNM Collections, but they are crushed.

Shape And Size.-Length $37 \mathrm{~mm}$, width $106 \%$ L, height $60 \%$ L. Greatest width anterior to center.

Apical System.-Anterior of center, distance from anterior margin to center of genital pores equal to $33 \%$ L. Ethmophractic with 3 genital pores; no pore in genital plate 2.

Ambulacra.-Anterior ambulacrum III not petaloid; dorsal region with enlarged pores short, extending approximately one-third distance from apical system to anterior margin; 28 enlarged porepairs (Plate 48: figure 4) in this region; first enlarged porepair in plate 11 ; total of 48 plates in ambulacrum.

Anterior petals (II and IV) and curving slightly anteriorly, depressed in groove with depth $2.1 \%$ $\mathrm{L}$, extending slightly more than one-half distance from apical system to margin; length $30 \% \mathrm{~L}$, width $9.4 \% \mathrm{~L}$. Interporiferous zone as wide as single poriferous zone; pores conjugate; 58 porepairs in petal.

Posterior petals ( $\mathrm{V}$ and I) straight, extending less than one-half distance from apical system to margin; depressed in groove with depth $2.4 \% \mathrm{~L}$; length $31 \% \mathrm{~L}$, width $9.4 \% \mathrm{~L} ; 64$ porepairs in each petal. Plates beyond petals with porepairs.

Peristome.-Anterior, located at distance from anterior margin to anterior edge of opening equal to $20 \% \mathrm{~L}$; opening small, width $13 \% \mathrm{~L}$, height $6.4 \% \mathrm{~L}$.

PERIPRoct.-High on posterior truncation, wider than high.

FAscioles.-Peripetalous fasciole broad, indented in paired interambulacra. Subanal fasciole broad, circumscribing a broad area, bilobed.

Tuberculation.-No large tubercles confined within peripetalous fasciole.

Oral Plate Arrangement.-Labrum very narrow, length $20 \% \mathrm{~L}$.

Occurrence.-Late Eocene, Finca Turibacoa, Majagua district, Ciego de Avila, Morón, Camagüey Province; Sievra Maraguan; $1 \mathrm{~km}$ E of San Antonio on Maraguan road, Camagüey Province, Cuba.

Comparison with Other Species.-Cyclaster 
sanchezi is clearly congeneric with $C$. drewryensis, also from the late Eocene of Cuba. Both species have ethmophract apical systems with 3 genital pores, narrow short petals, short regions in the anterior ambulacrum with enlarged porepairs, and small peristome. $C$. sanchezi differs in having a larger, lower test and a less anterior peristome.

\section{Genus Eupatagus L. Agassiz, 1847}

Herreraster Sánchez Roig, 1951:52.

Zanolettiaster Sánchez Roig, 1952c: 14.

Neopatagus Sánchez Roig, 1953b:258.

Test generally large, low, anterior ambulacrum with minute porepairs, petals large, broad, closed, apical system ethmolytic with 4 genital pores usually close together, large primary tubercles enclosed within peripetalous fasciole, both peripetalous and subanal fasciole present.

Habitat.-The living habits of the modern species of Eupatagus have not been described. Probably the echinoids live buried in sand. Presence of fascioles indicate a burrowing habit, but the small pores in the dorsal portion of ambulacrum III indicate a lack of funnel-building tubefeet. Therefore, it is doubtful that Eupatagus could bury in fine sediment. The living habits are known of a genus very similar to Eupatagus, namely Plagiobrissus. $P$. grandis (Gmelin) lives (Kier and Grant, 1965:37) buried in sand and builds no tunnel to the sediment-water interface.

Comparison with Species outside of Cuba.Most of the Cuban specimens of Eupatagus can be referred to E. cubensis (Cotteau), E. clevei (Cotteu), or E. alatus Arnold and Clark. E. cubensis is unlike any other species of this genus in the Western Hemisphere. Its large, very low test with many large tubercles within the peripetalous fasciole easily distinguishes it from all other species from this region. This difference is not surprising considering that no other species of Eupatagus is known from the Miocene of the Western Hemisphere. (Eupatagus depressus Jackson from the Miocene of Puerto Rico is herein considered a synonym of $E$. cubensis.) The genus was very common to the Eocene, with approximately 64 species reported from all over the world. It later became more restricted with only 17 species in the Oligocene and only 14 in the Miocene. Only 5 species are known today, and all are in the Indo-West Pacific.

Although Sánchez Roig (1949:201) reports Eupatagus antillarum (Cotteau) from Cuba, I have found no specimen from Cuba of that species.

Eupatagus clevei occurs in the Oligocene-Miocene of Cuba and the Eocene of Panama, St. Bartholomew, Florida, Jamaica, and Curacao. It is characterized by its long, wide petals and small tubercles within the peripetalous fasciole.

Eupatagus alatus is common in the Eocene of Cuba and Jamaica and is quite similar to E. clevei differing only in having shorter posterior petals and interporiferous zones, which are usually more constricted at the ends of the petals.

Specimens are rare of $E$. sanchezl (Lambert), $E$. turibacoensis Sánchez Roig, E. santanae Sánchez Roig, and E. siboneyensis Weisbord. E. sanchezi bears very little resemblance to any other species in the Western Hemisphere because of the few large, deeply scrobiculated primary tubercles within its peripetalous fasciole. E. turibacoensis and $E$. santanae are very similar to $E$. clevei and $E$. alatus. E. siboneyensis is much narrower than any other Eupatagus in the Western Hemisphere.

Remarks.-Herreraster is herein considered a subjective synonym of Eupatagus. Although the holotype of Herreraster is lost, a topotypic specimen identified by Sánchez Roig as belonging to this species is indistinguishable from Eupatagus clevei (Cotteau), which occurs at a nearby locality. $E$. cleve $i$ is clearly a Eupatagus having the large test, broad petals, subanal and peripetalous fascioles, and larger tubercles within the fasciole typical of this genus.

Zanolettiaster was considered by Fischer (1966: U586) a synonym of Eupatagus. Its type-species, $Z$. herrerae Sánchez Roig, is herein considered a synonym of $E$. clevei.

Sánchez Roig (1953b:258) erected a new genus Neopatagus for some species previously referred to Eupatagus, with type-species Eupatagus cubensis (Cotteau). I can see no differences that could distinguish generically this species (redescribed below) from the type-species of Eupatagus. 
TABLE 5.-Disposition herein of Cuban species of Eupatagus

\begin{tabular}{|c|c|c|c|}
\hline Disposition & Miocene & $\begin{array}{l}\text { Oligocene- } \\
\text { Miocene }\end{array}$ & Eocene \\
\hline $\begin{array}{l}\text { Recognized species } \\
\text { (Synonyms) }\end{array}$ & $\begin{array}{l}\text { E. cubensis } \\
\text { (? Brissoides } \\
\quad \text { brevipetalum) } \\
\text { (? B. elongatum) } \\
\text { (? B. herrerae) } \\
\text { (? B. lajasensis) } \\
\text { (? B. lamberti) } \\
\text { (? B. laucesi) } \\
\text { (? B. mayor) } \\
\text { (? B. munozi) } \\
\text { (? B. planus) } \\
\text { (? B. zanolettii) } \\
\text { (? Maretia estenozi) } \\
\text { E. sanchezi } \\
\text { (? E. habanensis) }\end{array}$ & 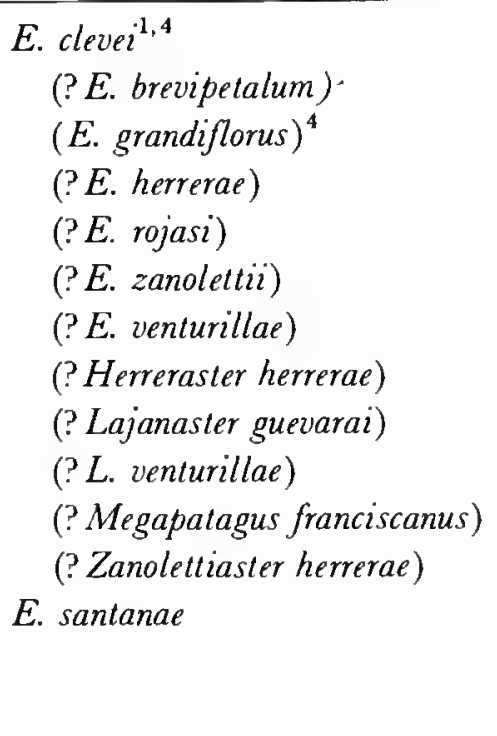 & $\begin{array}{l}\text { E. } \text { alatus }^{4} \\
\quad \text { (? E. brodermann }) \\
\text { (? E. caobaense) } \\
\text { (? E. casanovai) } \\
\text { (? E. pinarensis) } \\
\text { E. siboneyensis } \\
\text { E. turibacoensis } \\
\quad \text { (? E. calistoides) } \\
\text { (? Megapatagus turibacoensis) }\end{array}$ \\
\hline $\begin{array}{l}\text { Unrecognizable } \\
\text { species }\end{array}$ & & $\begin{array}{l}\text { Brissoides camagueyanus } \\
\text { B. minutus } \\
\text { B. palmer } \\
\text { B. santanae } \\
\text { E. avilensis } \\
\text { E. depressus } \\
{ }^{3} \\
\text { Lajanaster hernandezi }\end{array}$ & Brissoides stefaninii \\
\hline
\end{tabular}

\footnotetext{
${ }^{1}$ Some specimens from the Eocene. ${ }^{2}$ Oligocene-Miocene. ${ }^{3}$ Preoccupied. ${ }^{4}$ This taxon not previously reported from Cuba.
}

Although 41 species (Table 5) described from Cuba can be referred to Eupatagus, I can recognize only 7 . Eight of the 41 are unrecognizable because the type specimens were not available to me (lost or on loan) and Sánchez Roig's illustrations of them are not adequate for comparison with other species. These include:

Brissoides camagueyanus Sánchez Roig (1949:206, pl. 25: fig. 1).

Brissoides minutus Sánchez Roig (1949:205).

Brissoides palmeri Sánchez Roig (1949:205, pl. 25: figs. 4, 5).

Brissoides santanea Sánchez Roig (1949:210, pl. 25: figs. 2, 3; not Eupatagus santanae Sánchez Roig, 1951:47, pl. 37: fig. 2).

Brissoides stefaninii Lambert and Sánchez Roig (1949:207, pl. 23: fig. 1).

Eupatagus avilensis Sánchez Roig (1951:45, pl. 33: figs. 2, 3).

Lajanaster hernandezi Sánchez Roig (1949:195, pl. 23: figs. 2, 3). (The specimen labelled as the type in the collection is not the specimen figured by Sánchez Roig; it does not have the same dimensions; its petals are far wider than those in Sánchez Roig's illustration. For this reason I cannot redescribe this species. This particular species appears from Sánchez Roig's figures to be a Eupatagus; its petals are too wide for Lajanaster).

Twenty-eight of the species are considered herein as probable synonyms. Most of the type specimens are badly weathered and many distorted by postmortem compression. This alteration has caused them to differ, not only in their shape but also in the character of their petals and other features. The pores of a petaloid porepair diverge from each other as they pass inward through the test. Therefore, in a more heavily weathered specimen the pores of a pair will be farther apart than in a less-weathered specimen of the same species. This difference makes the 
petals appear very different suggesting that the specimens may not be conspecific. Furthermore, Sánchez Roig had very few specimens of most of these species and could not be aware of the amount of variation that can occur within one species of Eupatagus.

Many of the species occur at the same locality, 11 from "Cervantes" farm at San José de las Lajas and 7 from "La Venturilla" farm at Realengo, Charco Hondo. It is unlikely that so many species would occur at the same locality unless the deposition of the sediment occurred over a long period of time permitting the evolution of so many species.

It is not possible to be certain of the status of most of the assignments of these species. The type specimens are poorly preserved. Many are lost or not available for study, and none were collected from measured sections so that the relative ages of most of them are not known. Therefore, most of my assignments are provisional, and only if more specimens become available can the uncertainties be resolved.

\section{Key to Cuban Species of Eupatagus}

1. Large tubercles in deep scrobicules within peripetalous fascioles ..... 2 Small tubercles not in deep scrobicules within peripetalous fascioles . . 3

2. Few tubercles .............. E. sanchezi (Lambert), new combination Many tubercles ......................... E. cubensis (Cotteau)

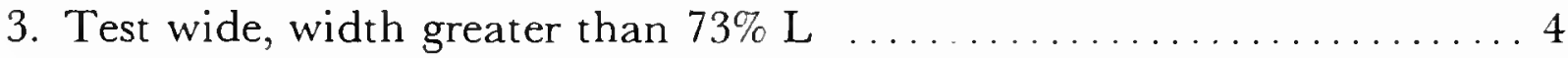
Test narrow, width less than $73 \% \mathrm{~L} \quad \ldots . \ldots$... E. siboneyensis Weisbord

4. Test large with long, wide petals, posterior extending almost to margin with greatest width of interporiferous zones near end of petals

E. clevei (Cotteau)

Test of moderate size with posterior petals not reaching margin, interporiferous zones constricted at ends of petals ................ 5

5. Porepairs in same poriferous zone close together

...... E. turibacoensis Sánchez Roig and E. santanae Sánchez Roig

Porepairs in same poriferous zone more widely separated

E. alatus Arnold and Clark

\section{Eupatagus alatus Arnold and Clark}

Figure 34; Plate 54; Plate 55: Figures 1, 2

Eupatagus alatus Arnold and Clark, 1927:63, pl. 13: figs. 4-7; 1934:155.

?Eupatagus caobaense Sánchez Roig, 1952c:13, pl. 6:fig. 10.

?Eupatagus brodermanni Sánchez Roig, 1953c:159, pl. 9: figs. 1, 4.

?Eupatagus casanovai Sánchez Roig, 1953c:159, pl. 9: figs. 2, 3.

?Eupatagus (Spatangomorpha) pinarensis Sánchez Roig, 1953c: 157, pl. 7: figs. $3,4$.

Material.-Sánchez Roig described 4 species (see above) of Eupatagus from the same locality. The type specimens of these species are not avail- able, but from a study of Sánchez Roig's illustrations and examination of 24 specimens of Eupatagus in the USNM Collections from the typelocality, these 4 species appear to be synonyms of $E$. alatus from the Eocene of Jamaica.

Many of the specimens are badly weathered and distorted. Because of these differences in preservation, some specimens superficially appear to belong to different species. The shape of their tests differ as a result of postmortem distortion. Highly weathered specimens have the petaloid pores greatly enlarged making the petals appear to be dissimilar. Because the pores diverge from each other as they pass into the test, specimens which are more weathered have the pores of a 
pair more widely separated than do less-weathered specimens. The number of pores in the petals relative to the length of the test, the length of the petals relative to each other and number of plates beyond the petals are similar in all the specimens, suggesting that they are all conspecific.

I have compared the Cuban specimens with 19 Jamaican specimens of $E$. alatus in the USNM
Collections and with the holotype and many paratypes at the MCZ and can see no significant differences. A photograph of a Jamaican specimen is included (Plate 55: figs. 1, 2) for comparison with the Cuban specimens. The description below is based on the Cuban specimens.

Shape AND Size.-Test large, length 38 to 75 mm (mean $56 \mathrm{~mm}$ ); width 77 to $93 \% \mathrm{~L}$ (mean

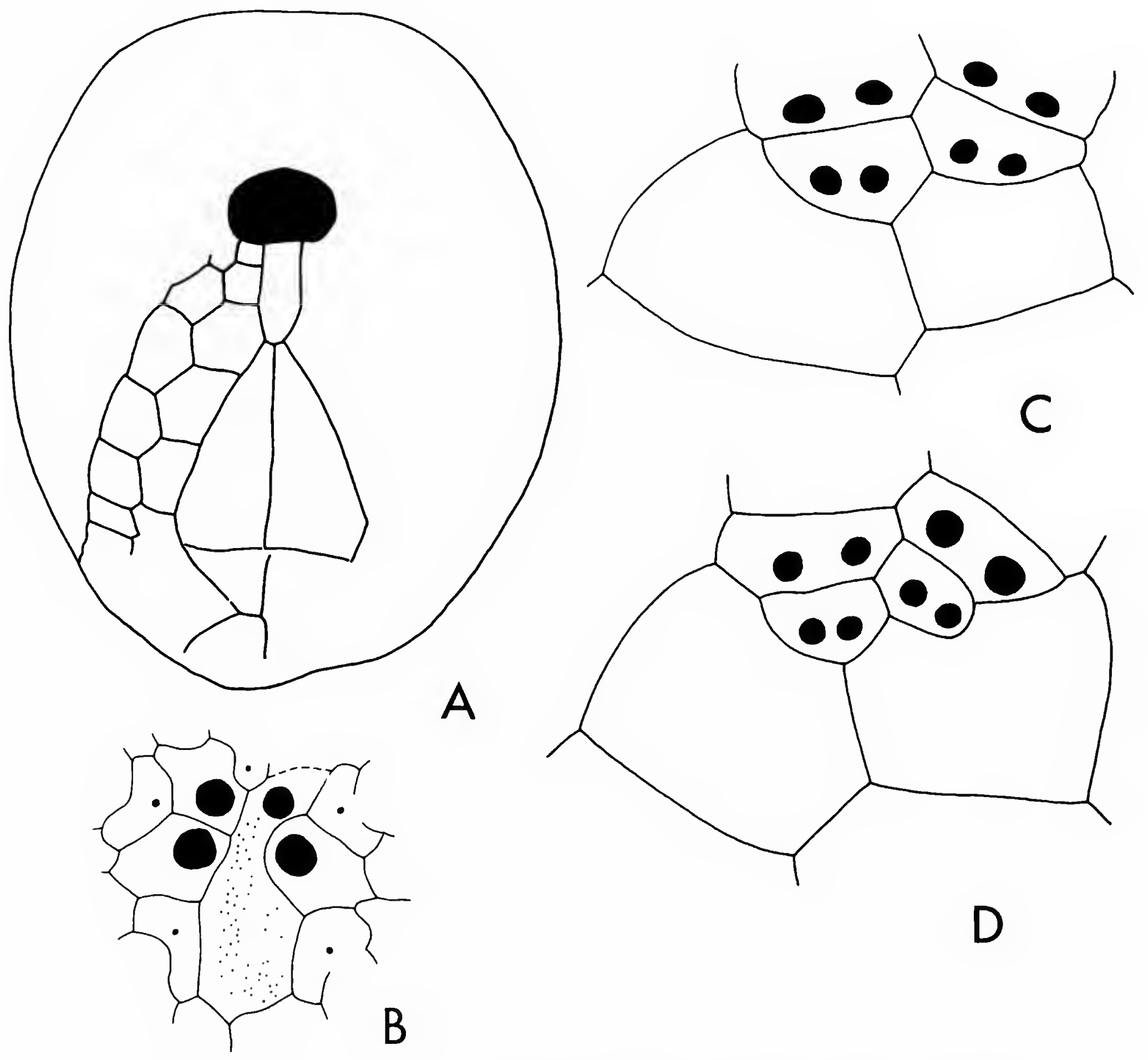

Figure 34.-Eupalagus alalus Arnold and Clark, Eocene, Loma Caoba, San Diego de los Baños, Pinar del Rio Province: A, ventral plate arrangement of USNM 341263, $\times 2$; B, apical system of USNM 341256, $\times 12$; c, plate arrangement at end of petal I of USNM 341262, $\times 15$; D, petal II of USNM $341262, \times 15$. 
83); with greatest width central; height 43 to $56 \%$ L (mean 51); greatest height posterior; slight anterior groove.

Apical System.-Anterior, located at distance from anterior margin to center of apical system equal to 24 to $36 \% \mathrm{~L}$ (mean 28); 4 genital pores (Figure 34B, Plate 54: figure 6), ethmolytic with genital plate 2 extending posteriorly separating posterior ocular plates.

AMBULACRA.-Anterior ambulacrum not petaloid, pores small, nonconjugate anisopores (as defined by Smith, 1980:62) having the inner pore of pair anterior, slit-like, outer pore round with prominence separating them. According to Smith (1980:64) the tubefoot that extended through this kind of porepair was sensory in function; 64 plates in ambulacrum III of specimen $67 \mathrm{~mm}$ long.

Anterior petals (II and IV) long, extending almost to margin, length 29 to $45 \%$ L (mean 34); petals wide with width 12 to $15 \%$ L (mean 13); interporiferous zones wide, width 3.9 to $7.2 \% \mathrm{~L}$ (mean 5.0); poriferous zones narrow, width 3.5 to $4.4 \% \mathrm{~L}$ (mean 3.9); petals closing distally. Five specimens show sutures of plates at end of petal; two (Figure $34 \mathrm{c}$ ) have $1 \frac{1}{2} / 2$ plates of anterior poriferous zone occluded, enclosed by first ambulacral plate beyond petal; other three with last plate not occluded in posterior poriferous zones; four specimens with $1 \frac{1}{2}$ plates occluded, one with no occluded plate. Specimen $37 \mathrm{~mm}$ long with 52 petaloid porepairs, $48 \mathrm{~mm}$ long with $54 ; 65 \mathrm{~mm}$ long with $64 ; 76 \mathrm{~mm}$ long with 66 ; first porepair in petal II or IV in plates 13, 14, or 15.

Posterior petals (V and I) extending less than two-thirds distance from apical system to margin; length 32 to $48 \% \mathrm{~L}$ (mean 39); petals wide with width 11 to $15 \% \mathrm{~L}$ (mean 12); interporiferous zones wide, width 3.7 to $6.9 \% \mathrm{~L}$ (mean 4.7 ); poriferous zones narrow, width 3.7 to $4.5 \% \mathrm{~L}$ (mean 4.0); petals closing distally. Five specimens show sutures of plates at end of petals (Figure $34 \mathrm{c}$ ); four have $2 \frac{1}{2} 2$ plates of anterior poriferous zone occluded, enclosed by first ambulacral plate beyond petal, one with $1 \frac{1 / 2}{2}$ plates occluded; in posterior poriferous zones 4 specimens have $1 \frac{1}{2}$ plates occluded, one has $2 \frac{1}{2}$. Specimen $37 \mathrm{~mm}$ long with 58 petaloid porepairs, $44 \mathrm{~mm}$ long with
$60,65 \mathrm{~mm}$ long with $68,76 \mathrm{~mm}$ long with 68 . In none of the specimens is it possible to determine the number of plates beyond the petals.

All petals flush with surface of test; pores strongly conjugate with deep furrow joining pores (Plate 54: figure 7); outer pore more elongate than inner.

Peristome.-Anterior, distance from anterior margin to anterior edge of peristome 18 to $26 \% \mathrm{~L}$ (mean 23); width 13 to $17 \% \mathrm{~L}$ (mean 16); height 8.2 to $13 \% \mathrm{~L}$ (mean 11 ).

Periproct.-Well preserved on 2 specimens; high on posterior truncation, sloping slightly so that periproct slightly visible from above; opening higher than wide, height 16 to $21 \% \mathrm{~L}$ (mean 18 ); width 10 to $15 \% \mathrm{~L}$ (mean 13).

Fascioles.-Peripetalous fasciole passing around petals, not indented in interambulacra, width approximately $0.8 \% \mathrm{~L}$, crossing ambulacra II or IV on plates 12,13, or 14; not clear on what other plates.

Subanal fasciole circumscribing broad shield with dorsal tract passing below lower edge of periproct approximately one-half distance from lower edge to ventral side of test; width of shield approximately $37 \% \mathrm{~L}$, height $21 \% \mathrm{~L}$.

TuBerCulation.-Large, irregularly arranged tubercles confined within peripetalous fasciole in all interambulacra (Plate 54: figure 7).

Oral Plate Arrangement.-Most of plate arrangement not visible on any specimens; labrum (Figure 34A) long, narrow, length approximately $15 \% \mathrm{~L}$, width $7 \% \mathrm{~L}$; extending posteriorly to middle of third adjacent ambulacral plate. Plastron (Figure $34 \mathrm{~A}$ ) composed of 4 plates: 2 sternal plates measurable in only one specimen, length $29 \% \mathrm{~L}$, combined width $28 \% \mathrm{~L} ; 2$ poststernal plates much smaller, length $12 \% \mathrm{~L}$, greatest combined width $23 \% \mathrm{~L}$.

Occurrence.-Middle to late Eocene, Loma Caoba, San Diego de los Baños, Pinar del Rio Province, Cuba; Eocene, W of Springfield towards Seven Rivers, St. James Parish, Jamaica. One specimen from Camagüey Province in the USNM Collections was collected by Palmer and appears to belong to this species. It is from Palmer loc. 1640, late Eocene, deep cut N of Grua 9, 
Ramal Juan Criollo, Camagüey Province, Cuba.

Comparison with Other Species. - This species is very similar to E. turibacoensis Sánchez Roig from the late Eocene of Camagüey Province. It differs only in having a blunter anterior surface and in having the porepairs in the same poriferous zone appear to be closer together. These differences may or may not be systematically significant; only one specimen is available of E. turibacoensis.

Eupatagus alatus differs from the lectotype (designated by Cooke, 1959:90) of E. antillarum (Cotteau) (Plate 61: figures 1, 2) from the Eocene of St. Bartholomew in having a broader test with wider petals and a much higher peristome. It differs from the late Eocene Floridian specimens that Cooke referred to E. antillarum (which belong to a different species, Eupatagus mooreanus Pilsbry) in having shorter posterior petals, a less-pointed posterior and blunter anterior surface.

Eupatagus clevei (Cotteau) from St. Bartholomew, Panama, Jamaica, Curacao, and Florida differs from $E$. alatus in its much narrower test, wider petals and lower peristome.

E. alatus is distinguished from Eupatagus carolinensis Clark from the middle Eocene, Castle Hayne Limestone of North Carolina by its wider petals, more divergent anterior petals, smaller peristome, and smaller tubercles within the peripetalous fasciole. It differs from Eupatagus wilsoni Kier also from the Castle Hayne in having its apical system much more anterior, more petaloid porepairs, generally wider test, and larger tubercles within the peripetalous fasciole.

\section{Eupatagus clevei (Cotteau)}

Plate 61: figures 3-6; Plates 62-66

Euspatangus clevei Cotteau, 1875:44, pl. 8: figs. 1-4. Euspatangus grandiflorus Cotteau, 1875:45, pl. 8: figs. 5, 6. Eupatagus clevei (Cotteau).-Guppy, 1882:199._Jackson, 1922:90, pl. 16: figs. 1, 2.-Cooke, 1948:92, pl. 22: fig. 9.-Fischer, 1951:83, fig. 18, pl. 7: figs. 1-3.-Cooke, 1959:89, pl. 41: figs. 6-8; 1961:26, pl. 10: figs. 2-5.Zachos and Shaak, 1978:921, pl. 1: fig. 1.

Eupatagus grandiflorus (Cotteau).-Jackson, 1922:89, pl. 15: figs. 5, 6.-Molengraaff, 1929:72, pl. 24: figs. 1, 2, pl. 25: fig. 1.-Arnold and Clark, 1934:156.-Cooke, 1959:89.Zachos and Shaak, 1978:921.

Brissoides grandiflorus (Cotteau)._Sánchez Roig, 1949:208.

?Eupatagus (Gymnopalagus) venturillae Sánchez Roig, 1951:43, pl. 26: figs. 1, 2.

?Eupalagus (Gymnopatagus) rojasi Sánchez Roig, 1951:42, pl. 34: fig. 3.

?Eupatagus (Gymnopalagus) zanolelli Sánchez Roig, 1951:43, pl. 32: fig. 3 [not Brissordes zanolettii Sánchez Roig, 1952c:12, pl. 7: figs. 1, 2].

Lajanaster guevarai Sánchez Roig, 1951:53, pl. 24: figs. 2-4.

?Eupatagus (Plagiobrissus) herrerae Sánchez Roig, 1951:46, pl. 25: figs. 1, 2 [not Herreraster herrerae Sánchez Roig, 1951:53, pls. 30, 31; not Brissoides herrerae Sánchez Roig, 1924:82, pl. 10: figs. 1, 2].

?Eupatagus (Gymnopatagus) brevipetalum Sánchez Roig, 1951:44, pl. 33: fig. 1, pl. 38: fig. 1 [not Brissoides brevipetalum Sánchez Roig, 1924a: 84, pl. 11: figs. 1, 2.

?Herreraster herrerae Sánchez Roig, 1951:53, pls. 30, 31 [not Brissoides herrerae Sánchez Roig, 1982a:58, pl. 10: figs. 1, 2; not Eupatagus herrerae Sánchez Roig, 1951:46, pl. 25: figs. $1,2$.

?Lajanaster venturillae Sánchez Roig, 1951:54, pl. 25: figs. 3, 4. ?Zanoletliaster herrerae Sánchez Roig, 1952c: 15, pl. 8: figs. 1, 2, pl. 9: fig. 4.

?Megapalagus franciscanus Sánchez Roig, 1953a:59, pl. 11: 2 figs.

?Eupatagus ingens Zachos, 1968:161, fig. 1.-Zachos and Shaak, 1978:921, pl. 1: figs. 2-4.

Material.-Many species have been erected for specimens that differ only slightly from each other; all appear conspecific with E. clevei. Most of the differences are the result of postmortem distortion, or they are phenotypic variations, which are expected to occur in specimens of the same species. Guppy (1882:192), Cooke (1948:93; 1959:89) and Zachos and Shaak (1978:921) consider E. grandiflorus (Cotteau) and E. clevei (Cotteau) to be synonymous. Both come from the Eocene of St. Bartholomew.

Sánchez Roig erected many new species of Eupatagus for specimens that appear conspecific with each other and $E$. clevei. They are all from the same locality and include $E$. venturillae (Plate 62: figures 1, 2), E. brevipetalum (Plate 62: figures 3-6), E. herrerae (Plate 65: figures 1-4), E. zanoletti (Plate 66: figures 4-6), Lajanaster venturillae (Plate 65: figures 5, 6; Plate 66: figures 1, 2), L. guevaral and Zanolettiaster herrerae (Plate 61: figures 5, 6). E. rojası Sánchez Roig (Plate 64: figures 3-5) is 
found near this locality. Its apical system is more central than in the holotype of $E$. clevei, but this appears to only be due to postmortem distortion. The two species are similar in having long, broad petals. The holotype of E. zanoletti Sánchez Roig is lost, but a topotypic specimen (Plate 66: figures 4-6) referred to this species by Sánchez Roig is indistinguishable from $E$. clevei.

The holotype of Megapatagus franciscanus Sánchez Roig (Plate 63) is also very similar to $E$. clevei.

Although the holotype of Herreraster herrerae Sánchez Roig is lost, a topotypic specimen (Plate 64: figures 1,2 ) has the same long, wide petals so typical of $E$. clevei.

Eupatagus ingens Zachos from the Eocene of Florida also appears to be a synonym of $E$. clever.

Eupatagus hildae Hawkins from Jamaica is probably synonymous with $E$. clevei. Both species have a large test with long, wide petals and the same general appearance. As only one specimen is known of $E$. hildae and its age is uncertain, I am unwilling to synonymize it with $E$. clevei.

The St. Bartholomew, American, and Jamaican specimens referred to $E$. clevei are Eocene; whereas, the Cuban specimens come from the Oligocene-Miocene. It is unusual for a spatangoid species to have such a long stratigraphic range. Perhaps, if better material was available, specific distinctions might be apparent between the $\mathrm{Cu}$ ban and Eocene specimens. I cannot separate them now.

Occurrence.-Types of E. clevei and E. grandiflorus from Eocene of St. Bartholomew. E. clevei has also been reported from Jamaica, Curacao, and from the late Eocene, USGS loc. 16889. Madden Airfield, $15 \mathrm{mi}(24 \mathrm{~km}) \mathrm{N}$ of central part of Panama City; Rio Tonosí, $300 \mathrm{ft}(91.4 \mathrm{~m})$ below the mouth of Quebrada Guerita (USGS 8289), Panama. E. ingens is from the late Eocene Ocala Limestone in Florida. The type specimens of Eupatagus brevipetalu, $E$. herrerae, $E$. venturillae, $E$. zanoletti, Lajanaster venturillae, L. guevarai, and Zanolettiaster herrerae came from beds referred to the Oligocene (Oligocene-Miocene herein) at "La Venturilla" farm, Realengo, Charco Hondo, Mo- rón, Camagüey Province, Cuba. The type of Eupatagus rojasi came from "Las Cabezadas" farm, Corral Naranjo, 12 km E of Marroquín, Morón, Camagüey Province. Herreraster herrerae came from "Las Cuevas" farm, Realengo, Charco Hondo, Ranchuelo district, Morón, Camagüey Province. The holotype of Megapatagus franciscanus is from "San Francisco de la Rosa" farm, Guadalupe district, Morón, Camagüey Province, Cuba. All of these localities were considered by Sánchez Roig to be Oligocene but are herein considered Oligocene-Miocene.

One poorly preserved specimen (ANSP 16638) in the Palmer Collection in the Academy of Natural Sciences of Philadelphia, probably belongs to the species. It is from Palmer locality no. 1476, riprap along Nuevitas beach, about $\mathrm{Km} 73$ on railroad to Pastelillo (taken from cut at $\mathrm{Km} \mathrm{74),}$ Camagüey Province, Cuba. Palmer assigned a late Eocene age to this locality.

Comparison with Other Species.-E. clevei resembles in many characters Eupatagus turibacoensis Sánchez Roig from the late Eocene of Cuba. Both species have large tests with the anterior ambulacrum flush or in a very slight groove; long, wide petals with wide interporiferous zones, and peristomes of similar outline and position. The holotype of $E$. turibacoensis has its petals slightly constricted near their extremities, whereas in $E$. cleve $i$ they are narrower and less constricted. However, the holotype of Megapatagus turibacoensis Sánchez Roig, which occurs with the lectotype of $E$. turibacoensis and is herein considered a probable synonym of it, has petals indistinguishable from E. clevei. Obviously, E. clevei and E. turibacoensis are very closely related and may be synonymous.

Remarks.-Of the Cuban specimens that I have seen and consider to belong to this species, none are well-enough preserved to show the nature of the tubercles within the peripetalous fasciole. They are visible, however, on specimens from the late Eocene of Panama that Cooke (1948:92) referred to Eupatagus clevei (Cotteau). One of the Panamanian specimens is crushed but has its tuberculation extremely well preserved (Plate 66: figure 3). The tubercles within the 
fasciole are only slightly larger than those outside and are not sunken in deep scrobicules.

\section{SYNONYMS}

\section{?Eupatagus brevipetalum Sánchez Roig \\ Plate 62: figures 3-6}

Material.-Only one specimen (SRC 4094), present in the Sánchez Roig Collection. This specimen was figured by Sánchez Roig (1951, pl. 33: fig. 1) and is the one he used for dimensions. It is herein selected as the lectotype. His second figured specimen has been lost.

The lectotype is very poorly preserved. The dorsal surface is very badly weathered with most of the tubercles absent and no trace of the fascioles. The adoral surface was covered with matrix and was not seen by Sánchez Roig. The test has been distorted by postmortem compression with the upper left side depressed.

Shape AND Size.-Length $77 \mathrm{~mm}$, width $85 \%$ L, height $49 \% \mathrm{~L}$; greatest width anterior, greatest height posterior.

Apical System.-Absent.

Ambulacra.-Anterior ambulacrum III not petaloid, in very slight groove; porepairs very small in adapical region.

Anterior petals (II and IV) extending fourfifths distance from apical system to margin; length $39 \% \mathrm{~L}$, greatest width $19 \% \mathrm{~L}$, interporiferous zone very wide, greatest width $9.6 \% \mathrm{~L}$; petals flush with rest of surface of test except for slight depression of poriferous zones. Pores conjugate; where pores not altered and enlarged by weathering, outer pore of pair more elongate than inner; 56 petaloid porepairs.

Posterior petals ( $\mathrm{V}$ and $\mathrm{I}$ ) extending two-thirds distance from apical system to margin, length $41 \% \mathrm{~L}$, greatest width $6.5 \% \mathrm{~L}$, greatest width of interporiferous zone $9.9 \% \mathrm{~L}$. Not possible to determine number of petaloid porepairs because of fracturing of test. Last $2 \frac{1}{2}$ plates in single poriferous zone of petal occluded, enclosed by first ambulacral plate beyond petal.

Peristome.-Anterior, located at distance from anterior margin to anterior edge of peristome equal to $21 \% \mathrm{~L}$. Width of opening $15 \% \mathrm{~L}$, height $7.4 \% \mathrm{~L}$.

PERIProct.-Located slightly below midpoint of slightly overhanging posterior truncation; higher than wide, height $15 \% \mathrm{~L}$, width $11 \% \mathrm{~L}$.

FASCIOLES.-Not preserved.

Oral Plate Arrangement.--Sutures not visible.

Occurrence.-Oligocene-Miocene, "La Venturilla" farm, Realengo, Charco Hondo, Morón, Camagüey Province, Cuba.

\section{?Eupatagus herrerae Sánchez Roig}

$$
\text { Plate 65: figures 1-4 }
$$

Material.-Only one specimen is known, the holotype (SRC 4060). This specimen is complete but heavily weathered, eradicating the tuberculation. The test is compressed to the left as viewed from above.

ShaPe and Size.-Length $84.0 \mathrm{~mm}$, width 67.9 $\mathrm{mm}(81 \% \mathrm{~L})$, height $41.6 \mathrm{~mm}$ (50\% L). Greatest width and height anterior; test smoothly inflated.

Apical System.-Four genital pores, ethmolytic with madreporite extending far beyond posterior ocular plates. Apical system anterior of center at distance from anterior margin to center of genital pores equal to $36 \% \mathrm{~L}$.

Ambulacra.-Anterior ambulacrum III not petaloid, flush adapically, slightly depressed from margin to peristome. Ambulacrum very narrow adapically, nature of pores and number of plates not known because of weathering.

Anterior petals (II and IV) long, extending almost to margin, length $42 \% \mathrm{~L}$. Petals wide, $15 \%$ $\mathrm{L}$ with wide interporiferous zone, $6.9 \% \mathrm{~L}$; petals flush with rest of surface of test. Poriferous zones narrow, conjugate, outer pore of pair slightly more elongate than inner; porepairs in first adapical 4 or 5 plates of anterior poriferous zone smaller than opposite porepairs in posterior zone; 76 petaloid porepairs.

Posterior petals (V and I) long, extending almost to margin, length $48 \% \mathrm{~L}$. Petals wide, $14 \%$ $\mathrm{L}$ with wide interporiferous zone, $6.3 \% \mathrm{~L}$; petals flush with test. Adapically, pores closer together 
in posterior poriferous zones; 82 petaloid porepairs.

Peristome.-Anterior, located medially on vertical posterior truncation; opening large, height $8.0 \% \mathrm{~L}$, width $16 \% \mathrm{~L}$.

Periproct.-Marginal, located on nearly vertical posterior truncation; height $17 \% \mathrm{~L}$, width $11 \%$ L (Plate 65: figure 4).

FASCiOLeS.-Peripetalous and subanal fasciole present but most of tract not preserved.

Oral Plate Arrangement.-Labrum long; length $12 \% \mathrm{~L}$; rest of plate sutures not clear.

Occurrence.-Oligocene-Miocene, old sugar house of "La Venturilla" farm, Realengo, Charco Hondo, Morón, Camagüey Province, Cuba.

\section{Eupatagus rojası Sánchez Roig}

Plate 64: figures 3-5

Material.-The holotype (SRC 4056) and only known specimen is very poorly preserved. The test is crushed and badly weathered with the tubercles eroded away and the peristome covered.

Shape And Size.-Length $116 \mathrm{~mm}$, width (est.) $85 \%$ L, height (est.) $50 \%$ L. Greatest width anterior, greatest height at apical system.

Apical System.-Because of distortion of the test, position of apical system uncertain. It is central on the specimen but was probably anterior originally before postmortem crushing. Ethmolytic, number of genital pores not discernible.

AMBULACRA.-Anterior ambulacrum III not petaloid, in slight groove, pores very small in adapical region, not markedly differentiated from pores on margin; width of ambulacrum at margin $7.4 \% \mathrm{~L}$.

Anterior petals (II and IV) extending to margin, length $56 \% \mathrm{~L}$, interporiferous zone very wide, width $7.5 \% \mathrm{~L}$, greatest width of petal $16 \% \mathrm{~L}$, petals flush with test. Poriferous zones narrow, $4.3 \% \mathrm{~L}$, pores conjugate, outer pore of pair larger and more elongate than inner; adapical porepairs in anterior poriferous zone smaller than in posterior poriferous zone; 98 petaloid porepairs.

Posterior petals ( $\mathrm{V}$ and I) extending almost to margin, length $53 \% \mathrm{~L}$, greatest width $17 \% \mathrm{~L}$, petals flush; interporiferous zone with width $7.8 \%$ L. Poriferous zones narrow, $4.3 \% \mathrm{~L}$; 96 petaloid porepairs. Last $2^{1 / 2}$ plates in single poriferous zone of petal occluded, enclosed by first ambulacral plate beyond petal.

Peristome.-Covered by hard matrix.

Periproct._-Position obscured by crushing, apparently large, higher than wide, height $14 \%$ L.

Fascioles. - Not discernible.

Oral Plate Arrangement.-Covered.

Occurrence.-Oligocene-Miocene, "Las Cabezadas," Coral Naranjo, $12 \mathrm{~km}$ E of Marroquín, Morón, Camagüey Province, Cuba.

\section{?Eupatagus venturillae Sánchez Roig}

$$
\text { Plate 62: figures 1, } 2
$$

Material.-Two specimens were used by Sánchez Roig in his original description. I suspect that they both did not come from the "Concepción" farm as stated by Sánchez Roig. One of the specimens (SRC 4027) is very similar in its color and matrix to specimens from "La Venturilla" farm, Realengo, Charco Hondo, Morón, Camagüey Province, Cuba. Because Sánchez Roig named the species $E$. venturillae, I suspect that this specimen came from there. In every other case in which he used that trivial name, the species has been from that locality. The other specimen is more yellow in color and may be from "Concepción" farm. In order to avoid basing the species on specimens from two localities, I herein select specimen 4027 (Sánchez Roig, 1951, pl. 26: fig. 1), which I believe is from " $\mathrm{La}$ Venturilla," as the lectotype; the other specimen (4704) is not included in the following description.

Shape And Size. - Length $99 \mathrm{~mm}$, width $82 \%$ $\mathrm{L}$, height $48 \% \mathrm{~L}$. Greatest width anterior, greatest height posterior.

Apical System.-Four genital pores, ethymolytic, madreporite extending posteriorly separating posterior ocular plates; located anterior of center at distance from anterior margin to center of genital pores equal to $37 \% \mathrm{~L}$. 
Ambulacra.-Anterior ambulacrum III not petaloid, in very slight groove at margin, pores very small in adapical region, not markedly differentiated from pores on margin of test; at margin width of ambulacrum $5.7 \% \mathrm{~L}$.

Anterior petals (II and IV) long, extending to margin; length $47 \% \mathrm{~L}$, greatest width $16 \% \mathrm{~L}$, interporiferous zones very wide, greatest width $7.8 \% \mathrm{~L}$, petals flush with test. Poriferous zones narrow $4.7 \% \mathrm{~L}$; pores conjugate, outer pore of pair larger and more elongated than inner; adapical porepairs and plates in anterior poriferous zone slightly smaller than in posterior poriferous zone; 84 petaloid porepairs.

Posterior petals ( $\mathrm{V}$ and $\mathrm{I}$ ) extending almost to margin, length $53 \% \mathrm{~L}$, greatest width $15 \% \mathrm{~L}$, interporiferous zone very wide, greatest width $7.0 \% \mathrm{~L}$, petals flush. Poriferous zone narrow $4.6 \%$ L; 90 petaloid porepairs.

Peristome.-Not preserved.

Periprocit.-Not preserved.

Fascioles.-Not preserved, but both peripetalous and subanal fascioles preserved on other specimens referrable to this species.

Tuberculation.-Specimen too weathered to determine presence of larger tubercles within peripetalous fasciole.

Oral Plate Arrangement.-Not presereved.

Occurrence.-Oligocene-Miocene, "La Venturillae" farm, Realengo, Charco Hondo, Morón, Camagüey Province, Cuba.

\section{?Lajanaster venturillae Sánchez Roig}

Figure 35; Plate 65: figures 5, 6; Plate 66: figures 1, 2

Material.-One of the two cotypes (SRC 4136) is present. This specimen was figured by Sánchez Roig (1951, pl. 25: fig. 4) and is herein selected as the lectotype. The specimen is badly weathered with most of the tuberculation eroded away.

Shape and Size.-Length $74 \mathrm{~mm}$, width $82 \%$ $\mathrm{L}$, height $48 \% \mathrm{~L}$; greatest width anterior of center, greatest height posterior.
Apical System.-Four genital pores, ethmolytic with madreporite (Figure 35A) extending posteriorly separating posterior ocular plates. Apical system anterior of center at distance from anterior margin to center of genital pores equal to $30 \% \mathrm{~L}$.

Ambulacra.-Anterior ambulacrum III not petaloid, in very slight groove at margin, pores very small in adapical region, not markedly differentiated from pores on margin of test, 76 plates in ambulacrum.

Anterior petals (II and IV) extending almost to margin, length $40 \% \mathrm{~L}$; petals very wide, greatest width $18 \% \mathrm{~L}$, closed distally. Interporiferous zone very wide, at greatest width $8.8 \% \mathrm{~L}$; petals flush with test except for slightly depressed poriferous zones. Poriferous zones narrow, $4.2 \% \mathrm{~L}$, pores strongly conjugate with deep groove joining pores of pair, outer pore slightly more elongate than inner. Adapical porepairs in anterior poriferous zone smaller than in posterior poriferous zone; 74 petaloid porepairs in petal.

Posterior petals (V and I) extending less than two-thirds distance from apical system to margin, length $44 \% \mathrm{~L}$; greatest width $17 \% \mathrm{~L}$; interporiferous zone very wide, greatest width $8.0 \% \mathrm{~L}$; poriferous zones narrow, $4.4 \% \mathrm{~L} ; 76$ petaloid porepairs. Last $2^{1 / 2}$ plates in inside poriferous zones ( $\mathrm{Vb}$ and Ia) occluded (Figure 35B); enclosed by first ambulacral plate beyond petal; last plates of petal of outside poriferous zones ( $\mathrm{Va}$ and $\mathrm{Ib}$ ) not occluded.

Peristome.-Large, width $18 \% \mathrm{~L}$, height $8.4 \%$ $\mathrm{L}$; anterior located at distance from anterior margin to anterior edge of peristome equal to $25 \% \mathrm{~L}$.

Periproct.-Located on posterior truncation tilting so opening slightly visible from above. Opening large, higher than wide but area damaged so that dimensions not known.

Fascioles.-Peripetalous fasciole not preserved; subanal fasciole circumscribing shieldshaped area below periproct.

Oral Plate Arrangement.-Plate sutures not clear.

Occurrence.-Oligocene-Miocene, old sugar house of "Venturilla" far, Realengo, Charco Hondo, Morón, Camagüey Province, Cuba. 

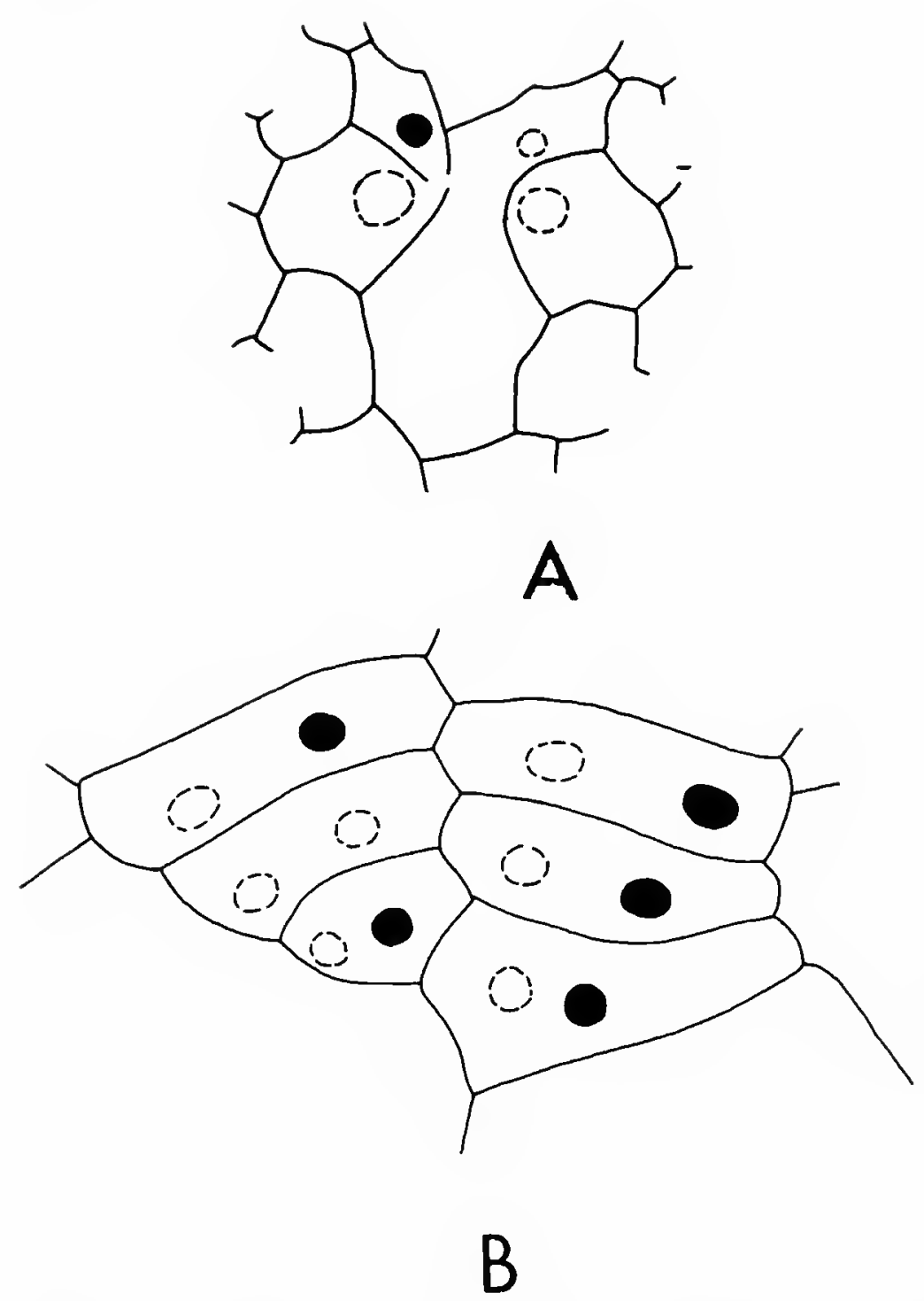

Figure 35.-Eupatagus clevei (Cotteau), lectotype of Lajanaster venturillae Sánchez Roig (=E. clevei), SRC 4136, × 10: A, apical system; B, plate arrangement at end of petal I.

\section{Megapatagus franciscanus Sánchez Roig \\ Plate 63}

Material.-Only one specimen known, the holotype (SRC 4473). This specimen is not distorted but is highly weathered, lacking tubercles and obscuring the fascioles. Peristome filled with matrix, test broken around periproct.

Shape and Size.-Length 127 mm, width 102 mm (80\% L), height $62 \mathrm{~mm}$ (49\% L); greatest width and height anterior.

Apical System.-Four genital pores, ethmolytic with madreporite extending far posterior of posterior ocular plates, anterior at distance from anterior margin to center of genital pores equal to $38 \% \mathrm{~L}$.
Ambulacra.-Anterior ambulacrum III not petaloid, in very faint groove, pores very small adapically, not markedly diffferentiated from pores on margin of test; greatest width of ambulacrum $0.65 \% \mathrm{~L}$.

Anterior petals (II and IV) extending to margin, flush, length $50 \% \mathrm{~L}$, greatest width $15 \% \mathrm{~L}$. Interporiferous zone very wide, greatest width $9.2 \% \mathrm{~L}$; poriferous zone narrow $2.9 \% \mathrm{~L}$, pores conjugate, outer pore more elongate than inner; adapical porepairs in anterior poriferous zone smaller than in posterior poriferous zone; 96 petaloid porepairs.

Posterior petals ( $\mathrm{V}$ and I) extending almost to margin, length $56 \% \mathrm{~L}$, greatest width $15 \% \mathrm{~L}$, interporiferous zone very wide $8.7 \% \mathrm{~L}$, poriferous zone narrow, $3.1 \% \mathrm{~L} ; 110$ petaloid porepairs.

PERISTOME.-Anterior, located at distance from anterior margin to anterior edge of peristome equal to $27 \% \mathrm{~L}$. Peristome filled with matrix, but width estimated to be $13 \% \mathrm{~L}$, height $6 \% \mathrm{~L}$.

Periproct.-Fractured obscuring opening; on slightly overhanging posterior truncation; height of opening estimated at $17 \% \mathrm{~L}$, width $13 \% \mathrm{~L}$.

Fascioles._-Obscured by weathering.

Oral Plate Arrangement.-Sutures not clear due to fracturing of test.

Occurrence.-Oligocene-Miocene, "San Francisco de la Rosa" farm, Guadalupe district, Morón, Camagüey Province, Cuba.

REMARKs. - Sánchez Roig (1953a:58) erected a new genus, Megapatagus, with this species as the type-species. Fischer (1966:U586) considers it to be a synonym of Eupatagus. I can see no characters distinguishing the two genera.

\section{Eupatagus cubensis (Cotteau)}

Plate 55: figures 3-5; Plates 56, 57

Breynia cubensis Cotteau, 1875:7; 1881:43, pl. 4: figs. 4-6; 1897:87, pl. 25: figs. 4-6.

Brissoides cubensis (Cotteau)._Lambert, 1915:17.—Sánchez Roig, 1926:109; 1949:200.

Eupatagus depressus Jackson, 1922:93, pl. 16, fig. 7 [not Megapatagus depressus Sánchez Roig, 1953a:60].

Eupatagus cubensis (Cotteau)._Jackson, 1922:94. 
?Brissoides lamberti Sánchez Roig, 1924b:79, pl. 12, fig. 1.Lambert in Lambert and Thiéry, 1924 [1909-1925]:451.

?Brissoides munozi Lambert in Sánchez Roig, 1924b:80, pl. 8: figs. 1, 2._Lambert in Lambert and Thiéry, 1924 [19091925]:451.-Sánchez Roig, 1926:103, pl. 28: figs. 1, 2, pl. 29: figs. 1, 2, pl. 30: fig. 1; 1949:197.

?Brissoides munozi Lambert, sub. sp. minor Sánchez Roig, 1924b:82, pl. 9, figs. 1, 2.

?Brissoides herrerae Sánchez Roig, 1924b:82, pl. 10: figs. 1, 2.-Lambert in Lambert and Thiéry, 1924 [1909-1925]: 451_Sánchez Roig, 1926:104, pl. 32: figs. 1, 2, pl. 33: fig. 1. [Not Eupatagus herrerae Sánchez Roig, 1951:46, pl. 25, figs. 1, 2.]

?Brissoides brevipetalum Sánchez Roig, 1924b:84, pl. 11: figs. 1, 2; 1926:106, pl. 34: fig. 1, pl. 35: fig. 1. [Not Eupatagus brevipetalum Sánchez Roig, 1951:44, pl. 33: fig. 1, pl. 38: fig. 1.]

?Brissoides elongatum Sánchez Roig, 1924b:86, pl. 13: figs. 1, 2.-Lambert in Lambert and Thiéry, 1924 [19091925]:451.-Sánchez Roig, 1926:107, pl. 36: fig. 1.

?Brissoides planus Sánchez Roig, 1924b:87, pl. 14: fig. 1.Lambert in Lambert and Thiéry, 1924 [1909-1925]:451.

Brissoides luacesi Sánchez Roig, 1924b: 79.

?Brissoides mayor Lambert in Sánchez Roig, 1924b:91; 1926: 108.

?Maretia estenozi Sánchez Roig, 1926:111, pl. 37: figs. 1, 2; 1949:215.

?Brissoides lajasensis Sánchez Roig, 1949:203, pl. 24: fig. 1

?Brissoides zanolettii Sánchez Roig, 1952c:12, pl. 7: figs. 1, 2 [not Eupatagus zanoletti Sánchez Roig, 1951:43, pl. 32: fig. 3].

Neopalagus cubensis (Cotteau)._Sánchez Roig, 1953b: 259.

Material. - This description is based on the holotype in the Cotteau Collection at the Université Claude Bernard, Lyons, France. The specimen is moderately well preserved, although the peristome and periproct are broken away and the test is too weathered to show the fascioles.

Shape And Size.-Length $87 \mathrm{~mm}$, width $80 \%$ $\mathrm{L}$, height $27 \% \mathrm{~L}$; greatest width anterior of center. Test flattened by postmortem distortion.

Apical System.-Anterior, distance from anterior margin to center of pores equal to $35 \% \mathrm{~L}$; no further details visible.

Ambulacra.-Anterior ambulacrum III not petaloid; pores minute adapically; not in groove where crossing margin.

Anterior petals (II and IV) extending twothirds distance from apical system to margin, length $29 \% \mathrm{~L}$, very wide, width $12 \% \mathrm{~L}$ with greatest width one-third distance from apical sys- tem to end of petal. Interporiferous zone wide, at greatest width $6.7 \% \mathrm{~L}$; poriferous zones at greatest width $2.8 \%$ L. Porepairs in anterior poriferous zones adapically smaller than in posterior poriferous zones of same petal; pores conjugate, 62 petaloid porepairs in petal. No plates occluded at end of petals.

Posterior petals (V and I) of length slightly more than one-half distance from apical system to margin, length $35 \% \mathrm{~L}$, width $13 \% \mathrm{~L}$. Interporiferous zones at greatest width $7.4 \% \mathrm{~L}$; poriferous zones $3.2 \% \mathrm{~L}$; pores strongly conjugate, 66 porepairs in petal. Last $2 \frac{1}{2} 2$ plates in single poriferous zone of petal occluded, enclosed by first ambulacral plate beyond petal.

Peristome.-Not preserved.

Periproct.-Not preserved.

Fascioles. - Not preserved.

Tuberculation.-Large primary tubercles confined within peripetalous fasciole, 13 tubercles in interambulacrum 2, 23 in interambulacrum 1, apparently none in interambulacrum 5 .

Oral Plate Arrangement.-Most of oral surface not preserved.

Occurrence.-Cotteau reports $E$. cubensis from the Eocene, Matanzas of Cuba; but Sánchez Roig records it from the Miocene at "Cervantes" farm, San José de las Lajas, Habana Province, Cuba. All the other species provisonally considered synonyms (except Eupatagus depressus and Brissoides zanolettii) are from "Cervantes" farm. E. depressus is from the Miocene, Ponce Limestone at a high bluff, $2 \mathrm{~km}$ SW of Juana Diaz, Puerto Rico. $B$. zanolettii is from the Oligocene-Miocene, El Blanquizal, Tamarindo district, Morón, Camagüey Province, Cuba.

A well-preserved specimen of E. cubensis (MCZ 4044) is from Palmer's locality 1660, which he considered to be Oligocene-Miocene. It is from a long cut $\mathrm{S}$ of switch on Ramal Valle, Central Jatibonico, cane railroad, Camagüey Province, Cuba. It is illustrated on Plate 56: figures 3-5.

REMARKs.-There is no evidence of an internal fasciole, and for this reason the species cannot be referred to Breynia. Although the fascioles are not visible on the holotype, the presence of an internal fasciole would be indicated by an abrupt change 
in the size of the petaloid porepairs adapically.

Eleven species of Eupatagus (Brissoides) have been reported from the "Cervantes" farm at San José de las Lajas. Most of these species were based on only one or two specimens each, and most of these specimens were not available to me for study. However, from a study of Sánchez Roig's illustrations and the few specimens available, I suspect that all of these species are synonyms of E. cubensis. Although they differ in such characters as length and width of petals and in the dimensions of the test, these differences probably fall within the range of variation to be expected within one species. This suggestion could be tested only if a large number of specimens could be collected in place in a measured section at the type-locality. Unfortunately, specimens are now rare at this locality.

Sánchez Roig himself doubted the validity of some of these species. He did not mention Eupatagus lamberti (Sánchez Roig), Eupatagus planus (Sánchez Roig), or Eupatagus elongatum (Sánchez Roig) in his compilation of the echinoids of Cuba (1949). Lambert (in Lambert and Thiéry, 1924 [1909-1925]:451) had earlier considered E. lamberti as a variety of $E$. herrerae (Sánchez Roig) and the other two species as varieties of $E$. munozi (Lambert). I have studied two specimens of $E$. munozi and cannot distinguish them from $E$. cubensis. Both species occur at the same locality. Their petals are indistinguishable, of approximately the same length, with similar numbers of porepairs, similar width of interporiferous and poriferous zones, and similar lanceolate shape. Their apical systems are similarly situated and the large tubercles within the peripetalous fasciole are of similar number, location, and size with both species lacking these tubercles in interambulacrum 5 . Finally, both species have very low, large tests.

Although the petals of Eupatagus estenozi (Sánchez Roig) are longer and narrower than those in the type specimens of $E$. cubensis, both species share a low test, anterior position of apical system, and lack of primary tubercules in the posterior interambulacrum. The significance of the difference in the length of petals is doubtful because of the great variation in petal length and width among all the species of Eupatagus at this one locality. A posterior petal in E. estenozi is $46 \% \mathrm{~L}$, in E. lamberti (Sánchez Roig) 42\% L, E. herrerae (Sánchez Roig) 40\% L, E. lajasensis (Sánchez Roig) 39\% L, E. planus (Sánchez Roig) and E. cubensis (Cotteau) 34\% L, E. munozi (lambert) 33$37 \%$ L, E. elongatum (Sánchez Roig) 33\% L, and E. brevipetalum (Sánchez Roig) 31\% L. (The length of the petals in E. luacesi (Sánchez Roig) and $E$. mayor (Lambert) cannot be determined because Sánchez Roig did not illustrate these species.) The presence of specimens with petal length and width grading between the two extremes convinces me that the type specimens of all these species may be conspecific, and I provisionally consider them to be synonyms of $E$. cubensis.

I have not seen any specimens of Eupatagus zanolettii (Sánchez Roig) from the Oligocene-Miocene of Camagüey Province; but from a study of Sánchez Roig's (1952c, pl. 7: figs. 1, 2) illustrations, it appears to be a synonym of $E$. cubensis.

Jackson's Eupatagus depressus from Puerto Rico is indistinguishable from $E$. cubensis and is herein considered a synonym. A new photograph of the holotype in the American Museum of Natural History is included in Plate 56: figure 5. Although Jackson said the Puerto Rican specimen was from the Oligocene, the label with the specimen says it is from the Ponce Limestone, which according to Gordon (1963:628) is Miocene.

\section{SyNONYMS}

\section{?Brissoides munozi Lambert}

\section{Plate 57: Figures 1-4}

Material. - The holotype is not in the Sánchez Roig Collection. The following description is based on one specimen (SRC 5497) in the Sánchez Roig Collection and one (USNM 352863) in the Smithsonian figured by Sánchez Roig (1926c, pl. 30: fig. 1). Both are badly weathered with fascioles obscured. The first measurement is of SRC 5497.

Shape and Size.-Test large, length 99 and $109 \mathrm{~mm}$; width 85 and $88 \% \mathrm{~L}$, very low; height 
23 and 19\% L. Although both specimens are slightly depressed by postmortem compression, the tests appear to have been originally very low.

Apical System.-Anterior, distance from anterior margin to center of genital pores 37 and $39 \% \mathrm{~L}$, ethmolytic, with genital plate 2 extending far posteriorly separating posterior ocular plates; 4 genital pores.

Ambulacra.-Anterior ambulacrum III depressed in slight trough extending from apical system to anterior margin; not petaloid, porepairs minute, not possible to count plates.

Anterior petals (II and IV) extending twothirds distance from apical system to margin, length 32 and $30 \% \mathrm{~L}$, petals wide, width 13 and $13 \% \mathrm{~L}$ with greatest width nearer apical system; poriferous zone with width 3.6 and $3.2 \% \mathrm{~L}$, interporiferous zones with greatest width 6.9 and $6.9 \%$ $\mathrm{L}$; porepairs minute adapically in anterior poriferous zones; 64 porepairs in petal in each specimen.

Posterior petals (V and I), longer than anterior, extending two-thirds distance from apical system to margin, length 37 and $33 \% \mathrm{~L}$, width 13 and $12 \% \mathrm{~L}$; poriferous zone with width 3.3 and $3.5 \%$ $\mathrm{L}$, interporiferous zones with greatest width 6.4 and $5.6 \% \mathrm{~L} ; 72-76$ porepairs in petal.

Peristome.-Anterior, located at distance from anterior edge of opening to anterior margin equal to 26 and 24 percent L. Opening small, width $11 \% \mathrm{~L}$, height not clear.

Periproct.-Marginal, no further details visible.

Fascioles.-Not preserved.

Tuberculation.-Very large, deeply scrobiculated tubercles confined between petals in paired interambulacra; 28-31 tubercles in interambulacra 1 or $4,17-20$ in interambulacra 2 or 3.

Oral Plate Arrangement.-Entire length of labrum not preserved on either specimen but estimated on USNM 352863 to equal 19\% L. No other plate sutures visible.

Occurrence.-Miocene, holotype from San Antonio de Cabezas, Matanzas; "Cervantes" farm, San José de las Lajas, Habana Province, Cuba.

\section{?Maretia estenozi Sánchez Roig}

Plate 55: figure 5; Plate 56: figures 1, 2

Material.-Only one specimen is in the Sánchez Roig Collection (SRC 5491). This specimen is illustrated by Sánchez Roig (1926c, pl. 37: fig. 1) and is the holotype. Although the dorsal surface is well preserved, the ventral surface is almost entirely missing.

ShaPe And Size.-Length (est.) $97 \mathrm{~mm}$, width $82 \% \mathrm{~L}$, height $24 \% \mathrm{~L}$; test very low, slightly flattened because of postmortem compression.

Apical System.-Anterior, located at distance from anterior margin to center of genital pores equal to $33 \% \mathrm{~L}$, ethmolytic with genital plate 2 extending posteriorly separating posterior ocular plates; 4 genital pores.

AmBULACRA.-Anterior ambulacrum III not petaloid, not in groove but on flattened surface; pores microscopic, character not clear.

Anterior petals (II and IV) transverse, long, extending almost to margin, length $37 \% \mathrm{~L}$, greatest width adapical, $12 \% \mathrm{~L}$. Interporiferous zone at greatest width $5.4 \% \mathrm{~L}$; poriferous zone with width $3.0 \% \mathrm{~L}$, pores of both anterior and posterior poriferous zones greatly reduced in size; pores deeply conjugate; 74 porepairs in petal.

Posterior petals ( $V$ and I) longer than anterior, length $46 \% \mathrm{~L}$, greatest width $11 \% \mathrm{~L}$; interporiferous zones with width $5.5 \% \mathrm{~L}$, poriferous zone $3.4 \%$ L; 94 porepairs.

Peristome.-Not preserved.

Periproct.-Not preserved.

Fascioles.-Narrow peripetalous fasciole passing around extremities of petals, not indented in interambulacra. Subanal fasciole not present on holotype due to absence of region where it could occur, but Sánchez Roig reports its presence in cotype.

Tuberculation.-Large tubercles in sunken scrobicules confined within peripetalous fasciole in paired interambulacra; absent in interambulacrum 5. Tubercles arranged in single row on each plate; 38 in interambulacrum 2, 47 in interambulacrum 1.

Occurrence.-Although Brodermann (1949: 324) considered this species late Oligocene, Al- 
bear (1980, personal communication) considers the type-locality to be early to middle Miocene, "Cervantes" farm, San José de las Lajas, Habana Province, Cuba.

REMARKS.-This species must be referred to Eupatagus because of the presence of a peripetalous fasciole, not present on Maretia.

\section{Eupatagus sanchezi (Lambert), new combination}

Plate 58: figures 1-3

Brissoides sanchezi Lambert in Sánchez Roig, 1949:211, pl. 24: figs. $2,3$.

?Brissoides habanensis Sánchez Roig, 1949:204, pl. 23: fig. 4. Neopatagus sanchezi (Lambert)._-Sánchez Roig, 1953b:261.

Material.-Only one specimen known, the holotype (SRC 4765). This specimen is poorly preserved being badly distorted by postmortem compression. The peristomial area is broken away.

Shape AND Size.-Length $31 \mathrm{~mm}$, width $80 \%$ L, height uncertain. Greatest width anterior, greatest height posterior at sharply inflated plastron.

Apical System.-Anterior, distance of apical system from anterior margin equal to $35 \% \mathrm{~L}$; no further details visible.

AmbulaCRA.-Anterior ambulacrum III not petaloid, adapical pores minute, slight groove at margin, but because of postmortem distortion not possible to measure depth.

Anterior petals (II and IV) with length estimated at $26 \% \mathrm{~L}$, greatest width $9.6 \% \mathrm{~L}$; interporiferous widest adapically with width $3.8 \% \mathrm{~L}$; much narrower near end of petal; 32 porepairs estimated in petals; porepairs more widely separated from each other in same poriferous zone near end of petal than apically (Plate 58: figure 1). Pores conjugate, outer pore of pair more elongate and more adoral to inner.

Posterior petals (V and I) with length estimated at $31 \% \mathrm{~L}$, width $12 \% \mathrm{~L}$; interporiferous with greatest width $5.1 \% \mathrm{~L} ; 44$ porepairs. Posterior petals less constricted in width at their extremities than anterior petals.
Peristome.-Anterior, no further details visible.

Periproct.-Large, higher than wide, on posterior truncation probably overhanging, but test distorted and shape of truncation not certain.

Fascioles.-Peripetalous fasciole, narrow band not indented in interambulacra. Subanal fasciole circumscribing shield-shaped area below periproct with width $27 \% \mathrm{~L}$, height $21 \%$ L. 10 enlarged porepairs enclosed by fasciole.

Tuberculation.-Very large scrobiculated tubercles confined within peripetalous fasciole in paired interambulacra; 4 in anterior paired interambulacrum, 5 or 6 in posterior paired interambulacrum; largest tubercle with scrobicule with diameter of $2 \mathrm{~mm}(6.4 \% \mathrm{~L})$.

Occurrence.-Miocene, "La Noria" farm, Cojímar, Habana Province, Cuba. Although Sánchez Roig (1949:211) and Brodermann (1949:318) considered this species late Oligocene, Brönnimann and Rigassi (1963:466) report that the Cojímar Formation occurs at this locality. They date this formation as Miocene on the basis of foraminifera. The holotype of Eupatagus habanensis (Sánchez Roig) is from quarries on Rte. 23, left side of bridge, Vedado, Habana Province, Cuba. Sánchez Roig (1949:204) and Brodermann (1949:317) date this species as late Oligocene, but it is probably Miocene. Migliorinia habanensis (Sánchez Roig) occurs with the holotype of Eupatagus habanensis but has also been found at Rio Cojimar and at quarries at the entrance of Cojímar in beds Brönnimann and Rigassi consider to be Cojimar Formation. Furthermore, according to Albear (1981, personal communication) all the formations that Brodermann (1949, chart) attributes to the late Oligocene are now considered to be early Miocene.

REMARKS.-I suspect that Eupatagus habanensis (Sánchez Roig), known also from beds that Sánchez Roig refers to the late Oligocene of Habana Province, is a synonym of $E$. sanchezi. Both species have pointed posterior margins, petals of similar size and shape, and large primary tubercles in deeply sunken scrobicules within their peripetalous fascioles. Sánchez Roig's figured specimen of E. habanensis, is much larger than the holotype of 
E. sanchezi and as expected, has more numerous scrobiculate primary tubercles. Regrettably no specimens of $E$. habanensis were available for study.

Comparison with Other Species. - The test of the holotype is so badly distorted that it is difficult to compare it to other species, but the shape of its petals resemble those of Eupatagus antillarum (Cotteau) from the Eocene of St. Bartholomew. It differs in having far fewer, large tubercles dorsally. In $E$. antillarum there are at least 18 in interambulacrum 1 but only 5 in E. sanchezi.

$E$. sanchezi is likewise easily distinguished from all other species of Eupatagus, except E. habanensis, from Cuba by these very large tubercles with their deeply sunken scrobicules.

\section{Eupatagus santanae Sánchez Roig}

Plate 58: figures 4-7

Eupatagus (Plagiobrissus) santanae Sánchez Roig, 1951:47, pl.

37: fig. 2 [not Brissoides santanae Sánchez Roig, 1949:210, pl. 25: figs. 2,3$]$.

Material.-Only one specimen (SRC 4306) known (figured by Sánchez Roig and herein designated the lectotype. The cotype is no longer in the Sánchez Roig Collection. The lectotype is an undistorted test, badly weathered, with the peristomial and periproctal regions broken away.

Shape And Size.-Length $76 \mathrm{~mm}$, width $81 \%$ $\mathrm{L}$, height $48 \% \mathrm{~L}$; greatest width central, greatest height posterior.

Apical System.-Four genital pores, ethmolytic, with madreporite extending posteriorly far beyond posterior ocular plates. Apical system anterior of center at distance from anterior margin to center of genital pores equal to $32 \% \mathrm{~L}$.

Ambulacra.-Anterior ambulacrum III not petaloid, not in groove, porepairs in adapical region very small, not markedly differentiated from porepairs on margin of test; pores of pair arranged vertically.

Anterior petals (II and IV) extending twothirds distance from apical system to margin; length $38 \% \mathrm{~L}$, greatest width $12 \% \mathrm{~L}$, interporifer- ous zone very wide, greatest width $4.7 \% \mathrm{~L}$; petals flush with rest of surface of test. Poriferous zones narrow, $3.3 \% \mathrm{~L}$, pores conjugate, outer pore of pair slightly more elongated than inner; adapical porepairs in anterior poriferous zones smaller than in posterior poriferous zone; 68 petaloid porepairs.

Posterior petals ( $\mathrm{V}$ and I) extending two-thirds distance from apical system to margin, length $42 \% \mathrm{~L}$, width $11 \% \mathrm{~L}$, width of interporiferous zone $4.6 \% \mathrm{~L}$, width of poriferous zone $3.4 \% \mathrm{~L} ; 68$ petaloid porepairs. Last $1 \frac{1 / 2}{2}$ plates in single poriferous zone of petal occluded, enclosed by first ambulacral plate beyond petal.

Peristome.-Not preserved.

PERIProct.-On posterior truncation tilting slightly so that periproct would have been slightly visible from above; all except bottom edge of opening absent due to fracturing of test.

Fascioles.-Eradicated by weathering.

Tuberculation.-Large tubercles present adapically in paired interambulacra.

Oral Plate Arrangement.-Most of labrum missing; rest of plate suture of plastron not clear.

Occurrence. - Oligocene-Miocene, "Santa Inés" farm, Guadalupe district, Morón, Camagüey Province, Cuba.

Comparison with Other Species. - Eupatagus santanae is very similar and may be a synonym of E. turibacoensis Sánchez Roig from the late Eocene of Cuba. Both species have tests of similar shape, long flexuous petals that are constricted at their extremities, and apical systems in similar positions. The petals of the lectotype of $E$. santanae are narrower than those in the holotype of E. turibacoensis, but with only one specimen available of E. santanae, it is not possible to know the significance of this difference. Furthermore, the peristome is absent in the lectotype of E. santanae, making it impossible to compare its position and shape with that in E. turibacoensis.

If Brissoides santanae Sánchez Roig, 1949, is a Eupatagus (its type specimen is not available to me), then it will have priority over Eupatagus santanae Sánchez Roig, 1951. A new name would have to be assigned to the 1951 species. 


\section{Eupatagus siboneyensis Weisbord}

Plate 59: figures 1-3

Eupatagus siboneyensis Weisbord, 1934:78, pl. 8: figs. 7, 8.

I have nothing to add to Weisbord's description. Only two specimens are known and both are only fragments.

OccurRence.-Late Eocene, road cut at Loma Calisto, approximately $800 \mathrm{~m} \mathrm{SW}$ of the S end of the town of Nuevitas, on the road leading toward Belén, Camagüey Province, Cuba.

Comparison with Other Species. - Although very little is known of this species because of the fragmental nature of the two known specimens, it is easily distinguished from all the other Cuban species of Eupatagus by its very narrow test. Its petals also appear to have narrower interporiferous zones.

\section{Eupatagus turibacoensis Sánchez Roig}

Figure 36; Plate 59: figures 4-7; Plate 60

Eupatagus turibacoensis Sánchez Roig, 1953c: 157, pl. 8: figs. 3, 4.

?Megapatagus turibacoensis Sánchez Roig, 1953a:61, pl. 13: 2 figs.

?Eupatagus calistoides Sánchez Roig, 1953c:160, pl. 6: fig. 8.

Material.-The holotype (SRC 4050) and only specimen referred to this species by Sánchez Roig is moderately well preserved with an undistorted test. The upper surface is badly weathered obscuring the tuberculation.

Shape AND SizE.-Length $79 \mathrm{~mm}$, width $81 \%$ L, height $51 \%$ L. Greatest width central, greatest height posterior due to inflation of plastron.

Apical System.-Anterior, located at distance from anterior margin to center of apical system equal to $24 \% \mathrm{~L} ; 4$ genital pores, ethmolytic (Figure 36A) with genital plate 2 extending far posteriorly separating posterior ocular plates.

AmBUlacra.-Anterior ambulacrum III not petaloid, flush, not in groove. Porepairs minute adapically; part of area broken away making count of plates not possible.

Anterior petals (II and IV) extending almost to margin, length $39 \% \mathrm{~L}$, greatest width $14 \% \mathrm{~L}$; interporiferous zone very wide, greatest width $7.1 \% \mathrm{~L}$, petals flush with rest of surface of test. Poriferous zone narrow $3.7 \% \mathrm{~L}$, pores conjugate, outer pore of pair slightly more elongate than
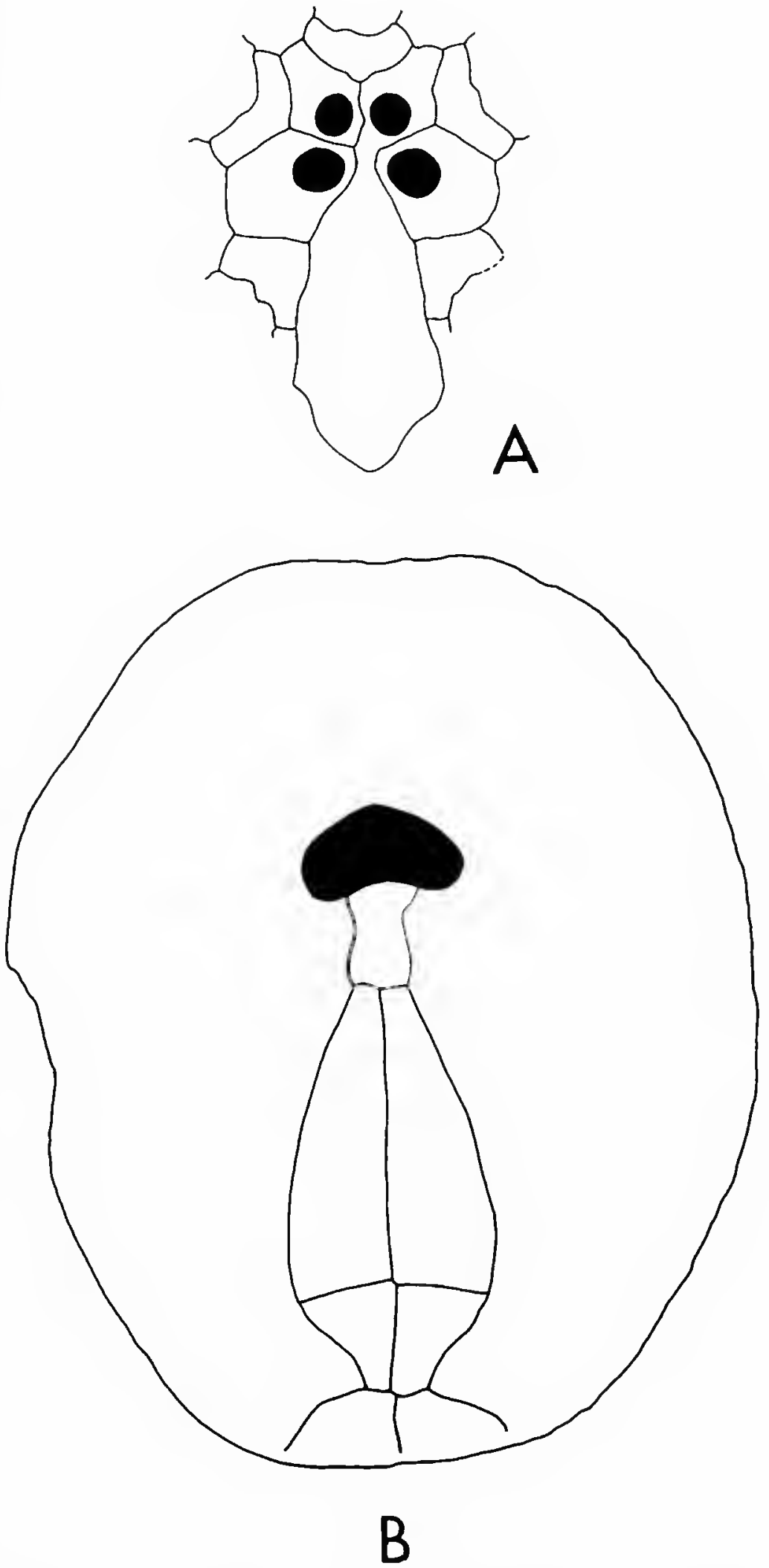

Figure 36.-Eupatagus turibacoensis Sánchez Roig, holotype, SRC 4050; A, apical system, B, plastron $\times 1.25$. 
inner; adapical porepairs in anterior poriferous zone smaller than in posterior poriferous zone; 66 petaloid porepairs; first petaloid pore in plate 15 or 16.

Posterior petals ( $\mathrm{V}$ and I) extending two-thirds distance from apical system to margin, length $44 \% \mathrm{~L}$; greatest width $13 \% \mathrm{~L}$, petals flush. Poriferous zones narrow, $3.7 \% \mathrm{~L}$; interporiferous zones wide, width $6.9 \% \mathrm{~L} ; 72$ petaloid porepairs. Last $1 \frac{1}{2}$ plates in single poriferous zone of petal occluded, enclosed by first ambulacral plate beyond petal.

Peristome.-Anterior, located at distance from anterior margin to anterior edge of peristome equal to $24 \% \mathrm{~L}$. Opening very large, wider than high, width $16 \% \mathrm{~L}$, height $9.4 \% \mathrm{~L}$. Phyllodes with 10 pores in ambulacrum III, 13 in IV, 10 or 11 in $\mathrm{V}$

Periproct.-Located near middle of posterior truncation, opening with height $18 \% \mathrm{~L}$, width $11 \% \mathrm{~L}$; enclosed by interambulacral plates 5-8.

Fascioles. - Most of peripetalous fasciole removed by weathering. Subanal fasciole enclosing area with width $37 \% \mathrm{~L}$, height $22 \% \mathrm{~L}$, crossing interambulacral plates 3,5 , and perhaps 4 , ambulacral plates 7-11.

Oral Plate Arrangement.-Labrum long, length $10 \% \mathrm{~L}$, extending posteriorly to anterior one-third of third adjacent ambulacral plate. Plastron long, composed of 2 pairs of plates; anterior pair with combined height $33 \% \mathrm{~L}$, width $22 \% \mathrm{~L}$; posterior pair with height $13 \% \mathrm{~L}$, width $19 \%$ L, narrowing sharply posteriorly (Figure 36в).

Occurrence.-Late Eocene, "Turibacoa" farm, Marroquín, Morón, Camagüey Province, Cuba. Holotype of Megapatagus turibacoensis from same locality. Holotype of Eupatagus calistoides from Eocene, in highway cut, Loma Calisto, Nuevitas, Camagüey Province, Cuba.

Comparison with Other Species.-This species is very similar to Eupatagus alatus Arnold and Clark from the Eocene of Jamaica and the middle to late Eocene of Cuba. The holotype of E. turibacoensis differs from specimens of $E$. alatus in having a less blunt anterior surface; the porepairs in the same poriferous zone in the petals appear to be further apart. These differences are slight and the species may be synonymous; but with only one specimen available of $E$. turibacoensis, it is not possible to know the significance of these differences.

E. turibacoensis resembles E. clevei (Cotteau), which is also found in the Oligocene-Miocene of Cuba differing primarily in having the petals in the holotype of $E$. clevei wider and more constricted at their extremities (compare Plate 59: figure 4 with Plate 61: figure 3). However, the petals in the holotype of Megapatagus turibacoensis Sánchez Roig (Plate 60: figure 4), herein considered a probable synonym of $E$. turibacoensis, are similar to those in E. clevei. These two species must have been closely related.

REMARKs.-I cannot distinguish this species from E. calistoides Sánchez Roig, also from the late Eocene of Camaguey Province, Cuba. The two species have similarly shaped tests, apical system in the same position, petals of similar shape and size with the first petaloid porepairs in plate 15 or 16 , and peristome of same outline and position. In both species the last $1 \frac{1}{2}$ plates in the posterior petals are occluded.

Likewise, Megapatagus turibacoensis Sánchez Roig, whose type specimen (SRC 4173) comes from the same locality as $E$. turibacoensis, appears to be a synonym. It differs only in having a larger, higher test with longer, wider petals; however, considering the variation known to be present in large populations of this genus, these differences may not be significant.

\section{SYNONYMS}

\section{?Eupatagus calistoides Sánchez Roig}

Plate 60: figures 1-3

MAterial. - The holotype (SRC 4774) is moderately well preserved showing the original shape of the test; but the region circumscribed by the subanal fasciole is missing.

Shape AND Size. - Length $47 \mathrm{~mm}$, width 39 mm (83\% L), height $22 \mathrm{~mm}$ (47\% L). Greatest 
width central, greatest height anterior but upper surface is nearly level, not sloping.

APICAL SYSTEM.-Four genital pores, ethmolytic with madreporite extending far beyond the posterior ocular plates. Apical system anterior of center at distance from anterior margin to center of genital pores equal to $28 \% \mathrm{~L}$.

AmBUlacra.-Anterior ambulacrum III not petaloid, not in groove, pores very small in adapical region, not markedly differentiated from pores on margin of test; approximately 72 plates in ambulacrum.

Anterior petals (II and IV) extending almost to margin, length $35 \% \mathrm{~L}$, greatest width $12 \% \mathrm{~L}$, interporiferous zone very wide, greatest width $5.3 \% \mathrm{~L}$, petals flush with rest of surface of test. Poriferous zones narrow, $3.8 \% \mathrm{~L}$, pores conjugate, outer pore of pair slightly more elongated than inner; adapical porepairs in anterior poriferous zone smaller than in posterior poriferous zone; 50 petaloid porepairs. First petaloid porepairs in plate 16 , total of 80 plates in ambulacrum.

Posterior petals (V and I) extending two-thirds distance from apical system to margin, length $41 \% \mathrm{~L}$; greatest width $12 \% \mathrm{~L}$, interporiferous zone very wide, greatest width $4.9 \% \mathrm{~L}$, petals flush. Poriferous zones narrow, $3.8 \% \mathrm{~L} ; 60$ petaloid porepairs. Last $1 \frac{1}{2} 2$ plates in single poriferous zone of petal occluded, enclosed by first ambulacral plate beyond petal.

Peristome.-Anterior, located at distance from anterior margin to anterior edge of peristome equal to $25 \% \mathrm{~L}$. Opening very large, wider than high, width $17 \% \mathrm{~L}$, height $11 \% \mathrm{~L}$.

PERIPROCT.-Located high on posterior truncation tilting so opening visible from above. Area fractured, but opening estimated as being height $17 \% \mathrm{~L}$, width $11 \% \mathrm{~L}$.

Fascioles.-Peripetalous and subanal fascioles present, but most of tracts not preserved. Larger tubercles confined within peripetalous fasciole.

Oral Plate Arrangement.-Labrum with length $13 \% \mathrm{~L}$; rest of plate sutures not clear.

Occurrence.-Late Eocene, "Turibacoa" farm, Marroquín, Morón, Camagüey Province, Cuba.

\section{?Megapatagus turibacoensis Sánchez Roig}

Plate 60: figures 4-6

Material.-Only one specimen known, the holotype (SRC 4173), which is poorly preserved, badly weathered, with large part of the test broken away.

Shape and Size.-Length (est.) $85 \mathrm{~mm}$, width $90 \%$ L, height $58 \%$ L, greatest width slightly anterior.

Apical System.-Anterior, exact position not clear because of distortion of test; plate sutures not clear.

AmBUlacra.-Anterior ambulacrum III not petaloid; porepairs minute adapically; part of area broken away making count of plates not possible.

Anterior petals (II and IV) extending to margin, length $48 \% \mathrm{~L}$, greatest width $18 \% \mathrm{~L}$; interporiferous zone very wide, greatest width $10 \% \mathrm{~L}$; petals flush with rest of surface of test; poriferous zones narrow, $4.0 \% \mathrm{~L}$; adapical porepairs in anterior poriferous zone smaller than in posterior poriferous zone, 82 petaloid porepairs.

Posterior petals ( $\mathrm{V}$ and I) extending more than two-thirds distance from apical system to margin, length $55 \% \mathrm{~L}$, greatest width $11 \% \mathrm{~L}$, petals flush. Poriferous zones narrow, 4.4\% L; 96 petaloid porepairs.

Peristome.-Large; no other details because of fracturing around peristome.

PERIPROCT.-Marginal, but no other details available.

Fascioles.-Because of weathering of test, only short portions of peripetalous and subanal fascioles preserved.

Oral Plate Arrangement.-Labrum with length $9.2 \% \mathrm{~L}$, extending posteriorly to anterior one-third of third adjacent ambulacral plate. Plastron long, composed of 2 pairs of plates; anterior pair with combined height $39 \% \mathrm{~L}$, width $23 \% \mathrm{~L}$, posterior pair much smaller but dimensions not clear.

Occurrence.-Late Eocene, "Turibacoa" farm, Marroquín, Morón, Camagüey Province, Cuba. 


\section{Unrecognizable Species of Eupatagus}

Eupatagus depressus (Sánchez Roig), preoccupied

Plate 67

Megapatagus depressus Sánchez Roig, 1953a:60, pl. 12 [not Eupatagus depressus Jackson, 1922].

Material.-Only the holotype (SRC 4476) is known. It is a very badly weathered specimen with all trace of fascioles and most of the dorsal tubercles absent. The test is distorted with the left side compressed. The test is slightly depressed by postmortem compression but probably not more than 5 to $10 \mathrm{~mm}$. The posterior is broken away and the peristome filled with matrix. The plate sutures are not clear.

This specimen is very similar to Eupatagus clevei (Cotteau) but differs in having the anterior poriferous zone of its petals less curved anteriorly. Its apical system is more central, but this may be due to postmortem distortion of the test. The species are probably distinct. Unfortunately, the binomen Eupatagus depressus (Sánchez Roig, 1953) is preoccupied by Eupatagus depressus Jackson, 1922. In order to maintain Sánchez Roig's species, it would be necessary to supply a new species name. Because the type specimen is so poorly preserved, it does not seem advisable to take this step.

Occurrence.-Oligocene-Miocene, "El Regalo" farm, Charco Hondo, Marroquín district, Morón, Camagüey Province, Cuba.

\section{Genus Fernandezaster Sánchez Roig, 1952}

Test large, flattened, ambulacrum III not petaloid, posterior petals confluent, occupying single groove adapically, periproct marginal; both peripetalous and subanal fascioles present.

REMARKS. - This genus belongs in the Brissidae because it has both a peripetalous and subanal fasciole. It is similar to Brissopsis and Metalia in having its posterior petals confluent proximally and diverging greatly distally. It differs from Brissopsis in having an extremely wide test. It differs from Metalia in apparently having a broader area enclosed by the subanal fasciole. Only the type-species is known and the genus is not known outside of Cuba.

Habitat.-Presence of fascioles and depressed petals indicate that this genus lived buried. Because of the poor preservation of the holotype and only known specimen, nothing is known of the pores in the anterior ambulacrum. Therefore, we do not know whether or not Fernandezaster had funnel-building tubefeet, permitting it to live buried in fine sediment.

\section{Fernandezaster mortenseni Sánchez Roig}

Plate 52: figures 4-5; Plate 53: figures 1, 2

Fernandezaster mortenseni Sánchez Roig, 1952c:18, pl. 10: figs. 1, 2.-Fischer, 1966:U588, fig. 476-2.

Material.-Only one specimen, the holotype (SRC 4240), is known of this species. This specimen is very poorly preserved with most of the test missing. None of the test is present ventrally and only a small part of the ambulacra and interambulacra 5 and 1 are present dorsally. The apical system, periproct, and peristome are absent. The test is extremely thin.

Shape and Size._Length $112 \mathrm{~mm}$, width (est.) $104 \% \mathrm{~L}$, height $40 \% \mathrm{~L}$; test very broad with greatest width central. Marginal outline very angular, almost hexangular.

Apical System-Anterior, located at distance from anterior margin to apical system equal to $32 \% \mathrm{~L}$; no other details visible.

AmbULACRA.-Anterior ambulacrum III in deep groove, not petaloid. The holes through the test, which look like inner pores, are not pores but are places where the test is especially thin and has weathered away.

Anterior petals (II and IV) straight, length $36 \%$ $\mathrm{L}$, width $8.1 \% \mathrm{~L}$, in deep groove of depth $3.8 \% \mathrm{~L}$; pores very large, inner pore of pair round, outer elongated tansversely.

Posterior petals (V and I) parallel and close together adapically and then turning sharply away from each other distally. Length $38 \% \mathrm{~L}$, width $7.5 \% \mathrm{~L}$; adapically for almost first half of length of petal, pores of ambulacra $\mathrm{Vb}$ and $\mathrm{Ib}$ 
much smaller than pores of outer poriferous zone of same petal; $66 \pm 4$ porepairs in each petal.

Peristome.-Anterior, estimated distance of anterior edge of opening from anterior margin equal to $15 \% \mathrm{~L}$. Peristome appears to have been labiate with width estimated at $7.5 \% \mathrm{~L}$, height $13 \% \mathrm{~L}$.

PERIPROCT.-Marginal, opening very large, apparently higher than wide but only partially preserved.

Fascioles.-Peripetalous fasciole very narrow, width $0.04 \% \mathrm{~L}$, deeply indented in interambulacra. Subanal fasciole narrow, only short tract preserved; area enclosed by fasciole extremely wide.

Tuberculation.-Test covered by very small tubercles.

Occurrence.-Oligocene-Miocene, in well on "Balbin" farm, San Pedro Bauta, Habana Province, Cuba.

\section{Genus Hernandezaster Sánchez Roig, 1949}

Test large, elongate, no anterior groove, apical system with 4 genital pores, ethmolytic, anterior ambulacrum not petaloid, porepairs very small dorsally, petals depressed, narrow; periproct inframarginal; probably both peripetalous and subanal fascioles.

Habitat.-Presumably this echinoid lived buried in coarse sediment. It lacks funnel-building tubefeet in the anterior ambulacrum as indicated by the lack of crowding of the pores in that region. Without these it probably could not have burrowed in fine sediment.

REMARKs.-Only one badly weathered specimen is known of this genus, and it is not possible to know which fascioles were present. Sánchez Roig (1949:212) stated that he observed part of a peripetalous fasciole. I suspect it was present originally, but I could find no trace of it on the specimen. Fascioles are very important in the classification of spatangoids and it is not possible to assign with certainty this genus to a family without knowledge of the nature of the fascioles. Mortensen (1950:405) stated that Sánchez Roig informed him that the apical system was ethmo- phract with the madreporite not extending beyond the posterior genital plates. However, the apical system is definitely ethmolytic with the madreporite not only separating the posterior genital plates but also the posterior ocular plates (Figure 37). If we could be certain that no subanal fasciole was present, then this species could be referred with some certainty to the Hemiasteridae as was done by Mortensen (1950:405) and Fischer (1966:U559). However, it is possible that a subanal fasciole was present and in that case this genus would be referred to the Brissidae. I agree with Sánchez Roig in believing that its strongest affinities are with genera of this family.

\section{Hernandezaster hernandezi Sánchez Roig}

Figure 37; Plate 68: figures 1-4

Hernandezaster hernandezi Sánchez Roig, 1949:212, pl. 33: figs. 3-5.-Mortensen, 1950:405, fig. 303a-c, pl. 2: fig. 5.Fischer, 1966:U559, fig. 444-1.

Material.-Only one specimen known, the holotype (SRC 4075). This specimen has an undistorted test but is badly weathered with all the fine tuberculation removed.

Shape AND Size.-Length $64 \mathrm{~mm}$, width 54 mm (85\% L), height $34 \mathrm{~mm}$ (53\% L). Greatest width central, greatest height posterior. Anterior margin rounded, posterior pointed.

Apical System.-Anterior, located at distance from anterior margin to center of genital pores equal to $38 \% \mathrm{~L} ; 4$ genital pores, ethmolytic with genital plate 2 extending posteriorly separating posterior genital and ocular plates (Figure 37 ).

Ambulacra.-Anterior ambulacrum III not petaloid, not in groove; porepairs minute dorsally; 50 plates.

Anterior petals (II and IV) long, extending almost to margin, length $38 \% \mathrm{~L}$, width $8.9 \% \mathrm{~L}$; petals curving slightly anteriorly subtending arc nearly 180 degrees; interporiferous zones narrow, narrower than single poriferous zones; porepairs conjugate, outer pores more elongate than inner; 66 petaloid porepairs; first petaloid porepair in plate 16 or 17 . Petals in groove with depth $2.3 \% \mathrm{~L}$. 


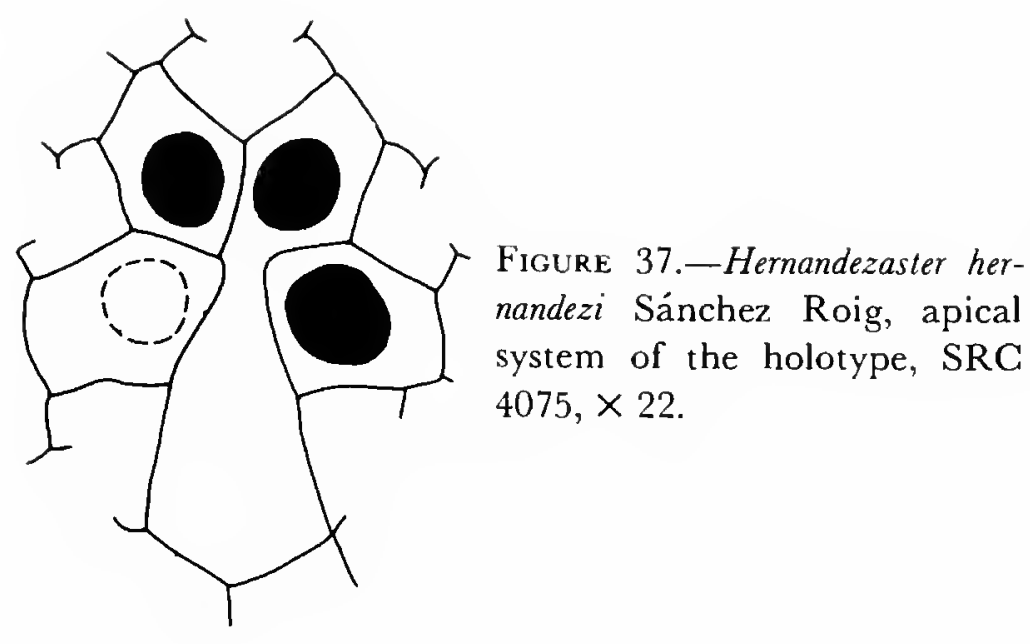

Posterior petals (V and I) two-thirds distance from apical system to margin, length $40 \% \mathrm{~L}$; width $8.3 \% \mathrm{~L}$, depth of groove $3.1 \% \mathrm{~L}$. Petals straight to slightly curving anteriorly distally; 76 petaloid porepairs.

Peristome.-Anterior, located at distance from anterior margin to anterior edge of peristome equal to $14 \% \mathrm{~L}$, opening wide, width $24 \% \mathrm{~L}$; height $6.2 \% \mathrm{~L}$ but part of labrum appears to be broken away.

Periproct.-Inframarginal, on overhanging truncation. Test around periproct fractured but opening appears to have been higher than wide, height $18 \% \mathrm{~L}$, width $12 \% \mathrm{~L}$.

Fascioles.-Not discernible presumably because of weathering of test.

Oral Plate Arrangement.--Sutures not clear but plastron appears to have been very broad.

Occurrence.-Miocene, "Santa Ana" farm, Majagua district, Ciego de Avila, Camagüey Province, Cuba. Although Sánchez Roig considered this locality late Oligocene, Albear (1980, personal communication) dates it as Miocene.

\section{Genus Lajanaster Lambert and Sánchez Roig, 1924}

Test large, apical system ethmolytic with 4 genital pores, anterior ambulacrum not petaloid, in very slight groove, pores minute petals narrow, inflated along interporiferous zones; large tubercles at anterior margin of paired petals; peripetalous and subanal fascioles present.

Remarks.-Five species have been referred to this genus, but only one, Lajanaster jacksoni Lambert and Sánchez Roig, is recognizable herein. None occur outside Cuba. No specimens in the Sánchez Roig Collection are of Lajanaster guevarai Sánchez Roig and none are known elsewhere. The illustrations of this species by Sánchez Roig are not very clear, but the petals are much wider than in the type-species of Lajanaster. This species appears to be a Eupatagus.

Lajanaster venturillae Sánchez Roig is herein considered a synonym of Eupatagus venturillae Sánchez Roig.

Lajanaster hernandezi Sánchez Roig appears also to be a Eupatagus, but the type specimen of this species has been lost. The specimen in the Sánchez Roig Collection labelled as the type specimen (SRC 4095) is not the specimen figured by Sánchez Roig. Its petals are far wider. It appears to be a Eupatagus venturillae Sánchez Roig.

No specimens are available of Lajanaster rojasi Sánchez Roig; but from Sánchez Roig's (1953a, pl. 10, upper figure) illustration, it can be seen that its petals are narrower as in the type-species of Lajanaster.

HABiTAT.-Species of this genus, having both peripetalous and subanal fascioles, could surely burrow but probably only in coarser sediment. The small pores in the dorsal portion of the anterior ambulacrum indicate that funnel-building tubefeet, necessary for echinoids burrowing in fine sediment were absent.

\section{Lajanaster jacksoni Lambert and Sánchez Roig}

Plate 52: figure 6; Plate 53: figures 3, 4

Lajanaster jacksoni Lambert and Sánchez Roig in Lambert and Thiéry, 1924 [1909-1925]:449.-Sánchez Roig, 1926:100, pl. 23: fig. 1, pl. 24: fig. 1, pl. 25: fig. 1, pl. 26: figs. 1, 2, pl. 27: figs. 1, 2; 1949:193, pls. 26, 27.-Mortensen, 1951, fig. 262.-Fischer, 1966, figs. 478-3a,b.

Material. - No specimens of this species are in the Sánchez Roig Collection, but one topotypic specimen identified on its label by Sánchez Roig is in the Smithsonian. This specimen (USNM 352866) is moderately well preserved, although partially flattened and with part of the ventral surface fractured. Two specimens from Cama- 
güey Province are in the Museum of Comparative Zoology, Harvard MCZ 4117, 4129).

Shape And Size.-Length $115 \mathrm{~mm}$, width $84 \%$ $\mathrm{L}$, test very low, height $24 \% \mathrm{~L}$; greatest width central, greatest height posterior at plastron. Interambulacra inflated slightly along midline forming slight ridge.

Apical System.-Anterior, distance from anterior margin to anterior edge $42 \% \mathrm{~L} ; 4$ genital pores, ethmolytic with genital plate 2 extending posteriorly separating posterior ocular plates.

Ambulacra.-Anterior ambulacrum III not petaloid, in slight groove adapically; adapical pores minute, not possible to count pores.

Anterior petals (II and IV) long, extending two-thirds distance from apical system to margin, length $31 \% \mathrm{~L}$, width $8.7 \% \mathrm{~L}$, maximum width of interporiferous zone near midlength of petal $3.2 \%$ $\mathrm{L}$; poriferous zone with width $1.7 \% \mathrm{~L}$, of equal length; 64 porepairs in petal.

Posterior petals (V and I) long, slightly longer than anterior petals, extending more than twothirds distance to margin, length $40 \% \mathrm{~L}$, width $9.6 \% \mathrm{~L}$, greatest width of interporiferous zone $3.1 \% \mathrm{~L}$, greatest width of poriferous zone $1.7 \% \mathrm{~L}$; 76 petaloid porepairs in each petal. Petals inflated along interporiferous zones, with poriferous zones slightly depressed, pores strongly conjugate, outer pore slightly elongate.

Peristome.-Anterior, located at distance from anterior margin to anterior edge of peristome equal to $27 \% \mathrm{~L}$; width $15 \% \mathrm{~L}$, height $6.6 \% \mathrm{~L}$.

Periproct.-Not preserved but according to Lambert and Sánchez Roig in Sánchez Roig (1926:100) circular, marginal, and visible from below.

Fascioles.-Only short portions of peripetalous fasciole visible on this specimen. Lambert and Sánchez Roig in Sánchez Roig (1926:101) report a subanal fasciole.

TuberCulation.-Large tubercles confined within peripetalous fasciole immediately anterior to anterior poriferous petals in paired interambulacra.

Oral Plate Arrangement.-Suturs not visible but plastron very narrow (Sánchez Roig, 1949, pl. 27).
Occurrence.-Miocene, "Cervantes" farm, San José de las Lajas, Habana Province; Oligocene-Miocene, Palmer loc. 1660, long cut S of Yswitch on Ramal Valle, Central Jatibonico cane railroad, Camagüey Province, Cuba.

\section{UnReCognizable Species of Lajanaster}

Lajanaster hernandezi Sánchez Roig

Lajanaster hemandezi Sánchez Roig, 1949:195, pl. 23: figs. $2,3$.

The type specimen has been lost.

Occurrence.-Late Oligocene but Albear (1980, personal communication) considers this locality to be Miocene. "Santa Ana" farm, Majagua district, Ciego de Avila, Camagüey Province, Cuba.

\section{Lajanaster rojasi Sánchez Roig}

Lajanaster rojasi Sánchez Roig, 1953a:58, pl. 10 [part].

No specimens are known of this species.

Occurrence._-Oligocene-Miocene, "Blanquizal" farm, Marroquín district, Morón, Camagüey Province, Cuba.

\section{Genus Macropneustes L. Agassiz, 1847}

Test large, low, broad, with anterior groove; paired petals long; large tubercles confined within peripetalous fasciole; peristome large; subanal fasciole present.

This genus is difficult to distinguish from $E u$ patagus. The petals are generally narrower and a distinct anterior groove is present in Macropneustes. The subgenus, Deakia, is distinguished from $\mathrm{Ma}$ cropneustes (Macropneustes) by its lower test and shorter petals.

Three species of this genus have been reported from Cuba: Macropneustes (M.) brodermanni Sánchez Roig, Macropneustes (M.) cubensis Cotteau, and Macropneustes (Deakia) armadilloensis Sánchez Roig. Only one of these is referred definitely to Macropneustes: M. (D.) armadilloensis. M. brodermanni is referred to Meoma. The holotype of M. cubensis 
is in the Cotteau Collection but is too poorly preserved to be generically identified with certainty.

Metalia palmeri Sánchez Roig is tentatively referred to Macropneustes (Macropneustes).

Habitat. - The presence of both a subanal and peripetalous fasciole indicates that this genus could burrow. The absence of large pores dorsally in ambulacrum III suggests an absence of funnelbuilding tubefeet and probably means that this genus could not maintain a burrow in fine sediment. It resembles Spatangus, which Nichols (1959:353) reports lives in shell gravel.

\section{Macropneustes (Deakia) armadilloensis Sánchez Roig, new combination, new status}

Plate 49: figures 5, 6; Plate 50: figures 1-3

Deakia armadilloensis Sánchez Roig, 1953c, pl. 10: figs. 1, 2.

Material.-Two specimens are present in the collection. The first specimen (SRC 4263) figured by Sánchez Roig (1953c, pl. 10: fig. 1) is herein selected as the lectotype. The second specimen (SRC 4262) is topotypic and probably is a paratype. The other specimen figured by Sánchez Roig (1953c, pl. 10: fig. 2) is no longer in the collection. The lectotype is flattened by postmortem depression and is badly weathered with the sutures, especially ventrally, greatly enlarged. The second specimen is also badly weathered with most of the ventral surface absent, but it is only slightly distorted. The first dimension in the following description is of the lectotype.

Shape AND Size.-Length 55 and $43 \mathrm{~mm}$; width 91 and $96 \%$ L; height of lectotype $32 \%$ L but specimen flattened after death, height of SRC 4262 is $39 \%$ L. Greatest width anterior, greatest height posterior.

Apical System.-Anterior, distance from anterior margin to center of pores 27 and $31 \% \mathrm{~L}$. Four genital pores, very close together, ethmolytic with genital plate 2 extending posteriorly separating posterior ocular plates.

AmBUlacra.-Anterior ambulacrum III not petaloid with very small pores in dorsal region; flush with test except for slight depression where crossing margin of test.

Anterior petals (II and IV) short, extending slightly more than one-half distance from apical system to margin, length 22 and $27 \% \mathrm{~L}$; petals with greatest width near apical system where width 8.2 and $9.6 \%$ L. Poriferous zones wide with pores conjugate, outer pore elongated; 36 and 36 porepairs in petal; dorsal pores in anterior poriferous zone greatly reduced in size relative to porepairs in dorsal posterior poriferous zone. No plates occluded at end of petals.

Posterior petals (V and I) slightly longer than anterior, extending less than one-half distance from apical system to margin of test, length 29 and $29 \% \mathrm{~L}$; greatest width 8.4 and $8.0 \% \mathrm{~L} ; 46$ and 40 porepairs in petal. No occluded plates at end of petals.

Peristome.-Anterior, located at distance from anterior margin to anterior edge of peristome 18 and $23 \%$ L. Opening wider than high, width 16 and $15 \% \mathrm{~L}$, height 6.6 and $5.7 \% \mathrm{~L}$. Phyllodes with pores in large peripodia; 7 in phyllode of ambulacrum II of specimen SRC 4262.

Periproct.-Only partially preserved on lectotype, marginal.

FAscioles._Only traces of peripetalous and subanal fascioles preserved. Peripetalous fasciole narrow, not indented in interambulacra.

Tuberculation.-Large tubercles with very large scrobicules confined within peripetalous fasciole in posterior region of paired interambulacra. Four to 6 large tubercles in posterior interambulacra; 2 in each anterior interambulacrum. Single row of secondary tubercles parallel to transverse suture between petaloid porepairs; 6 to 8 pores in each row at widest part of poriferous zone. Ventrally, many large tubercles with large scrobicules with eccentric mamelons.

Oral Plate Arrangment.-Labrum of length $10 \% \mathrm{~L}$, width $6.4 \% \mathrm{~L}$; sternal plates of length $44 \%$ $\mathrm{L}$, width (est.) $30 \%$ L. First plate in interambulacrum 1 followed by pair of plates.

Occurrence. - Late Eocene, "Armadillo" farm, Marroquín, Morón, Camagüey Province, Cuba.

Comparison with Other Species-This spe- 
cies is a typical brissid, having both a peripetalous and subanal fasciole, large tubercles confined within the peripetalous fasciole, and an ethmolytic apical system with the genital pores very close together as common in many brissids. Its short petals and broad, low test are quite similar to the type-species of the subgenus Deakia. Macropneustes (D.) armadilloensis is the only species of this subgenus known from the Western Hemisphere.

\section{Macropneustes? (Macropneustes ) cubensis Cotteau}

Plate 49: Figure 4

Macropneustes cubensis Cotteau, 1875:6; 1876:130; 1881:48, pl. 4: fig. 7.-Egozcue y Cía in Cotteau, 1897:91, pl. 23: figs. 1-4, pl. 25: fig. 7.-Sánchez Roig, 1924a:41.-Cooke, 1959:83, 84 .

Eupatagus cubensis (Cotteau).-Jackson, 1922:94.

Mauritanaster cubensis (Cotteau).-Sánchez Roig, 1926:118; 1949:227.-Mortensen, 1951:551.

I have seen the holotype of this species in the Cotteau Collection. It is too poorly preserved for generic identification. The specimen is very badly weathered; the presence or absence of fascioles is uncertain.

It is possible that two species are represented. The name Asterostoma castroi was applied by Egozcue to a specimen exhibited in the Universal Exposition of Paris. Cotteau (1875:6) later described Macropneustes cubensis for this species. Egozcue y Cía (in Cotteau 1897:91) discussed the situation and reported no difference between his specimen of Asterostoma castroi and the species described by Cotteau (1875:6). Lambert (1924a:42) disagreed, claiming that two species were represented and resurrected Asterostoma castroi with Egozcue as the author. However, as pointed out by Cooke (1959:84), Asterostoma castroi Egozcue is a manuscript name.

It is not clear whether 2 species are represented. The differences pointed out by Lambert between the 2 species may result only from differences in the preservation of the few specimens known.

Cooke considered the Cuban species to be a synonym of Macropneustes mortoni (Conrad, 1850) from the Eocene of southeastern United States, but they appear to be quite distinct. $M$. mortoni has two fascioles, whereas none are visible on the Cuban species. Furthermore, the American species has 4 genital pores and wider interporiferous zones. Only 3 genital pores are present in the 2 specimens of $M$. cubensis where the apical system is preserved.

Occurrence.-Miocene, St. Martin; "Cervantes" farm, San José de las Lajas, Habana Province, Cuba.

\section{Macropneustes? (Macropneustes) palmeri (Sánchez Roig), new combination}

Figure 38; Plate 48: figures 5, 6, 7; Plate 49: figures $1-3$

Metalia palmeri Sánchez Roig, 1953c:166 [new name for Antillaster cartagensis Sánchez Roig, 1949:188, pl. 22: fig. 2; not Metalia cartagensis Sánchez Roig, 1949:232].

Material.-Two cotypes in Sánchez Roig Collection. Specimen (SRC 4032) figured by Sánchez Roig (1949, pl. 22: fig. 2) is herein selected as the lectotype. It is poorly preserved, being badly weathered with the peristomial and posterior surface destroyed. The test is distorted with the right side depressed and the front compressed making the anterior surface steeper than original. The paralectotype (SRC 4031) is also badly weathered with most of its dorsal surface absent and the ventral surface badly fractured. The test, however, is undistorted showing the original shape.

Shape and Size.-Paralectotype $77 \mathrm{~mm}$ long, width $94 \% \mathrm{~L}$, height $42 \% \mathrm{~L}$; test low and broad with greatest width central, greatest height anterior. Lectotype estimated to have been $71 \mathrm{~mm}$ long.

Apical System.-Anterior, located on paralectotype at distance from anterior margin to center of genital pores equal to $31 \%$ L. Plates of apical system absent on both specimens.

Ambulacra.-Anterior ambulacrum III not petaloid; in slight groove where crossing anterior margin; pores in dorsal region very small; 54 plates in ambulacrum in lectotype. 

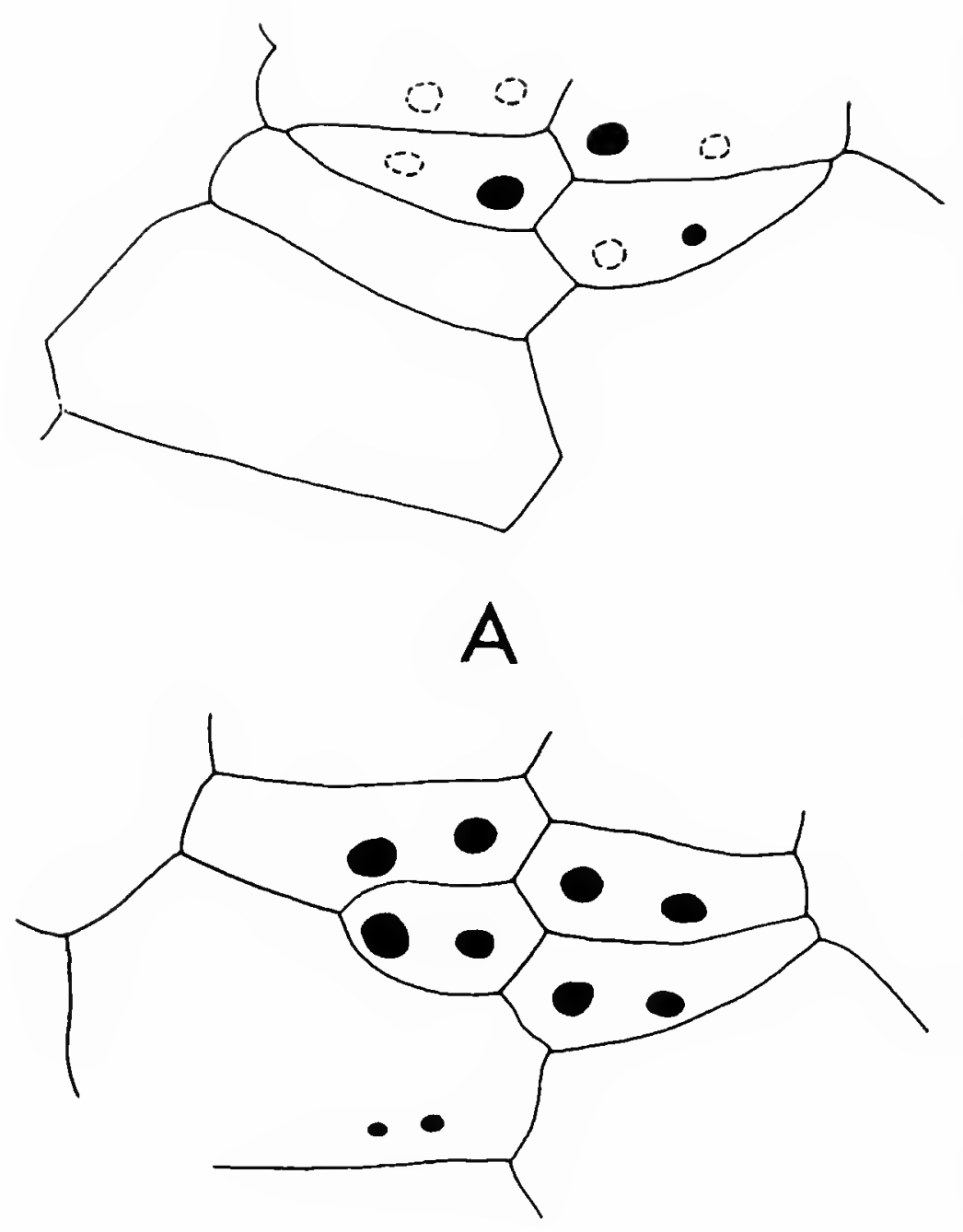

\section{B}

Ficure 38.-Macropneustes?' (Macropneustes) palmen (Sánchez Roig): A, plate arrangement at end of petal IV of the lectotype, SRC 4032, × 8; в, plate arrangement at end of petal $\mathrm{V}$ of paralectotype, SRC $4031, \times 8$.

Anterior petals (II and IV) curving anteriorly, length $34 \% \mathrm{~L}$ in lectotype, $30 \% \mathrm{~L}$ in paralectotype, width 9.7 and $11 \% \mathrm{~L}$; interporiferous zones narrower than poriferous. Dorsally, pores in anterior poriferous zones smaller than in posterior zones; 44 petaloid porepairs in lectotype. No plates occluded at end of petal in lectotype, one plate occluded in both zones of petal IV (Figure 38A).

Posterior petals ( $\mathrm{V}$ and $\mathrm{I}$ ) divergent, short, extending slightly more than onc-half distance from apical system to margin; length in lcctotype $39 \%$ L, width $11 \%$ L. Interporiferous zone narrower than single poriferous zonc; 52 petaloid porepairs in lectotype. One plate occluded at cnd of each petal in zone $\mathrm{Va}$ and Ia (Figure 38B) of lectotype. End of posterior petals not preserved in paralectotype.

Peristome.-Anterior, distance from anterior margin to anterior edge of peristome $18 \% \mathrm{~L}$; width of opening $13 \% \mathrm{~L}$ in paralectotype.

Periproct.-Absent.

Fascioles. - No traces of peripetalous fasciole preserved; probably originally present but removed by weathering. Only short track of subanal fasciole present; most of posterior surface broken away on both specimens.

Tuberculation.-Larger tubercles present in paired interambulacra presumably confined within peripetalous fasciole.

Oral Plate Arrangement.-Labrum absent; rest of plate sutures not clear.

Occurrence.-Oligocene-Miocene, SSE of Cartagena, $1 \mathrm{~km} \mathrm{~N}$ side of railroad, Las Villas Province, Cuba.

REMARKs. - It is not possible to know with certainty the genus to which this species belongs. Too many important morphological characters are unknown because of the poor preservation of the types. According to Mortensen (1951:532), Metalia is distinguished from Brissus by its narrower shield-shaped region enclosed by the subanal fasciole. Unfortunately the shape of this region is not clear on the types. In the type-species of Metalia, no large tubercles are confined within the peripetalous fasciole; but in this Cuban species large tubercles are present in the anterior and posterior paired interambulacra. Of all the genera of the Brissidae having large tubercles within the peripetalous fasciole, this species with its broad shape and narrow petals most resembles Macropneustes.

\section{Genus Meoma Gray, 1851}

Test large, apical system ethmolytic with 4 genital porcs, anterior ambulacrum in notch at margin, not petaloid, pores minute; petals narrow, sunken; periproct marginal to inframarginal; tubcrcles within peripetalous fasciole slightly larger; peripetalous fasciole deeply in- 
dented between petals, subanal fasciole bilobed; labrum short, not extending posteriorly past first adjoining ambulacral plates; sternal plates broad, episternal plates large, about one-half length of sternal plates.

Habitat.-Modern species of Meoma live buried in sand in tropical seas at a depth from 5 to $200 \mathrm{~m}$. These echinoids randomly ingest and pack their intestines with sediment. They probably cannot burrow in fine sediment. Their fascioles are poorly developed, and they lack funnel-building tubefeet in the anterior ambulacrum and around the periproct.

Comparison with Species outside of Cuba.Two Cuban species can be referred with some certainty to Meoma: Meoma antiqua Arnold and Clark and Meoma antillarum (Cotteau). Sánchez Roig's Meoma caobaensis, from the middle Eocene of Cuba appears to be a synonym of Meoma antiqua Arnold and Clark, previously known from the middle Eocene of Jamaica. $M$. antillarum of uncertain age from Cuba and perhaps from the Eocene of St. Bartholomew appears to be quite distinct from the other Cuban and Caribbean species of this genus.

Meoma? brodermanni (Sánchez Roig) and Meoma? gomezmazae (Sánchez Roig) are very similar to each other but are based on internal molds showing too few characters to permit certain generic identification. Both Cotteau (1875:40) and Sánchez Roig (1949:231) report Cuban specimens of Meoma clevei (Cotteau); but they never illustrated these specimens and none are available in the present collection. Therefore, it is not possible to confirm the presence of this Anguillan species in Cuba.

REMARKS. - The systematics of this genus have been reviewed by Chesher (1970).

\section{Meoma antillarum (Cotteau)}

Plate 51

Peripneustes antillarum Cotteau, 1875:7, 39, pl. 7: figs. 1-3.Cooke, 1959:83.

Macropneustes antillarum (Cotteau).-Guppy, 1882: 198.-Cotteau, 1897:95, pl. 29: figs. 1-3.-Jackson, 1922:85, pl. 15: fig. 1.
Schizobrissus antillarum (Cotteau).-Lambert in Lambert and Thiéry, 1924 [1909-1925]:494._Sánchez Roig, 1949: 229.

Meoma antillarum (Cotteau).-Chesher, 1970:755-758.

Material. - Two cotypes are available. The Cuban specimen in the Cotteau Collection at the Université Claude Bernard, Lyons, France, figured by Cotteau (1875, pl. 7: figs. 1-3) is herein selected as the lectotype. The other cotype is from the Eocene of St. Bartholomew and was originally in Cleve's collection, later in Guppy's and now is housed in the Smithsonian (USNM 214150). This specimen was figured by Jackson (1922, pl. 15: fig. 1). Later, Lambert (in Lambert and Thiéry, 1924 [1909-1925]:494) decided that this specimen was not conspecific with Cotteau's (1875, pl. 7: figs. 1-3) figured specimen of Peripneustes antillarum. Lambert made the cotype from the Eocene of St. Bartholomew the holotype of his new species, Schizobrissus jacksoni. The specimen is so badly weathered and crushed that it is not possible to determine whether or not it is conspecific with the lectotype of $P$. antillarum. Sánchez Roig (1949:230) credited S. jacksoni to Sánchez Roig and Lambert in Sánchez Roig (1949:230) stating that the type was a specimen from the Pleistocene of Habana. This action is not valid because Lambert (in Sánchez Roig, 1926:121) did not include this specimen in his description.

Fischer (1966:U594) stated that $P$. antillarum was the type-species of Peripneustes by original designation. I can see no designation of typespecies in Cotteau's description. Cooke (1959:83) designated Peripneustes clevei Cotteau as the typespecies.

Lambert (in Lambert and Thiéry, 1924 [1909-1925]:494) considered Peripneustes a synonym of Schizobrissus as did Fischer (1966:U594). Chesher (1970:755) pointed out that the holotype of the type-species of Schizobrissus, S. cruciatus (Agassiz), is so poorly preserved that it is not possible to be certain of its family. For this reason he thought it incorrect to synonymize Schizobrissus with Meoma. He referred $P$. antillarum to Meoma.

The lectotype is moderately well preserved although part of the test is missing, and the test is 
somewhat distorted. The following description is based on this specimen.

Shape and Size.-Test $112 \mathrm{~mm}$ long, width $84 \% \mathrm{~L}$, greatest width slightly posterior of center; greatest height $48 \% \mathrm{~L}$, anterior to center at apical system.

Apical System.-Anterior, distance from anterior margin $35 \% \mathrm{~L}$, ethmolytic, number of genital pores not clear but Cotteau (1875, pl. 7: fig. 3) shows 4 in his figure.

Ambulacra.-Anterior ambulacrum III not petaloid, depressed in deep groove. Anterior petals (II and IV) long, extending almost to margin, length $44 \% \mathrm{~L}$, width $7.3 \% \mathrm{~L}$, curving anteriorly distally. Interporiferous zone very narrow, approximately one-half width of single poriferous zone; 84 porepairs in petal.

Posterior petals (V and I) long, narrow, straight, extending four-fifths distance from apical system to margin, length $51 \% \mathrm{~L}$, width $7.3 \%$ $\mathrm{L}$; 88 porepairs in petal.

Peristome.-Anterior, distance from anterior edge of peristome to anterior margin $18 \% \mathrm{~L}$; width estimated at $19 \%$ L, height $3.8 \%$ L. Details of phyllodes not clear.

Periproct.-Not preserved.

FAScioles.- Peripetalous fasciole very narrow, width $1.4 \% \mathrm{~L}$, very angular in course around petals. Only anterior portion of subanal fasciole visible, very narrow, width $0.9 \% \mathrm{~L}$, enclosing a large area; because of poor preservation, not possible to know if fasciole complete.

Oral Plate Arrangement.-Not discernible.

Occurrence. - The lectotype is reported from the Cuban Eocene with no further locality data. Cotteau (1897:96) reports the species from Matanzas, Cuba. Sánchez Roig reports a specimen from the late Oligocene (now considered Miocene by Brönnimann and Rigassi, 1963:466) at "La Noria" farm, Cojimar, Habana Province, Cuba; but this specimen is no longer in the Sánchez Roig Collection.

Comparison with Other Species.-This species differs from Meoma brodermanni (Sánchez Roig) of uncertain age from Cuba in having its anterior petals curving anteriorly distally, whereas they are straight in $M$. brodermann. Furthermore, the petals in $M$. antillarum are narrower (a width of approximately $10 \% \mathrm{~L}$ as opposed to $7.3 \% \mathrm{~L}$ ) and longer (particularly the posterior ones whose length is equal to $51 \% \mathrm{~L}$ in $M$. antillarum versus $43 \% \mathrm{~L}$ in $M$. brodermanni).

Cooke (1959:83) considered $M$. antillarum as probably being the same species as Meoma clevei (Cotteau) from the Anguillan Miocene. Jackson (1922:85) and Chesher (1970:756) maintained them as separate species. I have compared the type specimens of both species; they appear to be quite distinct. $M$. antillarum has a much larger and wider test, which is more abruptly inflated at its apical system, and a much narrower peristome, which is situated much more anteriorly.

$M$. antillarum is very similar in its general appearance and petal arrangement to the living Meoma frangibilis Chesher from the Bay of Panama. It differs in having a less anterior apical system, straighter posterior petals, and less rounded anterior margin. It also resembles the living Meoma ventricosa (Lamarck) from Bermuda to Colombia, South America-in particular some of the more elongate specimens figured by Chesher (1970, fig. 4g, f). It differs in having a deeper anterior notch, more asymetrical test, and less rounded anterior margin. Chesher (1970:758) suggested that the Recent species of Meoma was probably derived from $M$. antillarum.

\section{Meoma antiqua Arnold and Clark}

Meoma anliqua Arnold and Clark, 1927:70, pl. 15: fig. 2. ?Meoma caobaensis Sánchez Roig, 1952c:16, pl. 11: figs. 2, 3.

Occurrence.-Debris at base of vertical cliffs, visible as one approaches from the Claremont Road, near Lucky Hill, St. Mary Parish, Jamaica. According to the 1958 geological map of Jamaica, Lucky Hill occurs in the middle Eocene Yellow Limestone. Middle Eocene, Loma Caoba, quarries of Caraballo, San Diego de los Baños, Pinar del Rio Province, Cuba.

Remarks.-The holotype and only known specimen of Meoma caobaensis is lost; but from 
Sánchez Roig's photographs, this species appears to be a synonym of the Jamaican Meoma antiqua. Its elongate test and petal arrangement are identical.

\section{Meoma? brodermanni (Sánchez Roig), new combination}

Plate 50: figures 4-6

Macropneustes brodermanni Sánchez Roig, 1953a:62, pls. 15, 16.

Material.-Only one specimen known, the holotype (SRC 4121). This specimen is a mold of the interior with none of the original test preserved.

Shape And Size.-Length $107.5 \mathrm{~mm}$, width $91 \% \mathrm{~L}$, height $49 \% \mathrm{~L}$; greatest width anterior, greatest height anterior at apical system.

Apical system.-Anterior, located at distance from anterior margin to center of genital pores equal to $30 \% \mathrm{~L}$. No other details preserved.

AmBUlacra.-Anterior ambulacrum III not petaloid, in deep groove crossing ambitus with depth $4.3 \%$ L. Anterior petals (II and IV) straight, extending almost to margin, length $39 \%$ L, width $10 \% \mathrm{~L}$; interporiferous zone appears to be slightly narrower than single poriferous zone. Petals depressed in groove with depth $4.3 \% \mathrm{~L}$.

Posterior petals (V and I) straight, extending two-thirds distance from apical system to margin, length $43 \% \mathrm{~L}$, width $9.7 \% \mathrm{~L}$; interporiferous zone narrower than single poriferous zone. Petals depressed in groove with depth $3.3 \% \mathrm{~L}$.

Peristome.-Very eccentric anteriorly, distance from anterior margin to anterior edge of peristome $10 \% \mathrm{~L}$; width estimated at $19 \% \mathrm{~L}$.

PERIPROCT.-Inframarginal, located high on overhanging posterior truncation; opening large, higher than wide, height estimated $17 \% \mathrm{~L}$, width estimated $13 \% \mathrm{~L}$.

FAscioles.-Not preserved.

Oral Plate Arrangement.-Labrum not preserved; impression of plates of plastron suggests that first pair of plastron plates (sternal) with length estimated at $47 \% \mathrm{~L}$, combined width estimated at $37 \% \mathrm{~L}$; second pair (episternal) with length estimated at $16 \% \mathrm{~L}$, combined width estimated at $37 \% \mathrm{~L}$.

Occurrence.-Age and locality uncertain, perhaps Casa Rabelo, Pinar del Rio Province, Cuba.

Comparison with Other Species.-Meoma brodermann is very similar to Meoma? gomezmazae (Sánchez Roig) from the Oligocene-Miocene of Cuba. Both species are known only from internal molds so many specific characters are not known. The apical system appears to be slightly more anterior in $M$. brodermanni; the test, slightly more depressed posterior to the apical system and the anterior groove, deeper at the margin. However, all these differences may be due to postmortem distortion of the test. The species may be synonymous; but with so many specific characters not preserved, I hesitate to synonymize them.

$M$. brodermanni is easily distinguished from Meoma antiqua Arnold and Clark from the middle Eocene of Cuba and Eocene of Jamaica by its much broader test. It is distinguished from Meoma clevei (Cotteau) from the Miocene of Anguilla by its much larger and broader test, wider petals, and wider, more anterior peristome. It differs from $M$. antillarum from the Eocene of Cuba in its shorter, straighter, and wider petals.

ReMARKs.-Because the only known specimen of this species is an internal mold, none of the external features of the plates are preserved. Therefore, nothing is known about the fascioles, tuberculation, or apical system. It is not possible to be certain of its generic affinities, but it appears to be a Meoma not Macropneustes. Chesher (1970:756) distinguishes Meoma from Macropneustes by the depressed petals and indented fascioles found in the former genus. Although nothing is known of the fascioles in this species, its petals are very depressed.

\section{Meoma clevei (Cotteau)}

Peripneustes clevei Cotteau, 1875:40, pl. 7: figs. 4-7.-Cooke, 1959:83.

Macropneustes clevei (Cotteau).-Guppy, 1882:198.-Cotteau, 1897:93, pl. 28: figs. 1-4. 
Schizobrissus clever (Cotteau)._Sánchez Roig, 1949:231. Meoma clevei (Cotteau).—Chesher, 1970:755, figs. 9a-c.

It is not certain that this species occurred in Cuba. Cotteau (1897:94) reported an internal mold of the species from the Cuban Miocene, but it has never been figured or described. Likewise, Sánchez Roig referred to this species a specimen from the Oligocene (now considered Miocene) of Cuba. The specimen is no longer in the Sánchez Roig Collection and was never illustrated by him.

Occurrence.-Miocene of Cuba and Anguilla. Sánchez Roig's specimen came from "La Noria" farm, Cojímar, Habana Province, Cuba.

\section{Meoma? gomezmazae (Sánchez Roig), new combination}

Plate 52: figures 1 -3

Macropneustes gomezmazae Sánchez Roig, 1953a: 63, pl. 17.

Material. - The holotype and only known specimen (SRC 4101) is an internal mold. Therefore, none of the features of the external surface of the test are preserved.

Shape And Size.-Length $99.0 \mathrm{~mm}$, width $86 \%$ L, height $48 \% \mathrm{~L}$; greatest height and width central.

Ambulacra.-Anterior ambulacrum III not petaloid, in slight groove at margin. Anterior petals (II and IV) straight, extending almost to margin, length estimated at $37 \% \mathrm{~L}$, width $9.7 \%$ $\mathrm{L}$; interporiferous zones narrower than single poriferous zone. Petals depressed in groove with depth $2.9 \%$ L.

Posterior petals (V and I) straight, extending two-thirds distance from apical system to margin; length $36 \% \mathrm{~L}$, width $9.7 \% \mathrm{~L}$. Petals depressed in groove with depth $24 \% \mathrm{~L}$.

Peristome.-Anterior distance from anterior margin to anterior edge of peristome $14 \% \mathrm{~L}$, width estimated at $18 \% \mathrm{~L}$.

Periproct.-Inframarginal, on overhanging posterior truncation; height greater than width, height estimated at $16 \% \mathrm{~L}$, width estimated at $13 \% \mathrm{~L}$.

Fascioles. - Not preserved.
Oral Plate Arrangement.-Labrum unknown. Sternal plates with length estimated at $46 \% \mathrm{~L}$, combined width $36 \% \mathrm{~L}$; episternal with length $15 \% \mathrm{~L}$, combined width $40 \% \mathrm{~L}$.

Occurrence.-Oligocene-Miocene, Matanzas, Matanzas Province, Cuba.

Comparison with Other Species.-This species is very similar to Meoma brodermanni (Sánchez Roig) and the two species may be synonymous. M. gomezmazae differs from $M$. brodermanni in having a shallower anterior groove, more posterior apical system, and in being more inflated posterior to the apical system. These differences may be due to postmortem distortion.

REMARKs.-As the only known specimen of this species in an internal mold and nothing is known of the external features of the test, it is not possible to be certain of its generic affinities. Its depressed petals indicate that it should be referred to Meoma not Macropneustes.

\section{Genus Metalia Gray, 1855}

\section{Metalia cartagensis Sánchez Roig}

Metalia cartagensis Sánchez Roig, 1949:232.

The type specimen is lost and no other specimens are known. The species has never been figured.

Occurrence.-Oligocene-Miocene, S of Cartagena at $1 \mathrm{~km}$ on $\mathrm{N}$ side of railroad, Las Villas Province, Cuba.

\section{Genus Migliorinia Checchia-Rispoli, 1942}

Test small, low, apical system ethmolytic with 4 genital pores, petals flush with narrow interporiferous zones; peripetalous and subanal fascioles present; periproct supramarginal, no larger tubercles within peripetalous fasciole.

Habitat. - Migliorinia presumably lived buried in sand or coarser sediment. It lacked funnelbuilding tubefeet as indicated by the lack of larger pores in the dorsal portion of its anterior ambulacrum. These tubefeet are essential for an echinoid to live in a burrow in fine sediment. 
Remarks.-Only two species are known of this genus-the type-species from the middle Eocene of Somaliland and the Miocene $M$. habanensis (Sánchez Roig) from Cuba.

\section{Migliorinia habanensis (Sánchez Roig)}

$$
\text { Plate 68: figures 5-7 }
$$

Brissoma habanensis Sánchez Roig, 1949:224, pl. 35: figs. 3, 4. Schizaster vedadoensis Sánchez Roig, 1949:270, pl. 45: fig. 8.

Material._Only one specimen (SRC 4773) is referrable to this species in the Sánchez Roig Collection. It is not the specimen originally figured by Sánchez Roig, but it is a cotype that is now selected as the lectotype. The specimen is moderately well preserved but is crushed.

Shape And Size.-Length $21 \mathrm{~mm}$, width 92\% $\mathrm{L}$, height indeterminate because of postmortem crushing; greatest width central.

Apical System.-Anterior, distance from anterior margin to center of genital pores equal to $39 \%$ L. Ethmolytic, with genital plate 2 separating posterior ocular plates; 4 genital pores.

AMBUlaCra.-Anterior ambulacrum III not petaloid, pores minute adapically in very faint groove at margin.

Anterior petals (II and IV) extending threefourths distance from apical system to margin; length $31 \% \mathrm{~L}$, wide, width $15 \% \mathrm{~L}$; adapically pores of anterior poriferous reduced in size. Interporiferous zones width of single poriferous zone, pores conjugate, 30 porepairs in petal. Petals flush, not depressed in groove.

Posterior petals ( $\mathrm{V}$ and I) approximately same length as anterior, extending two-thirds distance from apical system to margin, length $32 \% \mathrm{~L}$; pore in zones $\mathrm{Vb}$ and Ia greatly reduced in size adapically; 30 porepairs in petal.

Peristome.-Anterior, distance of anterior margin from anterior edge of opening equal to $30 \% \mathrm{~L}$, opening large, width $23 \% \mathrm{~L}$, height $14 \%$ L.

Periproct.-Inframarginal, but present position may be due to postmortem distortion; opening large, higher than wide.

Fascioles._Peripetalous fasciole broad, deeply indented in paired interambulacra. Only portions of subanal fasciole preserved.

Tuberculation.-No large tubercles confined within peripetalous fasciole.

Oral Plate Arrangement.-Plate sutures not clear.

Occurrence.-Miocene, quarries at $23 \mathrm{Ve}$ dado, left of the bridge, Habana Province, Cuba. Although Sánchez Roig (1949:225) considered the type-locality to be late Oligocene, the species has been collected at Rio Cojímar and quarries at the entrance of Cojímar. These localities are considered to be in the Miocene Cojimar Formation by Brönnimann and Rigassi (1963:466).

Remarks.-Sánchez Roig referred this species to Brissoma, a genus which Mortensen (1951:374) considered a subjective synonym of Brissopsis. The type-species of Brissoma is very similar to the typespecies of Brissopsis and is certainly not generically distinct.

This Cuban species differs from Brissopsis in having flush petals. Of all the genera of brissids, it seems to have the greatest affinities with $\mathrm{Mig}$ liorinia. It differs from the type-species, $M$. migiurtina Checchia-Rispoli from the Eocene of Somaliland in having broader petals.

The holotype (SRC 4208) of Schizaster vedadoensis Sánchez Roig is a very badly preserved specimen with its test crushed. However, its petals are identical to those in $M$. habanensis and it comes from the same locality. Without doubt it belongs to this species. It is too poorly preserved to permit description, but it is figured on Plate 68: figure 8 .

\section{Genus Rojasia Sánchez Roig, 1951}

Large, low test with deep anterior groove; narrow, depressed, long petals; peripetalous fasciole.

Habitat.-Presumably this echinoid lived buried in coarse sediment. It lacked funnel-building tubefeet in the anterior ambulacrum as indicated by the small pores there. Without these tubefeet it is unlikely that it could maintain a burrow in mud.

REMARKS.-Nothing is known of the nature of the peristome, oral plate arrangement, periproct 
or presence of a subanal fasciole. Therefore, it cannot be referred to a family with any certainty. As noted by Sánchez Roig and by Fischer (1966:U604), this genus resembles Schizobrissus. Only one species is known of this genus.

\section{Rojasia rojasi Sánchez Roig}

$$
\text { Plate } 69
$$

Rojasia rojasi Sánchez Roig, 1951:58, pl. 35, pl. 36: fig. 1.

Material.-Only one specimen, the holotype (SRC 3623), is known. The dorsal surface is well preserved but the ventral surface is completely absent.

Shape and Size. - Length 177 mm, width 94\% L, height $40 \% \mathrm{~L}$; greatest width anterior, greatest height anterior; test depressed greatly posterior to apical system; no evidence that depression due to postmortem compression.

Apical System.-Anterior, located at distance from anterior margin equal to $36 \%$ L. Nature of apical system not clear. Although Sánchez Roig states that there are 4 genital pores, it is not clear on the holotype.

Ambulacra.-Anterior ambulacrum III not petaloid, in deep groove, at margin groove with depth $9.4 \% \mathrm{~L}$; porepairs small adapically.

Anterior petals (II and IV) curving anteriorly, long, extending four-fifths distance from apical system to margin, length $42 \% \mathrm{~L}$, narrow, width $4.5 \% \mathrm{~L}$, depressed in deep groove; interporiferous zone narrower than single poriferous zone, pores conjugate; 104 porepairs in petal.

Posterior petals (V and I) longer than anterior, curving anteriorly, length $45 \% \mathrm{~L}$, width $4.5 \% \mathrm{~L}$; 100 porepairs in petal.

Peristome.-Unknown.

Periproct.-Unknown.

FAscioles.-Peripetalous fasciole distinct; indented in paired interambulacra.

Oral Plate Arrangement.-Unknown.

Occurrence.-Eocene, "El Maja" farm, Ma- jagua district, Ciego de Avila, Camagüey Province, Cuba.

\section{Suborder Asterostomatina A.G. Fischer, 1966}

\section{Family Asterostomatidae Pictet, 1857}

\section{Genus Asterostoma L. Agassiz, 1847}

Test large; apical system ethmolytic, with 4 genital pores; petals long, open, anterior petals transverse, no occluded plates at ends of petals; anterior ambulacrum not petaloid, with minute pores; ventrally ambulacra in deep grooves, with phyllodal pores not concentrated around peristome; periproct marginal to inframarginal, opening higher than wide; no fascioles; plastron amphisternous, slightly developed; in interambulacrum 2 first plate followed by pair of plates.

Habitat.-Presumably Asterostoma lived exposed on the sea floor. It lacked suckered tubefeet on its upper surface, which could have held detritus over the top of its test. It probably had short, slender spines, sparsely distributed over the dorsal surface but more common on the ventral side. Its tubercles are small, widely separated dorsally but more crowded ventrally. Its lack of fascioles suggests that Asterostoma could not burrow. Probably, it lived in deeper, dark water. I know of no modern irregular echinoid that lives uncovered in the shallow lighted part of the sea.

Asterostoma probably fed by passing food particles to its mouth with its phyllodal tubefeet, which were present along the length of the ventral ambulacra. Many of these tubefeet, as suggested by the small size of the pores, were probably too short to extend to the mouth. In order to reach the mouth, the particles must have been passed from tubefoot to tubefoot.

Distribution.-Six Cuban species have been referred to Asterostoma, but only two are recognizable: A. excentricum Agassiz and $A$. subcircularis. $A$. dickersoni Sánchez Roig and $A$. irregularis Sánchez Roig occur at the same locality with $A$. excentricum 
and are herein considered synonyms.

The holotype of Asterostoma jimenoi Cotteau from the Eocene or Miocene of Cuba has been lost. This species has been made the type-species of Prosostoma Pomel but too little is known of it to determine its affinities. It appears to be similar to Antillaster. Cotteau's Asterostoma cubense is an Antillaster.

Comparison with Species outside of Cuba.Asterostoma is known only in Cuba and Jamaica. A. excentricum is present in Jamaica. A. paresoni, new species, from the Eocene of Jamaica is easily distinguished from the Cuban species.

REMARKs.-Mortensen (1950:33) originally placed Asterostoma in his suborder Protosternata because he was misled by Cotteau's erroneous illustration showing a lack of a labrum and plastron. Later Mortensen (1951:563) learned that the type-species, Asterostoma excentricum Agassiz, had a labrum and an amphisternous plastron. He then referred the genus to the Paleopneustidae and rejected the family Asterostomatidae. Fischer (1966:U614) resurrected the family and created a new suborder, Asterostomatina, as a polyphyletic assemblage of spatangoids that had lost their petals or had them slightly developed, had no fascioles, or only traces of them, and lacked differentiation of spines in some genera. He considered them derived from highly specialized ancestors. Chesher (1968:159) removed two of the genera, Paleopneustes and Plesiozonus, and placed them in the family Paleopneustidae.

Asterostoma is so distinct from all the other genera in Fischer's concept of Asterostomatidae that I believe it must be maintained in a separate family. It differs from the genera Chesher (1968:159) and Henderson (1975:53) included in the Palaeopneustidae in having 4 genital pores, no occluded plates at the ends of its petals, and a pair of plates following the first plate in interambulacrum 2. It differs from the Paleopneustidae and all the other genera that Fischer referred to the Asterostomatidae in having a less developed plastron, its ventral ambulacra in grooves, and in having no concentration of large phyllodal pores around its peristome. On first impression,
Asterostoma appears to have no phyllodes. However, they are much longer than typical in other spatangoids and their pores are smaller. Instead of consisting of a few larger pores concentrated around the peristome, the phyllodes in Asterostoma include almost all the ventral ambulacra extending from the peristome to the margin. Their pores are quite small but are larger than those in the ambulacral plates between the petals and the phyllodes. They have peripodia typical of a phyllodal pore in a spatangoid but they are smaller.

\section{Asterostoma excentricum L. Agassiz}

Figure 39; Plates 70-75; Plate 76: figure 1

Asterostoma excentricum L. Agassiz in Agassiz and Desor, 1847:168.—d'Orbigny, 1856:280, pls. 906-908.-Desor, 1858:196, pl. 37: figs. 1, 2._Cotteau, 1871:183.-Duncan, 1889:202.-Egozcue y Cía in Cotteau, 1897:65, pl. 20: figs. 1, 2._Jackson, 1922:67._Sánchez Roig, 1924a:31; 1926:91.-Arnold and Clark, 1927:46, pls. 7, 8.-Sánchez Roig 1949:178-180, pl. 29: fig. 1, pl. 30: fig. 1.-Mortensen, 1950:36, figs. 35a-c; 1951:563, fig. 285.-Fischer, 1966, fig. 502-1a-c.

Asterostoma dickersoni Sánchez Roig, 1949:180, pl. 31: fig. 1, pl. 32: fig. 1.

Asterostoma irregularis Sánchez Roig, 1952b:7, pls. 2, 3.

Material.- The type specimen was in the zoology collections of the Muséum National d'Histoire Naturelle in Paris, but Dr. Jean Roman (1981, personal correspondence) believes that it is probably lost. The following description is based on eight specimens in the USNM Collections and the dimensions are of specimen ANSP 16684 in the Academy of Natural Sciences in Philadelphia. All the specimens, except one, are badly weathered with most of the ornamentation removed. The ventral plate arrangement is clear (Figure 39) on specimen UCB-A8396.

Shape and Size. - Test very large, length (est.) $160 \mathrm{~mm}$, width $138 \mathrm{~mm}(87 \% \mathrm{~L})$, height (est.) 74 $\mathrm{mm}(46 \% \mathrm{~L})$; greatest width anterior of center, greatest height central, posterior to apical system.

Apical System.-Anterior, distance from center of genital pores to anterior margin $26 \% \mathrm{~L}$; ethmolytic with 4 genital pores (Plate 76: figure 1), genital plate 2 extending far posteriorly be- 


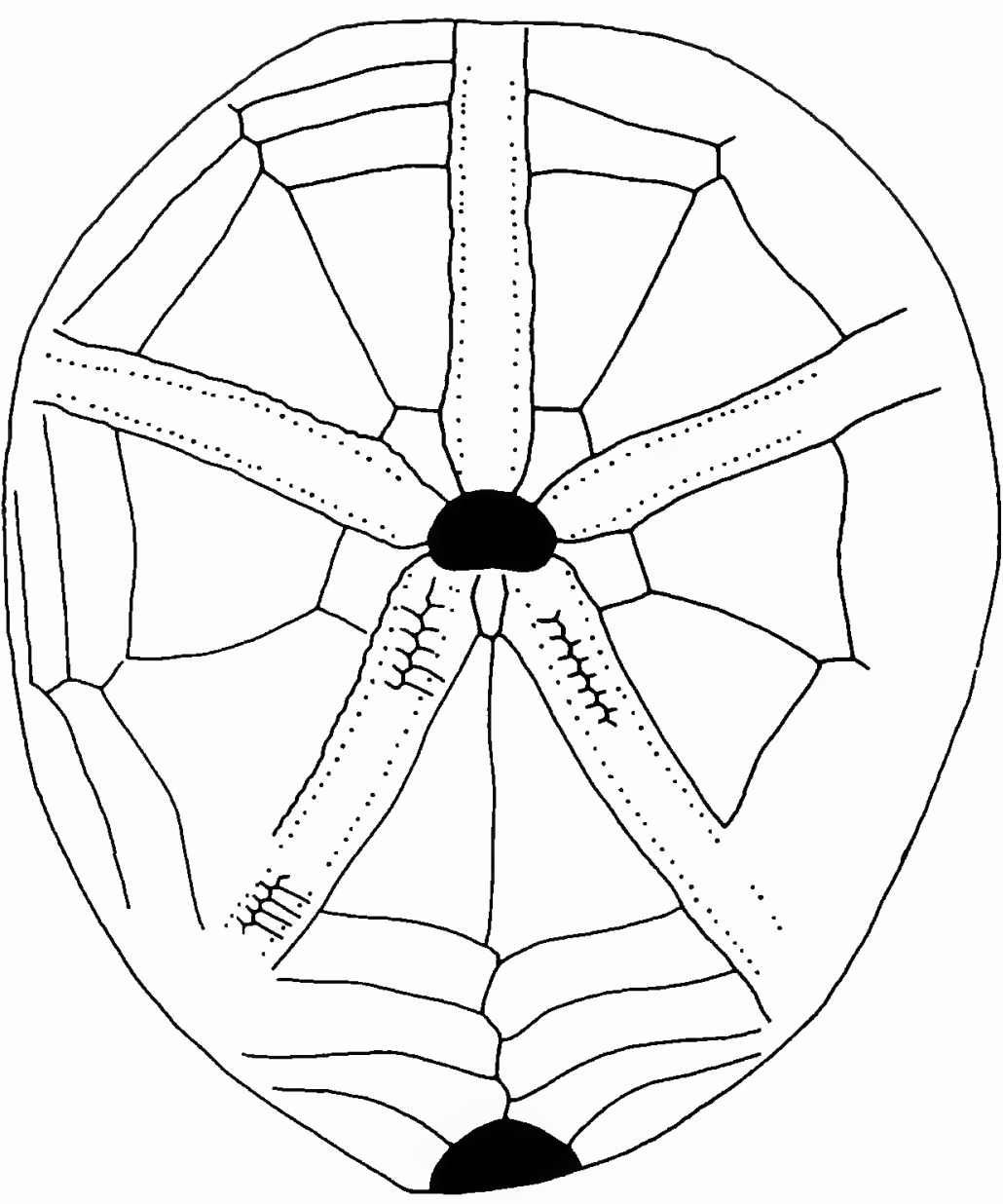

Figure 39.-Asterostoma excentricum Agassiz, ventral view of A8396, University of California, Berkeley, Museum of $\mathrm{Pa}$ leontology, $\times 0.6$.

tween posterior ocular plates.

AmbUlacra.-Anterior ambulacrum III not petaloid, flush with test from apical system to margin becoming depressed in groove on ventral side of test; adapically pores minute, pores paired for less than one-half distance from apical system to anterior margin, single for rest of length of ambulacrum to peristome.

Anterior petals (II and IV) very long, extending to margin, length $44 \% \mathrm{~L}$, greatest width at twothirds distance from apical system to end of petal, width $12 \% \mathrm{~L}$; greatest width of interporiferous zone $5.9 \%$ L. Porepairs with outer pore more elongate than inner; 112 porepairs in petal; first petaloid porepair in plate 43 (45 in specimen UCA8396). Petals very divergent, transverse flush with surface of test.

Posterior petals ( $\mathrm{V}$ and $\mathrm{I}$ ) very long, extending to margin, length $71 \% \mathrm{~L}$, greatest width $14 \% \mathrm{~L}$, open; interporiferous zone with greatest width $7.2 \% \mathrm{~L} ; 164$ porepairs in petal; first petaloid porepair in plate 40 (40 in specimen UC-A8396).

Ventrally, all ambulacra depressed in deep groove, which widens toward peristome, greatest depth $2.3 \%$ L. No occluded plates at end of petals. Ambulacral plates beyond petals at margin with minute single pores; pores increasing in size ventrally where each pore (Plate 72 : figure 4) has small neural canal on adoral side of pore surrounded by oblong peripodial area. These phyllodal pores extend from near margin to peristome becoming more widely separated from each other nearing peristome; 62 phyllodal pores in ambulacrum II, 22 smaller pores (probably for sensory tubefeet) between phyllode and end of petal; 56 phyllodal pores in I, 22 smaller; number in ambulacrum III not clear.

Peristome.-Central, distance from anterior edge of peristome to anterior margin of test $44 \%$ $\mathrm{L}$; width of opening $11 \% \mathrm{~L}$, height $6 \% \mathrm{~L}$; peristome with steep sides.

Periproct.-Inframarginal, opening very large, not preserved on specimen ANSP 16684 but present on specimen UC-A8396 (157 mm long) where height of opening is $11 \% \mathrm{~L}$ and width $12 \%$ L. Enclosed by interambulacral plates 5-8.

Fascioles.-None present. One specimen with tubercles well preserved where fascioles would have been preserved if originally present.

Tuberculation.-Tubercles very small, crenulate, and perforate; sparse dorsally where approximately 14 in 100 sq. $\mathrm{mm}$ area; tubercles on plastron no larger than on other interambulacra.

Oral Plate Arrangement.-Not clear on specimen ANSP 16684 but most sutures visible on specimen UC-A8396 (Figure 39). Labrum small, length $5.3 \% \mathrm{~L}$, extending back to second adjoining ambulacral plate. Next interambulacral plates paired, length $28 \% \mathrm{~L}$, combined width $30 \% \mathrm{~L}$; next interambulacral plate not distinguishable in width from succeeding plates.

Occurrence.-Eocene, Caraballo quarry, Loma Caoba, $5 \mathrm{~km}$ S of San Diego de los Baños, Pinar del Rio Province, Cuba. Eocene, hillsides above the Yallahs River, St. Thomas, in the Lucky Hill region in St. Mary and in the Spring Mount region, St. James, Jamaica.

Remarks.-Asterostoma irregularis Sánchez Roig 
and Asterostoma dickersoni Sánchez Roig occur at the same locality with $A$. excentricum. They all appear to be synonyms. The holotype of $A$. dickersoni (Plates 73, 74) is indistinguishable from $A$. excentricum in the length and width of its test, position of the apical system and peristome, length and arrangement of its petals, and position of its periproct. Although its test is lower than is common in A. excentricum, this difference probably falls within the range of variation of a species. Likewise, the holotype of $A$. irregularis (Plate 75) appears similar in all respects differing only in having a blunter anterior margin, an apparent result of postmortem distortion.

$A$. excentricum differs from $A$. subcircularis Sánchez Roig, also from the same locality, in having a more elongate, higher test with more anterior apical system. The first petaloid pores in ambulacrum II occur in plates 40-45 in $A$. excentricum, but in plate 35 in $A$. subcircularis, and in ambulacrum I in plate 40 as opposed to plate 36 in $A$. subcircularis. Finally the episternal plates are much lower in $A$. excentricum. In spite of these differences, these two species are very similar.

\section{SYNONYMS}

\section{Asterostoma dickersoni Sánchez Roig}

Plates 73, 74

Material.-One specimen, the holotype (SRC 4957), is moderately well preserved with undistorted test. The peristome is filled with hard matrix.

Shape And Size.-Length $165 \mathrm{~mm}$, width $86 \%$ L, height $35 \% \mathrm{~L}$; greatest width anterior to center, greatest height central. Posterior truncation slightly overhanging.

Apical System.-Anterior, located at distance from anterior margin to anterior edge of peristome equal to $31 \% \mathrm{~L}$. Ethmolytic with genital plate 2 separating posterior ocular plates, 4 genital pores.

Ambulacra.-Anterior ambulacrum III not petaloid, in very slight groove at margin, deeply depressed adorally like other ambulacra. Pores only slightly larger dorsally, changing from dou- ble to single pores above margin but exact position of change not clear; greatest width $13.4 \mathrm{~mm}$. Porepairs near center of plate, inner pore anterior and larger.

Anterior petals (II and IV) long, extending almost to margin, open, transverse, flush with rest of surface of test, length $52 \% \mathrm{~L}$, width $10 \% \mathrm{~L}$. Interporiferous area wide, width $6.1 \% \mathrm{~L}$, width of poriferous zone $3.0 \%$ L. Pores conjugate, outer pore more elongate than inner; 122 porepairs in petal; not possible to determine in which plate occurs first petaloid porepair.

Posterior petals (V and I) long, extending to margin, length $65 \% \mathrm{~L}$, width $11 \% \mathrm{~L}$; width of interporiferous zone $6.4 \% \mathrm{~L}$, poriferous zone $2.7 \%$ $\mathrm{L} ; 156$ porepairs in petal.

Peristome.-Anterior, distance from anterior margin to anterior edge of opening equal to $41 \%$ $\mathrm{L}$; no other details visible.

PERIPROCT.-Marginal to inframarginal, height of opening $9.7 \% \mathrm{~L}$, width $11 \% \mathrm{~L}$.

FASCIOLES.-None.

Occurrence.-Middle Eocene, Loma Caoba, San Diego de los Baños, Pinar del Rio Province, Cuba.

\section{Asterostoma irregularis Sánchez Roig}

\section{Plate 75}

Material.-One specimen, the holotype (SRC 4296), is moderately well preserved, although the test is fractured, the peristome is covered with matrix, and the apical system is missing. Test undistorted except for compression of anterior.

Shape And Size.-Length $140 \mathrm{~mm}$, width $91 \%$ $\mathrm{L}$, height $56 \% \mathrm{~L}$; greatest width anterior, greatest height central, posterior of apical system.

Apical System.-Anterior, located at distance from anterior margin to estimated location of center of genital pores equal to $27 \% \mathrm{~L}$.

Ambulacra.-Anterior ambulacrum III not petaloid, in very shallow groove dorsally, slight groove at margin, deep ventrally like other ambulacra. Pores double dorsally, single at margin and ventrally; position of change from double to single pore dorsal of margin but exact location not clear. Dorsally pore in each plate in anterior 
position of plate nearer medial suture; ventrally pore more posterior nearer outer suture.

Anterior petals (II and IV) transverse, open, flush with test, extending to margin, length $57 \%$ $\mathrm{L}$, greatest width $10 \% \mathrm{~L}$. Interporiferous zont approximately twice width of single poriferous zone, width $5.3 \% \mathrm{~L}$; width of poriferous zone $2.6 \% \mathrm{~L} ; \sim 110$ porepairs in petal; pores conjugate, outer pore of pair more elongate than inner. Not possible to determine in which plate the petaloid pores first occur.

Posterior petals (V and I) long, extending to margin, length $83 \% \mathrm{~L}$, width $12 \% \mathrm{~L}$, width of interporiferous zone $6.1 \% \mathrm{~L}$, width of poriferous zone $2.9 \%$ L. Petal with $158 \pm 3$ porepairs.

Peristome.-Anterior, distance from anterior margin to anterior edge of opening equal to $41 \%$ L.

Periproct.-Marginal to inframarginal, slightly visible from below; opening higher than wide, height $13 \% \mathrm{~L}$, width $10 \% \mathrm{~L}$.

FAscioles.-None.

Oral Plate Arrangement.-Plate sutures not clear.

Occurrence.-Middle Eocene, Caraballo quarry, Loma Caoba, San Diego de los Baños, Pinar del Rio Province, Cuba.

\section{Asterostoma pawsoni, new species}

Figure 40; Plate 78

Asterostoma excentricum. Arnold and Clark [part], 1927:46, 47 [not plates 7 or 8 which illustrate Asterostoma excentricum Agassiz].

Material.-Six specimens in the USNM Collections. Many of these specimens are very well preserved, having undistorted tests slightly weathered and showing details of tubercles and peripodia. The holotype is USNM 301378a; figured paratypes are USNM 301378b, 301378c.

Shape ANd Size. - Test of moderate size, length 87.5 to $71.3 \mathrm{~mm}$ (mean $80 \mathrm{~mm}$ ), width 82 to $73 \%$ L (S.D. 3.09, C.V. 5.08, N. 6), greatest width anterior to center; greatest height 59 to $50 \% \mathrm{~L}$ (S.D. 5.01, C.V. 11.27, N. 6), anterior at apical system or slightly posterior to apical system.
Apical System.-Anterior, distance from center of genital pores to anterior margin 32 to $28 \%$ L (S.D. 2.34, C.V. 9.76, N. 6); ethmolytic with 4 genital pores (Figure 40B), genital plate 2 extending far posteriorly between posterior ocular plates.

AmBUlaCra.-Anterior ambulacrum III not
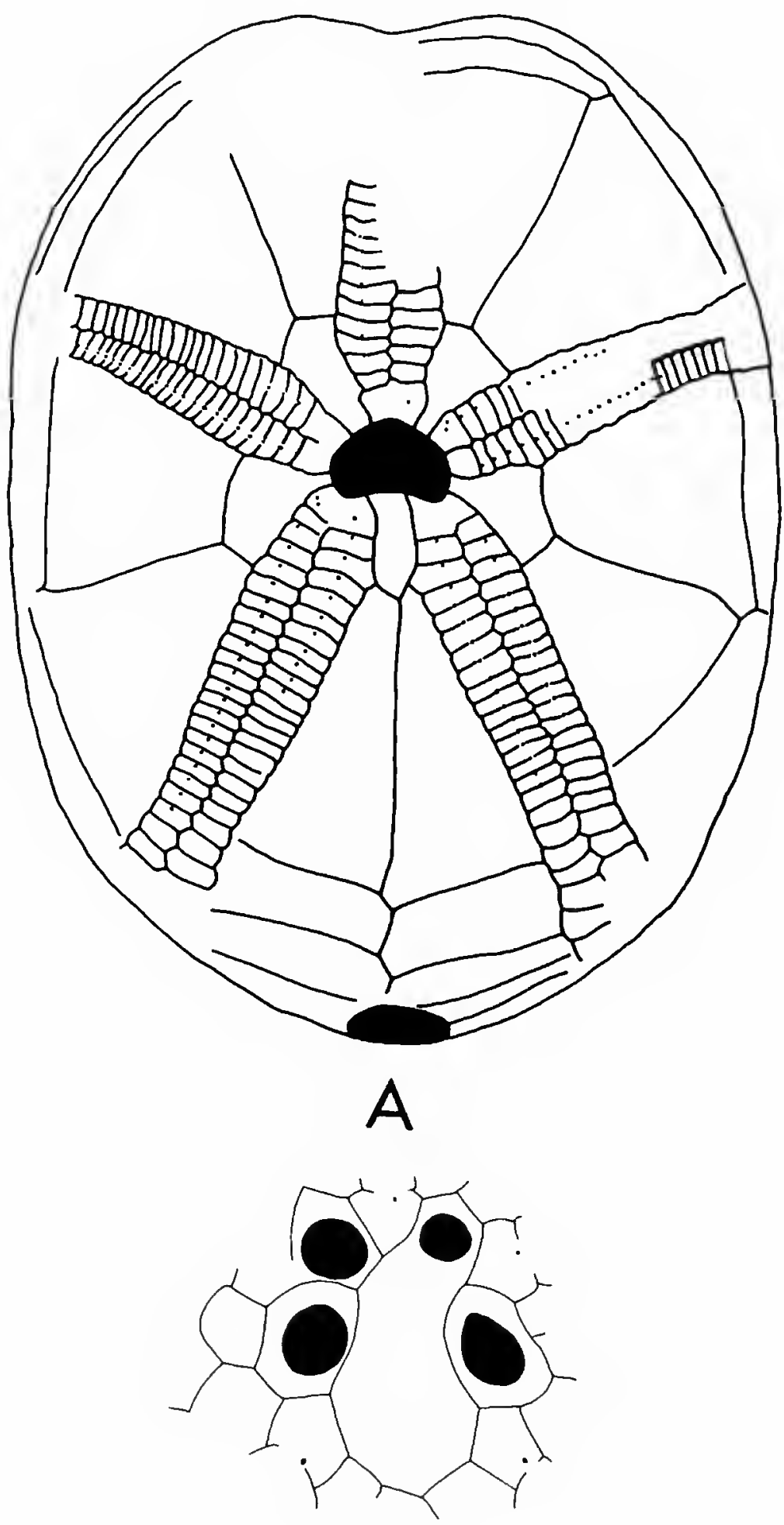

B

Figure 40.-Asterostoma palesoni, new specics: A, ventral view of the holotypc, USNM 301378a, $\times 1.5$; $\mathrm{B}$, apical view of paratype, USNM 301378b, $\times 8$. 
petaloid, flush with test adapically but becoming depressed in slight groove at margin; adapically porepairs minute, double pores extending to approximately one-half distance from apical system to margin with 32 porepairs in specimen $88 \mathrm{~mm}$ long, 74 single pores including phyllode, total of 106 plates.

Anterior petals (II and IV) long, flush, transverse, subtending arc of 180 degrees, extending two-thirds distance to margin, length 45 to $38 \%$ L (S.D. 4.34, C.V. 12.84, N. 6), greatest width 15 to $13 \%$ L (S.D. 0.96 , C.V. 8.53, N. 6), near end of petals; interporiferous zone wide, twice width of poriferous zone, width 6.5 to $5.1 \%$ L (S.D. 0.44, C.V. 9.30, N. 6); poriferous zone with greatest width 4.2 to $3.8 \%$ L (S.D. 0.35 , C.V 10.52. N. 6), zones narrowing distally; outer pore of pair more elongate than inner; in anterior poriferous zones outer pores oblique (Plate 78: figure 1); 74 petaloid porepairs in specimen $73 \mathrm{~mm}$ long, 86 in specimen $84 \mathrm{~mm}$ long, first petaloid porepair in plates 35-38.

Posterior petals ( $\mathrm{V}$ and I) very long, extending almost to margin, open, flush, length 70 to $61 \%$ L (S.D. 4.76, C.V. 8.95, N. 6), greatest width 18 to $15 \%$ L (S.D. 0.76, C.V. 6.06, N. 6), greatest width three-fourths distance from apical system to end of petal; interporiferous zone wide, twice width of poriferous zone, width 8.4 to $6.1 \% \mathrm{~L}$ (S.D. 0.35, C.V. 6.35, N. 6); poriferous zone with greatest width 4.6 to $3.9 \%$ L (S.D. 0.34 , C.V. 9.99, N. 6), zones narrowing distally; outer pore of pair more elongate than inner; 110 petaloid porepairs in specimen $73 \mathrm{~mm}$ long, 116 in specimen $84 \mathrm{~mm}$ long, first petaloid porepair in plates 30-34.

Ventrally, all ambulacra depressed in deep grooves, which widen towards peristome. No occluded plates at end of petals. Ambulacral plates beyond petals with minute single pores increasing in size in phyllode; phyllodes very long, extending almost to margin, widening gradually towards peristome but becoming more widely separated from each other nearing peristome (Plate 78: figure 6). Each phyllodal pore with neural canal on adoral side of pore, surrounded by oblong peripodial area (Plate 78: figure 5); 50 phyllodal pores in ambulacrum II, 42 in I, 32 in III; exact count difficult because of gradual transition from phyllodal pore to smaller pores between phyllode and end of petal.

Peristome.-Slightly anterior, distance from anterior edge of peristome to anterior margin of test 38 to $33 \%$ L (S.D. 3.37, C.V. 11.72, N. 6). Subpentagonal, width 14 to 9\% L (S.D. 0.90, C.V. 9.81, N. 6); height 7.9 to $6.3 \%$ L.

Periproct.-Inframarginal, visible from below, height greater than width, height 14 to $13 \%$ L (S.D. 0.43 , C.V. 3.87, N. 5), width 12 to $11 \%$ L (S.D. 0.51 , C.V 5.48, N. 4). Enclosed by interambulacral plates 4-8.

Fascioles.-None present. Some specimens so well preserved that their absence cannot be due to removal by weathering.

Tuberculation.-Tubercles very small, crenulate, perforate, sparce dorsally, slightly larger and more crowded ventrally. Tubercles on plastron not larger than on other interambulacra.

Oral Plate Arrangement.-Labrum long, narrow, length 11 to $7.5 \%$ L (S.D. 1.65 , C.V 22.65, N. 4) extending back to third adjacent ambulacral plate. Sternal plates in interambulacrum 5 not larger than corresponding plates in other interambulacra; height 32 to 29\% L (S.D. 1.05 , C.V. 4.28, N. 3). Episternal plates much lower with height 15 to $11 \%$ L (S.D. 1.32, C.V. 11.80, N. 4) not conspicuously higher than succeeding plates (Figure 40A). In interambulacrum 2 first plate followed by pair of plates.

Occurrence.-Eocene, hillsides above the Yallahs River, St. Thomas, in the Lucky Hill region in St. Mary, and in the Spring Mount region, St. James, Jamaica. Although Arnold and Clark (1927) did not know the age of these localities, they occur in the Eocene Yellow Limestone.

Remarks.-Arnold and Clark (1927:47) noted a gap in the size of specimens that they referred to Asterostoma excentricum Agassiz but saw no reason to group them into separate species. However, there are significant differences between the smaller and larger specimens and some of these differences are not size related. The larger specimens are obviously Asterostoma excentricum and are indistinguishable from Cuban specimens. A new species is erected here for the smaller specimens; 
it differs from $A$. excentricum in having a smaller, more elongate test, its first petaloid porepairs in ambulacrum II in plates $35-38$ versus $40-45$ in A. excentricum, and in plates $30-34$ in ambulacrum I versus 40 . This latter difference is significant because it is not age- or size-related. The first petaloid plate is introduced early in the growth of an echinoid, and, because new plates are added at the apical system, the number of plates between the end of the petal and the peristome remains constant throughout the life of the echinoid, regardless of its ultimate size. Furthermore, the labrum in $A$. pawsoni, new species, is longer with a length 11 to $7.5 \% \mathrm{~L}$ as compared to $5.3 \%$ $\mathrm{L}$ in $A$. excentricum; and it extends posteriorly to the third adjacent ambulacral plate instead of the second.

A. pawsoni, new species, differs from Asterostoma subcircularis Sánchez Roig from the Eocene of Cuba in its more elongate test and far higher sternal plates (compare Figures 40 and 41).

\section{Asterostoma subcircularis Sánchez Roig}

Figure 41; Plate 76: figures 2, 3; Plate 77

Asterostoma sub-circularis Sánchez Roig, 1952c:19, pl. 2: figs. 1, 2; pl. 11: fig. 1.

Material. - The holotype and only known specimen (SRC 4010) is moderately well preserved with the test only slightly distorted. The anterior appears to be slightly compressed.

Shape And Size.-Length 109 mm, width 90\% $\mathrm{L}$, height $55 \% \mathrm{~L}$; greatest width anterior of center, greatest height central, posterior to apical system. Dorsal surface highly inflated with steep sides; ventral surface slightly depressed.

Apical System.-Anterior, distance from apical system to anterior margin equal to $36 \% \mathrm{~L}$ but probably originally greater before postmortem distortion. Ethmolytic, with genital plate 2 extending posteriorly between posterior ocular plates (Figure 41A); 4 genital pores.

Ambulacra.-Anterior ambulacrum III not petaloid, in slight groove dorsally and at margin, deepening ventrally. Pores minute, not significantly larger in dorsal region. Greatest width of ambulacrum slightly above margin where width 9.6\% L. Pores paired only adapically becoming single high above margin; 140 plates in ambulacrum.

Anterior petals (II and IV) long, broad, open, only slightly depressed; extending almost to margin, curving distally anteriorly; length $53 \% \mathrm{~L}$, width $12 \% \mathrm{~L}$. Interporiferous zone at greatest
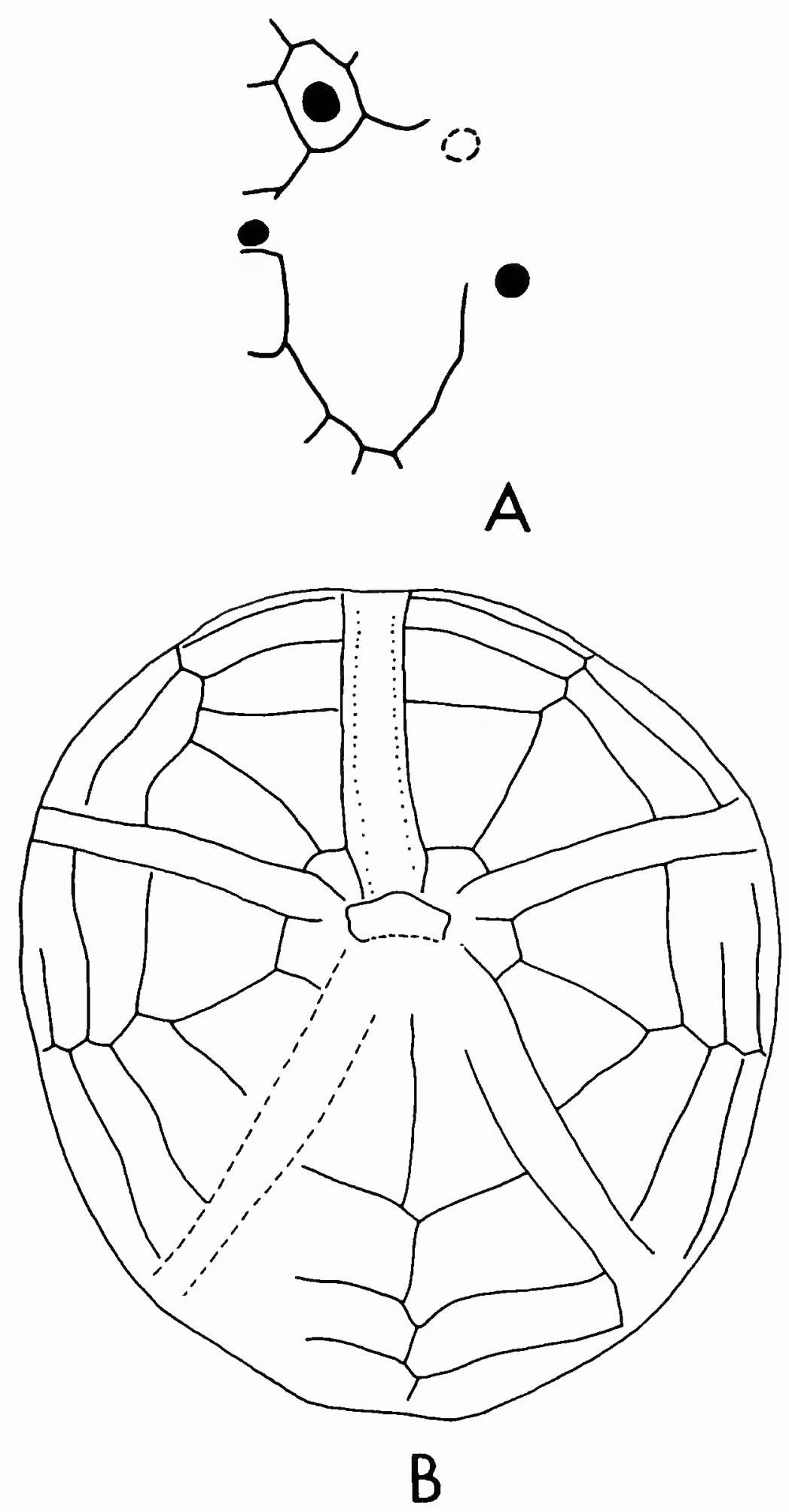

FigURE 41.-Asterostoma subcircularis Sánchez Roig, holotype, SRC 4010: A, apical system, $\times 6$; , ventral view, $\times 0.8$. 
width near midlength, width almost twice width of single poriferous zone, width $5.2 \% \mathrm{~L}$. Poriferous zone with greatest width $4.3 \mathrm{~L}$ outer pore more elongate than inner, conjugate; 98 porepairs in petal. No plates occluded at end of petal. First petaloid porepair in plate 35 .

Posterior petals ( $\mathrm{V}$ and I) long, extending almost to margin; length $72 \% \mathrm{~L}$, greatest width $15 \% \mathrm{~L}$. Interporiferous zones wide, greatest width $7.3 \% \mathrm{~L}$, greatest width of poriferous zone $4.5 \% \mathrm{~L}$; 130 porepairs in petal. No plate occluded at end of petal. First petaloid porepair in plate 36 .

Ventrally, all ambulacra depressed in deep grooves, which widen towards peristome except in ambulacra II and IV where distortion of test obscures widening. No occluded plates at end of petals. Ambulacral plates beyond petals at margin with minute single pores; pores increasing in size ventrally where each pore (where preserved) has small neural canal in adoral side of pore surrounded by oblong peripodial area. These phyllodal pores extend from near margin to peristome becoming more widely separated from each other nearing peristome; 60 phyllodal pores in ambulacrum II, 8 smaller pores (probably for sensory tubefeet) between phyllode and end of petal; 50 phyllodal pores in I, 20 smaller.

Peristome.-Anterior, located at distance from anterior edge of opening to anterior margin equal to $27 \% \mathrm{~L}$. Opening subpentagonal, wider than high, width $13 \% \mathrm{~L}$, height $5.8 \%$ L. Opening depressed with vertical sides.

Periproct.-Marginal, slightly visible from below, opening very large, higher than wide, height $12 \% \mathrm{~L}$, width $11 \% \mathrm{~L}$; located within interambulacral plates 5-10.

Fascioles.-None.

Tuberculation.-Test covered by small tubercles of approximately same size; more crowded on ventral side where evenly distributed.

Oral Plate Arrangement.-Length of labrum not clear; first 2 plates of plastron (Figure 41) with height estimated at $26 \% \mathrm{~L}$, combined width $26 \%$ L. Next pair of plates lower than first, greatest height $14 \% \mathrm{~L}$, but higher than next pair with greatest height $8 \% \mathrm{~L}$. First plate in paired interambulacra large, followed by 2 large paired plates.

Occurrence.-Middle Eocene, Loma Caoba, San Diego de los Baños, Pinar del Rio Province, Cuba.

Comparison with Other Species.-This species is very similar to Asterostoma excentricum Agassiz, which occurs with it. Its petals are indistinguishable and its periproct occurs within the same interambulacral plates. It differs in that its test is rounder and higher than $A$. excentricum and its apical system is more central. In $A$. excentricum the apical system is located at a distance from the anterior margin equal to $26 \% \mathrm{~L}$; whereas, in $A$. subcircularis it is $36 \% \mathrm{~L}$. Furthermore, the first petaloid pores in ambulacrum II occur in plates 40-45 in $A$. excentricum, but in plate 35 in $A$. subcircularis; in ambulacrum I in plate 40 (in 3 specimens where the count could be made) but plate 36 in $A$. subcircularis. Finally, the episternal plates in $A$. excentricum are much lower, $6 \% \mathrm{~L}$, than in $A$. subcircularis, $14 \% \mathrm{~L}$. These differences may fall within the range of variation within a species; but with so few specimens available, it is not possible to know. Therefore, it seems best to maintain $A$. subcircularis as a separate species.

\section{Genus Antillaster Lambert, 1909}

Test large, low to high; apical system ethmolytic with 3 or 4 genital pores; petals long, wide, open, flush with test, or very slightly depressed; anterior ambulacrum with small pores, in slight groove or flush with test; some plates occluded at ends of petals; peristome large; periproct large, inframarginal; tubercles small, no fascioles; plastron mesamphisternous with large labrum, narrow sternal plates, large episternal plates; in some species first plate in interambulacrum 1 followed by single plate.

Habitat.-These species of Antillaster probably lived on the top of the substrate. They lack the features normally found in burrowing spatangoids. No funnel building tubefeet were present in the anterior ambulacrum as indicated by their minute pores, which do not change in size mar- 
ginally, and by the fact that this ambulacrum is flush, not in a groove. Smith (1980:77) has shown that sensory tubefeet occur in this kind of ambulacrum. Likewise, no large pores are present in the anal region, indicating a lack of subanal tubefeet that could have maintained a sanitary drain if the echinoid lived in a burrow. Furthermore, no fascioles are present. Finally many of the species have very high tests, a character commonly associated with nonburrowing species.

No species of the genus are alive today, but Paleopneustes is very similar. Paleopneustes cristatus A. Agassiz has been seen alive from a submarine (Messing, 1981, personal communication) living on top of the substrate with its test not covered with sediment. Chesher (1968:134) suggests that the Recent Paleopneustes tholoformis Chesher could not burrow as indicated by its high test and the large number of live, unbroken specimens captured by surface trawls.

Species of Antillaster probably passed organic material and sediment into their mouths with their well-developed penicillate phyllodal tubefeet. The large peripodia in their phyllodes with pronounced ridges indicate the presence of these tubefeet. Specimens of the Recent Paleopneustes cristatus Agassiz tightly pack their intestines with bottom material (Lewis, 1963:362).

Antillaster presumably lived in fairly deep, tropical water. All living species of the Paleopneustidae occur in depths of 70-800 m (Henderson, 1975:53). Only two species live today north of the tropics in the northwestern Pacific. Henderson suggests that this distribution pattern results from the warming effect of the Kuroshia Current, which sweeps north from the tropics and sustains a warm-water fauna where the two species live.

Evolution.-The earliest Cuban species referred to Antillaster are A. arnoldi Clark from the Eocene and possibly Oligocene-Miocene and $A$. albeari, new species, from the middle or late Eocene. They have low, elongate tests with 4 genital pores and a normal plate arrangement in interambulacrum 1. Later species, such as $A$. fernandezi (Sánchez Roig), A. cubensis (Cotteau), and $A$. lamberti Jeannet from the late Oligocene or Miocene have much higher, wider tests, with only 3 genital pores and interambulacrum 1 with the first plate followed by a single plate. Probably the Recent species of Paleopneustes are descended from species like $A$. lamberti Jeannet. They share the high test, 3 genital pores, and second single plate in interambulacrum 1.

Comparison with Other Species outside Cuba.-The genus Antillaster is confined to the Caribbean and northeastern South America. It has never been found in North America. Antillaster lamberti Jeannet is found in the Miocene of Venezuela and the Oligocene-Miocene of Cuba. Antillaster arnoldi Clark is from the Eocene(?) of Jamaica and the Eocene or Oligocene-Miocene of Cuba. Antillaster bonairensis Pijpers from the late Eocene of Bonaire (Dutch West Indies) resembles most $A$. arnoldi Clark but differs in having a more anterior apical system, more pointed posterior margin, and higher test. Antillaster vaughani (Jackson) occurs in the Oligocene-Miocene of Antigua, Mexico, and Cuba.

One specimen of Antillaster is in the USNM Collections from the Miocene at Falcón, Venezuela. It resembles very much Antillaster lamberti Jeannet in its large, high test and wide petals but differs in having shorter, broader petals (Figure 42; Plate 87: figure 4).

As pointed out by Sánchez Roig (1926:97), Eupatagus elegans Jackson (1922:94) should be referred to Antillaster. This species, from the Miocene of Puerto Rico, lacks the fascioles typical of Eupatagus. Tuberculation on the holotype is extremely well preserved, but there are no signs of any fascioles. Furthermore, the tubercles are not larger within the area that would have been circumscribed by a peripetalous fasciole. Its petals are similar to those found in Antillaster, and it has the large labrum typical of that genus. Photographs of the holotype and a paratype of this species are on Plate 79.

Although Sánchez Roig (1949:182) reports $A$. elegans from the Oligocene of Cuba, I found no specimens in the Sánchez Roig Collection that I could be certain belonged to that species.

Remarks.-Sánchez Roig's Pseudoasterostoma is 


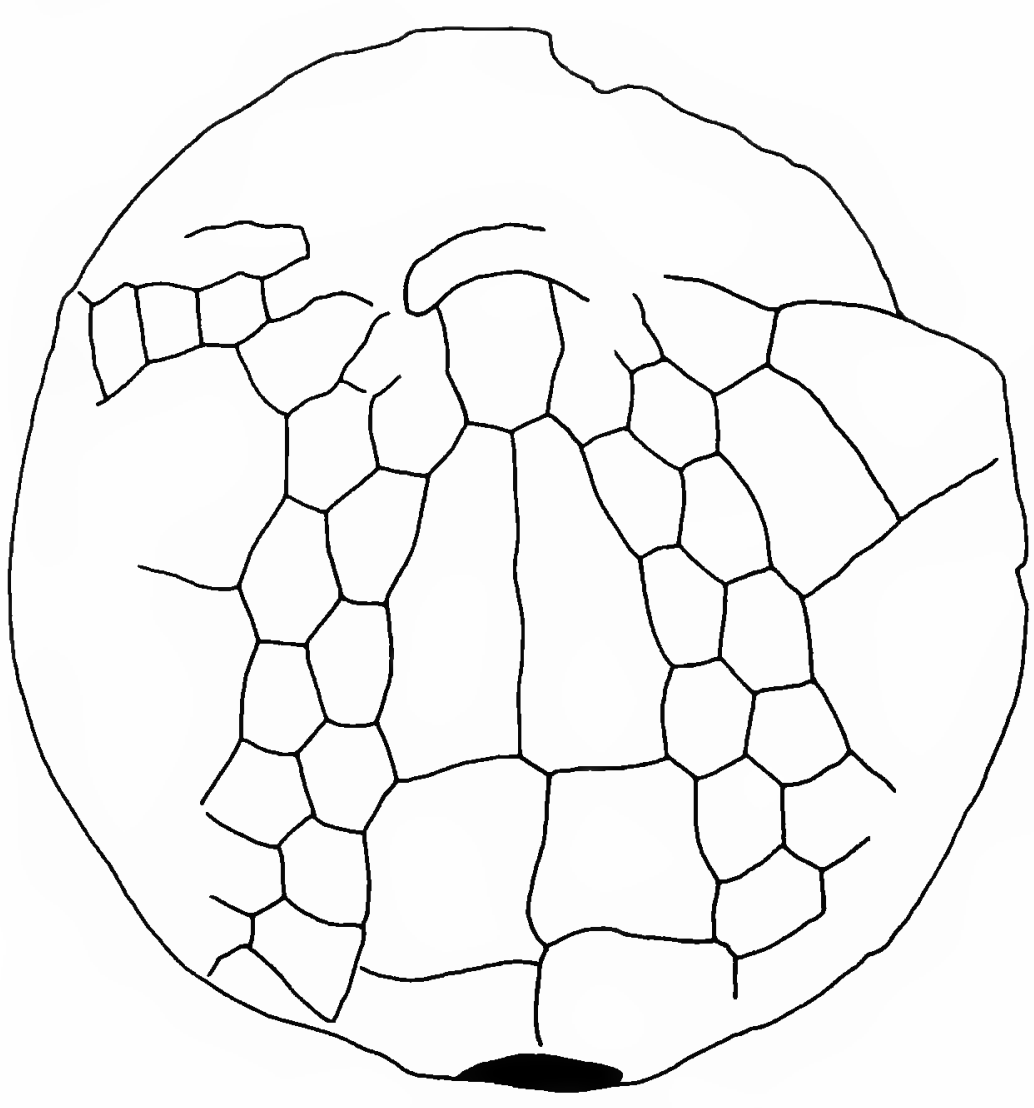

Figure 42.-Antillaster sp., ventral view of USNM 341261, Miocene, Falcón, Venezuela, $\times 0.75$.

an objective synonym of Antillaster. Both genera have the same type-species.

Henderson (1975:52) noted the similarity between Antillaster and Paleopneustes and considered Antillaster to be a subgenus of Paleopneustes. He noted that they differ only in that the pores of a porepair in Antillaster are dissimilar with the outer pore much more elongate than the inner. Although the genera are very similar, this difference is very strongly developed in the type-species of Antillaster and seems to warrant generic differentiation.

The species that have been referred to Antillaster fall into two groups. One group includes all those species having a large, very high, steeply sided test, with a flat ventral surface and very wide petals. This group includes the type-species $A$. cubensis (Cotteau), A. lamberti Jeannet, $A$. bonairensis Pijpers, and $A$. fernandezi Sánchez Roig. The apical system and oral plate arrangement are not known in $A$. cubensis and $A$. bonairensis; but in $A$. lamberti and $A$. fernandezi, only 3 genital pores are present and the first plate in interambulacrum 1 is followed by a single plate.

The second group includes all those species with generally lower tests, often more elongate, with more rounded ventral surfaces and narrower petals. This group includes $A$. vaughani (Jackson), $A$. sanchezi Lambert, $A$. arnoldi Clark, $A$. estenozi Sánchez Roig, and $A$. albeari, new species. In three of these species, $A$. vaughani, $A$. albeari, and $A$. arnoldi, the apical system is preserved; there are four genital pores. In two species, the oral plates are known and the first plate of interambulacrum $l$ is followed by a pair of plates.

I do not separate these two groups as subgenera because of the existence of some transitional species, such as $A$. bonairensis, which could be placed in either group. Furthermore, it is not known whether all the species in the second group have four genital pores and the normal plate arrangement in interambulacrum 1 of a pair of plates following the first plate.

Apparently, in Antillaster some plates are always occluded at the ends of the petals. This occlusion occurs in all species in which the plate sutures are visible, including $A$. arnoldi Clark, $A$. vaughani (Jackson), A. lamberti Jeannet, $A$. fernandezi Sánchez Roig, and $A$. sanchezi Lambert.

Although genera of the Paleopneustidae are supposed to have double pores in their phyllodes (Chesher, 1968:159; Henderson, 1975:51), the pores are single in all the species of Antillaster in which the specimens are well-enough preserved to permit determination (see $A$. lamberti, p. 138).

Seventeen species have been described from Cuba, but only six are recognizable. Many of these 17 species appears to be synonyms. $A$. $d e$ pressus Sánchez Roig, A. expansus Sánchez Roig, $A$. guevarai Sánchez Roig, and $A$. herrerae Sánchez Roig are considered synonyms of $A$. vaughani Jackson. The Cuban species are from the OligoceneMiocene of Camagüey and are all very similar in appearance.

A. habanensis (Sánchez Roig) is considered herein to be a synonym of $A$. lamberti Jeannet from Venezuela. Likewise, $A$. jaumei Sánchez Roig and $A$. fernandez Sánchez Roig are too similar to be specifically separated. $A$. arnoldi Clark from 
TABLE 6.-Disposition herein of Cuban species of Antillaster

\begin{tabular}{|c|c|c|c|c|}
\hline Disposition & Miocene & $\begin{array}{l}\text { Oligocene- } \\
\text { Miocene }\end{array}$ & $\begin{array}{l}\text { Eocene- } \\
\text { Miocene }\end{array}$ & Eocene \\
\hline $\begin{array}{l}\text { Recognized species } \\
\text { (Synonyms) }\end{array}$ & $\begin{array}{l}\text { A. cubensis } \\
\text { A. sanchezi } \\
\quad \text { (A. flexuosus) }\end{array}$ & $\begin{array}{l}\text { A. fernandezi } \\
\quad \text { A. jaumei }) \\
\text { A. lamberti } \\
\quad \text { (A. habanensis) } \\
\text { A. vaughani } \\
\quad \text { (A. depressus) } \\
\quad \text { (A. expansus) } \\
\text { (A. guevarai) } \\
\text { (A. herrerae) }\end{array}$ & $\begin{array}{l}\text { A. arnoldi } \\
\quad(\text { A. rojasi })\end{array}$ & A. albeari ${ }^{2}$ \\
\hline $\begin{array}{l}\text { Unrecognizable } \\
\text { species }\end{array}$ & A. estenozi & $\begin{array}{l}\text { A. cartagensis } \\
\text { A. giganteus }\end{array}$ & & \\
\hline $\begin{array}{l}\text { Referred to other } \\
\text { genera }\end{array}$ & & $\begin{array}{l}\text { A. brachypetalus } \\
\text { [to? Macropneustes] } \\
\text { A. mortenseni } \\
\text { [to Pericosmus] }\end{array}$ & & \\
\hline
\end{tabular}

Jamaica and $A$. rojasi Sánchez Roig are indistinguishable, as are $A$. flexuosus Sánchez Roig and $A$. sanchezi Lambert whose type specimens are from the same locality.

Three species, A. estenozi Sánchez Roig, A. cartagensis Sánchez Roig, and $A$. giganteus were very poorly illustrated and their types are lost. No suggestion can be made of their relationships with the other species. A. mortenseni Sánchez Roig has fascioles and is referred to Pericosmus, and $A$. brachypetalus Sánchez Roig is probably a Macropneustes. These assignments are summarized in Table 6 , and the recognizable species are keyed below. One new species is described.

\section{Key to Cuban Species of Antillaster}

1. Test high, 3 genital pores, broad petals $\ldots \ldots \ldots \ldots \ldots \ldots \ldots$

Test low, 4 genital pores, petals narrow to broad .............. 4

2. Interporiferous zones of petals narrow, equal in width to single poriferous zone ............. fernandezi (Sánchez Roig), new combination

Interporiferous zones wide, twice width of single poriferous zone ..... 3

3. Petals extenaing to margin .................. cubensis (Cotteau)

Petals shorter, not reaching margin ............ A. lamberti Jeannet

4. Test elongate, petals broad $\ldots \ldots \ldots \ldots \ldots \ldots \ldots \ldots \ldots$

Test wide, petals narrow $\ldots \ldots \ldots \ldots \ldots \ldots \ldots \ldots$

5. Poriferous zones flush $\ldots \ldots \ldots \ldots \ldots \ldots \ldots \ldots \ldots$. arnoldi Clark

Poriferous zones depressed $\ldots \ldots \ldots \ldots \ldots \ldots$. . albeari, new species

6. Apical system anterior, anterior petals very divergent, almost 180 degrees ............... A. vaughani (Jackson), new combination

Apical system central, anterior petals not transverse

A. sanchezi Lambert 


\section{Antillaster albeari, new species}

Plates 80,81

Diagnosis.- Species characterized by large, wide, low test with depressed poriferous zones and slightly inflated interambulacra.

Material.-One very well-preserved specimen with no distortion in shape of test. Plate sutures not visible. Specimen ANSP 16631, Academy of Natural Sciences of Philadelphia.

Shape And Size.-Length $137 \mathrm{~mm}$, width $88 \%$ L, greatest width anterior; height $47 \% \mathrm{~L}$, with greatest height posterior to center. Anterior notch well developed; margin smoothly rounded; ventral side not flat with peristome slightly depressed.

Apical System.-Anterior, located at distance from anterior margin to center of genital pores equal to $30 \%$ L. Ethmolytic, with genital plate 2 extending posteriorly separating posterior ocular plates, 4 genital pores.

Ambulacra.-Anterior ambulacrum III not petaloid, in groove extending from apical system and deepening to peristome; depth of notch at margin 2.2\% L. Pores not enlarged dorsally, no large peripodia, presumably dorsal tubefeet were sensory.

Anterior petals (II and IV) long, extending to margin, curving very slightly anteriorly; length $49 \% \mathrm{~L}$, width $11 \% \mathrm{~L}$; very divergent, subtending an angle of nearly 180 degrees; posterior poriferous zones curving more anteriorly at end of petal than anterior poriferous zones. Interporiferous zones very wide, at greatest width nearly 3 times width of single poriferous zone, width $6.7 \% \mathrm{~L}$. Poriferous zones depressed below general surface level of test, greatest width $2.8 \% \mathrm{~L}$; pores strongly conjugate with deep furrow joining pores, with inner pore of pair slightly elongated transversely, outer pore greatly elongated; 134 porepairs in petal. Not possible to determine number of plate bearing first petaloid porepair.

Posterior petals ( $\mathrm{V}$ and $\mathrm{I}$ ) very long, extending to margin, straight, length $61 \% \mathrm{~L}$, width $12 \% \mathrm{~L}$. Interporiferous zones more than twice width of poriferous, narrowing slightly distally, greatest width $6.7 \%$ L. Poriferous zones with width $3.1 \%$ L; 158 porepairs in petal.
Plate sutures not clear; hence presence or absence of occluded plates at ends of petals not known. Pores beyond petals single.

Peristome.-Anterior, located at distance from anterior margin to anterior edge of peristome equal to $30 \% \mathrm{~L}$. Opening large, width $15 \% \mathrm{~L}$, height $4.5 \% \mathrm{~L}$, labiate. Phyllodes well developed, pores single, 12 pores in ambulacrum III, 20 in II, $10-11$ in I.

Perlproct.-Opening on very slightly overhanging truncation, not visible from above or below; higher than wide, height $13 \% \mathrm{~L}$, width $9.9 \%$ L.

FASCIOLES.-None.

Oral Plate Arrangement.-Plate sutures not visible.

Occurrence.-Middle to late Eocene, Palmer loc. 1003, $\mathrm{N}$ of Carretera Central, 2.1-2.2 mi (3.5 $\mathrm{km}$ ), on road to San Diego de los Baños, Pinar del Rio Province, Cuba.

Comparison with Other Species. - This species resembles most Antillaster arnoldi Clark from the Eocene? of Jamaica and possibly OligoceneMiocene of Cuba. It differs in having a wider test with depressed poriferous zones and inflated interambulacral areas. In $A$. arnoldi the petals are flush with the general surface of the test and the interambulacra are not inflated.

Antillaster albeari also resembles $A$. bonairensis Pijpers from the late Eocene of Bonaire. The Cuban species differs in having a lower, wider test with a more vertically truncated posterior margin and petals with depressed poriferous zones.

\section{Antillaster arnoldi Clark}

Figure 43; Plate 82

Antillaster arnoldi Clark in Arnold and Clark, 1927:62, pl. 15: fig. 3, pls. 16, 17.—Sánchez Roig, 1949:186.

Antillaster rojasi Sánchez Roig, 1951:50, pl. 37: fig. 1, pl. 38 : fig. 2.

The holotype of $A$. rojasi is virtually indistinguishable specifically from the holotype of $A$. arnoldi from Jamaica. Sanchez Roig noted the similarity between the two species but separated 
them on the basis of the lower test and shorter and less distinct petals in $A$. rojasi. The test is lower, but this difference probably falls within the range of variation expected within a species. I do not see any difference between the species in the length of the petals or their distinctness.

Occurrence.-Eocene, near Spring Mount, W of Springfield road, St. James Parish, Jamaica. Oligocene-Miocene, holotype of $A$. rojasi Sánchez Roig, "La Venturilla" farm, Realengo, Charco Hondo, Morón, Camagüey Province, Cuba. Sánchez Roig (1949:187) reports a specimen of $A$. arnoldi from the late Oligocene from "Santa Ana" farm, Majagua district, Ciego de Avila, Camagüey Province, Cuba. I have not seen this specimen.

\section{SYNONYM}

\section{Antillaster rojasi Sánchez Roig}

Figure 43; Plate 82

Material.-One specimen, the holotype (SRC 4133 ), is very badly weathered and much of the test is broken away.

Shape And Size.-Length $110 \mathrm{~mm}$, width $79 \%$ $\mathrm{L}$, height $51 \% \mathrm{~L}$; greatest width anterior, greatest height central, posterior to apical system.

Apical System.-Four genital pores, ethmolytic, anterior of center at distance from anterior margin to center of genital pores equal to $29 \% \mathrm{~L}$.

Ambulacra.-Anterior ambulacrum III not petaloid, in slight groove; nature of adapical pores obscured by weathering and fracturing of test.

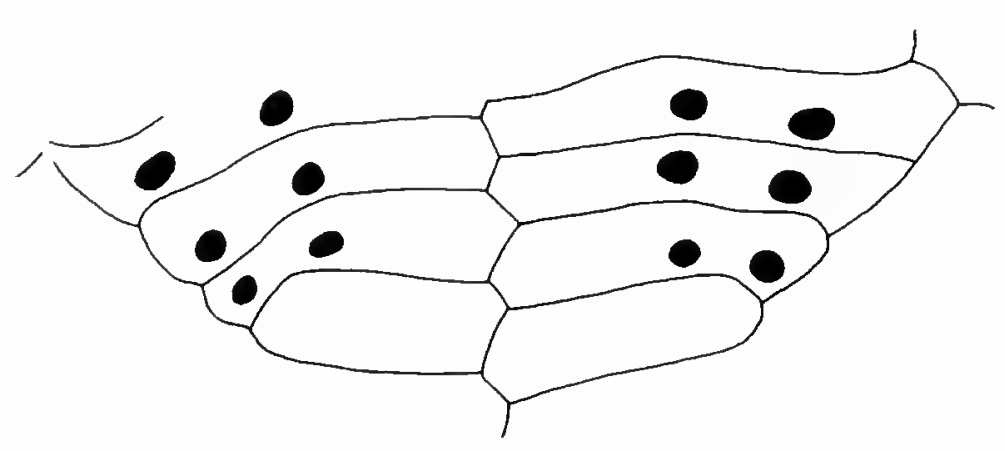

Figure 43.-Antzllaster arnoldi Clark, end of petal I showing occluded plates in the holotype of Antillaster rojasi Sánchez Roig (= A. arnoldi), SRC 4133, × 4.5.
Anterior petals (II and IV) extending to margin, length $49 \% \mathrm{~L}$, greatest width near end of petal $14 \% \mathrm{~L}$. Petals straight to very slightly curving anteriorly, flush with test; open, with interporiferous zone increasing in width distally with greatest width $6.0 \%$ L. Poriferous zone with greatest width two-thirds distance from apical system to end of petal where width $4.8 \% \mathrm{~L}$; pores conjugate, outer pore elongate than inner; 98 petaloid porepairs. Test too weathered and fractured to permit determination of presence or absence of occluded plates.

Posterior petals (V and I) very long, extending to margin, length $64 \% \mathrm{~L}$, width (est.) $14 \% \mathrm{~L}$ with greatest width near end of petal. Petals straight, flush, open with interporiferous zone increasing in width distally with greatest width $4.9 \% \mathrm{~L}$. Poriferous zone with greatest width two-thirds distance from apical system to end of petal where width $4.7 \% \mathrm{~L}$, zone narrowing sharply at end of petal; 134 petaloid porepairs. Last $3 \frac{1}{1 / 2}$ plates in single poriferous zone of petal occluded (Figure 43 ), enclosed by first ambulacral plate beyond petal.

Peristome.-Anterior, distance from anterior margin to anterior edge of peristome $26 \% \mathrm{~L}$; opening deeply depressed, wider than high, width $13 \% \mathrm{~L}$, height $5.4 \% \mathrm{~L}$; lip large, pointed.

Periproct.-Posterior region broken away.

Fascioles.-None visible but test so badly weathered that they would not have been preserved had they been present originally.

Oral Plate Arrangement.-Sutures of labrum and plastron not clear. In interambulacrum 1 first plate followed by pair of plates.

Occurrence.-Oligocene-Miocene, "La Venturilla" farm, Realengo Charco Hondo, Morón, Camagüey Province, Cuba.

\section{Antillaster cubensis (Cotteau)}

Asterostoma cubensis Cotteau, 1870:272; 1871:181, pl. 16: figs. 2-4, pl. 17: figs. 2-4; 1875:6, 46; 1881:27; 1897:67, pl. 21:

figs. 1, 2.-Jackson, 1922:67._Sánchez Roig, 1924a:32. Antillaster cubensis (Cotteau).-Lambert in Lambert and Thiéry, 1924 [1909-1925]:440.-Lambert in Sánchez Roig, 1924a:43; 1926:92; 1949:185.-Mortensen, 1950, fig. 180.-Fischer, 1966, figs. 503, 504-4a, b. 
Archaeopneustes cubensis (Cotteau).-Gregory, 1892:167.

Pseudoasterostoma cubensis (Cotteau)._Sánchez Roig, 1952b:5, pl. 1: fig. 1.

The holotype of this species is no longer in the Cotteau Collection.

Occurrence.-Miocene, Matanza; "Cervantes" farm, San José de las Lajas, Habana Province, Cuba. I have studied the two specimens Cotteau (1875:46) reported from the Eocene of St. Bartholomew, but they cannot be referred with any certainty to this species or even to Antillaster. They are small fragments too badly weathered for identification.

\section{Antillaster fernandezi (Sánchez Roig), new combination}

Plate 83

Pseudoasterostoma fernandezi Sánchez Roig, 1952b:6, pl. 6: fig. 1.

Antillaster jaumei Sánchez Roig, 1953a:64, pl. 15: fig. 2.

Material.-Only one specimen in collection, the holotype (SRC 4107). This specimen lacks its left side and posterior, most of its peristome, and oral surface. It is compressed and has been cut in two.

Shape AND Size.-Test $105 \mathrm{~mm}$ long, width (est.) $90-95 \mathrm{~mm}(86-91 \% \mathrm{~L})$, height $60-65 \mathrm{~mm}$ $(57-62 \% \mathrm{~L})$; greatest height posterior to center. Oral surface flat.

Apical System.-Anterior of center, at distance from anterior margin to center of genital pores $32 \%$ L. Ethmolytic with narrow genital plate 2; 3 genital pores, no pore visible in genital plate 2 .

AmbulaCra.-Anterior ambulacrum III not petaloid, in very slight groove. Pores very small except in phyllodes where in peripodia. Width of ambulacrum midway between apical system and margin $10 \% \mathrm{~L}$.

Anterior petals (II and IV) extending one-third distance from apical system to margin, length $50 \% \mathrm{~L}$, greatest width $13 \% \mathrm{~L}$. Petals straight, flush with test except for very shallow, narrow groove along middle of interporiferous zone; interporiferous zone at greatest width approxi- mately same width as single poriferous zone, greatest width $3.0 \%$ L. Pores slightly conjugate with outer pore more elongate transversely than inner. Petal with 84 porepairs. Last 1/1/2 plates in single poriferous zone of petal occluded, enclosed by first ambulacral plate beyond petal.

Posterior petals ( $\mathrm{V}$ and $\mathrm{I}$ ) extending one-third distance from apical system to margin, length $58 \% \mathrm{~L}$, greatest width $12 \% \mathrm{~L}$; petals straight; 92 porepairs.

Peristome.-Anterior, distance from anterior margin to anterior edge of peristome estimated at $22 \% \mathrm{~L}$; no other features of peristome visible.

Periproct.-Not preserved.

FASCIOLES.-None.

Oral Plate Arrangement.-Most of oral surface absent.

Occurrence.-Oligocene-Miocene, well in San Pedro, Habana Province, Cuba. The holotype of Antillaster jaumei Sánchez Roig is from the early Miocene, Somorrostro quarries, Habana, Habana Province, Cuba.

Comparison with Other Species.-This species is easily distinguished from Antillaster lamberti Jeannet also from the late Oligocene-Miocene of Cuba (and Eocene? of Jamaica) by its much narrower petals with narrower interporiferous zones. The interporiferous zones in A. fernandezi are equal in width to a single poriferous zone; whereas in $A$. lamberti, they are twice the width of a poriferous zone.

ReMarks.-I can see no significant difference between the holotypes of $A$. fernandezi and $A$. jaumei (Sánchez Roig). Both are large, high specimens with broad petals of similar shape and length; both have only 3 genital pores.

\section{SYNONYM}

\section{Antillaster jaumei Sánchez Roig \\ Plate 83: figures 3-5}

MATERIAL.-There are only 2 specimens in the Sánchez Roig Collection, the holotype, and a second specimen that is crushed, not topotypic, and not used in this description. The holotype (SRC 4505) is badly weathered with little more 
than one-half of the specimen preserved. The adoral surface is missing and the test is distorted, with the right anterior region depressed.

ShaPe and Size.-Test estimated to be 110 mm long with width $100 \% \mathrm{~L}$, height $64 \% \mathrm{~L}$.

Apical System.-Position probably slightly anterior of center, at distance from anterior margin to center of genital pores $41 \% \mathrm{~L}$ (est.). Three genital pores, no pore in genital plate 2 , ethmolytic with genital plate 2 extending far posteriorly (Plate 83: figure 4) separating posterior ocular plates.

Ambulacra.-Anterior ambulacrum III not petaloid, in very slight groove. Dorsal region with double pores appears to be very short, less than $15 \mathrm{~mm}$ long, but test too weathered to be certain; near apical system porepairs near anterior edge of each plate. Greatest width of ambulacrum 12 $\mathrm{mm}$.

Petals flush with surface of test, long, extending to margin (as viewed from above), wide and open distally with interporiferous zones equal to width of single poriferous zone; pores slightly conjugate, outer pore slightly more elongate than inner.

Anterior petals (II and IV) straight to slightly curving anteriorly, length $56 \% \mathrm{~L}$, width $10 \% \mathrm{~L}$, with 96 porepairs. Length of posterior petal unknown.

Peristome.-Not preserved.

Periproct.-Not preserved.

Fascioles.-None visible.

Oral Plate Arrangement.-Not preserved.

Occurrence.-Early Miocene, Somorrostro quarries, Habana, Habana Province, Cuba.

\section{Antillaster lamberti Jeannet}

Figure 44; Plates 88, 89; Plate 90: figure 1

Antillaster lamberti Jeannet, 1928:36, pl. 4: figs. 14, 15.Cooke, 1961:24, pl. 11: figs. 1, 2.-Henderson, 1975:52, fig. $11 \mathrm{f}$.

Pseudoasterostoma habanensis Sánchez Roig, 1952b:6, pl. 5: fig. 1 .

I have studied 4 specimens of this species from the late Miocene of Venezuela and have found no features that distinguish it from the holotype of Antillaster habanensis (Sánchez Roig) from Cuba.
Although the poriferous zones in the holotype of $A$. lamberti appear to be narrower than in the holotype of $A$. habanensis, this is probably only because the holotype of $A$. lambert $i$ is more weathered. One of the specimens referred to $A$. lamberti by Cooke (1961:24), whose petals are well preserved, has poriferous zones as wide as in the holotype of $A$. habanensis (compare Plate 89: figure 1 to Plate 90: figure 1). Cooke's specimens came from rocks of the same age and region in Venezuela as the holotype of $A$. lamberti and are conspecific with it.

Henderson (1975:52, fig. 11f) observed that interambulacrum 1 in $A$. lamberti has its first plate followed by a single, unpaired plate. A similar plate arrangement is evident in one of the USNM specimens (USNM 362351) of this species, but a second specimen (USNM 638639) has two plates following the first.

Although the presence of double pores in the phyllode is considered a family character of the Paleopneustidae, the phyllodal pores in $A$. lamberti are definitely single. Cooke's figured specimen (USNM 638639) of this species has its phyllodes well preserved. The peripodia are very well developed with a single pore occurring in the adoral portion of each peripodia.

A strongly sculptured ridge occupies a large part of the peripodia. The shape of this ridge is difficult to describe in words but is well illustrated on Plate 87: figure 4 in a specimen of Antillaster sp. from the Miocene of Venezuela.

Occurrence.-Miocene, La Vela beds, which according to Cooke (1961:24) and Eames and Savage (1975:363) are late Miocene. Sabanas Altas, Falcón (type, fide Jeannet), Venezuela. La Vigía, $10 \mathrm{~km}$ SW of Pueblo Nuevo, Paraguaná district, Falcón (Creole Petroleum Co. 7824), Venezuela. Cerro La Luz near Quebrada Larga, $3 \mathrm{~km} \mathrm{~W}$ of Pueblo Nuevo (Mene Grande Petroleum Co. B-6295), Venezuela. Oligocene-Miocene, holotype of $A$. habanensis, on margin of deep cut along hill approximately $1 \mathrm{mi}(1.6 \mathrm{~km}) \mathrm{E}$ of Casa Blanca, Habana Province, Cuba.

Comparison with Other Species.-This species is very similar to Antillaster fernandezi Sánchez Roig and $A$. jaumei Sánchez Roig from Cuba in 
having 3 genital pores and a large, very high test. It differs in having much wider interporiferous zones.

\section{SYNONYM}

\section{Antillaster habanensis (Sánchez Roig)}

Figure 44; Plates 88, 89

Material.-Only one specimen, the holotype (SRC 4114), is known. This specimen is badly distorted by compression along the anteroposterior axis causing the apical system and the apical portions of the anterior petals to be pushed under the apical portions of the posterior petals. Furthermore, the area around the peristome is absent.

Shape and Size.-Test estimated to have been approximately $120 \mathrm{~mm}$ long, width $108 \mathrm{~mm}(90 \%$ L) (est.); height $80 \mathrm{~mm}(67 \%$ L). Oral surface flat.

Apical System.-Absent, probably slightly anterior of center.

AMBULACRA.-Anterior ambulacrum III not petaloid; in very slight groove. Pores very small throughout dorsal portion of ambulacrum; pores paired, arranged parallel to length of ambulacrum; 48 plates. Width of ambulacrum midway between apical system to peristome $13 \% \mathrm{~L}$.

Anterior petals (II and IV) extending fourfifths distance from apical system to margin; length $56 \% \mathrm{~L}$; greatest width $16 \% \mathrm{~L}$. Petals curving anteriorly, flush with test except for very slight groove running down middle of interporiferous zone; interporiferous zone at greatest width almost twice width of single poriferous zone, greatest width $6.1 \% \mathrm{~L}$. Pores conjugate with outer pore greatly elongated transversely, almost slit-like. Last $1 \frac{1}{2}$ plates in single poriferous zone of petal occluded, enclosed by first ambulacral plate beyond petal.

Posterior petals ( $\mathrm{V}$ and I) extending almost four-fifths distance from apical system to margin; length $59 \% \mathrm{~L}$; greatest width $17 \% \mathrm{~L}$; petals straight. Interporiferous zone at greatest width almost twice width of single poriferous zone, greatest width $7.0 \% \mathrm{~L}$; 102 porepairs in petal. Last $2 \frac{1}{2}$ plates in single poriferous zone of petal occluded (Figure 44B), enclosed by first ambulacral plate beyond petal.

Peristome.-Absent.

PERIPROCT.-Marginal on tilted truncation; width $14 \% \mathrm{~L}$, height $12 \% \mathrm{~L}$. Anterior edge of opening in interambulacral plate 4 .

Fascioles.-None.

Oral Plate Arrangement.-Labrum destroyed, plastron mesamphisternous (Figure 44A).

Occurrence.-Oligocene-Miocene, on margin of deep cut along hill approximately $1 \mathrm{mi}(1.6$ km) E of Casa Blanca, Habana Province, Cuba.
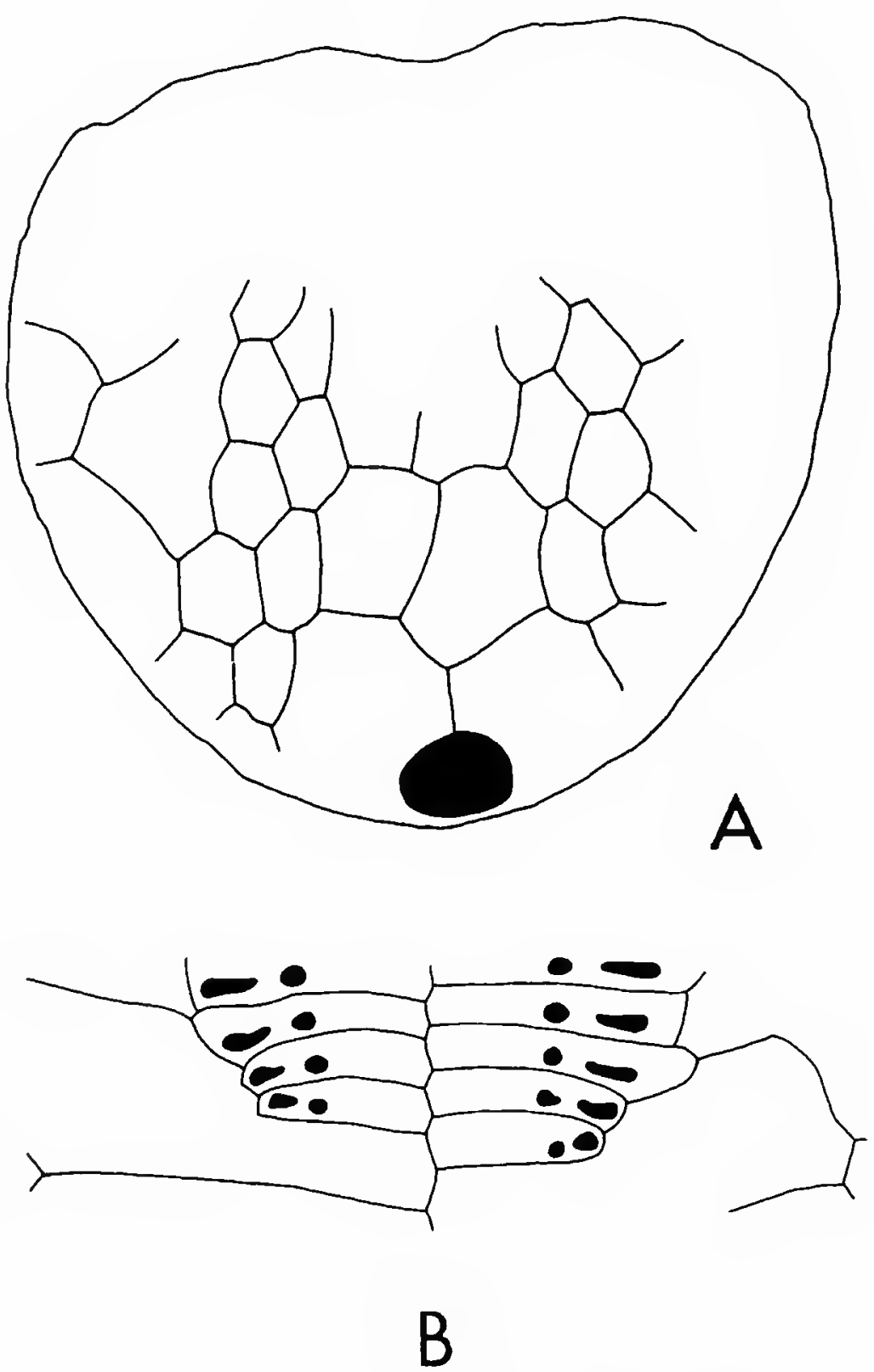

FIGURE 44.-Antillaster lamberti Jeannet, holotype of Antillaster habanensis (Sánchez Roig) (= A. lamberti), SRC 4114: A, ventral view, $\times 0.75$; $\mathrm{B}$, end of petal $\mathrm{V}, \times 4$. 


\section{Antillaster sanchezi Lambert}

Plate 90: figures 2-4

Maurilanaster cubensis-Sánchez Roig, 1924a, pl. 7 [not Mauritanaster cubensis Cotteau, 1875].

Antillaster sanchezi Lambert in Lambert and Thiéry, 1924 [1909-1925]:440._Sánchez Roig, 1926:96, pl. 17: fig. 2, pl. 18: figs. 1, 2; 1949:184.

Antillaster flexuosus Lambert in Lambert and Thiéry, 1924 [1909-1925]:440._Lambert in Sánchez Roig, 1924a:43; 1926:95, pl. 19: figs. 1, 2, pl. 20: figs. 1, 2, pl. 21: figs. 1, 2; 1949:183.

Antillaster castroi. Lambert in Sánchez Roig, 1924a:43, pl. 6: figs. 1, 2 [not Antillaster castroi Egozcue y Cía (name on label) in Cotteau, 1897:92, pl. 23].

Material. - The holotype is lost. Although topotypic specimens are in the Sánchez Roig Collection, they are too poorly preserved to permit writing a description of the species. One specimen (SRG 4511) has 31/2 plates occluded at the end of petal IV in the posterior poriferous zone (IVb) and in petal $\mathrm{I} 2^{1 / 2}$ in poriferous zone Ia, $3^{1 / 2}$ in Ib.

Occurrence.-Although Sánchez Roig (1949: 185) considered the type-locality of both $A$. sanchezi and $A$. flexuosus to be late Oligocene, Albear (1980, personal communication) places it in the early to middle Miocene. "Cervantes" farm, San José de las Lajas, Habana Province, Cuba.

Comparison with Other Species.-This species is very similar to $A$. vaughani (Jackson) from the Oligocene-Miocene of Cuba, Mexico, and Antigua in having a low test with narrow petals but appears to differ in having less divergent anterior petals and a more central apical system.

Remarks. - This species is very similar to $A n$ tillaster flexuosus Lambert, which occurs at the same locality. Although the type specimens of both species are lost, Sánchez Roig's (1926) illustrations show them to have petals very similar in shape, length, and angle of divergence. Their apical systems appear to be similarly situated; their tests appear to have the same shape. They are herein considered synonyms.

\section{SYNONYM}

\section{Antillaster flexuosus Lambert}

The holotype and figured specimens arc lost. Two specimens referred to this species are in the
Sánchez Roig Collection, but are too poorly preserved to classify on a specific level.

Occurrence.-Although Sánchez Roig considered the type-locality to be late Oligocene, Albear (1980, personal communication) places it in the early or middle Miocene. "Cervantes" farm, San José de las Lajas, Habana Province, Cuba.

\section{Antillaster vaughani (Jackson), new combination}

Plates 84-86; Plate 87: figures 1-3

Eupalagus vaughani Jackson, 1922:96, pl. 17: fig. 2, pl. 18: figs. $1,2$.

Eupalagus mexicanus Jackson, 1937:234, pl 14, pl. 15: fig. 1. Antillaster herrerae Sánchez Roig, 1951:49, pls. 27, 28. Antillaster depressus Sánchez Roig, 1951:51, pl. 29. Antillaster expansus Sánchez Roig, 1953a:63, pl. 18. Antillaster guevarai Sánchez Roig, 1952b:9, pl. 4:figs. 1, 2.

I have studied specimens of Eupatagus vaughani Jackson from the Oligocene-Miocene of Antigua, Eupatagus mexicanus Jackson from the OligoceneMiocene of Mexico, Antillaster herrerae Sánchez Roig, Antillaster depressus Sánchez Roig, Antillaster expansus Sánchez Roig and Antillaster guevarai Sánchez Roig from the Oligocene-Miocene of Cuba and cannot distinguish them from each other.

The specimens labelled "Antillaster giganteus Sánchez Roig" in the Sánchez Roig Collection, also from the Oligocene-Miocene of Cuba, appear to be conspecific with $A$. vaughani. However, because Sánchez Roig never figured $A$. giganteus and because these specimens are not topotypic, their identity cannot be verified.

The type specimens of $A$. vaughani are not wellenough preserved to show the presence of any fascioles. The holotype of $A$. mexicanus shows its tuberculation and no fascioles are present. Their absence confirms that these species should be referred to Antillaster not Eupatagus.

Occurrence.-All are Oligocene-Miocene. Holotype of $A$. vaughani, Antigua Formation, bluff on $\mathrm{N}$ side of Willoughby Bay, Antigua. Holotype of A. mexicanus, Meson Formation, $\mathrm{S}$ end of Cerro La Puerta, Hacienda Santa Fé, Topila, Canton Ozuluama, Veracruz, Mexico. Holotype of $A$. herrerae, "Santa Clara" farm, Loma La Calera, 
Marroquín district, Morón, Camagüey Province, Cuba. A non-type specimen in the Sánchez Roig Collection is from "Ajocicado" farm, Chamban, Camagüey Province, Cuba. The topotype of $A$. depressus is from approximately $3 \mathrm{mi}(4.8 \mathrm{~km}) \mathrm{SE}$ of Arroyo Blanco, "Pantano Verde" farm, Camagüey Province, Cuba. The holotype of $A$. guevarai is from Loma Mendoza, Marroquín, Morón, Camagüey Province, Cuba. The topotypic specimen studied was from "El Maja” farm, Majaqua district, Ciego de Avila, Camagüey Province, Cuba.

\section{SYNONYMS}

Antillaster depressus Sánchez Roig

Plate 85

Material.-The specimen labelled as the type is not the one figured by Sánchez Roig in his original description. The holotype is lost and a topotype (SRC 4501) is herein described. This specimen is slightly depressed anterior to the apical system. The ventral surface is fractured and the test is weathered.

Shape and Size.-Test very large, length 144 mm, width $91 \%$ L, height $30 \%$ L. Posterior truncation overhanging making periproct visible from below. Greatest height is at apical system. Test may have been originally higher before postmortem distortion.

ApICAl System.-Anterior, located at distance from anterior margin to center of genital pores equal to $35 \%$ L. Ethmolytic with genital plate 2 extending far posteriorly separating posterior ocular plates; 4 genital pores.

Ambulacra.-Anterior ambulacrum III not petaloid; porepairs in adapical region very small. Anterior petals (II and IV) long, extending to margin, length $40 \%$ L, width $8.3 \%$ L, open, curving anteriorly. Interporiferous zones at greatest width $1 \frac{1}{2}$ times width of single poriferous zone; pores conjugate, outer pore of pair elongated transversely; 96 porepairs in petal.

Posterior petals (V and I) long, extending to margin, length $54 \% \mathrm{~L}$, greatest width $9.0 \% \mathrm{~L}$. Interporiferous zone almost twice width single poriferous zone; 122 porepairs in petal.

Peristome.-Anterior, distance from anterior margin to anterior edge of peristome $27 \% \mathrm{~L}$. Opening large, width $17 \% \mathrm{~L}$, height $7.4 \% \mathrm{~L}$. Phyllodes not clear because of poor preservation.

PERIPROCT.--Located on overhang of posterior margin, visible from below; width estimated at $11 \% \mathrm{~L}$, height $13 \% \mathrm{~L}$.

Fascioles.-None visible.

Oral Plate Arrangement.-Not discernible.

Occurrence.-Oligocene-Miocene, approximately $3 \mathrm{mi}(4.8 \mathrm{~km}) \mathrm{SE}$ of Arroyo Blanco, "Pantano Verde" farm, Camagüey Province, Cuba.

\section{Antillaster expansus Sánchez Roig}

$$
\text { Plate } 86
$$

Material.-The holotype is not in the Sánchez Roig Collection. One specimen (SRC 4480), labelled as the type, is not the specimen figured by Sánchez Roig. It is topotypic but is too poorly preserved to permit its selection as the neotype. Most of its adoral surface is absent, the periproctal region is broken away, and the apical region is badly fractured obscuring the character of the system.

Occurrence.-Oligocene-Miocene, "El Maja" farm, Majagua district, Ciego de Avila, Camagüey Province, Cuba.

\section{Antillaster guevarai Sánchez Roig \\ Figure 45; Plate 87: figures $1-3$}

Material.-The holotype (SRC 4509) is a moderately well-preserved specimen with an undistorted test. The test is heavily weathered, the plate sutures enlarged, and most of the tubercles eroded away. Four other specimens are in the collection. They are either poorly preserved or not from type-locality and are not used in the following description.

Shape And Size.-Test $87 \mathrm{~mm}$ long, width $90 \%$ L, height $39 \%$ L. Greatest width central, greatest height anterior.

ApICAL System.-Anterior, at distance from anterior margin to center of genital pores equal 
to $30 \% \mathrm{~L}$; ethymolytic with genital plate 2 extending far posteriorly separating posterior ocular plates (Figure 45D); 4 genital pores.

AmBULACRA.-Anterior ambulacrum III not petaloid, flush with test; pores in adapical region not markedly larger than at margin; width of ambulacrum at margin $7.9 \% \mathrm{~L} ; 72$ plates.

Anterior petals (II and IV) extending almost to margin, very divergent, curving slightly anteriorly, flush, length $41 \% \mathrm{~L}$, width $9.9 \% \mathrm{~L}$. Interporiferous zones narrow, equal in width to poriferous zones; pores conjugate, outer pore more elongate than inner; petal with 66 porepairs; first petaloid porepair in plate 21 . No plates occluded at end of petal.

Posterior petals (V and I) extending four-fifths distance from apical system to margin, length $49 \% \mathrm{~L}$, width $11 \% \mathrm{~L} ; 84$ porepairs in petal. Occlusion of plates at end of petal variable: in petal $\mathrm{V}$, poriferous zone $\mathrm{Va}$ with $1 \frac{1}{2} 2$ plates occluded, none in poriferous zone $\mathrm{Vb}$ (Figure 45в); in petal I $1 \frac{1}{2}$ plates are occluded in zone Ia, none in Ib (Figure 45c). Pores beyond petals and in phyllodes appear to be single; but because of enlargement of pores by weathering, it is not possible to be certain.

Peristome.-Anterior, distance from anterior margin to anterior edge of peristome $23 \% \mathrm{~L}$; opening large, width $19 \% \mathrm{~L}$, height $6.6 \% \mathrm{~L}$. Phyllodes large, apparently single pored, 17 pores in ambulacrum III, 25 in IV, 12 in V.

Periproct.-Nor preserved.

Fascioles.-None visible.

Oral Plate Arrangement.-Labrum large, length $9.5 \% \mathrm{~L}$, width $11 \% \mathrm{~L}$, extending back to third adjacent ambulacral plate. Plastron (Figure 45A) composed of 4 plates; first pair with (combined) length $33 \% \mathrm{~L}$, width $29 \% \mathrm{~L}$; second pair smaller with combined length $13 \% \mathrm{~L}$, width $24 \%$ L. Interambulacrum 1 with first plate followed by pair of plates (Fig. 45A).

Occurrence.-Oligocene-Miocene, Loma Mendoza, Marroquín, Morón, Camagüey Province, Cuba.

Figure 45.-Antillaster vaughani (Jackson), holotype of Anitlaster guevarai Sánchez Roig (= A. vaughani), SRC 4509: A, ventral view, $\times 1$; , end of petal $\mathrm{V}, \times 6$; $\mathrm{C}$, petal $\mathrm{I}, \times 6$; , apical system of SRC $4509, \times 9$.
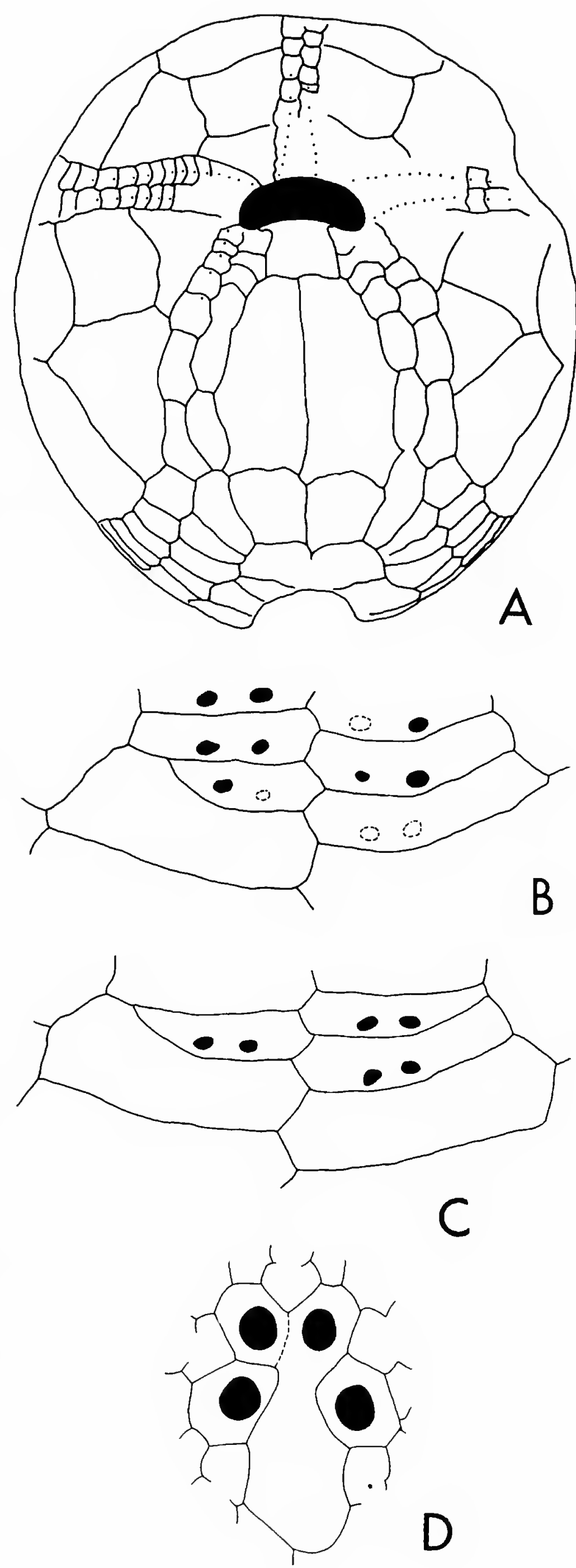


\section{Antillaster herrerae Sánchez Roig}

Plate 84

Material.-The holotype (SRC 4469) has an undistorted test, which is weathered enough to reveal plate sutures.

Shape AND Size.-Length $126 \mathrm{~mm}$, width 92\% $\mathrm{L}$, height $51 \% \mathrm{~L}$; greatest width slightly anterior of center, greatest height posterior of apical system. Posterior truncation overhanging.

Apical System.-Anterior, located at distance from anterior margin to center of genital pores equal to $35 \%$ L. Ethmolytic, with genital plate 2 extending posteriorly between posterior ocular plates, 4 genital pores, with anterior pores closer together than posterior.

AMBULACRA.-Anterior ambulacrum III not petaloid, in faint groove from apical system to peristome; groove deepest at peristome. Adapical portion of ambulacrum covered with matrix; pores single adorally. Petals flush except for very slightly depressed poriferous zones; outer pore slightly more elongated than inner, slightly conjugate, open distally; petals extending almost to margin; pores decreasing in size at end of petals (Plate 84: figure 3).

Anterior petals (II and IV) curving slightly anteriorly, with length $50 \% \mathrm{~L}$, greatest width $8.9 \% \mathrm{~L}$, greatest width of interporiferous zone $4.5 \% \mathrm{~L}$, poriferous zone $2.6 \% \mathrm{~L}$.

Posterior petals (V and I) with length $60 \% \mathrm{~L}$, greatest width $9.1 \% \mathrm{~L}$, greatest width interporiferous zone $4.4 \% \mathrm{~L}$, poriferous zone $2.9 \% \mathrm{~L}$. Petal II with $\sim 94$ porepairs, petal $\mathrm{V}$ with $\sim 112$.

Peristome.-Anterior, located at distance from anterior margin to anterior edge of peristome equal to $21 \% \mathrm{~L}$. Opening large, width $19 \% \mathrm{~L}$, height $7.5 \% \mathrm{~L}$; labiate. Phyllodes of ambulacra II and IV curved (Plate 84: figure 2); single pores in peripodia, 17 in ambulacrum III, 24 (est.) in $\mathrm{IV}$, number in $\mathrm{V}$ not clear.

Periproct.-On overhanging posterior truncation, slightly visible from below; width estimated at $17 \% \mathrm{~L}$, height uncertain. Opening in plates 3-8.

Fascioles.-None visible.

Oral Plate Arrangement.-Labrum large, broad, width $13 \% \mathrm{~L}$, height $11 \% \mathrm{~L}$; extending posteriorly to middle of third or fourth (not clear which) adjacent ambulacral plate. Plastron composed of 4 plates, anterior 2 largest with length 29\% L; posterior with length (est.) $17 \%$ L. Character of plates in interambulacrum 1 not clear on holotype; but on another specimen of this species, the first plate in interambulacrum 1 is followed by a pair of plates.

Occurrence.-Oligocene-Miocene. "Santa Clara" farm, Loma La Calera, Marroquín district, Morón, Camagüey Province, Cuba. A nontype specimen in the Sánchez Roig Collection is from "Ajocicado" farm, Chamban, Camagüey Province, Cuba.

\section{Unrecognizable Species of Antillaster}

\section{Antillaster cartagensis Sánchez Roig}

Antillaster cartagensis Sánchez Roig, 1949:188, pl. 22: fig. 2.

The holotype and only known specimen is lost.

Occurrence.-Oligocene-Miocene, $1 \mathrm{~km}$ N of railroad SSE of Cartagena, Las Villas Province, Cuba.

\section{Antillaster estenozi Sánchez Roig}

Antillaster estenozi Sánchez Roig, 1949:189, pl. 22: fig. 1.

The holotype and only known specimen is lost. Sánchez Roig's illustration is not adequate to permit comparison of this species with others.

Occurrence.-Although Sánchez Roig considered the type-locality to be late Oligocene, Albear (1980, personal communication) places it in the early or middle Miocene. "Cervantes" farm, San José de las Lajas, Habana Province, Cuba.

\section{Antillaster giganteus Sánchez Roig}

Antillaster giganteus Sánchez Roig, 1951:48.

The specimen labelled as the type (SRC 4868) does not correspond in its dimensions to those given by Sánchez Roig; neither is it from the type-locality. Because Sánchez Roig never figured 
it, I cannot be certain that the specimens in the Sánchez Roig Collection belong to this species and therefore cannot redescribe the species.

Occurrence.-Oligocene-Miocene, holotype from "Las Mercedes" farm, Majagua district, Ciego de Avila, Camagüey Province, Cuba. Other specimens in the Sánchez Roig Collection are from "El Maja" farm, Corral Concepción, Ciego de Avila, Camagüey Province, Cuba.

\section{Genus Moronaster Sánchez Roig, 1952}

Unfortunately no specimens of the two species that Sánchez Roig referred to this genus are available. These species were based on badly weathered specimens, and there is no way of knowing whether or not they had fascioles. The validity of the genus cannot be determined. From Sánchez Roig illustrations, the species appear to belong to either Pericosmus or Antillaster.

\section{Moronaster moronensis Sánchez Roig}

Moronaster moronensis Sánchez Roig, 1952b: 14, pl. 9: figs. 1, 2.

No specimens of this species are now in the Sánchez Roig Collection or are known elsewhere.

Occurrence._Eocene, 'Armadillo' farm, Marroquín district, Camagüey Province, Cuba.

\section{Moronaster santanae Sánchez Roig}

Brissolampas santanae Sánchez Roig, 1949:190, pl. 22: figs. 3,4 .

Moronaster santanae—Sánchez Roig, 1952b:15.

No specimens of this species are now in the Sánchez Roig Collection or are known elsewhere.

Occurrence.-Eocene, "Santa Ana" farm, Marroquín district, Morón, Camagüey Province, Cuba.

\section{Incertae Sedis}

\section{Genus Brissopatagus Cotteau 1863 \\ Brissopatagus? rojasi Sánchez Roig}

Brissopatagus rojasi Sánchez Roig, 1953c: 164, pl. 9: figs. 5, 6.

The type specimen is no longer in the Sánchez Roig Collection and the other specimens are too poorly preserved to permit redescription of this species.

Occurrence.-Late Eocene, Concepción Corral, Guadalupe district, Morón; "Armadillo" farm, Marroquín; "Santa Ana", Marroquín, Morón, Camagüey Province, Cuba.

REMARKs.-Not enough is known of this species to be certain of its generic assignment. It lacks the large depressions in front of the anterior petals typical of Brissopatagus according to Henderson and Fell (1969:14). 


\section{Literature Cited}

Agassiz, L., and P. Desor

1847. Catalogue raisonné des espèces, des genres et des familles d' Echinines. Annales des Sciences Naturelles, Zoologie (Paris), series 3, 7:129-168; 8:4-35, 355380, plates $15,16$.

Arnold, B.W., and H.L. Clark

1927. Jamaican Fossil Echini, with Descriptions of New Species of Cainozoic Echinoidea by H.L. Hawkins. Memoirs of the Museum of Comparative Zoology (Harvard), 50(1): 1-84, figures 1-3, plates 1-22.

1934. Some Additional Fossil Echini from Jamaica. Memoirs of the Museum of Comparative Zoology (Harvard), 54(2): 139-156, plates 1-5.

Baker, A.N.

1969. Two New Heart-Urchins, Including a New Species of Cyclaster, from New Zealand Waters (Echinoidea, Spatangoida). Records of the Dominion Museum, 6(16):265-273, figures 1-22, plates 1,2.

Bather, F.A.

1934. Chelonechinus n.g., a Neogene Urechinid. Bulletin of the Geological Society of America, 45(5):799-874, figures 1-18, plates 108-110.

Bermúdez, P.J.

1961. Las formaciones geologicas de Cuba. Geologia Cubana, 1:1-177, figure 1 .

Bermúdez, P.J., and R. Hoffstetter

1959[1960]. Cuba et îles adjacentes. In R. Hoffstetter, editor, Lexique Stratigraphique International, volume 5 (Amérique Latine), fascicle 2c, 140 pages, 1 map. Paris: Centre National de la Recherche Scientifique.

Brodermann, J.

1949. Significacion estratigrafica de los Equinodermos fosiles cubanos. In M. Sánchez Roig, Los equinodermos fosiles de Cuba. Paleontologia Cubana, 1:305-330, 3 unnumbered tables.

Brönnimann, P., and D. Rigassi

1963. Contribution to the Geology and Paleontology of the Area of the City of La Mabana, Cuba, and Its Surroundings. Eclogae Geologicae Helvetiae, 56(1): 193-480, figures 1-75, plates 1-26.

Chesher, R.H.

1968. The Systematics of Sympatric Species in West Indian Spatangoids: A Revision of the Genera Brissopsis, Plethotaenia, Paleopneustes, and Saviniaster. Studies in Tropical Oceanography (Institute of Marine Sciences, University of Miami), 7:1-168, figures $1-25$, plates $1-35$.
1970. Evolution in the Genus Meoma (Echinoidea: Spatangoida) and a Description of a New Species from Panama. Bulletin of Marine Science, 20(3):731-761, figures 1-9.

Conrad, T.A.

1850. Descriptions of One New Cretaceous and Seven New Eocene Fossils. Proceedings of the Academy of Natural Sciences of Philadelphia, series 2, 2:39-41, illustrations.

Cooke, C.W.

1942. Cenozoic Irregular Echinoids of Eastern United States. Journal of Paleontology, 16(1):1-62, plates $1-8$.

1948. Eocene Echinoids from Panama. Journal of Paleontology, 22(1):91-93, plate 22.

1959. Cenozoic Echinoids of Eastern United States. United States Geological Survey Professional Paper, 321:1-106, plates 1-43.

1961. Cenozoic and Cretaceous Echinoids from Trinidad and Venezuela. Smithsonian Miscellaneous Collections, 142(4):1-35, plates 1-14.

Cortázar, D. De

1880. Descripción de un nuevo equinodermo de la Isla de Cuba, Encope ciae n. sp. Comisión del Mapa Geologico de España, Boletin, 7:227-232, plates G, H.

Cotteau, G.H.

1870. Sur le genre Asterostoma, de la famille des Echinocorydées. Comtes Rendus des Séances de l'Academie des Sciences, 70:271-273.

1871. II: Notice sur le genre Asterostoma. Société Géologique de France, Memoire, (2)9(2):177-184, plates 16, 17.

1875. Description des Echinides Tertiaires des îles St. Barthélemy et Anguilla. Kongliga Svenska Vetenskaps-Akademiens Handlinger, 13(6):1-47, plates 1-8.

1876. Echinides tertiares des îles Saint-Barthélemy et d'Anguilla. Bulletin de la Société Géologique de France, (3) 5: 126-130.

1881. Description des échinides fossiles de lîle de Cuba. Annales de la Société Géologique de Belgique, 9(Memoire 4): 1-49, plates 1-4.

1897. Descripción de los equinoides fósiles de la Isla de Cuba por M.G. Cotteau, adicionada por D. Justo Egozcue y Cía. Boletín de la Comision del Mapa Geológico de España, 22:1-99, plates 1-29.

de Loriol, P.

1887. Notes pour servir à l'étude des Echinodermes. Recheil Zoologie Suisse, series 7, 1(4)365-407, plates 15-18. 
Desor, P.J.E.

1858. Synopsis des échinides fossiles. 490 pages, 44 plates. Paris \& Wiesbaden.

Dickerson, R.E., and W.S.W. Kew

1917. The Fauna of a Medial Tertiary Formation and the Associated Horizons of Northeastern Mexico. Proceedings of the California Academy of Sciences, series 4, 7(5):125-156, plates 17-26a.

d'Orbigny, A.D.

1856. Echinodermes. In Paléontologie Française, series 1 (Terrains Crétacés), 6: 598 pages, plates 801-1006. [Completed by G. Cotteau.]

Duncan, P.M.

1889. A Revision of the Genera and Great Groups of the Echinoidea. Journal of the Linnean Society of London, Zoology, 23(141):1-311.

Durham, J.W.

1961. Miocene Echinoids from the Valle Central, Costa Rica. Journal of Paleontology, 35(3):480-488, figures 1, 2, plates 67, 68 .

Eames, F.E., F.T. Banner, W.H. Blow, and W.J. Clarke

1962. Fundamentals of Mid-Tertiary Stratigraphical Correlation. 163 pages, 17 plates. Cambridge, England: Cambridge University Press.

Eames, F.E., and R.J.G. Savage

1975. The Sequence of Tertiary Faunas. In A.M. Davies, Tertiary Faunas, A Text-Book for Oilfield Palaeontologists and Students of Geology, volume 2, 447 pages, 34 figures, 4 tables. New York: American Elsevier.

Fischer, A.G.

1951. The Echinoid Fauna of the Inglis Member, Moodys Branch Formation. Florida Geological Survey, Geological Bulletin, 34(2):49-101, figures 1-18, plates 1-7.

1966. Spatangoids. In R.C. Moore editor, Treatise on Invertebrale Paleontology, part U(Echinodermata 3), 2:U543-U628, figures 427-514. New York: Geological Society of America, Inc.

Goldfuss, A.

1826. Petrefacta [Germaniae:] Musei Universitatis Regiae Borussicae Rhenanae Bonnensis nec non Hoeninghusiani Crefeldensis, 1(1):1-76, plates 1-25.

Gordon, W.

1963. Middle Tertiary Echinoids of Puerto Rico. Journal of Paleontology, 37(3):628-642, figures 1-4, plates 79-81, table 1.

Gray, J.E.

1855. Catalogue of the Recent Echinida or Sea-Eggs in the British Museum, Part I: Echinida Irregularia. iv +69 pages, plates 1-6. London.

Gregory, J.W.

1892. Archaeopneustes abruplus, a New Genus and Species of Echinoid from the Oceanic Series in Barbados. Quarterly Journal of the Geological Society of London, 48:163-169, plate 4 .
Guppy, R.

1882. On the Fossil Echinodermata of the West Indies. Proceedings of the Scientific Association of Trinidad, 2(4):193-199. [Reprint 1921, Bulletin of American Paleonlology, 8(35):103-109.]

Henderson, R.A.

1975. Cenozoic Spatangoid Echinoids from New Zealand. New Zealand Geological Survey, Paleontological Bulletin, 46:1-129, figures 1-17, plates 1-18.

Henderson, R.A., and H. Fell

1969. Taimanawa, a New Genus of Brissid Echinoids from the Tertiary and Recent Indo-West Pacific with a Review of the Related Genera of Brissopatagus and Gillechinus. Breviora, 320:1-29, figures 1-3, plates $1-5$.

Jackson, R.T.

1918. Fossil Echini of the Panama Canal Zone and Costa Rica. United Stales National Museum Bulletin, 103:103-116, figures 1-3, plates 46-52.

1922. Fossil Echini of the West Indies. Contributions to the Geology and Paleontology of the West Indies, 306:1-103, figures 1-6, plates 1-18. Carnegie Institution of Washington.

1937. Mexican Fossil Echini. Proceedings of the United States National Museum, 84(3015):227-237, plates 12-15.

Jeannet, A.

1928. Contribution à l'étude des Échinides Tertiaires de la Trinité et du Vénézuela. Mémoires de la Sociélé Paléontologique Suisse, 48:1-49, figures 1-12, plates $1-6$.

Kier, P.M.

1974. Evolutionary Trends and Their Functional Significance in the Post-Paleozoic Echinoids. Journal of Paleontology, 48(2) (Memoir 5):1-96, figures 178 , table 1 , chart 1 .

1975. The Echinoids of Carrie Bow Cay, Belize. Smithsonian Contributions to Zoology, 206: 45 pages, 8 figures, 12 plates, 2 tables.

1980. The Echinoids of the Middle Eocene Warley Hill Formation, Santee Limestone, and Castle Hayne Limestone of North and South Carolina. Smithsonian Contributions to Paleobiology, 39: 102 pages, 26 figures, 22 plates.

Kier, P.M., and R.E. Grant

1965. Echinoid Distribution and Habits, Key Largo Coral Reef Preserve, Florida. Smithsonian Miscellaneous Collections, 149(6):1-68, figures 1-15, plates $1-16$.

Lambert, J.M.

1915. Echinides néogènes des Antilles anglaises. Sociélé et Academie d'Agriculture, Sciences, Artes el Belles Lettres, Department de l'Aube, Memoire, 79:17-33, plate 3.

1922. Nouvelles observations sur quelques Echinides néogènes de l'île d'Anguilla. The Annals and Magazine of Natural History, series 9, 9:587-596, plate 9 . 
1928. Sur deux Echinides fossiles de Cuba. Bulletin de la Sociélé Geologique de France, series 4, 28:19-21, figures $1,2$.

1932. Note sur le groupe des Oligopygus, la nouvelle familee des Haimeidae, et sur quelques Echinides fossiles de Cuba. Bulletin de la Société Geologique de France, series 5, 1(1931):289-304, 3 figures, plate 17.

Lambert, J.M., and P. Thiéry

1909-1925. Essai de nomenclature raisonnée des Echinides. 607 pages, 15 plates. Chaumont: Librairie L. Ferriere.

Lemoine, J.

1921. Abstract 314 Roig, Esqualidos des Mioceno y Plioceno de la Habana. Revue de Géologie el des Sciences Connexes (Liege), 2:121.

Lewis, J.B.

1963. The Food of Some Deep-Water Echinoids from Barbados. Bulletin of Marine Science of the Gulf and Caribbean, 12/13(2):360-363.

Lovén, S.

1874. Études sur les Echinoidées. Kongliga Svenska Vetenskaps-Akademiens Handlingar, new series, 11(7): 91 pages, 53 plates.

McNamara, K.J., and G.M. Philip

1980. Australian Tertiary Schizasterid Echinoids. Alcheringa, 4:47-65, figures 1-9.

In press. Large Fossil Spatangoid Echinoids from the Tertiary of Australia. Palaeontographica.

Michelin, $\mathrm{H}$.

1855. Sur les oursins vivants et fossiles des Antilles et du Golfe du Méxique. Bulletin de la Société Geologique de France, series 2, 12:756-759.

Molengraatf, G.J.H.

1929. Beschrijving van de Echiniden uit het BovenEoceen van Curacao. In J.H. Gerard, Geologie en Geohydrologie van het eiland Curacao, pages 72-83, plates 24-28, maps. Delft: Drukkerij J. Waltman, Jr.

Mortensen, $\mathrm{T}$.

1950. Spatangoida. In T. Mortensen, A Monograph of the Echinoidea, 5(1): 432 pages, 315 figures, 25 plates. Copenhagen: C.A. Reitzel.

1951. Spatangoida. In T. Mortensen, A Monograph of the Echinoidea, 5(2): 593 pages, 286 figures, 64 plates. Copenhagen: C.A. Reitzel.

Nichols, D.

1959. Changes in the Chalk Heart-Urchin Micraster Interpreted in Relation to Living Forms. Philosophical Transactions of the Royal Society of London, $\mathrm{B}(693) 242: 347-437,46$ figures, plate 9 .

Palmer, R.H.

1948. List of Palmer Cuban Fossil Localities. Bulletins of American Paleontology, 31(128):1-458, 2 maps.
Parra, A.

1787. Descripción de diferentes piezas de historia natural, las mas del ramo marítimo. 195 pages, 75 plates. Havana.

Pijpers, $\mathrm{P}$.

1933. Geology and Palaeontology of Bonaire (D.W.I.). Geographische en Geologische Mededeelingen (Utrecht), 8:1-103, figures 1-157, plates 1, 2.

Randazoo, A., and H. Saroop

1976. Sedimentology and Paleoecology of Middle and Upper Eocene Carbonate Shoreline Sequences, Crystal River, Florida, U.S.A. Sedimentary Geology, 15:259-291, figures 1-12.

Sagra, R. de la

1855. Historia Fisica Política y Natural de la Cuba. Volume 8 (Atlas de Zoologia), part 2 (Paléontologia).

Sánchez Roig, M.

1920. Escualidos del Mioceno y Plioceno de la Habana. Boletín de Minas, 6:1-16, 27 figures, 12 plates.

1924a. Revision de los Equinidos fosiles cubanos. Memorias de la Sociedad Cubana de Historia Natural "Felipe Poey," 6:6-50, plates 1-7.

1924b. Neuvas especes de equinidos fosiles Cubanos. Memorias de la Sociedad Cubana de Historia Natural "Felipe Poey," 6:75-92, plates 8-14.

1926. Contribucion a la Paleontologia Cubana: Los Equinodermos Fôsiles de Cuba, Boletin de Minas, 10:1-179, plates 1-43.

1949. Los equinodermos fosiles de Cuba. Paleontologia Cubana, 1:1-330, plates 1-50.

1951. Faunula de Equinodermos fosiles del Terciario, del termino municipal de Moron, Provincia de Camagüey. Memorias de la Sociedad Cubana de Historia Natural "Felipe Poey," 20(2):37-64, plates 2340.

1952a. El genero Cubanaster (Equinidos fosiles irregulares). Torreia, 16:3-8, plates 1-3.

1952b. Nuevos generos y especies de Equinoideos fosiles Cubanos. Torreia, 17:1-18, plates 1-9.

1952c. Neuvos generos y especies de equinodermos fosiles Cubanos. Memorias de la Sociedad Cubana de Historia Natural "Felipe Poey," 21(1):1-30, plates 1-15.

1952d. Paleontologia Cubana: Revision de los Equinodermos Fosiles del Grupo Cassiduloida. Memoria de la Sociedad Cubana de Historia Natural "Felipe Poey," 21(1):47-57, plates 16-17.

1952e. Revision de los Clypeasteridos Cubanos. Revista de Agricultura (Habana), pages 118-155, plates 1-16.

1953a. Algunos Equinoideos fósiles Cubanos. Revista de Agricultura (Habana), pages 53-67, plates 1-21.

1953b. Dos nuevos generos de Equinoideos cubanos: Lamberlona y Neopalagus. Memorias de la Sociedad Cubana de Historia Natural "Felipe Poey," 21(3):257-262, plates 27-29. 
1953c. Neuvos equinodos fosiles de Cuba. Anales de la Academis de Ciencias Medicas, Fisicas y Naturales de la Habana, 91(2):135-176, plates 1-12.

Serafy, D.K.

1979. Echinoids (Echinodermata:Echinoidea). Memoirs of the Hourglass Cruises, 5(3):1-120, figures 1-47, tables 1-30.

Smith, A.B.

1980. The Structure, Function, and Evolution of Tube Feet and Ambulacral Pores in Irregular Echinoids. Paleontology, 23(1):39-83, figures 1-15, plates 1-6.

Stephenson, D.C.

1963. The Spines and Diffuse Fascioles of the Cretaceous Echinoid Echinocorys scutata Leske. Paleontology, 6:458-470, 6 figures.

Van den Bold, W.A.

1965. Middle Tertiary Ostracoda from Northwestern Puerto Rico. Macropaleontology, 11(4):381-414, figure 1, plates $1-7$, tables $1-5$.
Wagner, C.D., and J.W. Durham

1966. Holasteroids. In R.C. Moore, editor, Treatise on Invertebrate Paleontology, part U (Echinodermata 3), 2:U523-U543, figures 414-426. New York: Geological Society of America, Inc.

Weisbord, N.

1934. Some Cretaceous and Tertiary Echinoids from Cuba. Bulletins of American Paleontology, 20 (70C): 165-270, plates $1-9$.

Zachos, L.

1968. A New Echinoid from the Ocala Limestone. Quarterly Journal of the Florida Academy of Sciences, 31(3):161-164, figure 1.

Zachos, L., and G. Shaak

1978. Stratigraphic Significance of the Tertiary Echinoid Eupatagus ingens Zachos. Journal of Paleontology, 52(4):921-927, figures 1-6, plate 1, table 1 .

Žitt, J.

1981. Aguayoaster Sánchez Roig (Echinoidea) from Cuba. Casopsis pro Mineralogii a Geologii, 26(3):273-284, figures 1-3, plates 1-4. 
Plates 1-90 


\section{PLATE 1}

\section{Cardiaster palmerz Sánchez Roig}

1-3. Dorsal, ventral and right side views of the lectotype, SRC 4024, Late Cretaceous, "Cantabria" farm, Agua district, Cienfuegos, Santa Clara (now Las Villas) Province, Cuba, $\times 1.5$.

Echinocorys ovatus Leske cubensis Sánchez Roig

4-6. Dorsal, ventral, and right side views of the holotype, SRC 4069, Late Cretaceous, Palenque, near Cienfuegos, Santa Clara (now Las Villas) Province, Cuba, $\times 1$. 

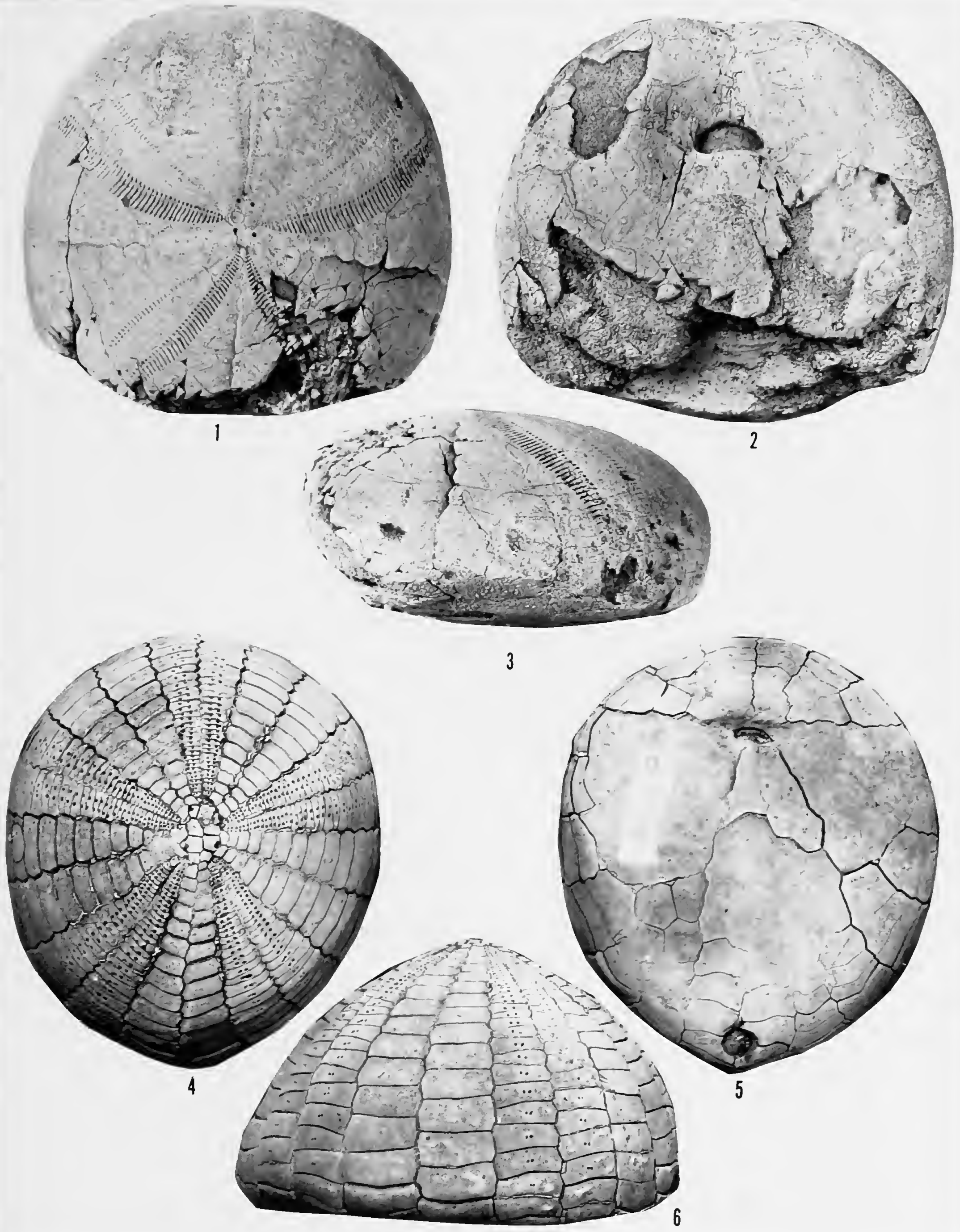


\section{PLATE 2}

Echinocorys ovalus Leske villarensis Sánchez Roig

1-4. Dorsal, ventral, rear, and right side of the holotype, SRC 4174, Late Cretaceous, Sancti Spiritus, near Ciudad, Santa Clara (now las Villas) Province, Cuba, $\times 1.4$.

5. Apical system of same specimen, $\times 4$. 


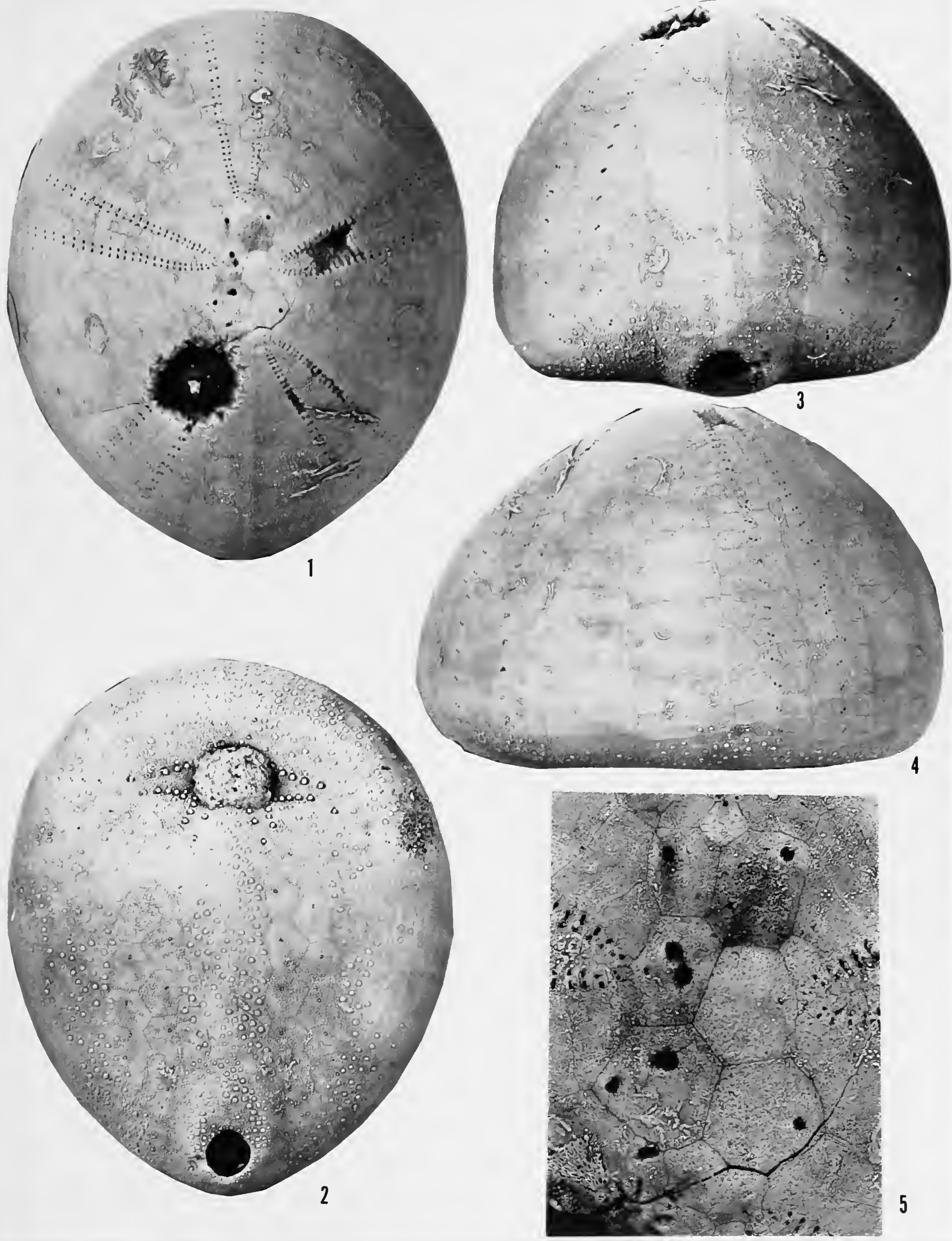




\section{PLATE 3}

\section{Sanchezaster habanensis Lambert}

1. Dorsal view of holotype, SRC 4958, Eocene, quarries of Tejar "Consuelo," Ciénaga, Habana Province, Cuba, $\times 1$.

2. Tuberculation on plates in apical region of paratype, USNM 341248, same locality as above, $\times 3$.

3. Plates in ambulacrum V near the periproct on dorsal side, USNM 341248 , same locality as above, $\times 3$.

4. Ventral ambulacral plates, USNM 341248 , same locality as above, $\times 3$. 

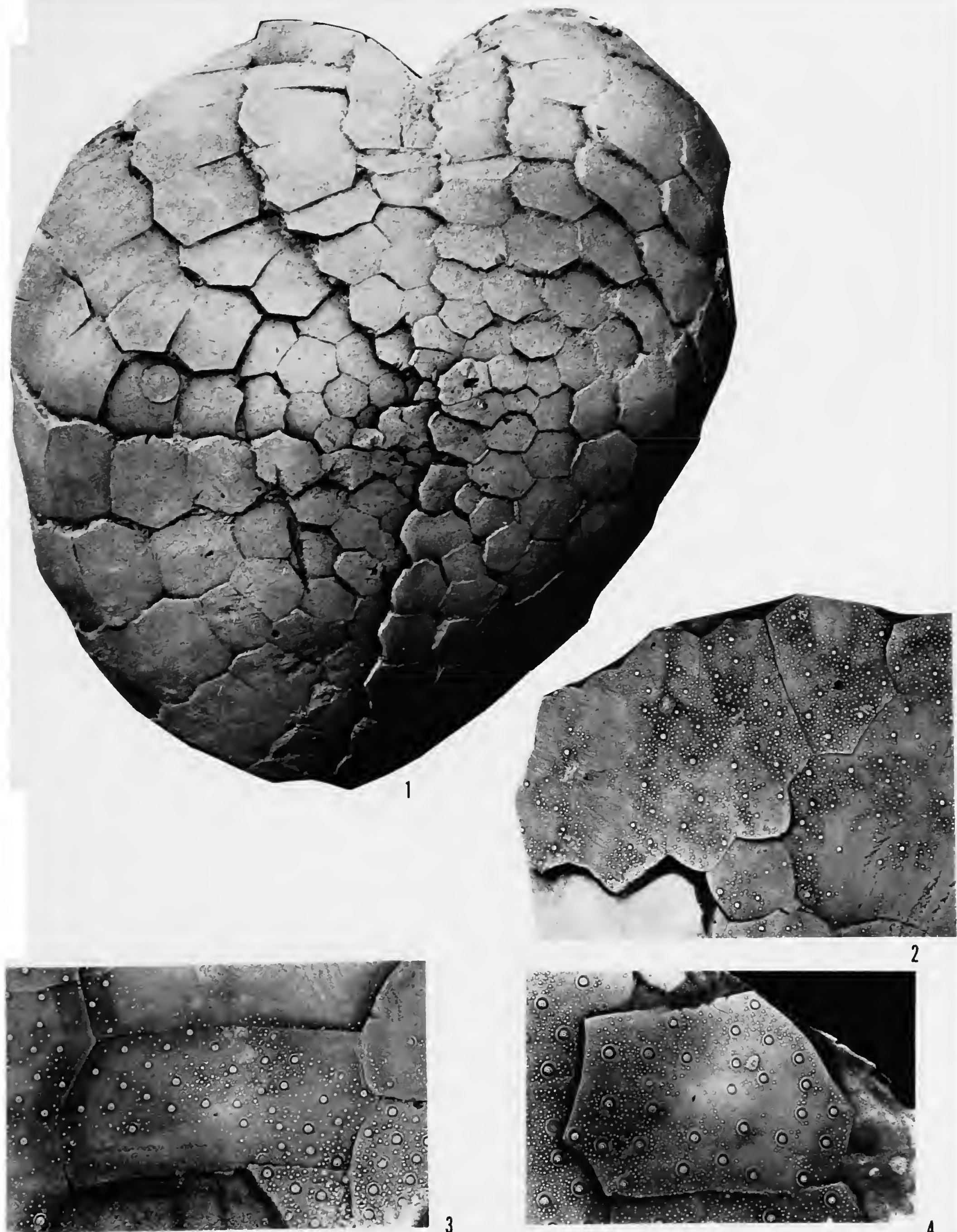


\section{PLATE 4}

Sanchezaster habanensis Lambert

1, 2. Dorsal and ventral views of paratype, USNM 341249, Eocene, quarries of Tejar "Consuelo" Ciénaga, Habana Province, Cuba, $\times 1$. 


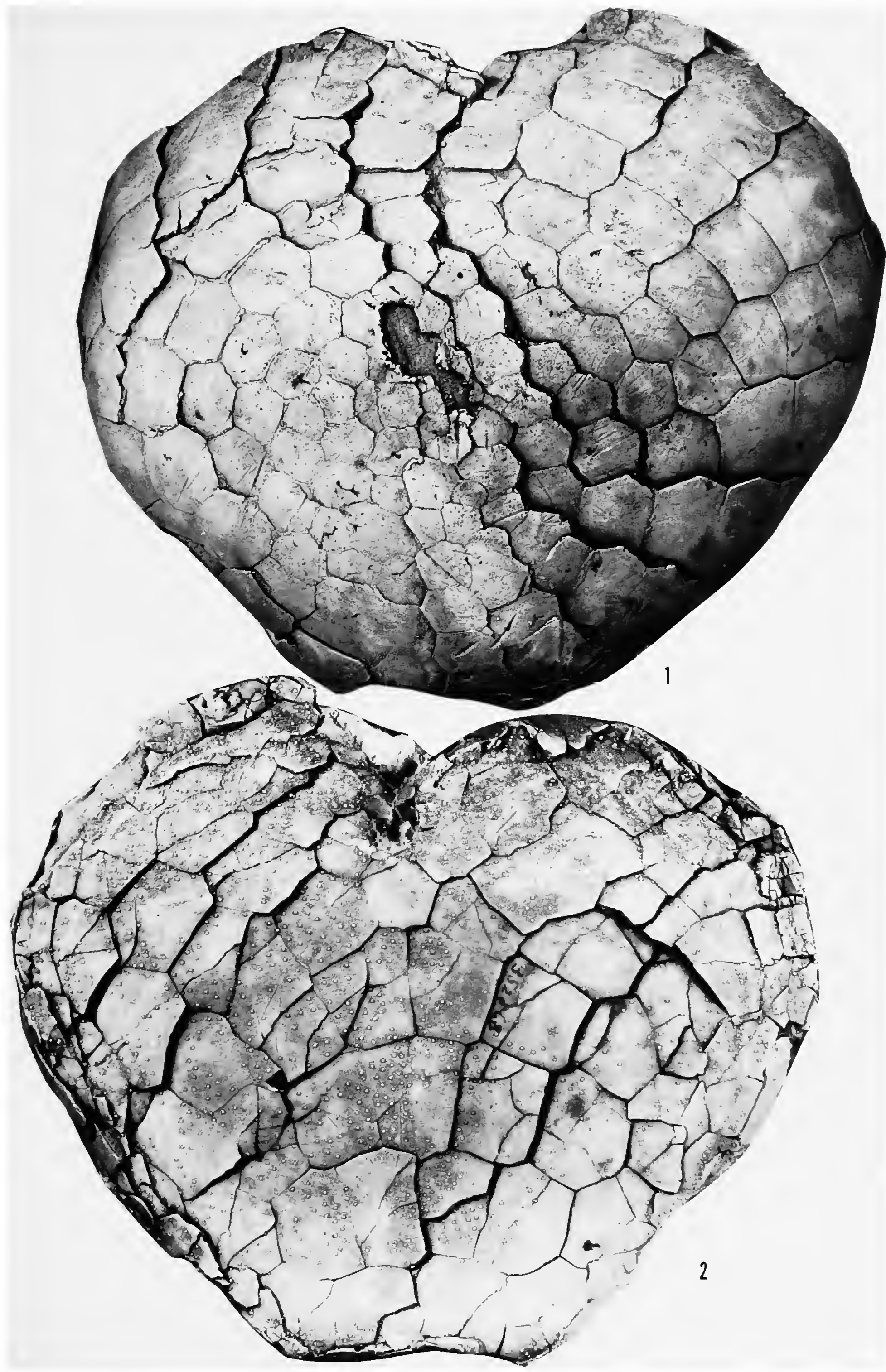


PLATE 5

\section{Sanchezaster habanensis Lambert}

1, 2. Dorsal and ventral views of paratype, MCZ 3510, Eocene, quarries of Tejar "Consuelo," Cienaga, Habana Province, Cuba, $\times 1$. 


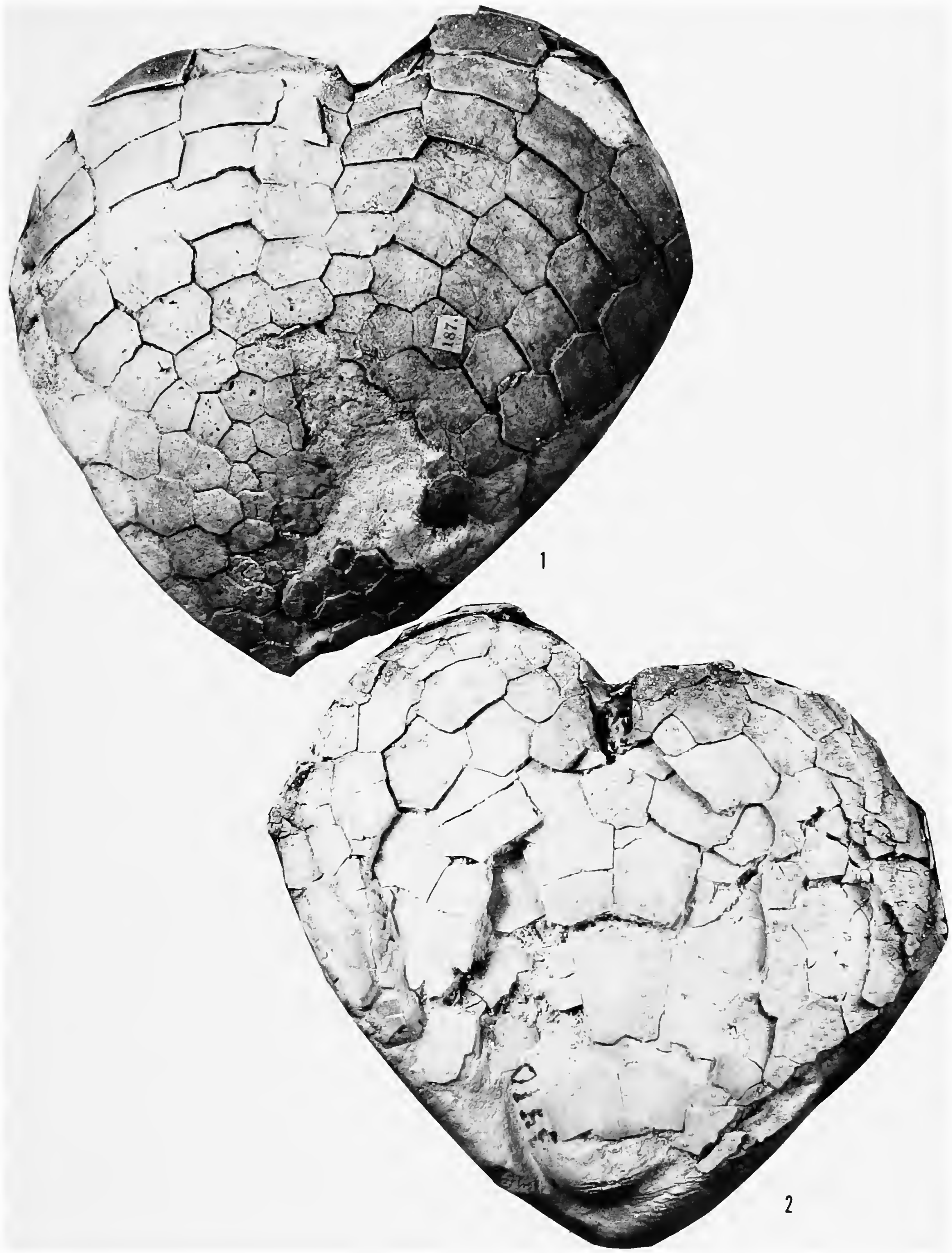




\section{PLATE 6}

\section{Douvillaster triangularis (Sánchez Roig)}

1-3. Dorsal, right side, and ventral views of the holotype, SRG 4722, Cretaceous, Palmer loc. 128, silicified marine sediments, one league S of Santa Clara, Santa Clara (now Las Villas) Province, Cuba, $\times 1$.

4. Portion of ambulacrum III on dorsal side of same specimen, $\times 6$.

5. Portion of petal $\mathrm{V}$ of same specimen, $\times 6$. 

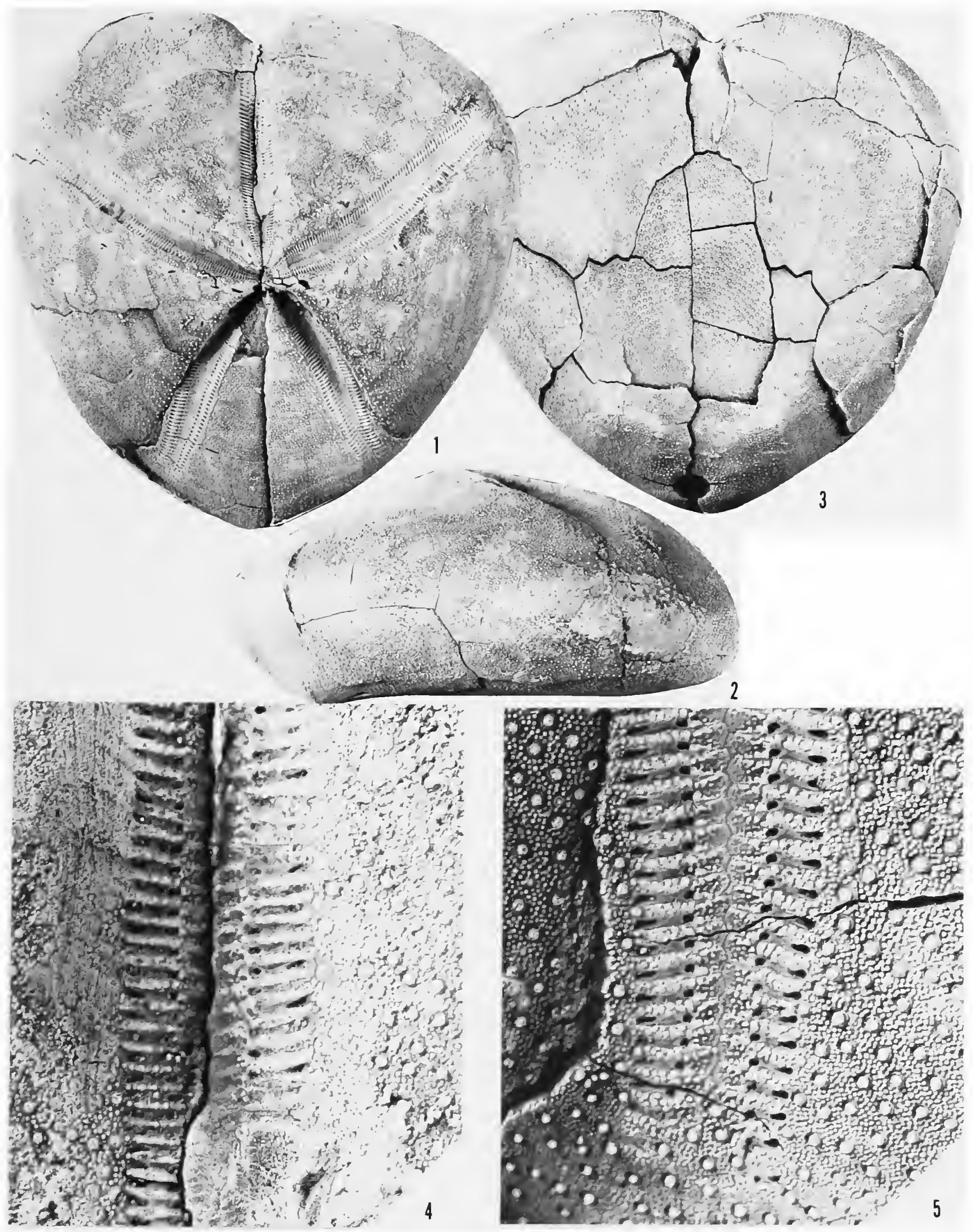


\section{PLATE 7}

Hemiaster? (Trachyaster) gonzalezmunozi Sánchez Roig

1-3. Dorsal, right side, ventral views of the holotype, SRC 4248, Late Cretaceous, "Concepción de Montalvo" farm, Rodas, Las Villas Province, Cuba, $\times 1$.

\section{Hemiaster (Trachyaster) herrerae (Lambert and Sánchez Roig)}

4-7. Dorsal, right side, rear, and front views of the holotype, SRC 4857, Cretaceous?, Jesús del Monte, Tamarindo, Habana Province, Cuba, $\times 1.5$.

8. Ambulacrum III of the holotype, $\times 6$. 

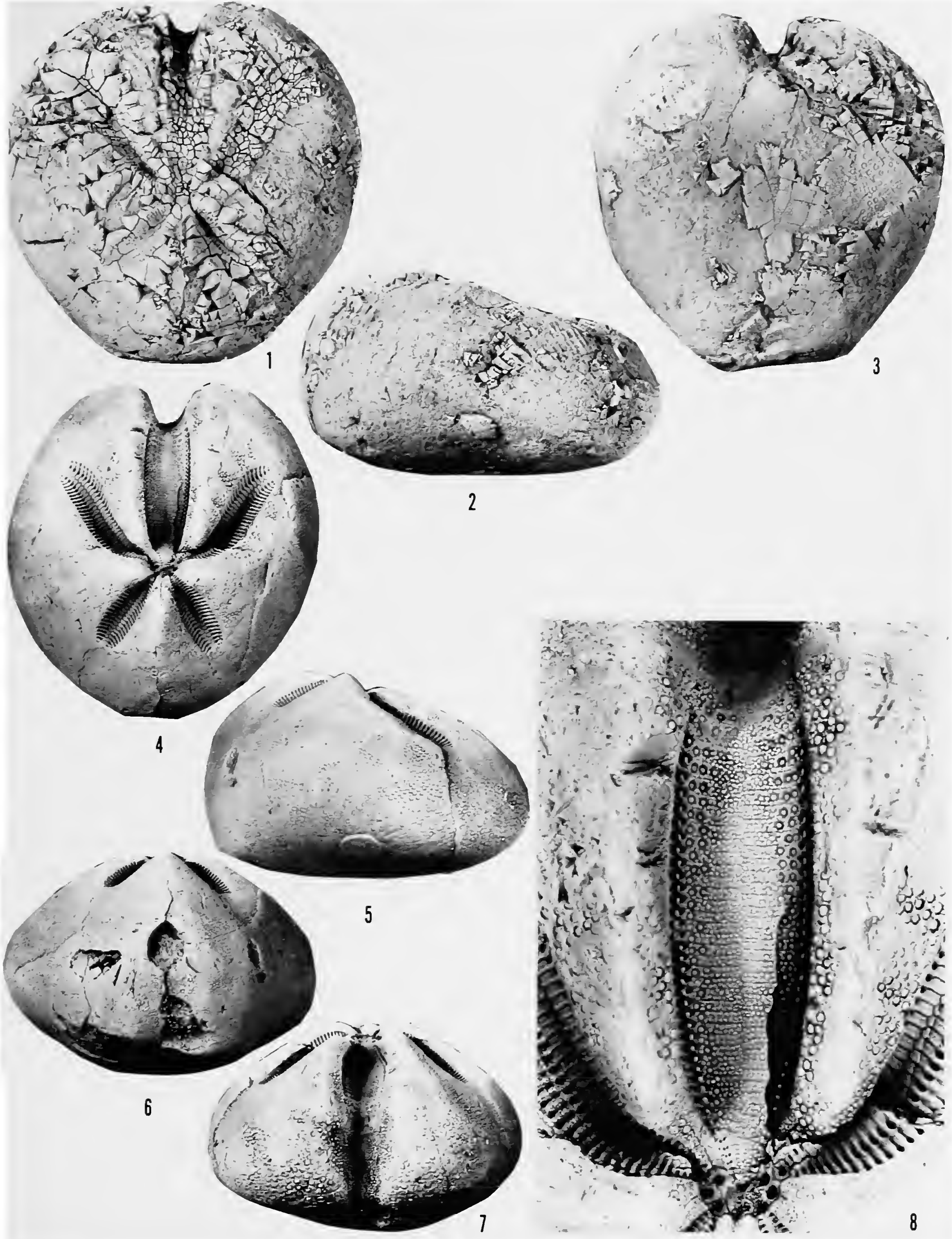


\section{PLATE 8}

Hemiaster (Trachyaster) herrerae (Lambert and Sánchez Roig)

1. Apical system of the holotype, SRC 4857, Cretaceous?, Jesús del Monte, Tamarindo, Habana Province, Cuba, $\times 15$. (See also Plate 7.)

\section{Hemiaster (Hemiaster) madrugensis Weisbord}

2-4. Dorsal, right side, and ventral views of the holotype PRI 3804, Late Cretaceous, on the property of Central San Antonio, $150 \mathrm{~m}$ NW of the sugar cane loading rack at Esperanza switch, $10 \mathrm{~km} \mathrm{E}$ of the mill and town of Madruga, near the eastern boundary of Habana Province, Cuba, $\times 2$.

Hemiaster (Hemiaster) siboneyensis Weisbord

5-7. Dorsal, right side, and ventral views of holotype, PRI 3805, Late Cretaceous, same locality as figures $2-4$ above, $\times 2.5$. 


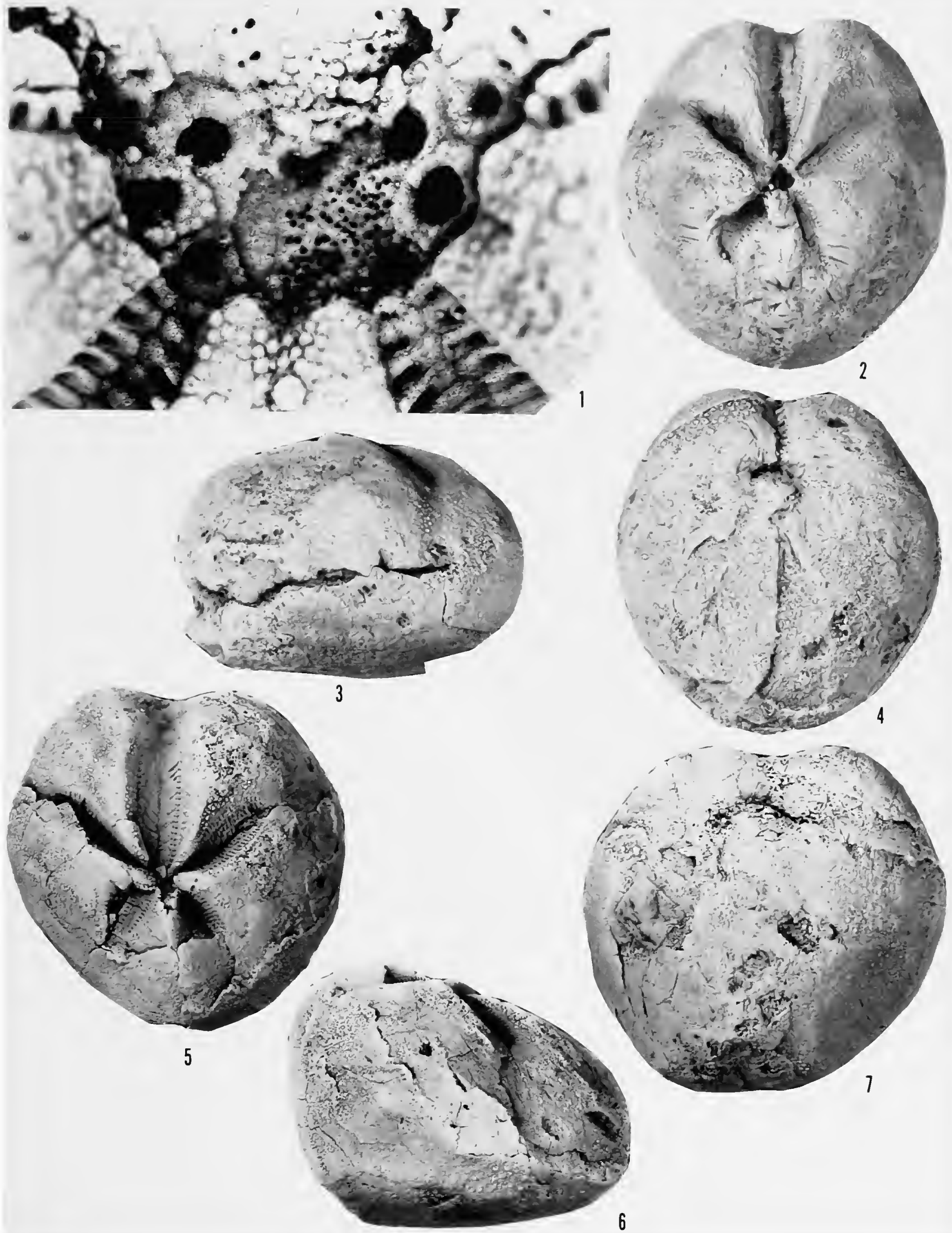




\section{PLATE 9}

\section{Pericosmus aguayoi (Sánchez Roig)}

1-3. Dorsal, ventral, and right side views of the holotype of Pericosmus giganteus Sánchez Roig (= P. aguayoi), SRC 4130, Oligocene-Miocene, "Pedro Hernandez" farm, Tamarindo, Morón, Camagüey Province, Cuba, $\times 1$. 


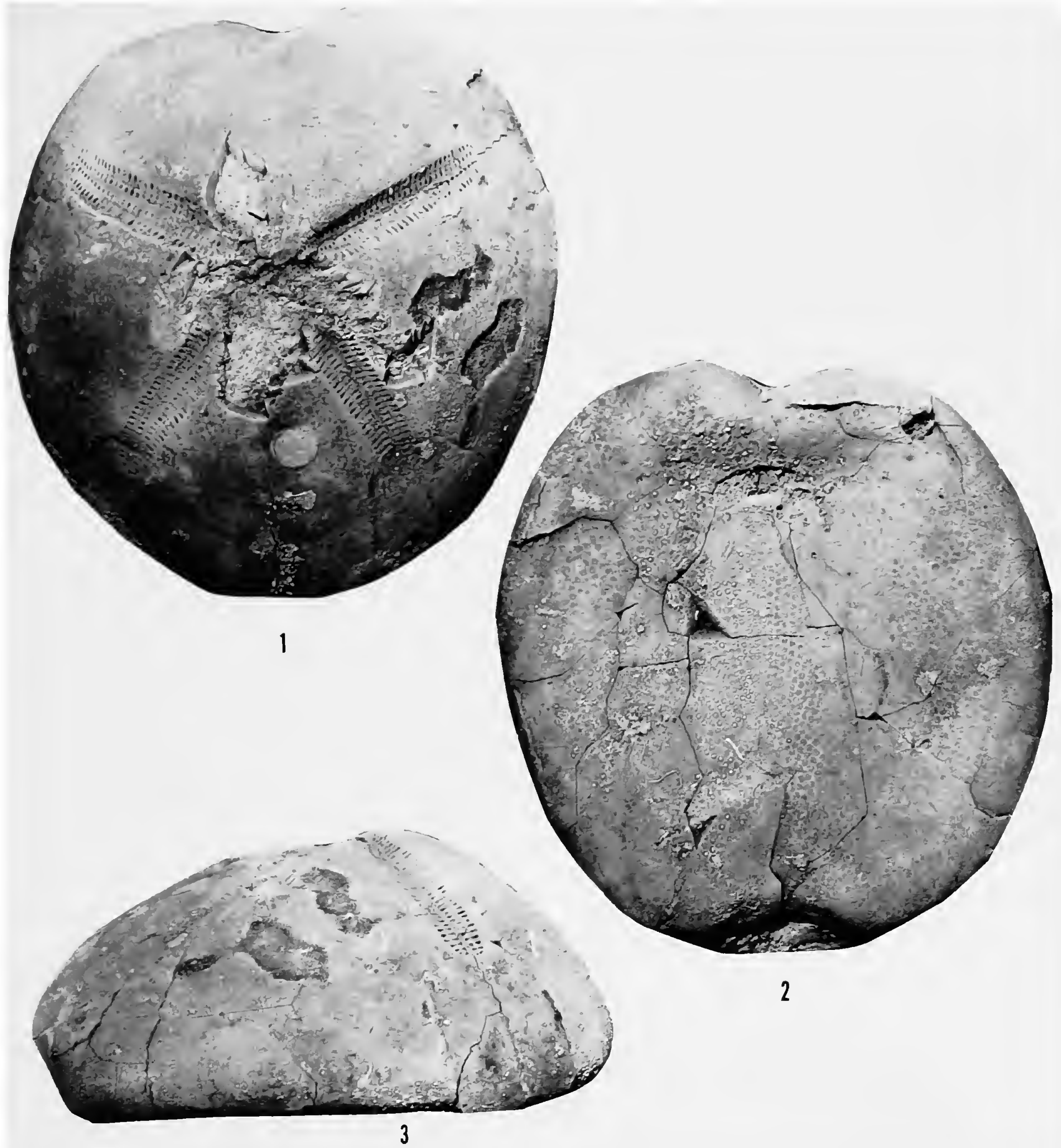




\section{PLATE 10}

\section{Pericosmus aguayoi (Sánchez Roig)}

1-4. Dorsal, ventral, right side, and rear views of the holotype, SRC 4268, Oligocene-Miocene, "Santa Ana" farm, Majagua district, Ciego de Avila, Camagüey Province, Cuba, $\times 1$.

5, 6. Dorsal and right side views of holotype of Mauritanaster depressus Sánchez Roig $(=P$. aguayoi), SRC 4139, Oligocene-Miocene, "Santa Ana" farm, Majagua district, Ciego de Avila, Camagüey Province, Cuba, $\times 1$. 

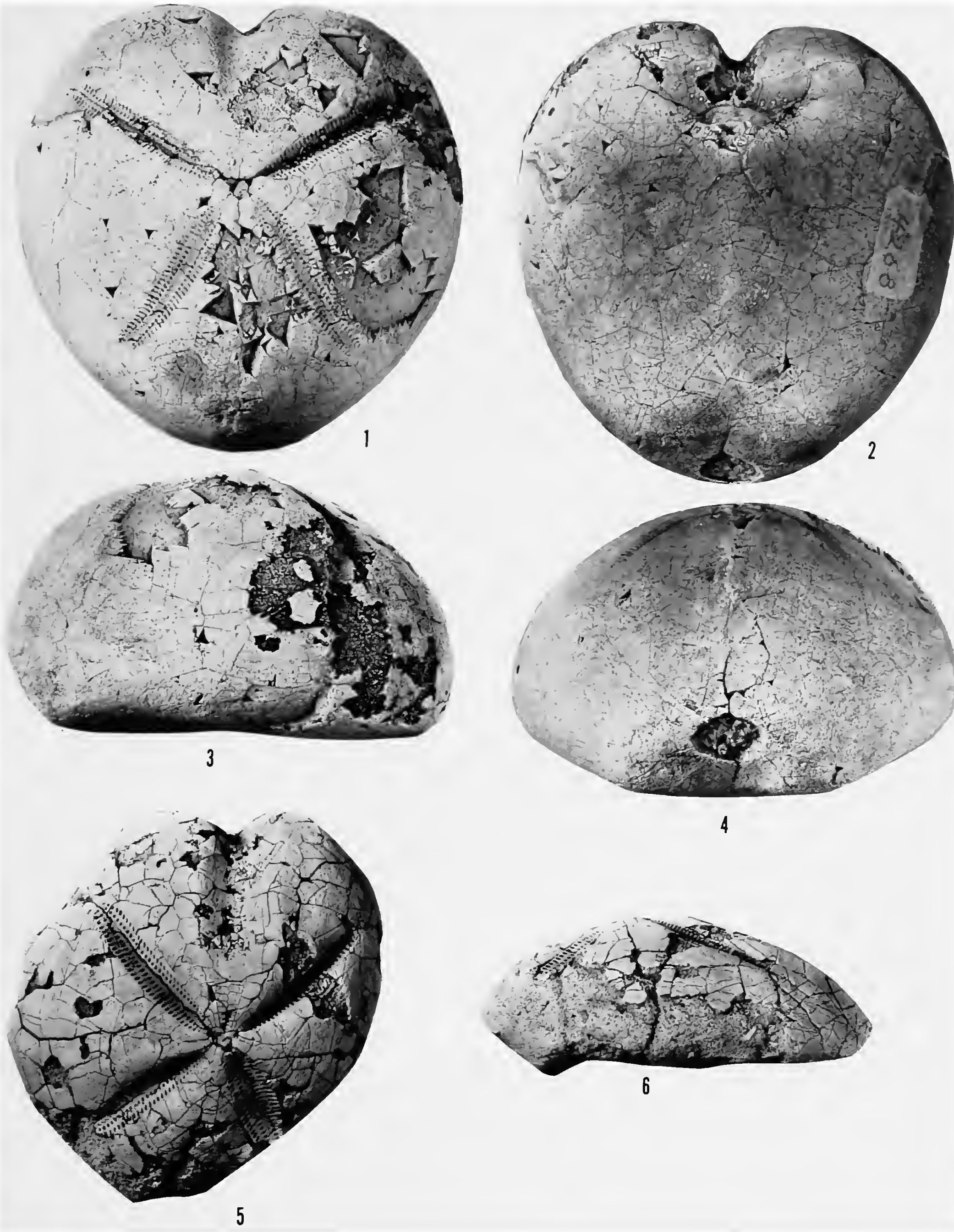

4

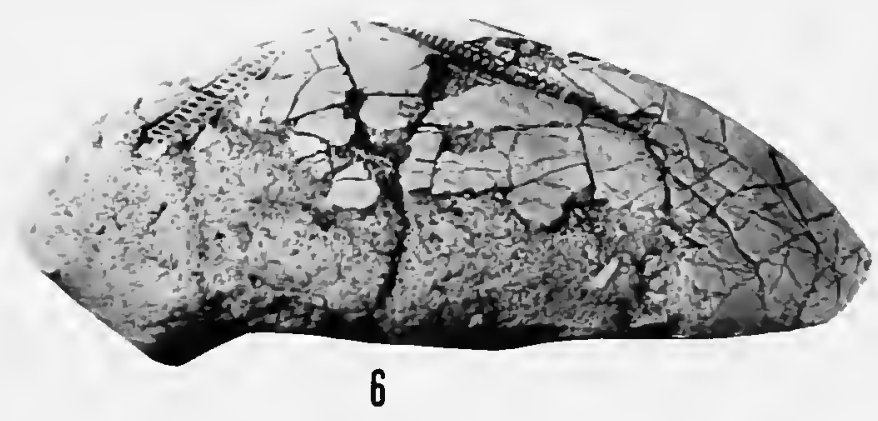




\section{PLATE 11}

Pericosmus aguayoi (Sánchez Roig)

1-3. Dorsal, left side, and ventral views of holotype of Mauritanaster marroquinensis Sánchez Roig (= P. aguayoi), SRC 4357, Oligocene-Miocene, "Blanquizal" farm of the estate of Campanioni, Marroquín district, Morón, Camagüey Province, Cuba, $\times 1$.

4-6. Dorsal, right side, and ventral views of lectotype of Periocosmus valenzuelai Sánchez Roig (=P. aguayoi), SRC 4021, Miocene, "Sunset" farm (formerly "Gerona") on highway between Cayajabos and Artemisa, Pinar del Rio Province, Cuba, $\times 1$.

\section{Pericosmus atolladosae (Sánchez Roig)}

7-9. Dorsal, right side, and ventral views of the holotype, SRC 4190, Eocene, "Atolladosa" farm, Majagua district, Ciego de Avila, Camagüey Province, Cuba, $\times 1$. 

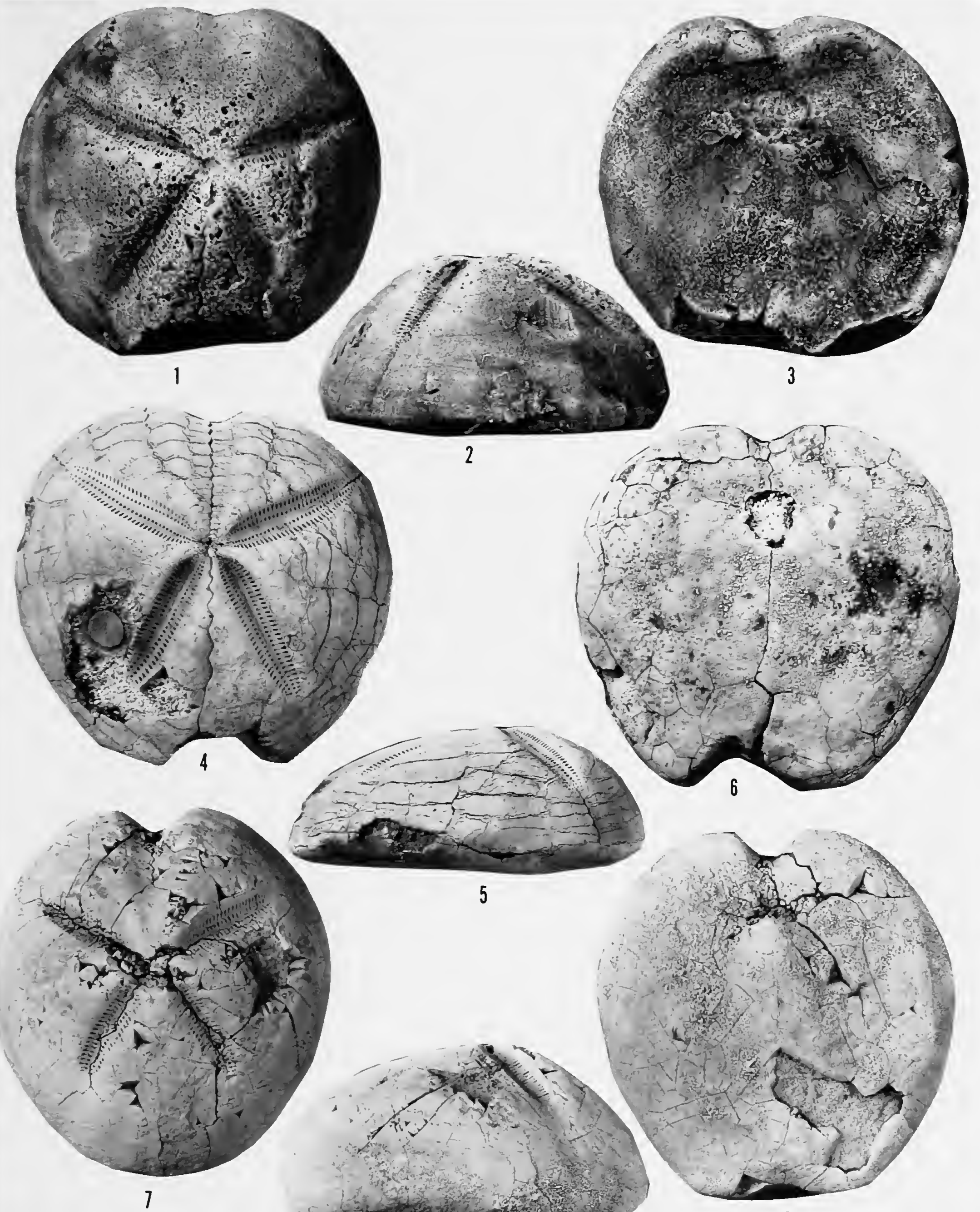

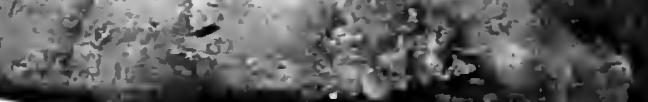
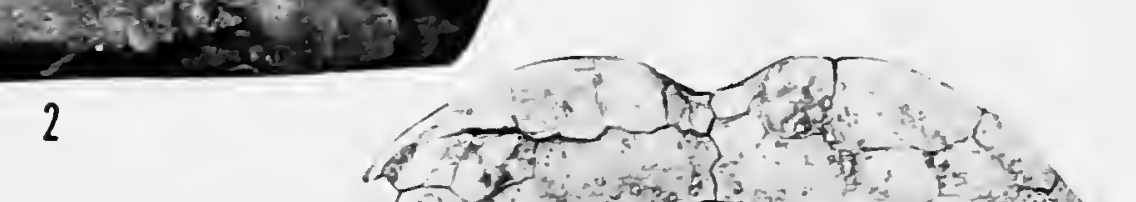
PLATE 12

Pericosmus atolladosae (Sánchez Roig)

1-4. Dorsal, rear, right side, and ventral views of the holotype of Pericosmus rojasi Sánchez Roig (= P. atolladosae), SRC 4300, Eocene, "Atolladosa" farm, Majagua district, Ciego de Avila, Camagüey Province, Cuba, $\times 1$.

5-8. Dorsal, right side, rear, and ventral views of the lectotype of Pericosmus zanolettiz Sánchez Roig (= P. atolladosae), SRC 4239, late Eocene, Loma "Los Constantinos," "La Ventura" farm, Marroquín district, Morón, Camagüey Province, Cuba, $\times 1$.

Pericosmus blanquizalensis Sánchez Roig

9-11. Dorsal, right side, and ventral views of the holotype, SRC 4106, Oligocene-Miocene, "Blanquizal" farm, Tamarindo district, Morón, Camagüey Province, Cuba $\times 1$. 

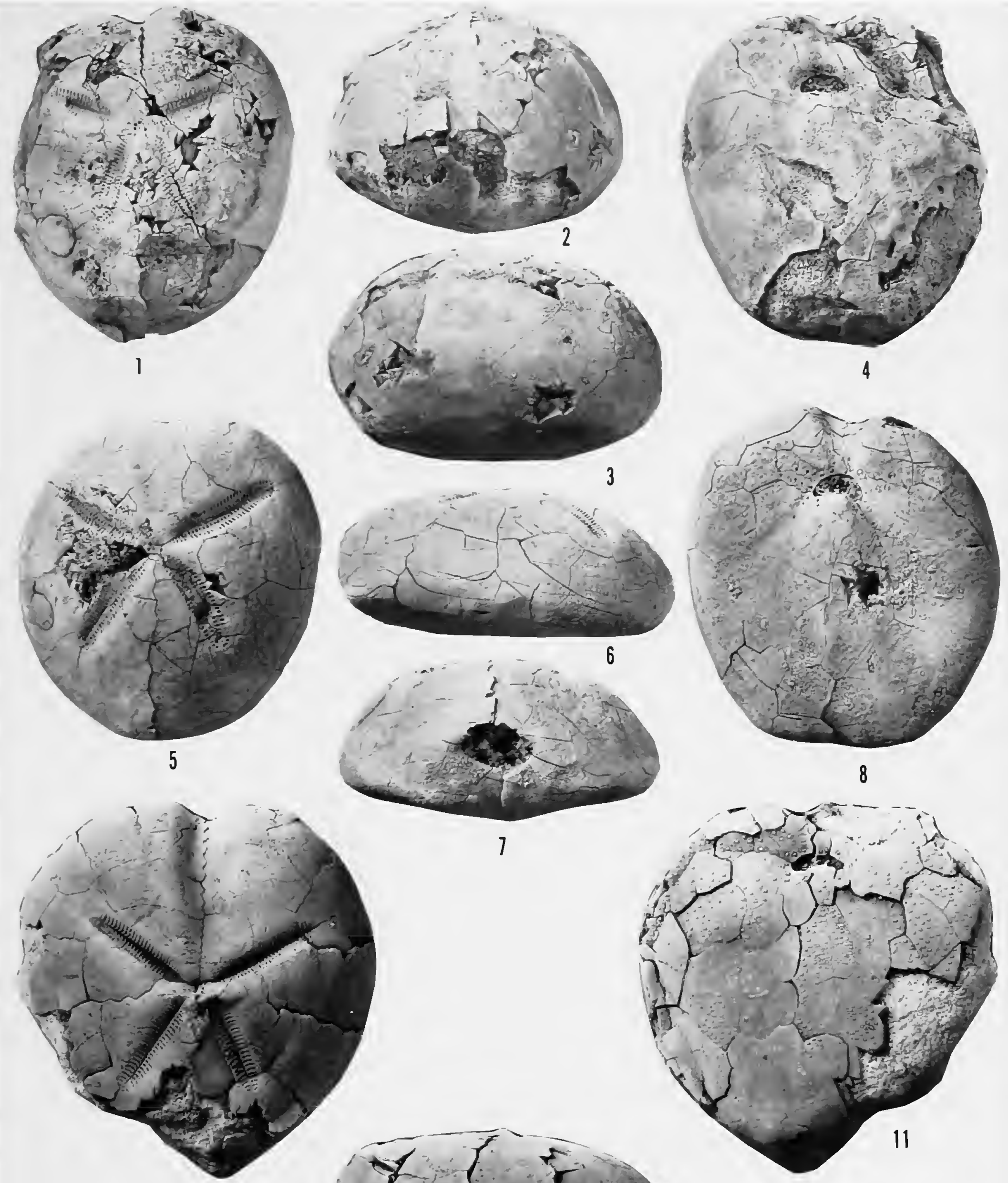

9

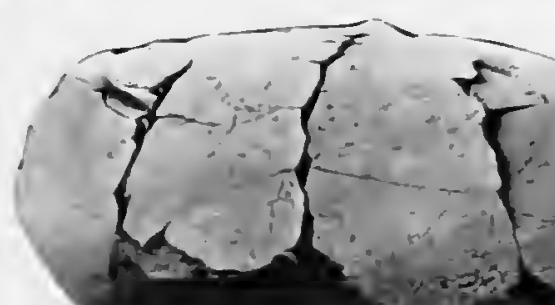


PLATE 13

\section{Pericosmus camagueyanus Sánchez Roig}

1-4. Dorsal, rear, ventral, and right side views of lectotype, SRC 4202, Oligocene-Miocene, $12 \mathrm{~km}$ NE of Jatibonico, Camagüey Province, Cuba, $\times 1$.

Pericosmus mortenseni (Sánchez Roig)

5-7. Dorsal, right side, and ventral views of the holotype, SRC 4185, Oligocene-Miocene, "Blanquizal" farm, Tamarindo, Morón, Camagüey Province, Cuba, $\times 1$. 


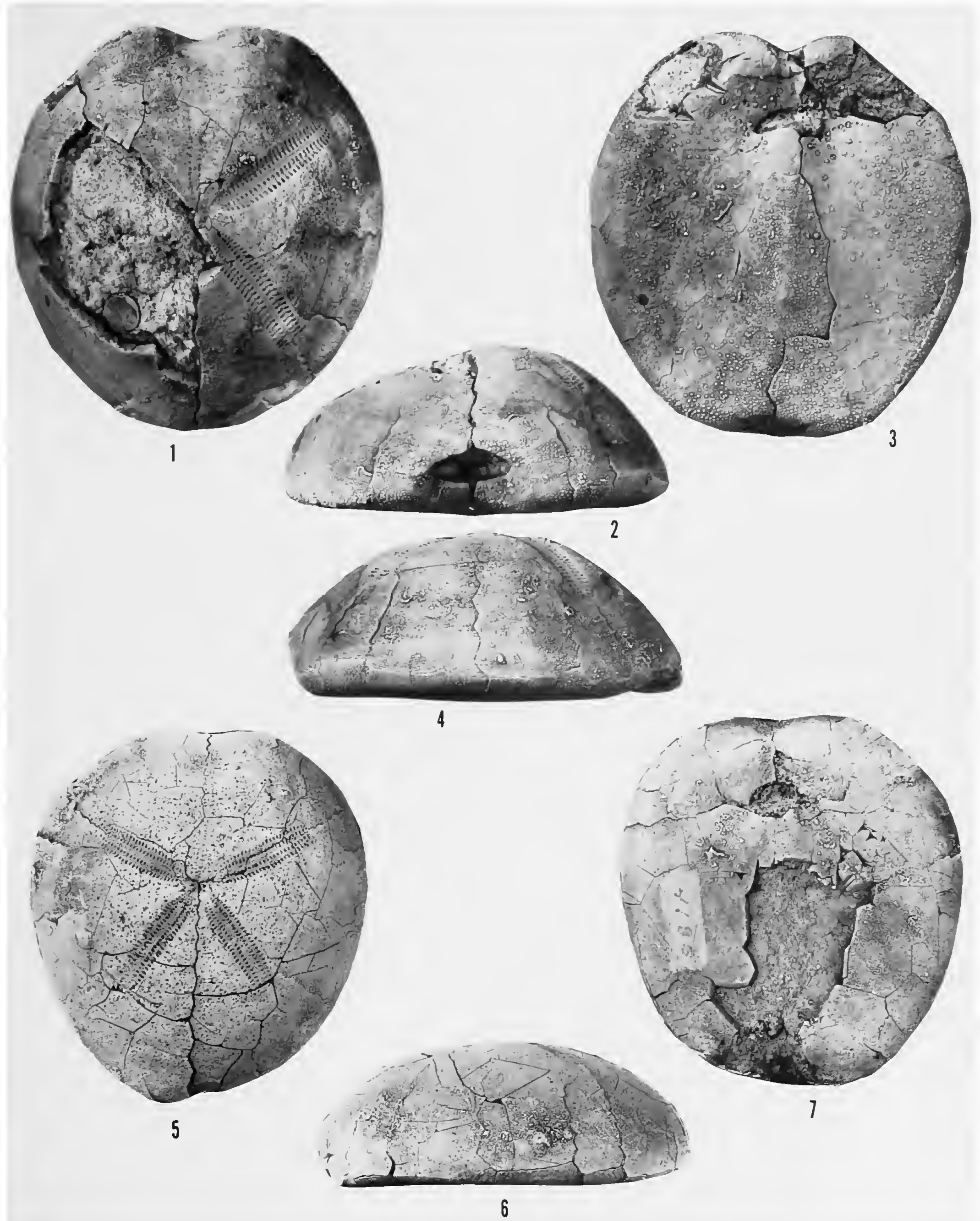




\section{PLATE 14}

\section{Schizaster bathypetalus Arnold and Clark}

1-3. Dorsal, ventral, and right side views of a topotype of Schizaster pentagonalis Sánchez Roig (= S. bathypetalus), SRC 4762, middle Eocene, Loma Caoba, San Diego de los Baños, Pinar del Rio Province, Cuba, $\times 1$.

4. Peripodium in phyllode of ambulacrum III of same specimen, $\times 22$.

5. Peripodia in ambulacrum III on dorsal side of same specimen, $\times 10$.

6. Dorsal view of lectotype of Schizaster gigas Sánchez Roig (=S. bathypetalus), SRC 4946, middle Eocene, Loma Caoba, San Diego de los Baños, Pinar del Rio Province, Cuba, $\times 1$. 


\section{PLATE 15}

\section{Schizaster bathypetalus Arnold and Clark}

1. Dorsal view of a paratype, MCZ 3442, Eocene, in the Spring Mount Region, S and W towards Seven Rivers, St. James Parish, Jamaica, $\times 1$.

2. Dorsal view of the holotype, MCZ 3294, Eocene, same locality as above, $\times 1$.

3. Dorsal view of Schizaster gigas Sánchez Roig ( $=$ S. bathypetalus) USNM 341250, middle to late Eocene, Loma Caoba, San Diego de los Baños, Pinar del Rio Province, Cuba, $\times 1$.

4. Rear view of Schizaster gigas Sánchez Roig ( $=$ S. bathypetalus), ANSP 16653, Eocene, Loma Caoba, San Diego de los Baños, Pinar del Rio Province, Cuba, $\times 1$.

5-7. Dorsal, ventral, and right side views of Schizaster gigas Sánchez Roig (= S. bathypetalus), SRC 5001, middle to late Eocene, Loma Caoba, San Diego de los Baños, Pinar del Rio Province, Cuba, $\times 1$. 


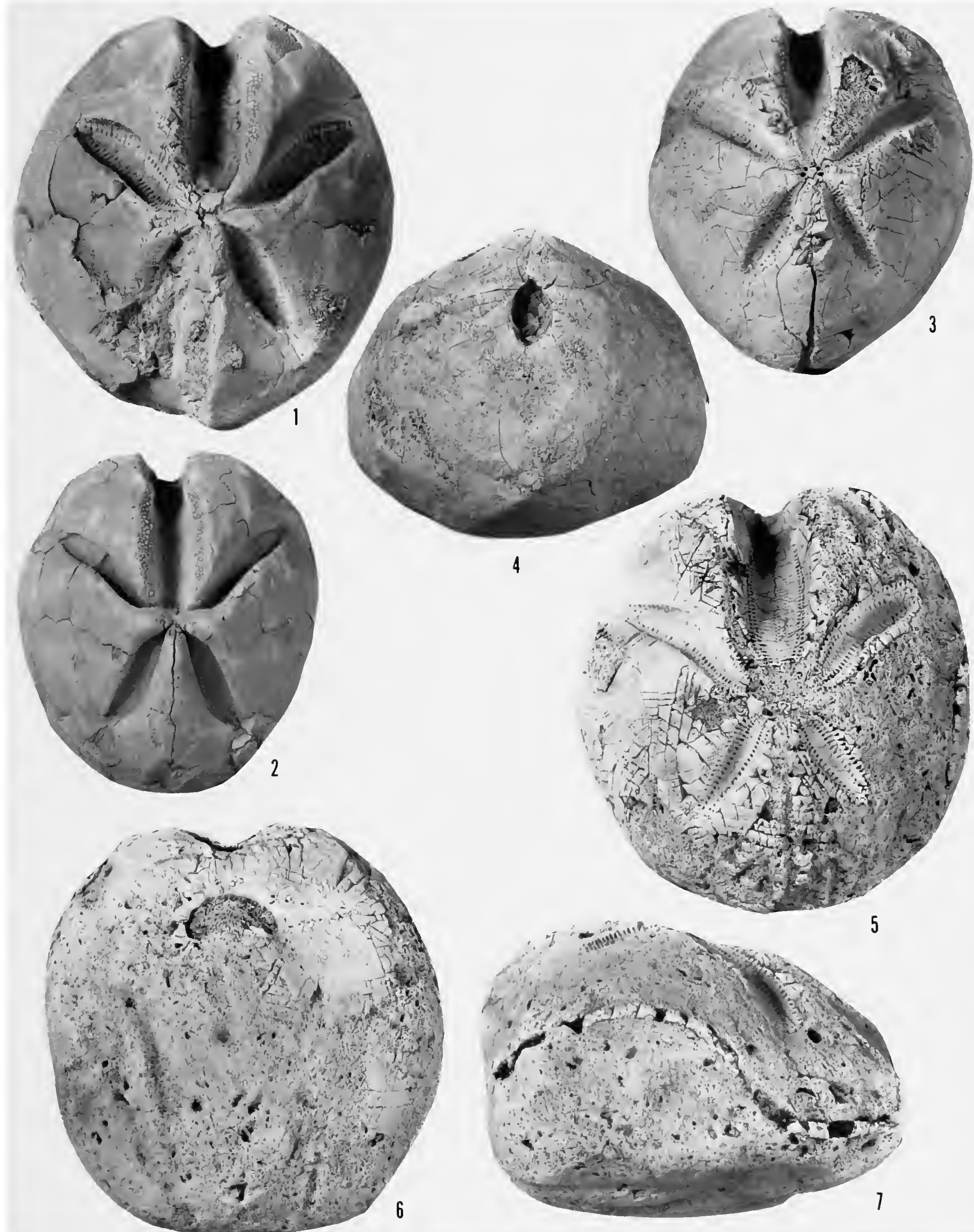




\section{PLATE 16}

\section{Schizaster camagueyensis (Weisbord)}

1-3. Dorsal, right side, and ventral views of the holotype, PRI 3831, late Eocene, $4 \mathrm{~km}$ ENE of Loma Calisto, from cut along railroad between Nuevitas and Pastelillo, about $2 \mathrm{~km}$ $\mathrm{SE}$ of Nuevitas railroad station, Camagüey Province, Cuba, $\times 3$.

\section{Schizaster cariagensis (Sánchez Roig)}

4-7. Dorsal, front, right side, and ventral views of the holotype, SRC 4219, OligoceneMiocene, SSE of Cartagena, $1 \mathrm{~km} \mathrm{~N}$ side of railroad, Las Villas Province, Cuba, $\times 1$. 

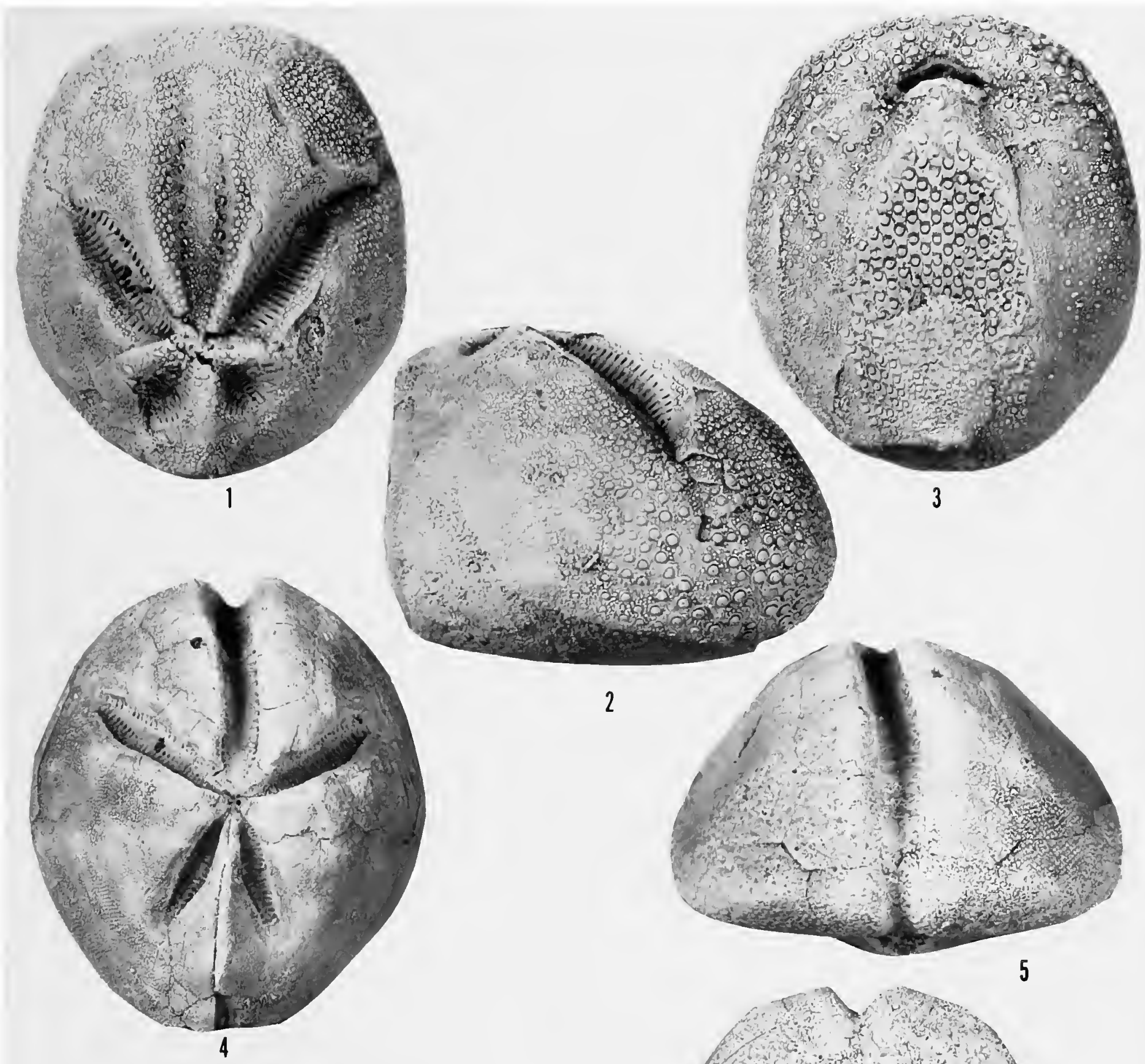

H.

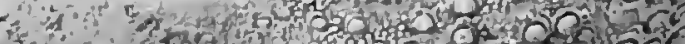

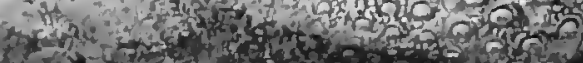

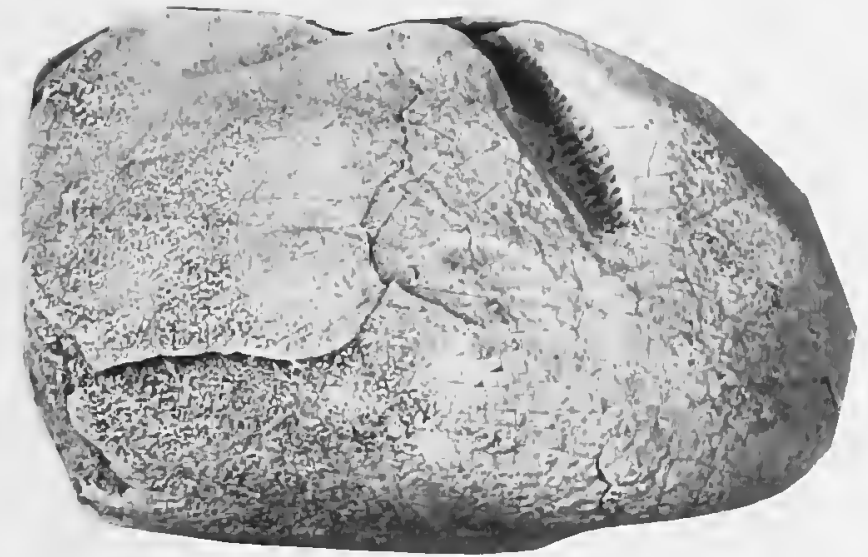

2
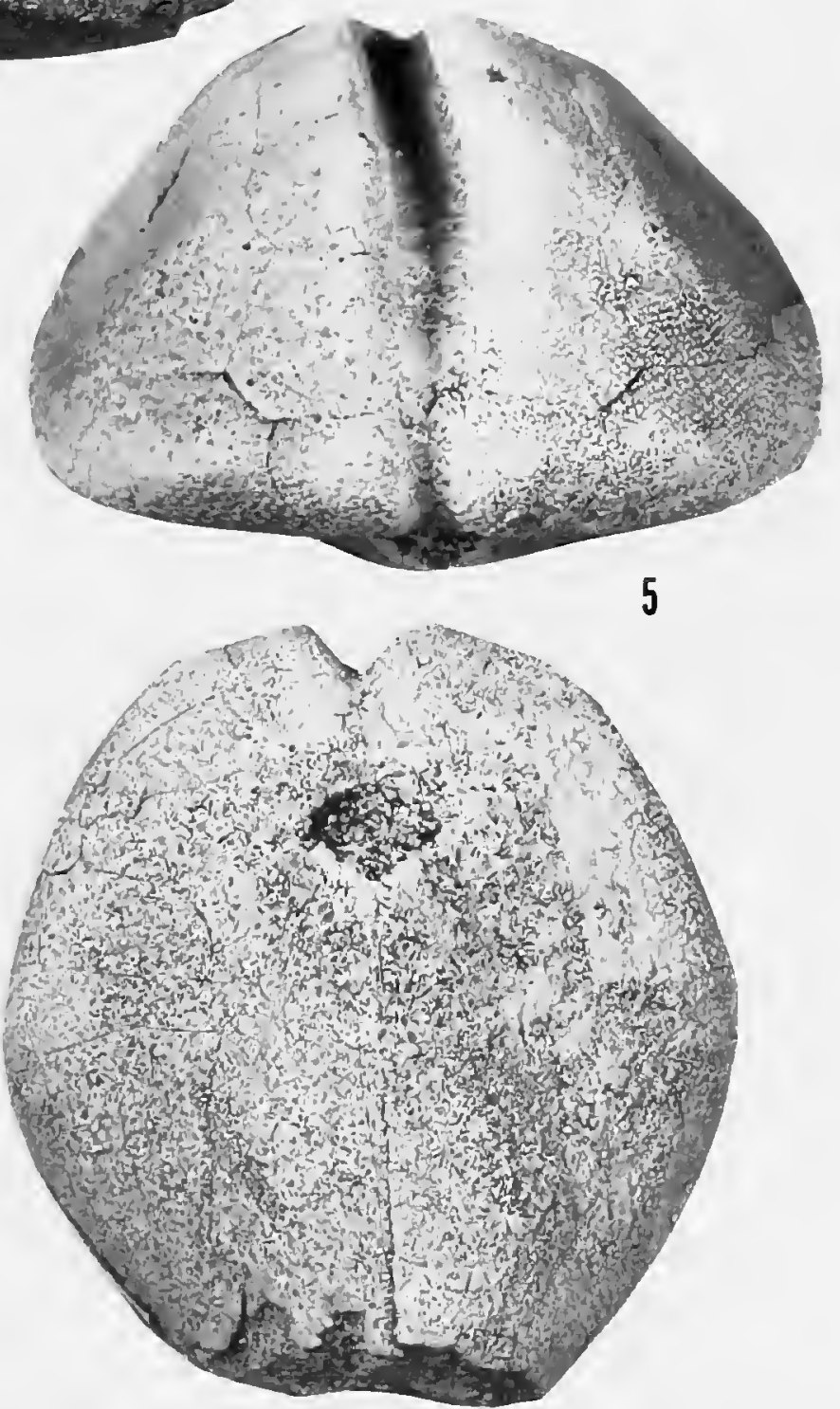


\section{PLATE 17}

\section{Schizaster cubilabellae (Weisbord)}

1-3. Dorsal, right side, and ventral views of the holotype, PRI 3833, late Eocene, from cut along the railroad between Nuevitas and Pastelillo, about $2 \mathrm{~km}$ SE of Nuevitas railroad station, Camagüey Province, Cuba, $\times 2.5$.

Schizaster delgador (Sánchez Roig)

4-6. Dorsal, ventral, and right side views of holotype, SRC 4211, Oligocene-Miocene, "Cervantes" farm, San José de las Lajas, Habana Province, Cuba, $\times 1$. 

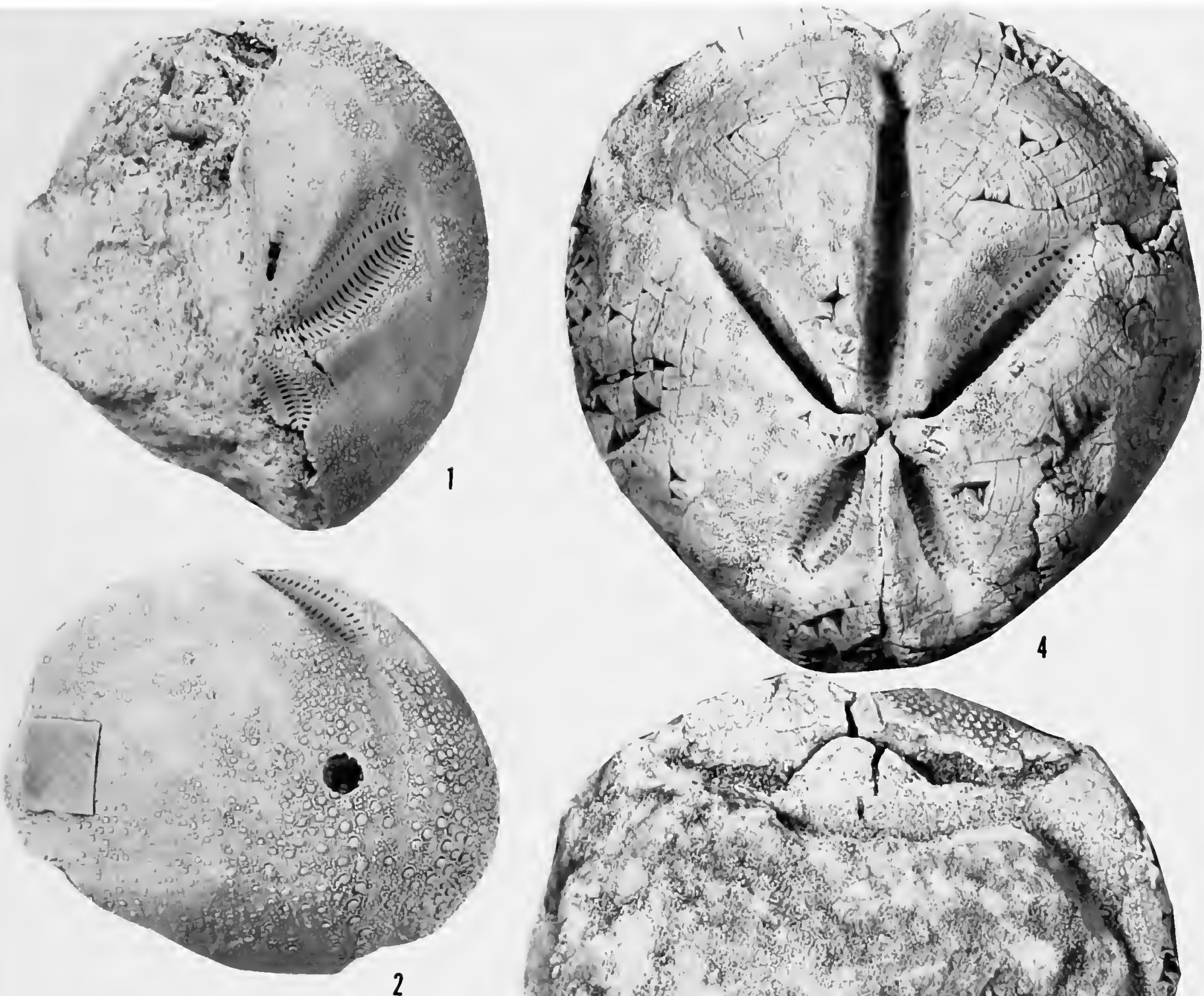

2
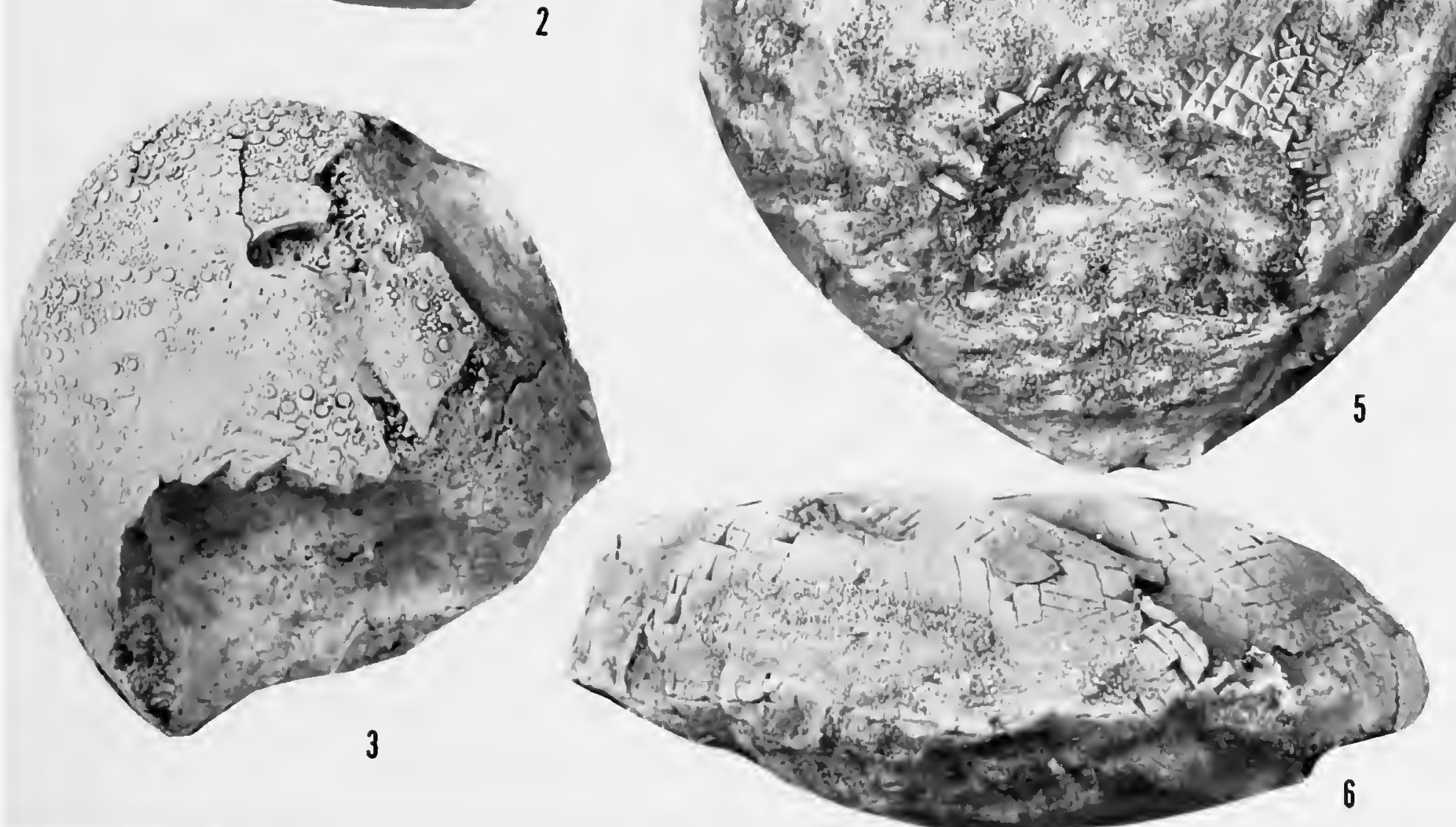


\section{PLATE 18}

\section{Schizaster egozcuei Lambert}

1-4. Dorsal, right side, rear, and ventral views of a topotypic specimen, SRC 4234, OligoceneMiocene, Cienfuegos, Santa Clara (now Las Villas) Province, Cuba, $\times 1$.

\section{Schizasler fernandezi Sánchez Roig}

5-8. Dorsal, right side, rear, and ventral views of the holotype, SRC 4148, Miocene, "Las Cuevas" estate, Km 186 on highway from Pinar del Rio to Guane, Pinar del Rio Province, Cuba, $\times 2$.

9-11. Dorsal, rear and right side views of topotype, SRC 4147, Miocene, same locality as figures $5-8$ above, $\times 2$. 


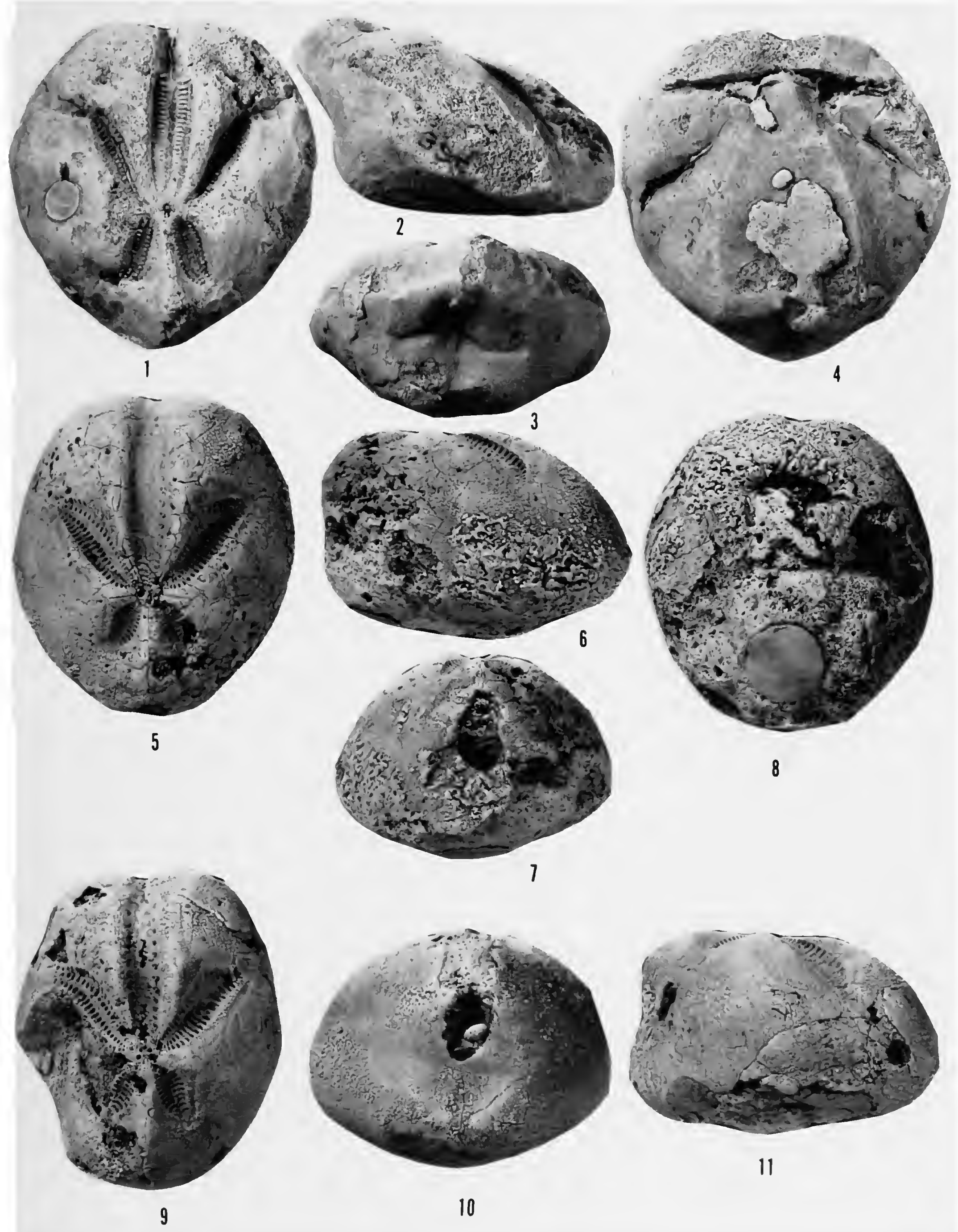




\section{PLATE 19}

\section{Schizaster gerthi Pijpers}

1-4. Dorsal, ventral, rear, and right side views of Schizaster clarki (Sánchez Roig) (= S. gerthi), ANSP 16674a, Eocene, Loma Caoba, 5 km S of San Diego de los Baños, Pinar del Rio Province, Cuba, $\times 1.5$.

5. Dorsal view of topotype of Schizaster clarki $(=S$. gerthi $)$, USNM 341252, Eocene, Loma Caoba, $3 \mathrm{~km} \mathrm{~S}$ of San Diego de los Baños, E of old road to Cantera, Pinar del Rio Province, Cuba, $\times 2.5$.

6. Dorsal view of paratype of Schizaster gerthi, University of Utrecht; late Eocene, SE of Seroe Montagne, W. Bonaire, $\times 1$.

7. Anterior ambulacra of specimen in figure $5, \times 6$.

8. Phyllode II of specimen in figures $1-4, \times 20$. 

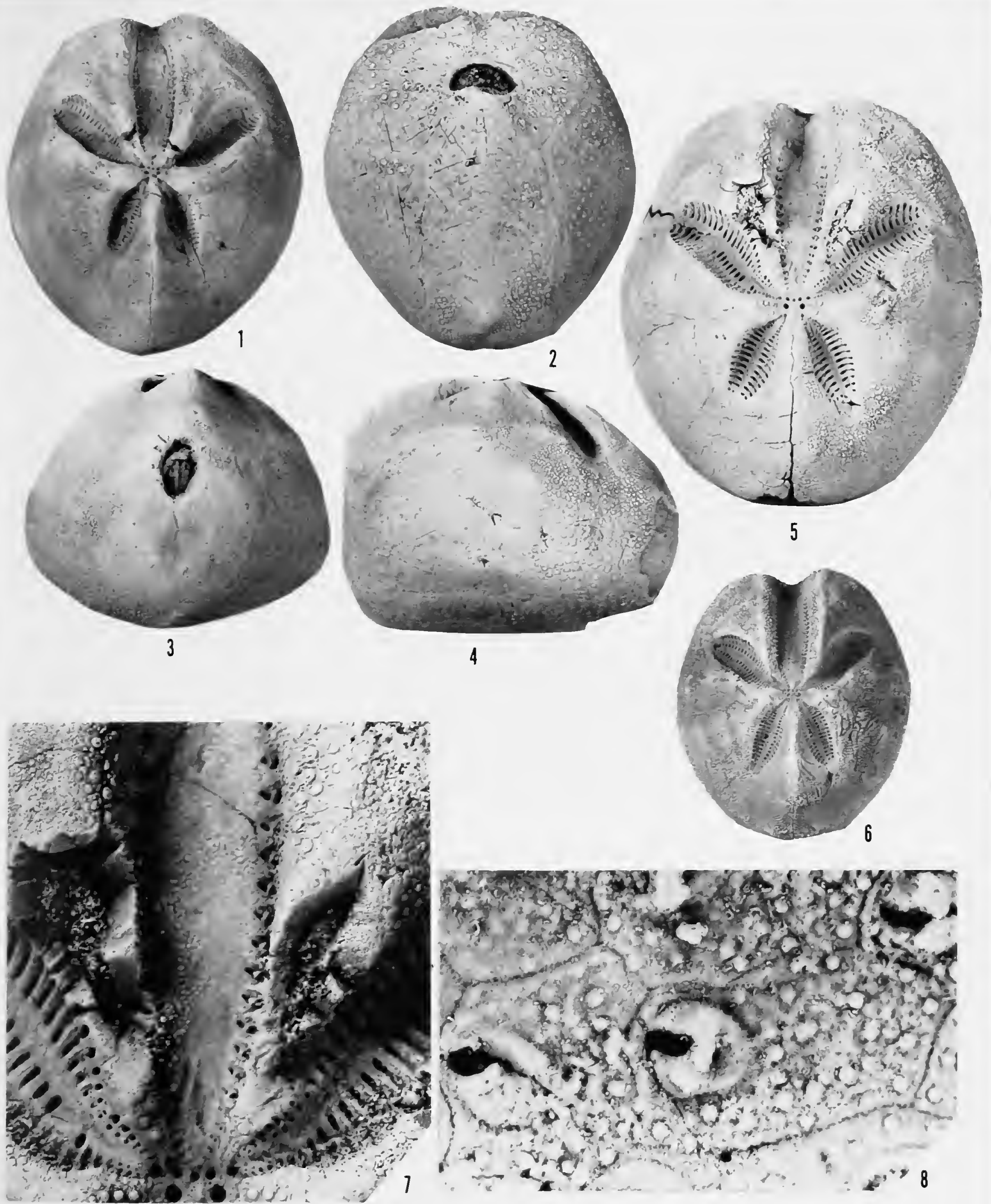

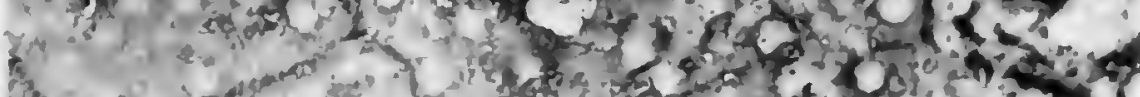

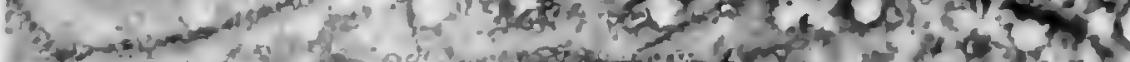

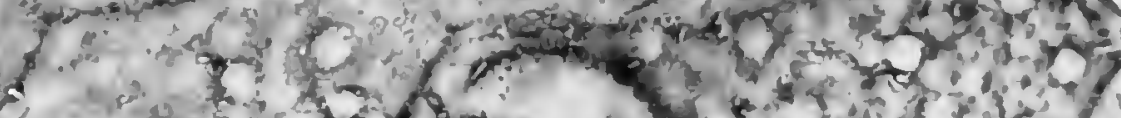

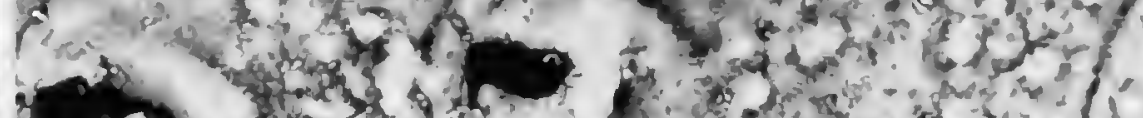

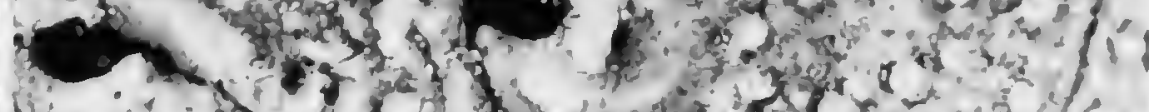

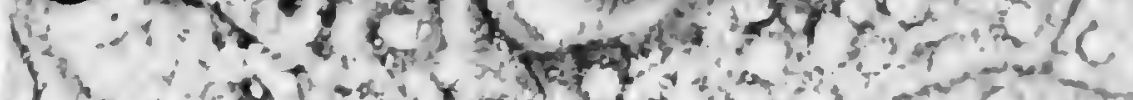

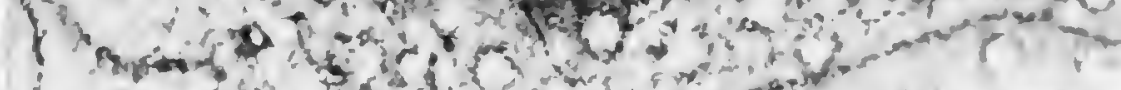
$6 x+4=0,8$ 


\section{PLATE 20}

\section{Schizaster llagunoi Lambert and Sánchez Roig}

1-4. Dorsal, ventral, rear, and left side views of the lectotype, SRC 4217, middle Eocene, estate of Doña Juana, Santiago de las Vegas, Habana Province, Cuba, $\times 1$.

\section{Schizaster munozi Sánchez Roig}

5-7. Dorsal, right side, and ventral views of topotype of Paraster tschopi Palmer (= S. munozi), MCZ 4040, Oligocene-Miocene, Palmer locality 1553, Km 202 United Railroad, 0.5 km $\mathrm{S}$ of Km 213 on Central Highway, $23 \mathrm{~km}$ E of Colon church, Mantanzas Province, Cuba, $\times 1$.

8. Peristomal region of same specimen, $\times 3$. 

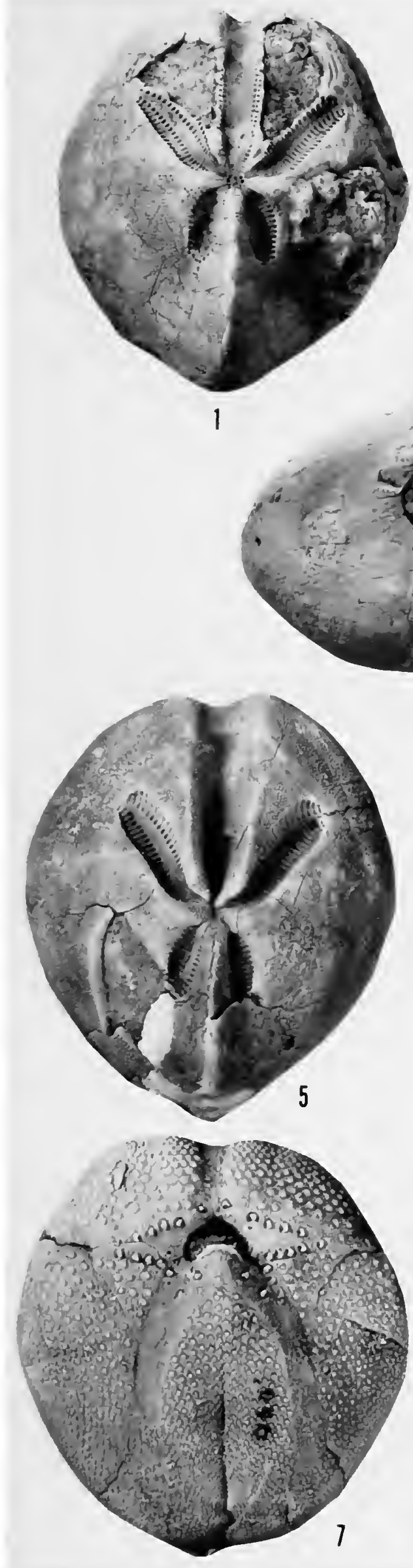
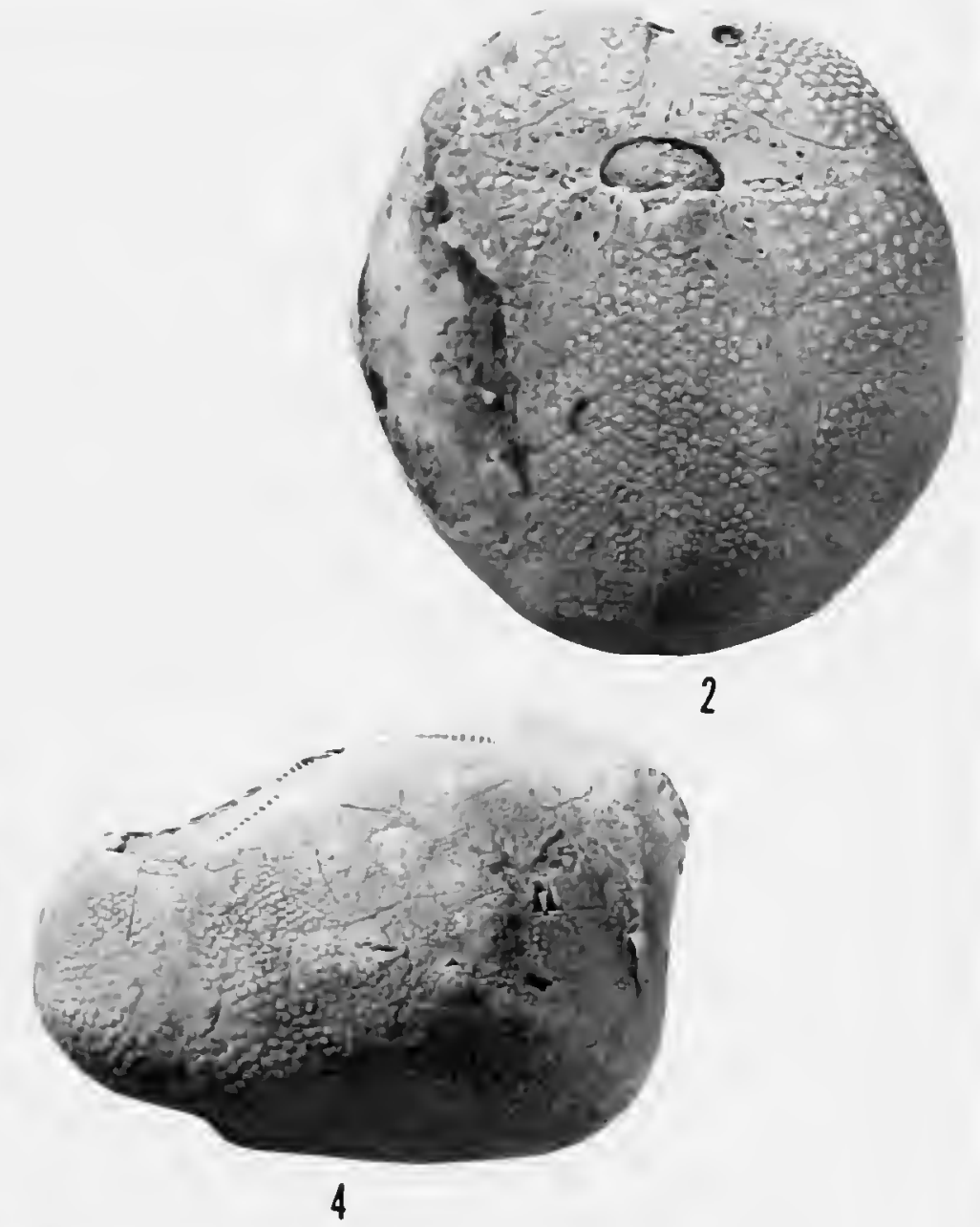

3

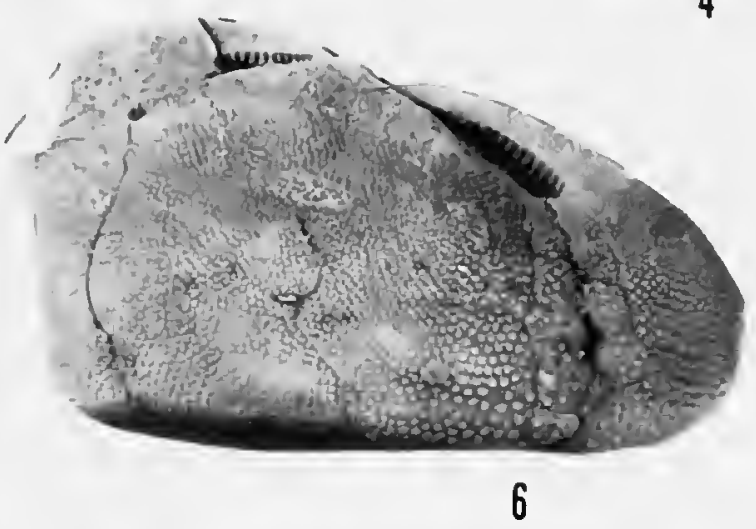

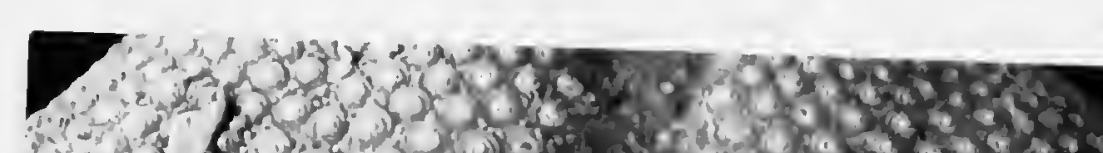

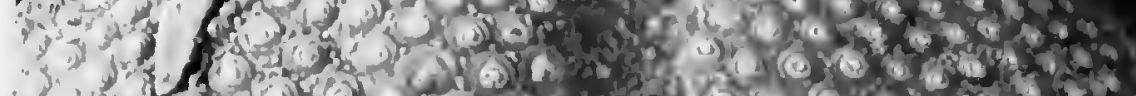

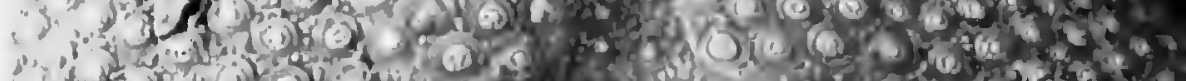
Pu

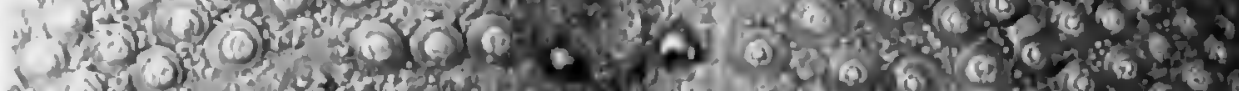

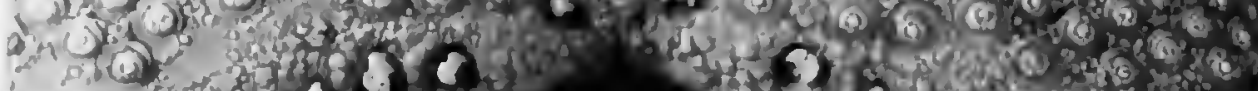

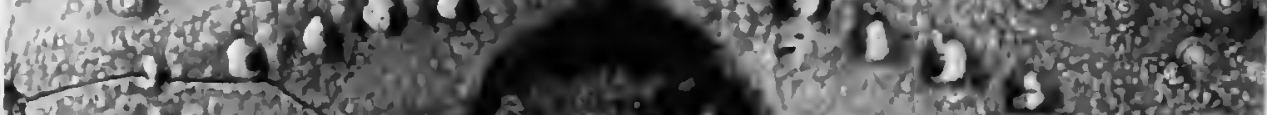

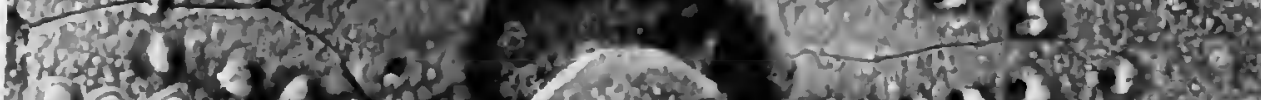

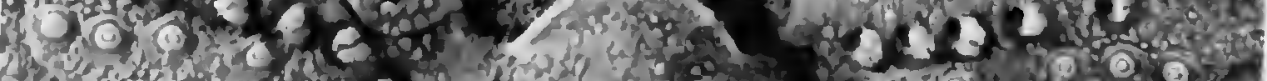

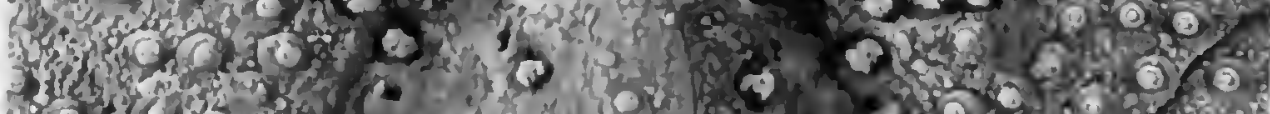

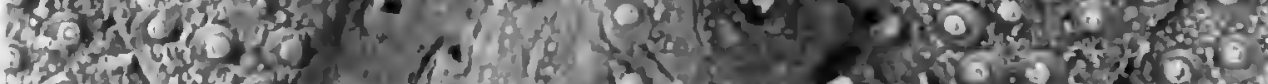

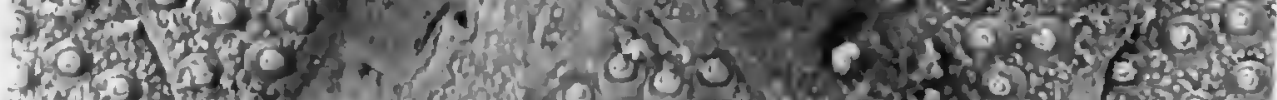

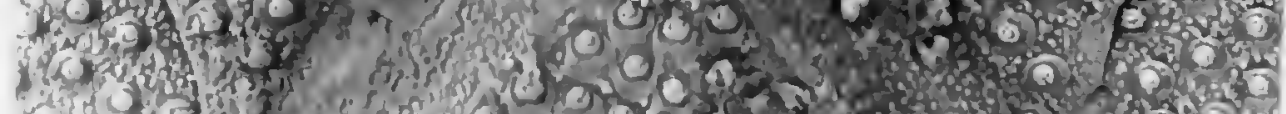

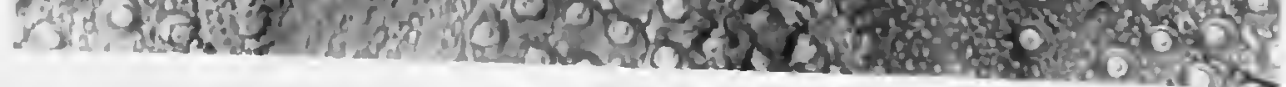




\section{PLATE 21}

\section{Schizaster munozi Sánchez Roig}

1-4. Dorsal, ventral, rear, and right side views of the holotype of Paraster ischopi Palmer $(=S$. munozi), SRC 4255, Oligocene-Miocene, Palmer locality 1553, Km 202 United Railroad, $0.5 \mathrm{~km} \mathrm{~S}$ of Km 213 on Central Highway, $23 \mathrm{~km}$ E of Colon church, Matanzas Province, Cuba, $\times 1$.

5-8. Dorsal, ventral, right side, and rear views of the holotype of Schizaster riveroi Sánchez Roig (= S. munozi), SRC 4194, early Miocene, quarry on the outskirts of Cardenas, Matanzas Province, Cuba, $\times 1.25$. 


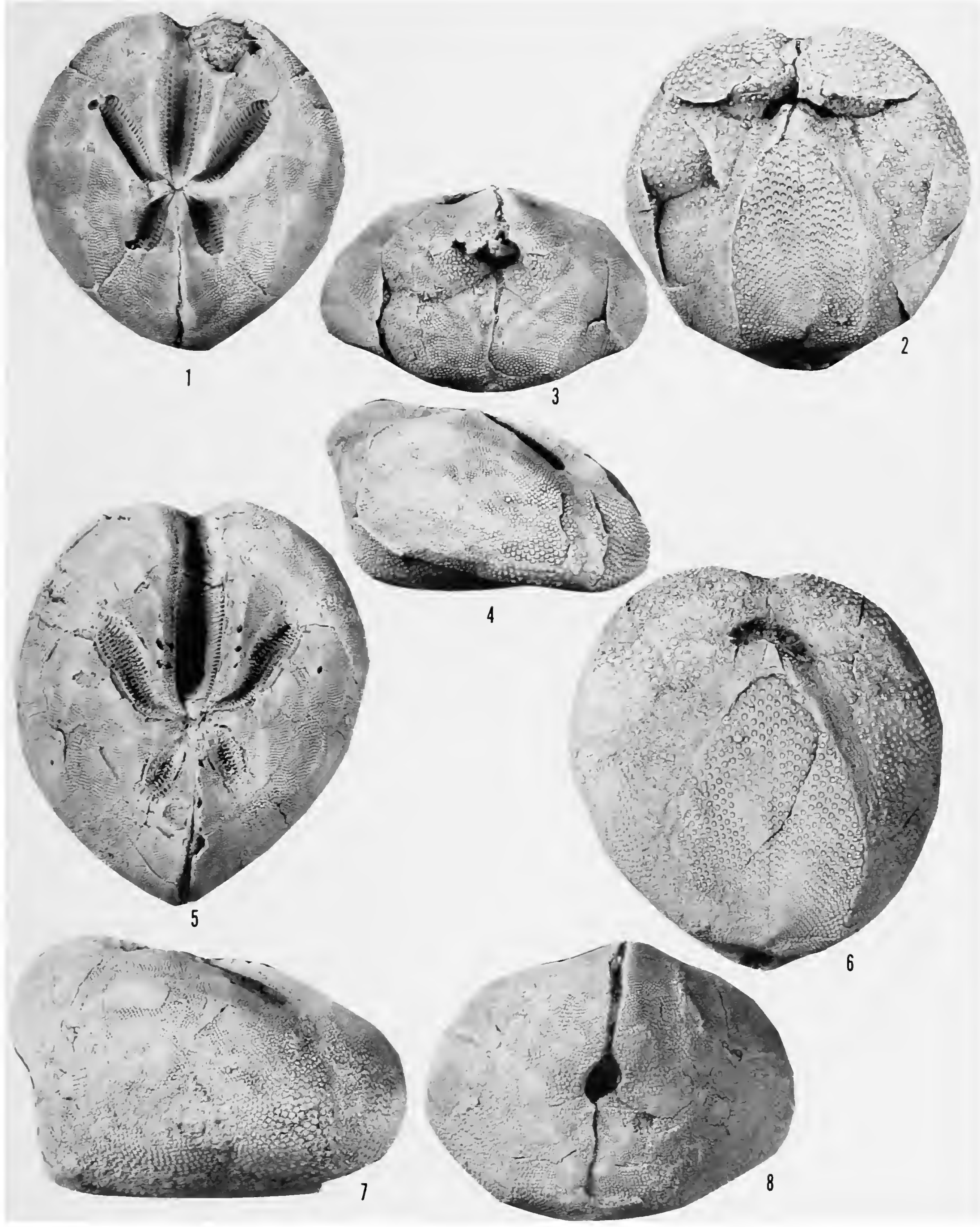


PLATE 22

\section{Schizaster munozi Sánchez Roig}

1-3. Dorsal, right side, and ventral views of the holotype, SRC 4224, late Oligocene, quarry near Cabezas, Matanzas Province, Cuba, $\times 1$.

4-6. Dorsal, right side, and ventral views of the lectotype of Schizaster salutis Sánchez Roig (= S. munozi), SRC 4187, early Miocene, Lastra estate, La Salud, Habana Province, Cuba, $\times 1$.

7-9. Dorsal, right side, and ventral views of the lectotype of Paraster orientalis Sanchez Roig (=S. munozi), SRC 4254, Oligocene-Miocene, roadcut in Central Highway, Km $753.5 \mathrm{E}$ of Habana, $18.5 \mathrm{~km}$ W of Holguin, Oriente Province, Cuba, $\times 2$. 

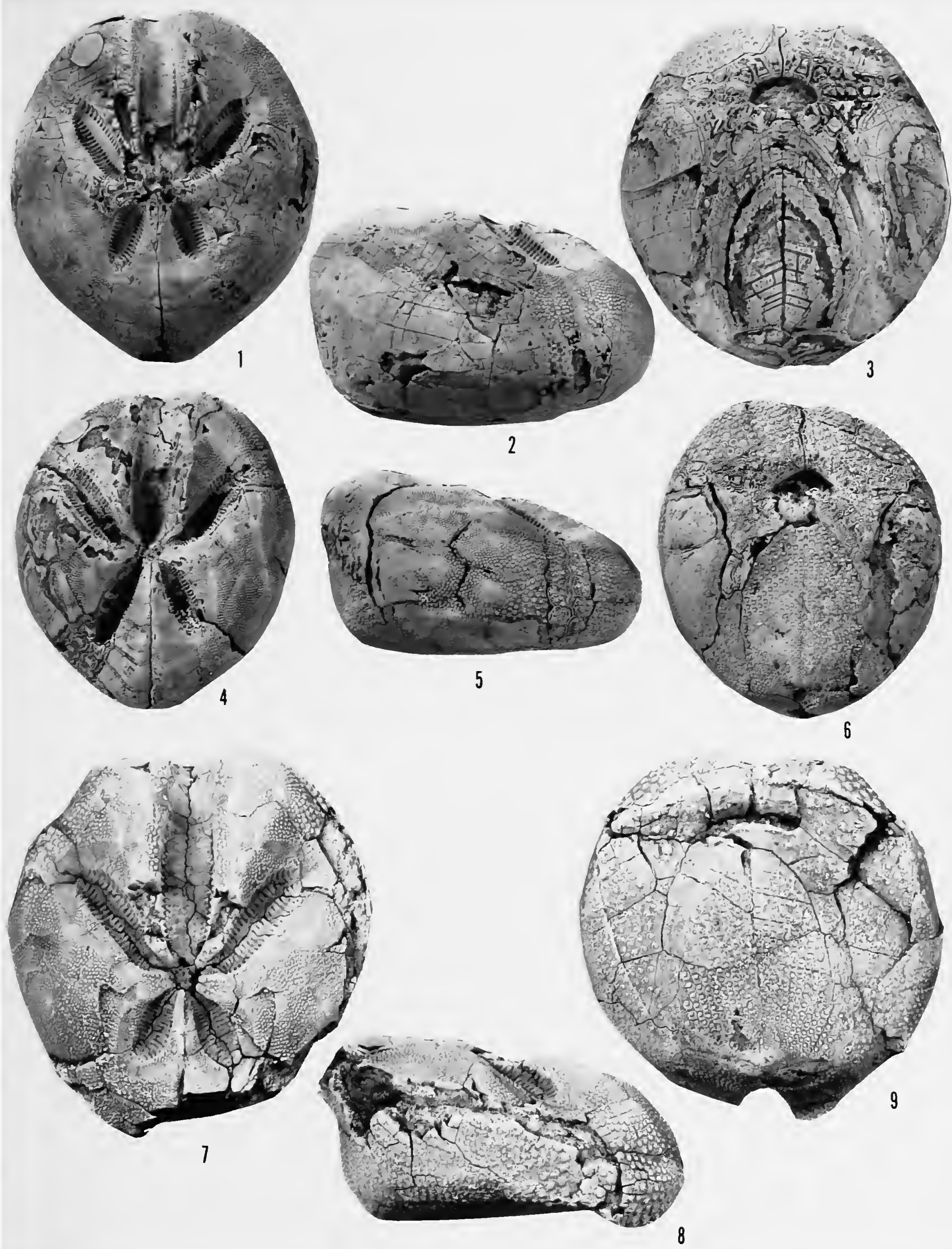
PLATE 23

Schizaster munozi Sánchez Roig

1. Dorsal view of the lectotype of Schizaster guirensis Sánchez Roig (= S. munozi), SRC 4251, early Miocene, Maria Teresa farm, Km 40-41, on highway from San Antonio de los Baños to Guira, Habana Province, Cuba, $\times 1$.

\section{Schizaster nuevitasensis (Weisbord)}

2-4. Dorsal, right side, and ventral views of the holotype, PRI 3830, late Eocene, Weisbord loc. 714, from lenticular marls between Nuevitas and Pastelillo along railroad cut, about $2 \mathrm{~km}$ SE of Nuevitas railroad station, Camagüey Province, Cuba, $\times 2$.

5. Phyllode II of same specimen, $\times 10$. 

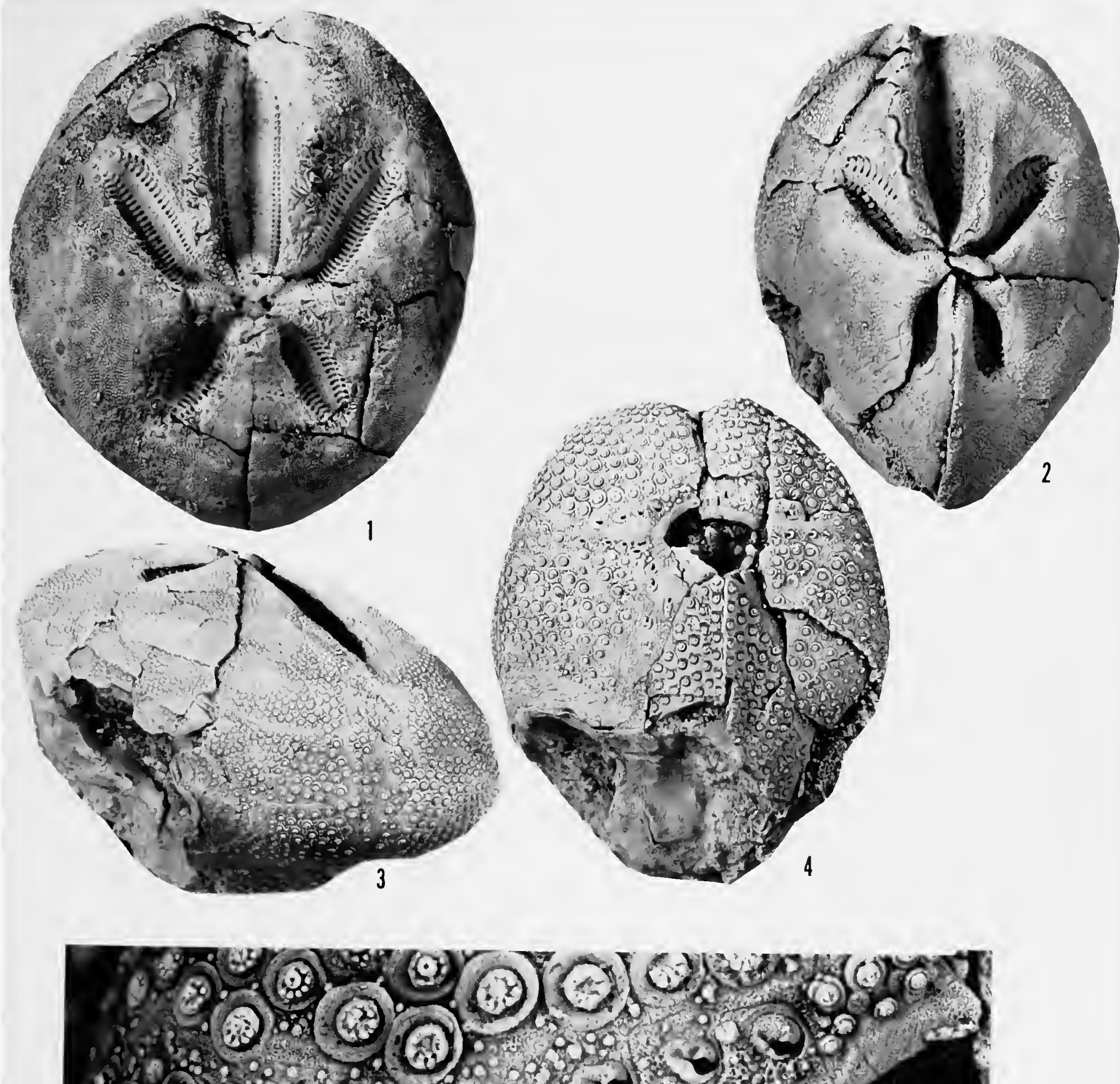

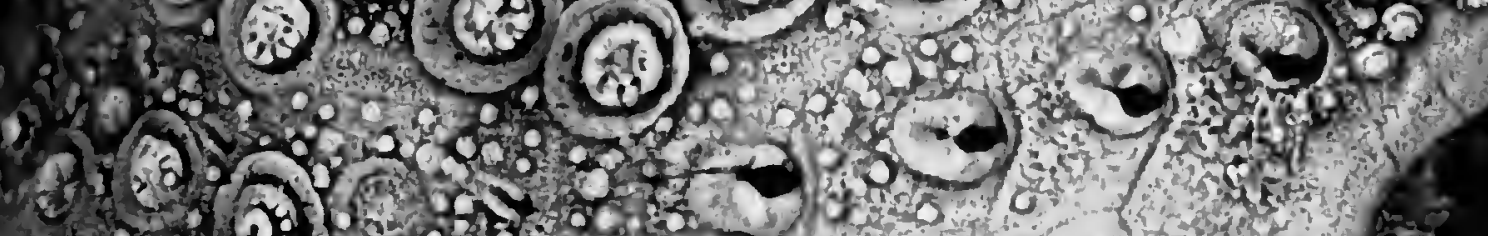
at (4)

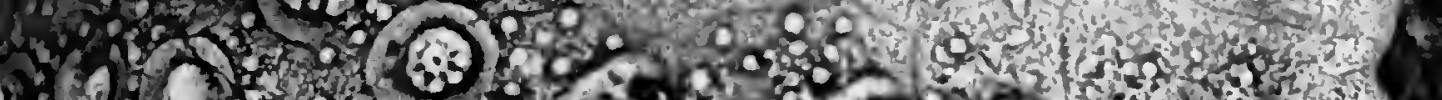

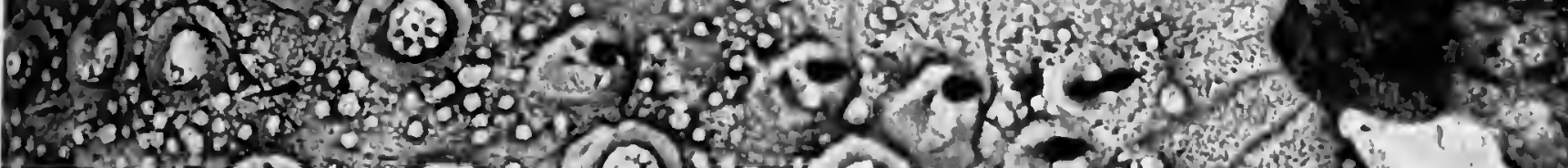

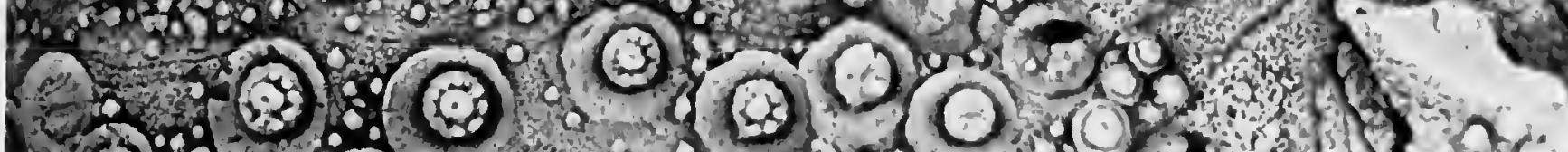

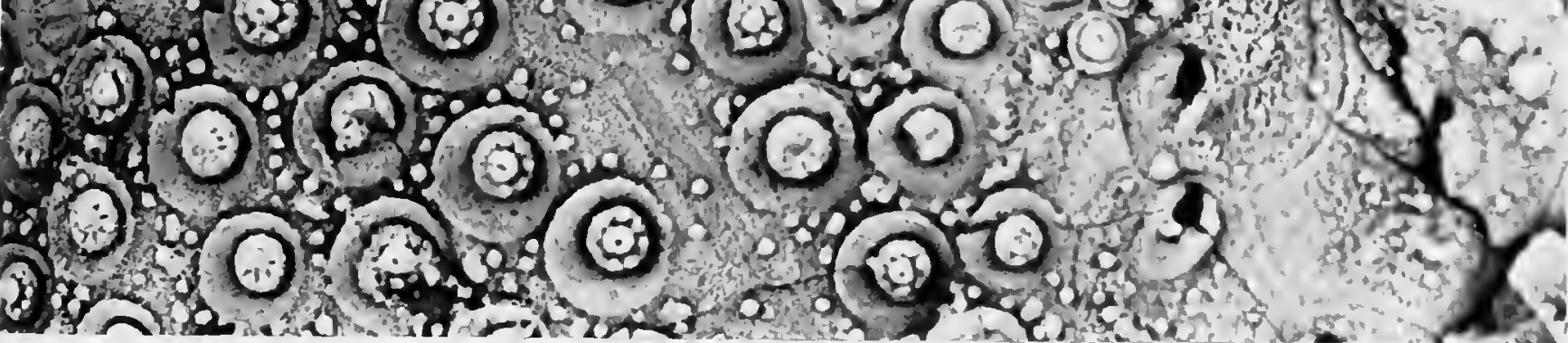




\section{PLATE 24}

\section{Schizaster formelli, new species}

1-3. Dorsal, right side, and ventral views of the holotype, ANSP 16675a, Eocene, Palmer loc. $687 \mathrm{a}, 15 \mathrm{mi}(24 \mathrm{~km}) \mathrm{E}$ of Camagüey on Maraguan road from Guanabanito River, Camagüey Province, Cuba, $\times 2.5$.

4-7. Dorsal, ventral, rear, and right side views of paratype, ANSP 16675b, Eocene, same locality as holotype, $\times 3$. 

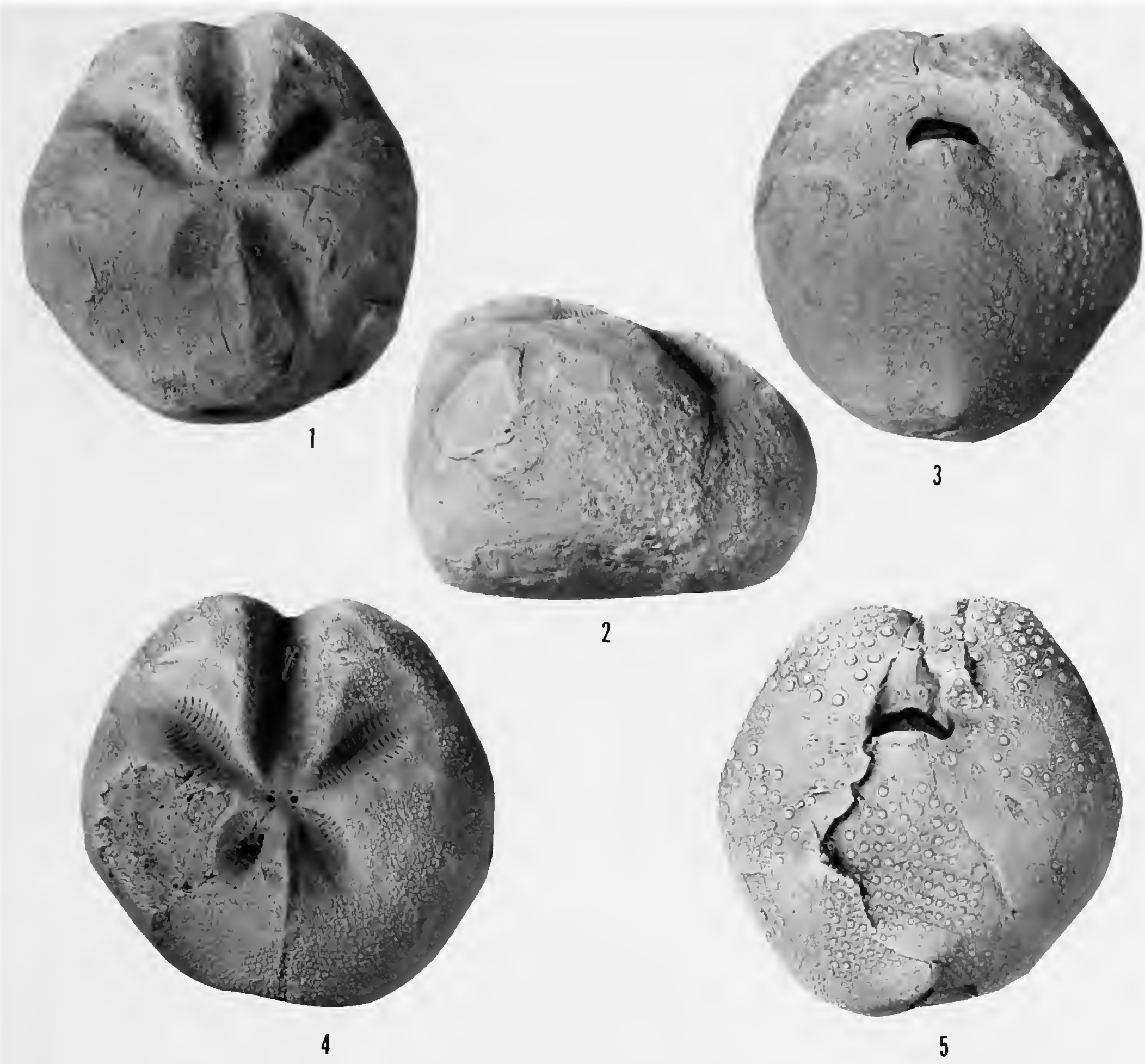

5
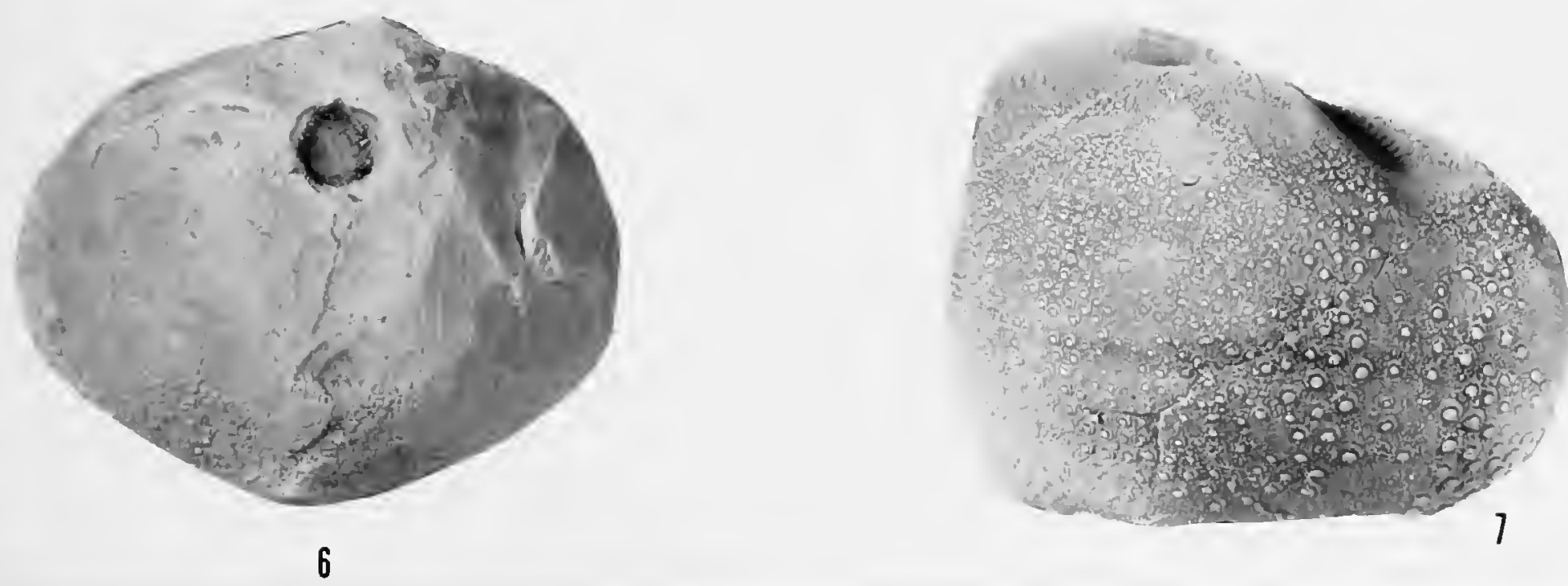


\section{PLATE 25}

\section{Schizaster rojasi Sánchez Roig}

1-4. Dorsal, ventral, rear, and right side views of the lectotype, SRC 4186, Oligocene-Miocene, "Blanquizal" farm, Cuatro Caminos, Marroquín, Morón, Camagüey Province, Cuba, $\times 1.5$.

\section{Schizaster sanctamariae Sánchez Roig}

5-8. Dorsal, rear, right side, and ventral views of holotype, SRC 4161, Oligocene-Miocene, $1.75 \mathrm{mi}(2.8 \mathrm{~km}) \mathrm{N}$ of Santa Maria del Rosario, Habana Province, Cuba, $\times 2$. 

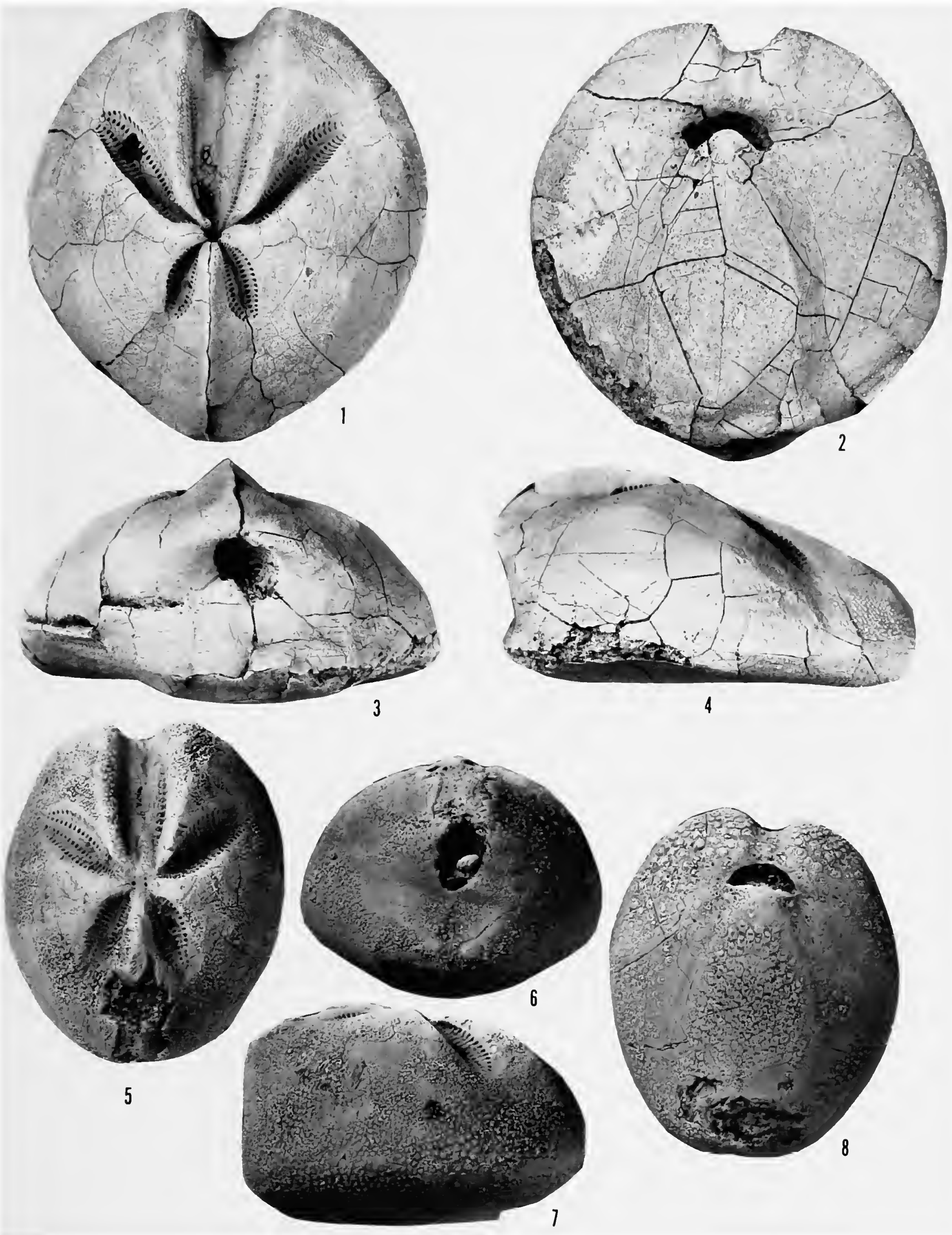


\section{PLATE 26}

\section{Schizaster santanae Sánchez Roig}

1-4. Dorsal, ventral, right side, and rear views of the lectotype, SRC 4266, middle to late Eocene, "Santa Ana" estate, Ciego de Avila, Majagua district, Camagüey Province, Cuba, $\times 1.5$.

5. Apical region of same specimen, $\times 20$. 

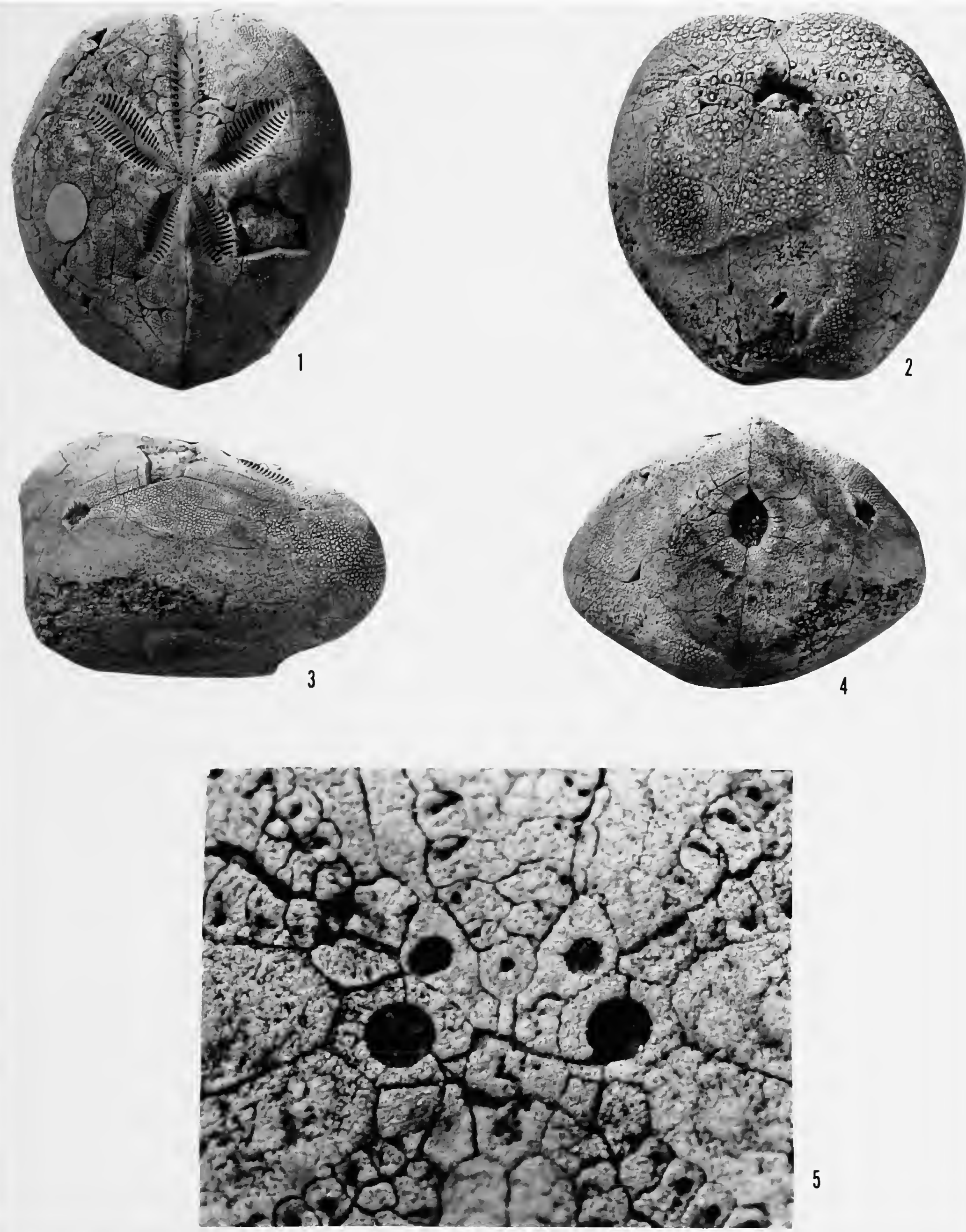


\section{PLATE 27}

\section{Schizaster subcylindricus Cotteau}

1, 2. Dorsal and right side views of the lectotype, USNM 214177a, Eocene, St. Bartholomew Limestone, St. Bartholomew, $\times 2.5$.

3. Dorsal view of specimen of Schizaster brachypelalus Arnold and Clark ( $=S$. subcylindricus), USNM 301378, Eocene, Jamaica, $\times 2.5$.

4-7. Dorsal, rear, right side, and ventral veiws of Cuban specimen, USNM 217364, Eocene, Loma Caoba, 5 km S of San Diego de los Baños, Pinar del Rio Province, Cuba, × 2.5. 


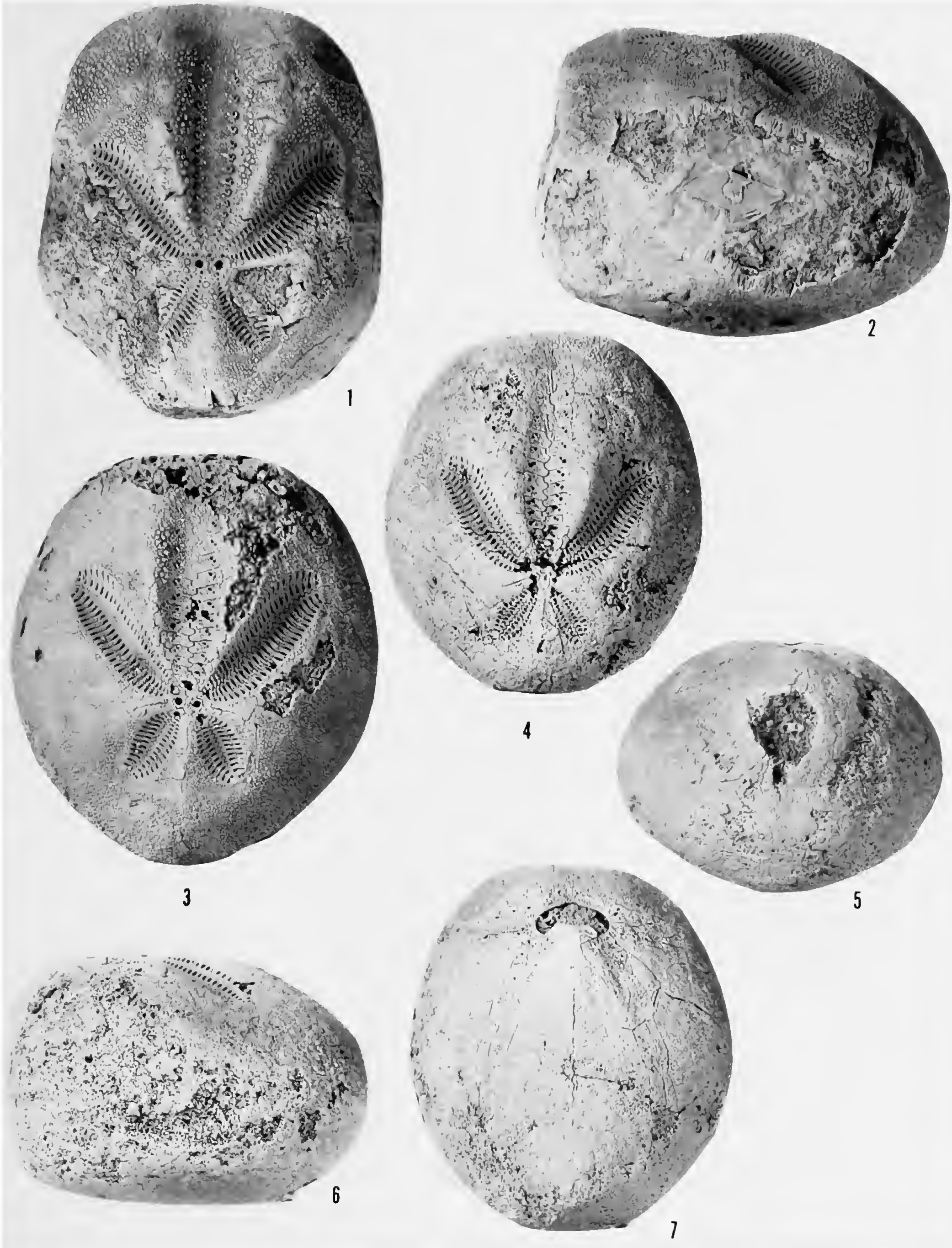




\section{PLATE 28}

\section{Schizaster subcylindricus Cotteau}

1-4. Dorsal, ventral, right side, and rear views of holotype of Schizaster brachypetalus Arnold and Clark (= S. subcylindricus) MCZ 3295, Eocene, near Abington, SW of Green Harbour, Hanover Parish, Jamaica, $\times 2$.

\section{Schizaster cubensis d'Orbigny}

5. Right side view of the holotype, MNHN 11934, Pliocene or Recent, Cuba, $\times 3$.

\section{Schizaster pastelilloensis (Weisbord)}

6-8. Dorsal, ventral, and right side views of the holotype, PRI 3832, Late Eocene, from cut along the railroad between Nuevitas and Pastelillo, about $2 \mathrm{~km} \mathrm{SE}$ of Nuevitas railroad station, Camagüey Province, Cuba, $\times 2.5$. 

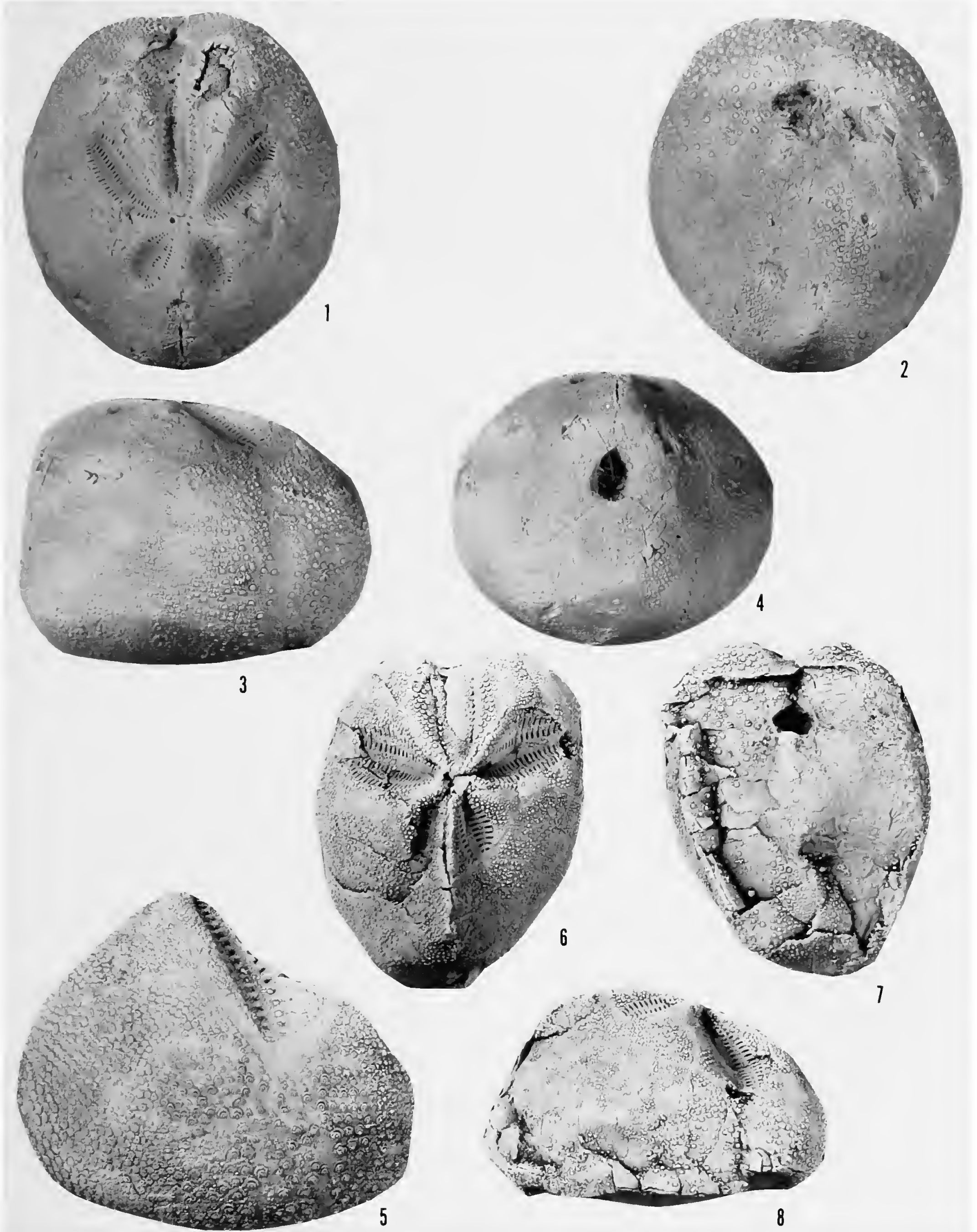
PLATE 29

\section{Agassizia clevei Cotteau}

1-3. Dorsal, right side, and rear views of a topotype of Agassizia avilensis Sánchez Roig (=A. clevei), SRC 4750, Oligocene-Miocene, Carretera Central, both sides, $425.5 \mathrm{~km} \mathrm{E}$ of Habana, $36.1 \mathrm{~km} \mathrm{~W}$ of Ciego between Ciego de Avila and Jatibonico, Camagüey Province, Cuba, $\times 2$.

4, 5. Dorsal and ventral views of the holotype of Agassizia avilensis Sánchez Roig (= A. clevei), SRC 4749, Oligocene-Miocene, same locality as that of SRC $4750, \times 2.5$.

6. Dorsal view of the lectotype herein designated, USNM 214171a (formerly 115407), Miocene, Anguilla Formation, Anguilla, $\times 4$.

7. Dorsal view of the paralectotype, herein designated, USNM 214171b (formerly 115407), from same locality as figure 6 above, $\times 4$. 

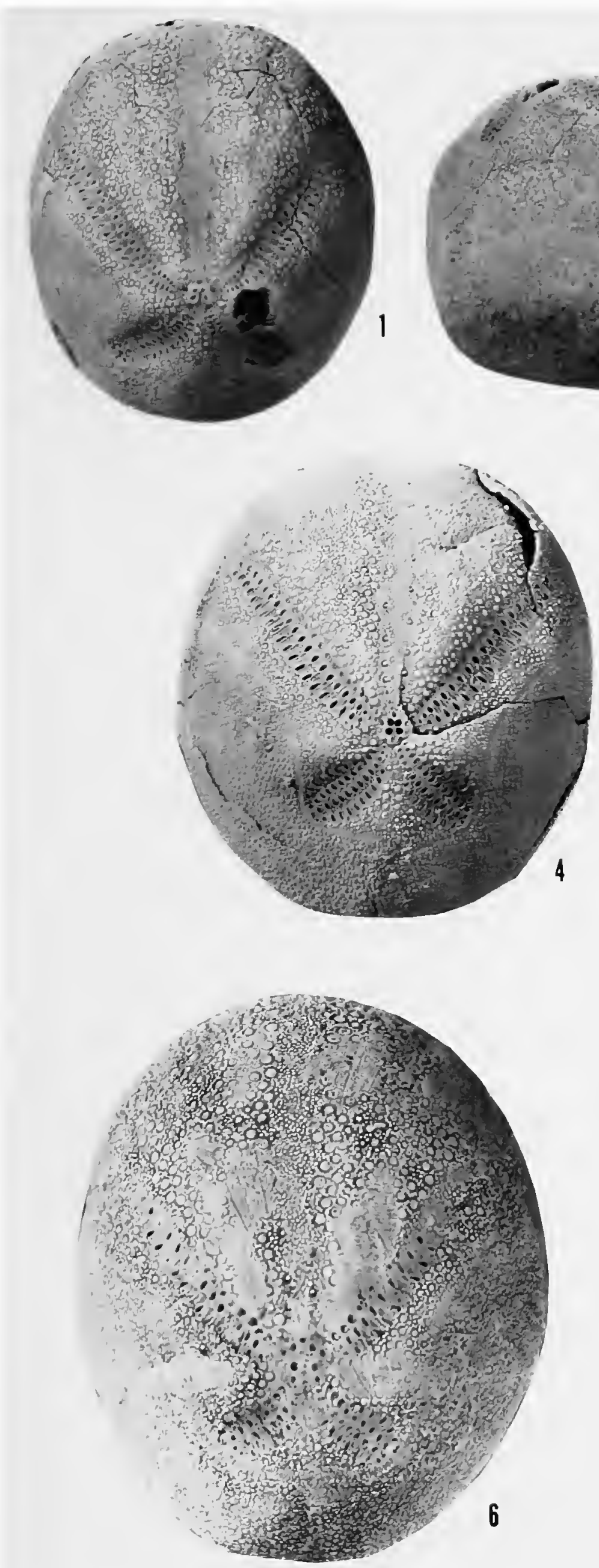

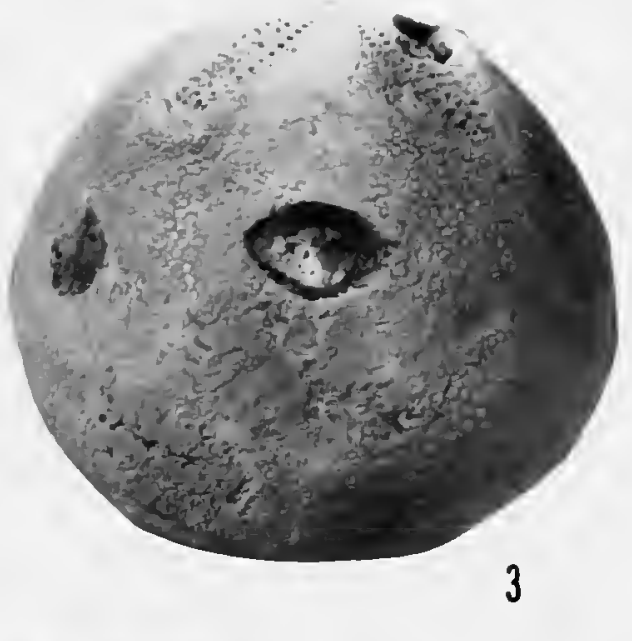

2
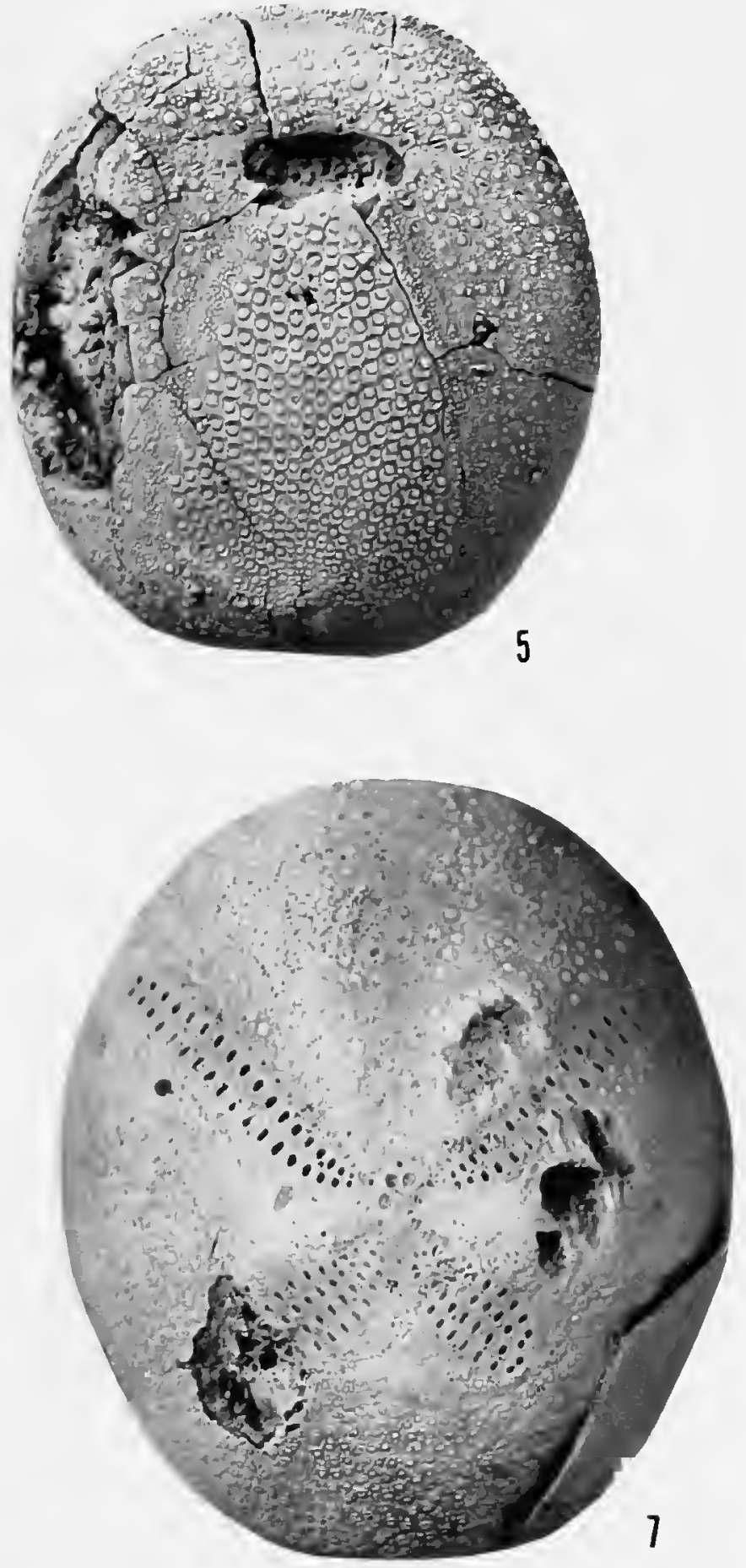
PLATE 30

\section{Agassizia clevei Cotteau}

1-4. Dorsal, right side, ventral, and rear views of topotype of Agassizia avilensis Sánchez Roig (= A. clevei), MCZ 4121, Oligocene-Miocene, Carretera Central, both sides, $425.5 \mathrm{~km} \mathrm{E}$ of Habana, $36.1 \mathrm{~km} \mathrm{~W}$ of Ciego between Ciego de Avila and Jatibonico, Camagüey Province, Cuba, $\times 3$.

5-7. Dorsal, right side, and ventral views, MCZ 4124. Oligocene-Miocene, roadcuts at Arroyo la Palma, $8.2 \mathrm{~km}$ SE of bridge over Río Zaza or $12.8 \mathrm{~km}$ SE of Sancti Spiritus, Santa Clara (now Las Villas) Province, Cuba, $\times 2.5$. 


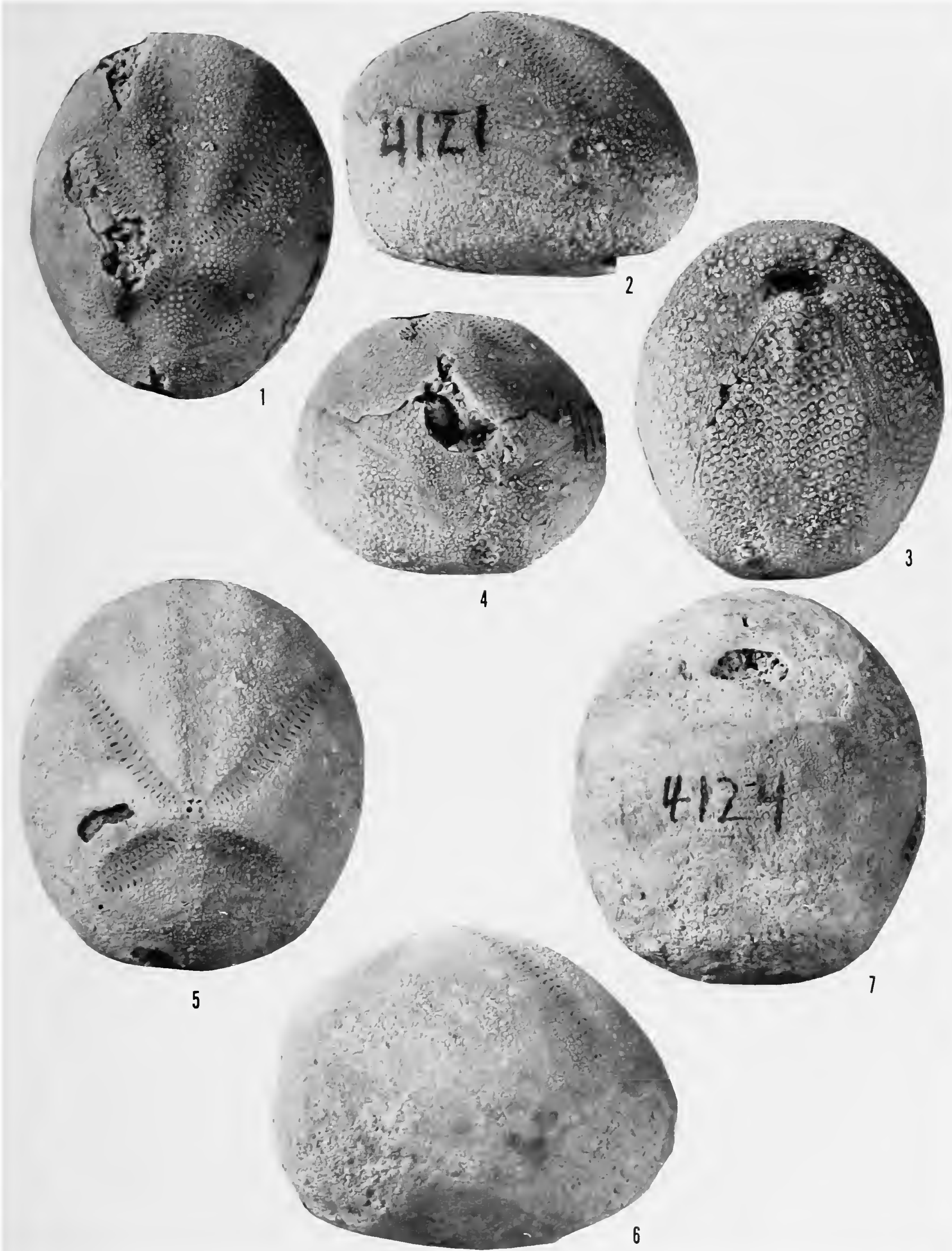




\section{PLATE 31}

\section{Agassizia clevei Cotteau}

1-3. Dorsal, right side, and ventral views of the holotype of Agassizia caribbeana Weisbord (= A. clevei), PRI 3834, late Eocene, Loma Calisto, Camagüey Province, Cuba, $\times 2$.

4-6. Dorsal, right side, and ventral views of the paratype of Agassizia caribbeana Weisbord (= A. clevei), PRI 3835, late Eocene, between Nuevitas and Pastelillo, Camagüey Province, Cuba, $\times 3$.

7. Dorsal view of holotype of Agassizia camagueyana Weisbord (= A. clevei), PRI 3839, Oligocene-Miocene, $\mathrm{Km} \mathrm{440,} \mathrm{central} \mathrm{highway} \mathrm{between} \mathrm{Jatibonico} \mathrm{and} \mathrm{Ciego} \mathrm{de} \mathrm{Avila,}$ Camagüey Province, Cuba, $\times 2.5$.

8. Dorsal view of Agassizia floridana de Loriol (= A. clevei) USNM 341253; Eocene, Crystal River Formation, St. Catherine Rock Company quarry, west of St. Catherine, Sumter Co., Florida, $\times 4$. 


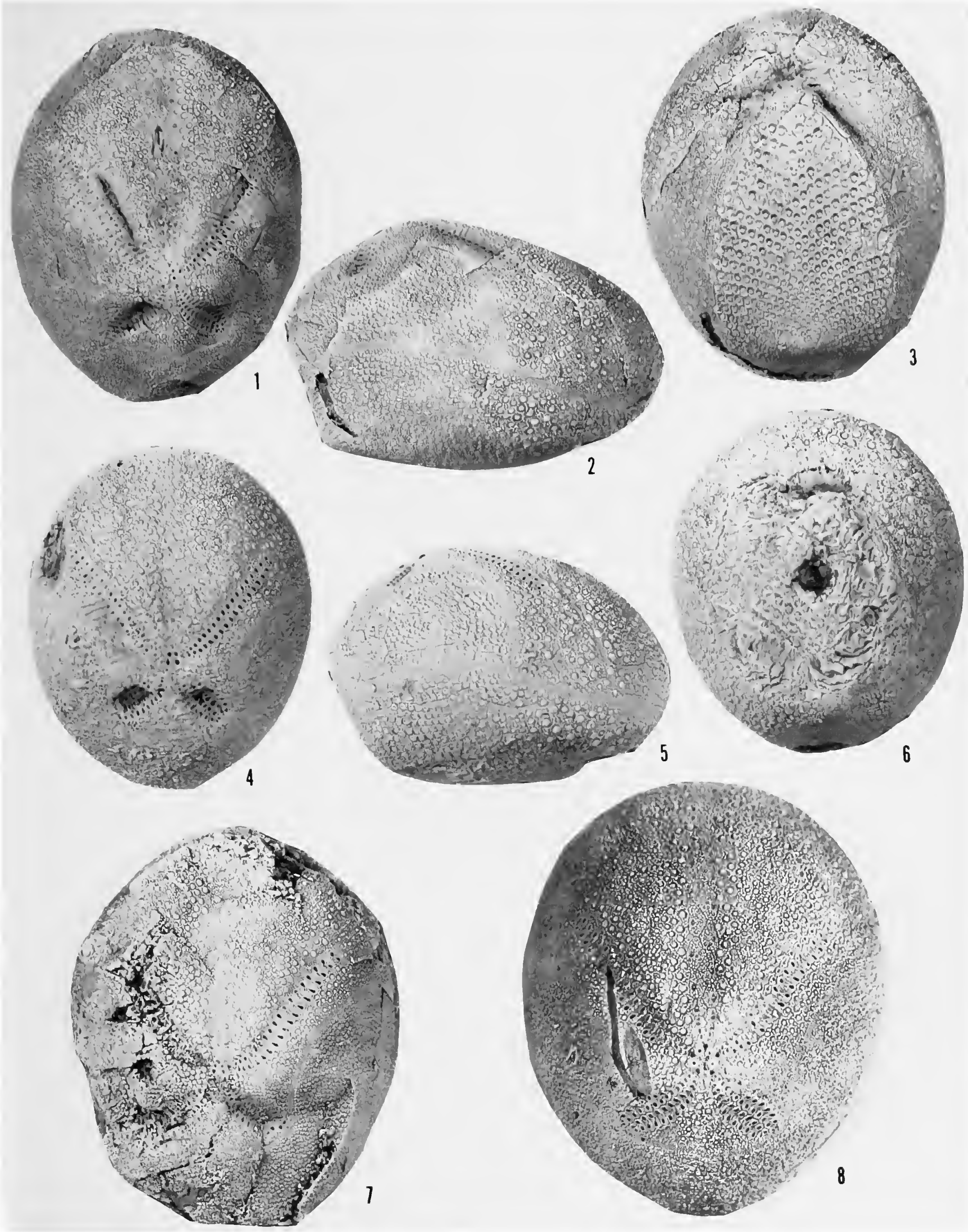




\section{PLATE 32}

\section{Agassizia inflata Jackson}

1-3. Dorsal, right side, and ventral views of the holotype, USNM 325610, Eocene, St. Bartholomew Limestone, St. Bartholomew, $\times 3$.

4-6. Dorsal, right side, and ventral views, USNM 341254, Oligocene-Miocene, $43.1 \mathrm{~km} \mathrm{~W}$ of Ciego de Avila, Camagüey Province, Cuba, $\times 3$. 

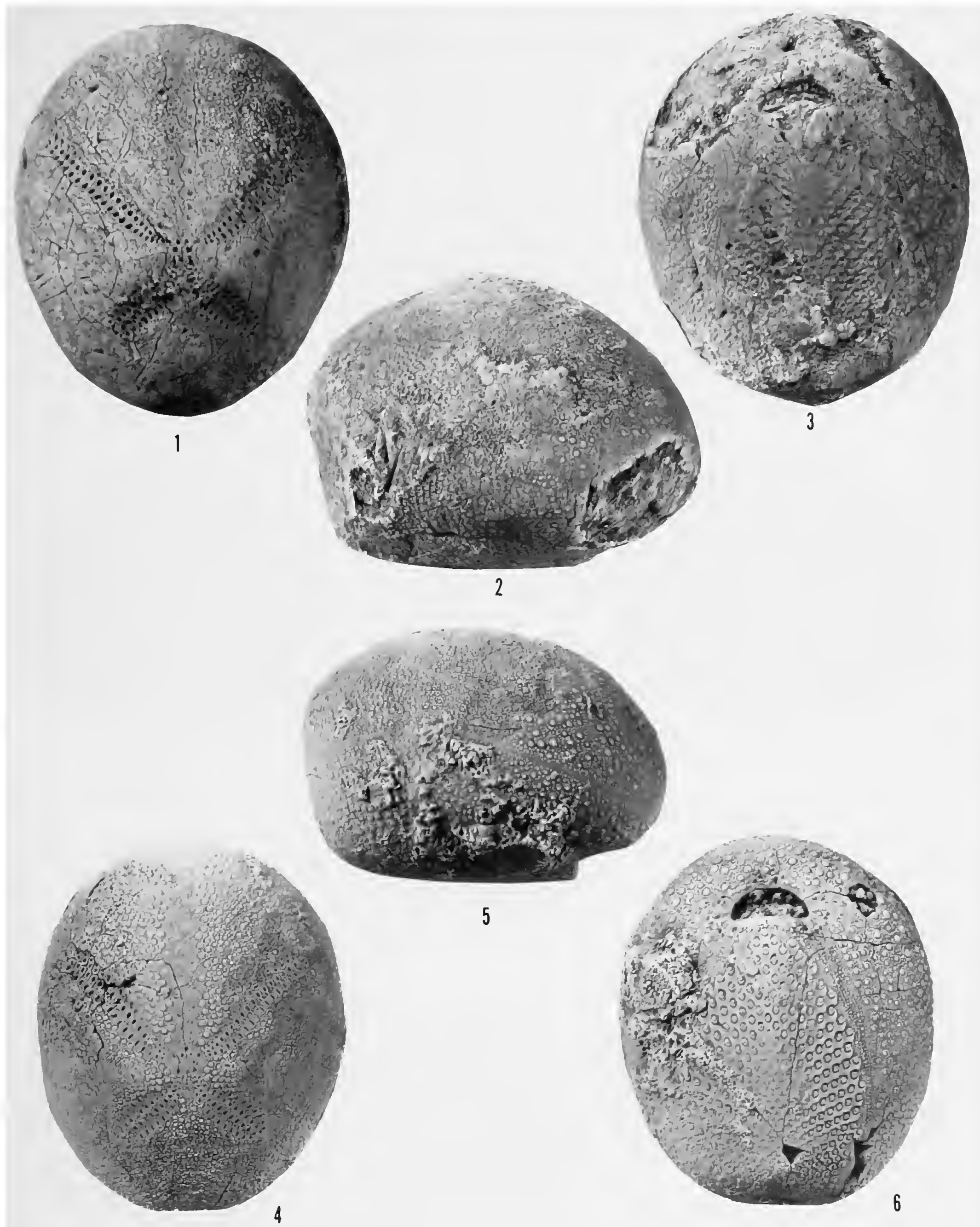


\section{PLATE 33}

\section{Agassizia pinarensis Sánchez Roig}

1-5. Dorsal, ventral, front, rear, and right side views of the holotype, SRC 4160, Miocene, extreme $\mathrm{N}$ of Consolación del Sur, Pinar del Rio Province, Cuba, $\times 2.5$.

Agassizia alveari Sánchez Roig

6-9. Dorsal, rear, right side, and ventral views of the lectotype, SRC 4084, Oligocene-Miocene, $42 \mathrm{~km}$ W of Ciego de Avila, $419.7 \mathrm{~km}$ on Central Highway, Camagüey Province, Cuba, $\times 1.5$. 


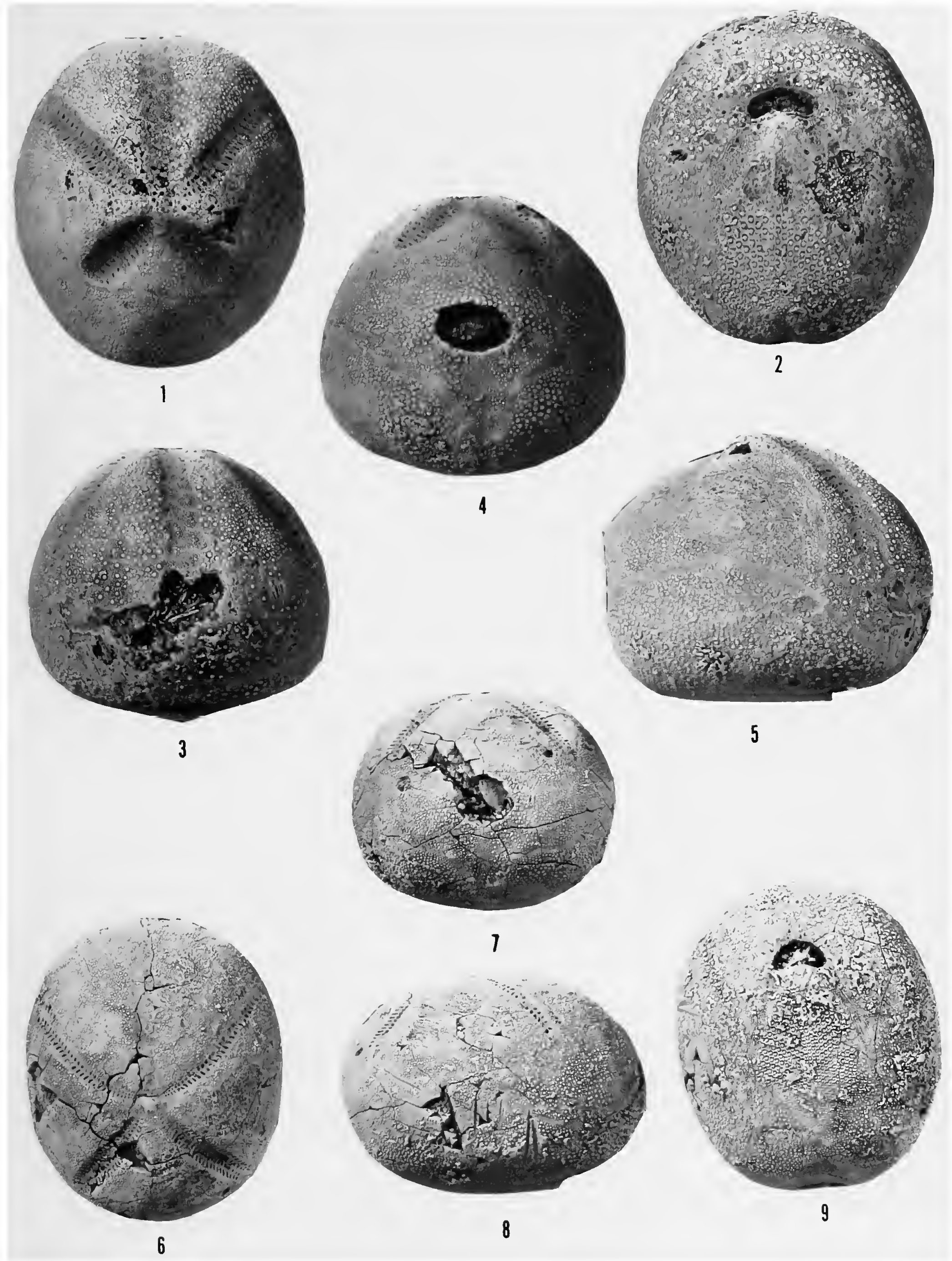




\section{PLATE 34}

\section{Caribbaster lovent (Cotteau)}

1-4. Dorsal, right side, rear, and ventral views, ANSP 16664, late Eocene, E of Arroyo Blanco, $150 \mathrm{~m}$, in road to Majagua, Camagüey Province, Cuba, $\times 2.5$.

5,6. Dorsal and right side of holotype, USNM 214175 (formerly 115411), Eocene, St. Bartholomew, $\times 2$.

7-10. Dorsal, rear, right side, and ventral views of the holotype of Hypselaster perplexus Arnold and Clark (=C. loveni), MCZ 3292, Eocene, Spring Mount, St. James Parish, Jamaica, $\times 2$.

(Photograph reduced to 90 percent.) 


\section{PLATE 35}

Lambertona lamberti (Sánchez Roig)

1. Dorsal view of the lectotype, SRC 4959, early Eocene, quarries of Tejar Conseulo, Cerro, Ciénaga, Habana Province, Cuba, $\times 1$.

2. Peristome of paralectotype, USNM 352864, early Eocene, $\times 4$. (See also Plate 36.) 


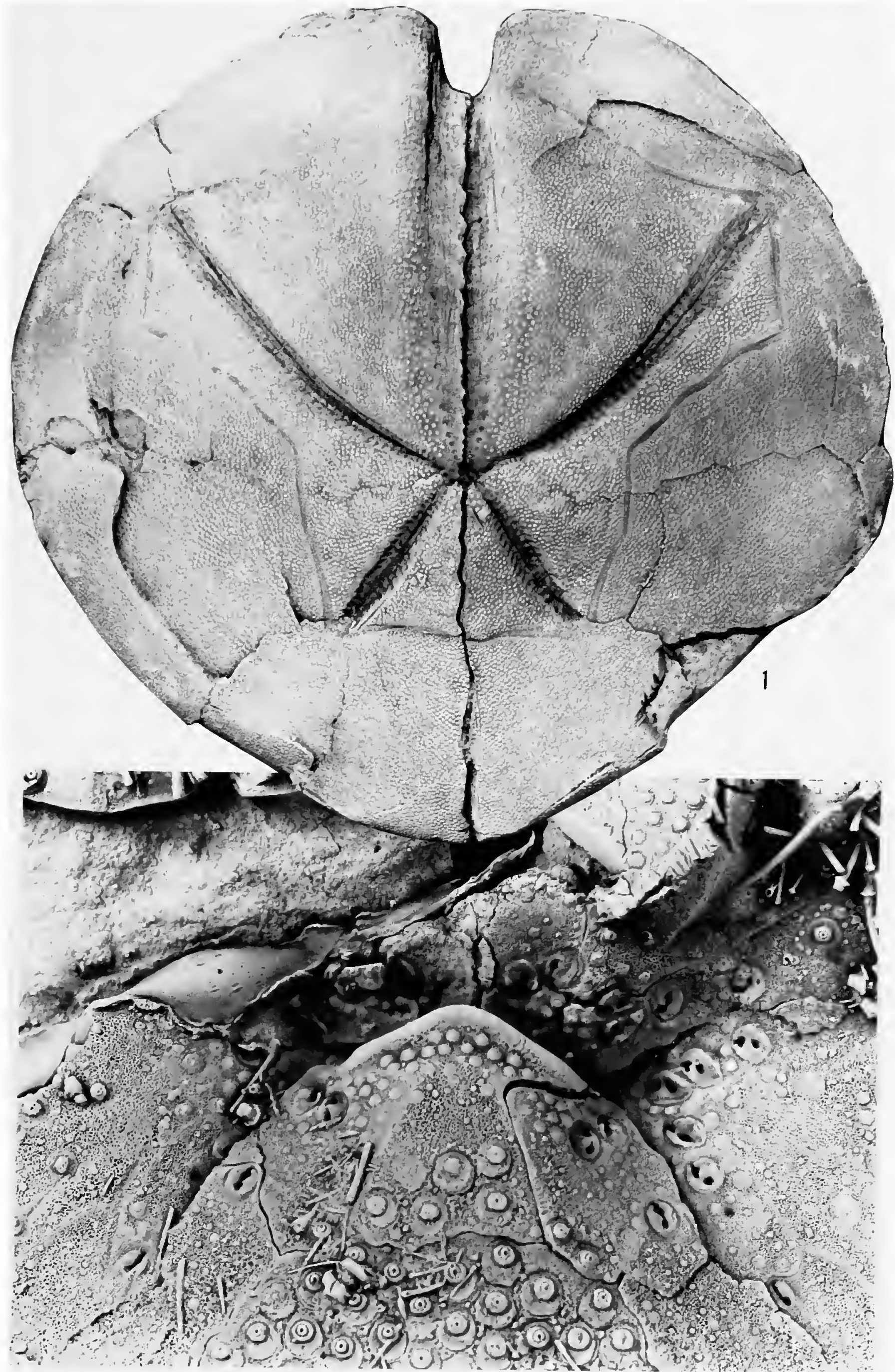


PLATE 36

\section{Lambertona lamberti (Sánchez Roig)}

1, 2. Dorsal and ventral views of paralectotype, USNM 352864, early Eocene, quarries of Tejar Consuelo, Cerro, Ciénaga, Habana Province, Cuba, $\times 1$.

3. Spines on ventral side in anterior interambulacrum of the same specimen, $\times 6$. 


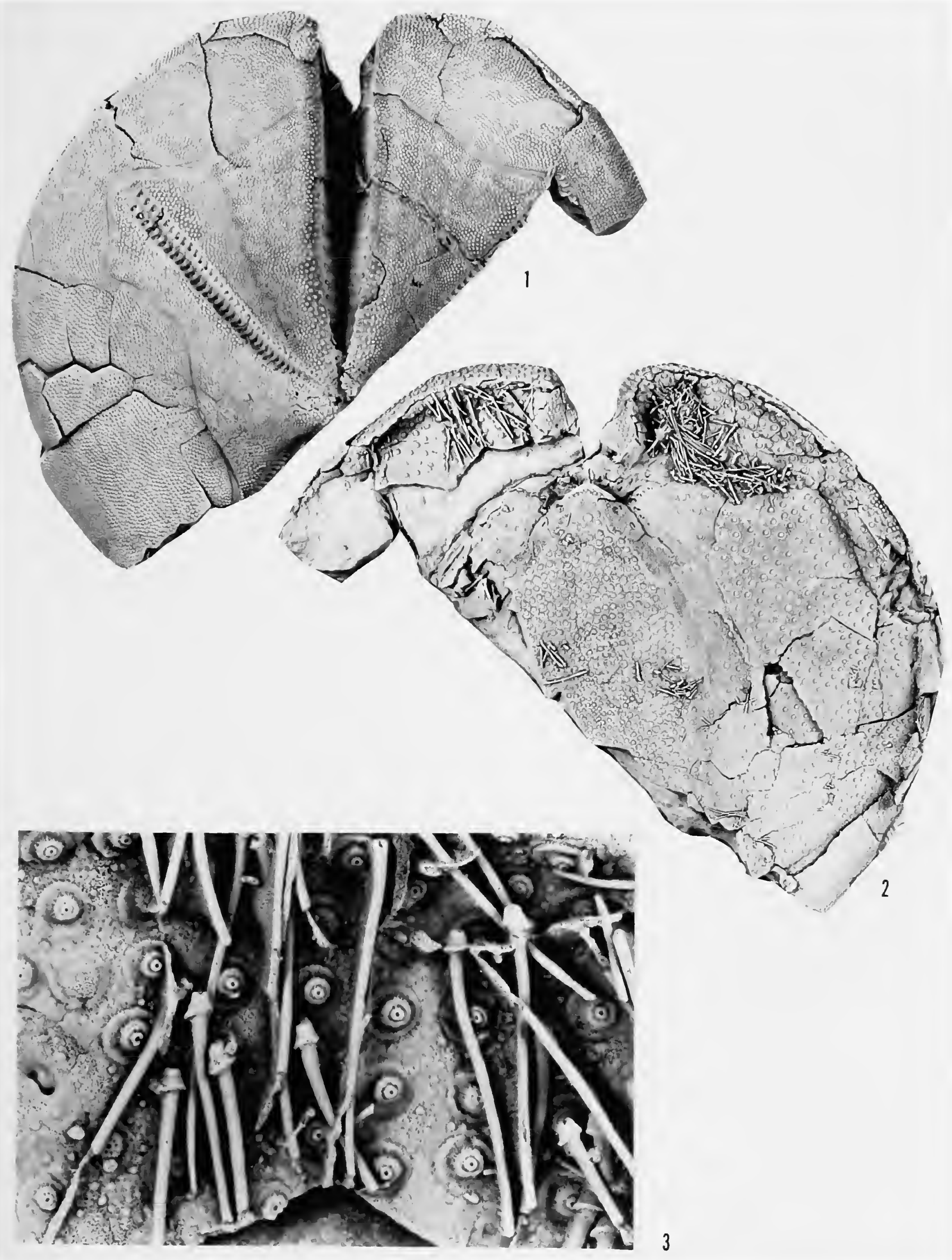




\section{PLATE 37}

\section{Linthia brodermanni Sánchez Roig}

1-4. Dorsal, ventral, front, and right side views of lectotype, SRC 4851, Late Cretaceous, W edge of Batey Dos Hermanos, in mulberry patch (Palmer loc. 1833), Las Villas Province, Cuba, $\times 1.5$.

5-8. Dorsal, ventral, rear, and right side views of lectoparatype, SRC 4858, Late Cretaceous, from fields $\frac{1}{2} \mathrm{~km} \mathrm{~W}$ of Central Manuelita, along cane railroad (Palmer loc. 1729), Las Villas Province, Cuba, $\times 1.5$. 

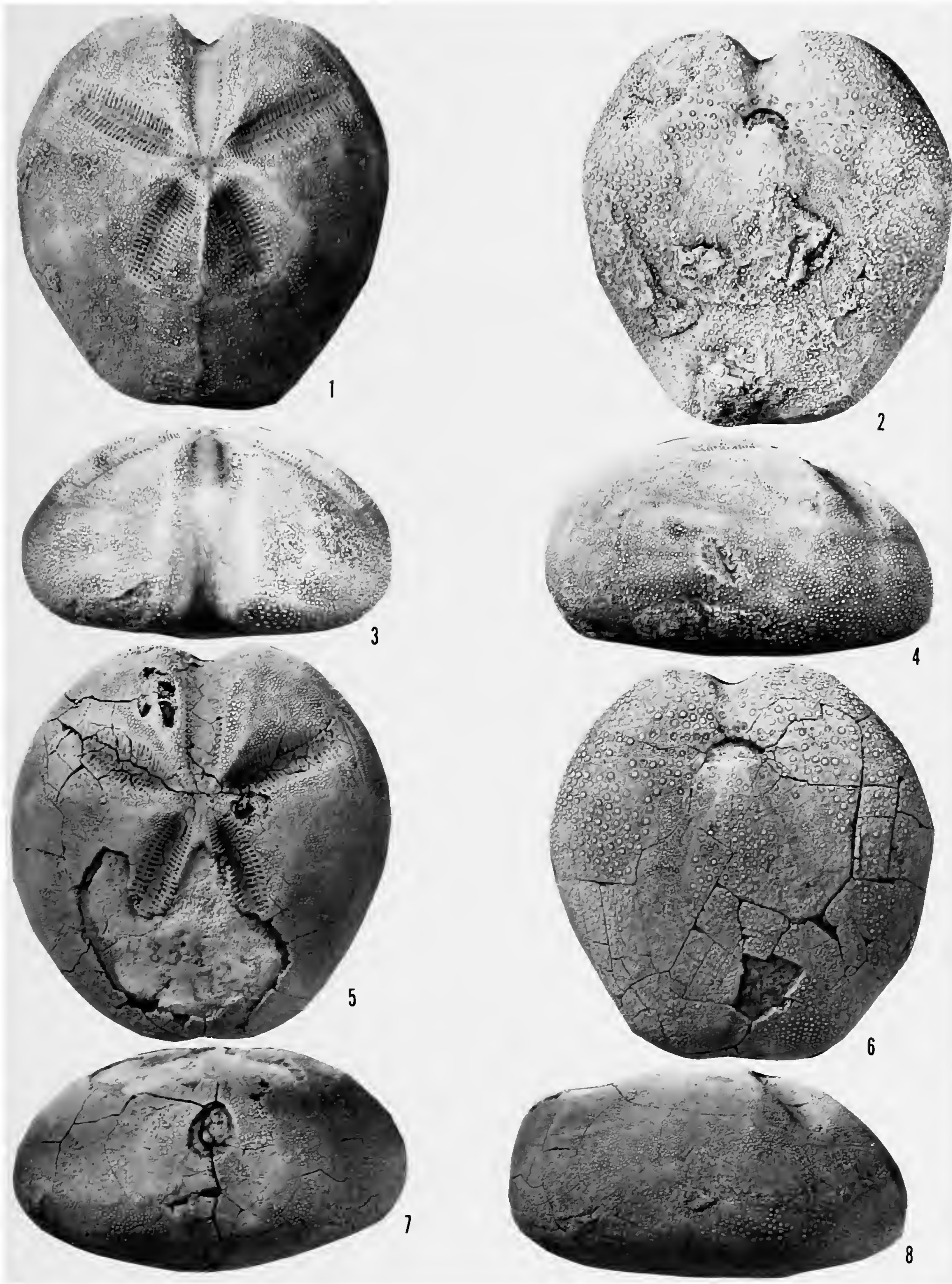
PLATE 38

\section{Linthia brodermanni Sánchez Roig}

1-3. Dorsal, right side and rear views of holotype of Micraster elevatus Sánchez Roig(= $L$. brodermanni), SRC 4256, Late Cretaceous, W edge of Batey Dos Hermanos, in mulberry patch (Palmer loc. 1833), Las Villas Province, Cuba, $\times 1$.

4-6. Dorsal, ventral and right side views of lectotype of Hemiaster lamberii Sánchez Roig $(=L$. brodermanni), SRC 4864, Late Cretaceous, same locality as above, $\times 1.5$. 


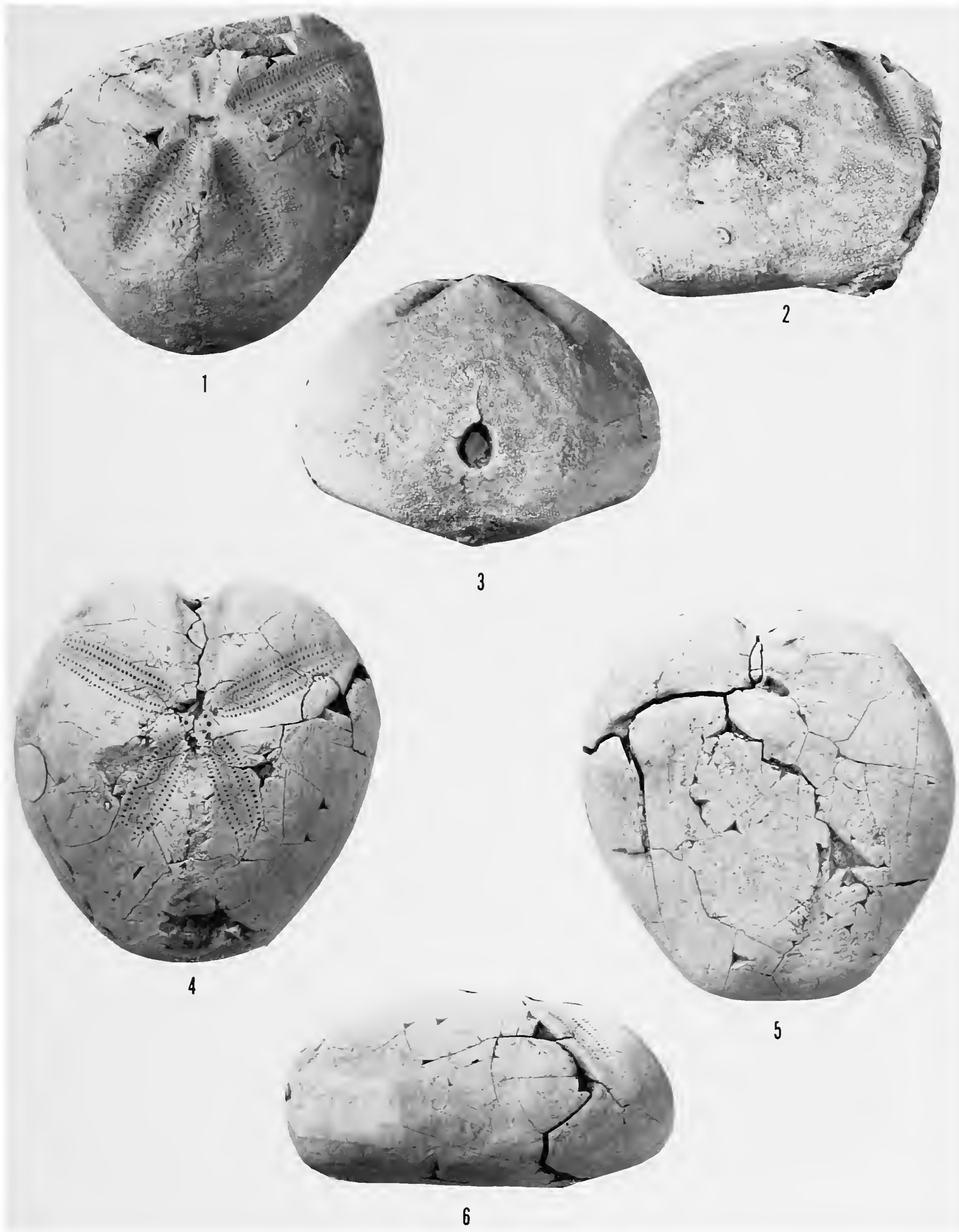




\section{PLATE 39}

\section{Linthia brodermanni Sánchez Roig}

1-3. Dorsal, right side, and ventral views of the holotype of Linthia alta Sanchez Roig (= L. brodermanni), SRC 4223, Late Cretaceous, W edge of Batey Dos Hermanos, in mulberry patch (Palmer loc. 1833), Las Villas Province, Cuba, $\times 1$.

4-7. Dorsal, ventral, right side, and rear views of the holotype of Linthia gonzalezmunozi Sánchez Roig (= L. brodermanni), SRC 4247, Late Cretaceous (Senonian), Abra de Castellón, Cumanayagua, Las Villas Province, Cuba, $\times 2$. 


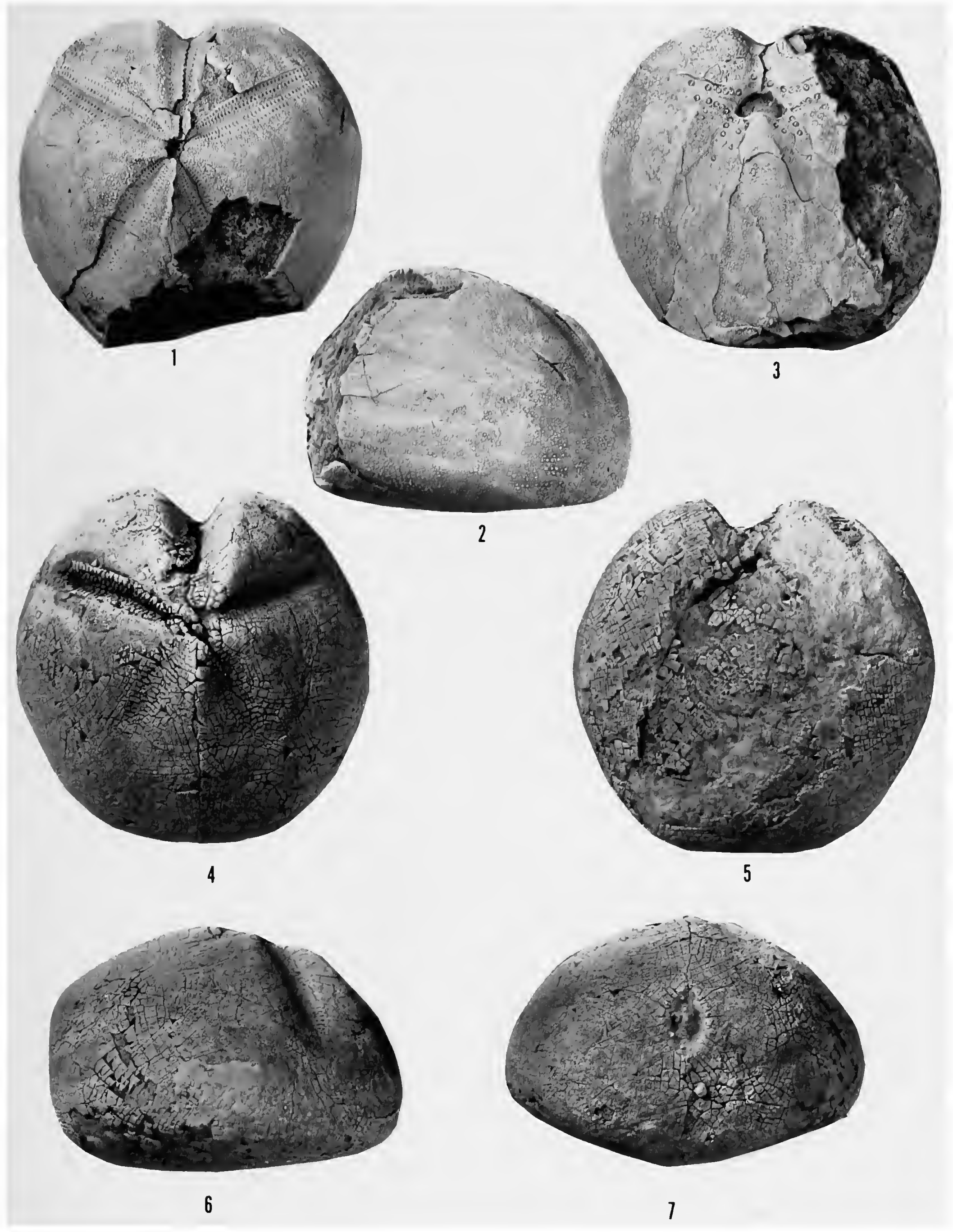




\section{PLATE 40}

Linthia monteroae, new species

1-4. Dorsal, right side, ventral, and rear views of holotype, ANSP 16656, Eocene (Palmer loc. 1085), E of Arroyo Blanco, $150 \mathrm{~m}$, in road to Majagua, Camagüey Province, Cuba, $\times 1$.

\section{Linthı ?avilensıs Sánchez Roig}

5-7. Dorsal, ventral, and right side views of the holotype, SRC 4158, Late Cretaceous, "Maniadero" farm, 7.5 km, W Jicotea, Camagüey Province, Cuba, X 2. 

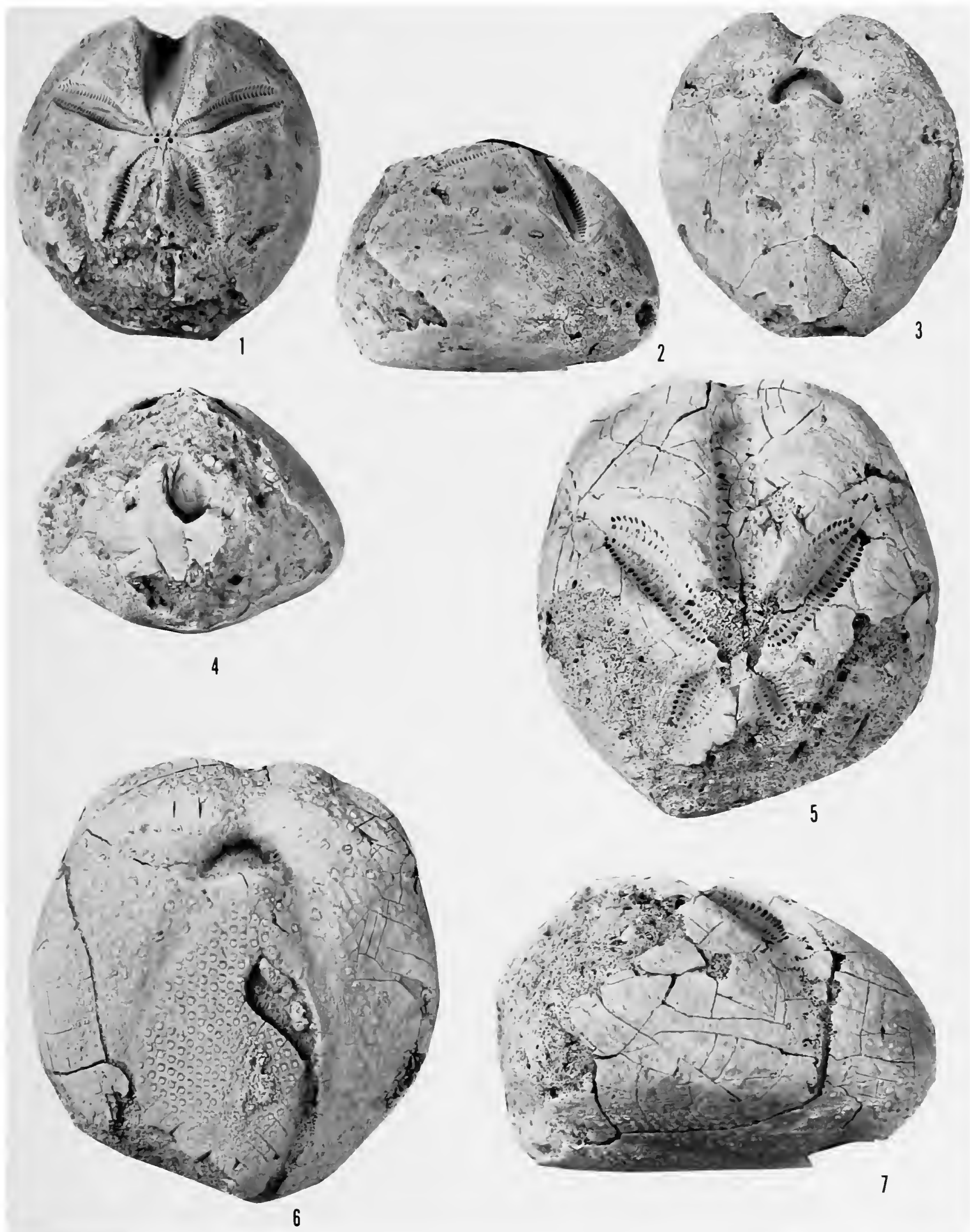


\section{PLATE 41}

\section{Prenaster parous Palmer}

1-4. Dorsal, rear, right side, and ventral views of ANSP 16649, late Eocene (Palmer loc. 1085), E of Arroyo Blanco, $150 \mathrm{~m}$, in road to Majagua, Camagüey Province, Cuba, $\times 2.5$.

5. View of apical area and ambulacrum III in same specimen, $\times 10$.

\section{Prenaster jeanneti Pijpers}

6-8. Dorsal, right side, and ventral views of a paratype, B898, Rijksuniversiteit Utrecht, late Eocene, SW of Seroe Montagne, Bonaire, $\times 2.5$. 


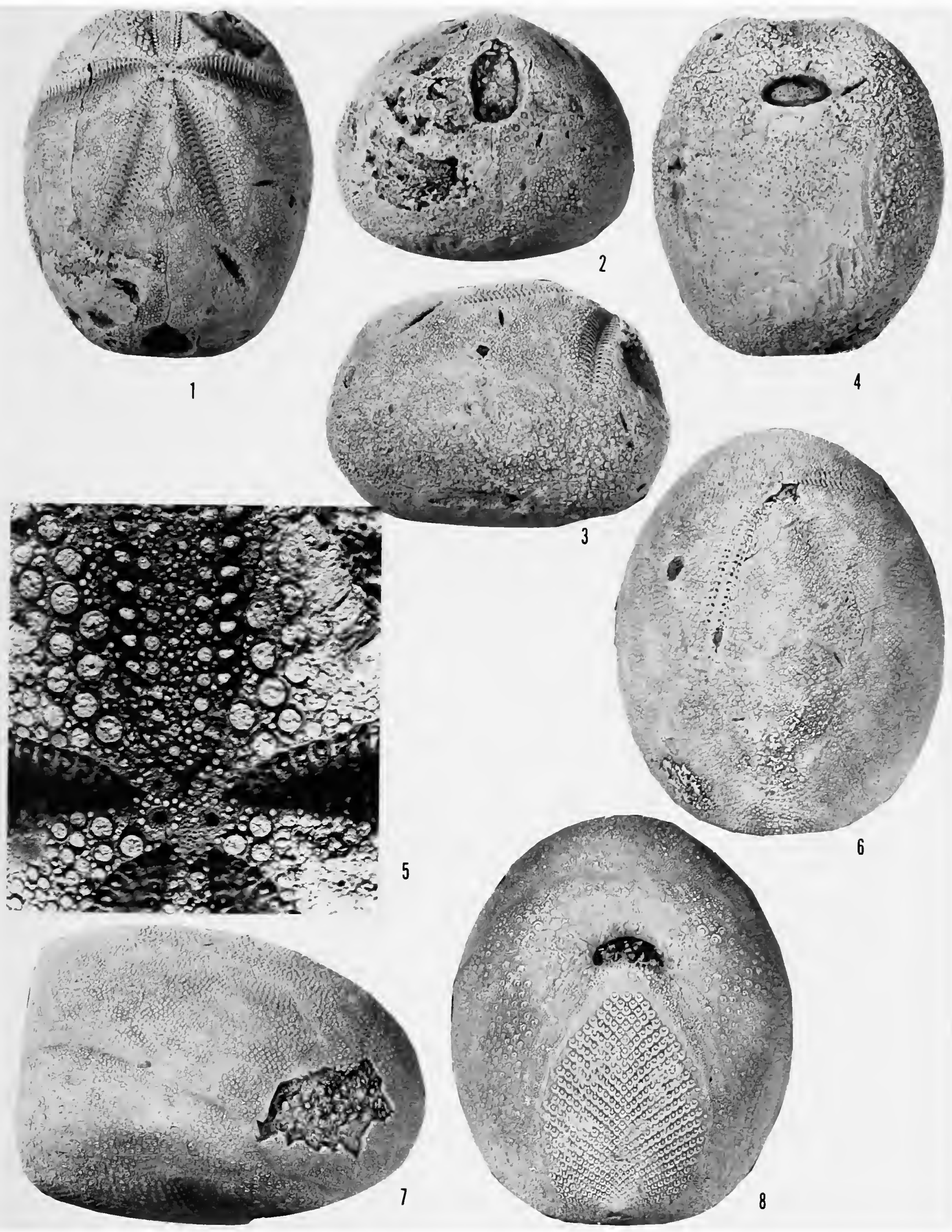




\section{PLATE 42}

Habanaster sanchezi Lambert

1-4. Dorsal, rear, right side, and ventral views of lectotype, SRC 4081, late Eocene, quarry of "Consuelo" tileworks, Cerro, Cienaga, Habana Province, Cuba, $\times 3$.

5, 6. Dorsal and ventral views of USNM 341255, Eocene, W side Avenida de los Presidentes near University of Habana, Habana Province, Cuba, $\times 3$. 


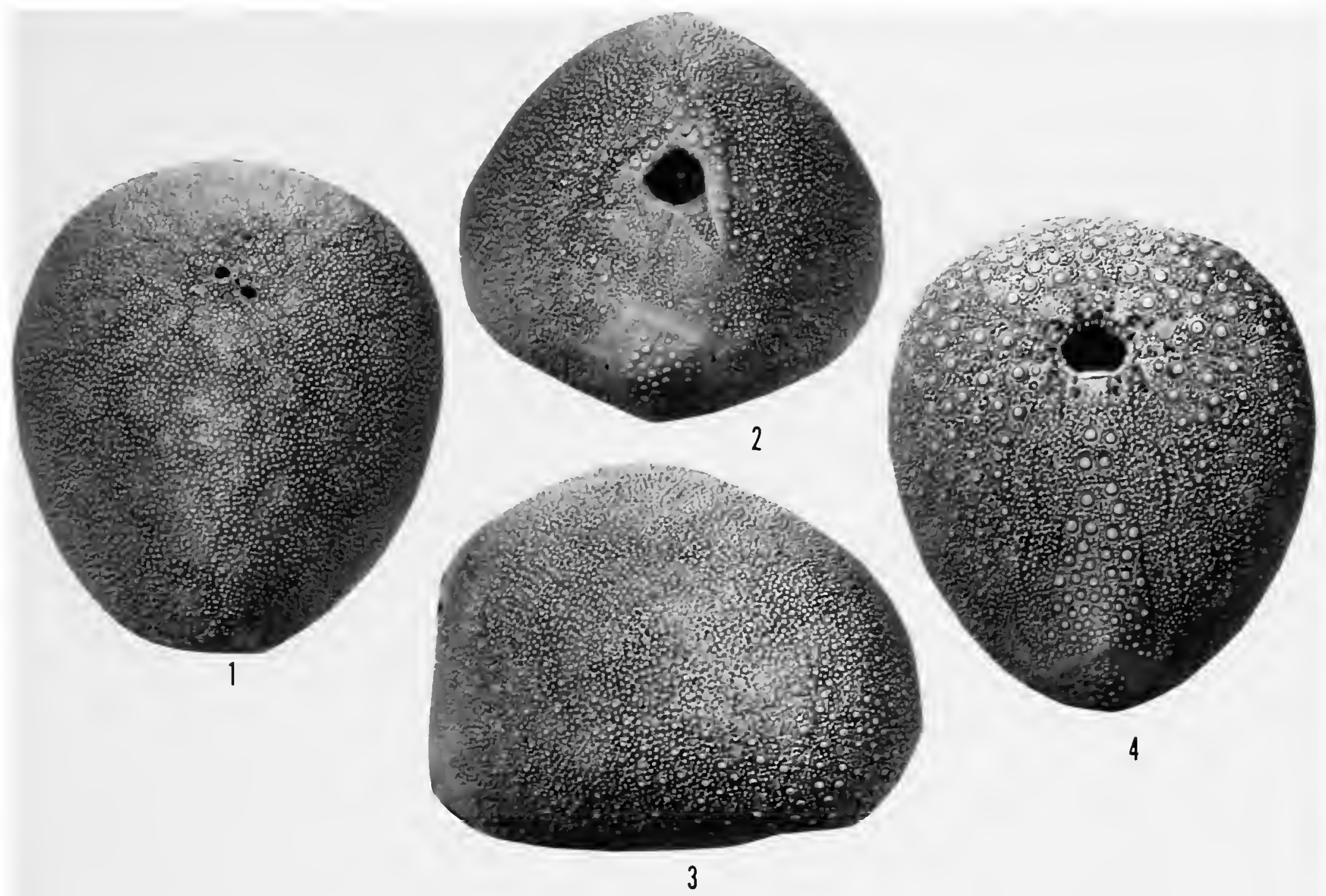

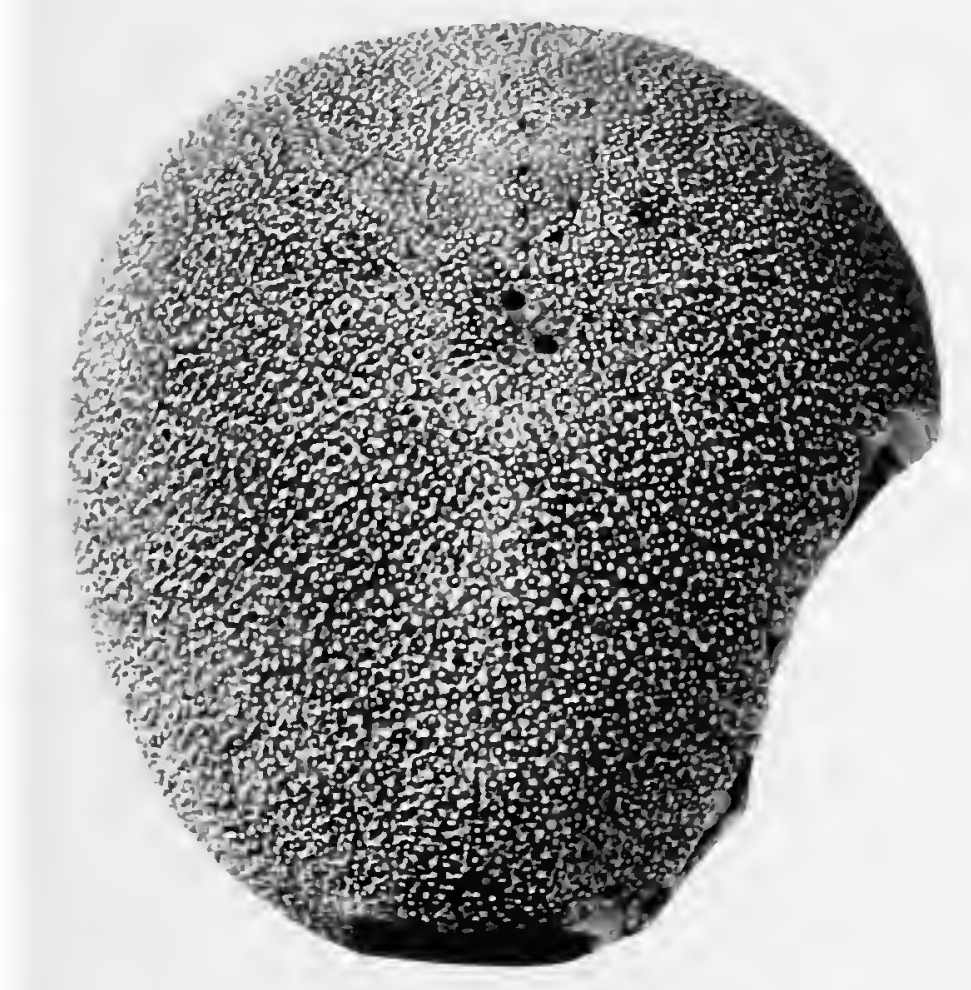

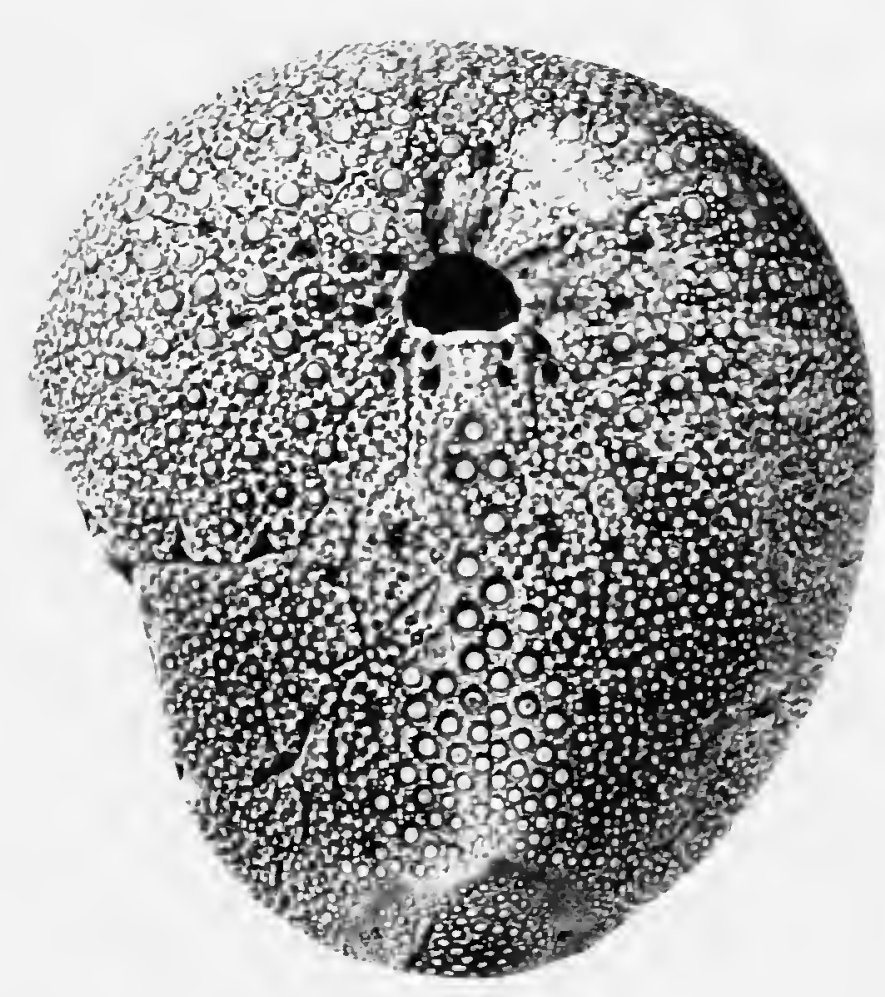

6 


\section{PLATE 43}

\section{Brissus cabrerai (Sánchez Roig)}

1-3. Dorsal, ventral, and right side views of lectotype, SRC 4191, late Eocene, Armadillo farm, Marroquín district, Camagüey Province, Cuba, $\times 1$.

Brissus camagueyensis Weisbord

4-6. Left side, dorsal, and ventral views of holotype, PRI 3838, late Eocene, in road cut at Loma Calisto, approximately $800 \mathrm{~m} \mathrm{SW}$ of the S end of town of Nuevitas, on the road leading toward Belén, Camagüey Province, Cuba, $\times 2$. 

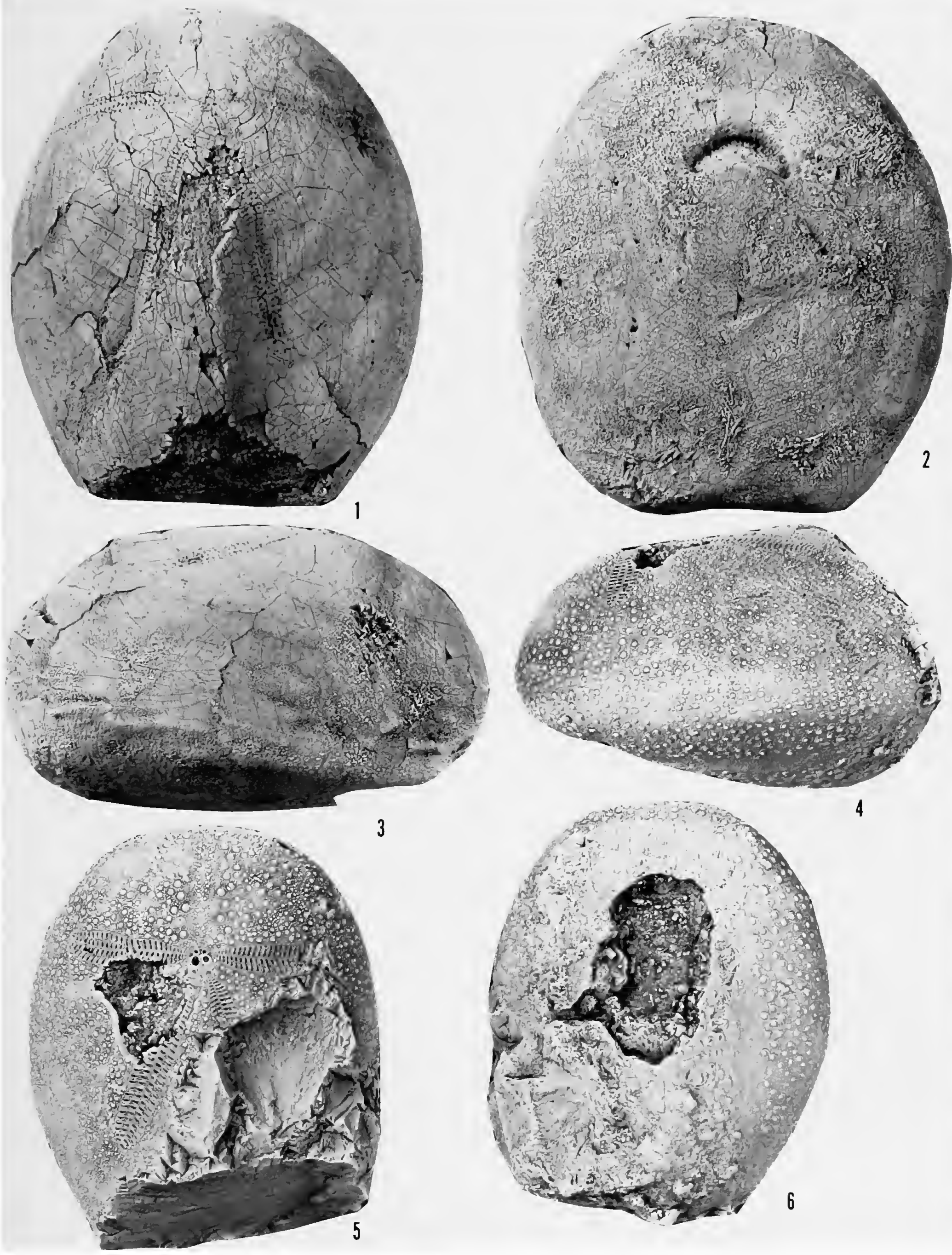


\section{PLATE 44}

\section{Brissus caobaense Sánchez Roig}

1-4. Dorsal, rear, right side, and ventral views of the lectotype, SRC 4726, middle to late Eocene, Loma Caoba, San Diego de los Baños, Pinar del Rio Province, Cuba, $\times 1$.

\section{Brissus durhami (Sánchez Roig)}

5-8. Dorsal, ventral, rear, and right side views of the holotype, SRC 4055, middle to late Eocene, Caraballo quarry, Loma Caoba, San Diego de los Baños, Pinar del Rio Province, Cuba, $\times 1$. 

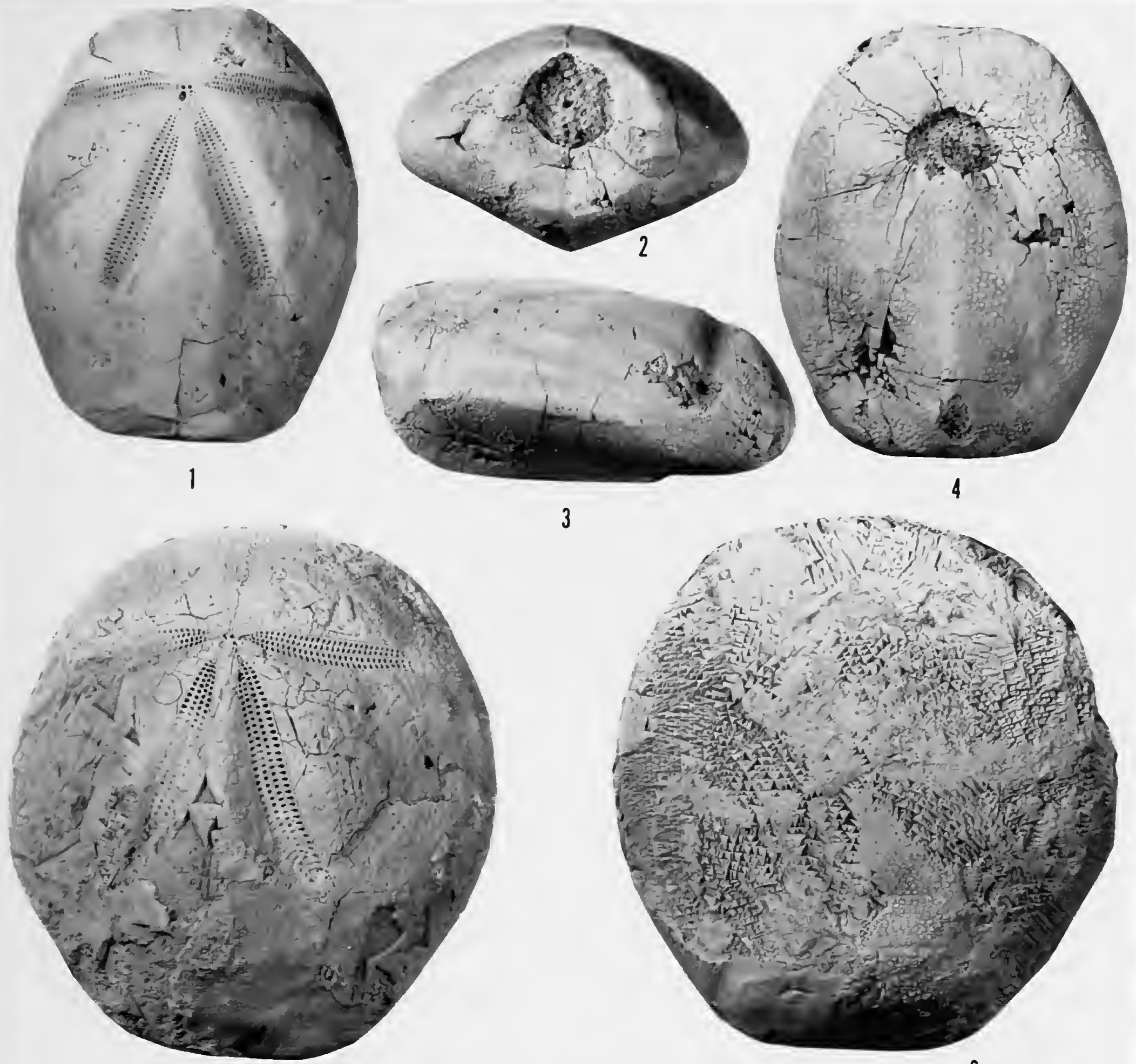

3

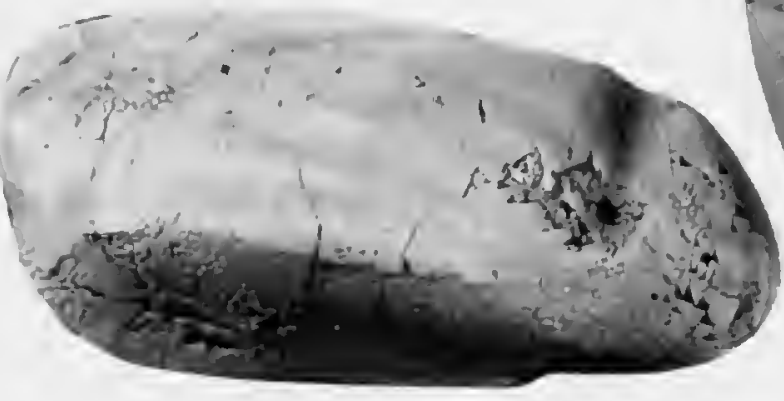

4

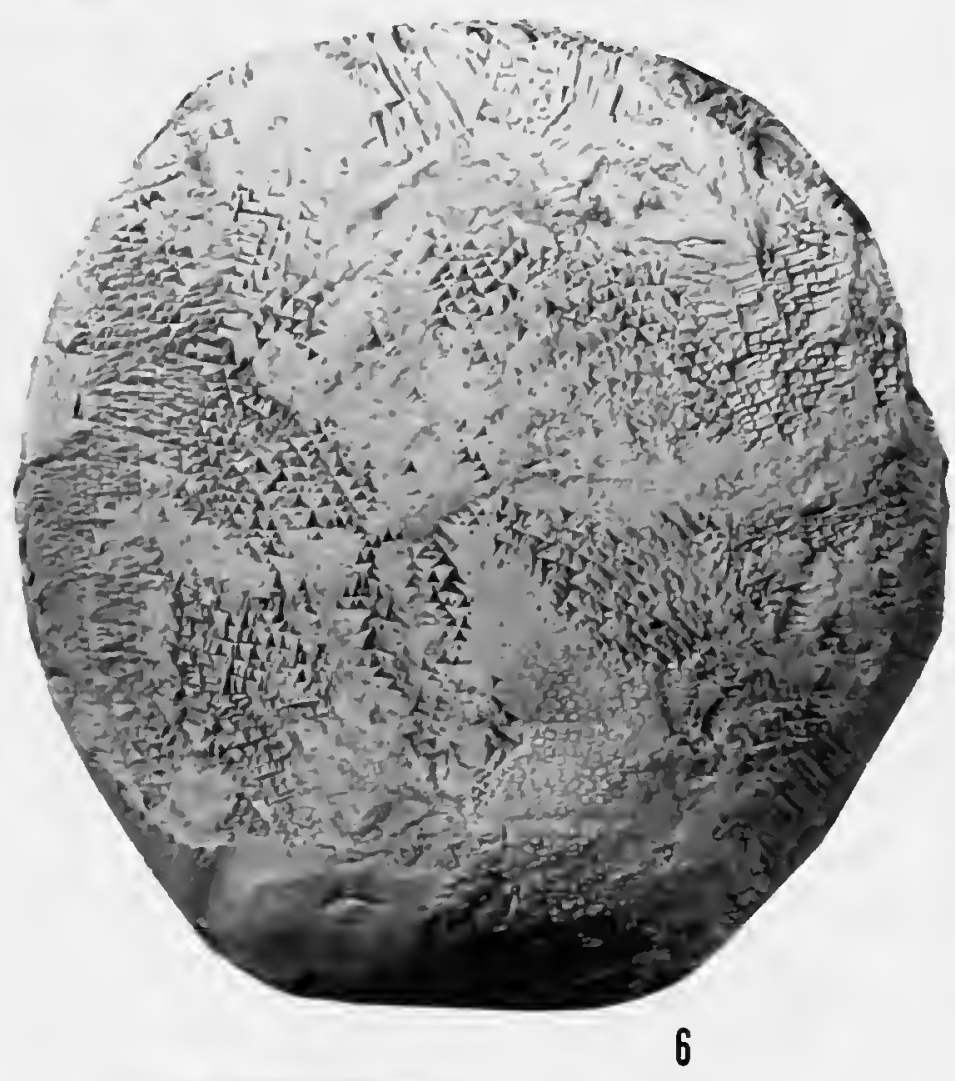

5
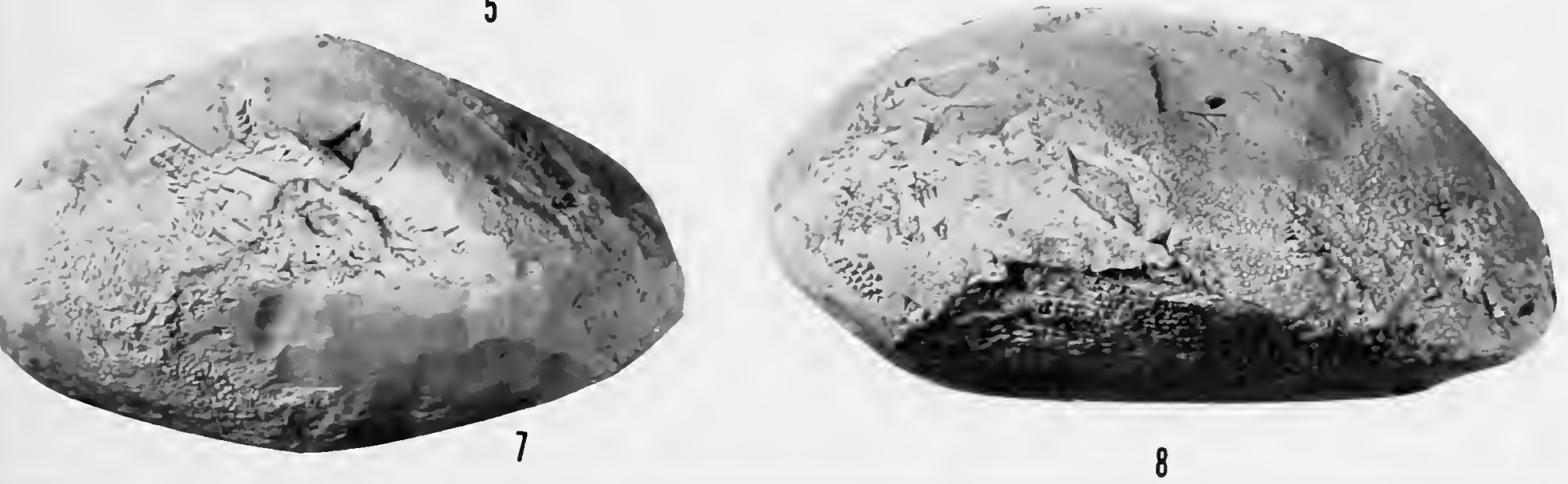
PLATE 45

Brassus minutus (Sánchez Roig)

1-3. Dorsal, left side, and ventral views of the holotype, SRC 4954, Oligocene-Miocene, "Santa Ana" farm, Majagua district, Ciego de Avila, Camagüey Province, Cuba, $\times 3$.

\section{Brissopsis aguayoi Sánchez Roig}

4-7. Dorsal, ventral, rear, and left side views of the holotype, SRC 4720, Oligocene-Miocene, "Las Cuevas de Pedro Pozo" farm, Realengo, Charco Hondo, Morón, Camagüey Province, Cuba, $\times 2$. 

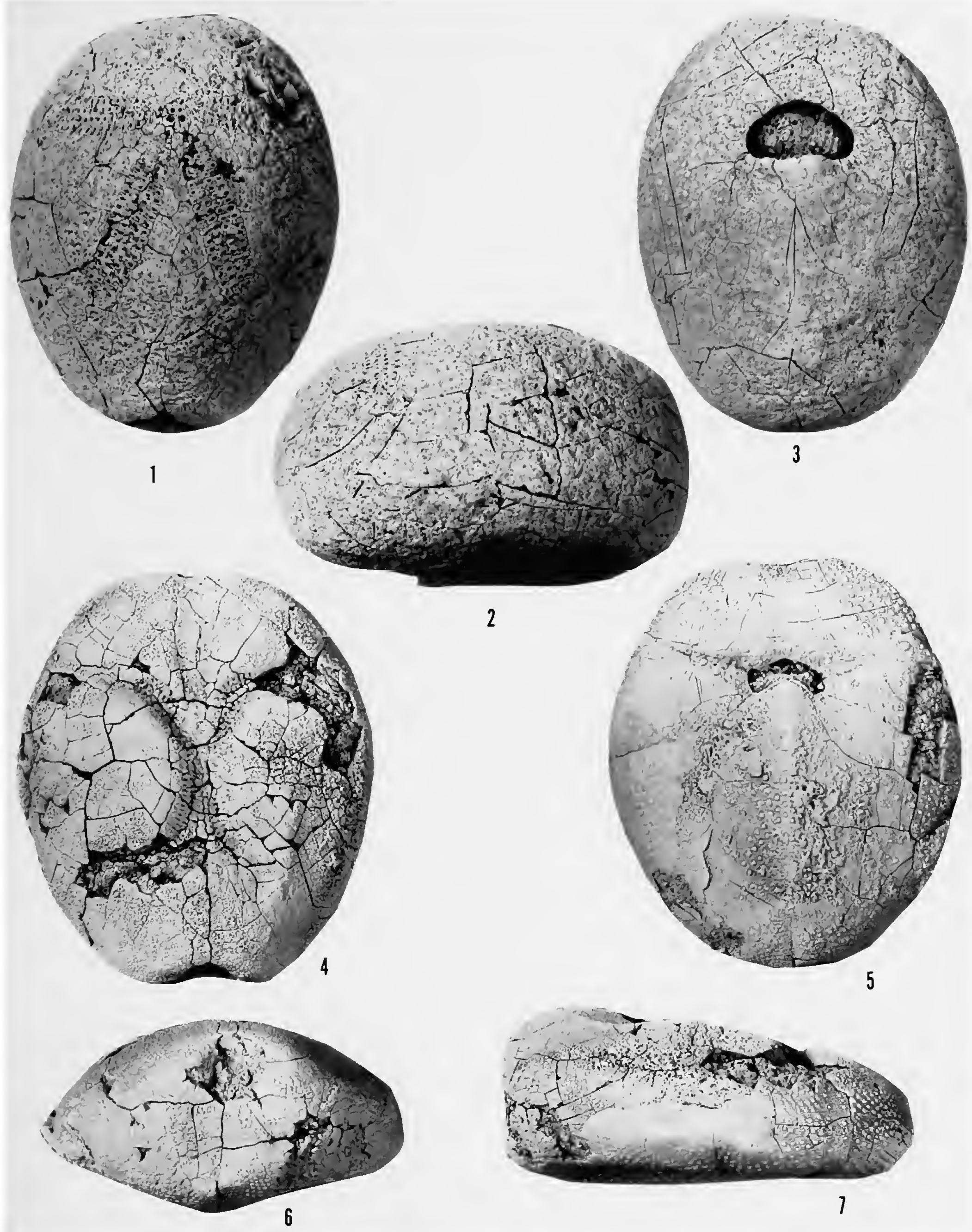


\section{PLATE 46}

\section{Brissopsis jimenoi Cotteau}

1, 2. Dorsal and ventral views of the lectotype, Cotteau Collection, Université Claude Bernard, Lyons, France, Miocene, Cienfuegos, San Martin, Santa Clara (now Las Villas) Province, Cuba, $\times 1$.

\section{Cyclaster dreweryenszs Cooke}

3-6. Dorsal, ventral, right side, and rear views of Cyclaster brodermanni Sánchez Roig (=C. drewryensis), ANSP 16651a, late Eocene, Palmer loc. 1640, deep cut $\mathrm{N}$ of Grua 9, Ramal Juan Criollo, Camagüey Province, Cuba, $\times 3$. 

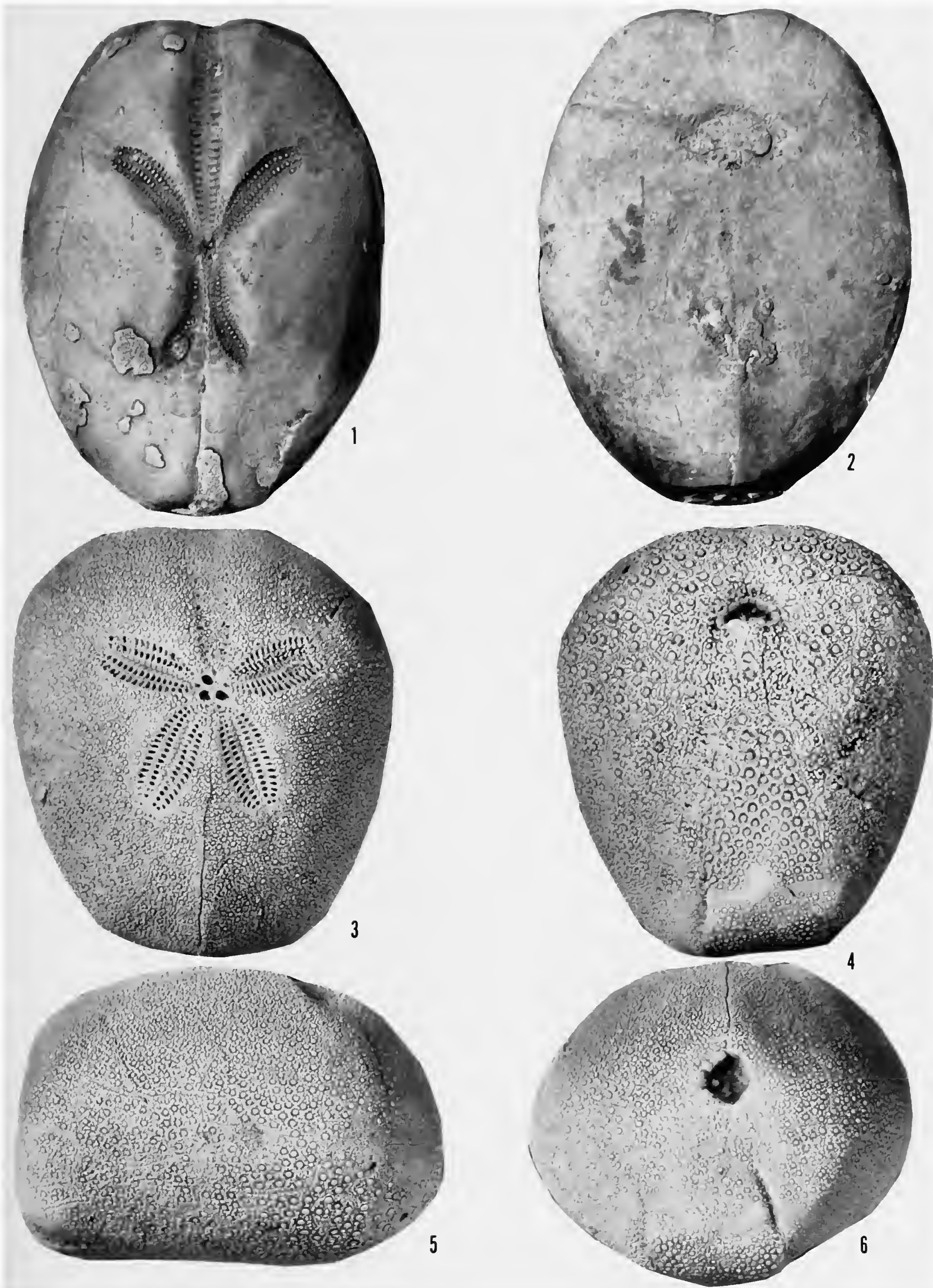


\section{PLATE 47}

\section{Cyclaster drewryensis Cooke}

1-4. Dorsal, ventral, right side, and rear views of topotype of Palmeraster palmeri Sánchez Roig (= C. drewryensis), UCB-A8394a, late Eocene, Finca Concepción, Morón, Camagüey Province, Cuba, $\times 2$.

5, 6. Dorsal and right side of the paratype, USNM 154148, early Oligocene, Red Bluff clay, What ley, Alabama, $\times 2$. 
NUMBER 55
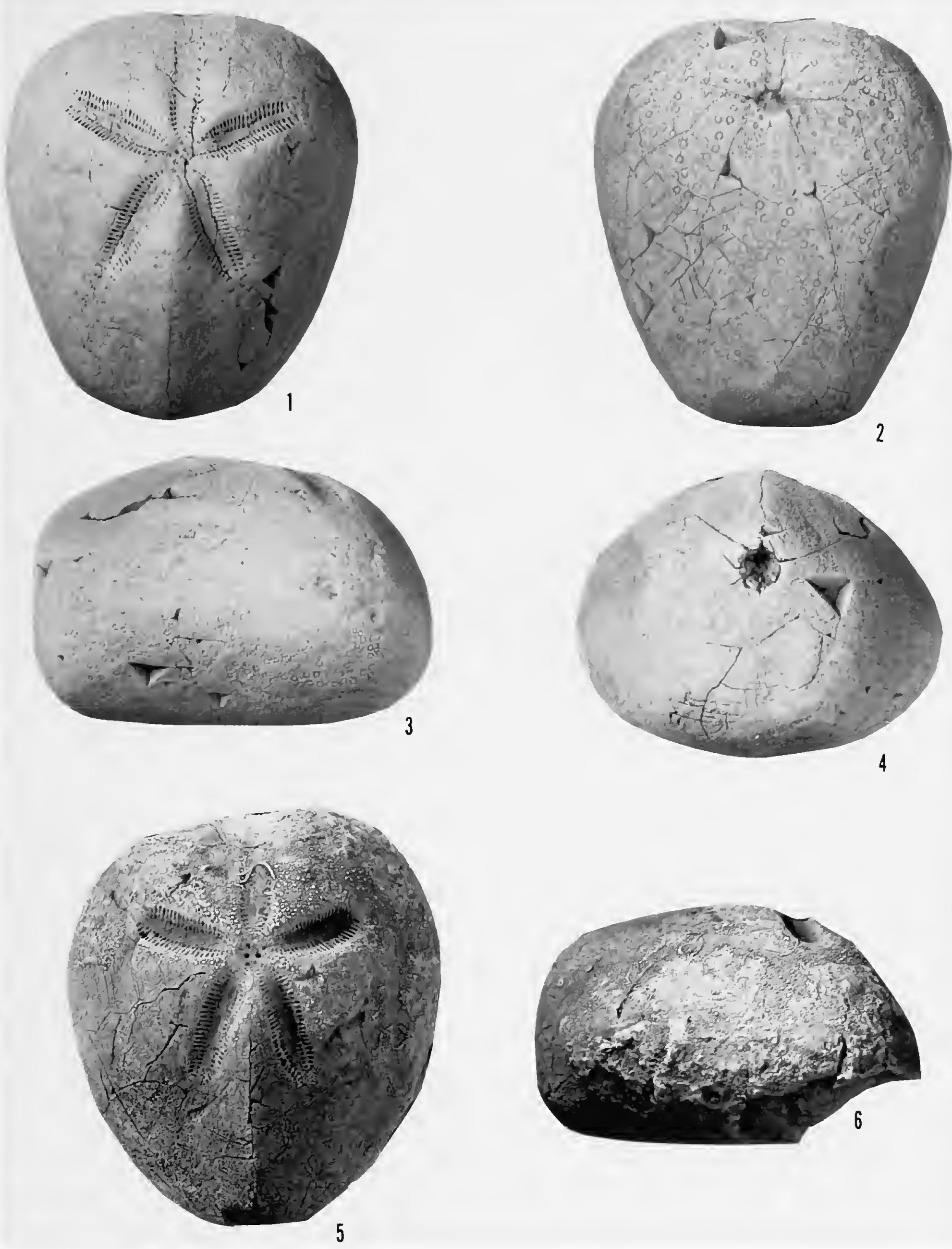


\title{
PLATE 48
}

\author{
Cyclaster sanchezi Lambert
}

1-3. Dorsal, ventral, and left side views of SRC 5452, late Eocene, Finca Turibacoa, Majagua district, Ciego de Avila, Morón, Camagüey Province, Cuba, $\times 2$.

4. Peripodia in ambulacrum III on dorsal side of same specimen, $\times 30$.

$$
\text { Macropneustes? (Macropneustes) palmeri (Sánchez Roig) }
$$

5-7. Dorsal, right side, ventral views of the lectotype, SRC 4032, Oligocene-Miocene, SSE of Cartagena, $1 \mathrm{~km} \mathrm{~N}$ side of railroad, Las Villas Province, Cuba, $\times 1$. 

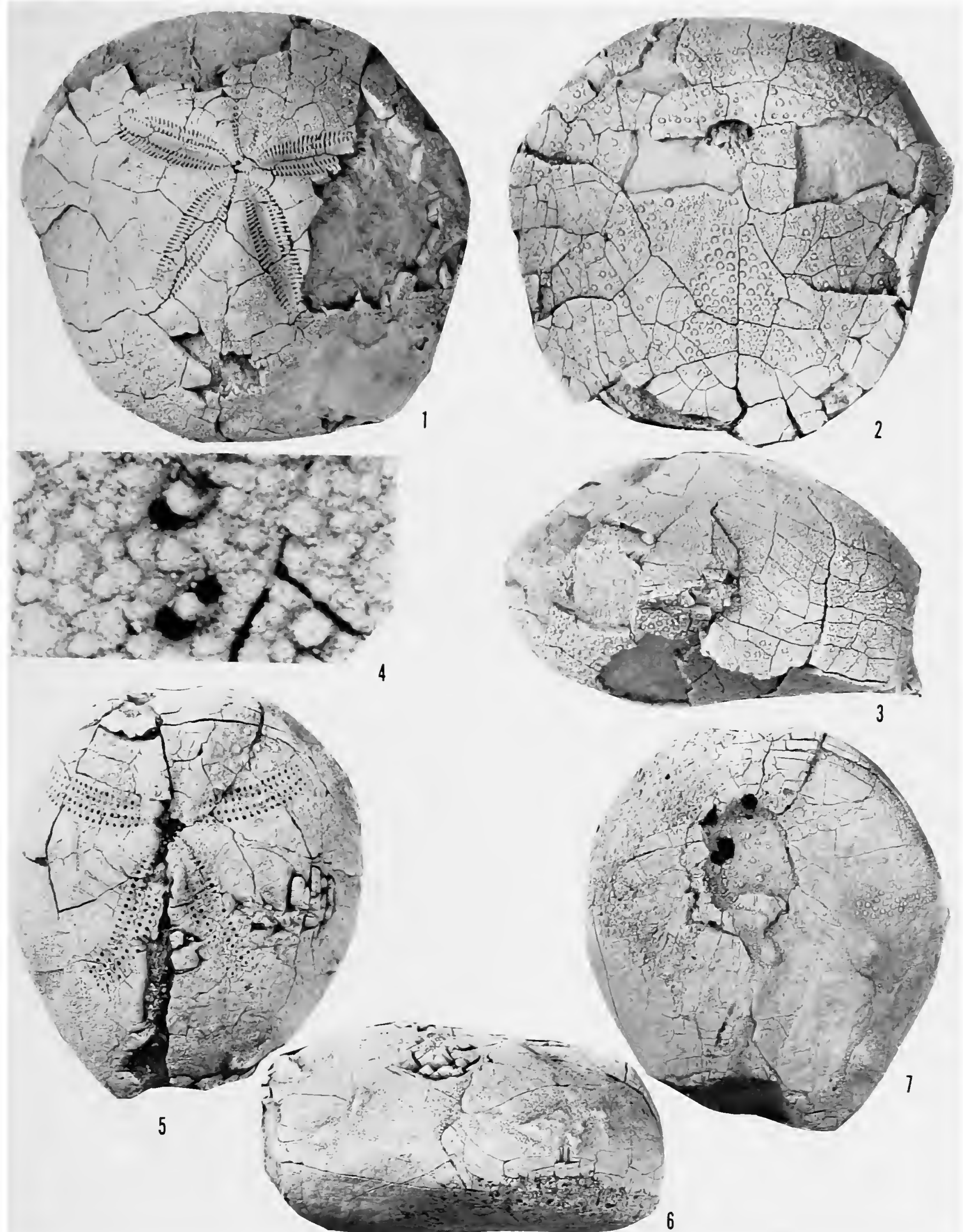
PLATE 49

Macropneustes? (Macropneustes) palmeri (Sánchez Roig)

1-3. Dorsal, right side, and ventral views of the paralectotype, SRC 4031, Oligocene-Miocene, SSE of Cartagena, $1 \mathrm{~km} \mathrm{~N}$ side of railroad, Las Villas Province, Cuba, $\times 1$.

\section{Macropneustes? (Macropneustes) cubensis Cotteau}

4. Dorsal view of holotype, Cotteau Collection, Université Claude Bernard, Lyons, France, Miocene, San Martin, Cuba, $\times 1$.

\section{Macropneustes (Deakia) armadilloensis Sánchez Roig}

5,6. Dorsal and right side views of topotype, SRC 4262, late Eocene, "Armadillo" farm, Marroquin, Morón, Camagüey Province, Cuba, $\times 1.5$. 

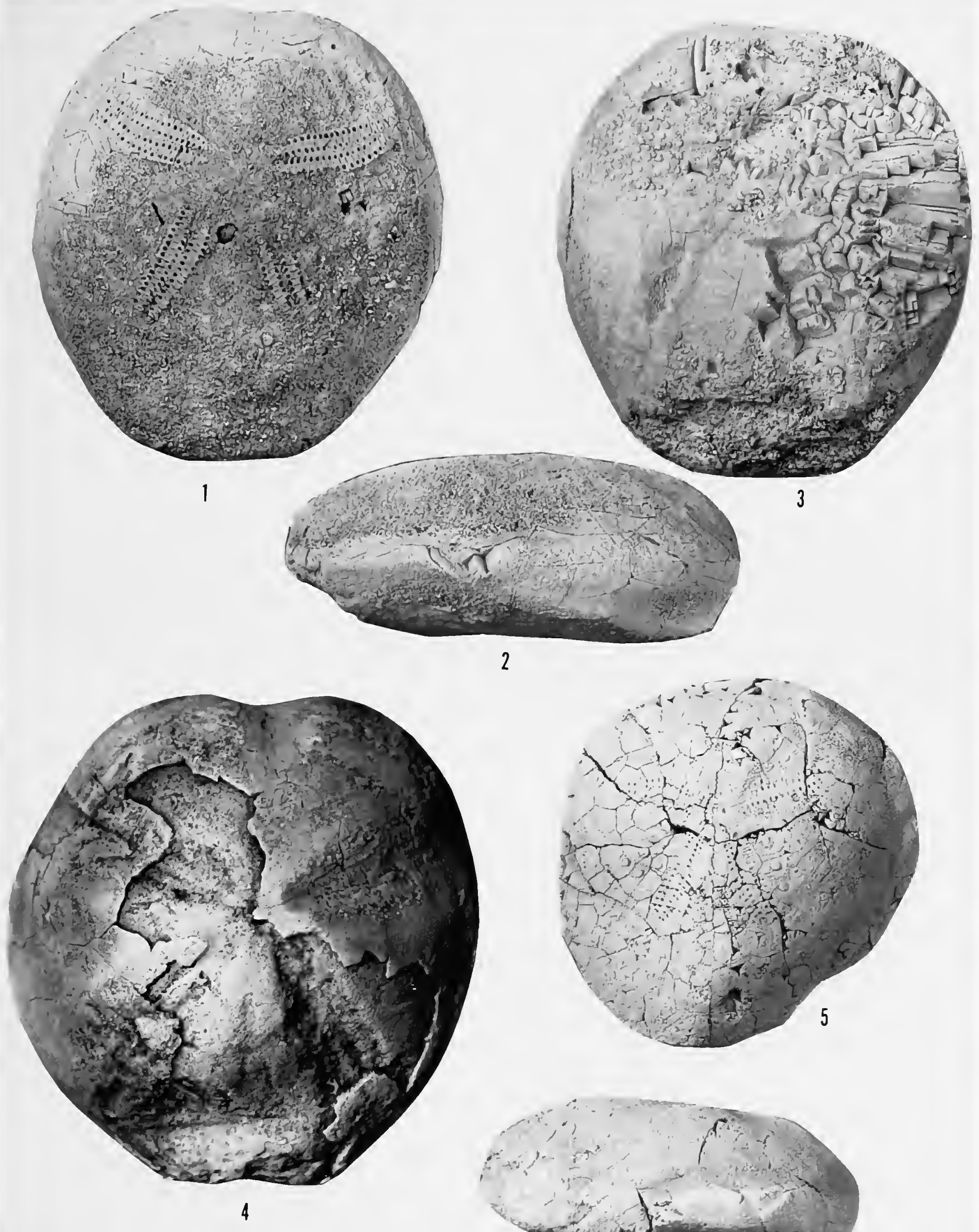

2
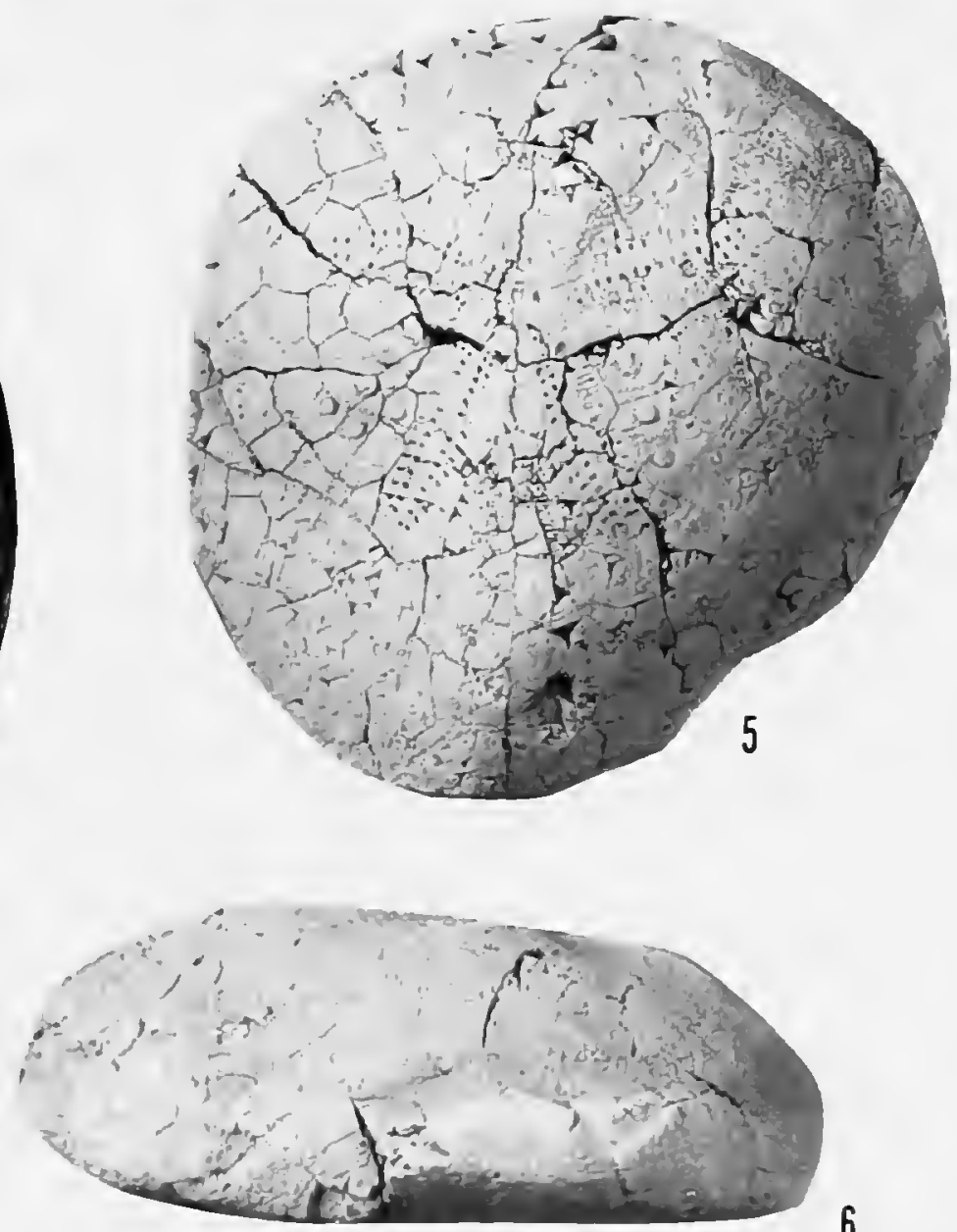
PLATE 50

Macropneustes (Deakia) armadilloensis Sánchez Roig

1-3. Dorsal, right side, and ventral views of the lectotype, SRC 4263, late Eocene, "Armadillo" farm, Marroquín, Morón, Camagüey Province, Cuba, $\times 1.5$.

Meoma? brodermann (Sánchez Roig)

4-6. Dorsal, right side, and ventral views of the holotype, SRC 4121, age uncertain, locality uncertain but perhaps from Casa Rabelo, Pinar del Rio Province, Cuba, $\times 0.75$. 

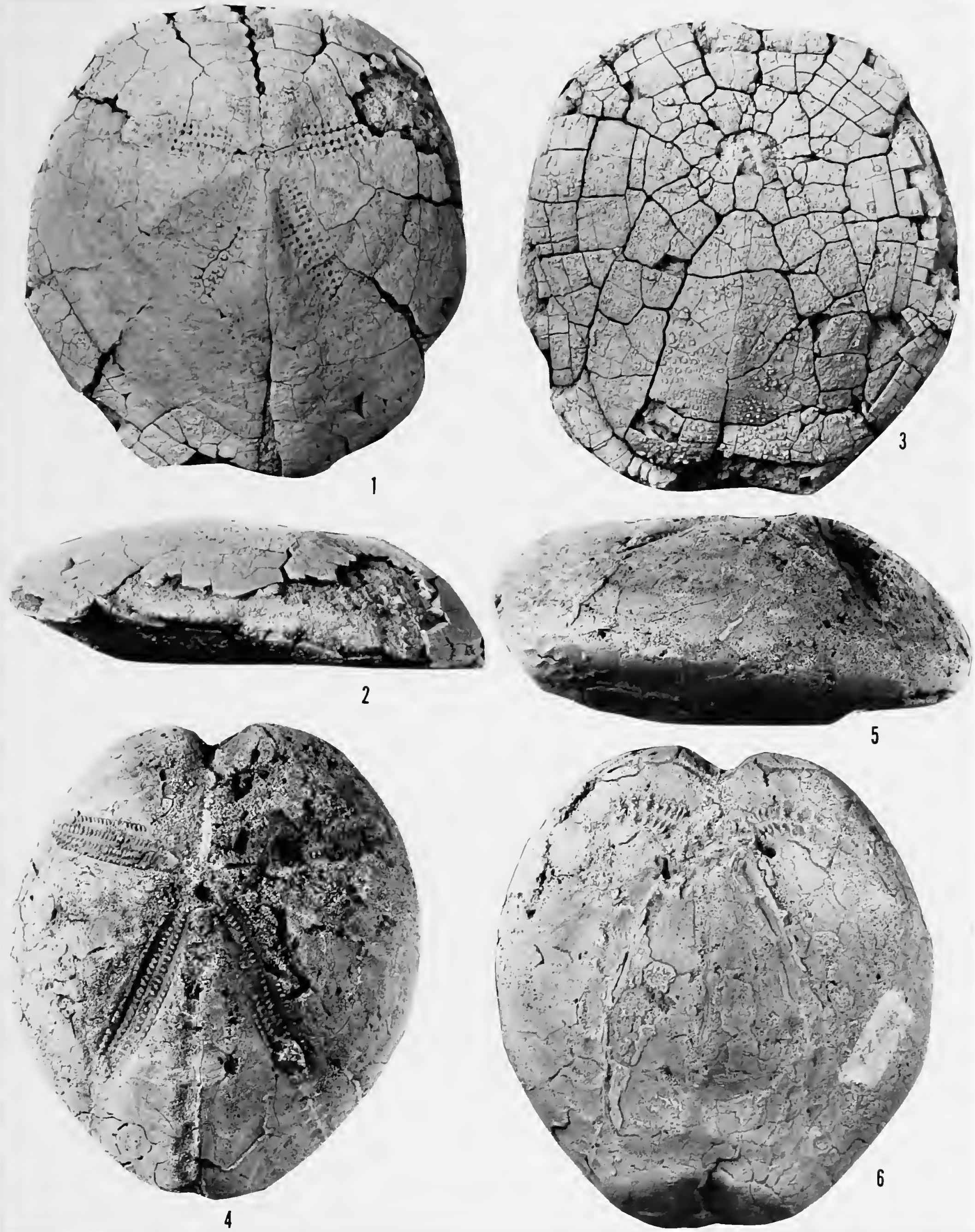
PLATE 51

\section{Meoma antillarum (Cotteau)}

1-3. Dorsal, ventral, and right side views of the lectotype, Cotteau Collection, Université Claude Bernard, Lyons, France, age and locality uncertain, $\times 1$. 

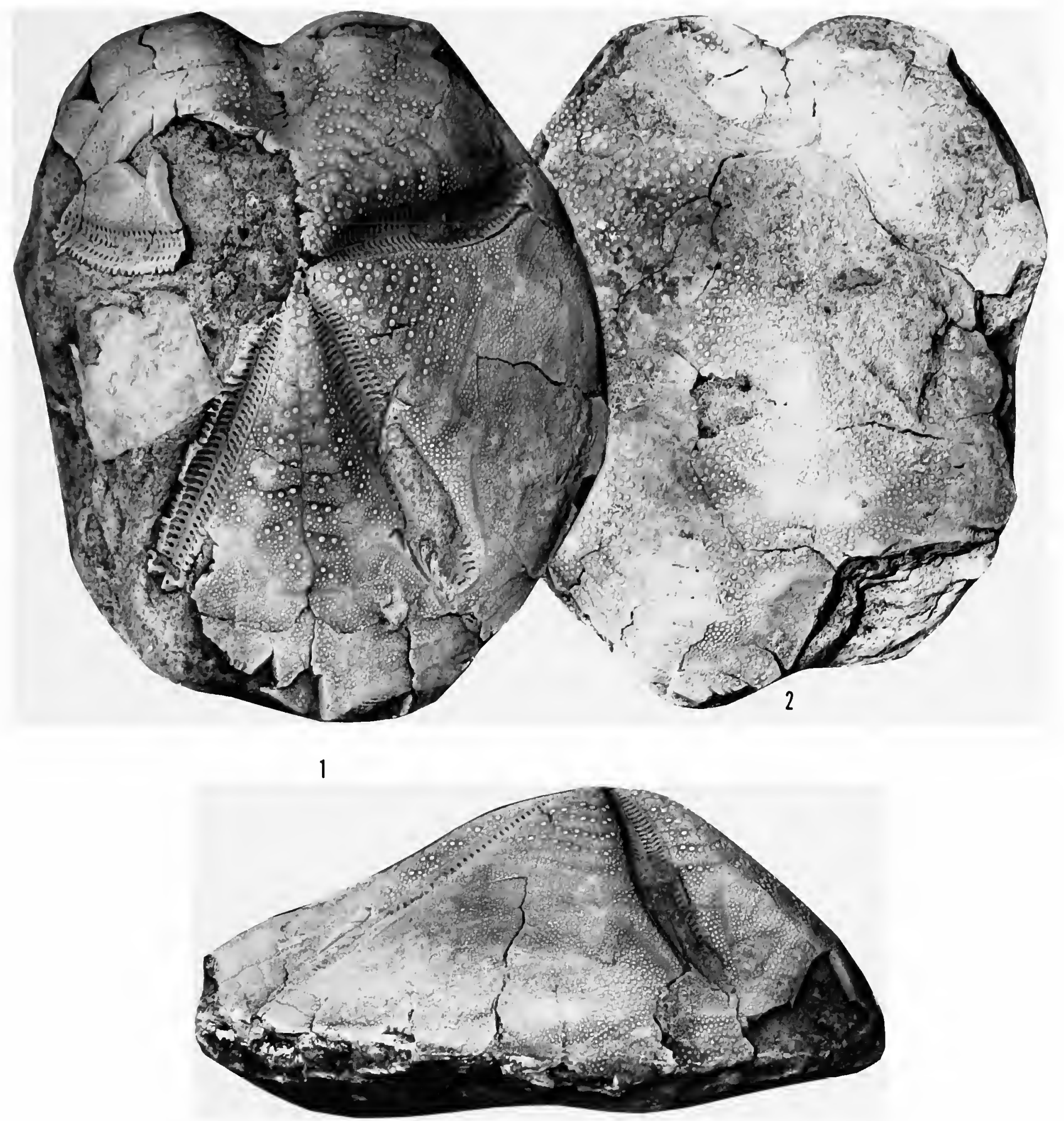


\section{PLATE 52}

Meoma? gomezmazae (Sánchez Roig)

1-3. Dorsal, right side, and ventral views of the holotype, SRC 4101, Oligocene-Miocene, Matanzas, Matanzas Province, Cuba, $\times 1$.

\section{Fernandezaster mortenseni Sánchez Roig}

4, 5. Rear and right side views of the holotype, SRC 4240, Oligocene-Miocene, in well on "Balbín" farm, San Pedro Bauta, Habana Province, Cuba, $\times$ 0.75. (See also Plate 53.)

Lajanaster jacksoni Lambert and Sánchez Roig

6. Right side of a topotype, USNM 352866, Miocene, "Cervantes" farm, San José de las Lajas, Habana Province, Cuba, $\times 1$. (See also Plate 53.) 

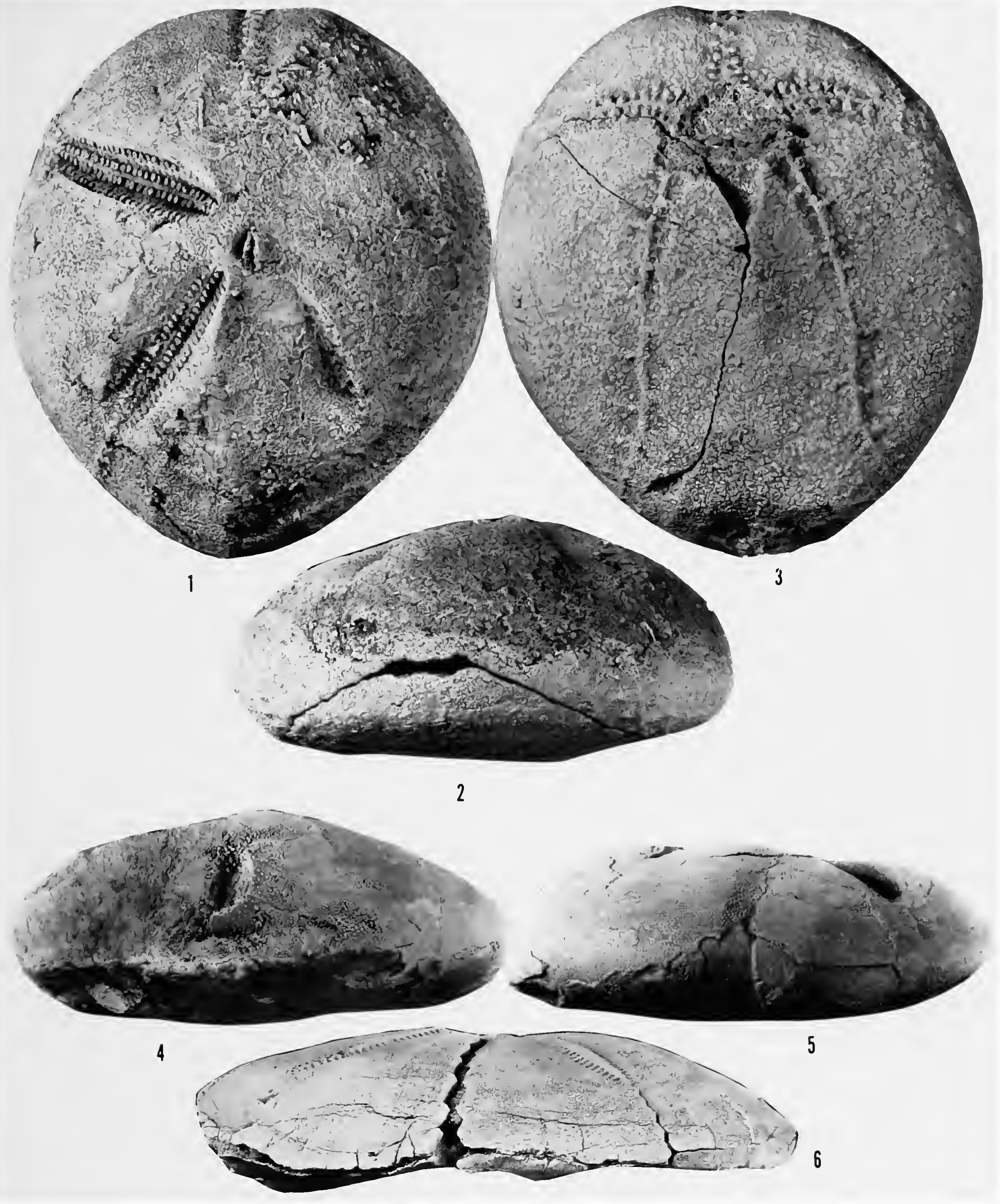


\section{PLATE 53}

\section{Fernandezaster mortenseni Sánchez Roig}

1, 2. Dorsal and ventral views of the holotype, SRC 4240, Oligocene-Miocene, in well on "Balbin" farm, San Pedro Bauta, Habana Province, Cuba, $\times 0.75$. (See also Plate 52.)

Lajanaster jacksoni Lambert and Sánchez Roig

3, 4. Ventral and dorsal views of a topotype, USNM 352866, Miocene "Cervantes" farm, San José de las Lajas, Habana Province, Cuba, $\times 1$. (See also Plate 52.) 

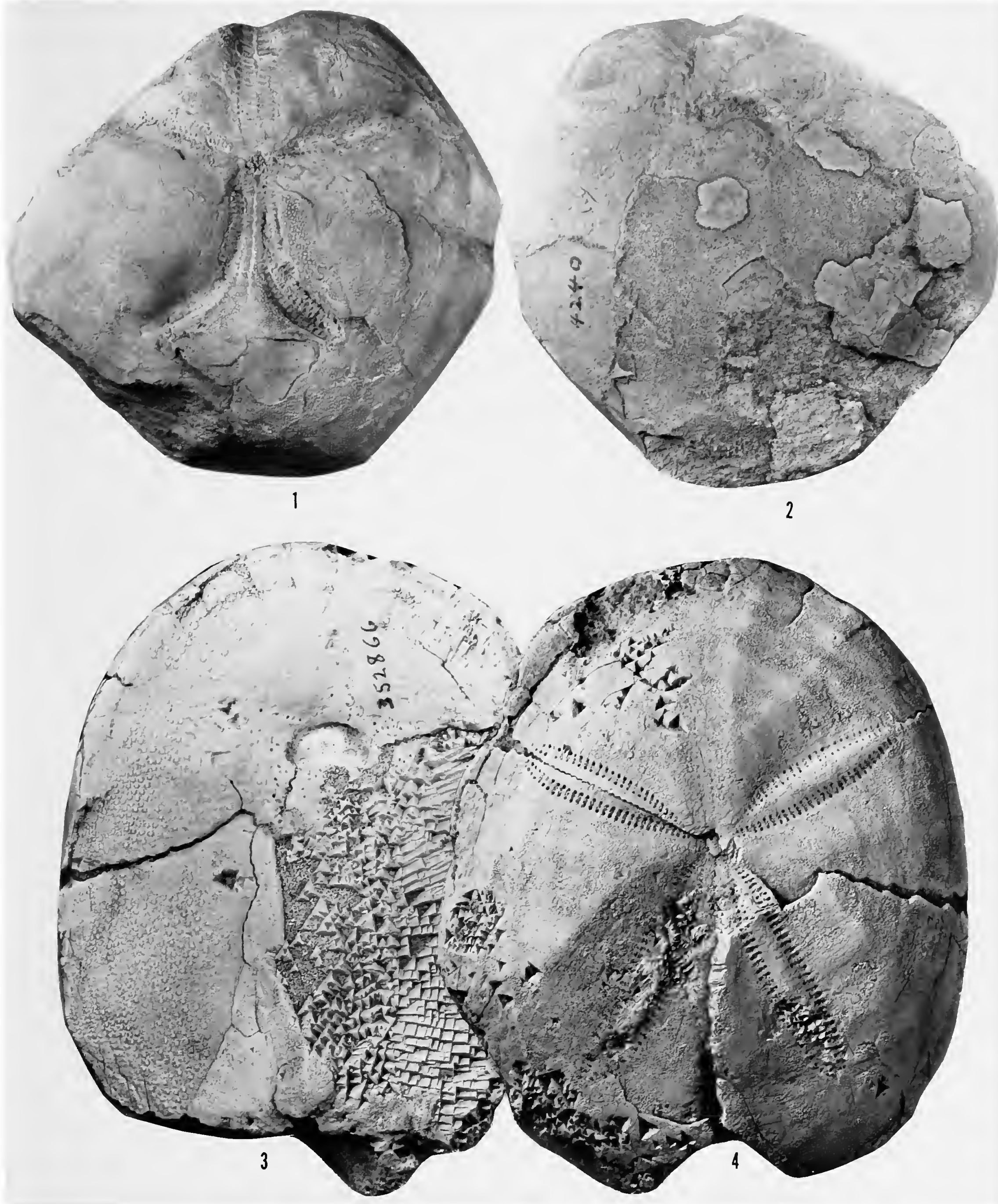


\section{PLATE 54}

\section{Eupatagus alatus Arnold and Clark}

1-3. Dorsal, right side, and ventral views, USNM 341256, middle to late Eocene, Loma Caoba, San Diego de los Baños, Pinar del Rio Province, Cuba, $\times 1$.

4, 5. Dorsal and rear views, USNM 341257, from same locality, $\times 1$.

6. Apical system, USNM 341256 , same specimen as in figures $1-3$ above, $\times 11$.

7. Petal I, USNM 341258, from same locality, $\times 2$. 

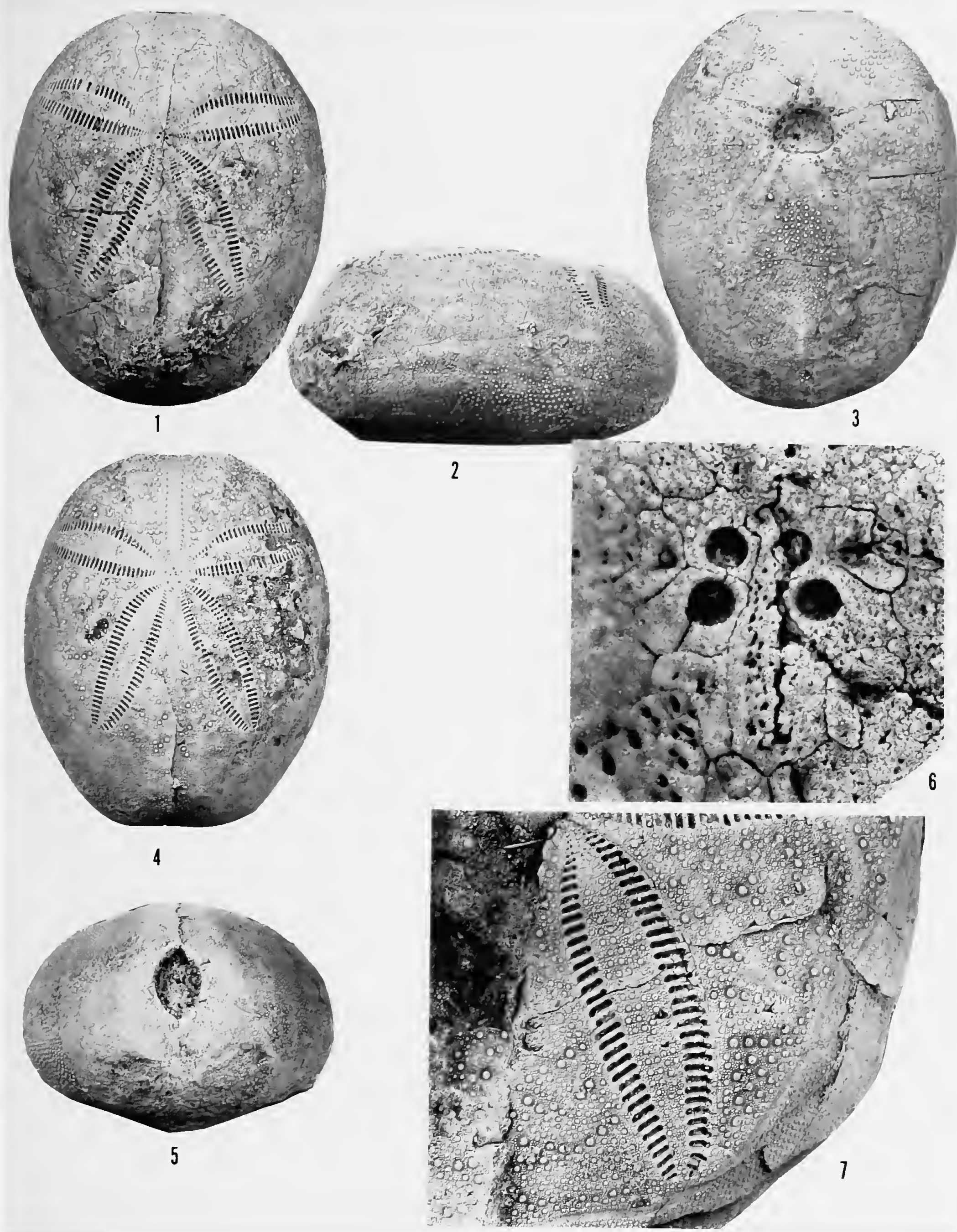


\section{PLATE 55}

\section{Eupalagus alatus Arnold and Clark}

1,2. Dorsal and ventral views, USNM 341259, Eocene, W of Springfield towards Seven Rivers, St. James Parish, Jamaica, $\times 1.5$.

\section{Eupalagus cubensis (Cotteau)}

3, 4. Dorsal and ventral views of holotype in Cotteau Collection, Université Claude Bernard, Lyons, France, Matanzas, Cuba, $\times 1$.

5. Right side of holotype of Maretia estenozi Sánchez Roig (= E. cubensis) SRC 5491, Miocene, "Cervantes" farm, San José de Las Lajas, Habana Province, Cuba, X 1. (See also Plate 56.) 


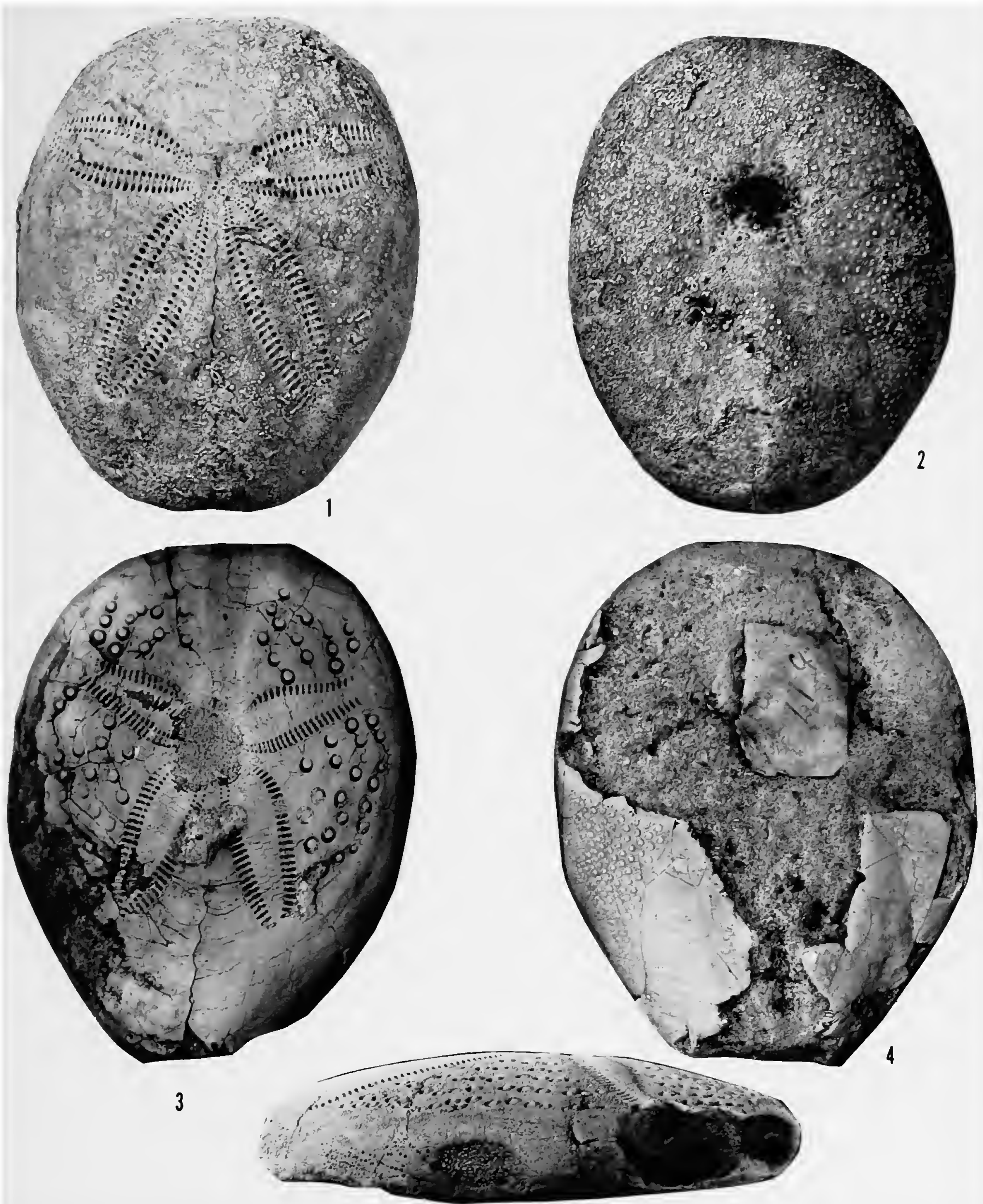




\section{PLATE 56}

\section{Eupatagus cubensis (Cotteau)}

1, 2. Dorsal and ventral views of holotype of Maretia estenozi Sánchez Roig (= E. cubensis), SRC 5491, of Miocene, "Cervantes" farm, San José de las Lajas, Habana Province, Cuba, $\times 1$. (A side view of this specimen is on Plate 55.)

3-5. Dorsal, right side, and ventral views, MCZ 4044, Oligocene-Miocene, Palmer loc. 1660, long cuts of switch on Ramal Valle, Central Jatibonico, cane railroad, Camagüey Province, Cuba, $\times 1$. 


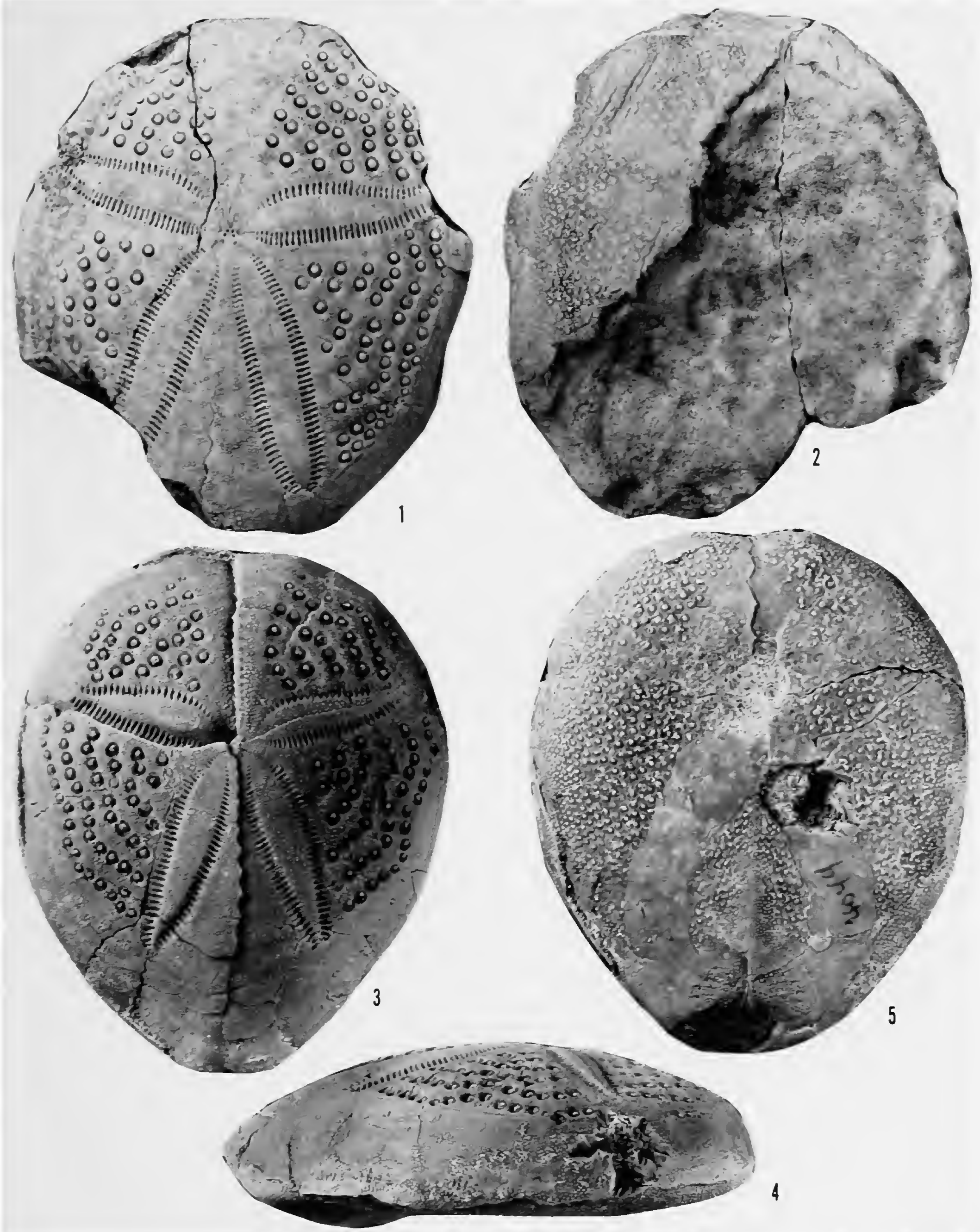


PLATE 57

\section{Eupatagus cubensis (Cotteau)}

1-3. Dorsal, ventral, and right side of hypotype of ?Brissoides munozi Lambert (= ?E. cubensis) USNM 352863, Miocene "Cervantes" farm, San José de las Lajas, Habana Province, Cuba, $\times 1$.

4. Dorsal view of topotype of Brissoides munozi Lambert (= ?E. cubensis), SRC 5497, Miocene, "Cervantes" farm, San José de las Lajas, Habana Province, Cuba, $\times 1$.

5. Dorsal view of the holotype of Eupatagus depressus Jackson (=E. cubensis) AMNH 18573, Miocene, Ponce Limestone at a high bluff, $2 \mathrm{~km}$ SW of Juana Diaz, Puerto Rico, $\times 1$. 


\section{PLATE 58}

Eupatagus sanchezi (Lambert)

1-3. Dorsal, left side, and ventral views of holotype, SRC 4765, Miocene, "La Noria" farm, Cojímar, Habana Province, Cuba, $\times 2$.

\section{Eupatagus santanae Sánchez Roig}

4-7. Right side, rear, dorsal, and ventral views of lectotype, SRC 4306, Oligocene-Miocene, "Santa Inés" farm, Guadalupe, district, Morón, Camagüey Province, Cuba, $\times 1$. 

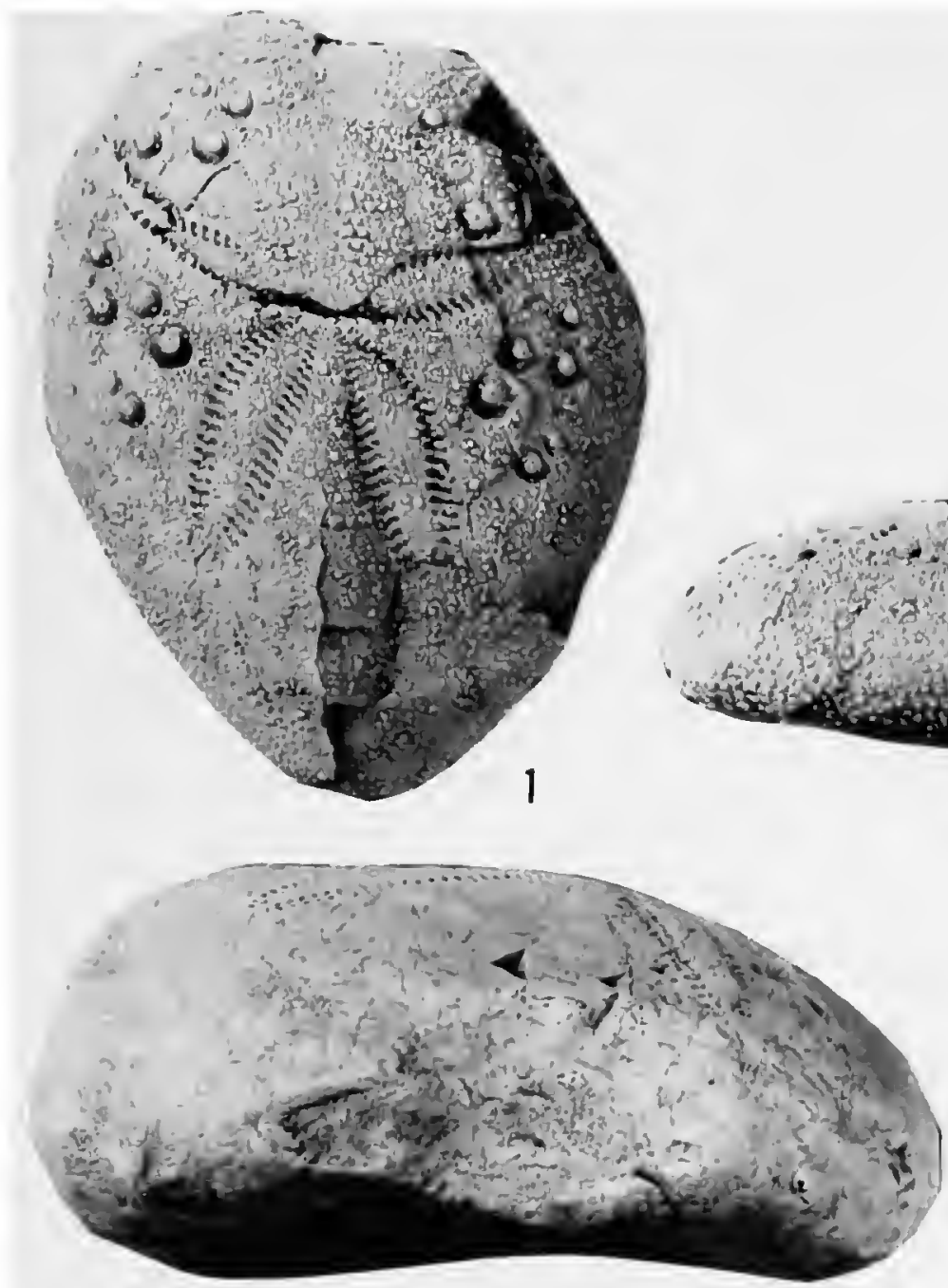

4

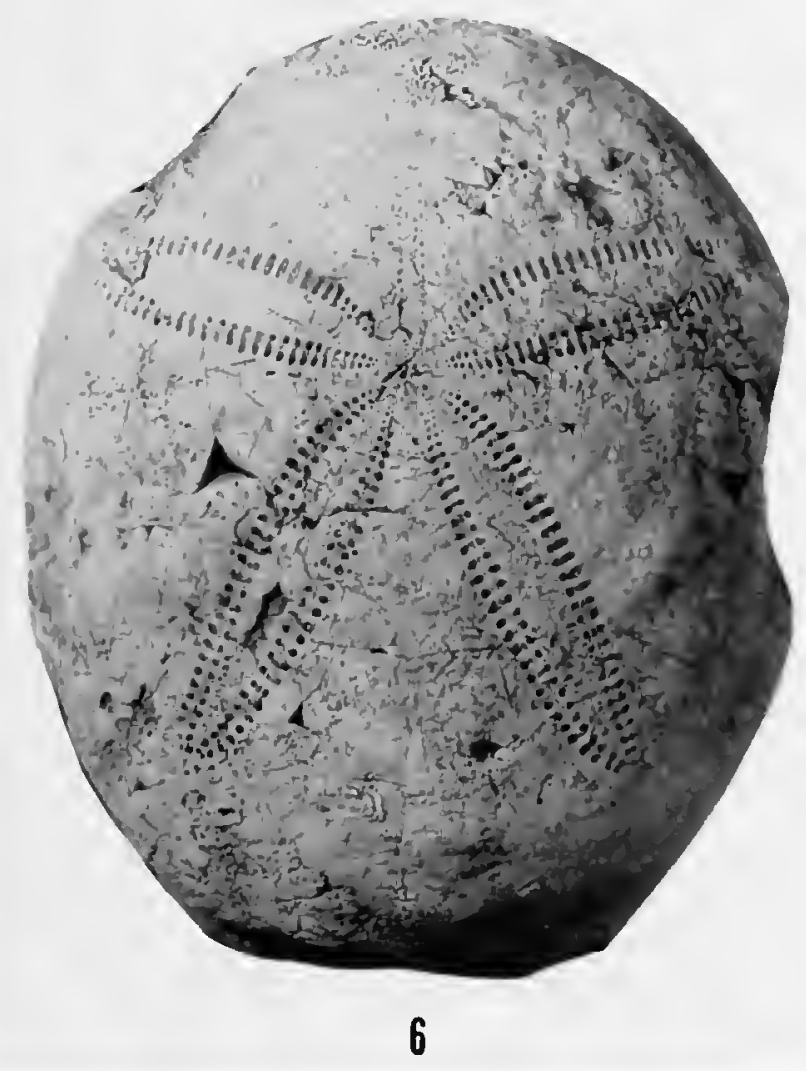

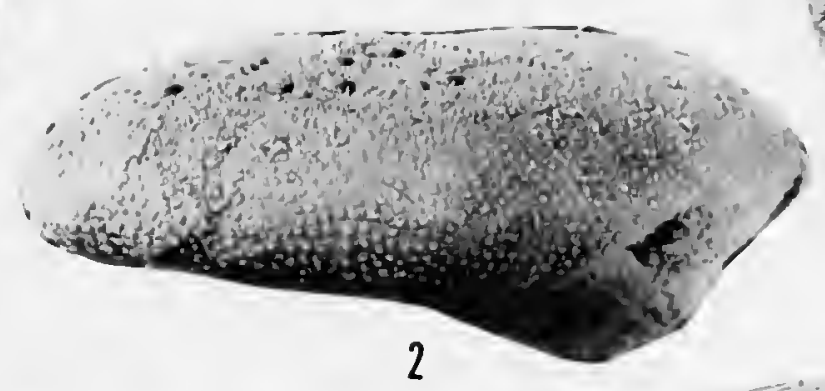
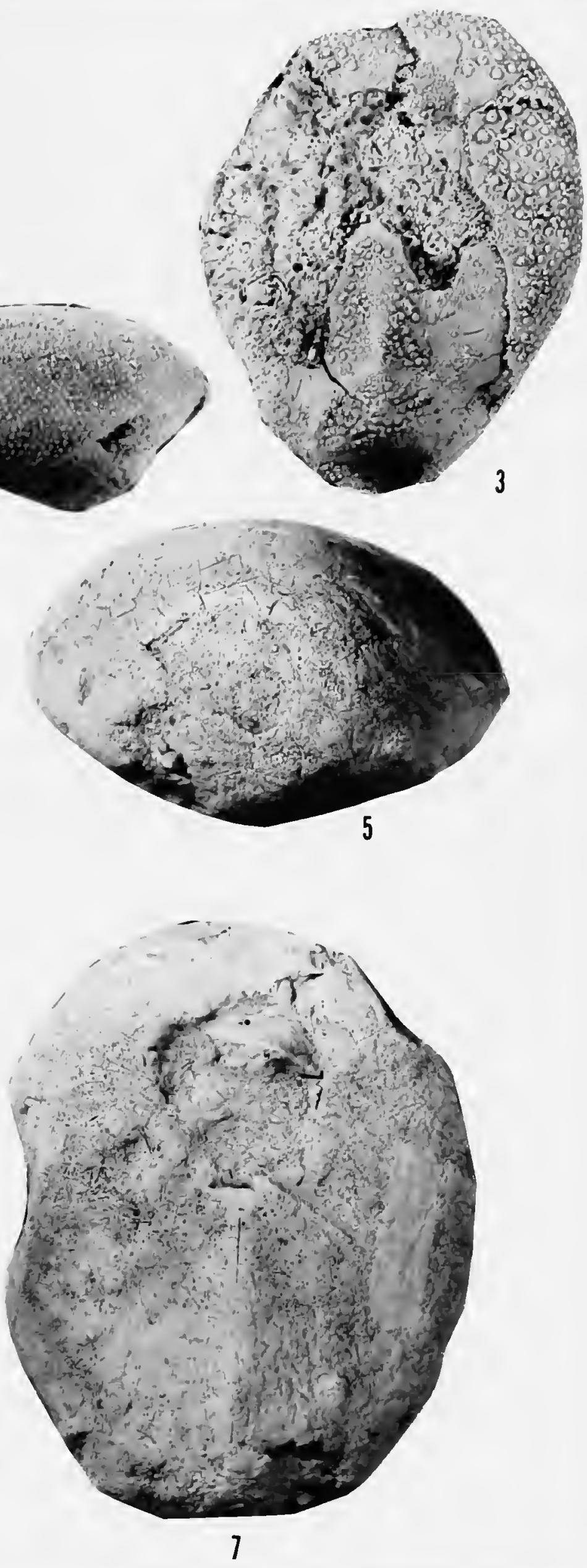


\section{PLATE 59}

\section{Eupatagus siboneyensis Weisbord}

1,2. Dorsal and ventral view of the paratype, PRI 898F, late Eocene, road cut at Loma Calisto, approximately $800 \mathrm{~m} \mathrm{SW}$ of the S end of the town of Nuevitas, on the road leading toward Belén, Camagüey Province, Cuba, $\times 2$.

3. Ventral view of holotype, PRI 3836, same locality as above, $\times 1.5$.

Eupatagus turibacoensis Sánchez Roig

4-7. Dorsal, ventral, rear, and right side views of holotype, SRC 4050, late Eocene, "Turibacoa" farm, Marroquín, Morón, Camagúey Province, Cuba, $\times 1$. 

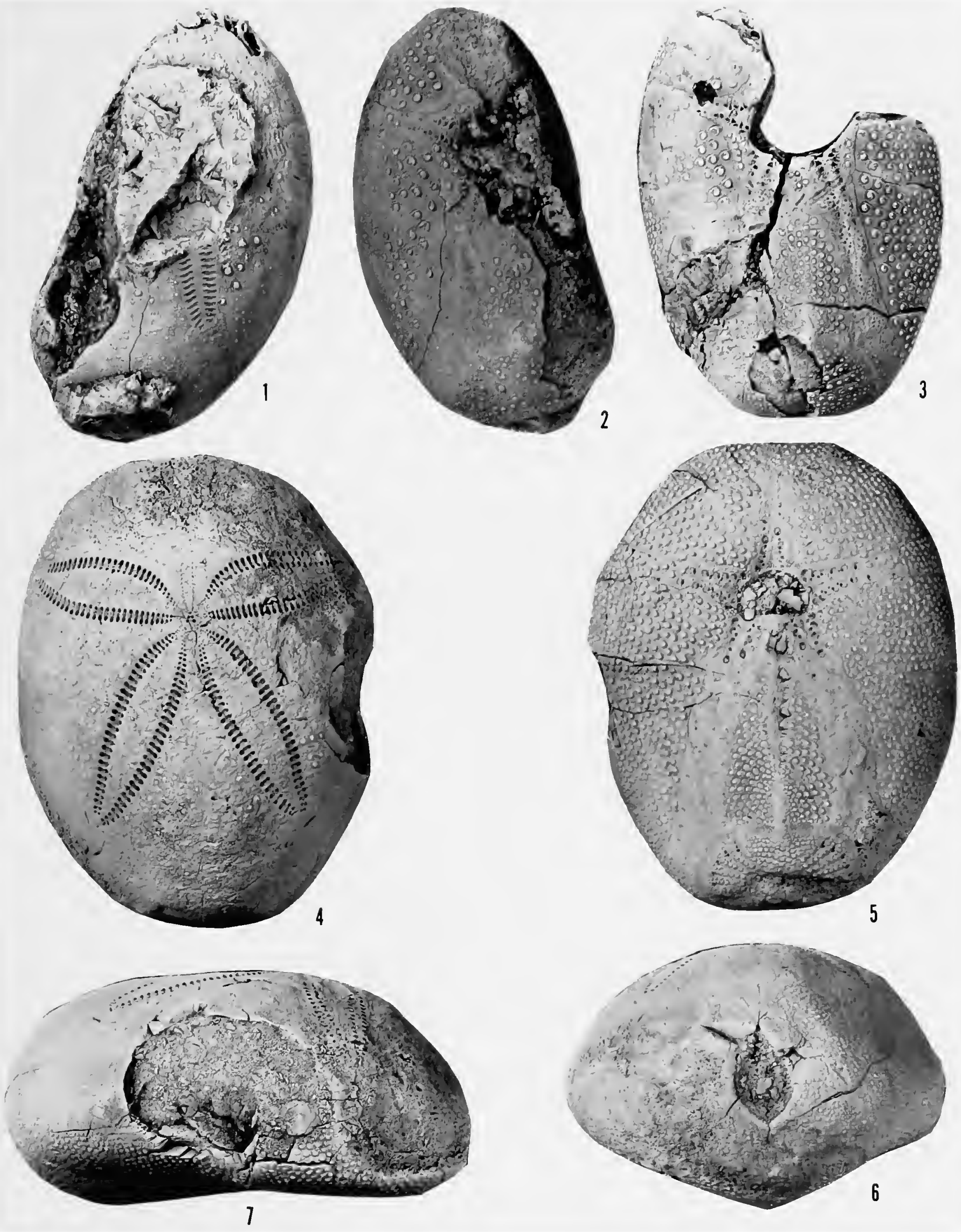


\section{PLATE 60}

\section{Eupatagus turibacoensis Sánchez Roig}

1-3. Dorsal, left side, and ventral views of holotype of ?Eupatagus calistoides Sánchez Roig (= E. turibacoensis), SRC 4774, late Eocene, "Turibacoa" farm, Marroquín, Morón, Camagüey Province, Cuba, $\times 1.5$.

4-6. Dorsal, right side, and ventral views, of holotype of ?Megapatagus turibacoensis Sánchez Roig (= E. turibacoensis), SRC 4173, late Eocene, same locality as above, $\times 1$. 

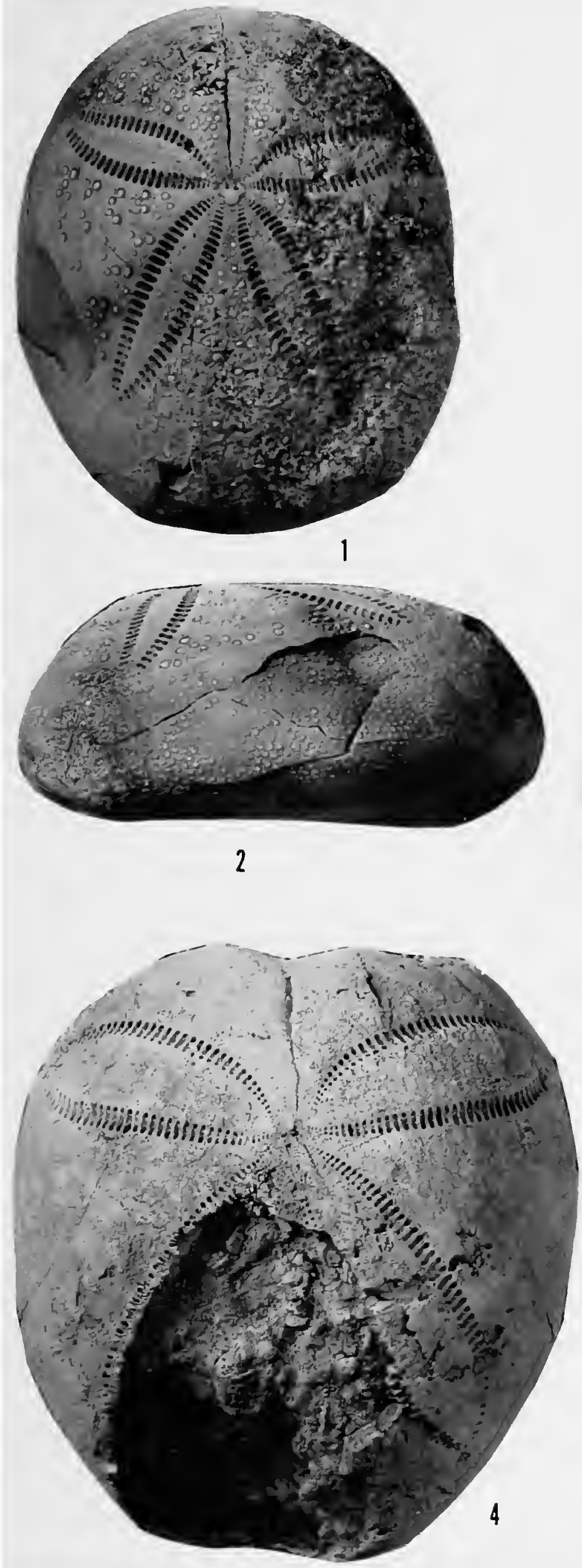
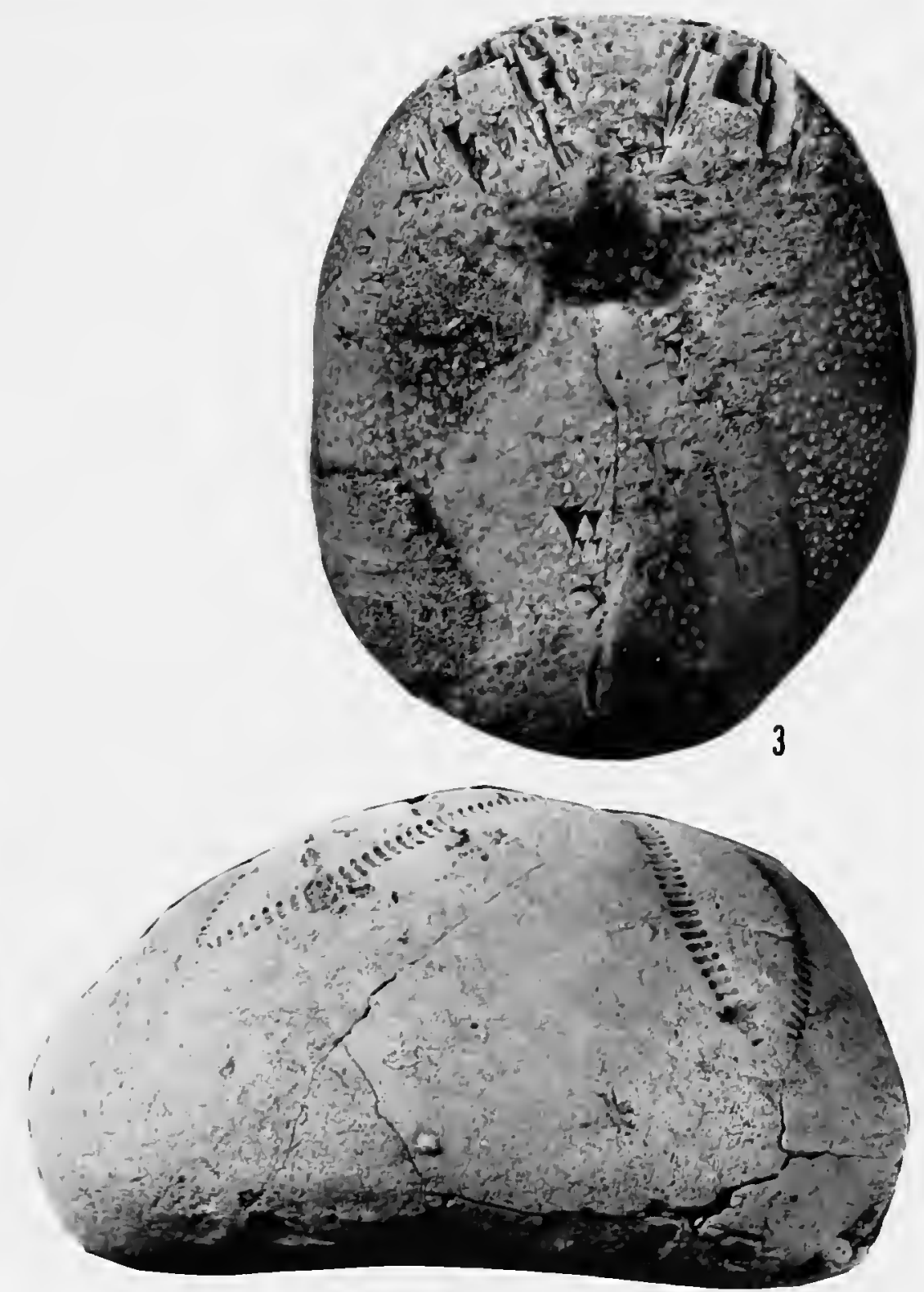

5

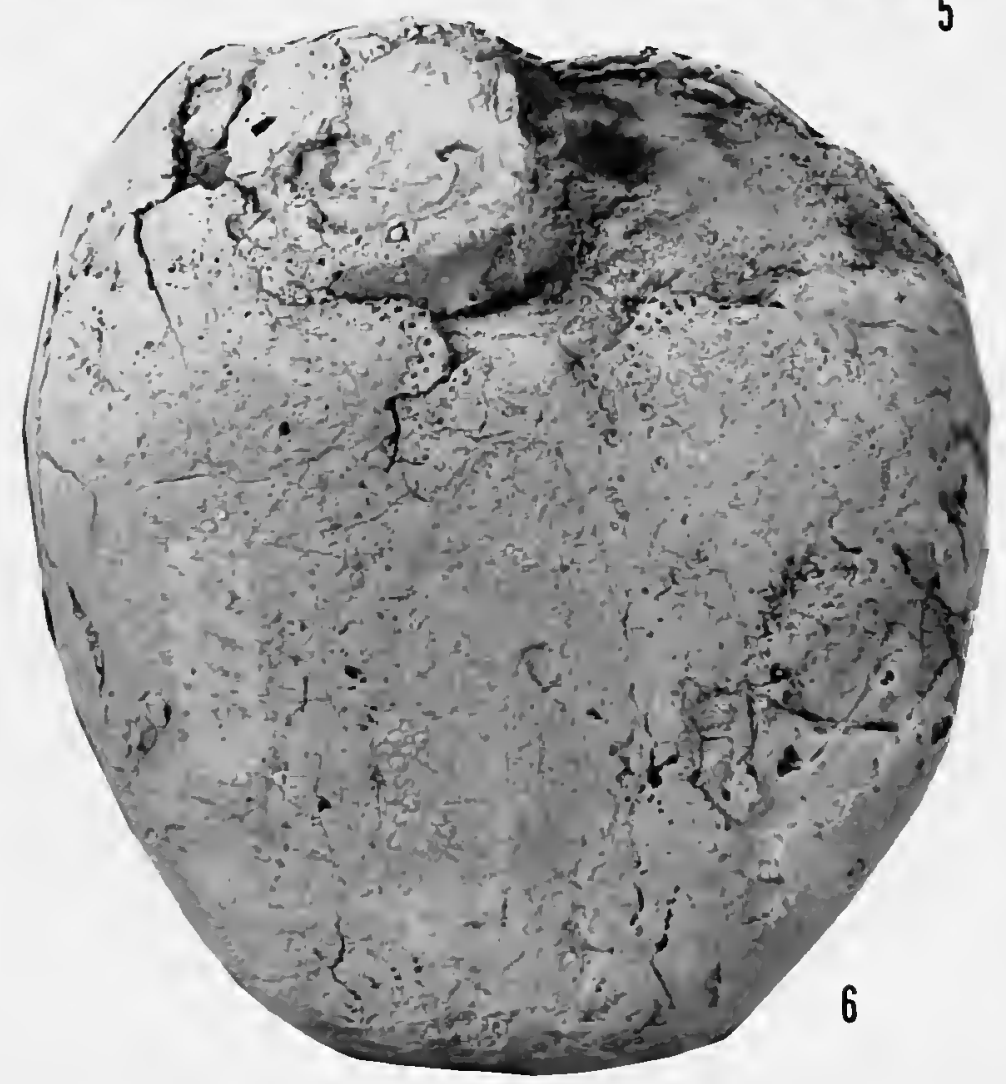




\title{
PLATE 61
}

\author{
Eupatagus antillarum (Cotteau)
}

1,2. Dorsal and ventral views of the lectotype, USNM 207225 (formerly 115395), Eocene, St. Bartholomew Limestone, St. Bartholomew, $\times 2$.

\section{Eupatagus clevei (Cotteau)}

3. Dorsal view of holotype, USNM 207223, Eocene, St. Bartholomew, $\times 1$.

4. Dorsal view of holotype of Eupatagus grandiflorus (Cotteau) (= E. clevei), USNM 207222, Eocene, St. Bartholomew, $\times 1$.

5, 6. Dorsal and left side views of holotype of Zanolettiaster herrerae Sánchez Roig ( = ? E. clevei, SRC 4070, Oligocene-Miocene, "La Venturilla" farm, Realengo, Charco Hondo, Marroquín district, Morón, Camagüey Province, Cuba, $\times 0.75$. 


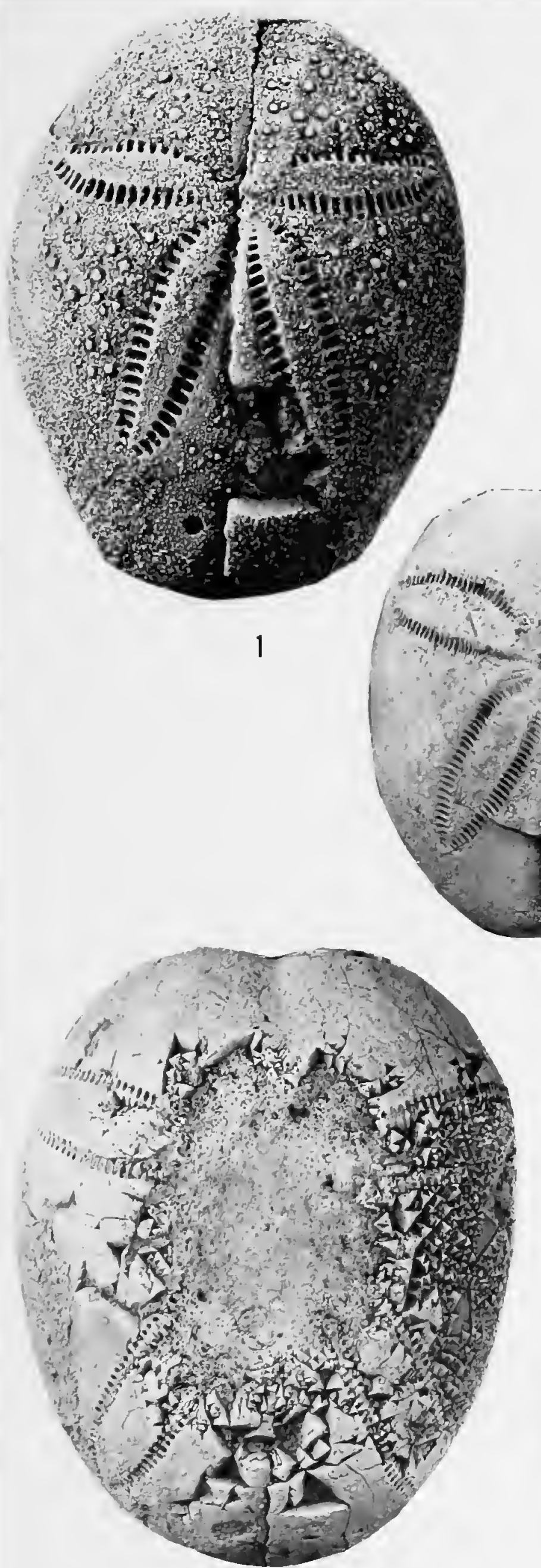




\section{PLATE 62}

\section{Eupatagus clevei (Cotteau)}

1,2. Right side and dorsal views of lectotype of Eupatagus venturillae Sánchez Roig (= ? E. clevei), SRC 4027, Oligocene-Miocene, probably from "La Venturilla" farm, Relengo, Charco Hondo, Morón, Camagúey Province, Cuba, $\times 1$.

3-6. Dorsal, ventral, right side, and rear views of lectotype of Eupatagus brevipetalum Sánchez Roig (= ? E. clevei), SRC 4094, Oligocene-Miocene, "La Venturilla" farm, Realengo, Charco Hondo, Morón, Camagüey Province, Cuba, $\times 1$. 


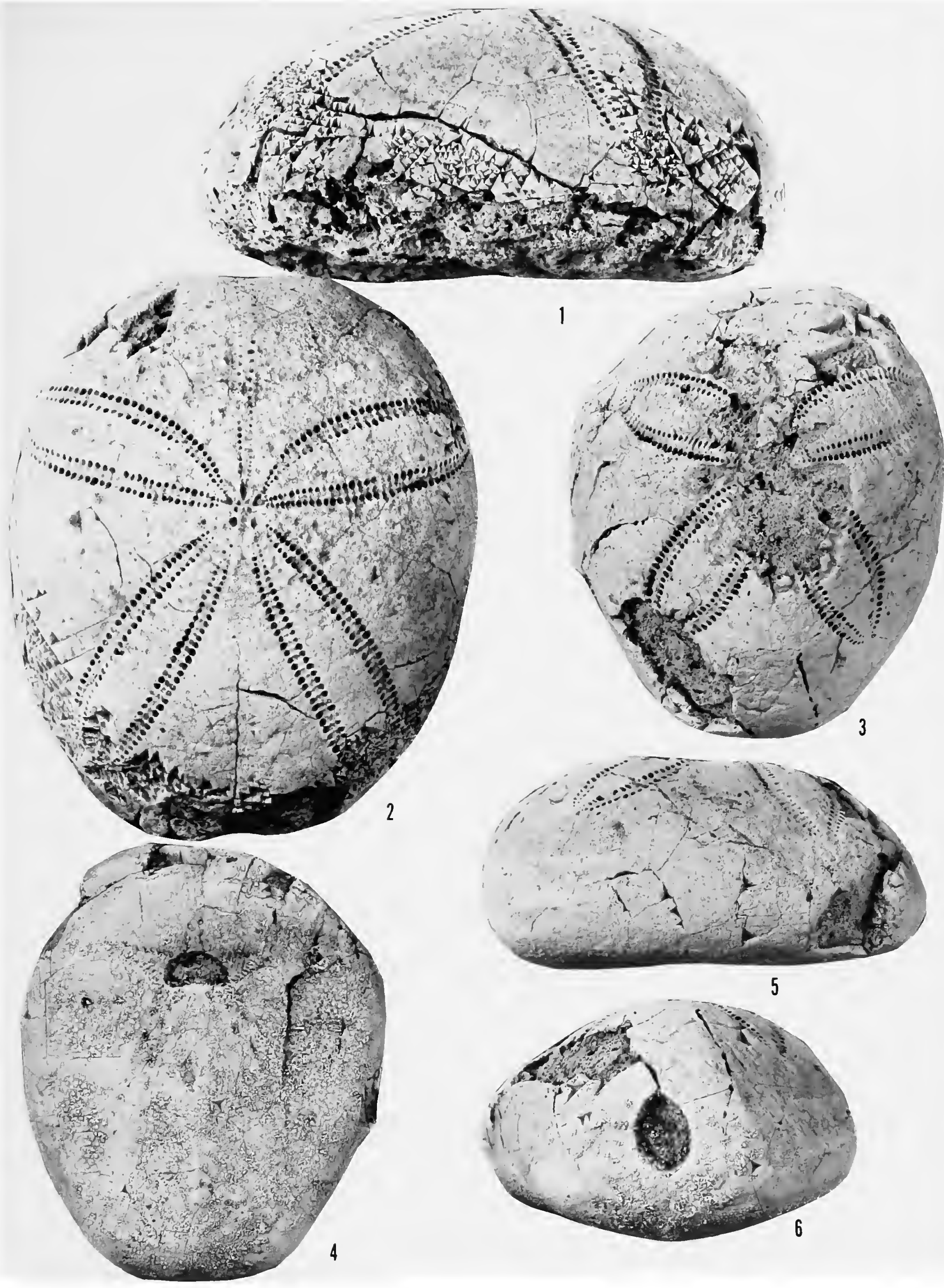




\section{PLATE 63}

\section{Eupatagus clevei (Cotteau)}

1-3. Dorsal, ventral, and right side views of holotype of Megapatagus franciscanus Sánchez Roig (=E. clevei), SRC 4473, Oligocene-Miocene, "San Francisco de la Rosa" farm, Guadalupe district, Morón, Camagüey Province, Cuba, $\times 1$.

(Photograph reduced to 90 percent.) 

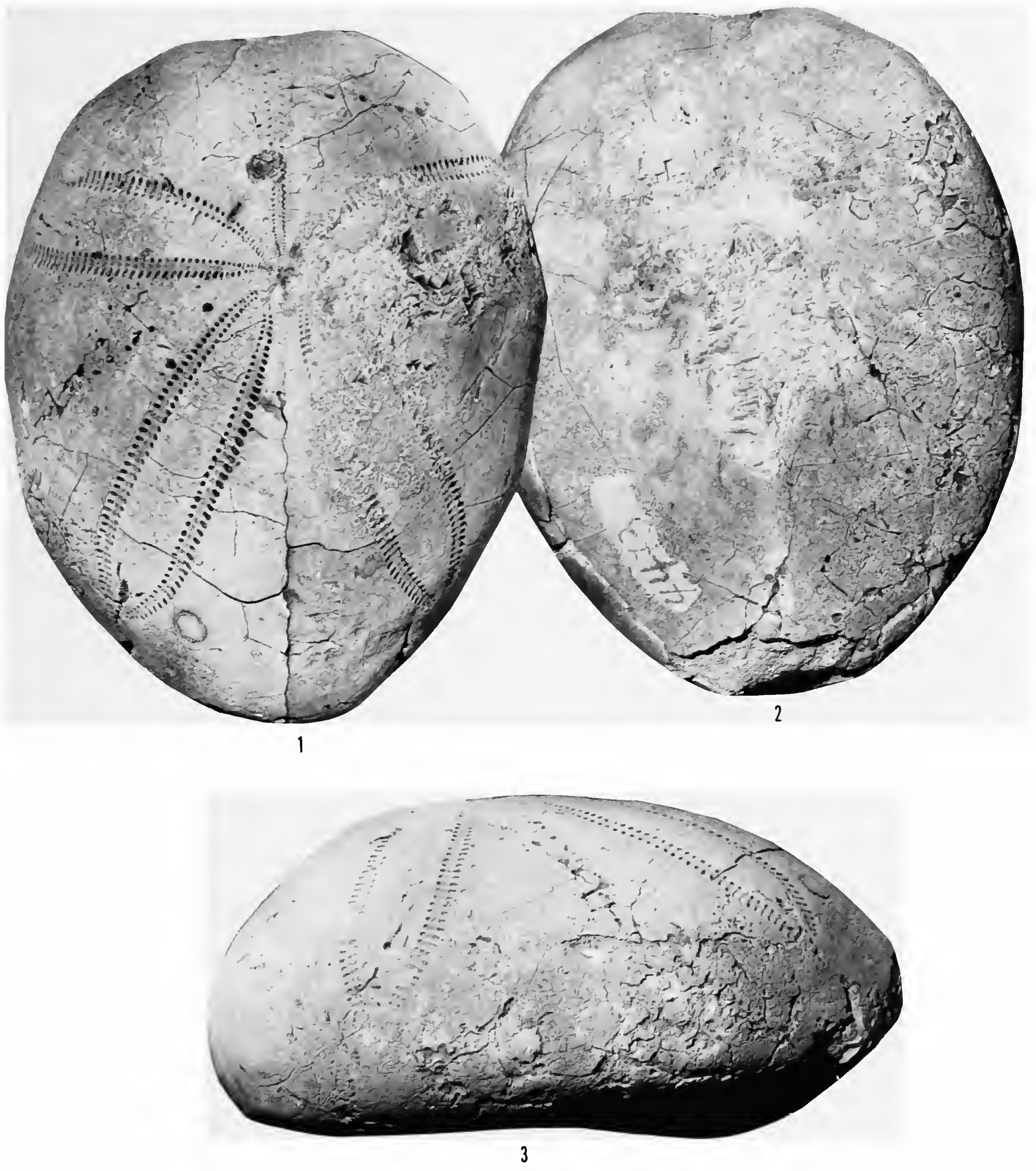


\section{PLATE 64}

\section{Eupatagus clevei (Cotteau)}

1, 2. Left side and dorsal views of topotype of Herreraster herrerae Sánchez Roig (=? E. clevei), SRC 4012, Oligocene-Miocene, "Las Cuevas" farm, Realengo, Charco Hondo, Ranchuelo district, Morón, Camagúey Province, Cuba, $\times 1$.

3-5. Dorsal, rear, and right side views of holotype of Eupatagus rojasi Sánchez Roig (= ? E. clevei), SRC 4056, Oligocene-Miocene, "Las Cabezadas" farm, Corral Naranjo, 12 km E of Marroquín, Morón, Camagüey Province, Cuba, X 0.75. 


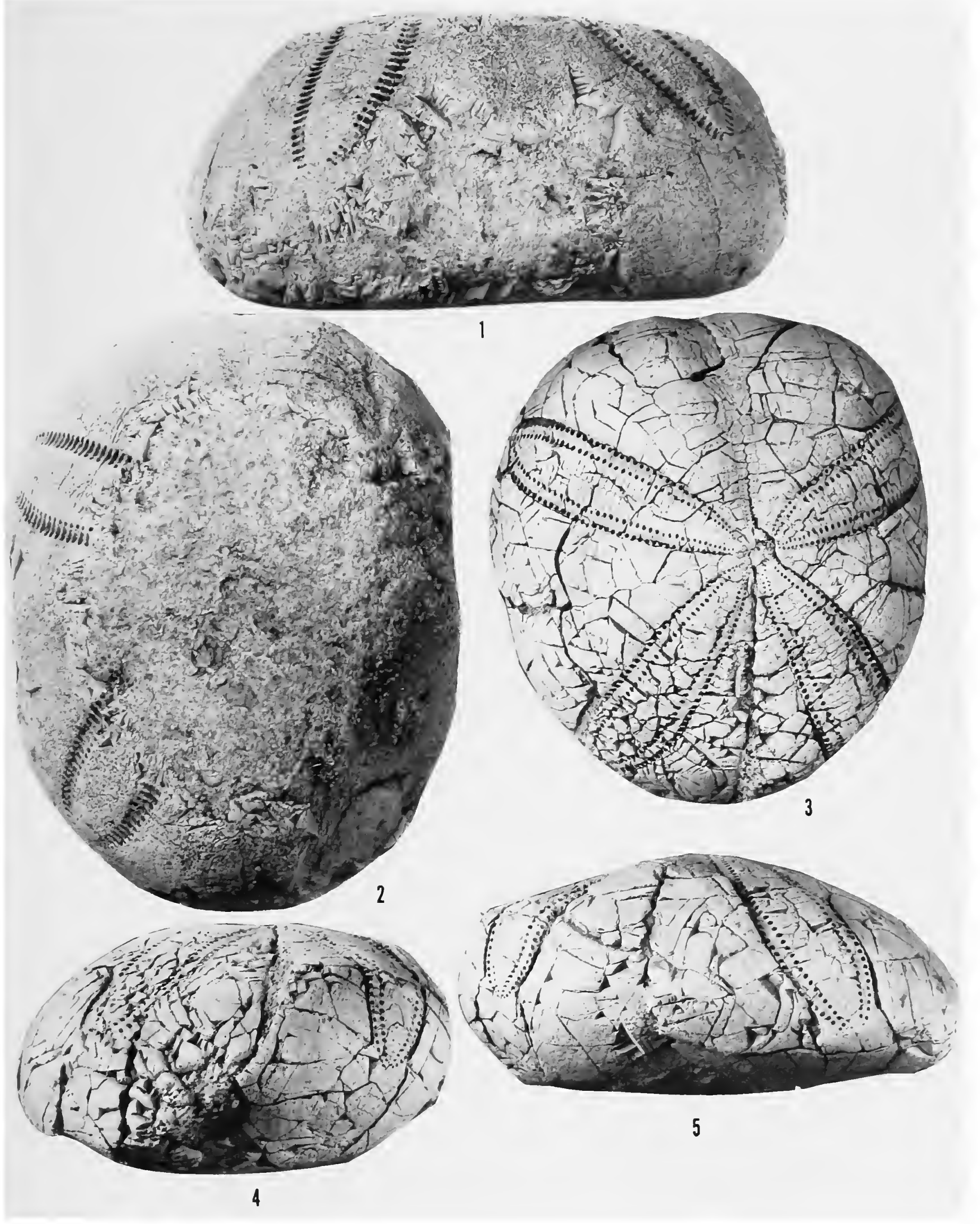




\section{PLATE 65}

\section{Eupatagus clevei (Cotteau)}

1-4. Dorsal, ventral, left side, and rear views of holotype of Eupatagus herrerae Sánchez Roig (= ? E. clevei), SRC 4060, Oligocene-Miocene, old sugar house of "La Venturilla" farm, Realengo, Charco Hondo, Morón, Camagüey Province, Cuba, $\times 1$.

5,6. Dorsal and ventral views of the lectotype of Lajanaster venturillae Sánchez Roig $(=? E$. clevei), SRC 4136, Oligocene-Miocene, same locality as above, $\times 1$. (Rear and side views are on Plate 66.) 

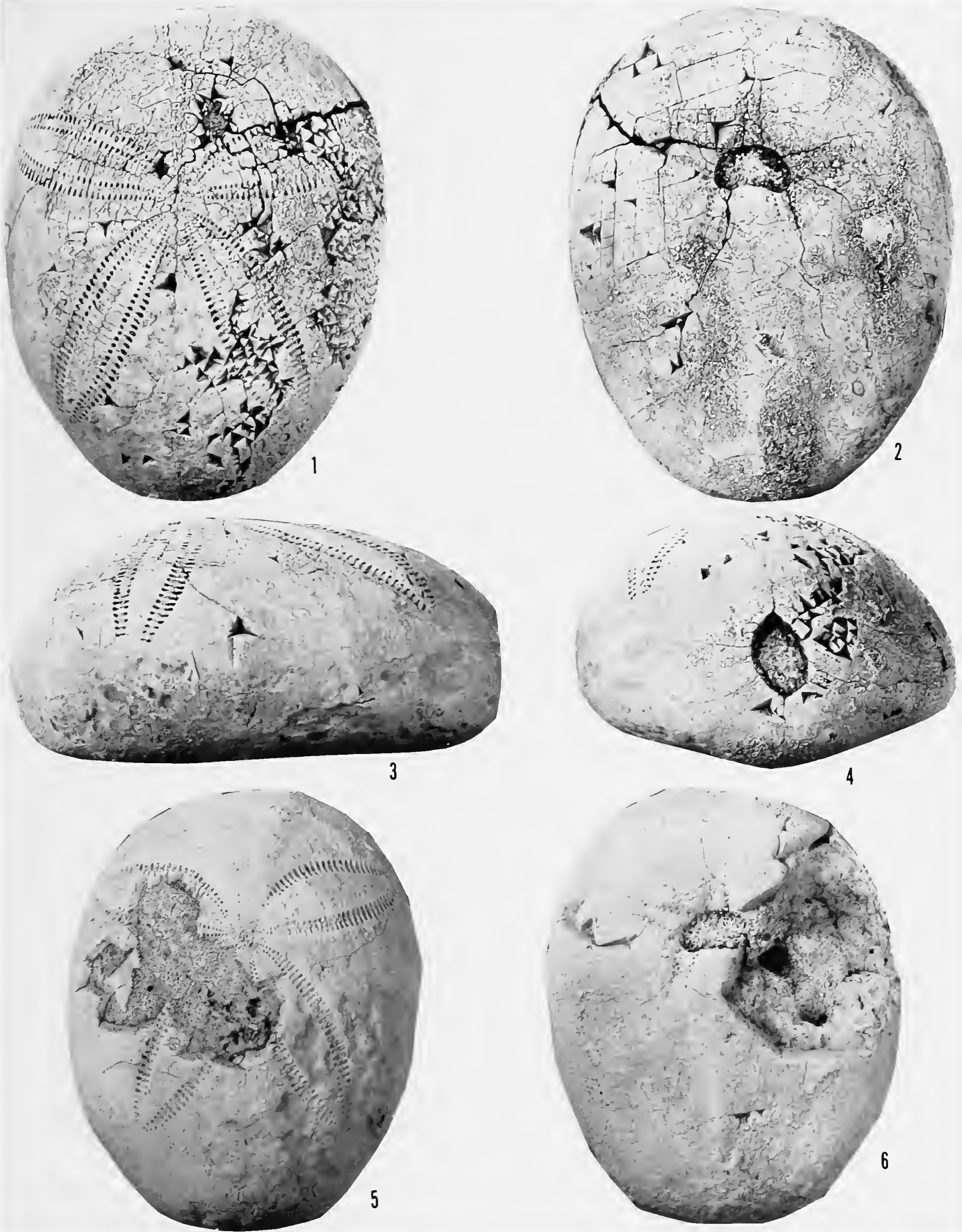


\section{PLATE 66}

\section{Eupatagus clevei (Cotteau)}

1,2. Right side and rear views of lectotype of Lajanaster venturillae Sánchez Roig (=? E. clevei), SRC $4136, \times 1$. (See Plate 65 for dorsal and ventral views of this specimen.)

3. Dorsal view of part of USNM 353895 showing tuberculation within peripetalous fasciole, late Eocene, USGS loc. 16889, Madden Airfield, $15 \mathrm{mi}(24 \mathrm{~km}) \mathrm{N}$ of central part of Panama City, $6 \mathrm{mi}(9.7 \mathrm{~km}) \mathrm{NE}$ of the Canal Zone, $\times 1$.

4-6. Dorsal, right side, and ventral views of topotype of Eupatagus zanoletti Sánchez Roig (= E. clevei), SRC 4412, Oligocene-Miocene, "La Venturilla" farm, Realengo, Charco Hondo, Morón, Camagüey Province, Cuba, $\times 1$. 

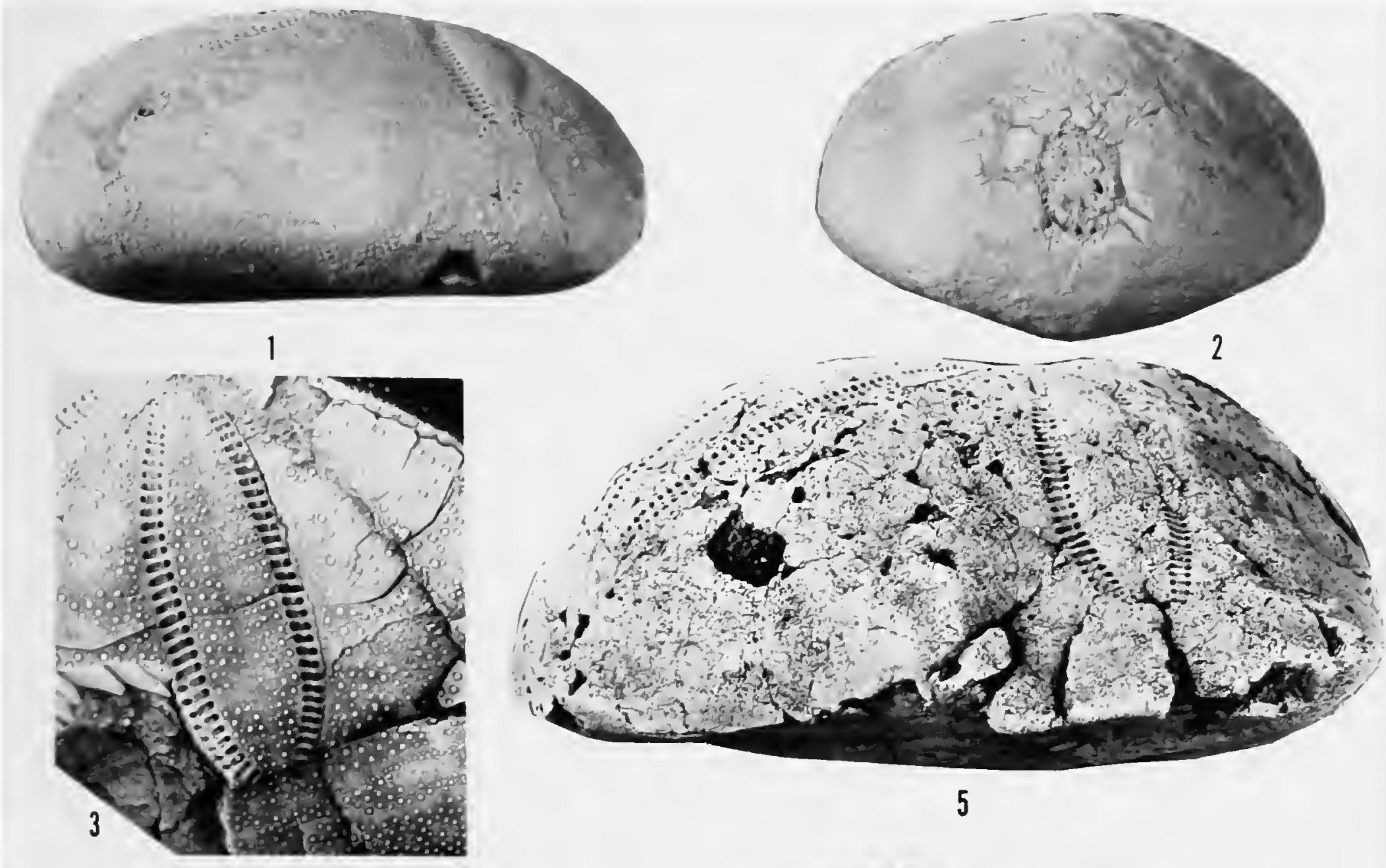

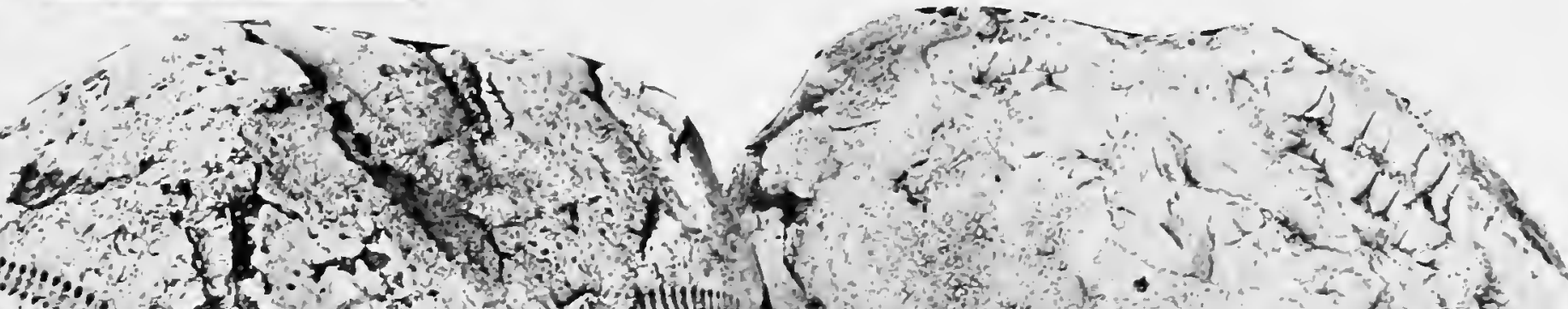
(n)

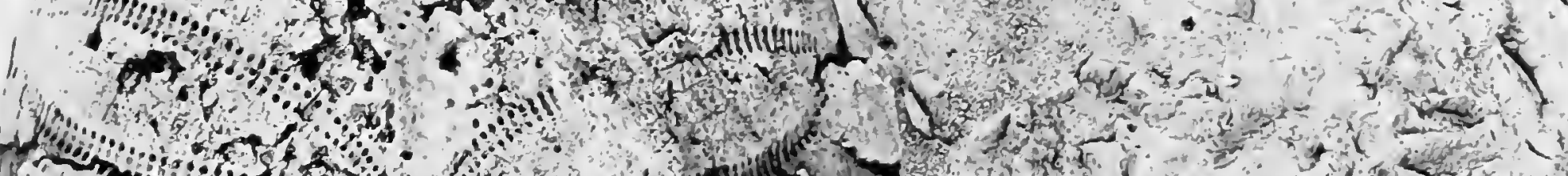

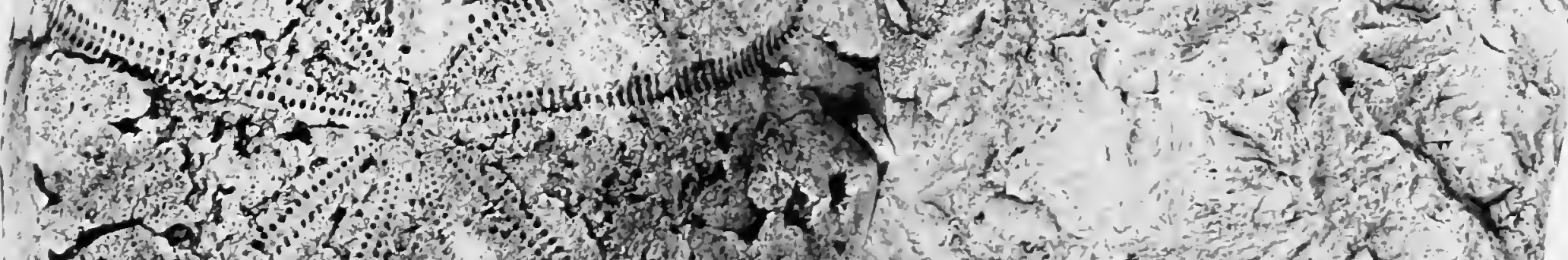

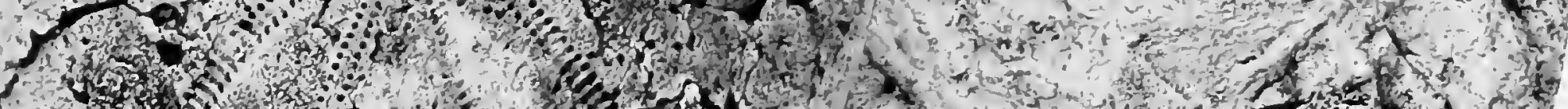
1. Wo

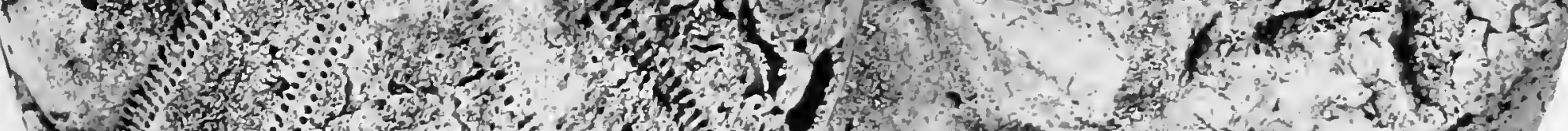

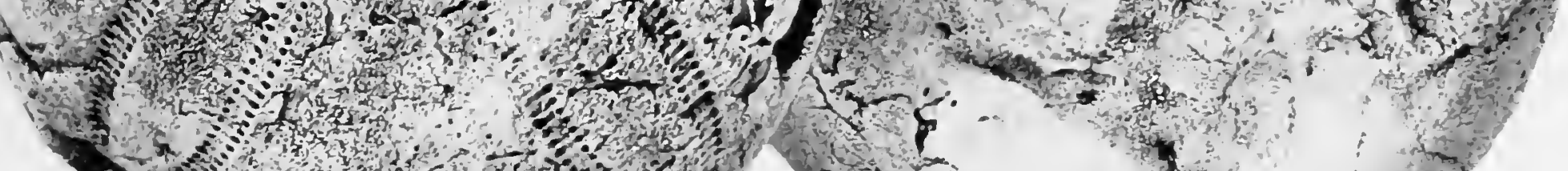

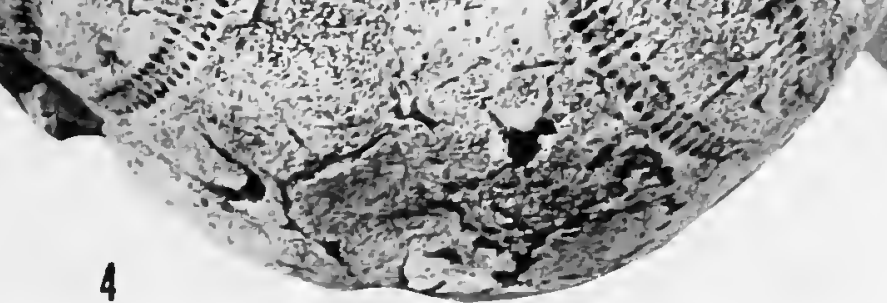

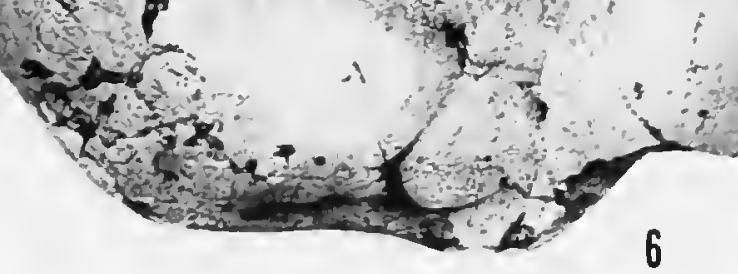




\section{PLATE 67}

Eupatagus depressus (Sánchez Roig)

1-3. Dorsal, ventral and right side of the holotype, SRC 4476, Oligocene-Miocene, "El Regalo" farm, Charco Hondo, Marroquín district, Morón, Camagüey Province, Cuba, $\times 0.75$. 


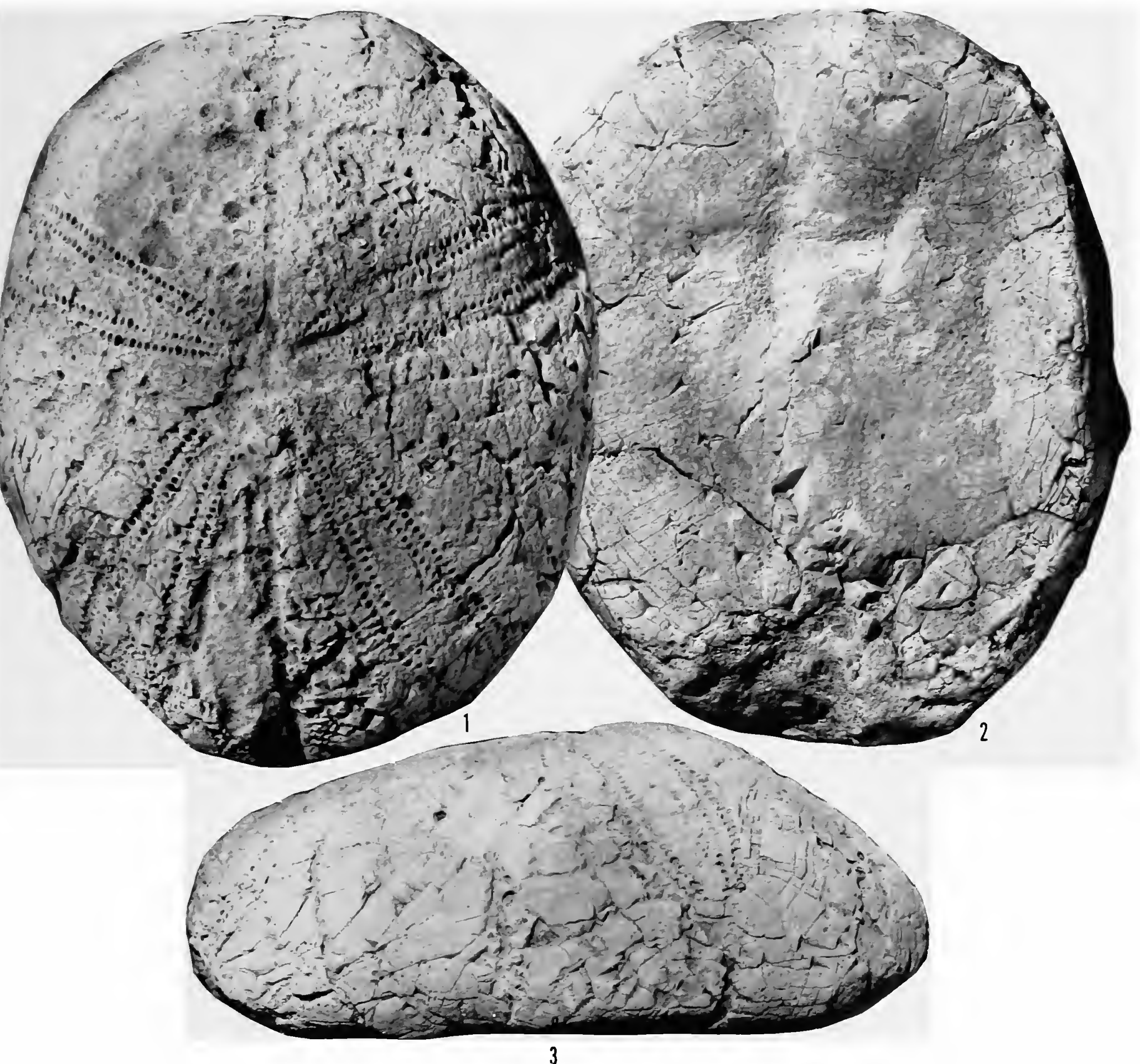




\section{PLATE 68}

\section{Hernandezaster hernandezi Sánchez Roig}

1-4. Dorsal, rear, right side, and ventral views of the holotype, SRC 4075, Miocene, "Santa Ana" farm, Majagua district, Ciego de Avila, Camagüey Province, Cuba, $\times 1$.

\section{Migliorinia habanensis (Sánchez Roig)}

5-7. Dorsal, right side, and ventral views of lectotype, SRC 4773, Miocene, quarries at 23 Vedado, left to the bridge, Habana Province, Cuba, $\times 3$.

8. Dorsal view of holotype of Schizaster vedadoensis Sánchez Roig $(=M$. habanensis $)$, SRC 4208, Miocene, quarries at 23 Vedado, left of the bridge, Habana Province, Cuba, $\times 1$. 


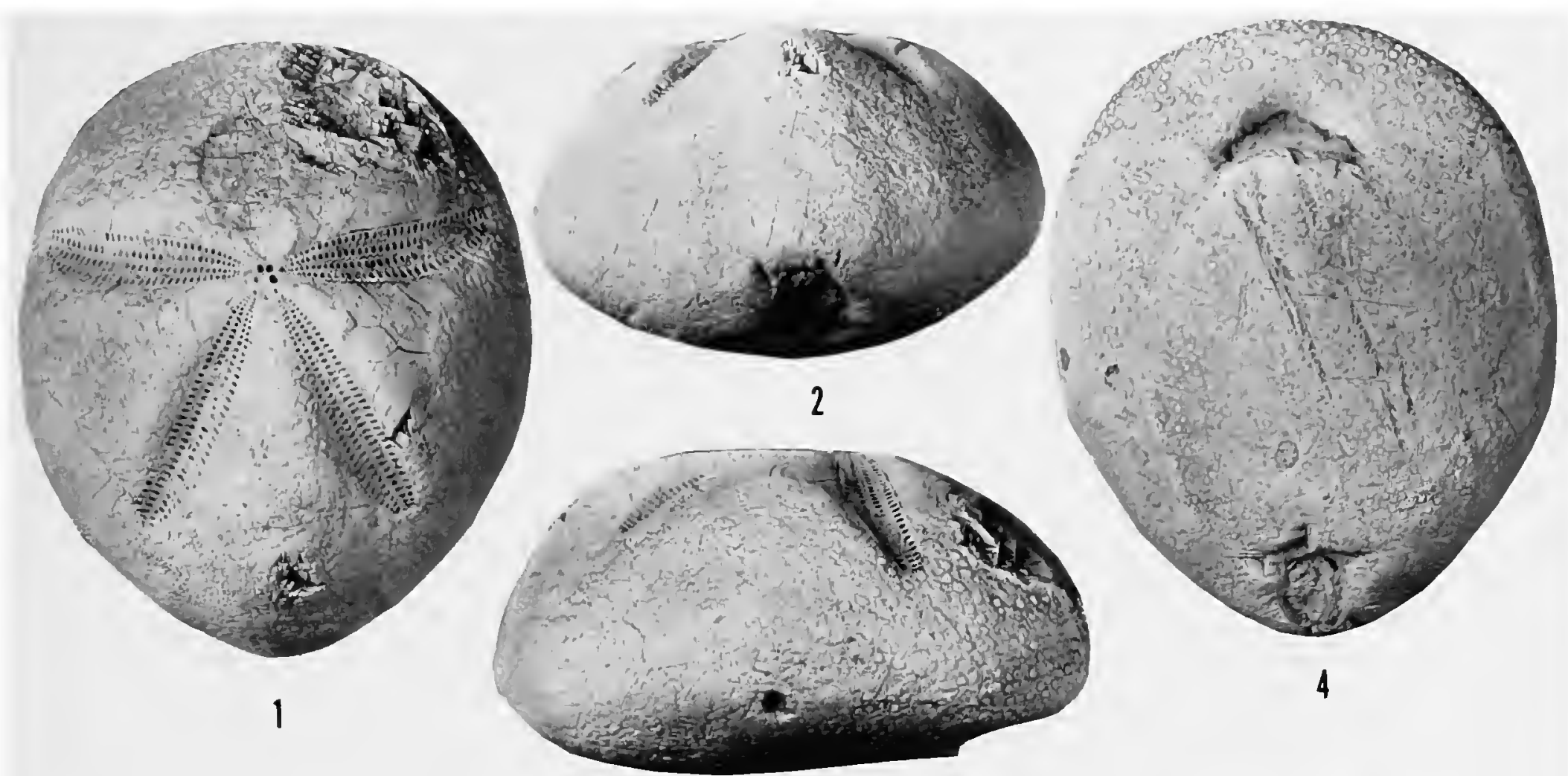

3
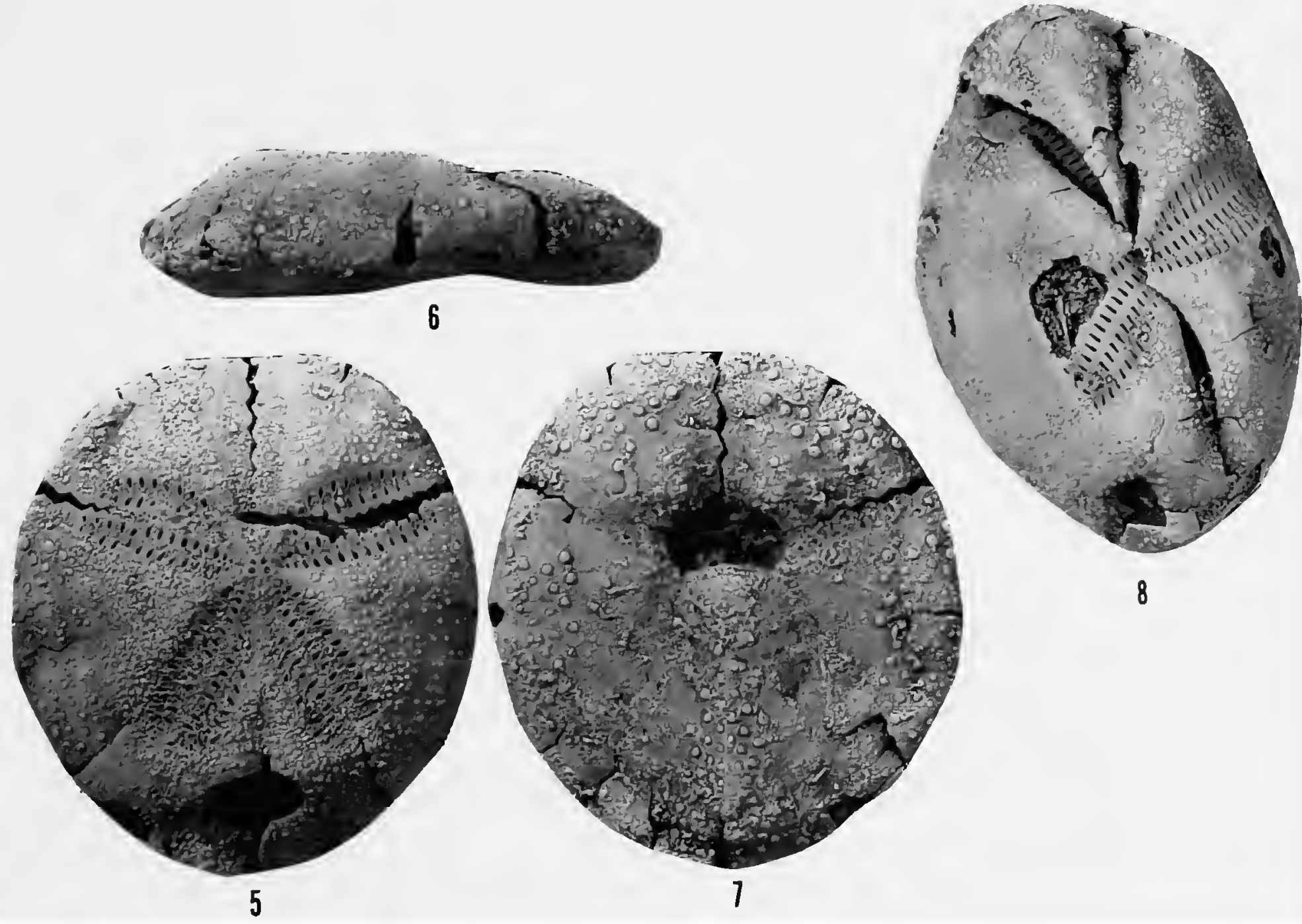


\section{PLATE 69}

\section{Rojasia rojasi Sánchez Roig}

1,2. Dorsal and right side views of the holotype, SRC 3623, Eocene, "El Maja" farm, Majagua district, Ciego de Avila, Camagüey Province, Cuba, $\times 0.75$. 

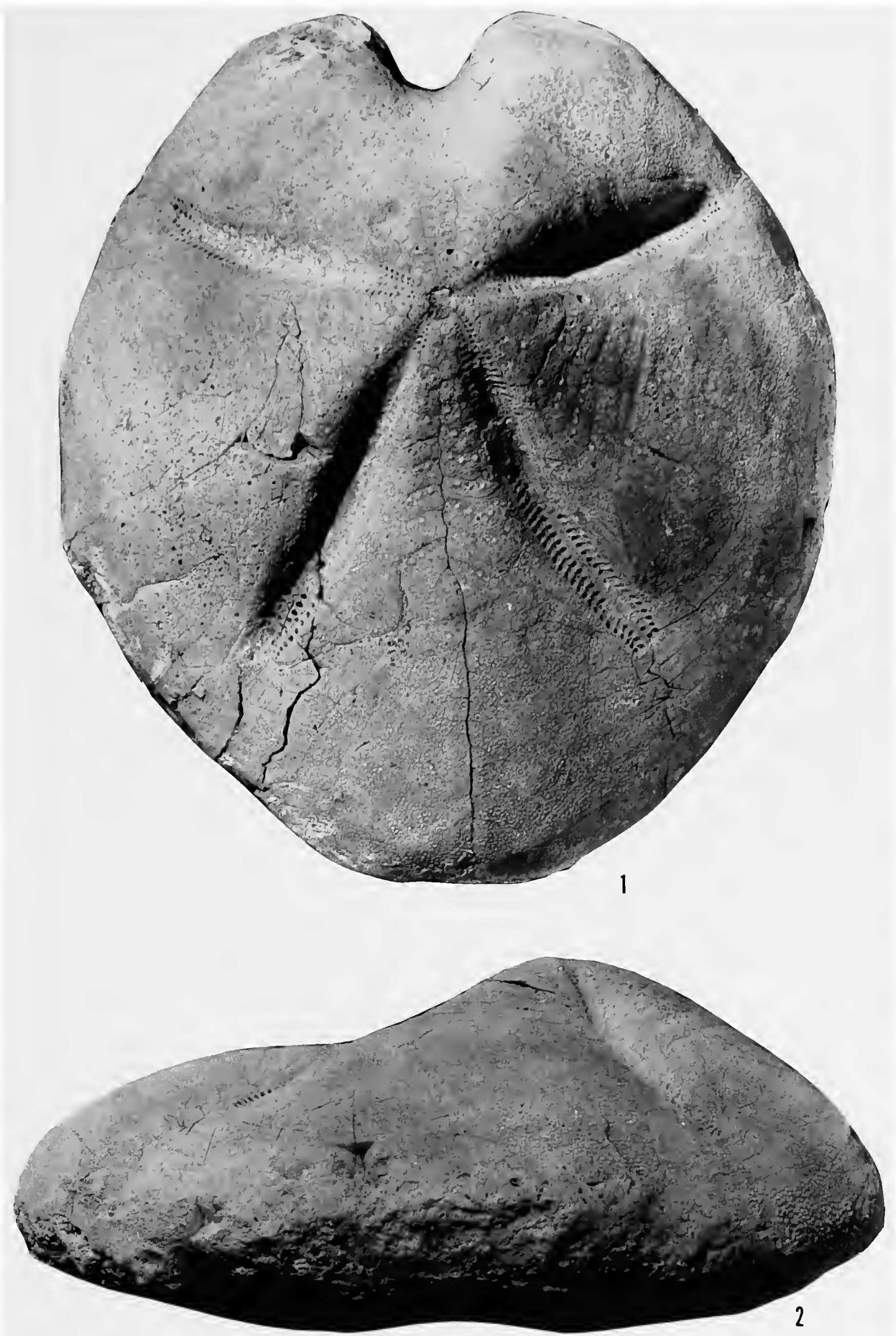


\section{PLATE 70}

\section{Asterostoma excentricum L. Agassiz}

Dorsal view of ANSP 16684, Eocene, Loma Caoba, $5 \mathrm{~km} \mathrm{~S}$ of San Diego de los Baños, Pinar del Rio Province, Cuba, $\times 1$. (See also Plates 71,72 .) 


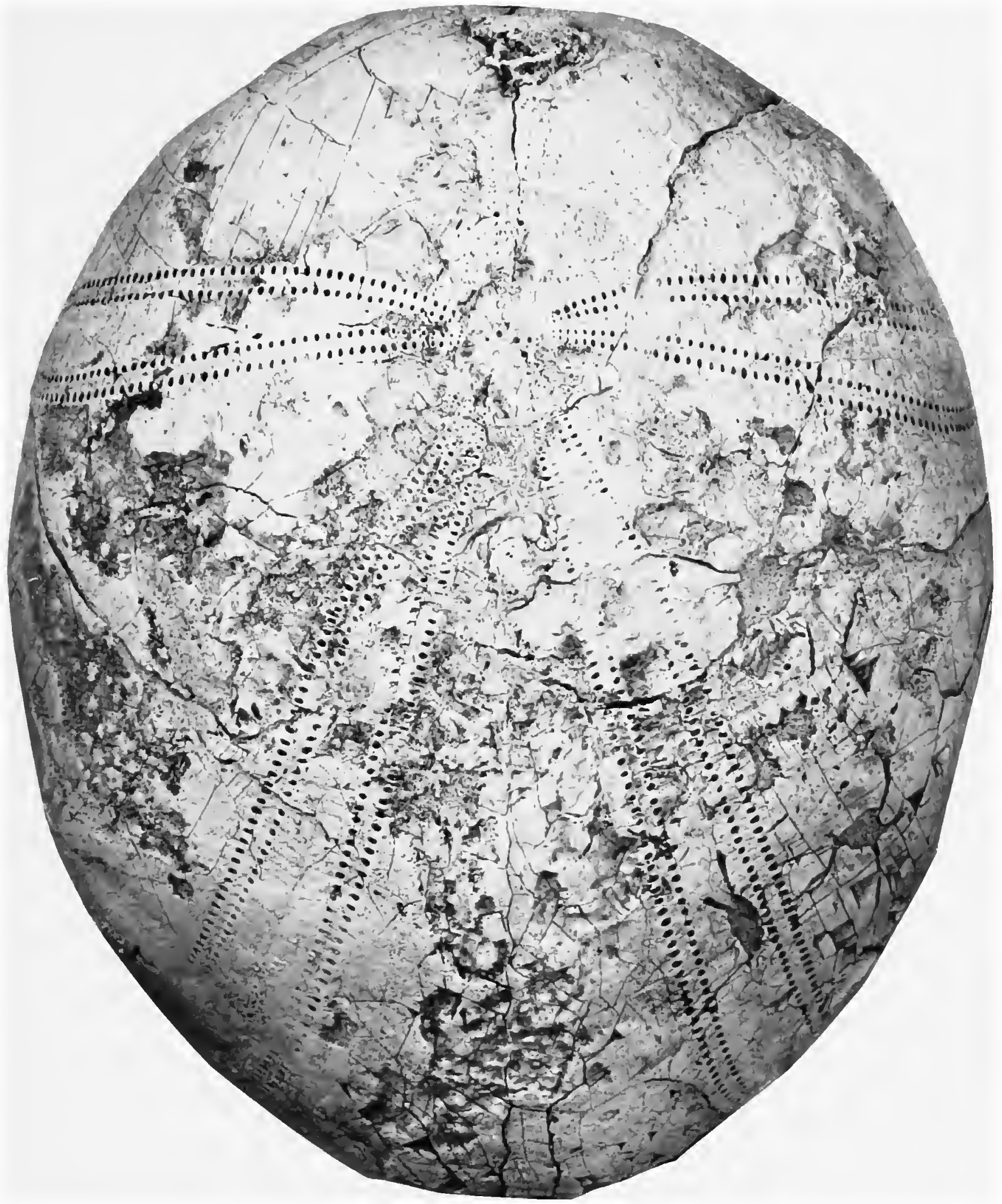




\section{PLATE 71}

\section{Asterostoma excentricum L. Agassiz}

Ventral view of ANSP 16684, Eocene, Loma Caoba, $5 \mathrm{~km} \mathrm{~S}$ of San Diego de los Baños, Pinar del Rio Province, Cuba, $\times 1$. (See also Plates 70, 72.) 


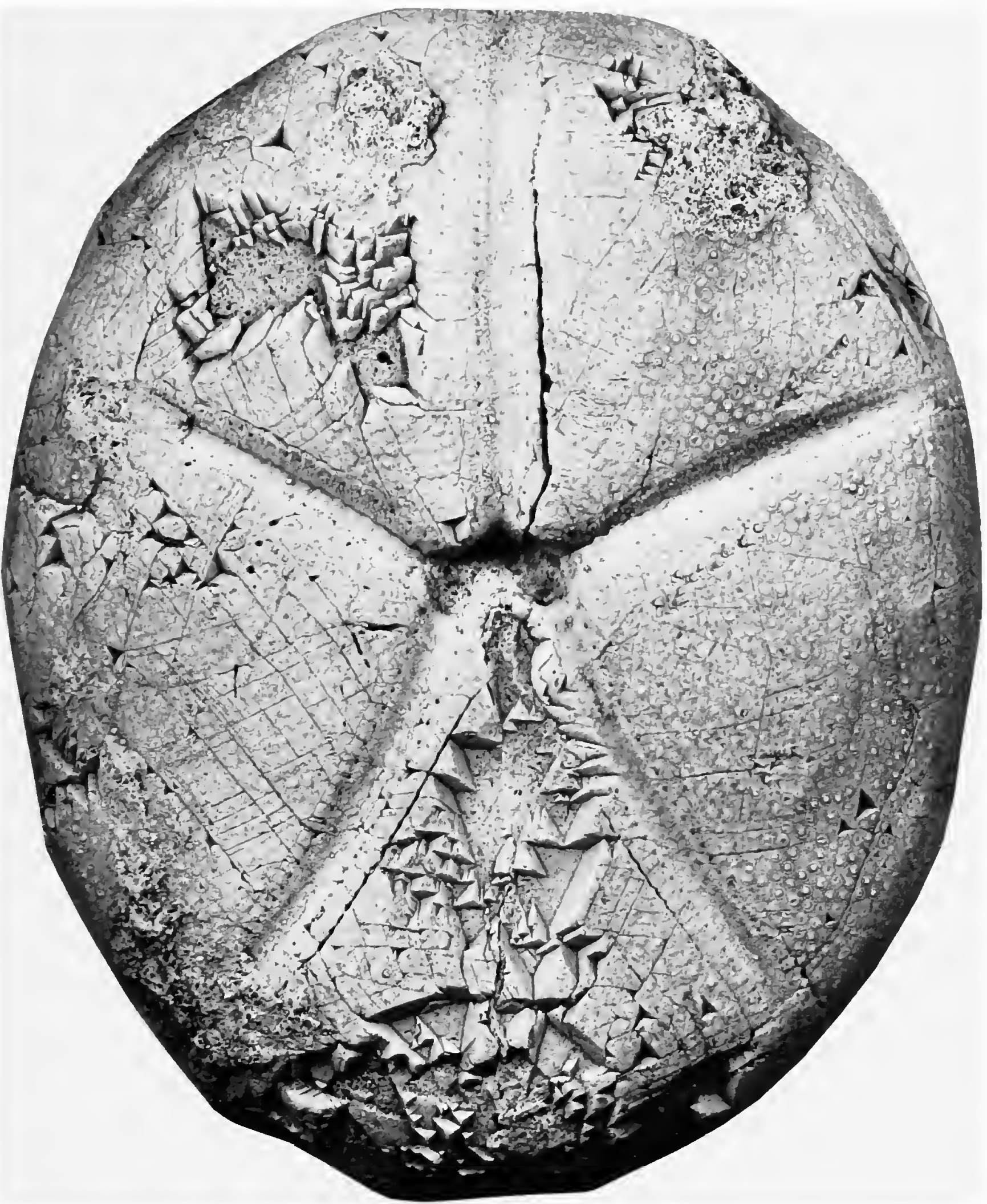




\section{PLATE 72}

\section{Asterostoma excentricum L. Agassiz}

1. Right side of ANSP 16684, Eocene, Loma Caoba, 5 km S of San Diego de los Baños, Pinar del Rio Province, Cuba, $\times 1$. (See also Plates 70, 71.)

2. View of tuberculation in interambulacrum 3 and ambulacrum II on the dorsal side of USNM 341260, Eocene, Loma Caoba, San Diego de los Baños, Pinar del Rio Province, Cuba, $\times 4$.

3. View of tuberculation in interambulacrum 3 on ventral side of same specimen as figure 2 above, $\times 4$.

4. Peripodia in ambulacrum III on ventral side midway between margin and peristome of same specimen as figure 2 above, $\times 21$. 


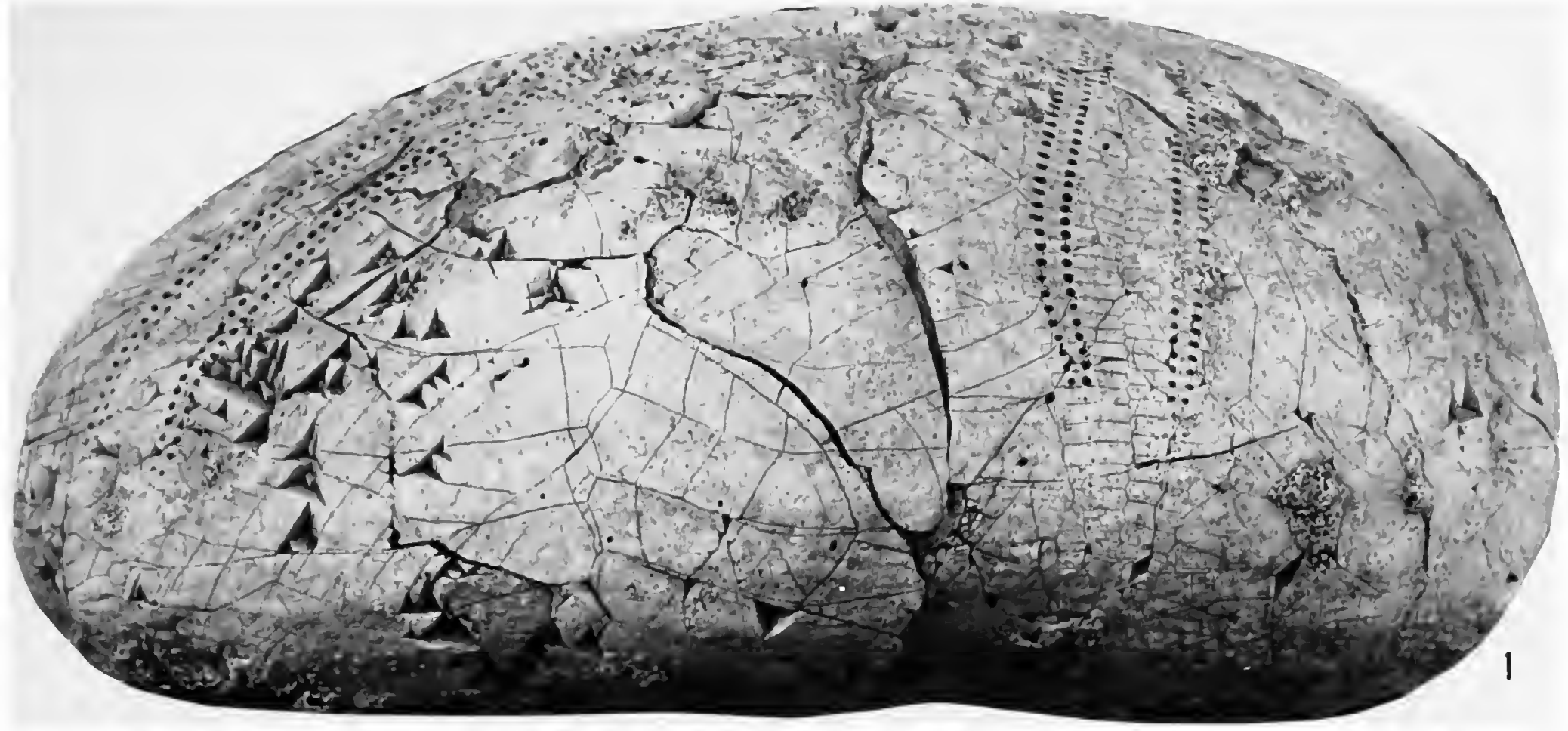

4. $0.0010 .0 \%$ 2. $0.70,0,0.0 \%$

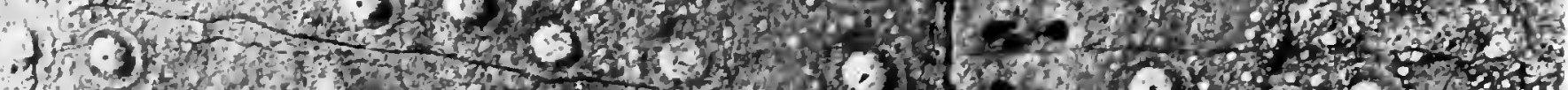
1.

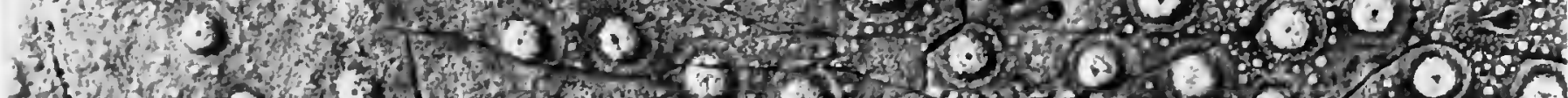

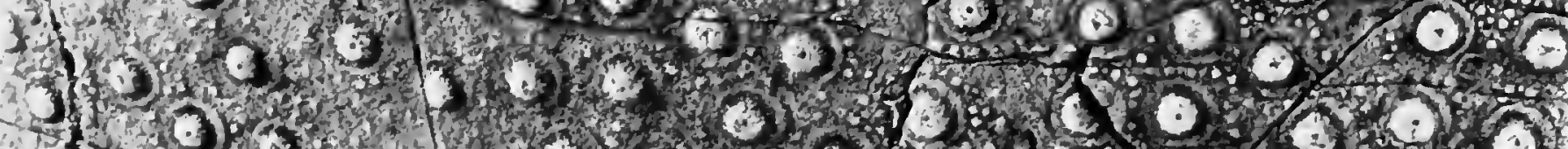

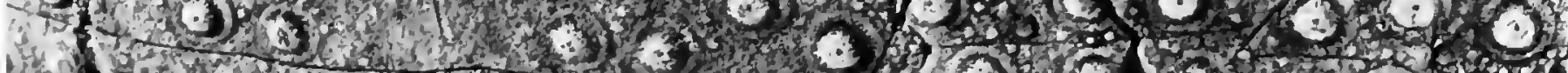

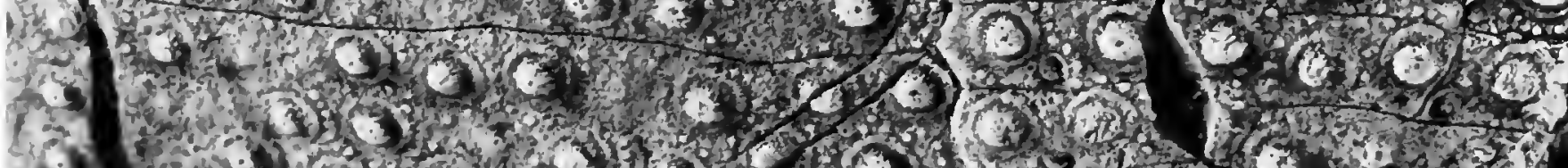

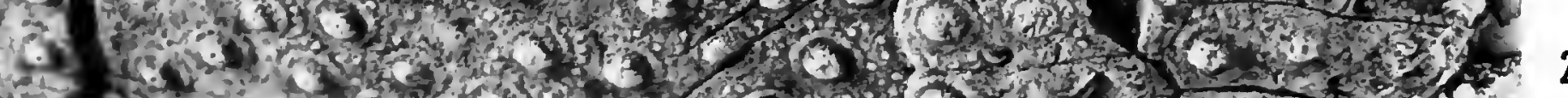

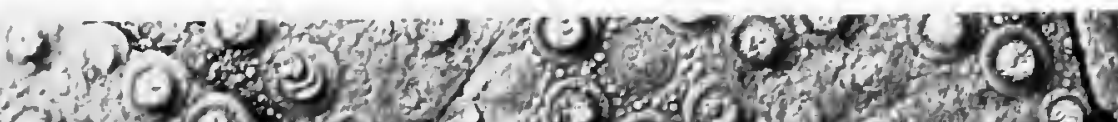

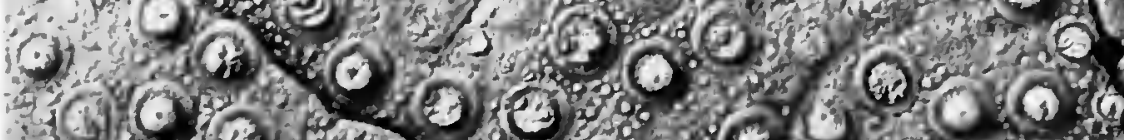

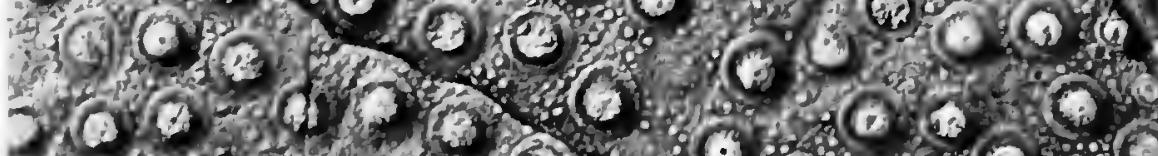

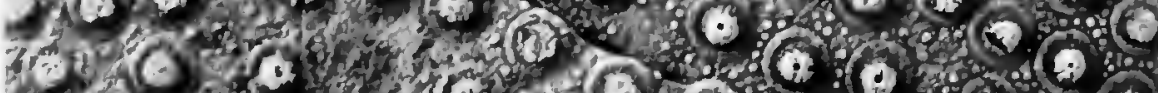

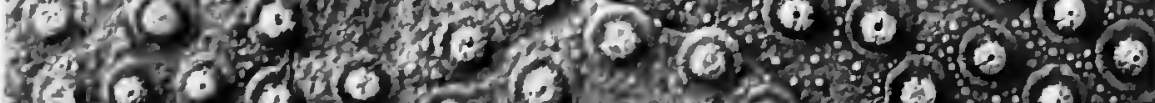
$100 \%$ o.6.

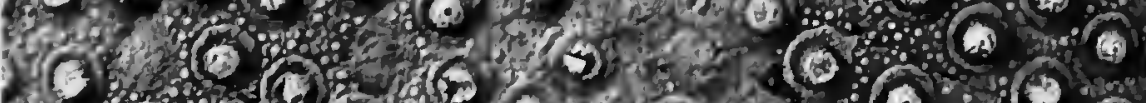

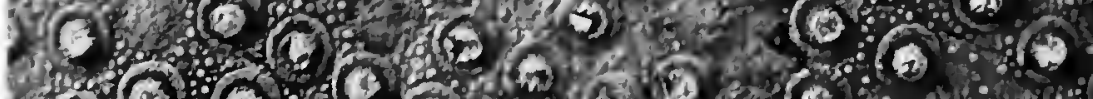

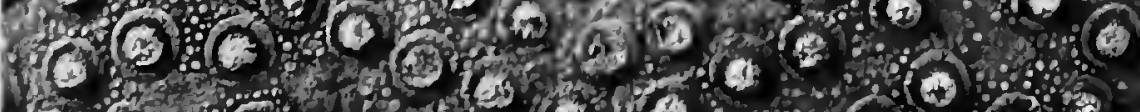

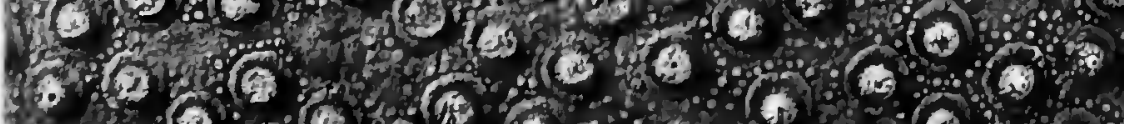

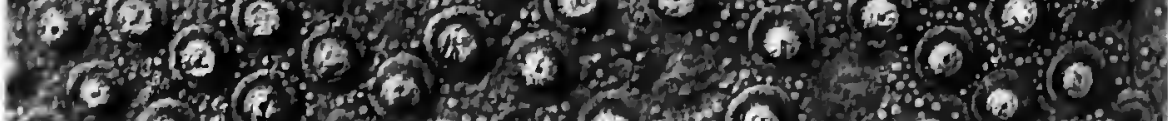

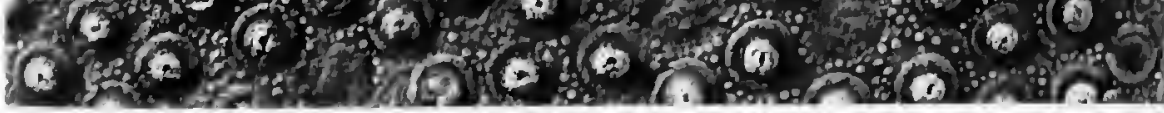

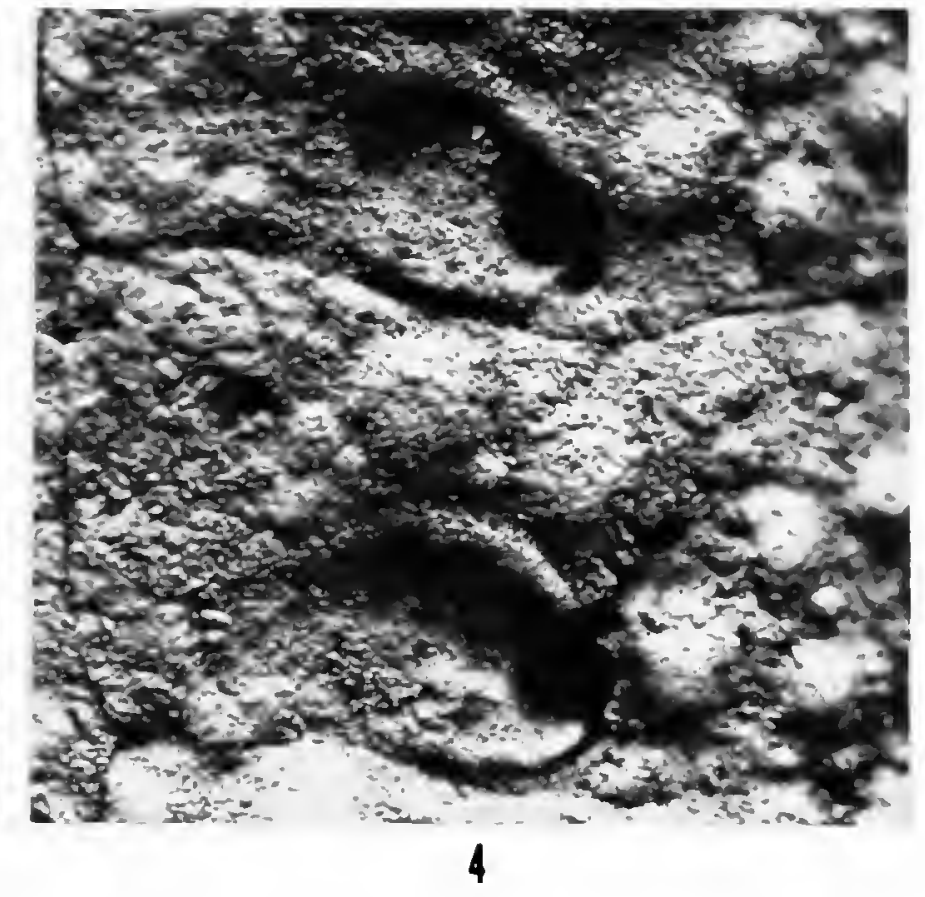




\section{PLATE 73}

\section{Asterostoma excentricum L. Agassiz}

1, 2. Dorsal and right side views of the holotype of Asterostoma dickersoni Sánchez Roig $(=A$. excentricum), SRC 4957, Eocene, Caraballo quarry, Loma Caoba, $5 \mathrm{~km}$ S of San Diego de los Baños, Pinar del Rio Province, Cuba, $\times 1$. 


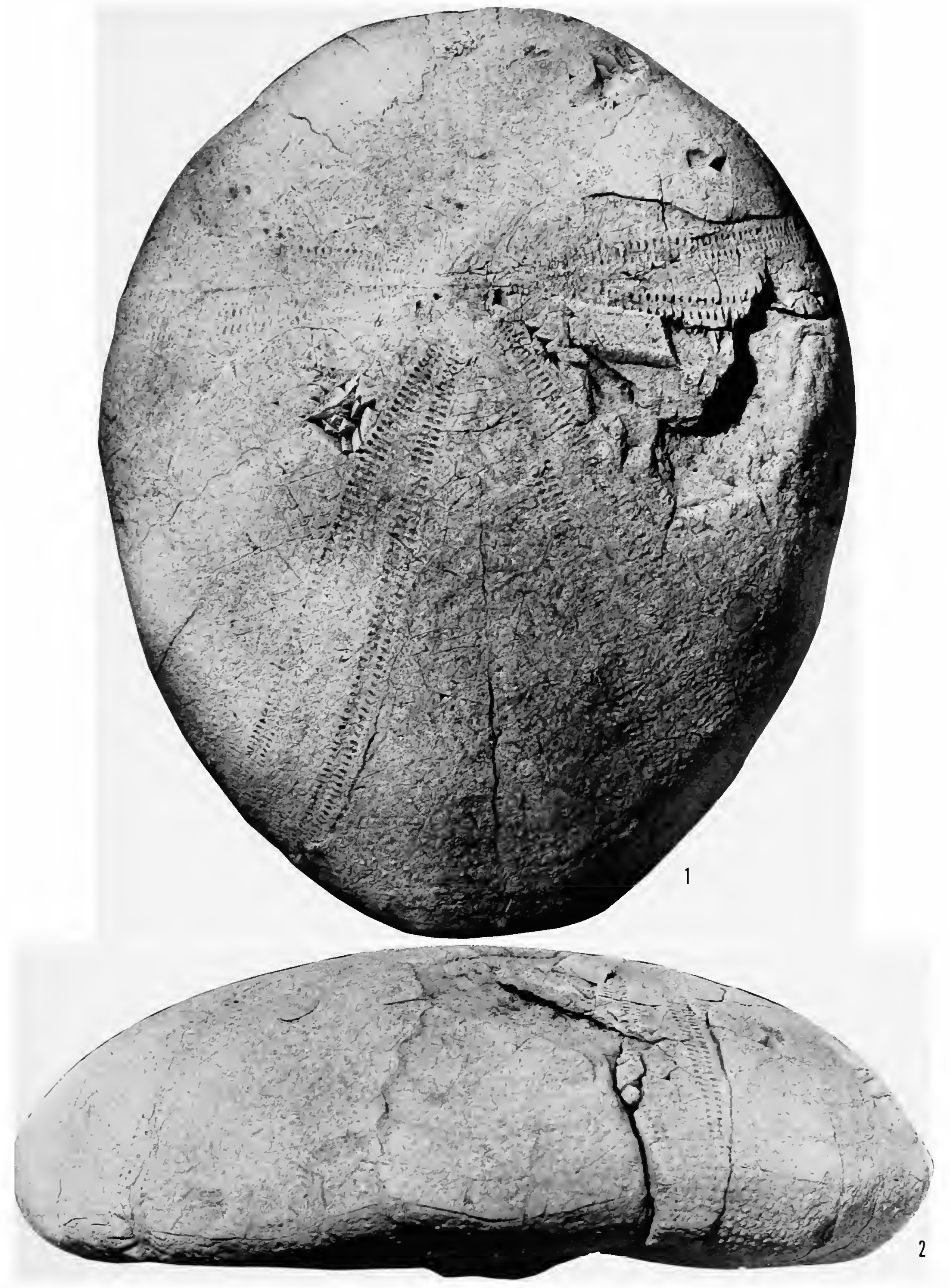




\section{PLATE 74}

\section{Asterostoma excentricum L. Agassiz}

Ventral view of the holotype of Asterostoma dickersoni Sánchez Roig (= A. excentricum), SRC 4957, Eocene, Caraballo quarry, Loma Caoba, $5 \mathrm{~km}$ S of San Diego de los Baños, Pinar del Rio Province, Cuba, $\times 1$. (See also Plate 73.) 


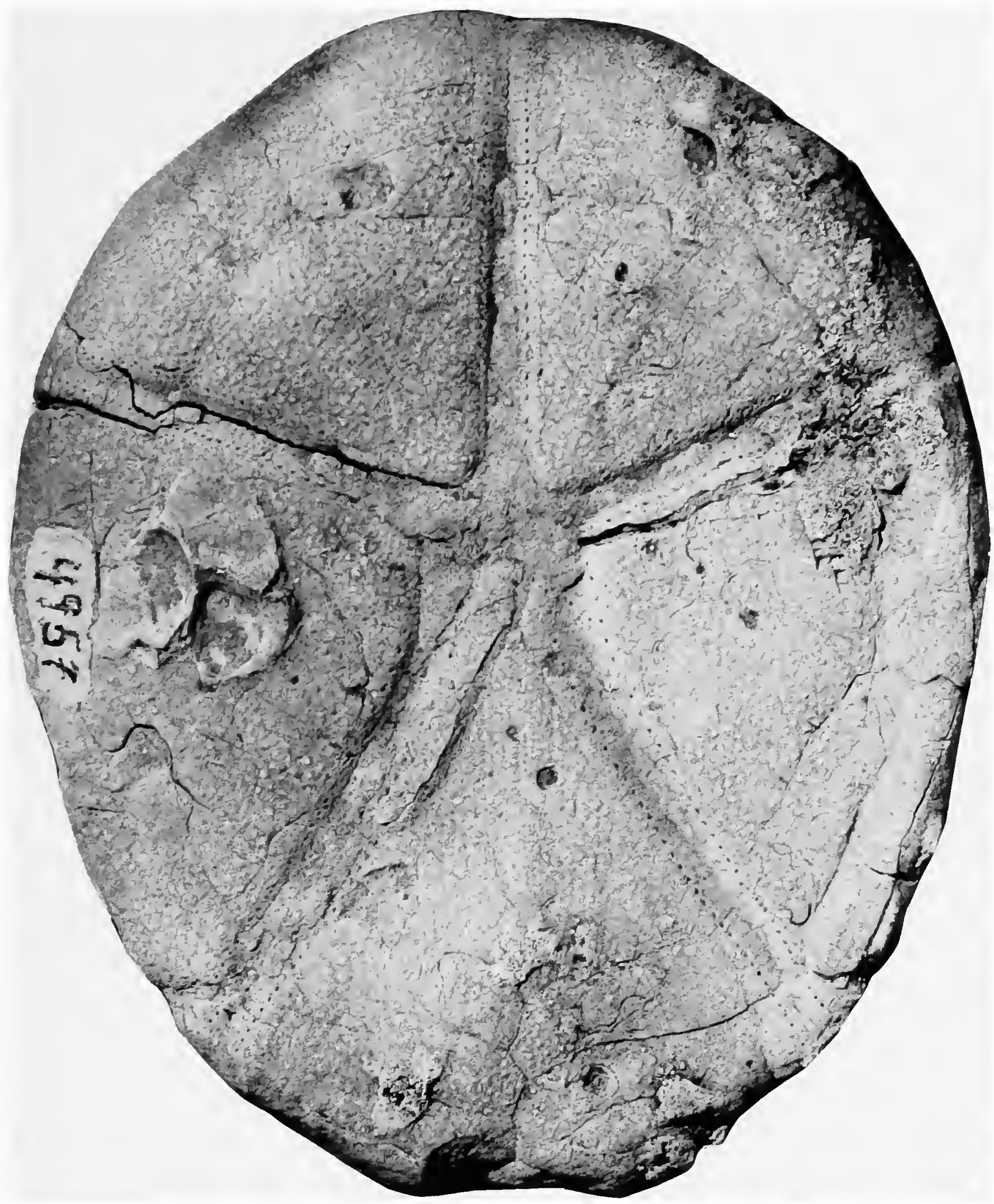




\section{PLATE 75}

\section{Asterostoma excentricum L. Agassiz}

1,2. Dorsal and ventral views of the holotype of Asterostoma irregularis Sánchez Roig $(=A$. excentricum), SRC 4296, Eocene, Caraballo quarry, Loma Caoba, $5 \mathrm{~km} \mathrm{~S} \mathrm{of} \mathrm{San} \mathrm{Diego} \mathrm{de}$ los Baños, Pinar del Rio Province, Cuba, $\times 1$.

(Photograph reduced to 90 percent.) 


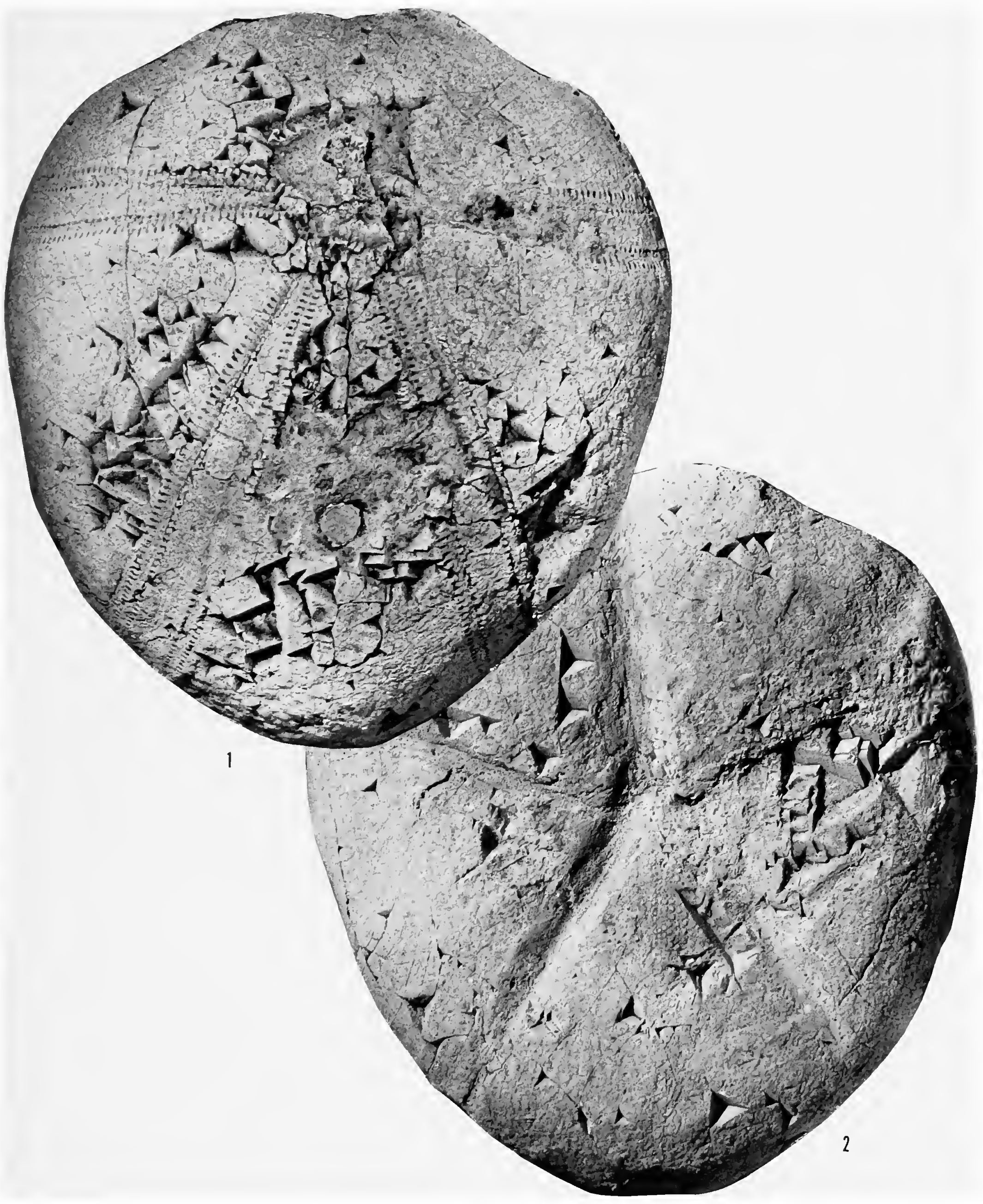




\section{PLATE 76}

\section{Asterostoma excentricum Agassiz}

1. Apical system of ANSP 16684, Eocene, Loma Caoba, $5 \mathrm{~km}$ S of San Diego de los Baños, Pinar del Rio Province, Cuba, $\times 21$.

Asterostoma subcircularis Sánchez Roig

2, 3. Right side and rear views of the holotype, SRC 4010, middle Eocene, Loma Caoba, San Diego de los Baños, Pinar del Rio Province, Cuba, $\times 1$. (See also Plate 77.) 


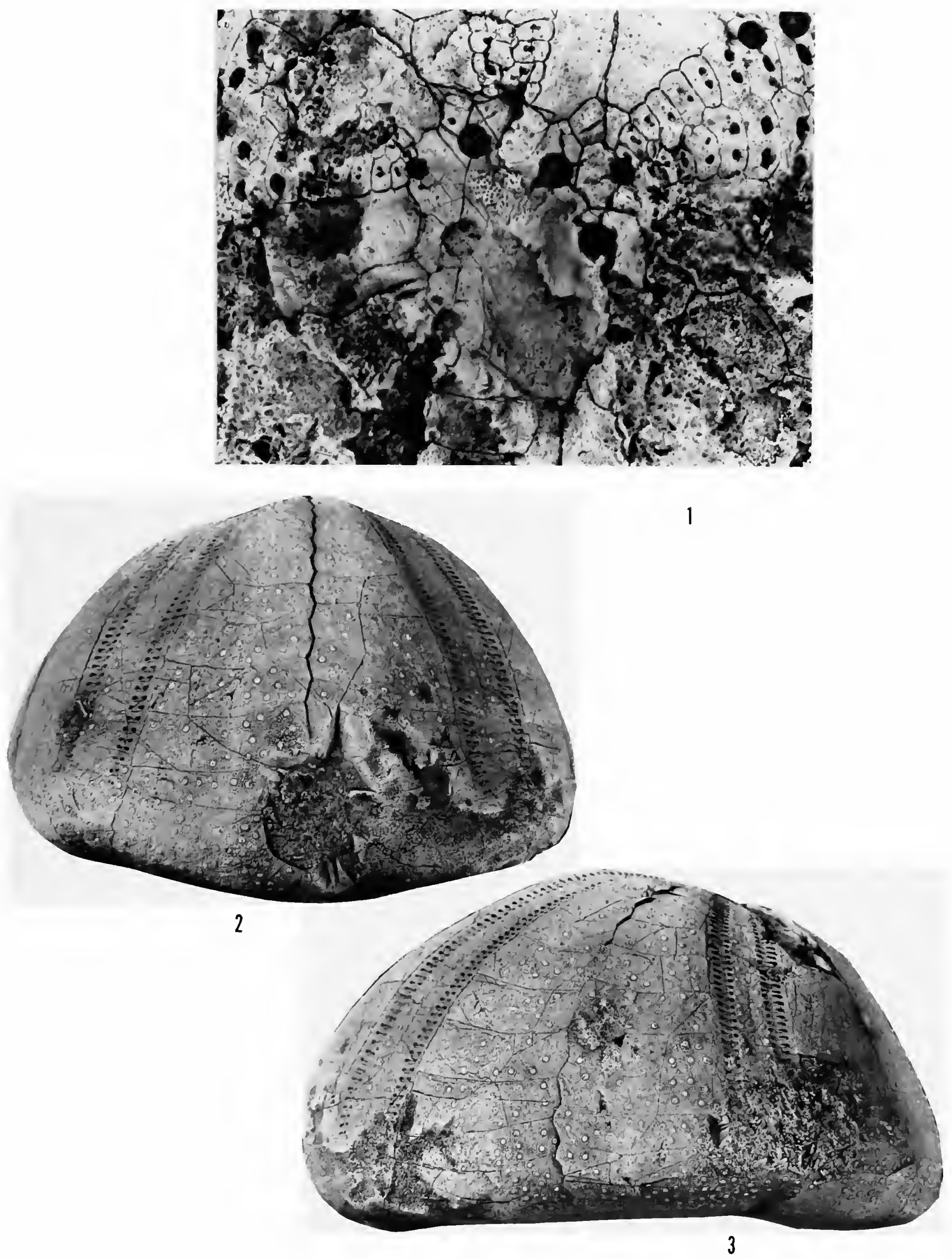


PLATE 77

\section{Asterostoma subcircularis Sánchez Roig}

1,2. Dorsal and ventral views of the holotype, SRC 4010, middle Eocene, Loma Caoba, San Diego de los Baños, Pinar del Rio Province, Cuba, $\times 1$. (See also Plate 76.) 


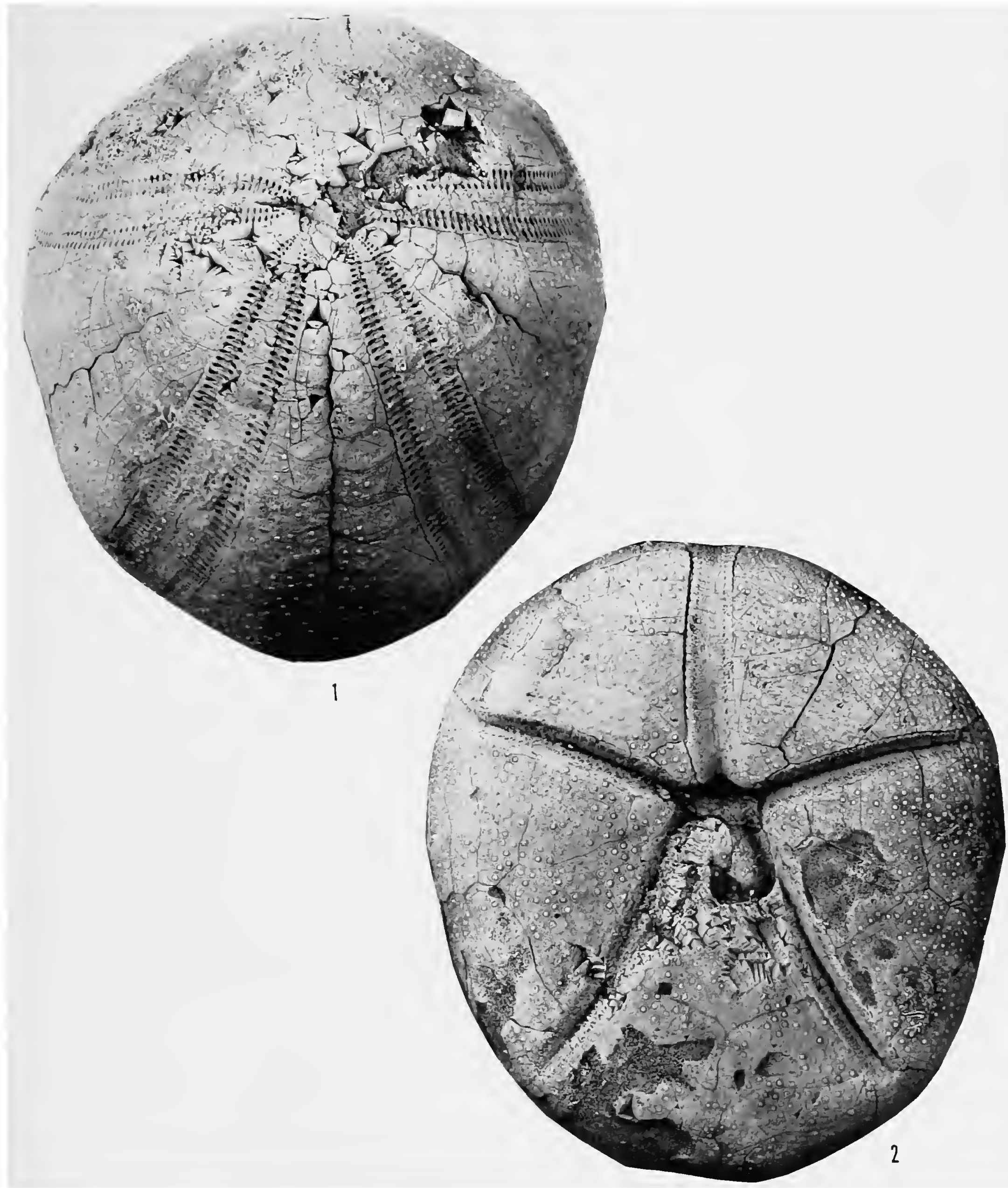




\section{PLATE 78}

\section{Asterostoma pawsoni, new species}

1-4. Dorsal, rear, ventral, and right side views of the holotype, USNM 301378a, Eocene, hillsides above the Yallahs River, St. Thomas, in the Lucky Hill region in St. Mary, and in the Spring Mount region, St. James, Jamaica, $\times 1$.

5. Peripodia in ambulacrum III on ventral side of paratype, USNM 301378b, same locality as above, $\times 22$.

6. Ambulacrum I on ventral side of same paratype, $\times 3$. 

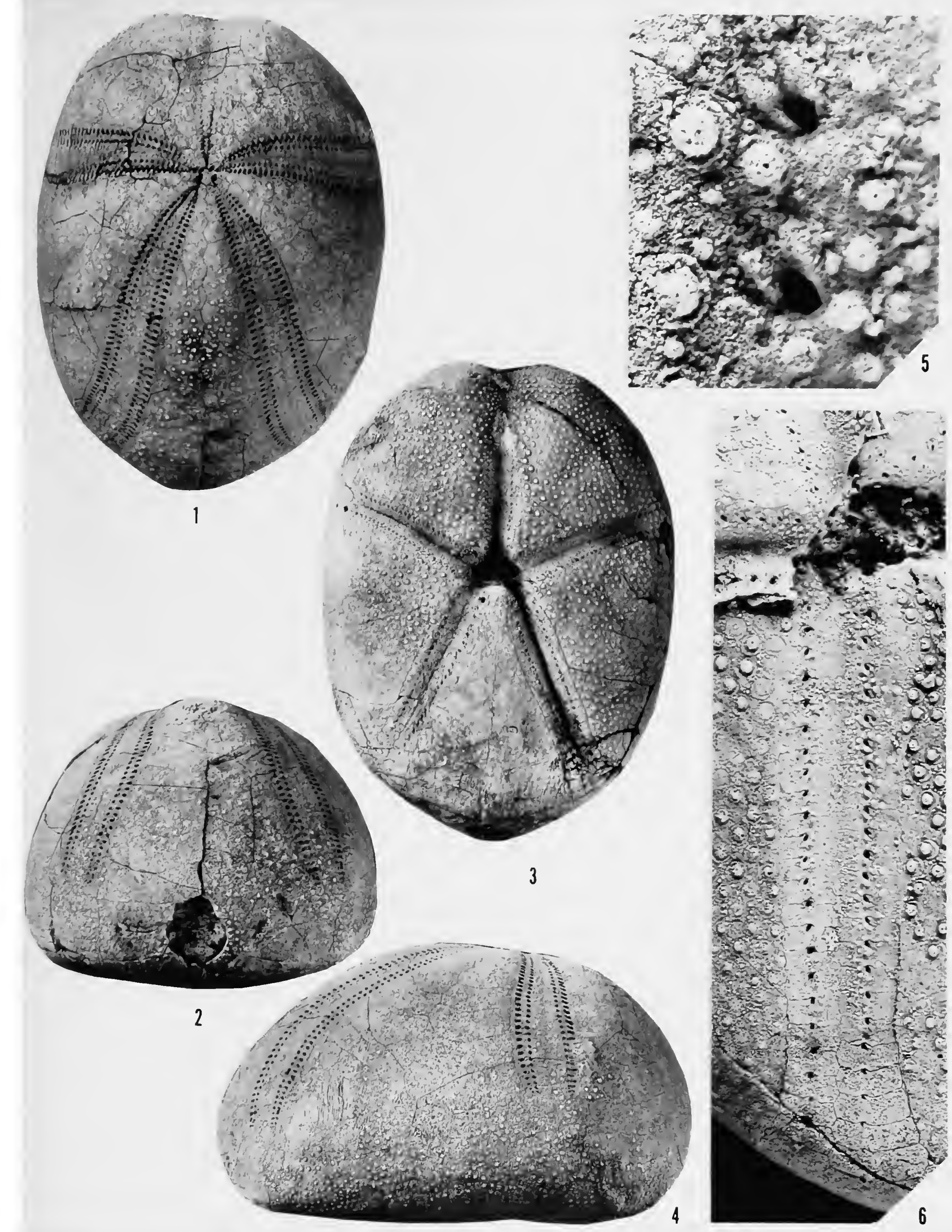


\section{PLATE 79}

\section{Antillaster elegans (Jackson)}

1. Dorsal view of the holotype, AMNH 18574, Miocene, Juana Diaz Formation, $2 \mathrm{~km}$ SW of Juana Diaz, Puerto Rico, $\times 1$.

2. Ventral view of the paratype, AMNH 18575 , from the same locality, $\times 1$. 


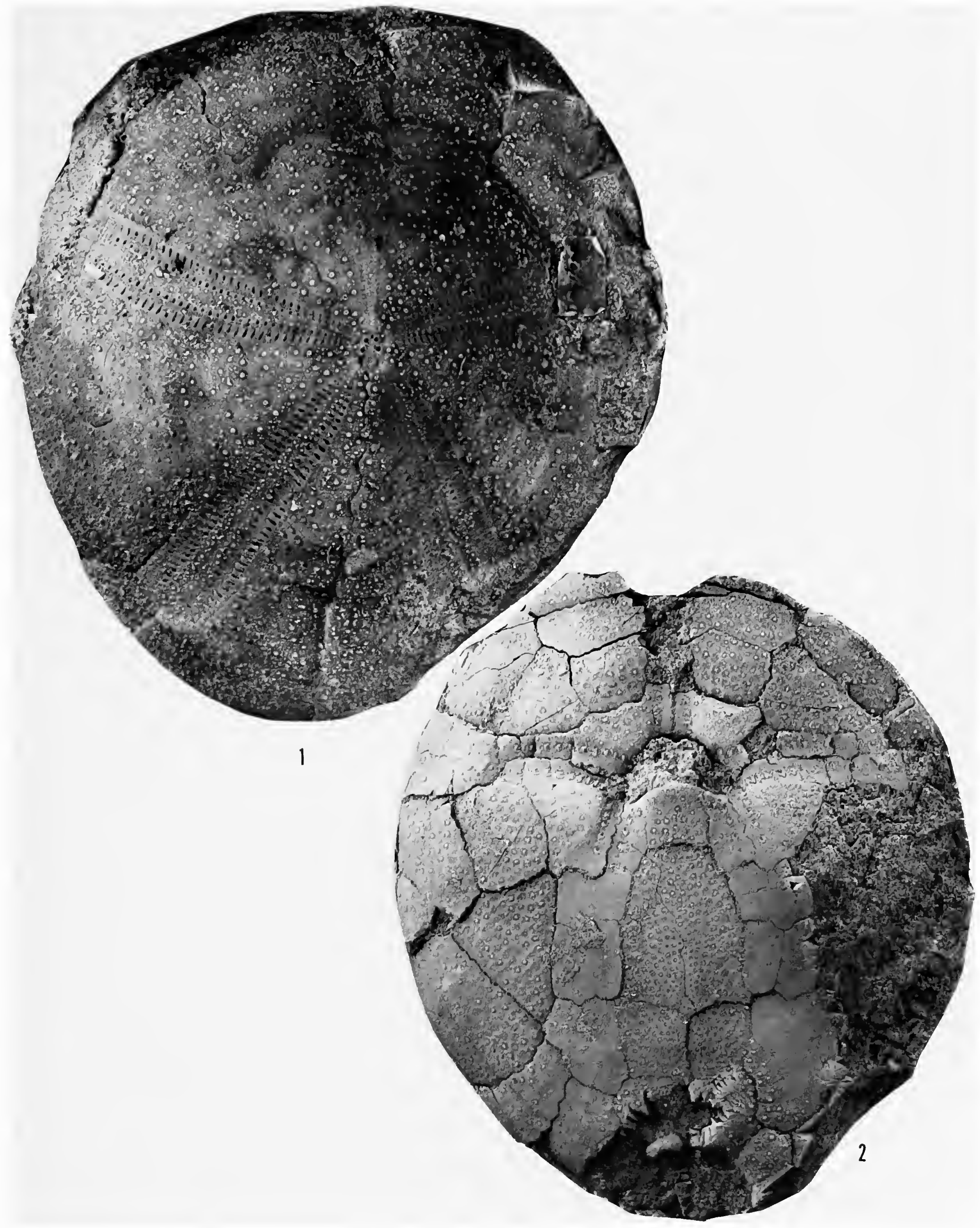


PLATE 80

Antillaster albeari, new species

1,2. Dorsal and rear views of the holotype, ANSP 16631, middle to late Eocene, Palmer loc. 1003, N of Carretera Central, 2.1-2.2 mi (3.5 km), on road to San Diego de los Baños, Pinar del Rio Province, Cuba, $\times 1$. (See also Plate 81.) 


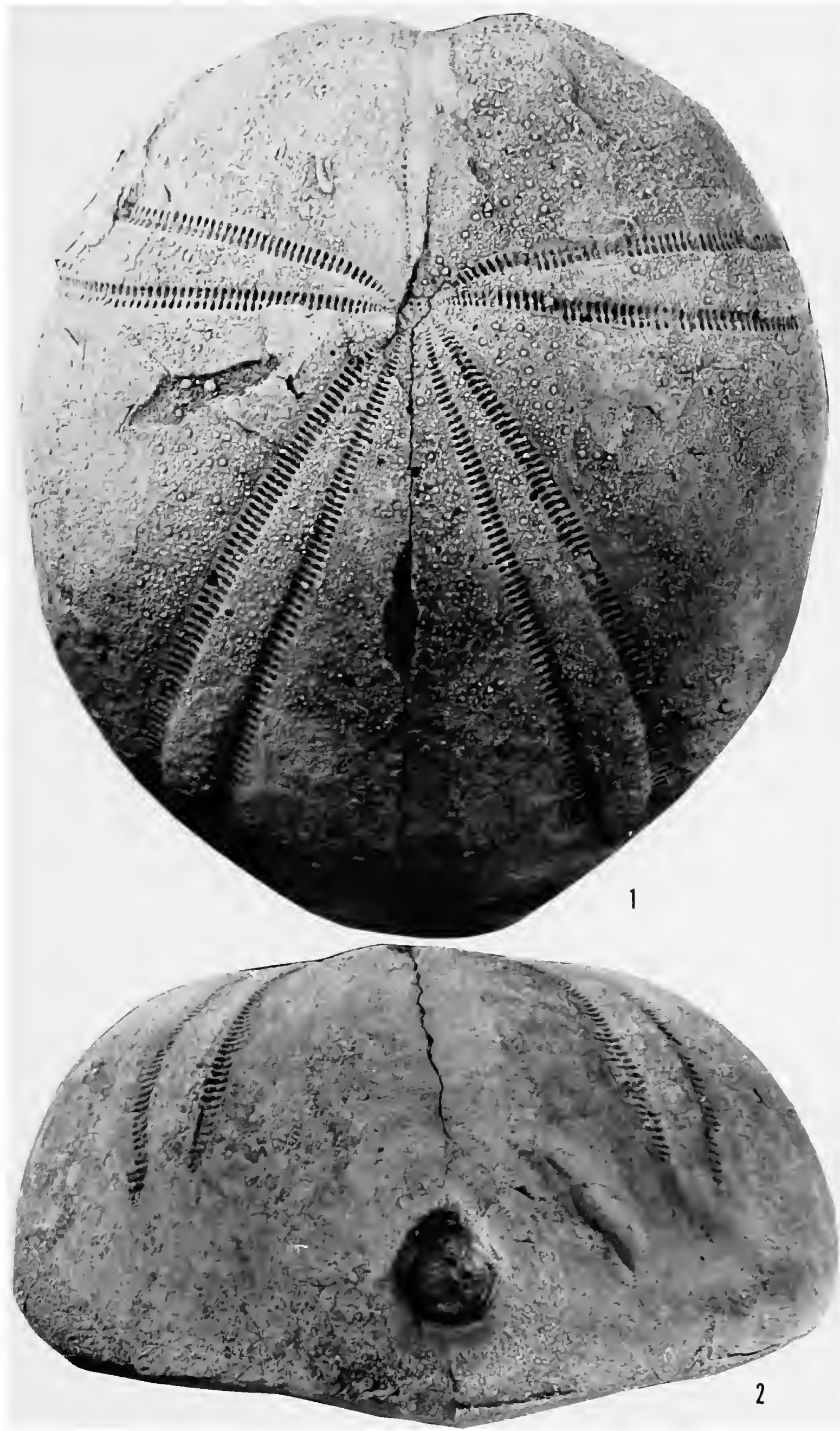




\section{PLATE 81}

\section{Antillaster albeari, new species}

1, 2. Ventral and right side views of the holotype, ANSP 16631, middle to late Eocene, Palmer loc. 1003, N of Carretera Central, 2.1-2.2 mi (3.5 km), on road to San Diego de los Baños, Pinar del Rio Province, Cuba, $\times 1$. (See also Plate 80 .) 

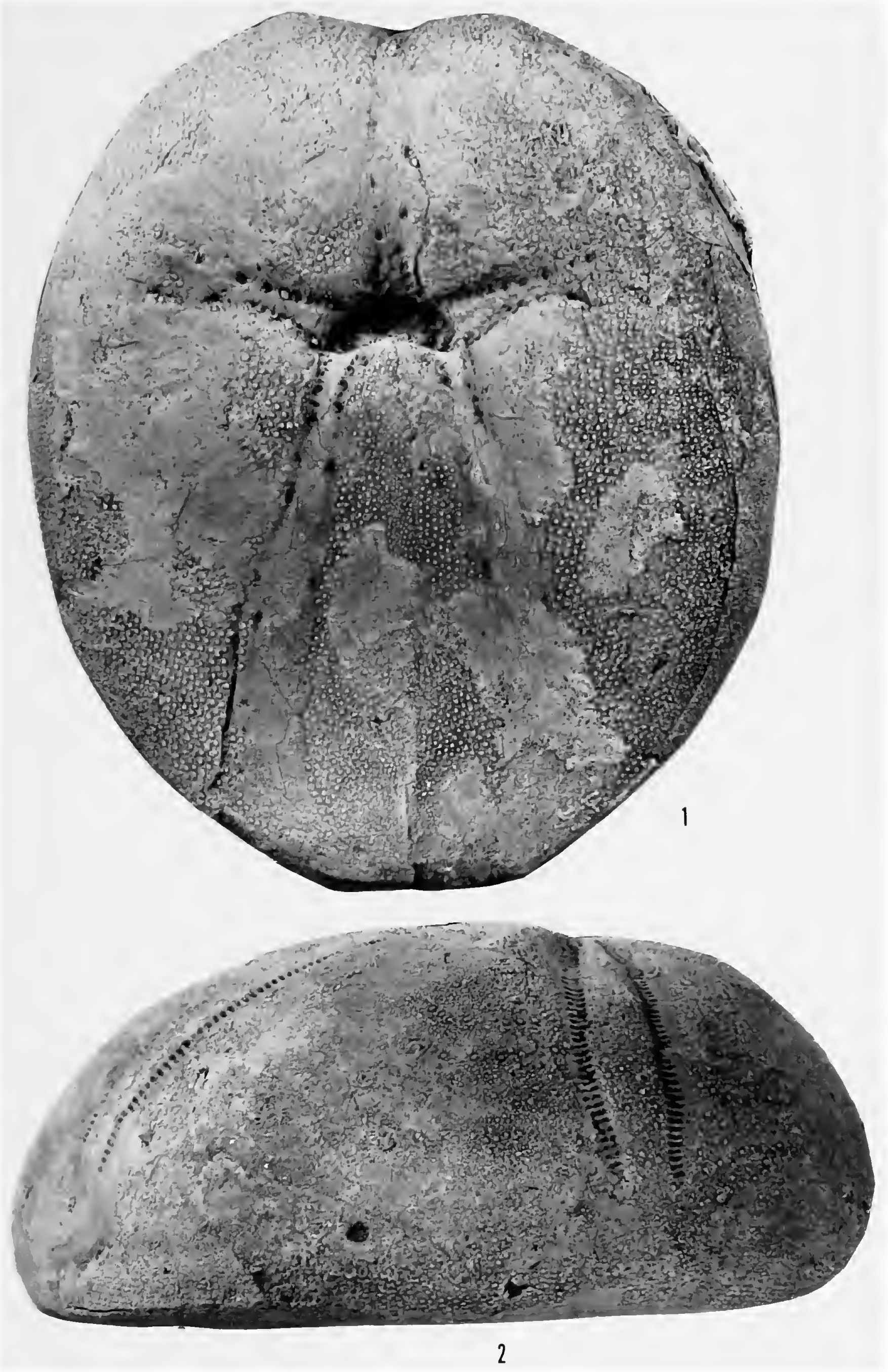


\section{PLATE 82}

\section{Antillaster arnoldi Clark}

1-3. Dorsal, right side, and ventral views of the holotype of Antillaster rojasi Sánchez Roig (= A. arnoldi), SRC 4133, Oligocene-Miocene, "La Venturilla" farm, Realengo, Charco Hondo, Morón, Camagüey Province, Cuba, $\times 1$. 


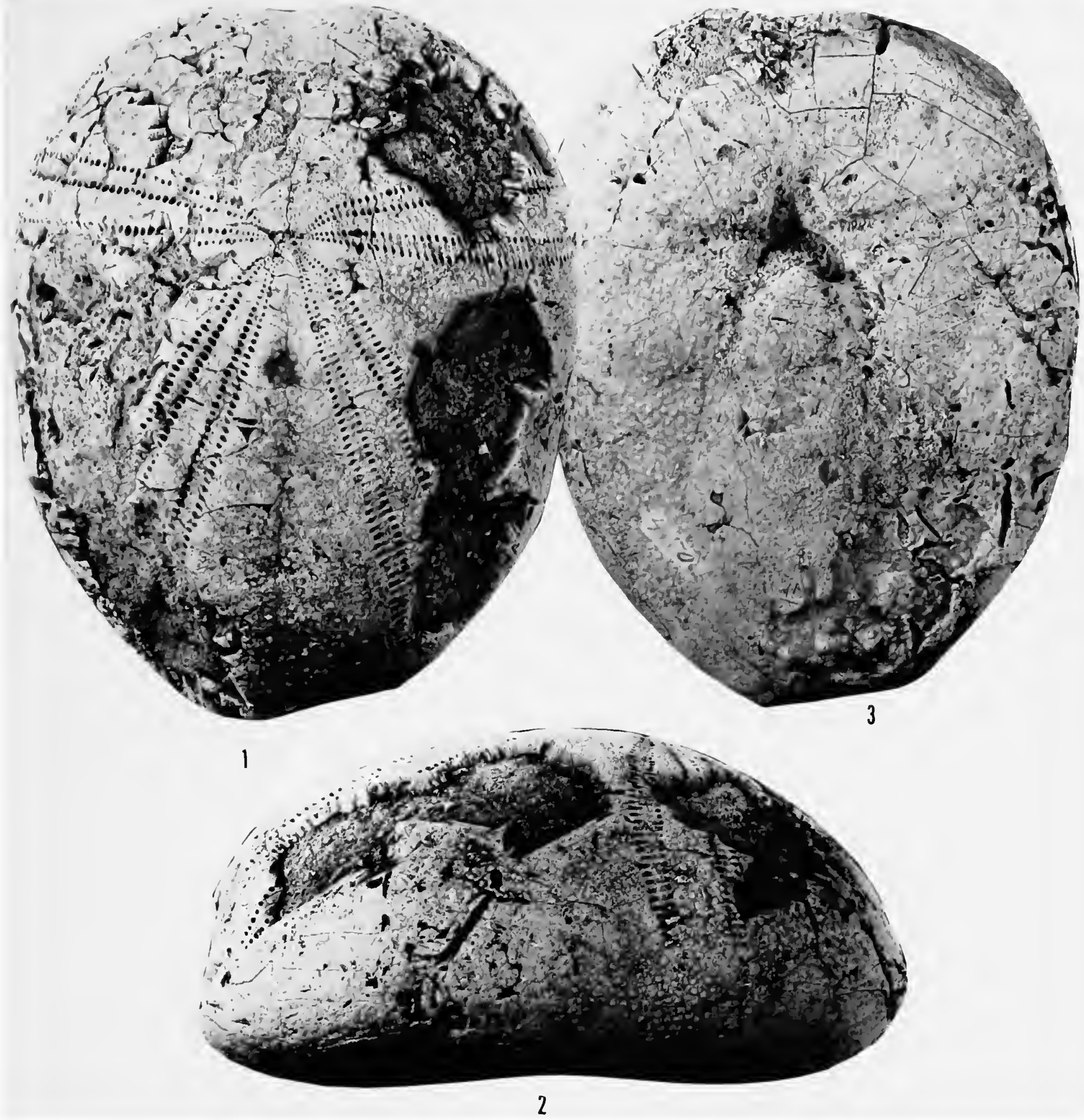




\section{PLATE 83}

\section{Antillaster fernandezi (Sánchez Roig)}

1, 2. Dorsal and right side views of the holotype, SRC 4107, Oligocene-Miocene, well in San Pedro, Habana Province, Cuba, $\times 1$.

3-5. Dorsal, apical region, and right side of the holotype of Antillaster jaumei Sánchez Roig (= A. fernandezl), SRC 4505, early Miocene, Somorrostro quarries, Habana, Habana Province, Cuba, $\times 0.75, \times 1, \times 0.50$, respectively. 


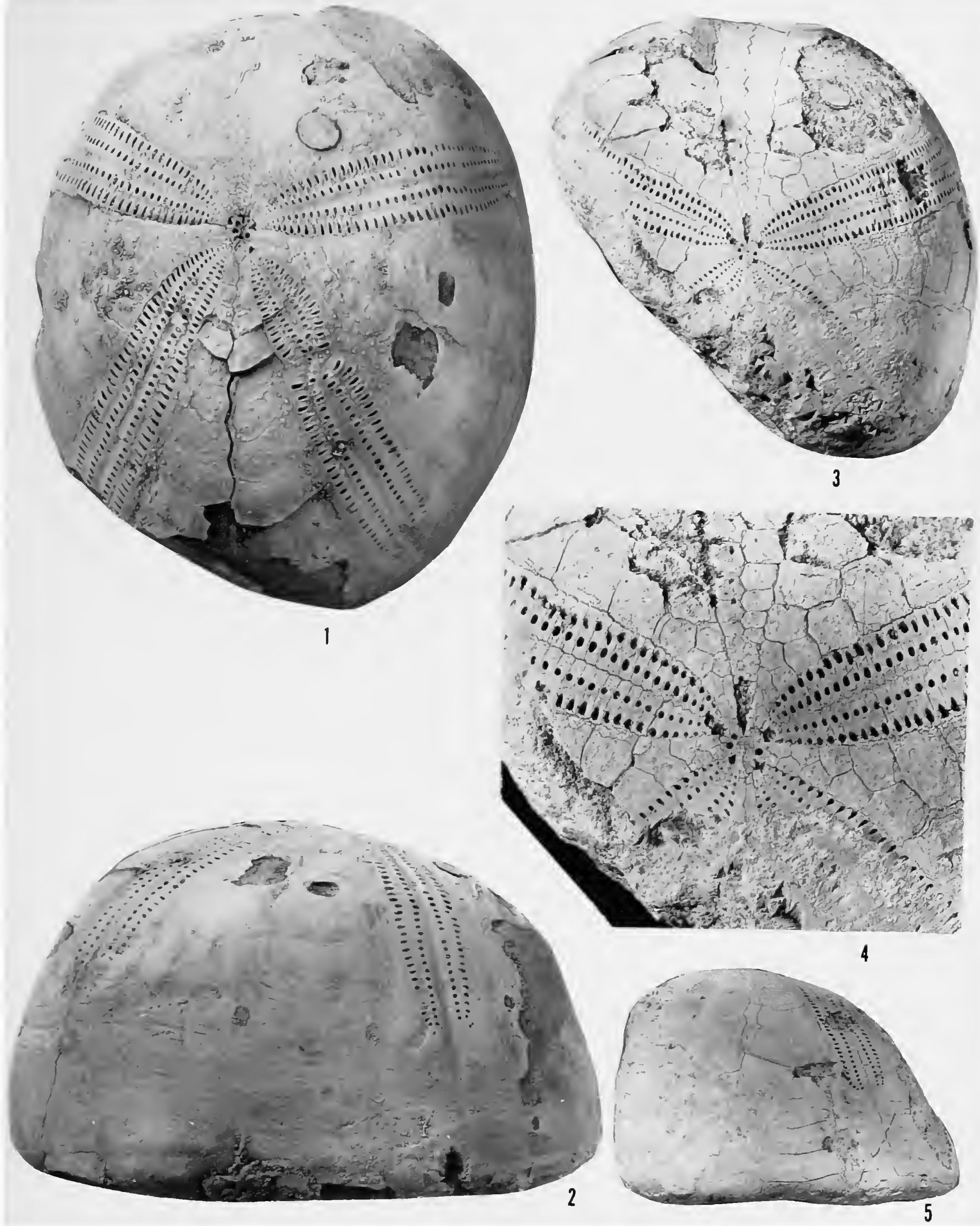




\section{PLATE 84}

\section{Antillaster vaughani (Jackson)}

1-3. Dorsal, ventral, and right side views of the holotype of Antillaster herrerae Sánchez Roig (= A. vaughani), SRC 4469, Oligocene-Miocene, "Santa Clara" farm, Loma La Calera, Marroquín district, Morón, Camagüey Province, Cuba, $\times 1$.

(Photograph reduced to 90 percent.) 


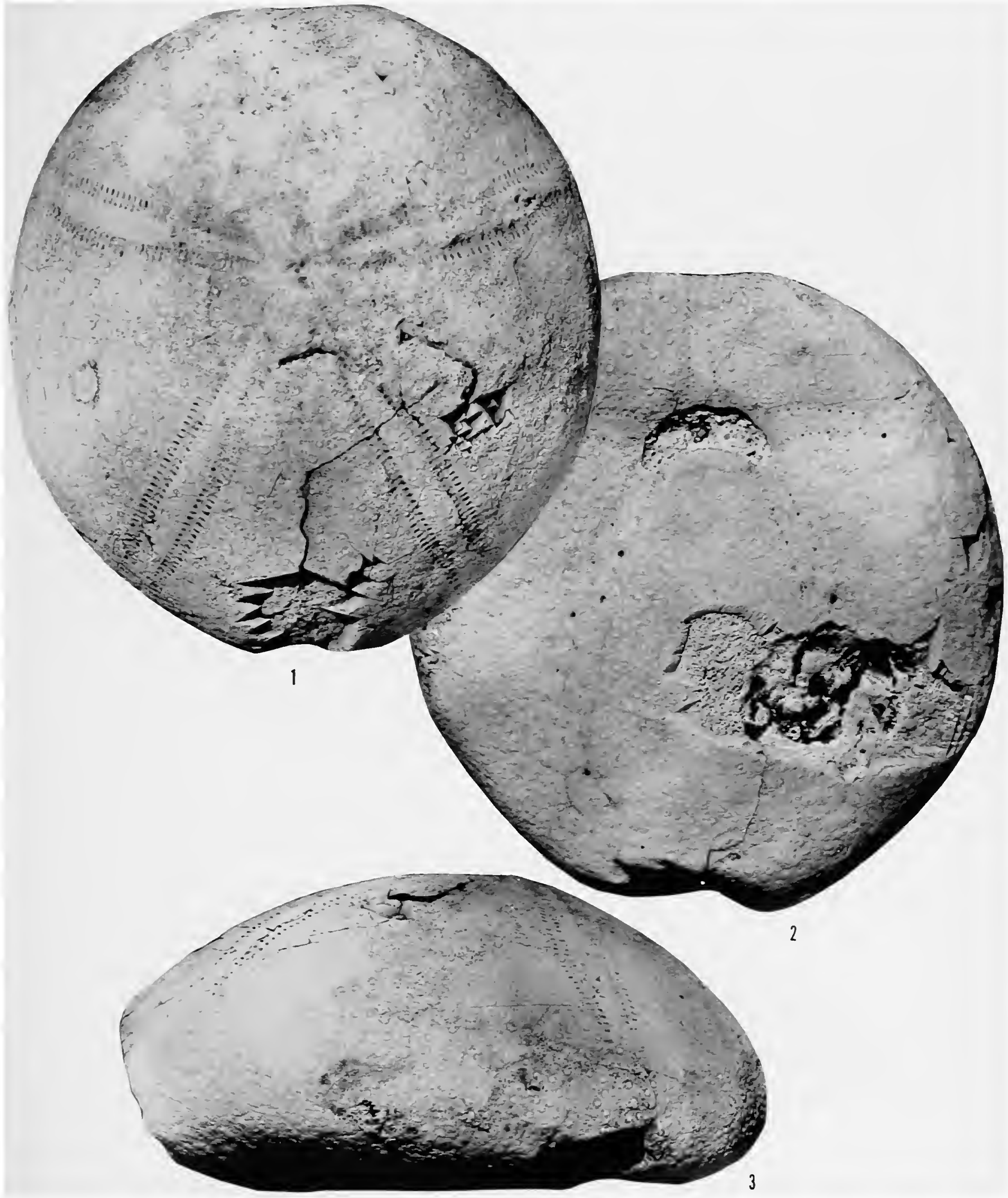




\section{PLATE 85}

Antillaster vaughani (Jackson)

1-3. Dorsal, right side, and ventral views of Antillaster depressus Sánchez Roig (= A. vaughani), SRC 4501, Oligocene-Miocene, approximately $3 \mathrm{mi}(4.8 \mathrm{~km}) \mathrm{SE}$ of Arroyo Blanco, "Pantano Verde" farm, Camagüey Province, Cuba, $\times 1$.

(Photograph reduced to 90 percent.) 


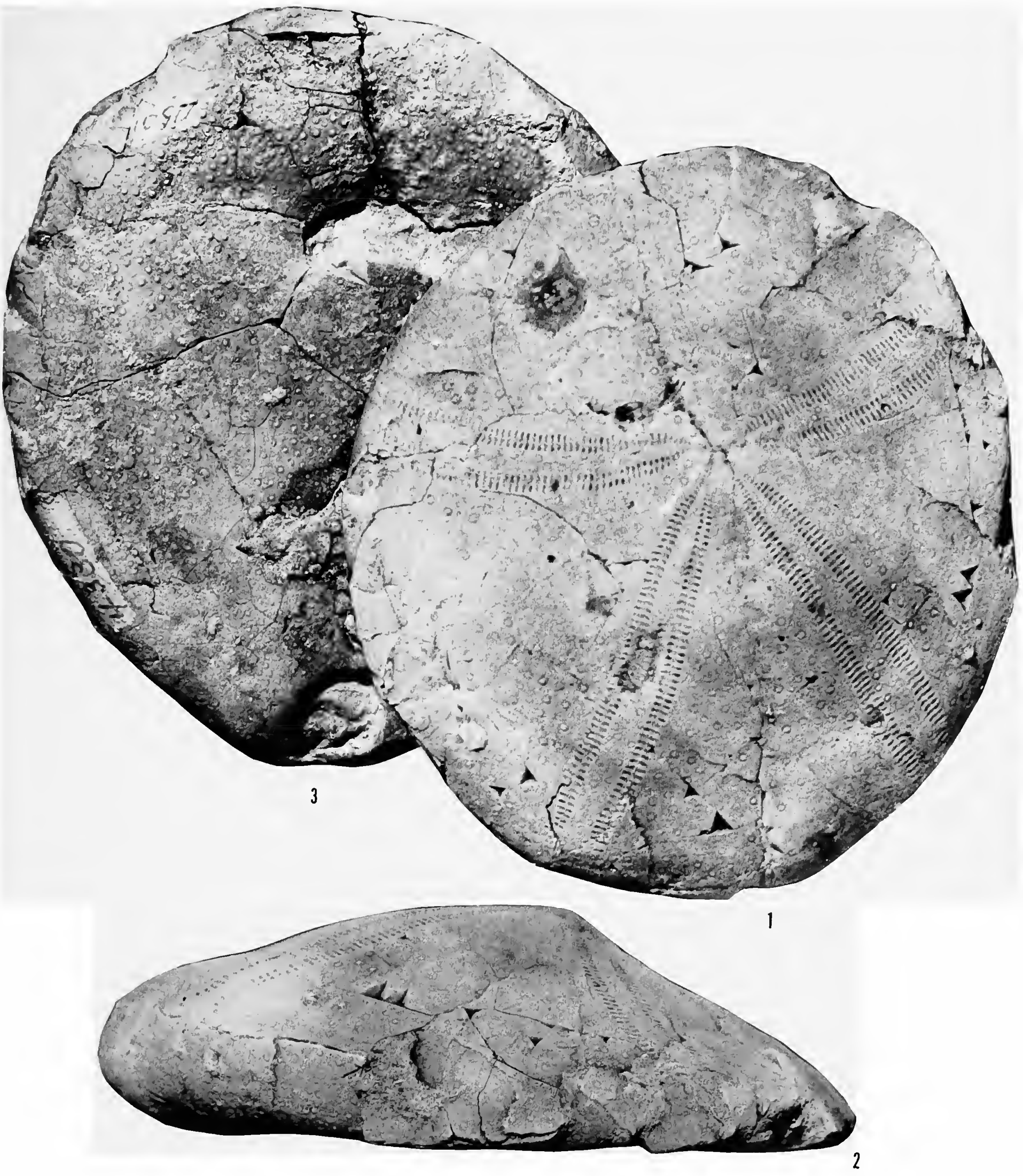




\section{PLATE 86}

Antillaster vaughani (Jackson)

1, 2. Dorsal, and right side views of a topotype of Antillaster expansus Sánchez Roig $(=A$. vaughani), SRC 4480, Oligocene-Miocene, "El Maja" farm, Majagua district, Ciego de Avila, Camagüey Province, Cuba, $\times 1$. 


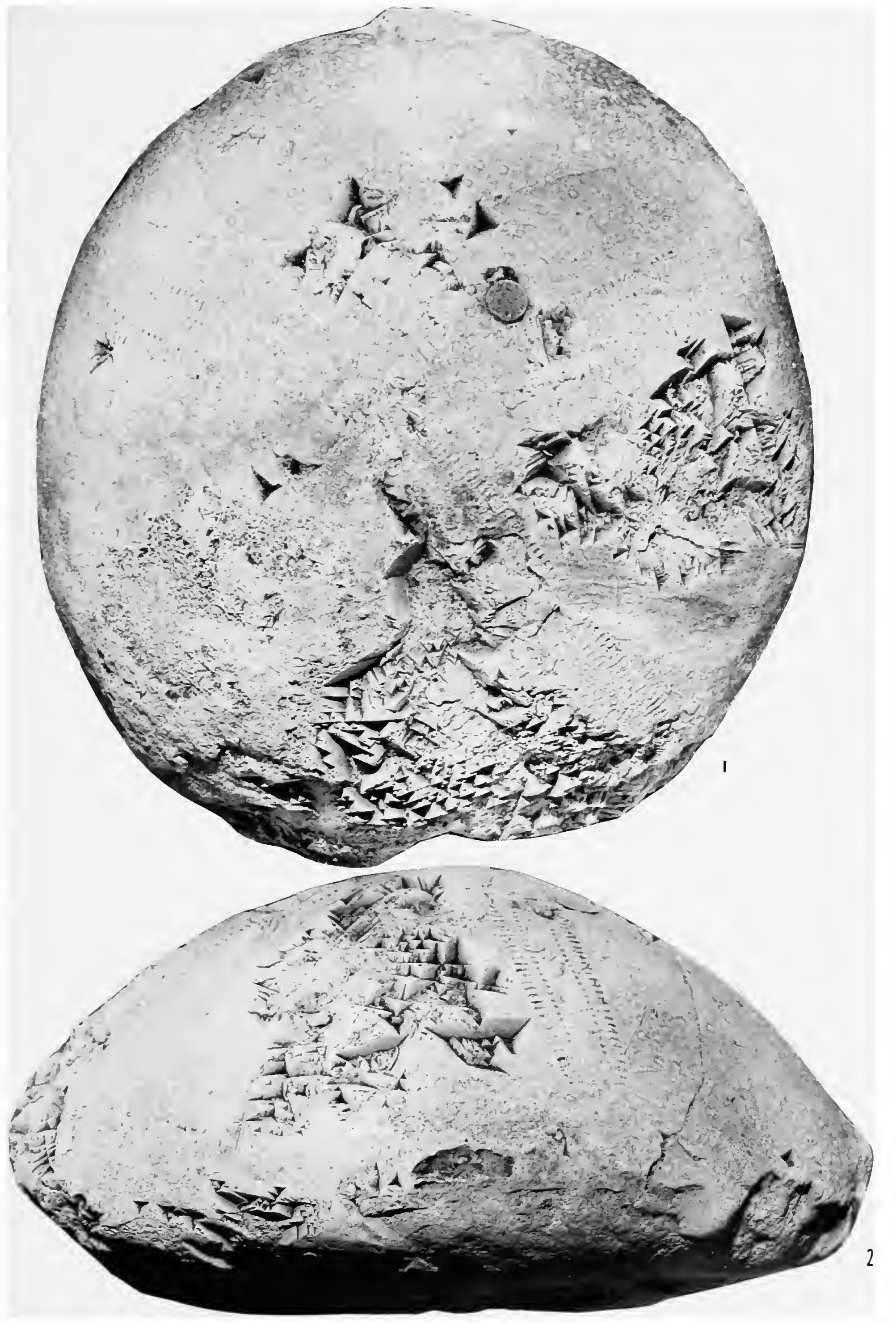




\section{PLATE 87}

\section{Antillaster vaughani (Jackson)}

1-3. Dorsal, right side, and ventral views of the holotype of Antillaster guevari Sánchez Roig (= A. vaughani), SRC 4509, Oligocene-Miocene, Loma Mendoza, Marroquín, Morón, Camagüey Province, Cuba, $\times 1$.

Antillaster sp.

4. Phyllode 2, USNM 341261, Miocene, Falcón, Venezuela, $\times 8$. 

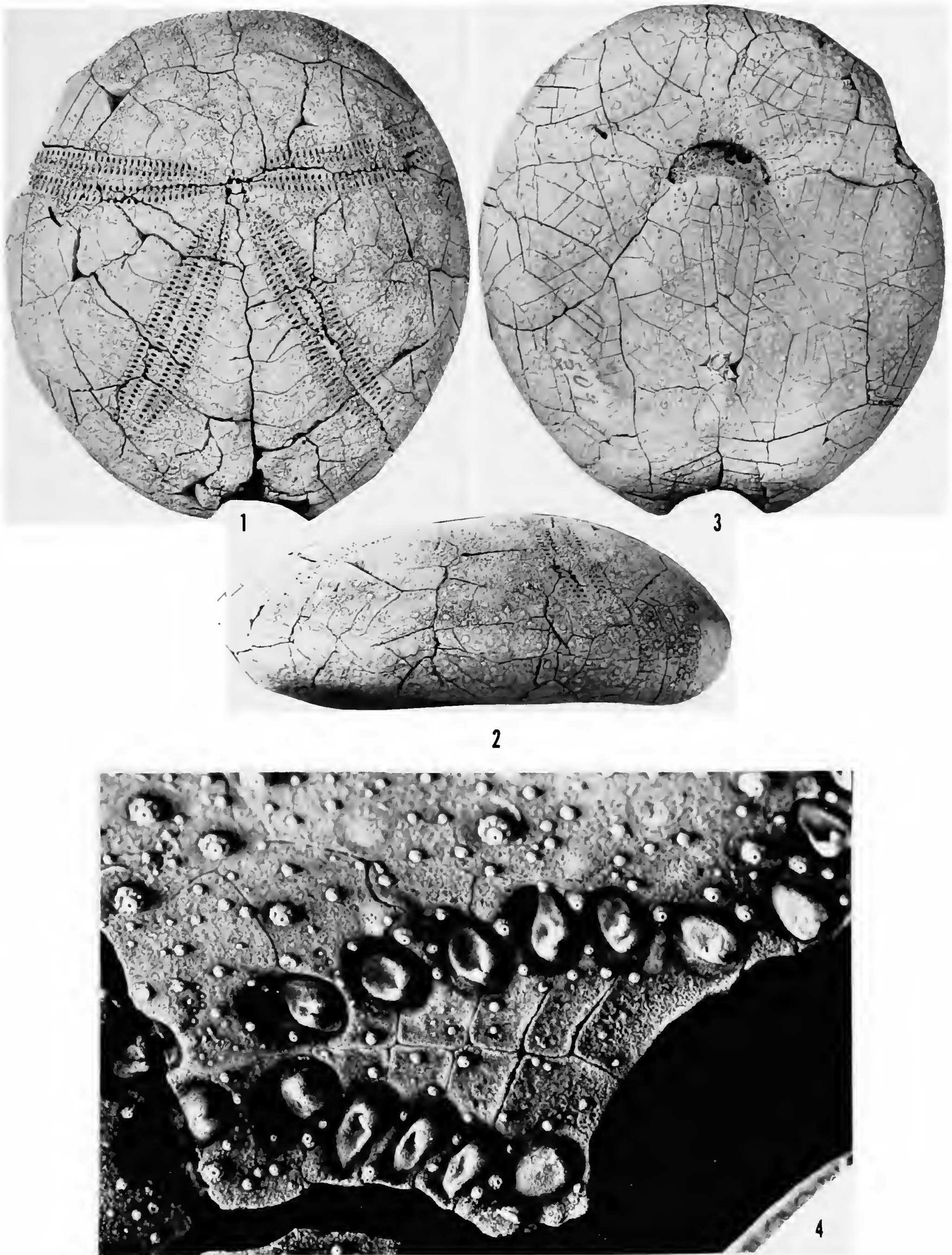


\section{PLATE 88}

\section{Antillaster lamberti Jeannet}

1,2. Dorsal and ventral views of the holotype of Antillaster habanensis (Sánchez Roig) (=A. lamberti), SRC 4114, Oligocene-Miocene, on margin of deep cut along hill approximately $1 \mathrm{mi}(1.6 \mathrm{~km}) \mathrm{E}$ of Casa Blanca, Habana Province, Cuba, $\times 1$. (See also Plate 89.) 


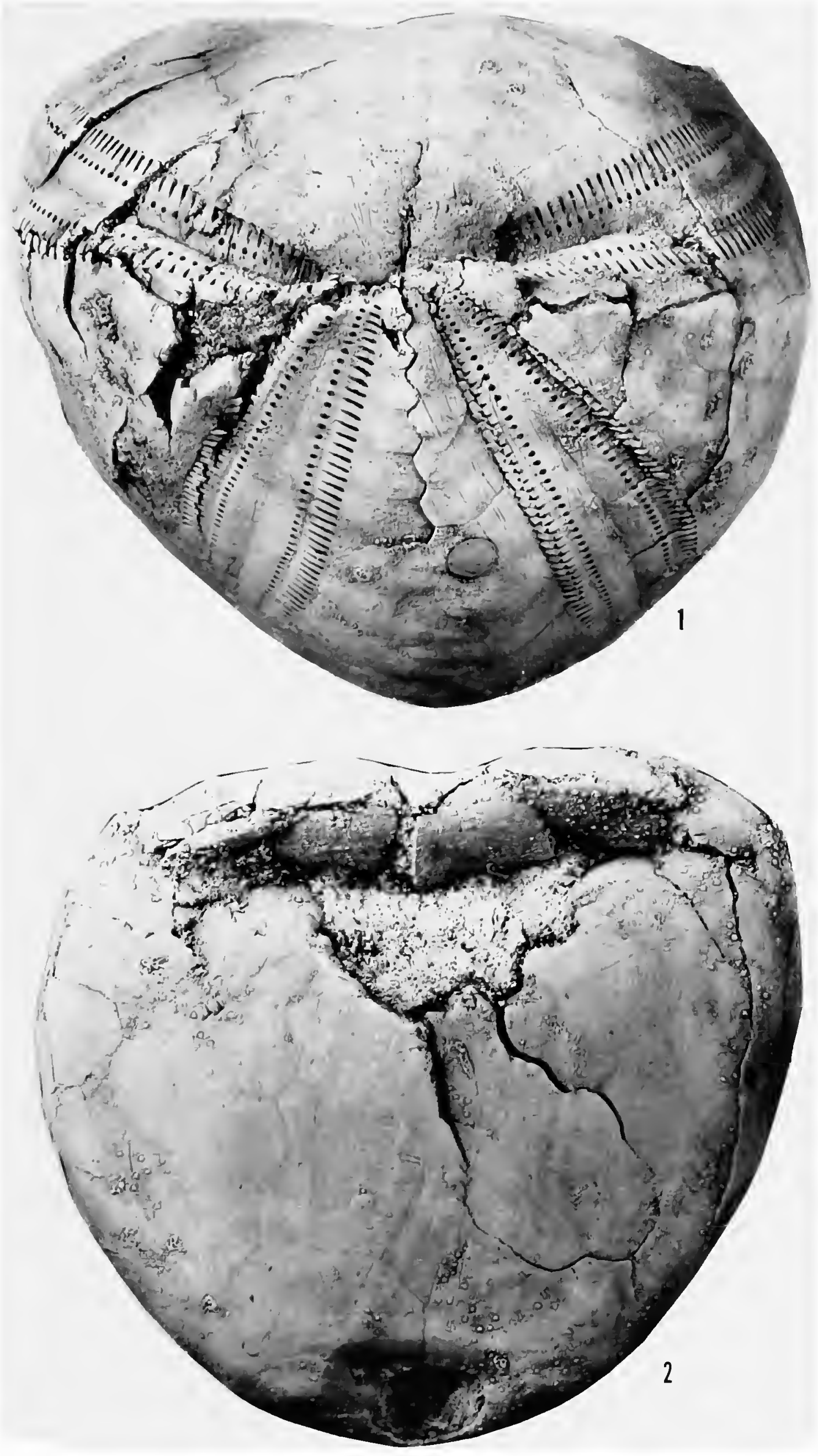




\section{PLATE 89}

\section{Antillaster lamberti Jeannet}

1,2. Right side and rear of the holotype of Antillaster habanensis (Sánchez Roig) (= A. lamberti), SRC 4114, Oligocene-Miocene, on margin of deep cut along hill approximately $1 \mathrm{mi}$ $(1.6 \mathrm{~km}) \mathrm{E}$ of Casa Blanca, Habana Province, Cuba, $\times 1$. (See also Plate 88.) 

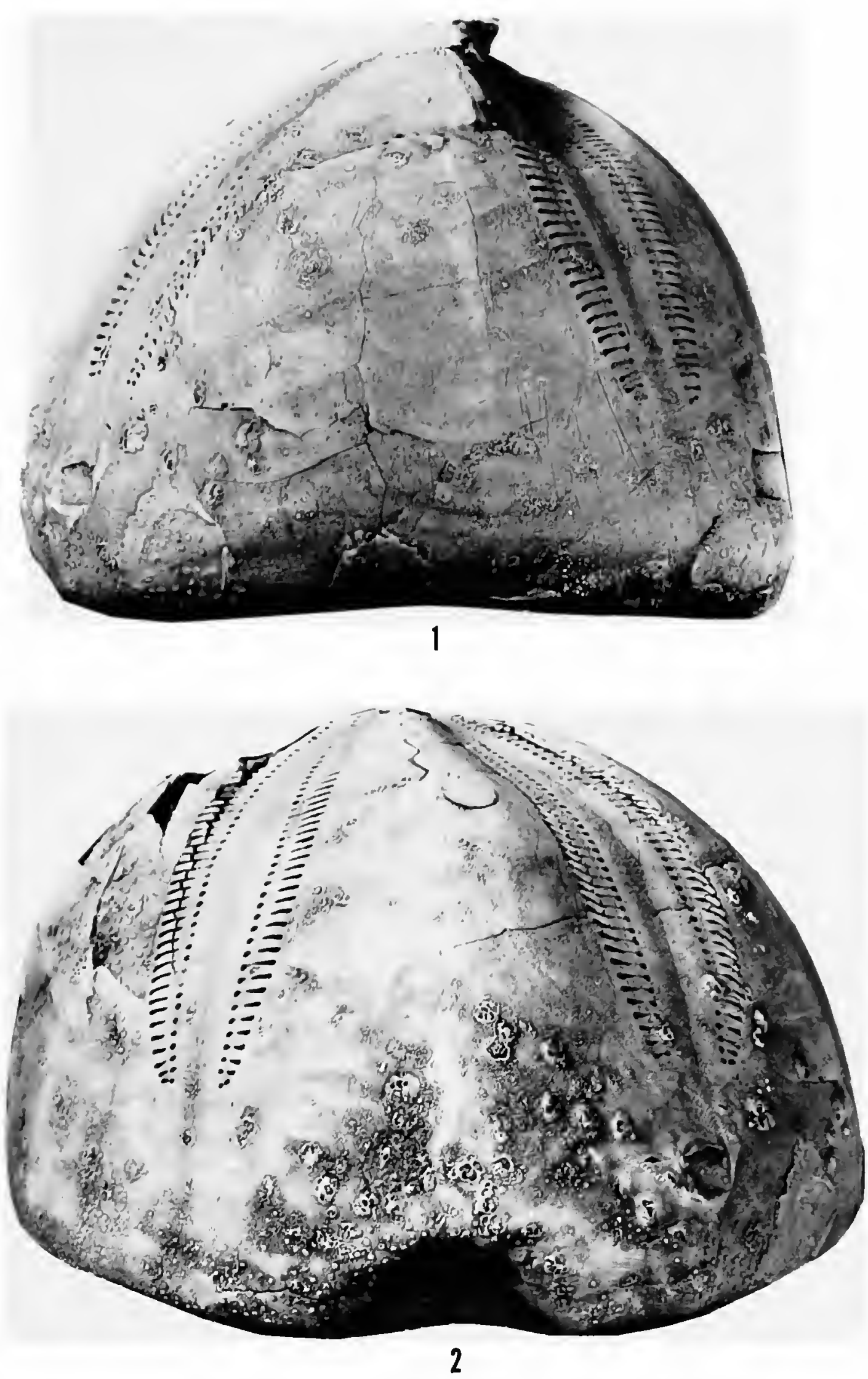


\section{PLATE 90}

\section{Antillaster lamberti Jeannet}

1. Left side view, USNM 638639, Miocene, La Vela beds, La Vigía, $10 \mathrm{~km}$ SW of Pueblo Nuveo, District of Paraguaná, Falćon, Venezuela, $\times 1$. (Also figured in Cooke, 1961, pl. 11: figs. 1, 2, pl. 12: fig. 5.)

\section{Antillaster sanchezi Lambert}

2-4. Dorsal, right side, and ventral views of a topotype, SRC 4511, early to middle Miocene, "Cervantes" farm, San Jośe de las Lajas, Habana Province, Cuba, $\times 1$. 

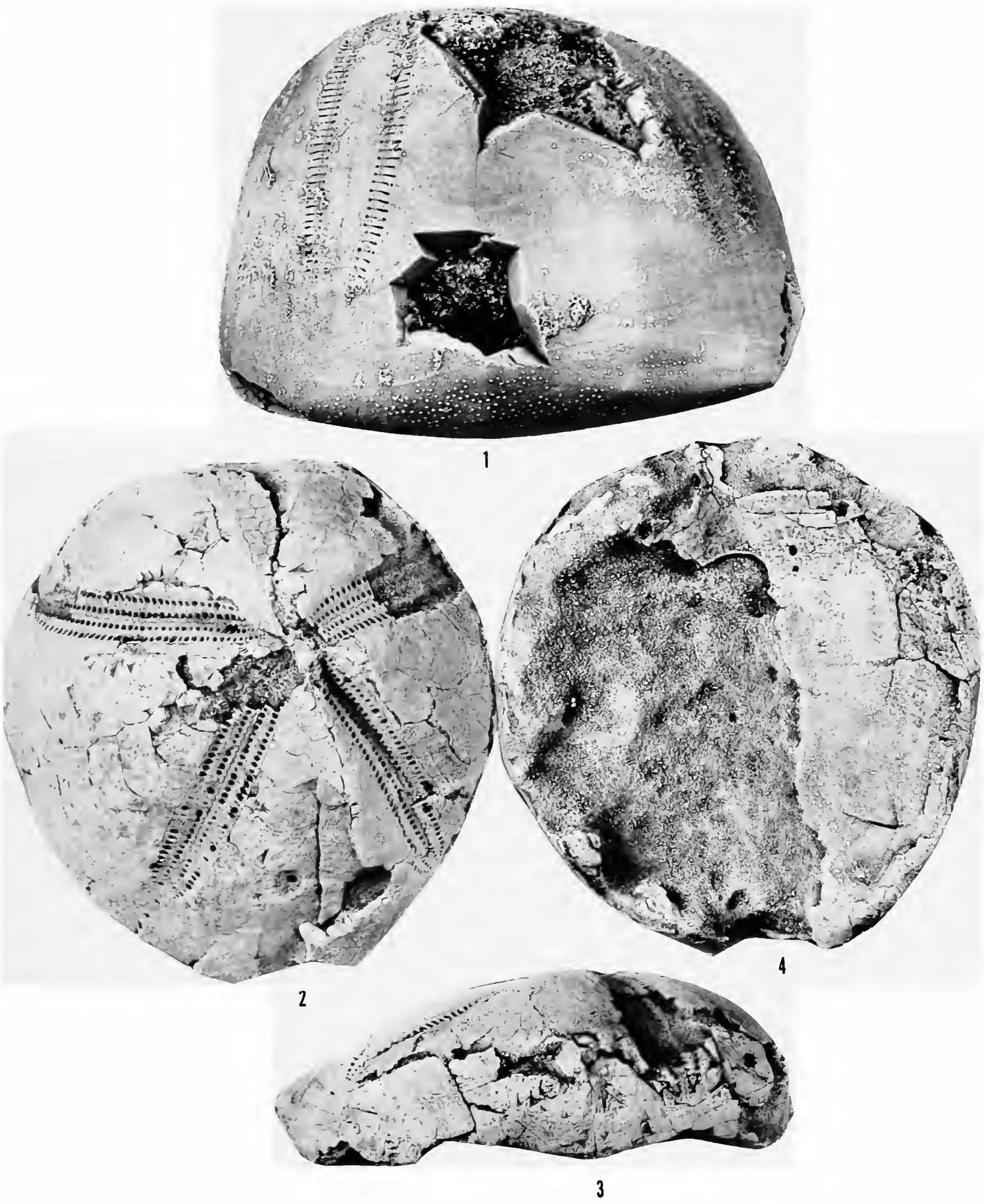


\section{Index}

(Synonyms and page numbers of principal accounts are in italics.)

abruptus, Plagiobrissus, 7

Agassizia, 59

alveari, 5, 61

avilensis, 62, 63

camagueyana, 62

caobaensis, 65

caribbeana, 62

clevei, $4,5,6,8,9,10,62,65$

conradi, 9 ,

egozcuei, 65

excentrica, 60

flexuosa, 66

floridana, 8, 62,

guanensis, 67

inflata, 4, 5, 7, 8, 9, 10, 65

lamberti, 67

mossomi, 8,

pinarensis, 6,65

porifera, 62

regia, 10 ,

scrobiculata, 60

wilmingtonica, 8, 65

Aguayoaster, 67

aguayoi, 4, 5, 67

nuevitasensis, 4, 5, 67

aguayoi, Aguayoaster, 4, 5, 67

Brissopsis, 86

Linthia, 21, 22

Pericosmus, 5, 21, 22

akabanus, Pericosmus, 21

alabamensis, Eupatagus, 8

Linthia, 74

Lovenia, 8

alatus, Eupatagus, 93, 95

albeari, Antillaster, 5, 135

alcaldei, Schizaster, 58

aloysii, Eupatagus, 9

alta, Linthia, 73, 74

altissimus, Schizaster, 7

alveari, Agassizia, 5, 61

americanus, Schizaster, 8, 36

angustus, Macropneustes, 7

Anisaster, 61

antillarum, Brissopsis, 9, 10

Eupatagus, 93, 98, 108

Macropneustes, 119
Meoma, 4, 119

Peripneustes, 119

Schizaster, 8

Schizobrissus, 119

Antillaster, 7, 8, 9, 131

albeari, 5, 135

arnoldi, 5, 7, 135

bonairensis, 9, 135

brachypetalus, 134

cartagensis, 117, 143

castroi, 140

cubensis, 8, 136

depressus, 140,141

elegans, 9, 132

estenozi, 143

expansus, 140,141

fernandezi, 5, 137

flexuosus, 140

giganteus, 143

guevarai, 140, 141

habanensis, 139

herrerae, 140, 143

jaumei, 137

lamberti, 5, 9, 138

mexicanus, 10 ,

mortenseni, 21

rojasi, 135,136

sanchezi, 6,140

vaughani, $5,7,8,10,140$

antillensis, Hemiaster, 19

Trachyaster, 19

antiqua, Meoma, 5, 7, 120

Aplospatangus, 47

Archaeopneustes cubensis, 137

arguta, Maretia, 8

armadilloensis, Deakia, 116

Macropneustes (Deakia), 5, 116

armiger, Schizaster, 8

arnoldi, Antillaster, 5, 7, 135

artemisae, Pericosmus, 22, 24

Asterostoma, 7, 8, 9, 124

cubensis, 136

dickersoni, 125, 127

excentricum, 5, 7, 125

irregularis, 125,127

jimenoi, 125 pawsoni, 7,128

subcircularis, 5,130

Asterostomatidae, 124

Asterostomatina, 124

atolladosae, Linthia, 28

Pericosmus, 4, 21, 28

atropos, Moira, 60

attenuatus, Eupatagus, 7

avilense, Eupatagus, 94

avilensis, Agassizia, 62, 63

Linthia, 4, 72

axiologus, Homoeopetalus, 7

bathypetalus, Schizaster, 4, 5, 7, 35, 36

beckeri, Ditremaster, 57

Schizaster, 8, 36, 57

biarritzensis, Brissopsis, 87

bidens, Pericosmus, 21

blanpiedi, Brissopsis, 87

blanquizalens's, Pericosmus, 5, 21, 31

bonairensis, Antillaster, 9, 135

brachypetalus, Antillaster, 134

Schizaster, 7, 56

brevipetalum, Brissoides, 98, 104

Eupatagus, 98, 100

Eupatagus (Gymnopatagus), 98

Breynia, cubensis, 103

Brisaster, 70

Brissidae, 81

Brissoides,

brevipetalum, 98

camagueyanus, 94

cubensis, 103

elongatum, 104

grandiflorus, 98

habanensis, 107

herrerae, 98, 104

lajasensis, 104

lamberti, 104

luacesi, 104

mayor, 104

minutus, 94

munozi, 104, 105

munozi minor, 104

palmeri, 94

planus, 104 
sanchezi, 107

santanae, 94, 108

stefaninii, 94

zanolettii, 98, 104

Brissolampas santanae, 144

Brissoma, 123

habanensis, 123

vonderschmitti, 9

Brissopatagus, 144

mexicanus, 10

rojasi, 144

Brissopsis, 86

aguayoi, 5,86

antillarum, 9,10 ,

biarritzensis, 8,87

blanpiedi, 8, 87

elongata, 86

jimenoi, 6, 9, 87

steinhatchee, 8 ,

Brissus, 81

brissus, 82

cabrerai, 4, 82

camagueyensis, 4, 5, 83

caobaense, $4,5,83$

durhami, 4, 5, 84

exiguus, 10,81

fabiani, 82

gigas, 82

glenni, 81

latecarinatus, 81

latidunensis, 82

minutus, 5, 82, 85

obesus, 81

sagrae, 82

scillae, 82

unicolor, 9,81

brissus, Brissus, 82

brodermanni, Cyclaster, 89, 90

Eupatagus, 95

Linthia, 4, 73

Macropneustes, 121

Meoma, 4, 121

cabrerai, Brissus, 82

Crucibrissus, 82

calistoides, Eupalagus, 109, 110

camagueyana, Agassizia, 62

camagueyanus, Brissoides, 94

Pericosmus, 5, 9, 21, 32

camagueyensis, Brissus, 83

Paraster, 39

Schizaster, 4, 5, 35, 39

caobaense, Brissus, 83

Eupalagus, 95
Schizaster, 58

caobaensis, Agassizia, 65

Meoma, 120

caraibensis, Linthia, 9

Cardiaster, 10, 11

cubensis, 4, 10

deciper, 10

leonensis, 11

palmeri, 4, 10, /l

Caribbaster, 7, 67

dyscritus, 7 ,

loveni, $4,5,7,8,68$

caribbeana, Agassizia, 62

carolinensis, Eupatagus, 98

Unifascia, 8

cartagensis, Antillaster, 117, 143

Metalia, 117

Paraster, 40

Schizaster, 5, 35, 36, 40

casanovai, Eupatagus, 95

castroi, Antillaster, 140

Chelonechinus, 13

crassus, 15

suvae, 14

clarcki, Paraster, 44

Prenaster, 78

clarki, Lovenia, 9

Paraster, 44

Prenaster, 78

clevei, Agassizia, 4, 5, 6, 8, 9, 10, 62, 65

Eupatagus, 93, 98

Euspatangus, 98

Macropneustes, 121

Meoma, 10, 120, 121

Peripneustes, 119, 121

Schizaster, 8, 10, 36, 48

Schizobrissus, 122

cojimarensis, Schizaster, 58

conradi, Agassizia, 9

Conoclypeus sanctispiritensis, 13

Conulus subrotundus, 13

cordatus, Pericosmus, 21

costaricensis, Plagiobrissus, 10

Schizaster, 10

crassus, Chelonechinus, 15

cretacica, Linthia, 77

cristatus, Paleopneustes, 132

Schizaster, 10

cruciatus, Schizobrissus, 119

Crucibrissus cabrerai, 82

cubanus, Pericosmus, 21, 35

cubensis, Antillaster, 8, 136

Archaeopneustes, 137

Asterostoma, 136
Breynia, 103

Brissoides, 103

Cardiaster, 4, 10

Echinocorys ovatus, 12

Eupatagus, 6, 103

Hemiaster, 58

Macropneustes, 117

Macropneustes (Macropneustes), 117

Mauritanaster, 117

Neopalagus, 104

Pseudoasterostoma, 137

Schizaster, 58

cubitabellae, Paraster, 41

Schizaster, 41

cumminsi, Plagiobrissus, 10

curvus, Plagiobrissus, 8

Cyclaster, 88

brodermanni, 89, 90

drewryensis, 4, 5, 8, 88

regalis, 88

sanchezi, 4, 68, 92

sterea, 8,88

Deakia, 115

armadilloensis, 116

deciper, Cardiaster, 10

defectus, Eupatagus, 7

delagadoi, Pericosmus, 21

Schizaster, 6, 21, 35

depressus, Antillaster, 140, 141

Eupatagus, 93, 103, 105

Mauritanaster, 21, 23, 25

Megapatagus, 103, 112

dewalquei, Hemiaster, 19

Hemiaster (Integraster), 19

dickersoni, Asterostoma, 125, I27

Disasteroida, 10

Ditremaster beckeri, 57

dixie, Plagiobrissus, 8

doederleini, Paraster, 36

Schizaster, 35

Douvillaster, 15

triangularis, 4, 15

variosulcatus, 16

drewryensis, Cyclaster, 88

dubia, Metalia, 7

dubius, Macropneustes, 10

dumblei, Lovenia, 10

Schizaster, 7, 10

durhami, Brissus, 4, 5, 84

Sandiegoaster, 82, 84

dyscritus, Caribbaster, 7

Macropneustes, 8

Schizaster, 68 
Echinocardium orthonotum, 9,

Echinocorys, 12

ovatus cubensis, 4,12

ovatus villarensis, 12

egozcuei, Agassizia, 65

Schizaster, 5, 42

elegans, Antillaster, 9, 132

Eupatagus, 132

elevatus, Micraster, 73, 76

Paleopneustes, 10

Plagiobrissus, 7

elongata, Brissopsis, 86

elongatum, Brissoides, 104

Eupatagus, 105

elongatus, Periaster, 8

Prenaster, 78

estenozi, Antillaster, 143

Eupatagus, 105

Maretia, 104, 106

Eupatagus, 2, 93

alabamensis, 8 ,

alatus, 5, 7, 93, 95

aloysii, 9 ,

antillarum, 93, 98, 108

attenuatus, 7 ,

avilensis, 94

brevipetalum, 98, 100, 104

brodermanni, 95

calistoides, 109, 110

caobaense, 95

carolinensis, 8,98

casanovai, 95

clevei, $5,7,8,9,10,93,98$

cubensis, 6, 103

defectus, 7 ,

depressus, 9, 22, 93, 103, 105

elegans, 132

elongatum, 105

estenozı, 105

gardnerae, 8 ,

grandiflorus, 7, 8, 98

habanensis, 107

herrerae, 98, 100, 104

hildae, 99

ingens, 8, 98, 99

lajasensis, 105

lamberti, 105

lawsonae, 8 ,

longipetalus, 7 ,

luacesi, 105

mayor, 105

mexicanus, 140

mooreanus, 98

munozi, 105 ocalanus, 8

pinarensis, 94

planus, 105

rojasi, 98,101

sanchezi, 6, 107

santanae, 5, 108

siboneyensis, 5, 109

turibacoensis, 5, 109

vaughani, 140

venturillae, 98,101

wilsoni, 8, 98

zanoletti, 99

zanolettii, 105

Eupatagus (Gymnopatagus) brevipetalum, 98

rojasi, 98

venturillae, 98

zanoletti, 98, 104

Eupatagus (Plagiobrissus) herrerae, 98 santanae, 108

Eupatagus (Spatangomorpha) pinarensis, 95

Euspatangus clevei, 98

grandiflorus, 98

excentrica, Agassizia, 60

excentricum, Asterostoma, 5, 7, 125

exiguus, Brissus, 10, 81

expansus, Antillaster, 140, 141

fabiani, Brissus, 82

Fernandezaster, 7, 112

mortenseni, 5, 112

fernandezi, Antillaster, 5, 137

Pseudoasterostoma, 137

Schizaster, 6, 35, 43

Schizaster (Schizaster), 43

flexuosa, Agassizia, 66

flexuosus, Antillaster, 140

floridana, Agassızıa, 8, 62

formelli, Schizaster, 4, 43

franciscanus, Megapatagus, 98, 99, 103

frangibilis, Meoma, 120

garciai, Linthia, 77

gardnerae, Eupatagus, 8

gerthi, Schizaster, 4, 5, 9, 35, 44

giganteus, Antillaster, 143

Pericosmus, 21, 22, 23, 24

gigas, Brissus, 82

Schizaster, 36

Victoriaster, 70

glenni, Brissus, 81

globulosus, Hemiaster, 20

Hemiaster (Integraster), 20

gomezmazae, Macropneustes, 122
Meoma, 5, 122

gonzalezmunozi, Hemiaster, 18

Hemiaster (Trachyaster), 4, 18, 19

Linthia, 73, 75

grandiflorus, Brissoides, 98

Eupatagus, 98

Euspatangus, 98

grandis, Plagiobrissus, 93

guanensis, Agassizia, 67

guevarai, Antillaster, 140, 141

Lajanaster, 98

guirensis, Schizaster, 47, 50

Habanaster, 7, 79

sanchezi, 4, 79

habanensis, Antillaster, 139

Brissoides, 107

Brissoma, 123

Eupatagus, 107

Migliorinia, 6, 107, I23

Pseudoasterostoma, 138

Sanchezaster, 4, 14

Schizaster, 58

hanoverensis, Linthia, 8

harmatuki, Linthia, 8

Hemiaster, 16, 17

antillensis, 19

cubensis, 58

dewalquei, 19

globulosus, 20

gonzalezmunozi, 18,19

herrerae, $4,16,18$

lamberti, 16, 73

madrugensis, $4,17,18,19$

minutus, 20

siboneyensis, 17,19

simpaticus, 20

texanus, 16, 19

Hemiaster (Hemiaster), 16

madrugenesis, 19

siboneyensis, 4 ,

Hemiaster (Integraster) dewalquei, 19 globulosus, 20

Hemiaster (Trachyaster), 16, 19

gonzalezmunozi, $4,18,19$

herrerae, 18

minutus, 20

simpaticus, 20

Hemiasteridae, 16

Hemiasterina, 16

Hemispatagus hoffmani, 35

Hernandezaster, 113

hernandezi, 6,113

hernandezi, Hernandezaster, 6, 113 
Lajanaster, 94, 114, 115

herrerae, Antillaster, 140, 143

Brissoides, 98, 104

Eupatagus, 98, 100, 104

Eupatagus (Plagiobrissus), 98

Hemiaster, 4, 16, 18

Herreraster, 98, 99

Opissaster, 18

Zanolettiaster, 93, 98

herrerai, Palmeraster, 88, 89

Herreraster, 93

herrerae, 98, 99

hexagonalis, Schizaster, 7

hildae, Eupatagus, 99

hoffmani, Hemispatagus, 35

Holasteridae, 10

hollandi, Linthia, 8

holmesii, Plagiobrissus, 9

Homoeopetalus axiologus, 7

Hypselaster perplexus, 7, 68

inflata, Agassizia, 65

ingens, Eupatagus, 98, 99

irregularis, Asterostoma, 125, 127

Isomicraster, 15

israelskyi, Pericosmus, 21

jacksoni, Lajanaster, 114

Schizobrissus, 119

jamaicensis, Lambertona, 69, 71

Metalia, 7

Victoriaster, 7, 69

jaumei, Antillaster, 137

jeanneti, Prenaster, 9

jimenoi, Asterostoma, 125

Brissopsis, 87

keiensis, Pericosmus, 21

kewi, Schizobrissus, 10

\author{
Lajanaster, 114 \\ guevarai, 98 \\ hernandezi, 94, 114, 115 \\ jacksoni, $6,1 / 4$ \\ rojasi, 114,115 \\ venturillae, 98, 102, 114 \\ lajasensis, Brissoides, 104 \\ Eupatagus, 105 \\ lamberti, Agassizia, 67 \\ Antillaster, 5, 9, 138 \\ Brissoides, 104 \\ Eupatagus, 105 \\ Hemiaster, 16, 73 \\ Lambertona, 4, 7, 70
}

Linthia, 16

Plagiobrissus, 9

Victoriaster, 70

Lambertona, 7, 69

jamaicensis, 69, 71

lamberti, 4, 7, 70

lyoni, 69

perdita, 70

perplexa, 69

laticarinatus, Brissus, 81

latidunensis, Brissus, 82

latus, Plagiobrissus, 7

lawsonae, Eupatagus, 8

leonensis, Cardiaster, 11

Linthia. 71

aguayoi, 21, 22

alabamensis, 74

alta, 73, 74

atolladosae, 28

avilensis, 4, 72

brodermanni, 4, 73

caraibensis, 9 ,

cretacica, 77

garciai, 77

gonzalezmunozi, 73, 75

hanoverensis, 8

harmatuki, 8

hollandi, 8

monteroae, 4,76

mooraboolensis, 70

obesa, 8

trechmanni, 7

variabilis, 72

wilmingtonensis, 8

llagunoi, Schizaster, 4, 35, 75

longipetalus, Eupatagus, 7

Lovenia alabamensis, 8,

clarki, 9,

dumblei, 10

mexicana, 10

loveni, Caribbaster, 4, 5, 7, 8, 68

Paraster, 9

Plagiobrissus, 7, 8

Prenaster, 68

Schizaster, 10, 48

luacesi, Brissoides, 104

Eupatagus, 105

Iyoni, Lambertona, 69

Macraster, 16

triangularis, 15

Macropneustes, 115, 121

antillarum, 119

angustus, 7 armadilloensis, 5, 116

brodermanni, 121

clevei, 121

cubensis, 117

dubius, 10

dyscritus, 8 ,

gomezmazae, 122

mortoni, 8,

palmeri, 5, 117

parvus, 7 ,

sinuosus, 8 ,

stenopetalus, 7 ,

Macropneustes (Deakia), 115

armadilloensis, 5, 116

Macropneustes (Macropneustes), 115

cubensis, 117

palmeri, 5, 117

madrugensis, Hemiaster, 19

Hemiaster (Hemiaster), 17, 18

malavassii, Plagiobrissus, 10

Maretia arguta, 8 ,

estenozi, 104, 106

subrostrata, 8 ,

marroquinensis, Mauritanaster, 21, 22, 24, 26

Pericosmus, 21

Mauritanaster cubensis, 117, 140

depressus, 21, 22, 23, 25

marraquinensis, 21, 22, 24, 26

mauritianus, Pericosmus, 21

major, Brissoides, 104

Eupalagus, 105

Magapatagus, 103

depressus, 103, 112

franciscanus, 98, 99, 103

turibacoensis, 109, 110,111

melanostomus, Pericosmus, 21

Mellitidae, 7

Meoma, 118, 121

antillarum, 4, 119

antiqua, 5, 7, 120

brodermanni, 4, 121

caobaense, 120

clevei, 10, 120, 121

frangibilis, 120

gomezmazae, 5, 122

roigi, 35

ventricosa, 120

Metalia, 118, 122

cartagensis, 117, 122

dubia, 7 ,

jamaicensis, 7 ,

palmeri, 117

mexicana, Lovenia, 10 
mexicanus, Antillaster, 10

Brissopatagus, 10

Eupatagus, 140

Micraster elevalus, 73, 76

Micrasteridae, 79

Micrasterina, 79

migiurtina, Migliorinia, 123

Migliorinia, 122

habanensis, 6, 107, 123

migiurtina, 123

minor, Brissoides munozi, 104

minutus, Brissoides, 94

Brissus, 5, 82, 85

Hemiaster (Trachyaster), 20

Neopatagus, 85

Trachyaster, 20

Moira atropos, 60

monteroae, Linthia, 4, 76

mooraboolensis, Linthia, 70

mooreanus, Eupatagus, 98

Moronaster, 144

moronensis, 144

santanae, 144

moronensis, Moronaster, 144

Schizaster, 59

mortenseni, Antillaster, 21

Fernandezaster, 112

Hernandezaster, 6, 113

Pericosmus, 5, 21, 33

mortoni, Macropneustes, 8

mossomi, Agassizia, 8

munozi, Brissoides, 104, 105

Eupatagus, 105

Schizaster, 5, 10, 35, 36, 47

Neolaganidae, 7

Neopatagus, 93

cubensis, 104

minutus, 85

sanchezi, 107

nuevitasensis, Aguayoaster, 4, 5, 67

Paraster, 53

Prenaster, 67

Schizaster, 4, 53

obesa, Linthia, 8

obesus, Brissus, 81

oblongus, Pericosmus, 21

ocalanus, Eupatagus, 8

Schizaster, 8

Oligopygoida, 7

Oligopygus, 5 ,

Opissaster herrerae, 18

oripntalis, Paraster, 47, 49 orthonotum, Echinocardium, 9

Paleopneustidae, 20, 125, 132

Paleopneustes, 4, 125, 132

cristatus, 132

elevatus, 10

tholoformis, 132

Palmeraster, 88

herrerai, 88,89

palmeri, 89, 90

zanolettii, 89

palmeri, Brissoides, 94

Cardiaster, 11

Macropneustes (Macropneustes), 5, 117

Metalia, 117

Palmeraster, 88, 90

panamensis, Schizaster, 10

Paraster, 36

camagueyensis, 39

cartagensis, 40

clarcki, 44

clarki, 44

cubitabellae, 41

doederleini, 36

loveni, 9 ,

nuevitasensis, 53

orientalis, 47,49

pastelilloensis, 59

pinarensis, 59

sandiegensis, 59

sierrai, 59

tampicoensis, 10

tschopi, 47, 50

parkinsoni, Schizaster, 36

parvus, Macropneustes, 7

Prenaster, 4, 77

pastelilloensis, Paraster, 59

Schizaster, 59

pawsoni, Asterostoma, 7, 128

pentagonalis, Schizaster, 36,38

perdita, Lambertona, 70

Periarchus, 7,

Periaster, 7 ,

elongatus, 8 ,

Pericosmus, 9, 20

aguayoi, 5, 21, 22

akabanus, 21

artemisae, 22, 24

atolladosae, 4, 21, 28

bidens, 21

blanquizalensis, $5,21,31$

camaqueyanus, 5, 9, 21, 32

cordatus, 21 cubanus, 21, 35

delgadoi, 21

depressus, 21

giganteus, 21, 22, 23

israelskyi, 10, 21

keiensis, 21

marroquinensis, 21

mauritianus, 21

melanostomus, 21

mortenseni, 5, 21, 33

oblongus, 21

roigi, 22,35

rojasi, $21,28,29$

stehlini, 9, 21

tenuis, 21

valenzuelai, 21, 22, 23, 26

zanolettii, 21, 28, 30

Pericosmus (Lambertona), 69

Peripneustes, 119

antillarum, 119

clevei, 119, 121

perplexa, Lambertona, 69

perplexus, Hypselaster, 68

Plagiobrissus, 7

pinarensis, Agassizia, 6, 65

Eupatagus, 94

Eupatagus (Spatangomorpha), 95

Paraster, 59

Schizaster, 59

Plagiobrissus, 93

abruptus, 7,

costaricensis, 10

cumminsi, 10

curvus, 8 ,

dixie, 8 ,

elevatus, 7 ,

grandis, 93

holmesii, 9 ,

lamberti, 9 ,

latus, 7 ,

loveni, 7, 8,

malavassii, 10

perplexus, 7 ,

robustus, 7 ,

planus, Brissoides, 104

Eupatagus, 105

Plesiozonus, 125

porifera, Agassizia, 62

Prenaster, 77

clarcki, 78

clarki, 78

elongatus, 78

jeanneti, 9 ,

loveni, 68 
nuevitasensis, 67

parvus, 4, 77

sanchezi, 78

Prosostoma, 125

Protoscutella, 7,

Protoscutellidae, 7,

Pseudoasterostoma, 132

cubensis, 137

fernandezi, 137

habensis, 138

regalis, Cyclaster, 88

regia, Agassizia, 10

Rhynobrissus rostratus, 9,

riveroi, Schizaster, 51

Schizaster (Aplospatangus), 47

robustus, Plagiobrissus, 7

roigi, Meoma, 35

Pericosmus, 22, 35

rojasi, Antillaster, 135, 136

Brissopatagus, 144

Eupatagus, 101

Eupatagus (Gymnopatagus), 98

Lajanaster, 114, 115

Pericosmus, 21, 28, 29.

Rojasia, 5, 124

Schizaster, 5, 53

Schizaster (Aplospatangus), 53

Rojasia, 7, 123

rojasi, 5,124

rostratus, Rhynobrissus, 9

sagrae, Brissus, 82

salutis, Schizaster, 47, 52

Sanchezaster, 7, 13

habanensis, 4, 14

sanchezi, Antillaster, 6, 140

Brissoides, 107

Cyclaster, 4, 68, 92

Eupatagus, 6, 107

Habanaster, 79

Neopatagus, 107

Prenaster, 78

sanctamariae, Schizaster, 5, 54 sanctispiritensis, Conoclypeus, 13

sandiegensis, Paraster, 59

Schizaster, 59

Sandiegoaster, 84

durhami, 82, 84

santanae, Brissoides, 94, 108

Brissolampas, 144

Eupatagus, 5, 108

Eupatagus (Plagiobrissus), 108

Moronaster, 144
Schizaster, 4, 35, 55

Schizaster, 35

alcaldei, 58

altissimus, 7 ,

americanus, 8, 36

antillarum, 8 ,

armiger, 8, 10

bathypetalus, 4, 5, 7, 35, 36,

beckeri, 8, 36, 57

brachypetalus, 7, 56

camagueyensis, 4, 5, 3539

caobaense, 58

cartagensis, 5, 35, 36, 40

clevei, $8,10,36,48$

cojimarensis, 58

costaricensis, 10

cristatus, 10 ,

cubensis, 58

cubitabellae, 4, 41

delgadoi, 6, 21, 35

doederleini, 35

dumblei, 7, 10,

dyscritus, 68

egozcuei, 5,42

fernandezi, 6, 35, 43

formelli, 4 ,

gerthi, 4, 5, 9, 35, 44

gigas, 36

guirensis, 47, 50

habanensis, 58

hexagonalis, 7 ,

llagunoi, 4, 35, 45

loveni, 10, 48

moronensis, 59

munozi, 5, 10, 35, 36, 47

nuevitasensis, 4, 53

ocalanus, 8 ,

panamensis, 10

parkinsoni, 36

pastelilloensis, 59

pentagonalis, 36,38

pinarensis, 59

riveroi, 51

rojasi, 5, 53

salutis, 47, 52

sanctamariae, 5, 54

sandiegensis, 59

santanae, 4, 35, 55

scillae, 42

sierrai, 59

studeri, 36

subcylindricus, $4,5,8,35,36,56$

tschopi, 48

vedadoensis, 123
Schizaster (Aplospatangus) riveroi, 47

rojasi,

Schizaster (Paraster), 36

Schizaster (Schizaster), 36

Schizasteridae, 35

Schizobrissus, 119

antillarum, 119

clevei, 122

cruciatus, 119

jacksoni, 119

kewi, 10

scillae, Brissus, 82

Schizaster, 42, 60

scrobiculata, Agassizia,

siboneyensis, Eupatagus, 109

Hemiaster, 17

Hemiaster (Hemiaster), 17

sierrai, Paraster, 59

Schizaster, 59

simpaticus, Hemiaster (Trachyaster), 20

Trachyaster, 20

sinuosus, Macropneustes, 8

Spatangoida, 15

stefaninii, Brissoides, 94

stehlini, Pericosmus, 9, 21

steinhatchee, Brissopsis, 8

stenopetalus, Macropneustes, 7

sterea, Cyclaster, 88

studeri, Schizaster, 36

subcircularis, Asterostoma, 5, 130

subcylindricus, Schizaster, 4, 5, 8, 35, 36,56

subrostrata, Maretia, 8

subrotundus, Conulus, 13

suvae, Chelonechinus, 14

tampicoensis, Paraster, 10

Tarphypygus, 5,

tenuis, Pericosmus, 21

texanus, Hemiaster, 16, 19

tholoformis, Paleopneustes, 132

Toxasteridae, 15

Toxasterina, 15

Trachyaster antillensis, 19

minutus, 20

simpaticus, 20

trechmanni, Linthia, 7

triangularis, Douvillaster, 15

Macraster, 15

tschopi, Paraster, 47, 50

Schizaster, 48

turibacoensis, Eupatagus, 109

Megapatagus, 109, 110, III 
unicolor, Brissus, 81

Unifascia carolinensis, 8,

Urechinidae, 13

valenzuelai, Pericosmus, 21, 22, 23, 26

variabilis, Linthia, 72

variosulcatus, Douvillaster, 16

vaughani, Antillaster, 5, 7, 8, 10, 140

Eupatagus, 140

vedadoensis, Schizaster, 123

ventricosa, Meoma, 120 venturillae, Eupatagus, 98, 101

Eupatagus (Gymnopatagus), 98

Lajanaster, 98, 102, 114

Victoriaster, 69, 70

gigas, 70

jamaicensis, 7, 69

lamberti, 70

villarensis, Echinocorys ovatus, 12

vonderschmitti, Brissoma, 9

wilmingtonensis, Linthia, 8 wilmingtonica, Agassizia, 8, 65

wilsoni, Eupatagus, 98

zanoletti, Eupatagus, 99, 104

Eupatagus (Gymnopatagus), 98

Zanolettiaster, 93

herrerae, 93, 98

zanolettii, Brissoides, 98, 104

Eupatagus, 105

Palmeraster, 89

Pericosmus, 21, 28, 30 




\section{REQUIREMENTS FOR SMITHSONIAN SERIES PUBLICATION}

Manuscripts intended for series publication receive substantive review within their originating Smithsonian museums or offices and are submitted to the Smithsonian Institution Press with Form S1-36, which must show the approval of the appropriate authority designated by the sponsoring organizational unit. Requests for special treatment-use of color, foldouts, casebound covers, etc.-require, on the same form, the added approval of the sponsoring authority.

Review of manuscripts and art by the Press for requirements of series format and style, completeness and clarity of copy, and arrangement of all material, as outlined below, will govern, within the judgment of the Press, acceptance or rejection of manuscripts and art.

Copy must be prepared on typewriter or word processor, double-spaced, on one side of standard white bond paper (not

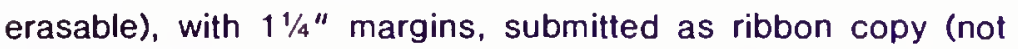
carbon or xerox), in loose sheets (not stapled or bound), and accompanied by original art. Minimum acceptable length is 30 pages.

Front matter (preceding the text) should include: title page with only title and author and no other information; abstract page with author, title, series, etc., following the established format; table of contents with indents reflecting the hierarchy of heads in the paper; also, foreword and/or preface, if appropriate.

First page of text should carry the title and author at the top of the page; second page should have only the author's name and professional mailing address, to be used as an unnumbered footnote on the first page of printed text.

Center heads of whatever level should be typed with initial caps of major words, with extra space above and below the head, but with no other preparation (such as all caps or underline, except for the underline necessary for generic and specific epithets). Run-in paragraph heads should use period/dashes or colons as necessary.

Tabulations within text (lists of data, often in parallel columns) can be typed on the text page where they occur, but they should not contain rules or numbered table captions.

Formal tables (numbered, with captions, boxheads, stubs, rules) should be submitted as carefully typed, double-spaced copy separate from the text; they will be typeset unless otherwise requested. If camera-copy use is anticipated, do not draw rules on manuscript copy.

Taxonomic keys in natural history papers should use the aligned-couplet form for zoology and may use the multi-level indent form for botany. If cross reférencing is required between key and text, do not include page references within the key, but number the keyed-out taxa, using the same numbers with their corresponding heads in the text.

Synonymy in zoology must use the short form (taxon, author, year:page), with full reference at the end of the paper under "Literature Cited." For botany, the long form (taxon, author, abbreviated journal or book title, volume, page, year, with no reference in 'Literature Cited") is optional.

Text-reference system (author, year:page used within the text, with full citation in "Literature Cited" at the end of the text) must be used in place of bibliographic footnotes in all Contributions Series and is strongly recommended in the Studies Series: "(Jones, 1910:122)" or ". . . Jones (1910:122)." If bibliographic footnotes are required, use the short form (author, brief title, page) with the full citation in the bibliography.

Footnotes, when few in number, whether annotative or bibliographic, should be typed on separate sheets and inserted immediately after the text pages on which the references occur. Extensive notes must be gathered together and placed at the end of the text in a notes section.

Bibliography, depending upon use, is termed "Literature Cited," "References," or "Bibliography." Spell out titles of books, articles, journals, and monographic series. For book and article titles use sentence-style capitalization according to the rules of the language employed (exception: capitalize all major words in English). For journal and series titles, capitalize the initial word and all subsequent words except articles, conjunctions, and prepositions. Transliterate languages that use a nonRoman alphabet according to the Library of Congress system. Underline (for italics) titles of journals and series and titles of books that are not part of a series. Use the parentheses/colon system for volume(number):pagination: "10(2):5-9." For alignment and arrangement of elements, follow the format of recent publications in the series for which the manuscript is intended. Guidelines for preparing bibliography may be secured from Series Section, SI Press.

Legends for illustrations must be submitted at the end of the manuscript, with as many legends typed, double-spaced, to a page as convenient.

Illustrations must be submitted as original art (not copies) accompanying, but separate from, the manuscript. Guidelines for preparing art may be secured from Series Section, SI Press. All types of illustrations (photographs, line drawings, maps, etc.) may be intermixed throughout the printed text. They should be termed Figures and should be numbered consecutively as they will appear in the monograph. If several illustrations are treated as components of a single composite figure, they should be designated by lowercase italic letters on the illustration; also, in the legend and in text references the italic letters (underlined in copy) should be used: "Figure 9b. " Illustrations that are intended to follow the printed text may be termed Plates, and any components should be similarly lettered and referenced: "Plate 9b. " Keys to any symbols within an illustration should appear on the art rather than in the legend.

Some points of style: Do not use periods after such abbreviations as "mm, ft, USNM, NNE." Spell out numbers "one" through "nine" in expository text, but use digits in all other cases if possible. Use of the metric system of measurement is preferable; where use of the English system is unavoidable, supply metric equivalents in parentheses. Use the decimal system for precise measurements and relationships, common fractions for approximations. Use day/month/year sequence for dates: "9 April 1976." For months in tabular listings or data sections, use three-letter abbreviations with no periods: "Jan, Mar, Jun, " etc. Omit space between initials of a personal name: "J.B. Jones."

Arrange and paginate sequentially every sheet of manuscript in the following order: (1) title page, (2) abstract, (3) contents, (4) foreword and/or preface, (5) text, (6) appendixes, (7) notes section, (8) glossary, (9) bibliography, (10) legends, (11) tables. Index copy may be submitted at page proof stage, but plans for an index should be indicated when manuscript is submitted. 
